\title{
CHARACTERIZATION RECOMMIENDATIONS FOR WASTE SITES AT THE SAVANNAH RIVER PLANT
}
D. E. Gordon
W. F. Johnson
D. S. Kaback
B. B. Looney
R. L. Nichols
C. B. Shedrow

Approved by:

J. C. Corey, Research Manager

Environmental Sciences Division

Savannah River Laboratory

November : 1987

E. i. du Pont de Nemours \& Co. Savannah River Laboratory Aiken, SC 29808

Prepared For The U. S. Department Of Energy Under Contract DE-AC09-76SR00001 


\section{Page}

List of Tables

vii

List of Figures

ix

Introduction and Summary

Acid/Caustic Basins

$A-1$

Asbestos Pits

B-1

Ash Basins

C-1

Ash Piles

D-1

Bingham Pump Outage Pits

E-1

Burning/Rubble Pits

F-1

CMP Pits

G-1

Coal Pile Runoff Containment Basins

$\mathrm{H}-1$

Earthen Basins

I-1

Erosion Control Sites

$\mathrm{J}-1$

F-Area Seepage Basins

$\mathrm{K}-1$

Fire Department Training Facility

$\mathrm{L}-1$

Ford Building Seepage Basin

$M-1$

Ford Building Waste Site

$\mathrm{N}-1$

Gas Cylinder Disposal Facility

$0-1$

Gunsite 720 Rubble Pit

$\mathrm{P}-1$

Gunsite Rubble Piles

Q-1

H-Area Seepage Basins

R-1 
K-Area Retention Basin $\quad \mathrm{T}-1$

L-Area 0 i1 and Chemical Basin U-1

Lumber Piles $\quad$ V-1

M-Area Settling Basin and Vicinity $W-1$

Metallurgical Laboratory Basin and Vicinity $\mathrm{X}-1$

Metals Burning Pit $\quad \mathrm{Y}-1$

Miscellaneous Chemical Basin $\quad$ Z-1

New TNX Seepage Basin AA-1

01d F-Area Seepage Basin $\quad$ BB-1

01d TNX Seepage Basin $\quad$ CC-1

Radioactive Waste Buria1 Grounds $\quad$ DD-1

Reactor Seepage Basins $\quad E E-1$

Rischer Road Metal Pit FF-1

Road A Chemical Basin GG-1

Rubble Piles $\quad \mathrm{HH}-1$

Rubble Pits. II-1

Sanitary Landfil1 JJ-1

Sanitary Sewage Sludge Disposal Pit $\quad$ KK-1

Savannah River Laboratory 0il Test Site LL-1

Savannah River Laboratory Seepage Basins

Scrap Metal Pile NN-1

Separations Area Retention Basins $00-1$ 
CONTENTS, Contd

Sewage Sludge App1ication Sites

PP-1

Silverton Road Waste Site

QQ-1

TNX Burying Ground

RR-1

Waste Oil Basins

SS-1

Glossary

Glos-1

References

Ref-1

Appendix

App-1 
$-1$

$-$

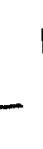

$-1$

-

$-1$

-

$-$

$-1$

-

- vi - 
Table

$\underline{\text { Page }}$

B.1 Asbestos Pit Building Numbers, Dimensions, and SRP Coordinates

$\mathrm{B}-2$

C.1 Location and Status of the Ash Basins $\quad$ C-2

F.1 Burning/Rubble Pit Locations, Building Numbers, SRP Coordinates, and Dimensions

$\mathrm{F}-2$

G.1 Building Numbers and SRP Coordinates for the CMP Pits

G-3

H.1 SRP Coordinates for the Coal Pile Runoff Containment Basins

$\mathrm{H}-2$

J.1 Erosion Control Site Building Numbers and SRP Coordinates

$\mathrm{J}-2$

Q.1 Gunsite Rubble Pile Building Numbers and SRP Coordinates

EE.1 Dimensions and SRP Coordinates of the $\mathrm{K}$ - and R-Area Reactor Seepage Basins

$\mathrm{EE}-4$

Appendix

Tables

1

Recommended Soil/Sediment Sampling Intervals and Analyses

App-2

2 Inorganic Analyses for Soil, Sediment, Waste, and Sludge Samples

App-4

3 Volatile Organic Analyses for Water, Soil, Sediment, Waste, and Sludge Samples

App-5

4 Radioactivity Analyses for Soil, Sediment, Waste, and Sludge Samples

App-7

5 Expanded Radioactivity Analyses for Water, Soil, Sediment, Waste, and Sludge Samples 
LIST OF TABLES, Contd

$\underline{\text { Table }}$

Page

6 Parameters for Groundwater Analyses for Waste Site Characterization App-9

$7 \quad$ EPA Appendix IX Constituents

App-11

8 EP Toxicity Analyses for Soil, Sediment, Waste, and Sludge Samples

App-17

9 Cross-Referenced Names for Chemicals on the EPA Appendix IX List

App-18

10

Groundwater Quality Review Criteria

App -31 


\section{LIST OF FIGURES}

Figure

$\underline{\text { Page }}$

A. 1 Location of the K-Area Acid/Caustic Basin on Girard

NW Quadrangle 7.5 Minute Series Topographic Map

A-2

A. 2 Locations of the L- and P-Area Acid/Caustic Basins on Girard NE Quadrangle 7.5 Minute Series Topographic Map

A-3

A.3 Location of the R-Area Acid/Caustic Basin on New Ellenton SE Quadrangle 7.5 Series Topographic Map

A-4

A. 4 Locations of the F- and H-Area Acid/Caustic Basins on New E1lenton SW Quadrangle 7.5 Minute Series Topographic Map

$A-5$

A.5 Proposed Locations for Monitoring We11s at the H-Area Acid/Caustic Basin

A-9

B.1 Location of the C-Area Asbestos Pits on New Ellenton SW and Girard NW Quadrangle 7.5 Minute Series Topographic Maps

$\mathrm{B}-3$

B.2 Location of the D-Area Asbestos Pit on Girard NW Quadrangle 7.5 Minute Series Topographic Map

$\mathrm{B}-4$

B.3 Location of the R-Area Asbestos Pit on New Ellenton SE Quadrangle 7.5 Minute Series Topographic Map

B-5

C.1 Location of the D-Area Ash Basins on Girard NW Quadrangle 7.5 Minute Series Topographic Map

$\mathrm{C}-3$

C.2 Proposed Monitoring Wel1 and Sampling Locations at the D-Area Ash Basins

$\mathrm{C}-5$

C.3 Location of the F-Area Ash Basins on New Ellenton SW Quadrangle 7.5 Minute Series Topographic Map

C-6

C.4 Proposed Monitoring Well and Sampling Locations at the F-Area Ash Basins

C.5 Location of the H-Area Ash Basin on New E1lenton SW Quadrangle 7.5 Minute Series Topographic Map

C.6 Proposed Monitoring We11 and Sampling Locations at the H-Area Ash Basin 


\section{LIST OF FIGURES, Contd}

\section{Figure}

C. 7 Location of the K-Area Ash Basin on Girard NW Quadrangle 7.5 Minute Series Topographic Map

$\mathrm{C}-13$

C.8 Proposed Sampling Locations at the K-Area Ash Basin

$\mathrm{C}-14$

C. 9 Location of the L-Area Ash Basin on Girard NW Quadrangle 7.5 Minute Series Topographic Map

$\mathrm{C}-16$

C.10 Proposed Monitoring We11 and Sampling Locations at the L-Area Ash Basin

$\mathrm{C}-18$

C.11 Location of the P-Area Ash Basin on Girard NE Quadrangle 7.5 Minute Series Topographic Map

C.12 Proposed Monitoring We11 and Sampling Locations at the P-Area Ash Basin

C.13 Location of the R-Area Ash Basin on New Ellenton SE Quadrangle 7.5 Minute Series Topographic Map

C.14 Proposed Monitoring We11 and Sampling Locations at the R-Area Ash Basin

$\mathrm{C}-24$

D.1 Location of the A-Area Ash Piles on New Ellenton SW Quadrangle 7.5 Minute Series Topographic Map

D-2

D. 2 Location of the C-Area Ash Piles on Girard NW Quadrangle 7.5 Minute Series Topographic Map

$\mathrm{D}-4$

D. 3 Proposed Sampling Locations at A-Area Ash Pile 788-2A

D-5

D.4 Proposed Monitoring Well and Sampling Locations at A-Area Ash Pile 788-A

D-6

D.5 Proposed Monitoring We11 and Sampling Locations at C-Area Ash Piles 188-C and 188-1C

D.6 Proposed Monitoring We11 and Sampling Locations at C-Area Ash Pile 188-2C

E.1 Location of the K-Area Bingham Pump Outage Pit on Girard NW Quadrangle 7.5 Minute Series Topographic Map

E. 2 Location of the L-Area Bingham Pump Outage Pits on the Girard NW and Girard NE Quadrangle 7.5 Minute Series Topographic Maps 
LIST OF FIGURES, Contd

Figure

$\underline{\text { Page }}$

E.3 Location of the P-Area Bingham Pump Outage Pit on Girard NE Quadrangle 7.5 Minute Series Topographic Map E-4

E.4 Location of the R-Area Bingham Pump Outage Pits on New Ellenton SE Quadrangle 7.5 Minute Series Topographic Map

E-5

E.5 Proposed Samp1ing Locations at the K-Area Bingham Pump Outage Pit

$E-7$

E.6 Proposed Sampling Locations at the L-Area Bingham Pump Outage Pits

$E-8$

E.7 Proposed Sampling Locations at the P-Area Bingham Pump Outage Pit

E-9

E.8 Proposed Sampling Locations at the R-Area Bingham Pump Outage Pits

E-10

F.1 Location of the A-Area Burning/Rubble Pits on New Ellenton SW Quadrangle 7.5 Minute Series Topographic Map F-3

F.2 Proposed Cluster Well and Sampling Locations for the A-Area Burning/Rubble Pits

$F-5$

F.3 Locations of the C-Area and Central Shops Area Burning/Rubble Pits on Girard NW Quadrangle 7.5 Minute Series Topographic Map

F-7

F.4 Proposed Cluster Well and Sampling Locations for the C-Area Burning/Rubble Pit

F-9

F.5 Proposed Cluster Well and Sampling Locations for the Central Shops Area Burning/Rubble Pits

F-11

F.6 Location of the D-Area Burning/Rubble Pits on Girard NW Quadrangle 7.5 Minute Series Topographic Map

F.7 Proposed Cluster Well and Sampling Locations for the D-Area Burning/Rubble Pits

F.8 Location of the F-Area Burning/Rubble Pits on New E1lenton NW Quadrangle 7.5 Minute Series Topographic Map F-17

F.9 Proposed Cluster Well and Sampling Locations for the F-Area Burning/Rubble Pits

F-18 
LIST OF FIGURES, Contd

$\underline{\text { Figure }}$

Page

F.10 Location of the K-Area Burning/Rubble Pit on Girard NW Quadrangle 7.5 Minute Series Topographic Map F-21

F.11 Proposed Cluster Well and Sampling Locations for the K-Area Burning/Rubble Pit

F.12 Locations of the L-Area and P-Area Burning/Rubble Pits on Girard NE Quadrangle 7.5 Minute Series Topographic Map F-24

F-13 Proposed Cluster Well and Sampling Locations for the L-Area Burning/Rubble Pit

F.14 Proposed Cluster We11 and Sampling Locations for the P-Area Burning/Rubble Pit

F.15 Location of the R-Area Burning/Rubble Pits on New Ellenton SE Quadrangle 7.5 Minute Series Topographic Map F-30

F.16 Proposed Cluster Well and Sampling Locations for the R-Area Burning/Rubble Pits

G.1 Location of the CMP Pits on Girard NW Quadrangle 7.5 Minute Series Topographic Map

G.2 Monitoring Well Locations at the CMP Pits G-4

G.3 Proposed Soil Gas Survey at the CMP Pits G-7

H.1 Location of the A-Area Coa1 Pile Runoff Containment Basin on New Ellenton SW Quadrangle 7.5 Minute Series Topographic Map

H.2 Existing Monitoring Wells and Proposed Samp1ing Locations at the A-Area Coal Pile Runoff Containment Basin

H.3 Location of the C-Area Coal Pile Runoff Containment Basin on Girard NW Quadrangle 7.5 Minute Series Topographic Map

H.4 Existing Monitoring Wells and Proposed Sampling Locations at the C-Area Coal Pile Runoff Containment Basin

H.5 Location of the D-Area Coal Pile Runoff Containment Basin on Girard NW Quadrangle 7.5 Minute Series 
H.6 Existing Monitoring We11s and Proposed Sampling Locations at the D-Area Coal Pile Runoff Containment Bas in

H.7 Location of the F-Area Coal Pile Runoff Containment Basin on New Ellenton SW Quadrangle 7.5 Minute Series Topographic Map

H.8 Existing Monitoring Wells and Proposed Sampling Locations at the F-Area Coal Pile Runoff Containment Basin

H.9 Location of the H-Area Coal Pile Runoff Containment Basin on New E1lenton SW Quadrangle 7.5 Minute Series Topographic Map

H.10 Existing Monitoring Wells and Proposed Sampling Locations at the H-Area Coal Pile Runoff Containment Bas in

H.11 Location of the K-Area Coal Pile Runoff Containment Basin on Girard NW Quadrangle 7.5 Minute Series Topographic Map

H.12 Existing Monitoring Wells and Proposed Sampling Locations at the K-Area Coal Pile Runoff Containment Basin

H.13 Location of the P-Area Coal Pile Runoff Containment Basin on Girard NE Quadrangle 7.5 Minute Series Topographic Map

H.14 Existing Monitoring Wells and Proposed Sampling Locations at the P-Area Coal Pile Runoff Containment Basin

I.1 Location of the C-Area Earthen Basin on New Ellenton SW and Girard NW Quadrangle 7.5 Minute Series Topographic Maps

I.2 Location of the K-Area Earthen Basin on Girard NW Quadrangle 7.5 Series Topographic Map

I.3 Location of the L-Area Earthen Basin on Girard NW and Girard NE Quadrangle 7.5 Minute Series Topographic Maps

I.4 Location of the P-Area Earthen Basin on Girard NE Quadrangle 7.5 Minute Series Topographic Map 
I.5 Location of the R-Area Earthen Basin on New Ellenton SE Quadrangle 7.5 Minute Series Topographic Map

J.1 Location of the C-Area Erosion Contro1 Site on Girard NW and New E1lenton SW Quandrangle 7.5 Minute Series Topographic Maps

J.2 Location of the F-Area Erosion Control Site on New E11enton NW Quandrangle 7.5 Minute Series Topographic Map J-4

J.3 Location of the H-Area Erosion Control Site on New Ellenton NW Quandrangle 7.5 Minute Series Topographic Map J-5

J.4 Location of the L-Area Erosion Control Site on New Ellenton NW Quandrangle 7.5 Minute Series Topographic Map J-6

J.5 Location of the Substation 51 Erosion Control Site on New Ellenton NW Quadrangle 7.5 Minute Series Topographic Map

J.6 Location of the 3G-Pumphouse Erosion Control Site on New Ellenton NW Quadrangle 7.5 Minute Series Topographic Map

J.7 Location of the P-Area Erosion Control Site on Girard NW Quadrangle 7.5 Minute Series Topographic Map

J.8 Location of the S-Area Erosion Control Site on New Ellenton SW Quadrangle 7.5 Minute Series Topographic Map

J.9 Location of the D-F Steamline Erosion Control Site on Girard NW Quadrangle 7.5 Minute Series Topographic Map

K.1 Location of the F-Area Seepage Basins on New Ellenton SW Quadrangle 7.5 Minute Series Topographic Map

L.1 Location of the Fire Department Training Facility on New E1lenton SW and Girard NW Quadrangle 7.5 Minute Series Topographic Maps

L.2 Proposed Sampling and Monitoring Well Locations at the Fire Department Training Facility

M.1 Location of the Ford Building Seepage Basin on New E1lenton SW and Girard NW Quadrangle 7.5 Minute Series Topographic Maps 
LIST OF FIGURES, Contd

Figure

M. 2 Proposed Sampling Locations at the Ford Building Seepage Basin

M-4

N.1 Location of the Ford Building Waste Site on New Ellenton SW and Girard NW Quadrangle 7.5 Minute Series Topographic Maps

$\mathrm{N}-2$

N.2 Proposed Sampling Locations for the Ford Building Waste Site

$\mathrm{N}-3$

0.1 Location of the Gas Cylinder Disposal Facility on Girard NE Quadrangle 7.5 Minute Series Topographic Map 0-2

P.1 Location of the Gunsite 720 Rubble Pit on Shel1 Bluff Landing and Girard NW Quadrangle 7.5 Minute Series Topographic Maps

$\mathrm{P}-2$

P.2 Proposed Sampling Locations at the Gunsite 720 Rubble Pit

$\mathrm{P}-3$

Q.1 Location of the Gunsite 51 Rubble Pile on Girard NW Quadrangle 7.5 Minute Series Topographic Map

Q-3

Q.2 Location of the Gunsite 72 Rubble Pile on Shelf Bluff Landing Quadrangle 7.5 Minute Series Topographic Map

Q-4

Q.3 Location of the Gunsite 102 Rubble Pile on New E1lenton SE Quadrangle 7.5 Minute Series Topographic Map Q-5

Q.4 Location of the Gunsite 113 Rubble Pile on Long Branch Quadrangle 7.5 Minute Series Topographic Map

R.1 Location of the H-Area Seepage Basins on New Ellenton SW Quadrangle 7.5 Minute Series Topographic Map

S.1 Location of the Hydrofluoric Acid Spill Area on New E1lenton SW and Girard NW Quadrangle 7.5 Minute Series Topographic Maps

S.2 Proposed Sampling Locations for the Hydrofluoric Acid Spil1 Area

T.1 Location of the K-Area Retention Basin on Girard NW Quadrangle 7.5 Minute Series Topographic Map

T.2 Proposed Sampling Locations at the K-Area Retention Bas in 
LIST OF FIGURES, Contd

Figure

Page

U.1 Location of the L-Area $0 i 1$ and Chemical Basin on Girard NW and Girard NE Quadrangle 7.5 Minute Series Topographic Maps

$\mathrm{U}-2$

U.2 Sampling Locations Within the L-Area Oil and Chemical Basin

$\mathrm{U}-4$

V.1 Location of the Central Shops Lumber Pile on New E1lenton SW and Girard NW Quadrangle 7.5 Minute Series Topographic Maps

$\mathrm{V}-2$

V.2 Location of the F-Area Lumber Pile on New E1lenton SW Quadrangle 7.5 Minute Series Topographic Map

$\mathrm{V}-3$

W.1 Location of the M-Area Settling Basin and Vicinity on New E1lenton SW Quadrangle 7.5 Minute Series

Topographic Map

W-3

X.1 Location of the Metallurgical Laboratory Basin on New Ellenton SW Quadrangle 7.5 Minute Series Topographic Map

$\mathrm{x}-3$

X.2 Metallurgical Laboratory Basin Sampling Locations X-4

X.3 Process Sewer Line Sampling Locations X-5

X.4 Carolina Bay Sampling-Locations $\quad X-7$

X.5 Proposed Monitoring Well Locations at the Metallurgical Laboratory Basin

$x-9$

Y.1 Location of the Metals Burning Pit on New Ellenton SW Quadrangle 7.5 Minute Series Topographic Map

$\mathrm{Y}-2$

Y.2 Location of Existing and Proposed Monitoring Well and Sampling Sites at the Metals Burning Pit

Y-3

2.1 Location of the Miscellaneous Chemical Basin on New E1lenton SW Quadrangle 7.5 Minute Series

Topographic Map

Z-2

2.2 Location of Proposed Cluster Well and Sampling Sites at the Miscellaneous Chemical Basin 
AA.1 Location of the New TNX Seepage Basin on Shell Bluff Landing Quadrangle 7.5 Minute Series Topographic Map

$\mathrm{AA}-2$

AA.2 Location of Monitoring Wells at the New TNX Seepage Basin

$\mathrm{AA}-4$

BB.1 Location of the 01d F-Area Seepage Basin on New Ellenton SW Quadrangle 7.5 Minute Series Topographic Map

BB-2

BB.2 Proposed Sampling Locations within the 01d F-Area Seepage Basin

BB-5

CC.1 Location of the 01d TNX Seepage Basin on Shell Bluff Landing Quadrangle 7.5 Minute Series Topographic Map

$\mathrm{CC}-3$

CC.2 Monitoring Well Location Map for the 01d TNX Seepage Bas in

CC-4

DD.1 Burial Grounds Showing Zones of Filled Trench Alpha, Intermediate- and Low-Level Beta-Gamma Waste, and

Solvent Storage and the Boundary of 643-28G MWMF

DD-2

DD.2 Location of the Radioactive Waste Burial Grounds on New Ellenton SW Quadrangle 7.5 Minute Series

Topographic Map

DD-5

DD.3 Topography and Drainage in the Radioactive Waste

Burial Grounds

DD-6

DD.4 Water-Table Map in the Immediate Vicinity of the

Burial Grounds

DD-7

DD.5 Vertical Head Relationships in Well Log from Burial Ground Wells

DD-8

DD.6 Burial Grounds Monitoring Wells

DD-9

DD.7 Protocol Monitoring Wells for the Existing and

Previous Radioactive Waste Disposal Facilities

DD-10 
LIST OF FIGURES, Contd

Figure

Page

EE.1 Location of the K-Area Reactor Seepage Basin on Girard NW Quadrangle 7.5 Minute Series Topographic Map

EE-2

EE.2 Location of the R-Area Reactor Seepage Basins on New E1lenton SE Quadrangle 7.5 Minute Series Topographic Map

$\mathrm{EE}-3$

EE.3 Proposed Sampling Locations within the R-Area Reactor Seepage Basins

EE-7

EE.4 Proposed Sampling Locations within the K-Area Reactor Seepage Basin

EE-8

FF.1 Location of the Risher Road Metal Pit on New Ellenton SW Quadrangle 7.5 Minute Series Topographic Map

$\mathrm{FF}-2$

FF.2 Proposed Sampling Locations at the Risher Road Metal Pit

$\mathrm{FF}-3$

GG.1 Location of the Road A Chemical Basin on New Ellenton SW Quadrangle 7.5 Minute Series Topographic Map

GG-2

GG.2 Existing Monitoring Wells and Proposed Sampling Locations for the Road A Chemical Basin

HH.1 Location of the A-Area Rubble Pile on New Ellenton SW Quadrangle 7.5 Minute Series Topographic Map

$\mathrm{HH}-2$

HH.2 Location of the Miscellaneous Rubble Pile on Girard NW Quadrangle 7.5 Minute Series Topographic Map

$\mathrm{HH}-3$

HH. 3 Location of the Rubble Pile at Cemetary Road, the Rubble Pile Between Cemetary Road and Brag Bray Road, the Rubble Pile at Road 781.1, and the Rubble Pile at Brag Bray Road

$\mathrm{HH}-4$

HH.4 Location of the SREL and Forestry Rubble Piles on New E11enton SW Quadrangle 7.5 Minute Series Topographic Map

$\mathrm{HH}-5$

HH.5 Location of the L-Area Rubble Pile on Girard NE Quadrangle 7.5 Minute Series Topographic Map

HH-6 
LIST OF FIGURES, Contd

Figure

HH.6 Location of the R-Area Rubble Pile on New Ellenton SE Quadrangle 7.5 Minute Series Topographic Map

$\mathrm{HH}-7$

II.1 Location of the A-Area Rubble Pit on New E1lenton

SW Quadrangle 7.5 Minute Series Topographic Map

I I -2

II.2 Location of the CS-Area Rubble Pits on New Ellenton SW and Girard NW Quadrangle 7.5 Minute Series

Topographic Maps

II -3

II.3 Location of the D-Area Rubble Pit on Girard NW Quadrangle 7.5 Minute Series Topographic Map

I I -4

II.4 Location of the F-Area Rubble Pits on New Ellenton SW Quadrangle 7.5 Minute Series Topographic Map

II.5 Location of the Forestry (G-Area) Rubble Pit on New Ellenton SW Quadrangle 7.5 Minute Series

Topographic Map

II -6

II.6 Location of the L-Area Rubble Pits on Girard NW and Girard NE Quadrangle 7.5 Minute Series

Topographic Maps

II.7 Location of the R-Area Rubble Pit on New Ellenton SE Quadrangle 7.5 Minute Series Topographic Map

JJ.1 Location of the Sanitary Landfill on New E1lenton SW Quadrangle 7.5 Minute Series Topographic Map

$\mathrm{JJ}-2$

JJ.2 Location Map of Existing and Proposed Sanitary Landfill Monitoring Wells and Soil Sampling Sites

KK.1 Location of the Sanitary Sewage Sludge Disposal Pit on New Ellenton SW and Girard NW Quadrangle 7.5 Minute Series Topographic Maps

KK.2 Location of Proposed Groundwater Monitoring Wells and Sampling Sites Around the Sanitary Sewage Sludge Disposal Pit

$\mathrm{KK}-4$

LI.1 Location of the SRL Oil Test Site on New Ellenton SW and Girard NW Quadrangle 7.5 Minute Series Topographic Maps

LL.2 Proposed Sampling Locations at the SRL Oil Test Site 


\section{Figure}

MM.1 Location of the SRL Seepage Basins on New Ellenton SW Quadrangle 7.5 Minute Series Topographic Map

MM-3

MM.2 SRL Seepage Basins Blueprint

MM-4

M.3 Monitoring We11 Location Map and Water-Table

Elevation Map for the SRL Seepage Basins

MM-6

NN.1 Location of the Scrap Metal Pile on Girard NE Quadrangle 7.5 Minute Series Topographic Map

$\mathrm{NN}-2$

NN.2 Proposed Sampling Locations at the Scrap Metal Pile

$\mathrm{NN}-3$

00.1 Location of the Separations Area Retention Basins on New E1lenton SW Quadrangle 7.5 Minute Series Topographic Map

$00-2$

00.2 Proposed Monitoring Well and Sampling Locations at the F-Area Retention Basin

$00-5$

00.3 Proposed Sampling Locations at H-Area Retention Basin

$00-6$

PP.1 Location of the Sewage Sludge Application Sites

PP.2 Location of the 40-Acre Hardwood and K-Area Borrow Pit Sludge Application Sites on Girard NW Quadrangle 7.5 Minute Series Topographic Map

PP.3 Location of the Road F and Lucy Sludge Application Sites on New Ellenton SW Quadrangle 7.5 Minute Series Topographic Map

PP.4 Location of the Kato Road, Lower Kato Road, and Orangeburg Sludge Application Sites on New Ellenton SW Quadrangle 7.5 Minute Series Topographic Map

PP.5 Location of the Par Pond and Second Par Pond Sludge Application Sites on Girard NE Quadrangle 7.5 Minute Series Topographic Map

QQ.1 Location of the Silverton Road Waste on New E1lenton SW Quadrangle 7.5 Minute Series Topographic Map

QQ.2 Location of Proposed Soil Gas Survey at the Silverton Road Waste Site 
LIST OF FIGURES, Contd

Figure

Page

QQ.3 Existing Monitoring Wells and Proposed Sampling

Locations at the Silverton Road Waste Site

QQ-5

RR.1 Location of the TNX Burying Ground on She11 Bluff

Landing Quadrangle 7.5 Minute Topographic Map

$R R-2$

RR.2 Location of the Burial Sites at the TNX Burying Ground

$\mathrm{RR}-4$

RR.3 Proposed Sampling Locations at the TNX Burying Ground RR-5

SS.1 Location of the Motor Shop Oil Basin on New Ellenton SW Quadrangle 7.5 Minute Series Topographic Map SS-2

SS. 2 Location of the D-Area Oil Basin on Girard NW

Quadrangle 7.5 Minute Series Topographic Map

SS-3

SS.3 Proposed Monitoring Well and Sampling Locations for the Motor Shop Oil Basin

SS-6

SS. 4

Proposed Sampling Locations for the D-Area 0il Basin

SS-7 
One hundred and sixty six disposal facilities that received or may have received waste materials resulting from operations at the Savannah River Plant (SRP) have been identified. These wastes range from innocuous solid and liquid materials (e.g., wood piles) to process effluents that contain hazardous and/or radioactive constituents. The waste sites have been grouped into 45 categories according to the type of waste materials they received (see Summary Table). Waste sites are located with SRP coordinates, a local Department of Energy grid system whose grid north is 36 degrees 22 minutes west of true north.

Department of Energy (DOE) policy is to close all waste sites at SRP in a manner consistent with protecting human health and the environment and complying with applicable environmental regulations (DOE, 1984). A uniform, explicit characterization program for SRP waste sites will provide a sound technical basis for developing closure plans. Several elements are summarized in the following individual sections including 1) a review of the history, geohydrology, and available characterization data for each waste site and 2) recommendations for additional characterization necessary to prepare a reasonable closure plan. Many waste sites have been fully characterized, while others have not been investigated at a11.

An environmental analysis of many of the waste sites was conducted as part of the National Environmental Policy Act (NEPA) review of waste management activities for groundwater protection at SRP (DOE, 1987). This analysis resulted in the preparation of Environmental Information Documents (EIDs) on the subject waste sites. In some cases the EIDs contain much of the information needed to develop closure plans. However, the data in other EIDs may need to be augmented for complete closure plan development.

The approach used in this report is to evaluate available groundwater quality and site history data. For example, groundwater data are compared to review criteria (1isted in the Appendix) to help determine what additional information is required. The review criteria are based on regulatory and DOE guidelines for acceptable concentrations of constituents in groundwater and soil. The recommendations for sampling of water, soil, and groundwater and the analyses of these samples are given for each of the 45 waste-site categories. Waste-site sampling patterns and soil depth collection schemes are also listed. Splits of all soil samples should be archived for later reference. Not all soil intervals should be analyzed; some should only be archived (see Appendix). At sites where new monitoring wells are proposed, one of the holes should be cored continuously, described geologically, and archived. A11 new monitoring wells should be logged geophysically. The chemical and radioactive analyses are specified to provide the necessary contaminant definition. Geophysical techniques are specified where relevant to gather required data. A summary of the characterization recommendations for the waste sites are given in the Summary Table. All elevations are given in meters above (or below) mean sea level. 
Over 200 soil cores to nominal depths of 3 or $6 \mathrm{~m}$ are recommended. Installation of over 100 groundwater monitoring wells, mostly to the water table, are suggested. The use of ground penetrating radar (GPR) to define backfilled waste site boundaries is specified for 26 individual waste sites. Soil gas surveys for the presence of volatile organic materials is recommended at 17 specific waste sites.

The characterization requirements for waste sites are based on technical considerations as well as RCRA Facility Investigations (RFI) specifications developed by the Environmental Protection Agency (EPA). Several of the solid waste management units at SRP have been identified by EPA for inclusion in an RFI evaluation. The data collected during the characterization phase will provide the technical basis for appropriate closure activities. A different characterization program may be implemented to better define site specific or area wide problems. 


\section{SURAARY OF WASTE-SITE CHARACTERIZATION RECOAONFNDATIONS}

$\begin{array}{ll}\text { WASTE-SITE CATEGORIES } & \text { CHARACTERIZATION RECOMMENDATIONS } \\ \text { Acid/Caustic Basins } & \begin{array}{l}\text { Four new water-table monitoring wells } \\ \text { at the H-Area Basin. }\end{array} \\ \text { Asbestos Pits } & \text { Air-quality monitoring. }\end{array}$

Ash Basins

D Area

Twelve soil cores to the water table; three new water-table monitoring wells.

F Area

Five soil cores to $6 \mathrm{~m}$; one core to above water table; seven new water-table monitoring wells.

H Area

Four soil cores to above water table; three new water-table monitoring wells.

K Area

Three soil cores to $6 \mathrm{~m}$; terrain conductivity survey.

L Area

Three soil cores to $6 \mathrm{~m}$; three new water-table monitoring wells.

P Area

Three soil cores to $6 \mathrm{~m}$; three new water-table monitoring wells.

R Area

Three soil cores to above water table; three new water-table monitoring wells.

Ash Piles

One soil core at each pile for a total of four cores (three cores to $4 \mathrm{~m}$ and one to the water table); three new water-table monitoring wells at each pile except at the A-Area Ash Pile (Building 288-2A) for a total of 9 wells.

Bingham Pump Outage Pits

GPR at each of the four sites; three soil cores to $6 \mathrm{~m}$ at each characterized pit for a total of 12 cores.

Burning/Rubble Pits

A Area

Soil gas survey; GPR; nine soil cores to $6 \mathrm{~m}$; up to two new wells constructed near an existing water-table well to form a cluster. 


\begin{tabular}{|c|c|}
\hline WASTE-SITE CATEGORIES & CHARACTERIZATION RECOMMENDATIONS \\
\hline C Area & $\begin{array}{l}\text { Nine soil cores to } 6 \mathrm{~m} \text {; one deep core to water } \\
\text { table; up to two new wells constructed near an } \\
\text { existing water-table well to form a cluster. }\end{array}$ \\
\hline Central Shops & $\begin{array}{l}\text { Soil gas survey; GPR; nine soil cores to } 6 \mathrm{~m} \text {; } \\
\text { two clusters of three wells (screened in the } \\
\text { Barnwell, McBean, and Congaree formations); } \\
\text { three new water table wells. }\end{array}$ \\
\hline D Area & $\begin{array}{l}\text { Soil gas survey; GPR; nine soil cores to } 6 \mathrm{~m} \text {; } \\
\text { up to two new wells constructed near an } \\
\text { existing water-table well to form a cluster. }\end{array}$ \\
\hline F Area & $\begin{array}{l}\text { Soil gas survey; GPR; nine soil cores to } 6 \mathrm{~m} \text {; } \\
\text { up to two new wells constructed near an } \\
\text { existing water-table well to form a cluster. }\end{array}$ \\
\hline K Area & $\begin{array}{l}\text { Soil gas survey; GPR; nine soil cores to } 6 \mathrm{~m} \text {; } \\
\text { one cluster of two wells, one each screened in } \\
\text { the (Barnwell, McBean, and Congaree) } \\
\text { formations. }\end{array}$ \\
\hline L Area & $\begin{array}{l}\text { Soil gas survey; GPR; seven soil cores to } 6 \mathrm{~m} \text {; } \\
\text { up to three new wells constructed near an } \\
\text { existing water-table well to form a cluster. }\end{array}$ \\
\hline P Area & $\begin{array}{l}\text { Soil gas survey; GPR; nine soil cores to } 6 \mathrm{~m} \text {; } \\
\text { up to two new wells constructed near an } \\
\text { existing water-table well to form a cluster. }\end{array}$ \\
\hline R Area & $\begin{array}{l}\text { Soil gas survey; GPR; nine soil cores to } 6 \mathrm{~m} \text {; } \\
\text { one cluster of three wells, one each screened } \\
\text { in the Barnwe11, McBean, and Congaree } \\
\text { formations. }\end{array}$ \\
\hline CMP Pits & $\begin{array}{l}\text { Soil gas survey; possibly additional water- } \\
\text { table monitoring wells depending on survey } \\
\text { results. }\end{array}$ \\
\hline
\end{tabular}

Coal Pile Runoff Containment Basins
A Area
Three soil cores to $6 \mathrm{~m}$.
C Area
Three soil cores to $6 \mathrm{~m}$. 


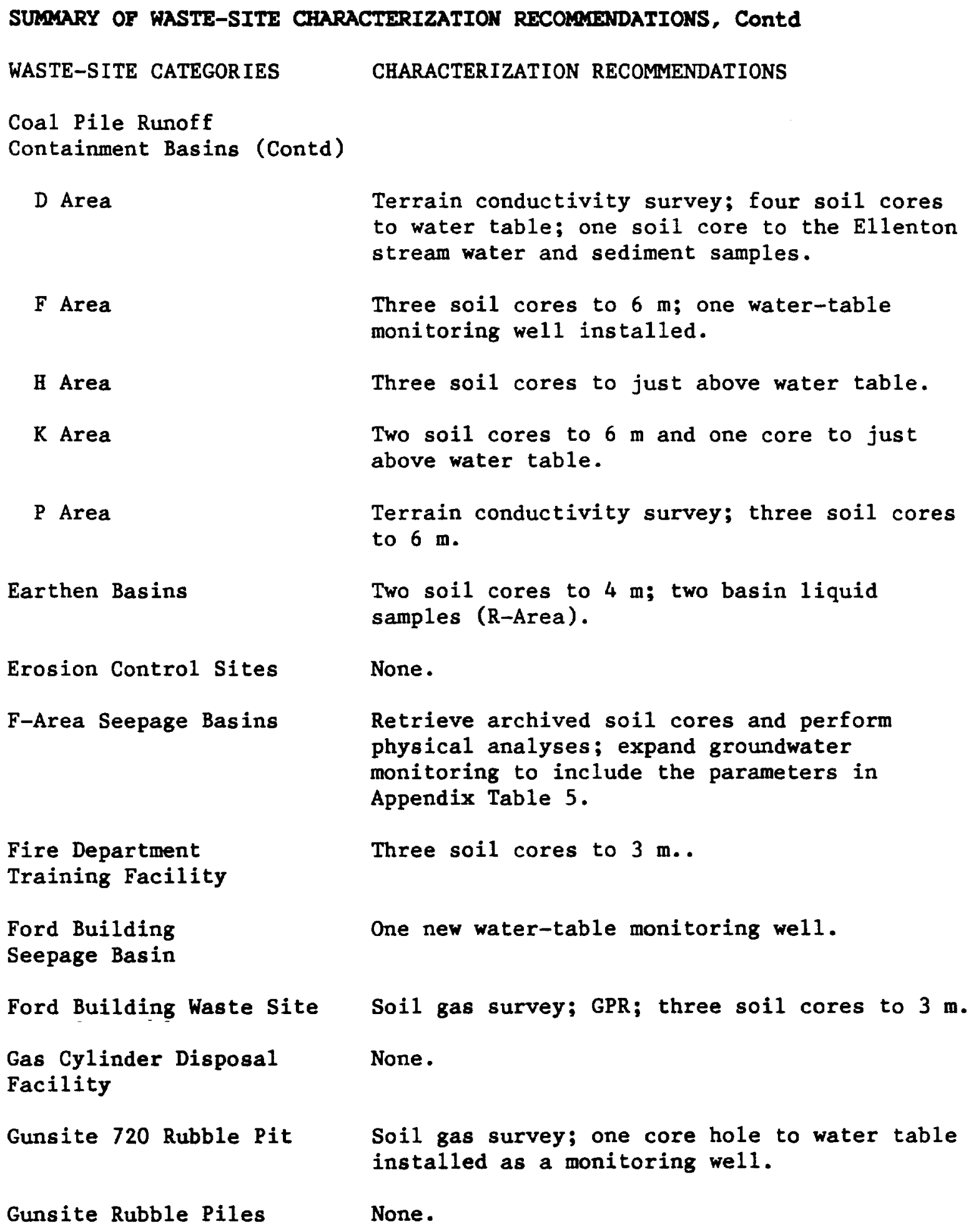

None. 
SURAARY OF WASTE-SITE CHARACTERIZATION RECOMAONDATIONS, Contd

WASTE-SITE CATEGORIES

H-Area Seepage Basins

Hydrofluoric Acid

Spill Area

K-Area Retention Basin

L-Area 0 il and

Chemical Basin

Lumber Piles

M-Area Settling Basin

and Vicinity

Metallurgical Laboratory

Basin and Vicinity

Metals Burning Pit

Miscellaneous Chemical Basin

New TNX Seepage Basin

Old F-Area Seepage Basin

01d TNX Seepage Basin

\section{CHARACTERIZATION RECOMMENDATIONS}

Retrieve archived soil cores and perform physical analyses; expand groundwater monitoring to include the parameters in Appendix Table 5 .

Three soil cores to $3 \mathrm{~m}$; perhaps a core hole to water table if contamination is found; excavation at site to determine source of GPR anomalies.

Three sediment cores to $6 \mathrm{~m}$; composite basin water sample; one deep core; stream water samples.

Retrieve archived samples and analyze for radionuclides.

Sampling to be performed as part of the Burning/Rubble Pits sampling program.

None.

Four new water-table monitoring wells.

Soil gas survey; GPR; three soil cores to $6 \mathrm{~m}$; one three-well cluster, screened at the water table, the Congaree Formation, and the McBean Formation.

Three soil cores to $6 \mathrm{~m}$; one three-well cluster, one well each screened at the water table, the Congaree Formation, and the McBean Formation.

None.

Two soil cores to just above water table.

Sample existing water-table monitoring wells for radionuclides outlined in Appendix Table 5. 
SURAARY OF WASTE-SITE CFARACTERIZATION RECOMENDATIONS, Contd

WASTE-SITE CATEGORIES

Radioactive Waste Burial

Grounds

Reactor Seepage Basins

K-Area

R-Area

Risher Road Metal Pit

Road A Chemical Basin

Rubble Piles

Rubble Pits

Sanitary Landfill

Sanitary Sewage Sludge

Disposal Pit

Savannah River Laboratory Oil Test Site

Savannah River Laboratory Seepage Basins

Scrap Metal Pile
CHARACTERIZATION RECOMMENDATIONS

Sample existing and protocol well clusters currently being drilled.

Three soil cores to $1 \mathrm{~m}$.

Fourteen soil cores to $3 \mathrm{~m}$; analyze watertable monitoring wells for expanded list of radionuclides in Appendix Table 5.

Three soil cores to $3 \mathrm{~m}$; four water-table monitoring wells may be necessary.

Three soil cores to $6 \mathrm{~m}$; possibly one watertable monitoring well.

One soil core to $6 \mathrm{~m}$ at each pile for a total of 10 soil cores.

GPR; one soil core to $6 \mathrm{~m}$ at each pit for a total of 11 soil cores.

Soil gas survey; eight $10-\mathrm{m}$ soil cores and two cores to the water table; one two-well cluster added to existing monitoring we11; outcrop samples of stream sediment and water.

Two soil cores to $3 \mathrm{~m}$; three new water-table monitoring wells, to be installed as cluster wells if organic contamination found.

Soil gas survey; eight $6-\mathrm{m}$ deep cores and six 3-m deep cores for a total of 14 cores; four new water-table monitoring wells around site.

Sampling of basin water; two additional wells constructed near an existing water-table well to form a cluster; analyze groundwater for radionuclides. (Appendix Table 5)

Three soil cores to $3 \mathrm{~m}$; possibly four watertable monitoring wells depending on soil core results. 


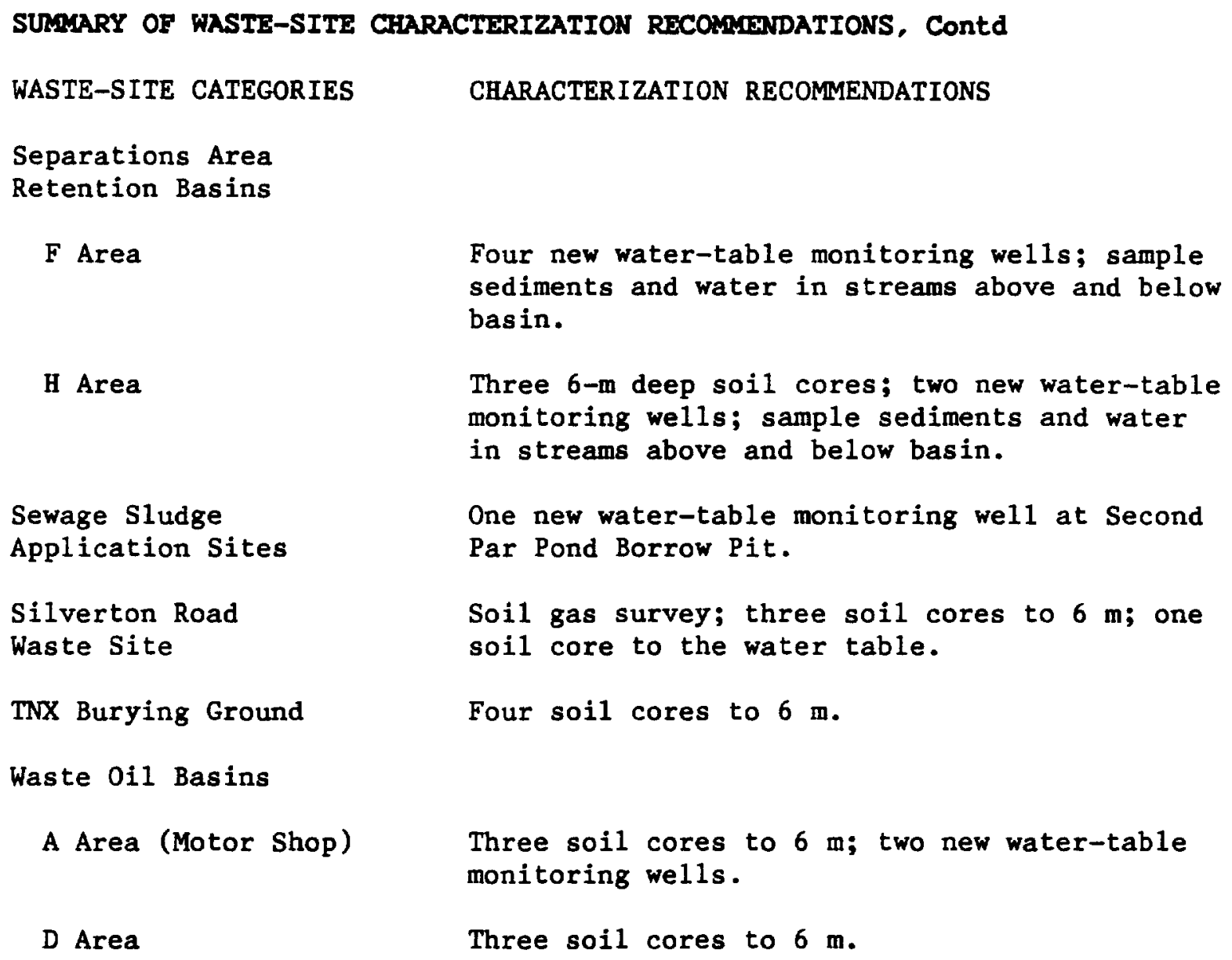

H Area

Three 6-m deep soil cores; two new water-table monitoring wells; sample sediments and water in streams above and below basin.

Sewage Sludge Application Sites

Silverton Road Waste Site

TNX Burying Ground

Waste 0il Basins
A Area (Motor Shop)
D Area

One new water-table monitoring well at Second Par Pond Borrow Pit.

Soil gas survey; three soil cores to $6 \mathrm{~m}$; one soil core to the water table.

Four soil cores to $6 \mathrm{~m}$.

Three soil cores to $6 \mathrm{~m}$; two new water-table monitoring wells.

Three soil cores to $6 \mathrm{~m}$. 


\section{Background}

\section{Site History}

There are six Acid/Caustic Basins at SRP located in the reactor and separation areas. Dilute sulfuric acid and sodium hydroxide solutions were used to regenerate ion exchange units for the water purification processes in the reactor and separations areas, and the spent dilute solutions were discharged through the Acid/Caustic Basins. Each basin has a total depth of $2.1 \mathrm{~m}$ and was equipped with an effluent weir set to maintain a nominal working water level of $0.92 \mathrm{~m}$. The basins were constructed between 1952 and 1954 and remained in service until either the operating area in which they were located was shut down or the in-process neutralization facilities became operational in 1982. All Acid/Caustic Basins are now inactive. Detailed information about the Acid/Caustic Basins can be found in Ward et al. (1987).

\section{Site Description}

The Acid/Caustic Basins are located in plant areas $R, P, L, K, F$, and $H$ (Figures A.1 through A.4). These basins are unlined earthen depressions with nominal dimensions of $15.2 \mathrm{~m}$ in length by $15.2 \mathrm{~m}$ in width by $2.1 \mathrm{~m}$ in depth. The closest plant boundary is approximately $7 \mathrm{~km}$ from the R-Area Acid/Caustic Basin. The building numbers and northeast corner coordinates for the basins are listed below.

\begin{tabular}{lllll} 
Area & B1dg. No. & & \multicolumn{3}{l}{ SRP Coordinates } \\
F & $904-74 G$ & N 78109 & E 55346 \\
H & $904-75 G$ & N 72201 & E 61331 \\
P & $904-78 G$ & N 43540 & E 66843 \\
K & $904-80 G$ & N 53185 & E 42647 \\
R & $904-77 G$ & N 55050 & E 74584 \\
L & $904-79 G$ & N 45275 & E 51234
\end{tabular}

Four groundwater monitoring wells have been installed at each of the Acid/Caustic Basins except the H-Area Acid/Caustic Basin. The wells are sampled quarterly as part of the Health Protection Department groundwater monitoring program. The $\mathrm{K}$-Area Acid/Caustic Basin is located at an elevation of approximately $79 \mathrm{~m}(260 \mathrm{ft})$. The depth to the water table is approximately $12 \mathrm{~m}$, and the water-table flow is to the south (Heffner et al., in press). The L-Area Acid/Caustic Basin is located at an elevation of approximate1y $72 \mathrm{~m}(235 \mathrm{ft})$. The depth to the water table is approximately $10 \mathrm{~m}$, and the groundwater flow is to the east. The P-Area 

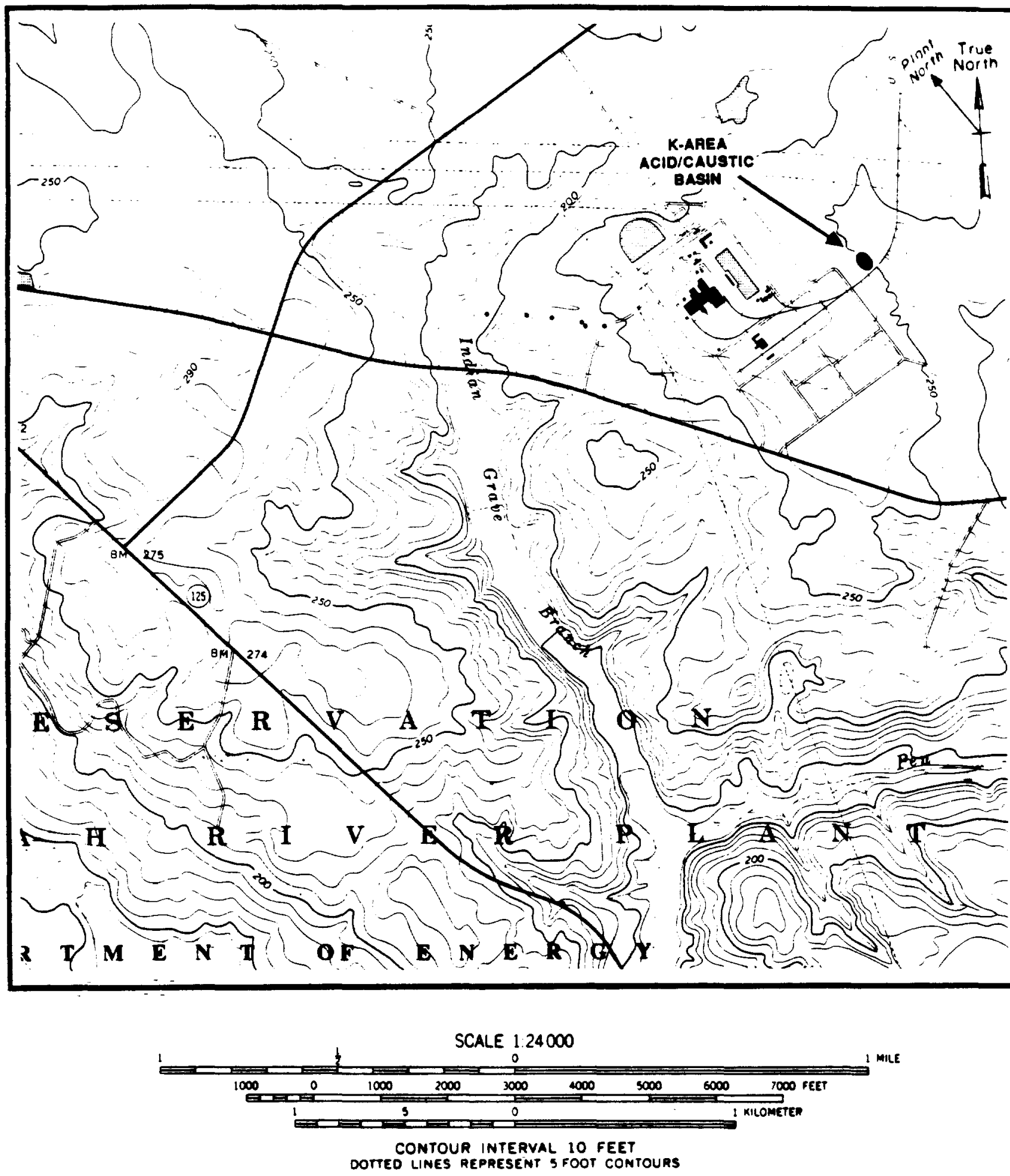

FIGURE A.1. Location of the K-Area Acid/Caustic Basin on Girard w quadrangle 7.5 Minute Series Topographic Map 
SCALE 124000

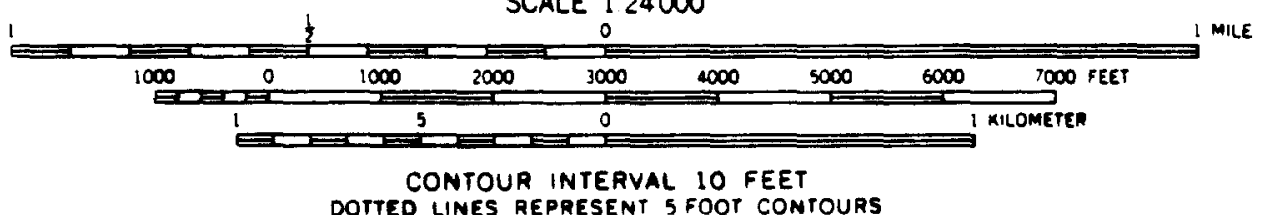

FIGURE A.2. Locations of the L- and P-Area Acid/Caustic Basins on Girard $\mathrm{NE}$ Quadrangle 7.5 Minute Series Topographic Map 

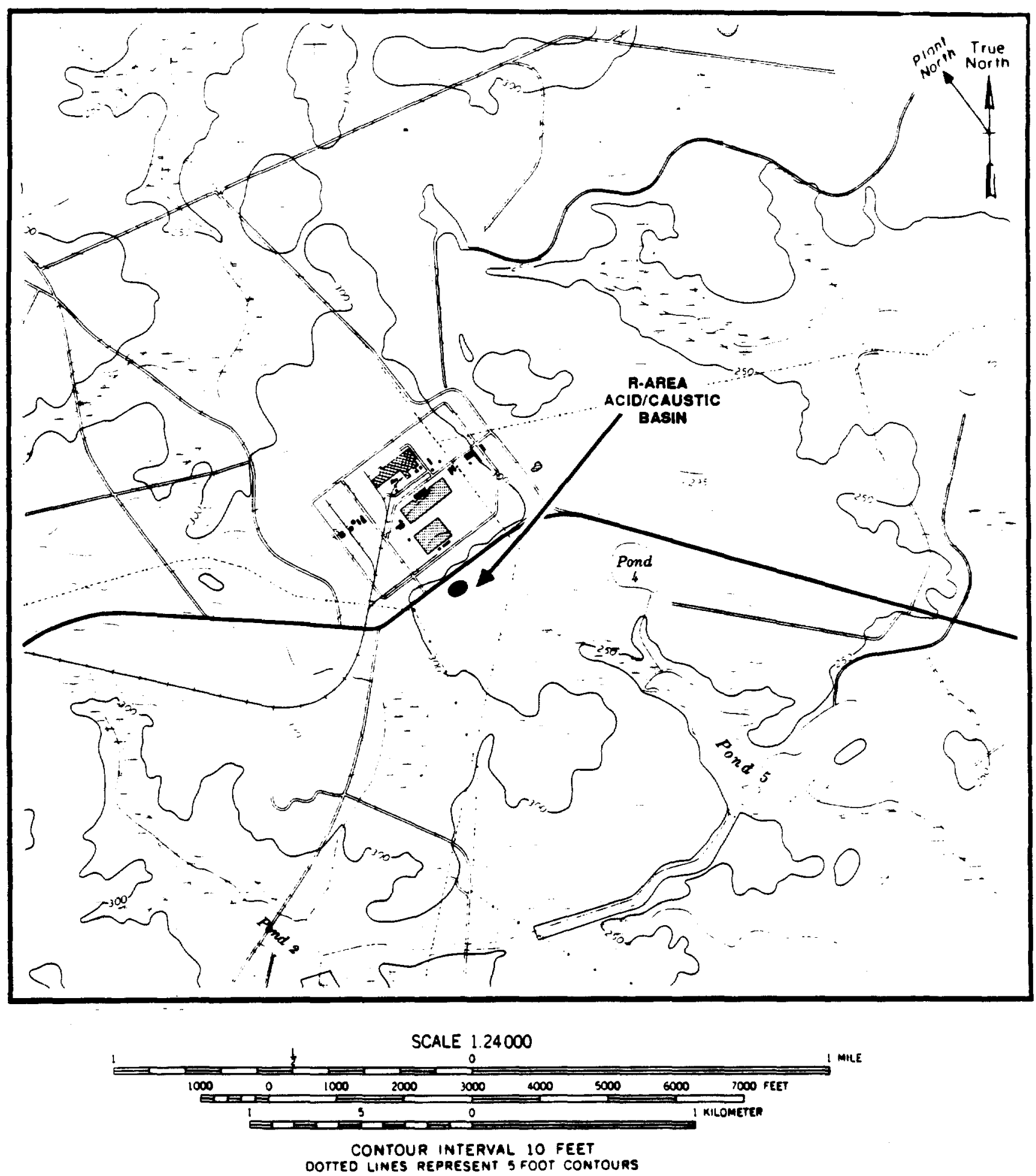

FIGURE A.3. Location of the R-Area Acid/Caustic Basin on New Ellenton SE Quadrangle 7.5 Series Topographic Map 

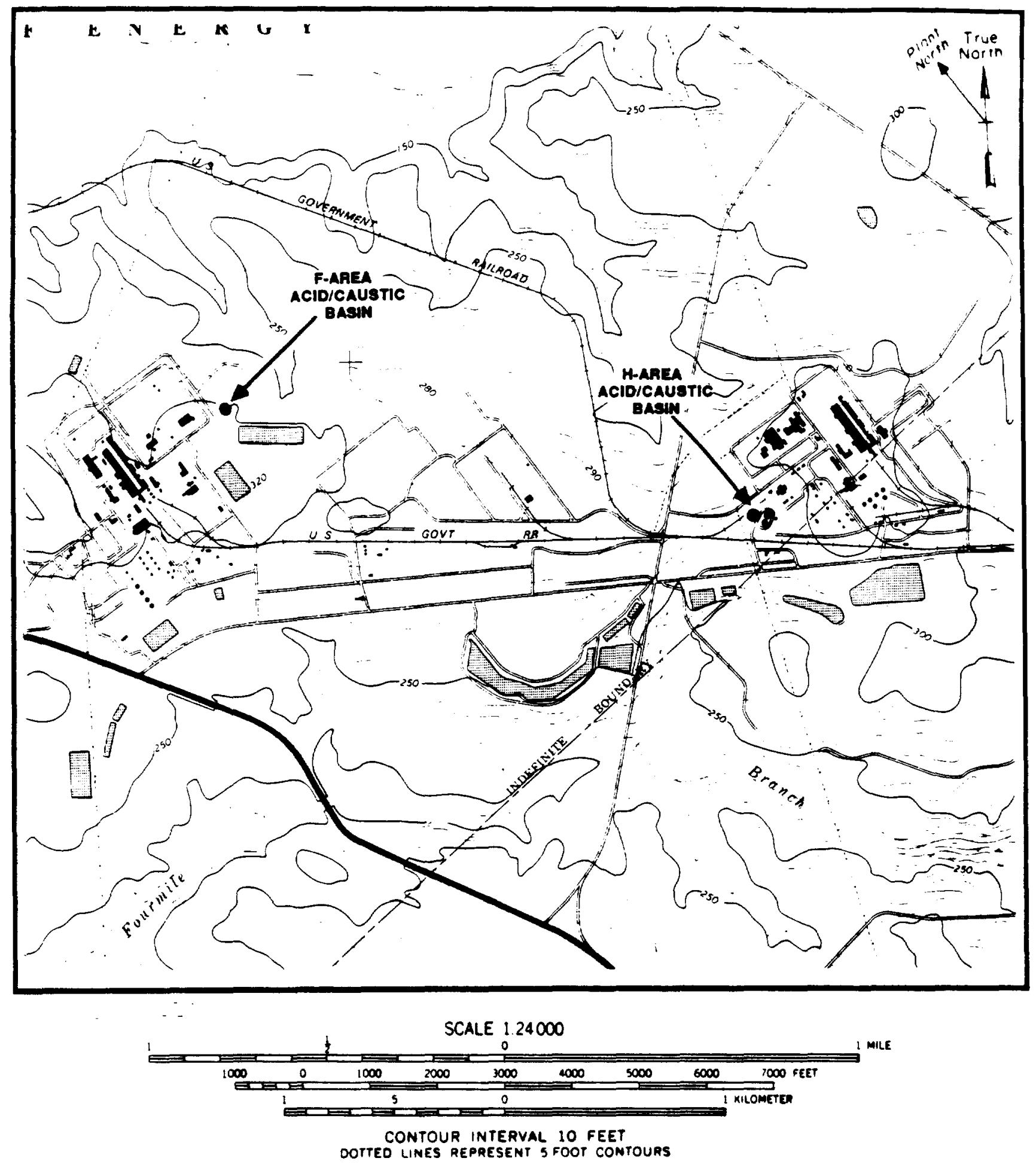

FIGURE A.4. Locations of the F- and H-Area Acid/Caustic Basins on New Ellenton Sw quadrangle 7.5 Minute Series Topographic Map 
Acid/Caustic Basin is located at an elevation of approximately $88 \mathrm{~m}$ $(290 \mathrm{ft})$. The depth to the water table is approximately $5 \mathrm{~m}$, and the groundwater flow is to the northeast toward Par Pond. The R-Area Acid/Caustic Basin is located at an elevation of $85 \mathrm{~m}(280 \mathrm{ft})$. The depth to the water table is approximately $1.5 \mathrm{~m}$, and the groundwater flow is to the south. The F-Area Acid/Caustic Basin is located at an elevation of approximately $95 \mathrm{~m}(312 \mathrm{ft})$. The depth to the water table is approximately $23 \mathrm{~m}$, and the groundwater flow is to the northwest toward Upper Three Runs Creek. The H-Area Acid/Caustic Basin is located an elevation of approximately $87 \mathrm{~m}(285 \mathrm{ft})$. Although there are no monitoring wells at this site, the depth of the water table may be extrapolated from area maps and is estimated to be approximately $11 \mathrm{~m}$.

Review of Available Data

A program to define the extent of chemical contamination at the six Acid/Caustic Basins was conducted during the third quarter of 1985 . This program included the sampling and analysis of sediment from beneath each of the basins. Three sediment sampling sites were established inside each basin. All sediment cores were taken to a depth of $1.5 \mathrm{~m}$ and were analyzed for specified metals, ions, radioactivity, and the organic chemicals 1isted in 40 CFR 261 Appendix VII per SW-846 methodology. EP toxicity tests were performed on the top $7.6 \mathrm{~cm}$ of sediment in each basin (Ward et al., 1987).

Analytical results from the characterization program indicate slightly elevated levels of chromium, mercury, lead, phosphate, copper, sodium, sulfate, barium, and selenium in the sediment samples from one or more of the basins. EP toxicity tests performed on the sediment samples from each of the basins indicate that the concentrations of each of the metals analyzed were below $1 \%$ of the guideline concentrations.

The groundwater monitoring data from wells at the Acid/Caustic Basins suggest that the groundwater at these sites has been slightly affected by basin seepage (Heffner et a1., in press). At the K-Area Acid/Caustic Basin, the groundwater quality in the vicinity of wells KAC 1 and KAC 3 has been characterized by elevated levels of sulfate, conductivity, and sodium. Sulfate levels in well $\mathrm{KAC} 1$ ranged from 166.0 to $1,180.0 \mathrm{mg} / \mathrm{L}$, with an average concentration of $492.9 \mathrm{mg} / \mathrm{L}$. In we11 $\mathrm{KAC} 3$, sulfate levels ranged from 116.0 to $765.0 \mathrm{mg} / \mathrm{L}$, with an average concentration of $434.0 \mathrm{mg} / \mathrm{L}$. The average sulfate concentrations in wells $\mathrm{KAC} 1$ and $\mathrm{KAC} 3$ were well above the groundwater quality review criteria (Appendix Tab1e 10). Conductivity levels in wells $\mathrm{KAC} 1(57.0$ to $1,871.0$ umhos $/ \mathrm{cm})$ and KAC 3 ( 352.0 to $1,448.0$ umhos $/ \mathrm{cm}$ ) were consistently above the SRP background level of 50 umhos/cm. In addition, sodium levels in wells $\mathrm{KAC}$ $1(21.6$ to $371.0 \mathrm{mg} / \mathrm{L})$ and $\operatorname{KAC} 3(11.1$ to $411.0 \mathrm{mg} / \mathrm{L})$ were above the groundwater quality review criteria (Appendix Table 10). Although sulfate, conductivity, and sodium levels were above the Appendix Table 10 groundwater quality review criteria concentrations in wells $\mathrm{KAC} 2$ and $\mathrm{KAC}$ 4 , they were not elevated above drinking water standards (Appendix Table 6). Sulfate, conductivity, and sodium concentrations have not shown any consistent increasing or decreasing trends since 1984 in these we11s. 
The groundwater monitoring data from the L-Area Acid/Caustic Basin indicate that the groundwater quality has not been significantly affected by the operation of the basin except for a slight influence on downgradient well LAC 4. Groundwater samples from downgradient well LAC 1 and sidegradient well LAC 2 have contained slightly elevated sulfate, sodium, and conductivity levels. In addition, groundwater quality at these wells has been characterized by low dissolved chemical constituent levels except for an isolated excursion for iron $(1.390 \mathrm{mg} / \mathrm{L})$ in well LAC 1 and trichloroethyene $(0.048 \mathrm{mg} / \mathrm{L}$ ) in well LAC 2 (Heffner et a1., in press). Iron at $1.390 \mathrm{mg} / \mathrm{L}$ is consistent with levels reported as naturally occurring in Barnwell Formation groundwater. Trichloroethyene is not related to past site activities. Groundwater samples from downgradient wel1 LAC 4 have consistent1y met the groundwater quality review criteria reported in Appendix Table 10.

Groundwater monitoring data from the P-Area Acid/Caustic Basin indicate that groundwater quality has been slightly influenced by the operation of the basin. Downgradient wel1 PAC 2 and upgradient we 11 PAC 1 contain low levels of sulfate, sodium, and conductivity. Groundwater quality in wells PAC 2 and PAC 1 has also been characterized by low dissolved chemical constituent levels with the exception of iron. The iron levels reported in these wells are consistent with naturally occurring iron levels in Barnwell Formation groundwater. Groundwater monitoring data indicate that groundwater quality in the vicinity of sidegradient well PAC 3 and upgradient wel1 PAC 4 has also been characterized by low dissolved chemical constituents with the exception of an isolated case for silver (Heffner et al., in press).

Groundwater monitoring data from the R-Area Acid/Caustic Basin indicate that groundwater quality has been slightly influenced by the operation of the basin, as demonstrated by the low levels of sulfate, sodium, and conductivity reported for both the upgradient and downgradient wells at this site. Groundwater quality has also been characterized by low dissolved chemical constituent levels with a single exception for lead.

The groundwater monitoring data from the F-Area Acid/Caustic Basin indicate that the basin has not had a significant influence on groundwater quality. Upgradient well FAC 3 has apparently been affected by the leaching of well grout, as indicated by the elevated $\mathrm{pH}$ and conductivity levels. Groundwater samples from downgradient well FAC 1 have been characterized by low dissolved chemical constituent levels with the exception of manganese, which was found at values above the groundwater quality review criterion (Appendix Table 10). Manganese also exceeded its criterion (Appendix Table 10) in sidegradient wel1 FAC 2. Groundwater from wells FAC 2 and FAC 4 is also characterized by elevated gross alpha and total radium levels and a single elevated excursion for mercury in FAC 2. Radioactivity and mercury are not related to past site activities. 


\section{Characterization Recommendations}

\section{Sampling}

After a review of the current data from this site, no additional characterization effort is recommended. The closure of these basins is currently under litigation for compliance with RCRA.

Because there are no monitoring wells at the H-Area Acid/Caustic Basin, four RCRA-type wells should be drilled to the water table to define groundwater flow and direction and the effects of the basin on groundwater quality. The approximate locations of the four proposed H-Area Acid/Caustic Basin groundwater monitoring wells are indicated in Figure A. 5 .

Chemical and Physical Analyses

Gamma logs should be taken at one of the wells to define the sediments beneath the basin. The newly installed wells should be sampled quarterly as part of the Health Protection Department groundwater monitoring program. The groundwater samples should be analyzed for the parameters listed in Appendix Table 6. 
H-AREA ACID/CAUSTIC BASIN

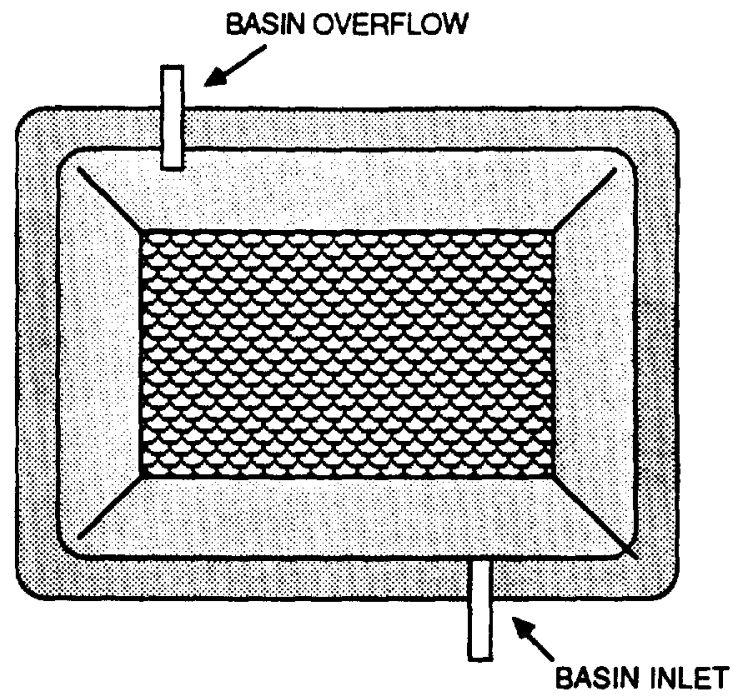

BASIN INLET

$\cdots$

\section{LEGEND:}

- PROPOSEd MOMITORING Well

NOT TO SCALE

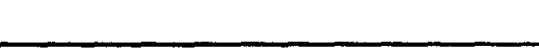




\section{Background}

\section{Site History}

Four pits were constructed at SRP for disposal of asbestos. Table B.1 lists the building numbers, SRP coordinates, and dimensions of the asbestos pits. There is no information on the amount of asbestos disposed of in the C- and D-Area pits. Approximately $120 \mathrm{~m}^{3}$ of asbestos insulation was disposed of in the R-Area Asbestos Pit. A11 of the asbestos pits have been closed by placing a minimum of $15 \mathrm{~cm}$ of compacted fill on the pit, grading to minimize erosion, treating the surface with lime and fertilizer, and seeding with permanent grasses.

\section{Site Description}

\section{C-Area Asbestos Pits}

The two C-Area Asbestos Pits are located 1,220 m northeast of C Area north of Road A-6.2 (Figure B.1) at an elevation of $82.4 \mathrm{~m}$ ( $270 \mathrm{ft}$ ). Surface drainage is to the southwest toward a tributary of Four Mile Creek.

D-Area Asbestos Pit

The irregularly shaped D-Area Asbestos Pit is located $1,220 \mathrm{~m}$ north of D Area north of Road A-4.61 (Figure B.2). The D-Area Asbestos Pit is at an elevation of $42.7(140 \mathrm{ft})$. Surface drainage is to the southwest toward the Savannah River.

R-Area Asbestos Pit

The R-Area Asbestos Pit is located in the west corner of the fenced operating area (Figure B.3). The R-Area Asbestos Pit is at an elevation of $100 \mathrm{~m}(330 \mathrm{ft})$. Surface drainage is to the southeast toward an intermittent stream that empties into Pond 2.

\section{Review of Available Data}

Currently there are no data available for any of the asbestos pits. 
TABLE B.1

Asbestos Pit Building Numbers, Dimensions, and SRP Coordinates (Northeast Corner)

\begin{tabular}{llllll} 
Site & B1dg. No. & & Dimensions (m) & & \multicolumn{2}{c}{ SRP Coordinates } \\
C Area & $080-21 G$ & $60 \times 300$ & N 69212 & E 49635 \\
& $080-22 G$ & $60 \times 300$ & N 69212 & E 49685 \\
& $080-20 G$ & $556 \times 294 \times$ & N 66747 & E 21797 \\
D Area & & $100 \times 160 \times$ & & \\
& & $70 \times 280$ & N 57120 & E 74700
\end{tabular}

B-2 


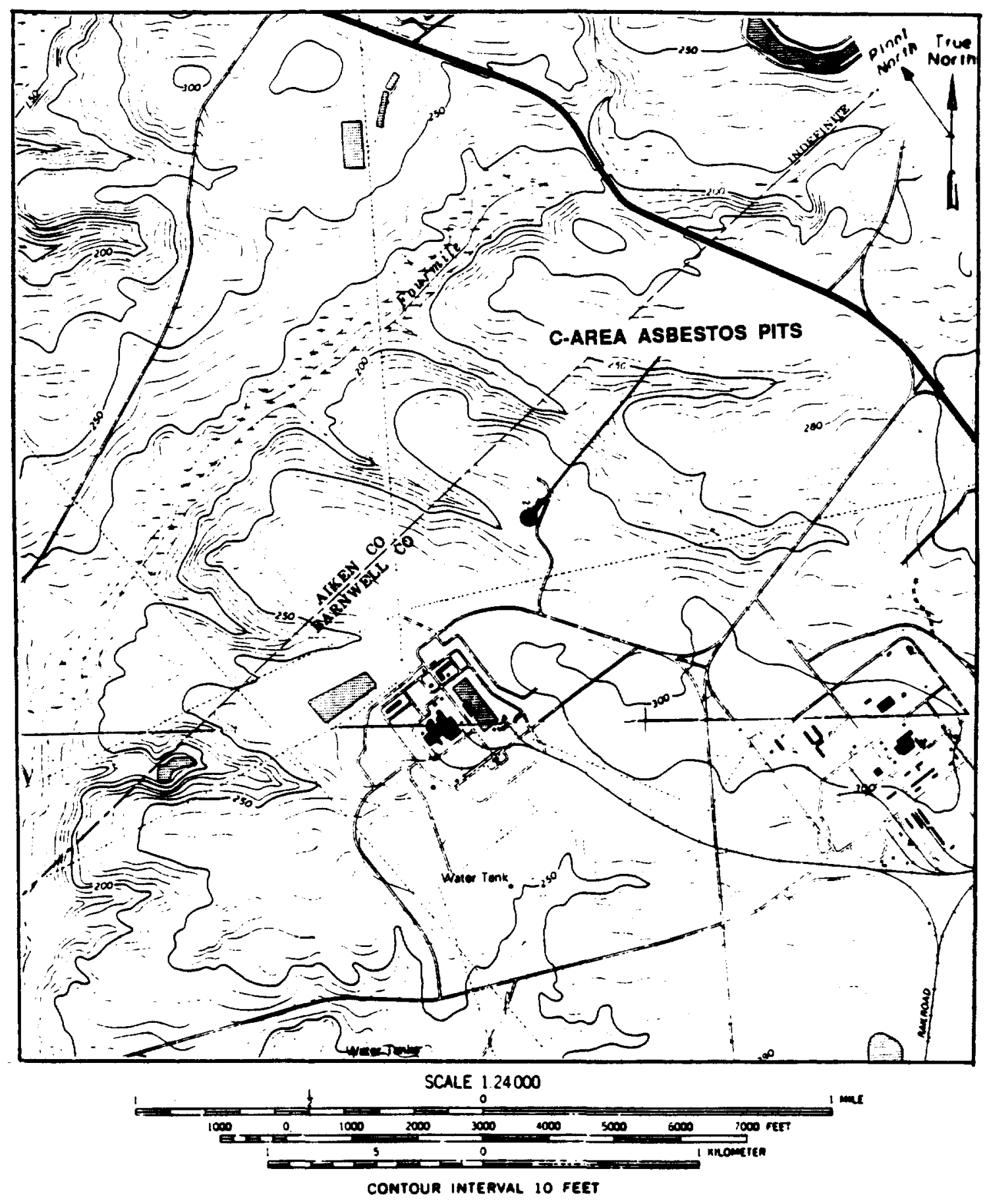

FIGURE B.1. Location of the C-Area Asbestos Pits on New Ellenton SW and Girard WW quadrangle 7.5 Minute Series Topographic Maps 


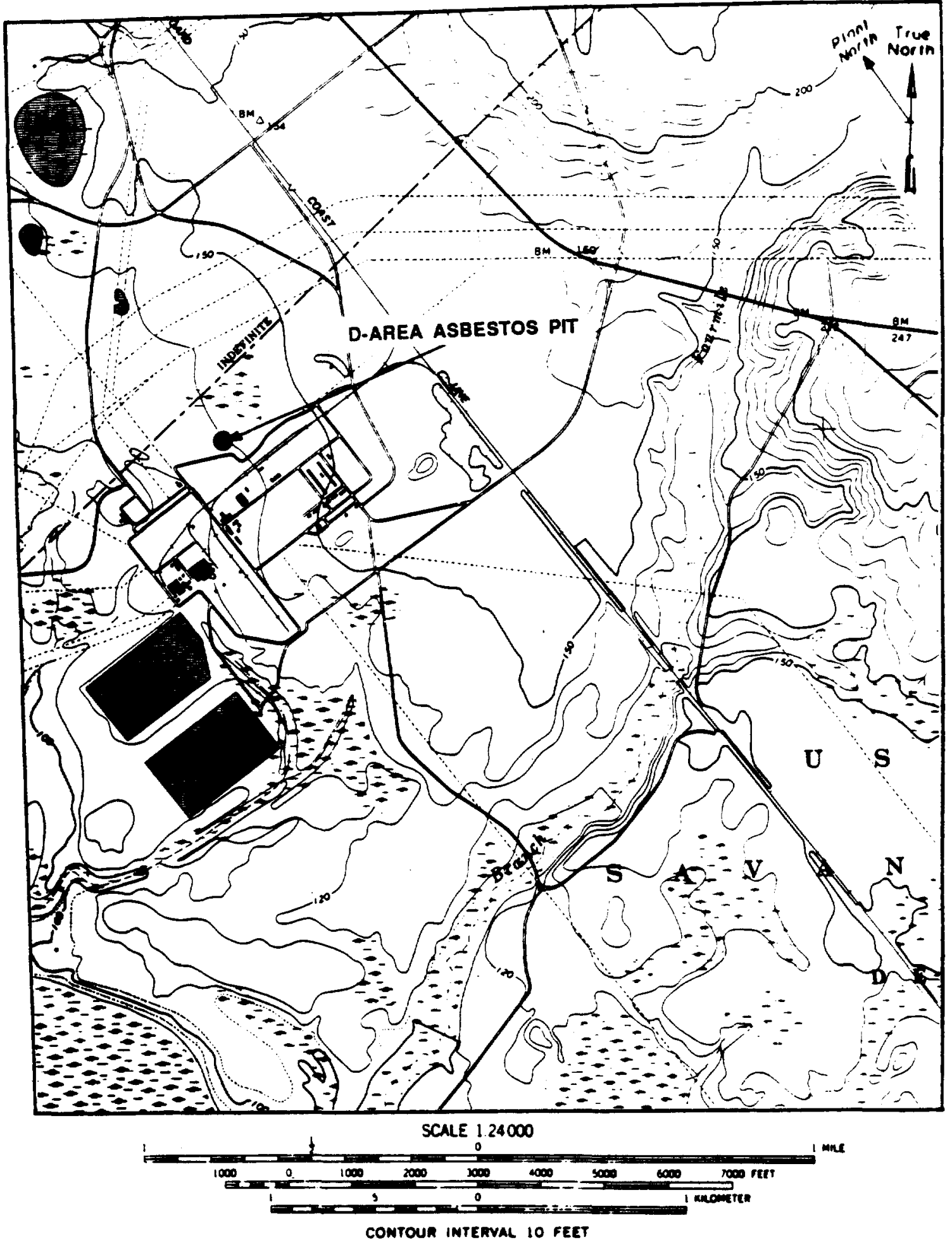

FIGURE B.2. Location of the D-Area Asbestos Pit on Girard NW Quadrangle 7.5 kinute Series Topographic Map 


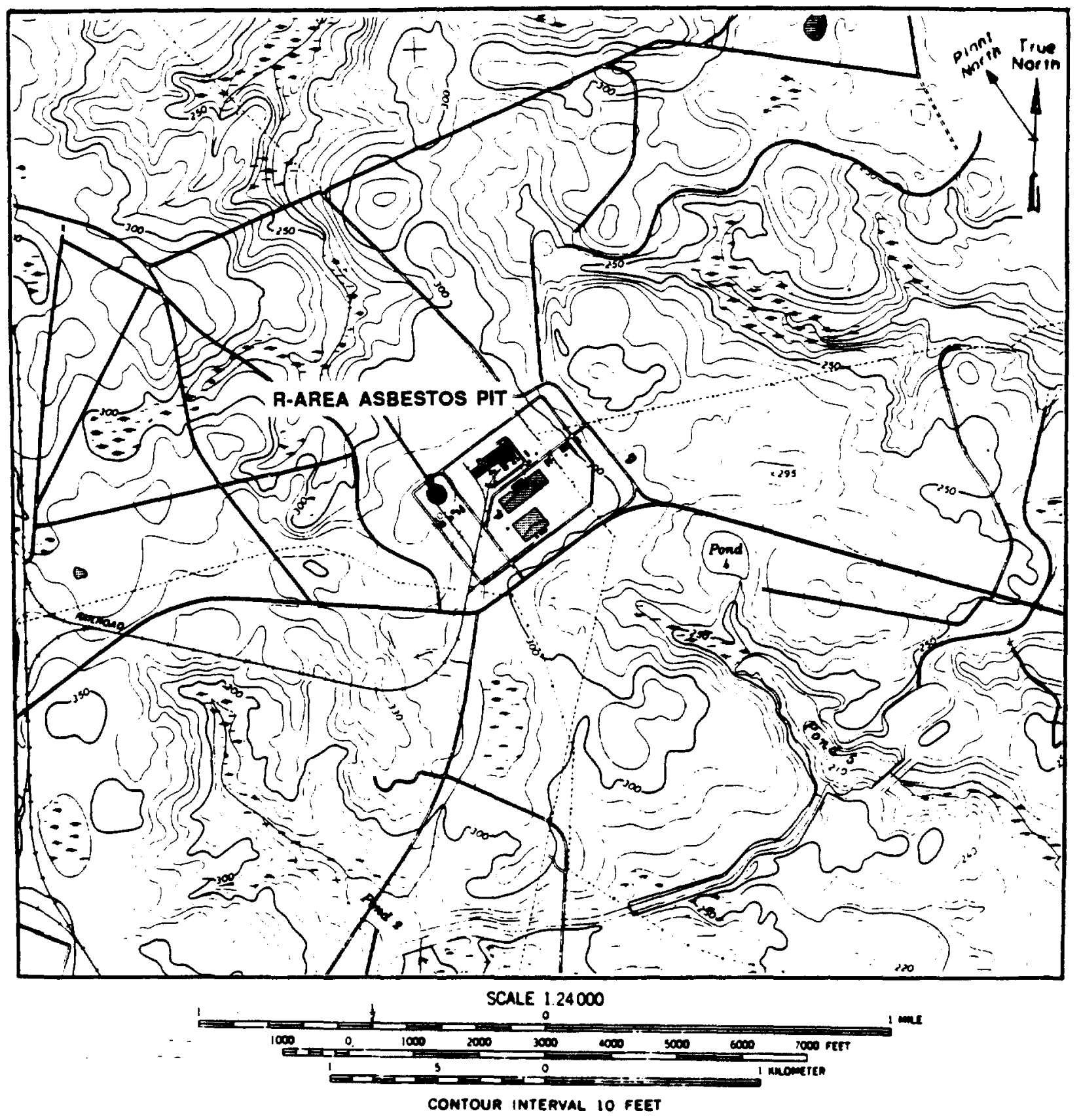

FIGURE B.3. Location of the R-Area Asbestos Pit on New Ellenton SE Quadrangle 7.5 Minute Series Topographic Map 


\section{Characterization Recommendations}

Air-quality monitoring for asbestos is recommended at one of the C-Area Asbestos Pits to verify closure efficacy. Week1y 8-hr dose measurements for one month should provide sufficient data to determine if the site is an inhalation hazard and requires any further action to reduce the amount of asbestos being released to the air. 


\section{Background}

\section{Site History}

The Ash Basins receive ash sluice water from the powerhouses in $D, F$, $H, K, L, P$, and $R$ areas. These basins have been in service since plant startup in 1951. Currently there are 10 ash basins onsite: 8 are active; 2 are no longer used. The building number, status, and SRP coordinates for the northeast corner of each basin are given in Table C.1. Site history information, descriptions, and available data were taken from Christensen and Gordon (1983) and Heffner et al. (in press).

The Ash Basins are located in areas that differ widely in surface topography and groundwater hydrology. Hence, each of the basins will be discussed separately.

\section{D-Area Ash Basins}

\section{Site Description}

The three D-Area Ash Basins are located southwest of the D-Area perimeter fence across the road from the D-Area Coal Pile Runoff Containment Basin (Figure C.1). The nearest plant boundary is approximately $1.5 \mathrm{~km}$ to the west. The basins cover an area of approximately 140,000 to $160,000 \mathrm{~m}^{2}$. Depths of the basins are approximately $3.7 \mathrm{~m}$. The basins received approximately $38,000 \mathrm{~m}^{3}$ of ash sluice water per year from 1951 until 1983. Since $1983,50,000 \mathrm{~m}^{3} / \mathrm{yr}$ have been disposed into the basins. The northwest-most basin of Building 488-D is presently being used for disposal of reject coal.

The three basins are located on a west-trending slope at an elevation of approximately $39 \mathrm{~m}(128 \mathrm{ft})$. Surface drainage is to the southwest toward a small tributary that flows into the Savannah River swamp, which occurs at an elevation of $27 \mathrm{~m}$ in this area.

SREL has recently installed seven monitoring wells in the vicinity of the D-Area Ash Basins and the D-Area Coal Pile Runoff Containment Basin. Two of these wells are located very close to the ash basins (Figure C.2). No water-level data are yet available from these two groundwater monitoring wells. Groundwater hydrology can be extrapolated from that known at the D-Area Coal Pile Runoff Containment Basin (CPRB). Data from 1986 for the D-Area CPRB indicate that flow is probably to the west-southwest, and depth to the water table is probably less than $2 \mathrm{~m}$. The area represents a site of groundwater discharge, with a vertical gradient upward. Hence, there is little likelihood for downward migration of contaminants below the water-table aquifer. 
TABLE C.1

Location and Status of the Ash Basins

\begin{tabular}{|c|c|c|c|c|c|}
\hline Site & No. & Building No. & SRP Coor & dinates & Status \\
\hline D Area & 3 & $\begin{array}{l}488-D \\
488-1 D \\
488-2 D\end{array}$ & 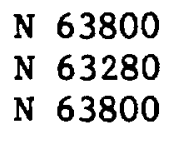 & $\begin{array}{ll}E & 19240 \\
E & 17650 \\
E & 17660\end{array}$ & $\begin{array}{l}\text { Active } \\
\text { Active } \\
\text { Active }\end{array}$ \\
\hline F Area & 2 & $\begin{array}{l}288-F \\
288-1 F\end{array}$ & $\begin{array}{l}N 78095 \\
N 77700\end{array}$ & $\begin{array}{l}\text { E } 55565 \\
\text { E } 54510\end{array}$ & $\begin{array}{l}\text { Active } \\
\text { Active }\end{array}$ \\
\hline H Area & 1 & $288-\mathrm{H}$ & N 70156 & E 61318 & Active \\
\hline K Area & 1 & $188-K$ & N 53121 & E 39687 & Active \\
\hline L Area & 1 & $188-\mathrm{L}$ & N 49600 & E 51280 & Inactive \\
\hline P Area & 1 & $188-P$ & N 41100 & E 65800 & Active \\
\hline R Area & 1 & $188-R$ & N 54800 & E 73600 & Inactive \\
\hline
\end{tabular}



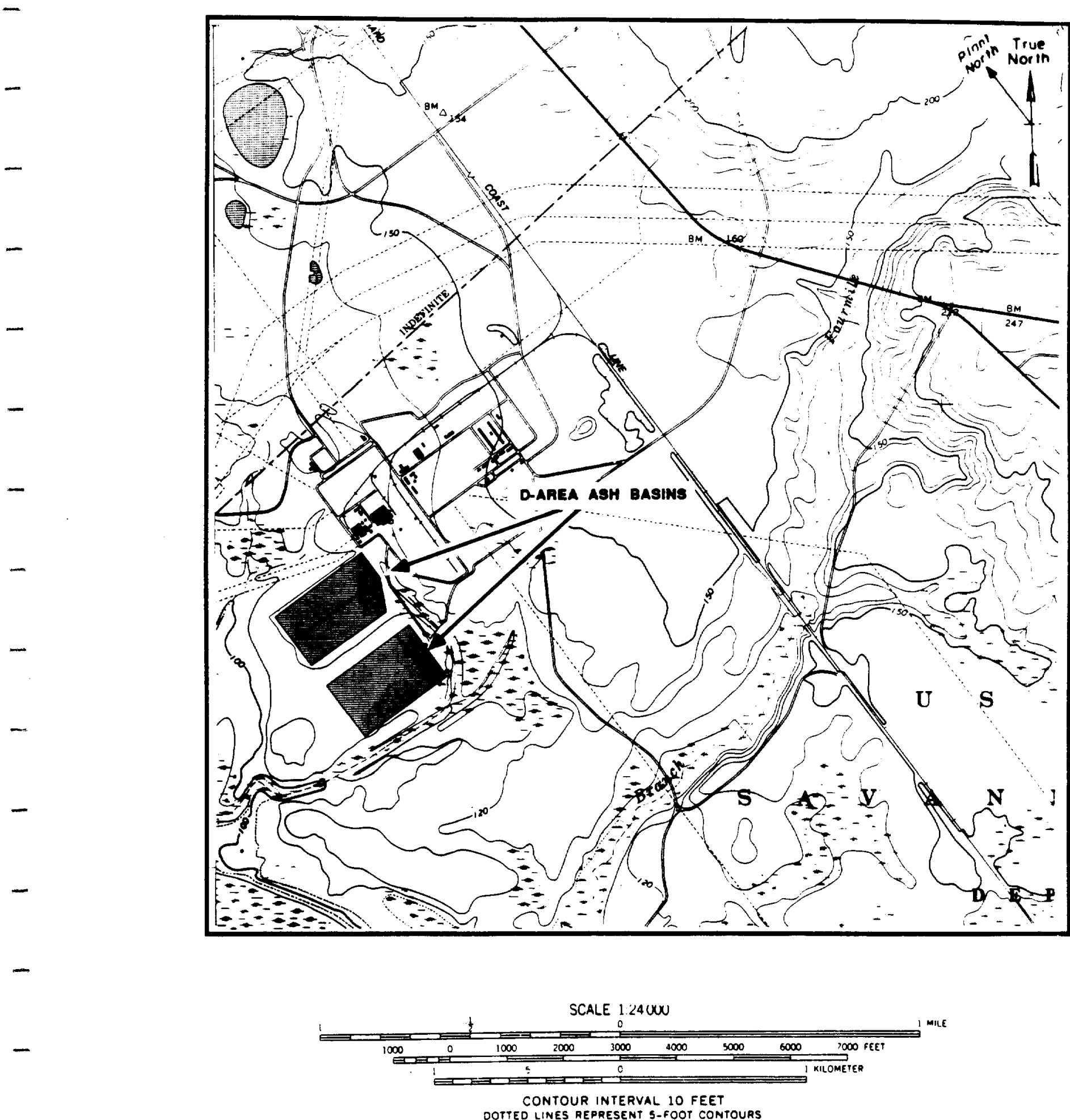

FIGURE C.1. Location of the D-Area Aah Basins on Girard NW quadrangle 7.5 Minute Series Topographic Map 
Review of Available Data

D-Area Ash Basins sludge was analyzed in 1978 for EP toxicity tests. Extractable metal concentrations in the sludge were less than RCRA criteria (40 CFR 261.24) (Christensen and Gordon, 1983). SREL has also collected numerous water, sediment, plant, and animal samples from the immediate area. Reviews of their works are presented in the following publications: Alberts et al. (1985), Alberts et al. (in press), Cherry and Guthrie (1979), Cherry et al. (1979), Skinner et al. (1978), and Wiener (1979). No groundwater chemistry data are yet available.

\section{Characterization Recommendations}

Sampling

Soil cores are recommended to determine the vertical extent of the contamination if any. Due to the shallow depth of the water table, all cores should be taken to the water table. Twelve cores, three from each basin, should be taken from within the confines of the basins (Figure C.2). Soils should be sampled for chemical analyses according to the parameters given in Appendix Table 1. Undisturbed samples of soils (sandy and clay-rich) will be needed to perform physical analyses. Splits of soil samples should be archived at SRP.

Groundwater monitoring wells are also recommended. Three monitoring wells located around the basins are recommended (Figure C.2). Data from these wells can be used in conjunction with data from the D-Area Coal Pile Runoff Containment Basin wells. One of the monitoring wells should be cored continuously. The core should be described geologically and archived. The monitoring wells should be logged geophysically for gamma resistivity, porosity, and caliper.

Chemical and Physical Analyses

Soils should be analyzed according to the parameters outlined in Appendix Table 1. Specific analytes (Class 4) are metals (Appendix Table 2), volatile organics (Appendix Table 3 ), and radioactivity (Appendix Table 4). These analyses are recommended due to the nature of the contaminants in the nearby Coal Pile Runoff Containment Basin wells. Groundwater analyses will follow the parameters given in Appendix Table 6. If elevated levels of radioactivity are found in the groundwater, expanded radiological analyses (Appendix Table 5) will be needed.

\section{F-Area Ash Basins}

\section{Site Description}

The two F-Area Ash Basins are located east of the F-Area perimeter fence (Figure C.3). The nearest plant boundary is approximately $10 \mathrm{~km}$ to the west. The two basins cover a total area of approximately 15,000 to $17,000 \mathrm{~m}^{2}$. Basin $288-F$ is $4.6 \mathrm{~m}$ deep; Basin $288-1 \mathrm{~F}$ is $2.4 \mathrm{~m}$ deep. 


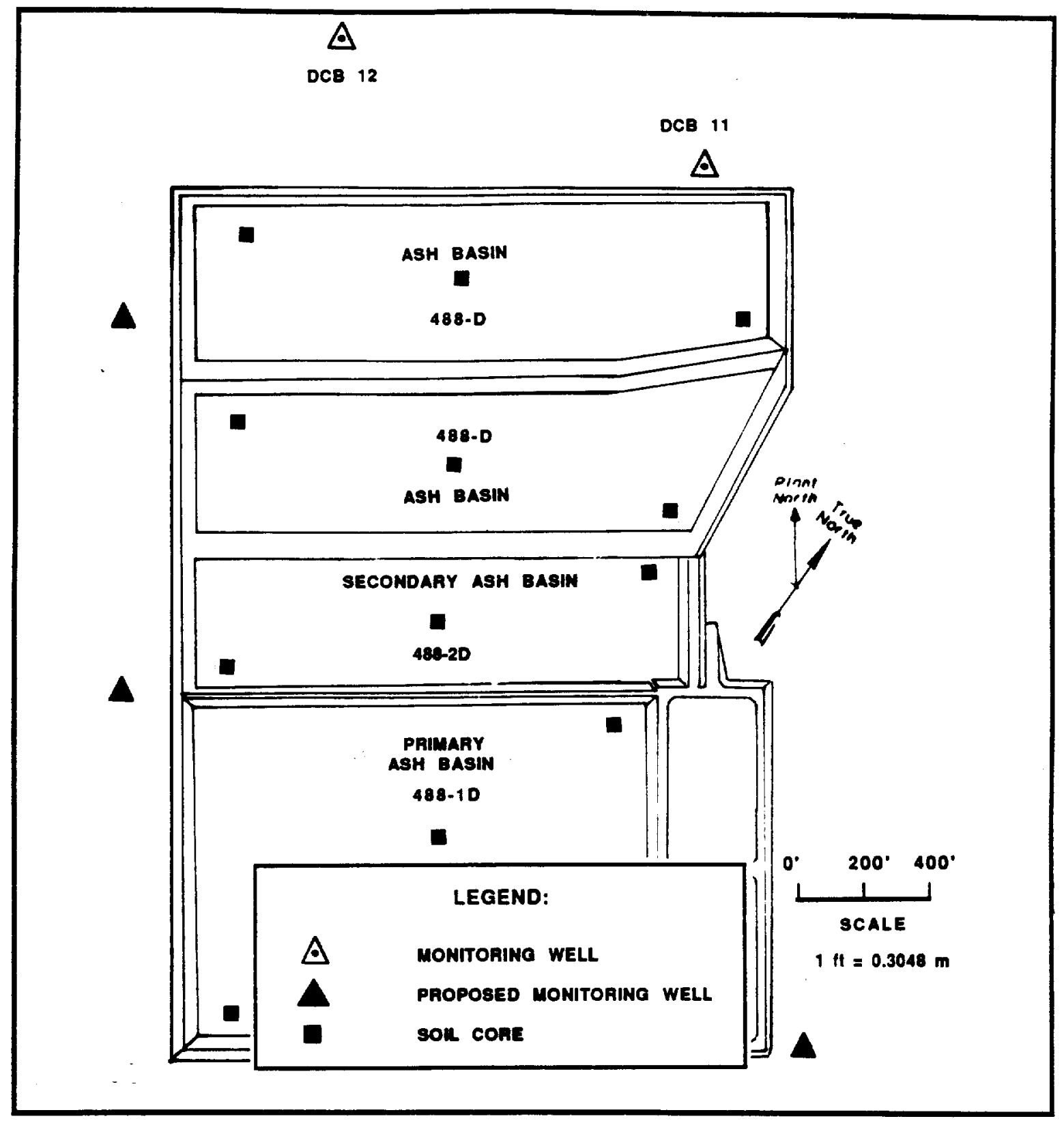

FIGURE C.2. Proposed Monitoring Well and Sampling Locations at the D-Area Ash Basins 


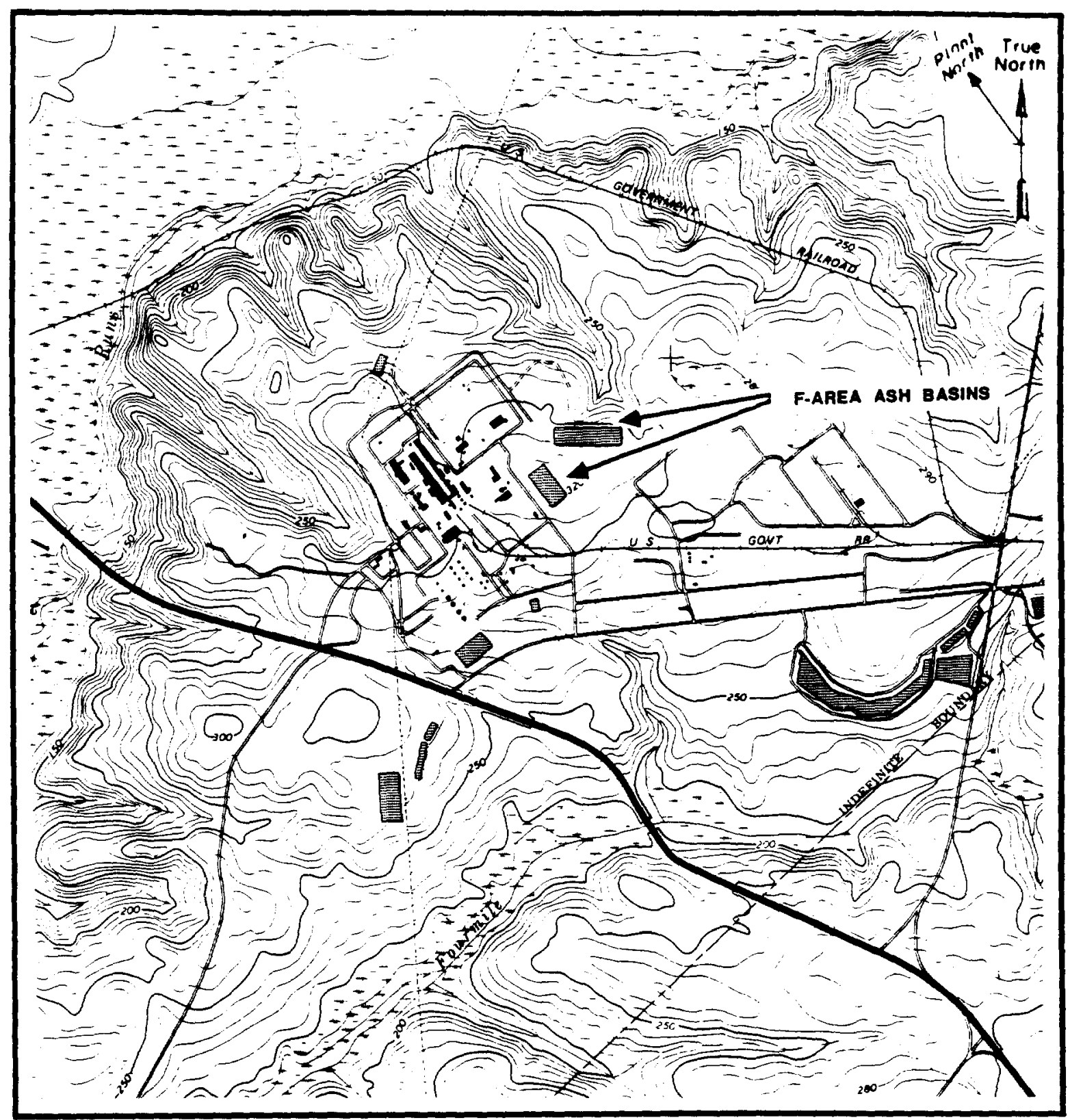

SCALE 124000

FIGURE C.3. Location of the F-Area Ash Basins on New Ellenton Sw quadrangle 7.5 Minute Series Topographic Map 
The two F-Area Ash Basins received approximately $11,500 \mathrm{~m}^{3}$ of ash sluice water from 1951 until 1984. Overflow from this site was discharged through NPDES Outfall F-7. Both basins are currently active.

The F-Area Ash Basins are located on the Aiken Plateau at elevations ranging from 90 to $95 \mathrm{~m}$ (295 to $310 \mathrm{ft}$ ). Surface drainage is to the north toward a small tributary of Upper Three Runs Creek.

Although there are no groundwater monitoring wells at this site, groundwater hydrology can be extrapolated from nearby wells at the F-Area Acid/Caustic Basin and the F-Area Coal Pile Runoff Containment Basin. Existing well data from 1986 suggest that the ash basins are located on a groundwater divide with flow both to the north and to the south and that the depth to the water table is approximately $25 \mathrm{~m}$.

Review of Available Data

No groundwater, soil, or sludge data have been collected at this site.

\section{Characterization Recommendations}

Sampling

Six soil cores, five taken to a depth of $6 \mathrm{~m}$ and one taken to immediately above the water table, are recommended for the two basins (Figure C.4). Three cores should be taken in each of the two basins. These cores should be used to determine the vertical extent of the contamination, if any. The water-table core should be used as a model for all the ash basins to test vertical migration of contaminants below an ash basin. Soils should be sampled for chemical analyses according to the parameters 1isted in Appendix Table 1. Splits of soil samples should be archived at SRP.

Seven groundwater monitoring wells are recommended (Figure C.4). One of the monitoring wells should be cored continuously, and the cores should be described geologically and archived. The monitoring wells should be logged geophysically for gamma, resistivity, porosity, and caliper.

\section{Chemical and Physical Analyses}

Soils should be analyzed according to the parameters given in Appendix Table 1. Specific analytes are metals (Appendix Table 2) and radioactivity (Appendix Table 4). Groundwater samples should be analyzed according to Appendix Table 6. Radioactivity should be monitored because elevated levels of radioactivity were detected in the groundwater at the nearby F-Area Acid/Caustic Basin. The source of the radioactivity is unknown because radioactive materials are not known to have been released to either the Acid/Caustic Basin or the Ash Basin. 


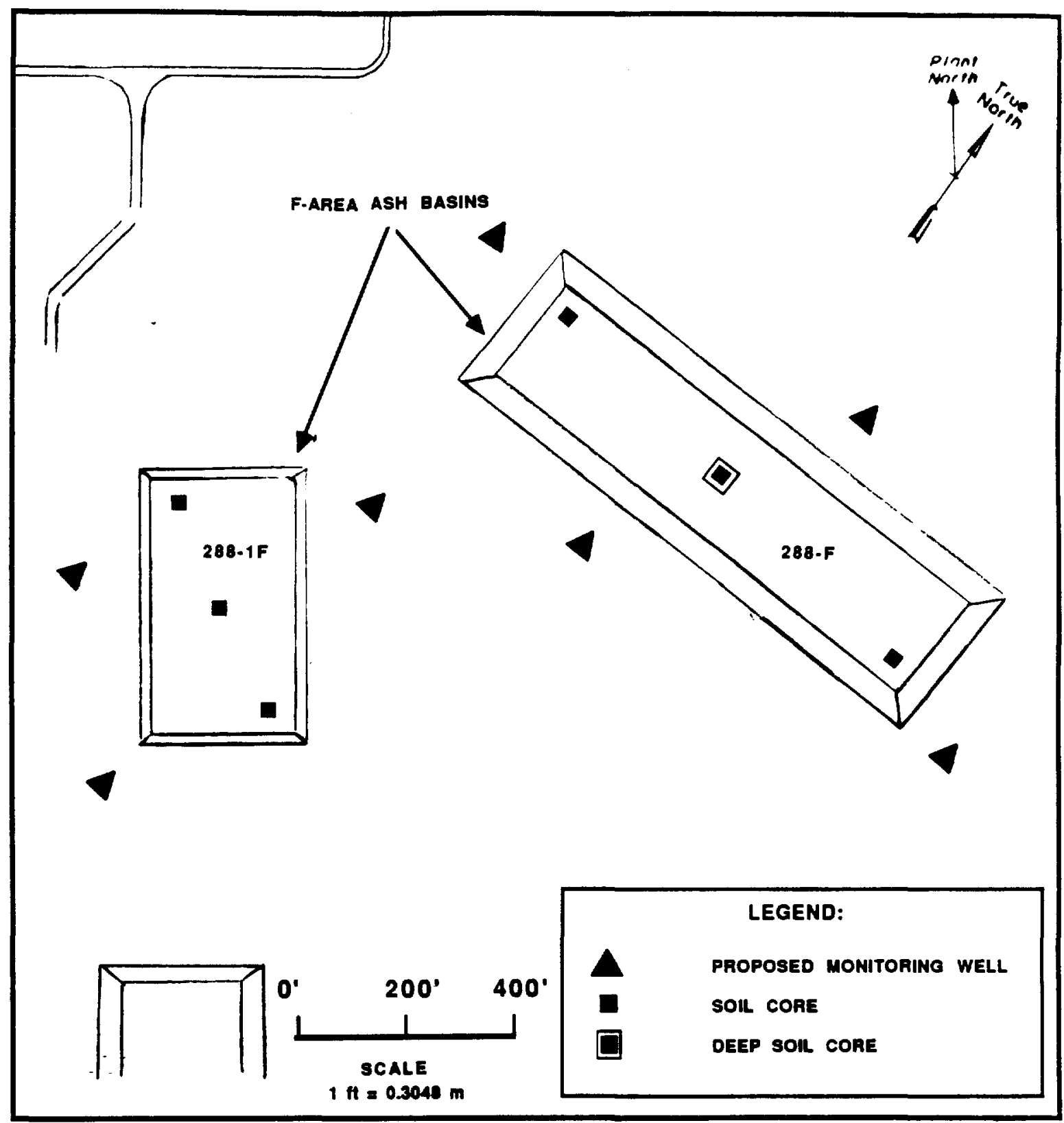

FIGURE C.4. Proposed Monitoring Well and Sampling Locations at the F-Area Ash Basins

$$
\text { C-8 }
$$




\section{H-Area Ash Basin}

\section{Site Description}

The H-Area Ash Basin is 1ocated south of the H-Area perimeter fence (Figure C.5). The nearest plant boundary is approximately $12.5 \mathrm{~km}$ to the west. The basin covers approximately $51,000 \mathrm{~m}^{2}$.

The basin has received approximately $10,000 \mathrm{~m}^{3}$ of ash sluice water each year since 1951. Overflow from this basin has been discharged through NPDES Outfall $\mathrm{H}-8$. The basin is currently active.

The basin is located on the Aiken Plateau at an elevation of approximately $88 \mathrm{~m}(290 \mathrm{ft})$. Surface drainage is to the west toward a tributary of Four Mile Creek.

Although there are no groundwater monitoring wells at this site, groundwater hydrology can be extrapolated from that known at the nearby H-Area Retention Basins and the H-Area Coal Pile Runoff Containment Basin. The H-Area Ash Basin may be located on a groundwater divide, because to the west at the H-Area Retention Basins groundwater flow is to the westsouthwest and to the east and at the H-Area Coal Pile Runoff Containment Bas in groundwater flow is to the north-northeast. Data from 1986 indicate that the depth to the water table is approximately 3 to $6 \mathrm{~m}$.

\section{Review of Available Data}

No groundwater, soil, or sludge data have been collected at this site.

\section{Characterization Recommendations}

\section{Sampling}

Four soil cores taken to immediately above the water table are recommended for the site (Figure C.6). These cores should be used to determine the vertical extent of the contamination, if any. Soils should be sampled for chemical analyses according to the parameters outlined in Appendix Table 1. Splits of soil samples will be archived at SRP.

Installation of three groundwater monitoring wells is also recommended (Figure C.6). One of the monitoring wells should be cored continuously. The cores should be described geologically and archived. All the monitoring wells should be logged geophysically for gamma, resistivity, porosity, and caliper. 

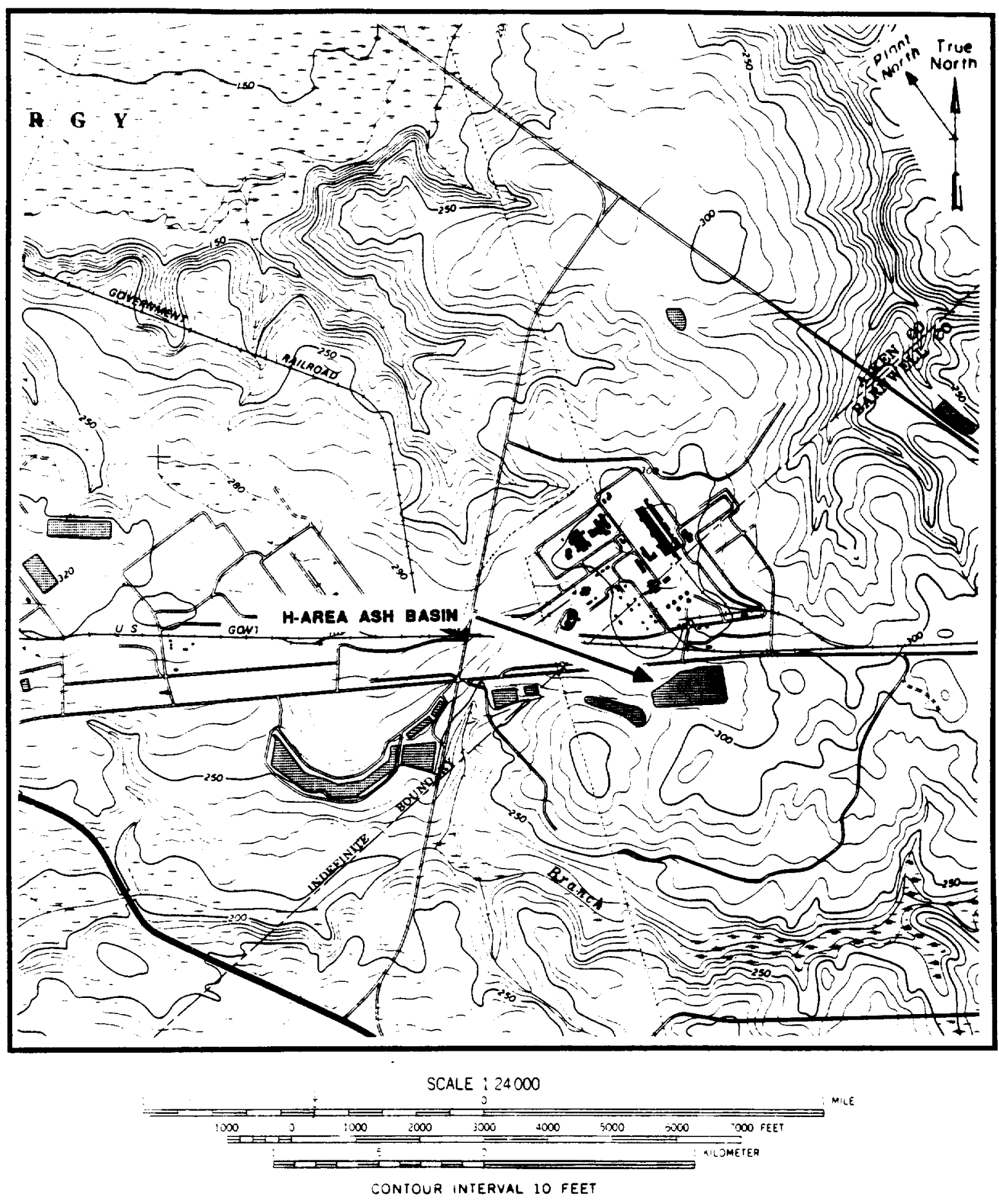

FIGURE C.5. Location of the H-Area Ash Basin on New Ellenton Sw Quadrangle 7.5 Minute Series Topographic Map 


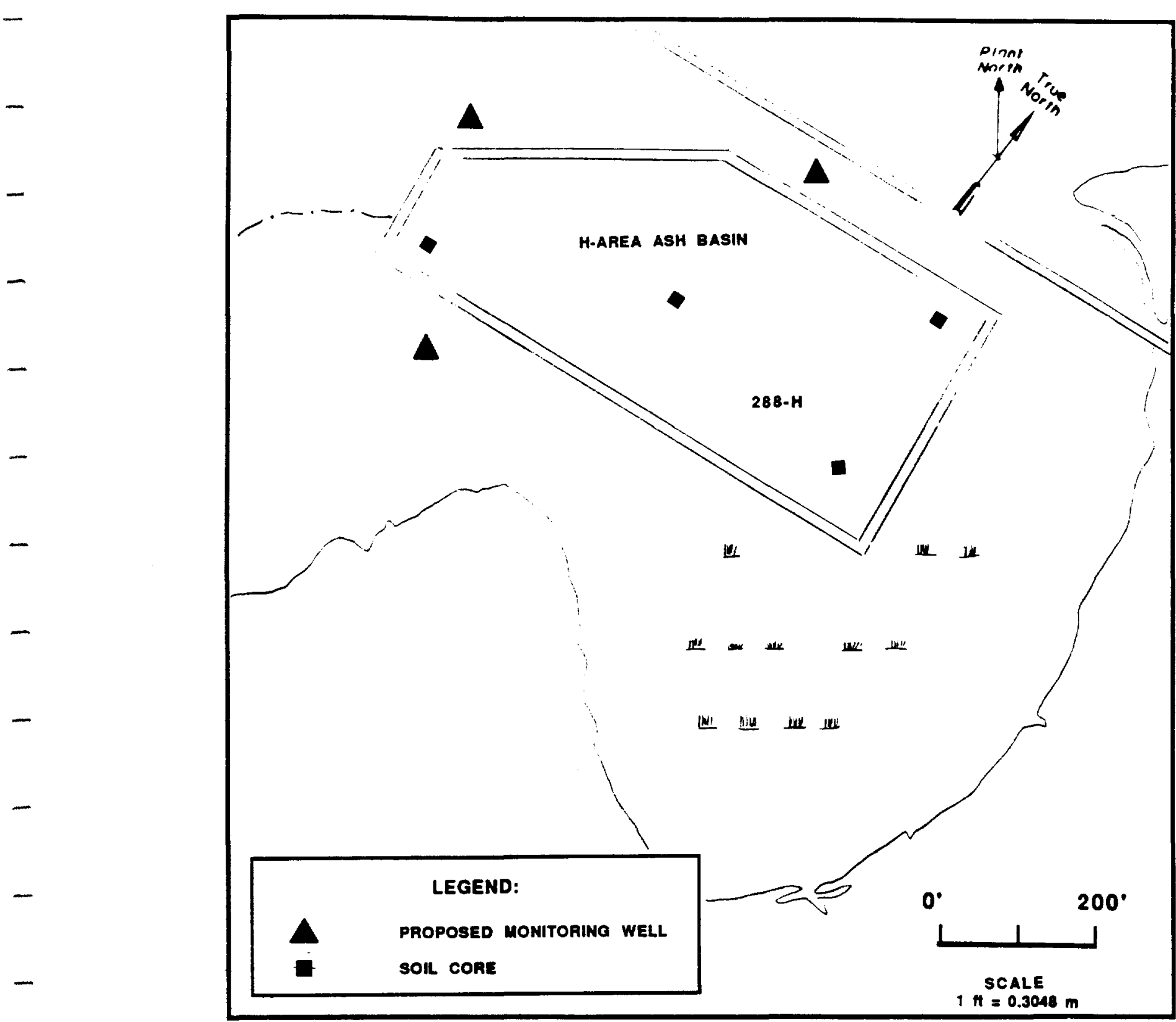

FIGURE C.6. Proposed Monitoring Well and Sampling Locations at the H-Area Ash Basin 
Chemical and Physical Analyses

Soils should be analyzed according to the parameters listed in Appendix Table 1. Specific analytes are metals (Appendix Table 2) and radioactivity (Appendix Table 4). Groundwater samples should be analyzed according to the parameters outlined in Appendix Table 6.

\section{K-Area Ash Basin}

\section{Site Description}

The $\mathrm{K}$-Area Ash Basin is located outside the $\mathrm{K}$-Area perimeter fence on the southwest edge of the area (Figure C.7). The nearest plant boundary is approximately $9 \mathrm{~km}$ to the west. The basin is approximately $45,000 \mathrm{~m}^{2}$.

The basin has received approximately $14,000 \mathrm{~m}^{3}$ of ash sluice water each year since 1951. Overflow from this basin could be directed through NPDES Outfa11 K-6. However, this has not been necessary to date.

The site is located on the Aiken Plateau at an elevation of approximately $75 \mathrm{~m}(245 \mathrm{ft})$. Surface drainage is to the west toward an unnamed tributary of Indian Grave Branch.

Four groundwater monitoring wells (KAB 1 through 4) were installed in the third quarter of 1983 (Figure C.8). Groundwater flow is to the west. Data from 1986 indicate that the depth to the water table is approximately $15 \mathrm{~m}$.

\section{Review of Available Data}

Elevated TDS levels are present in the groundwater surrounding this basin. TDS levels, however, are still below the groundwater quality review criterion (Appendix Table 10). No elevated levels of metals have been detected. Levels of gross alpha and radium above the groundwater quality review criteria (Appendix Table 10) have been detected in the downgradient we11. Levels of nonvolatile beta elevated above SRP background levels have also been measured.

\section{Characterization Recommendations}

Sampling

Three soil cores taken to a depth of $6 \mathrm{~m}$ are recommended (Figure C.8). These cores should be used to determine the vertical extent of the contamination, if any. Soils should be sampled for chemical analyses according to the parameters given in Appendix Table 1. 


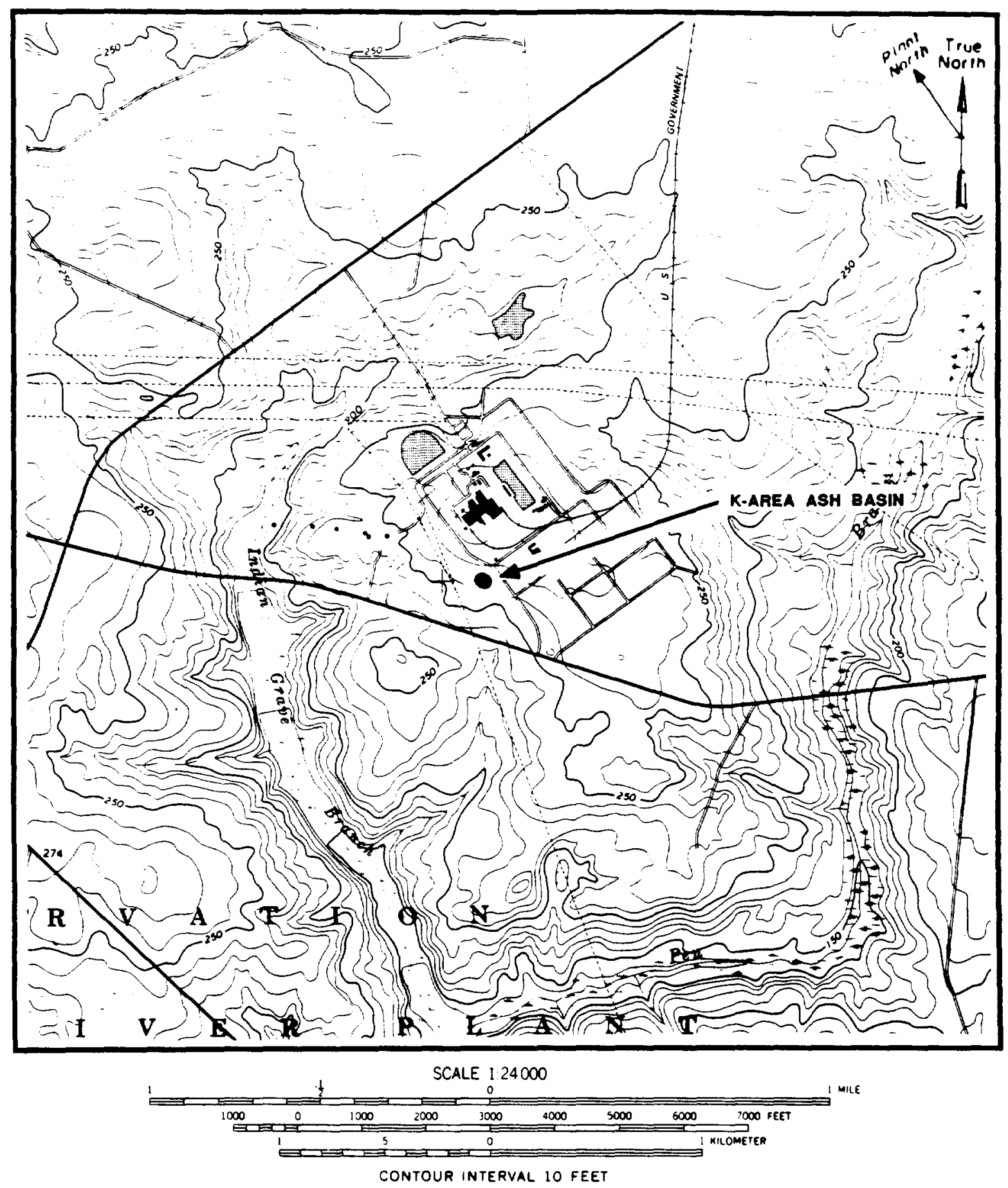

FIGURE C.7. Location of the K-Area Ash Basin on Girard NW quadrangle 7.5 Kinute Series Topographic Map 


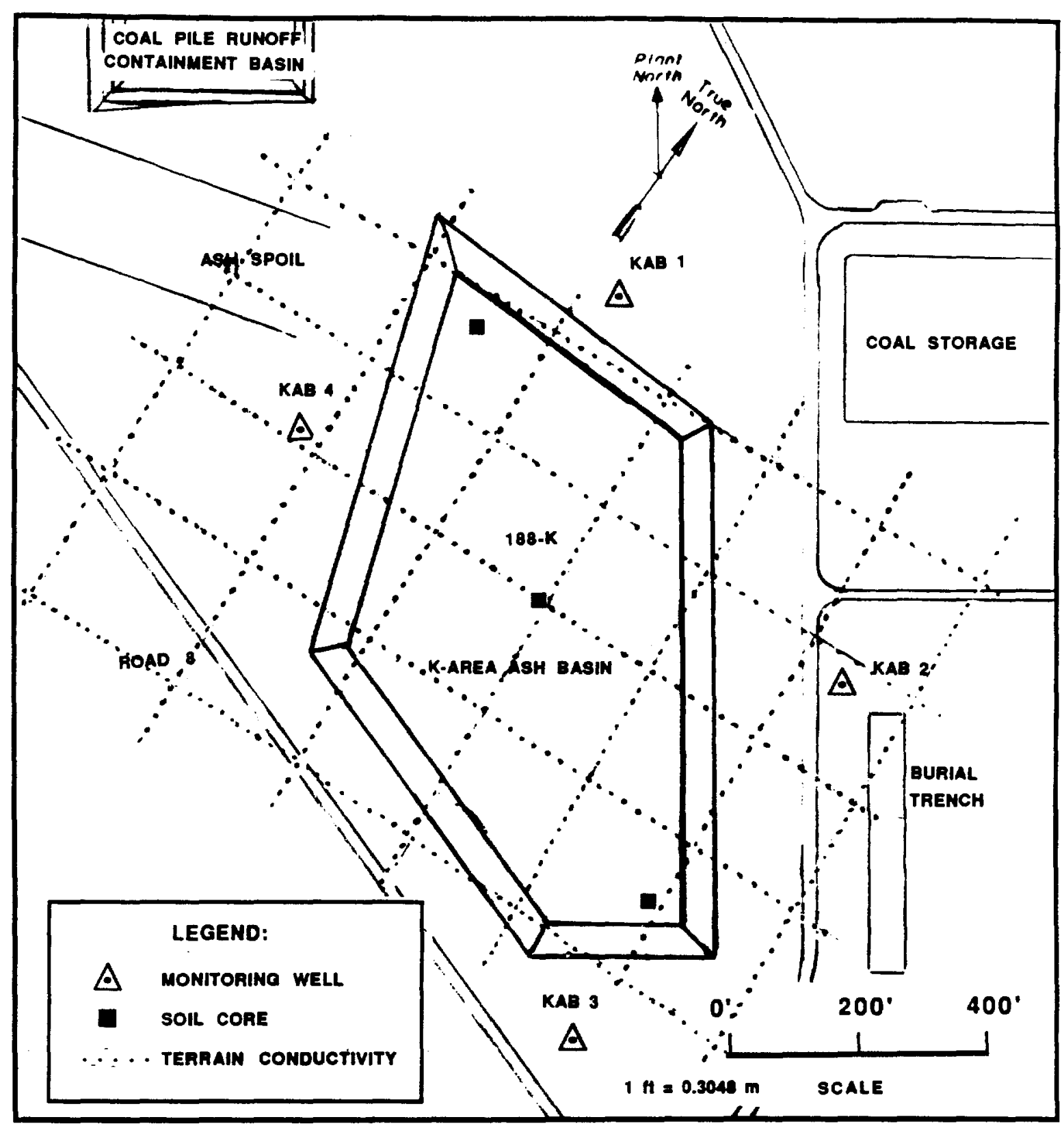

FIGURE C.8. Proposed Sampling Locations at the K-Area Ash Basin 
Splits of soil samples should be archived at SRP.

A terrain conductivity survey should be run to delineate the plume of elevated TDS levels in the groundwater. Due to the shallow depth to the water table, this method should work well at this site. It is possible that the plume of elevated-TDS water originates from the nearby $\mathrm{K}$-Area Coal Pile Runoff Containment Basin and not from the Ash Basin.

Chemical and Physical Analyses

Soils should be analyzed according to the parameters outlined in Appendix Table 1. Specific analytes are metals (Appendix Table 2) and radioactivity (Appendix Table 4). Groundwater should be analyzed according to the parameters in Appendix Table 6.

\section{L-Area Ash Basin}

\section{Site Description}

The L-Area Ash Basin is located north of the L-Area perimeter fence on the north side of Road 7 (Figure C.9). The nearest plant boundary is approximately $10 \mathrm{~km}$ to the south. The size of the basin is approximately $75,000 \mathrm{~m}^{2}$.

The L-Area Ash Basin received ash sluice water from 1951 until 1968. The basin is currently open and inactive.

The L-Area Ash Basin is located on the Aiken Plateau at an elevation of approximately $76 \mathrm{~m}(250 \mathrm{ft})$. Surface drainage is to the west toward a tributary of Pen Branch.

Although there are no groundwater monitoring wells at this site, the site hydrology can be extrapolated from wells located at the nearby L-Area Seepage Basin, L-Area $0 i 1$ and Chemical Basin, L-Area Acid/Caustic Basin, and L-Area Rubble Pit. Data from 1986 indicate that the groundwater flow direction is probably westward toward Pen Branch and that the depth to the water table probably ranges between 5 and $15 \mathrm{~m}$.

\section{Review of Available Data}

No groundwater, soil, or sludge data have been collected at this site. 

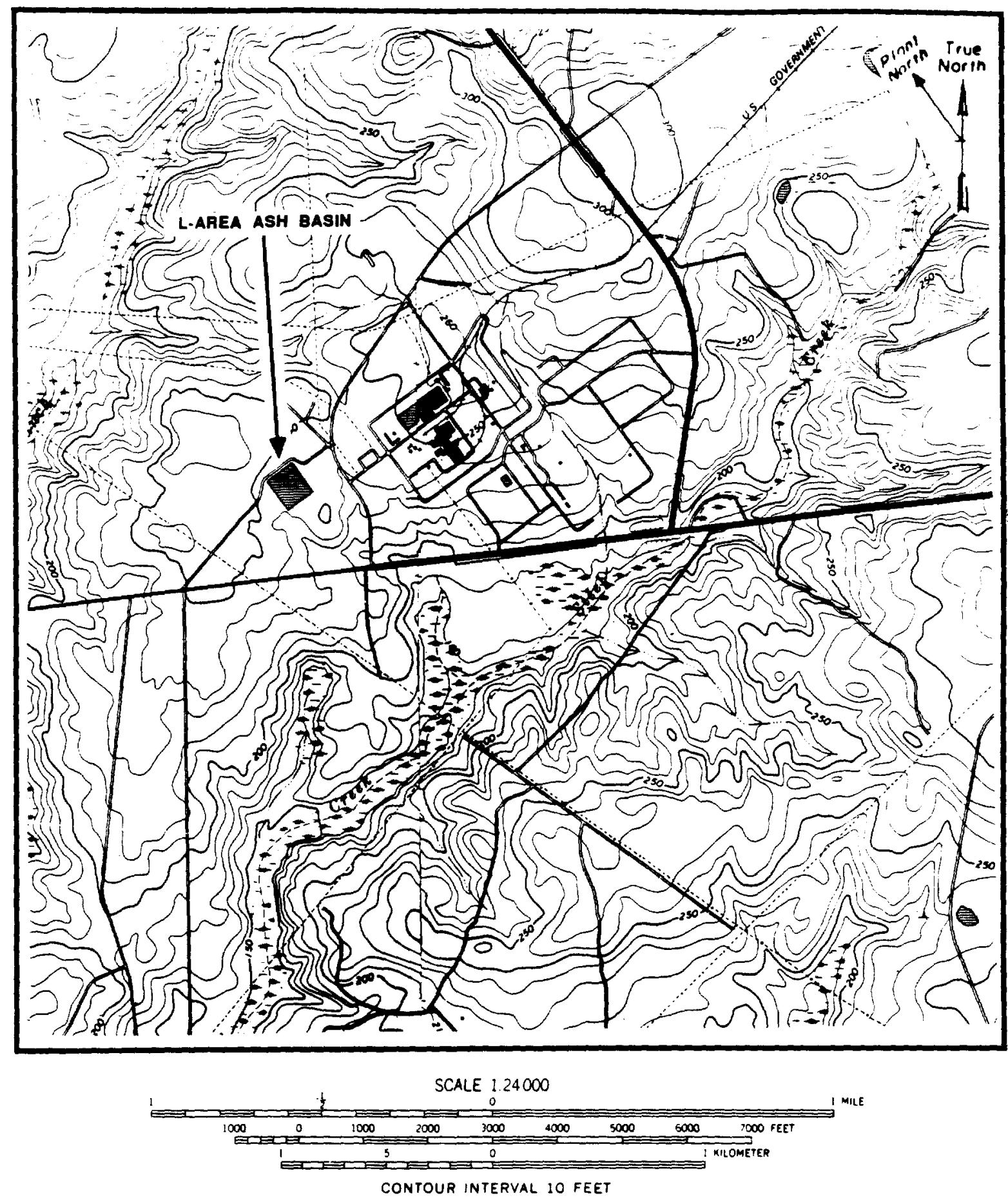

FIGURE C.9. Location of the L-Area Ash Basin on Girard NW Quadrangle 7.5 Minute Series Topographic Map 


\section{Characterization Recommendations}

Sampling

Three soil cores taken to a depth of $6 \mathrm{~m}$ are recommended for the site (Figure C.10). These cores should be used to determine the vertical extent of the contamination, if any. Soils should be sampled for chemical analyses according to the parameters given in Appendix Table 1. Splits of soil samples will be archived at SRP.

Installation of three groundwater monitoring wells is also recommended (Figure C.10). One of the monitoring wells should be cored continuous1y, and the cores should be described geologica11y and archived. A11 monitoring wells should be logged geophysically for gamma, resistivity, porosity, and caliper.

Chemical and Physical Analyses

Soil should be analyzed according to the parameters 1 isted in Appendix Table 1. Specific analytes are metals (Appendix Table 2) and radioactivity (Appendix Table 4). Groundwater should be analyzed according to the parameters outlined in Appendix Table 6.

\section{P-Area Ash Basin}

\section{Site Description}

The P-Area Ash Basin is located southeast of the P-Area perimeter fence (Figure C.11). The nearest plant boundary is approximately $7.5 \mathrm{~km}$ to the east. The basin covers an area of approximately $48,000 \mathrm{~m}^{2}$. Depth of the basin is approximately $3 \mathrm{~m}$. The basin receives approximately $14,000 \mathrm{~m}^{3}$ of ash sluice water per year.

The P-Area Ash Basin is located on the Aiken Plateau at an elevation of approximately $85 \mathrm{~m}(280 \mathrm{ft})$. Surface drainage is to the southeast toward a swamp at the headwaters of Meyers Branch.

AIthough there are no groundwater monitoring wells at this site, the site hydrology can be extrapolated from data from the nearby P-Area Coal Pile Runoff Containment Basin, P-Area Reactor Seepage Basin, P-Area Acid/Caustic Basin, and P-Area Burning/Rubble Pit. Groundwater flow is thought to be to the south-southwest in the area. Data from 1986 show that depth to the groundwater in the nearby P-Area Coal Pile Runoff Containment Basin wells (PCB series) is 6 to $9 \mathrm{~m}$. 


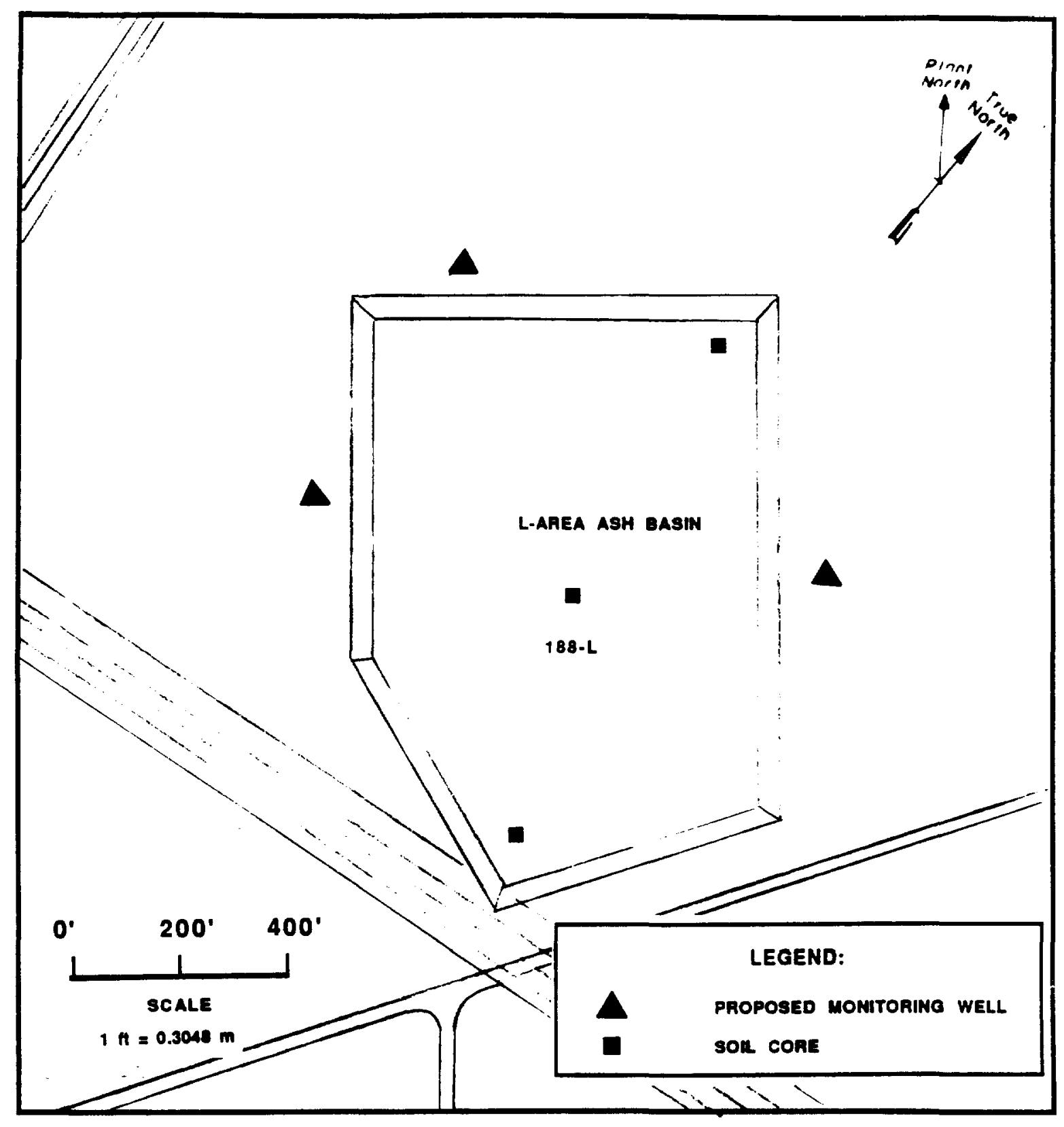

$-$

$-$

$-$

$-$

$-$

$-$

$-$

$-$

$-$

$-$

$-$

FIGURE C.10. Proposed Monitoring Well and Sampling Locations at the L-Area Ash Basin 

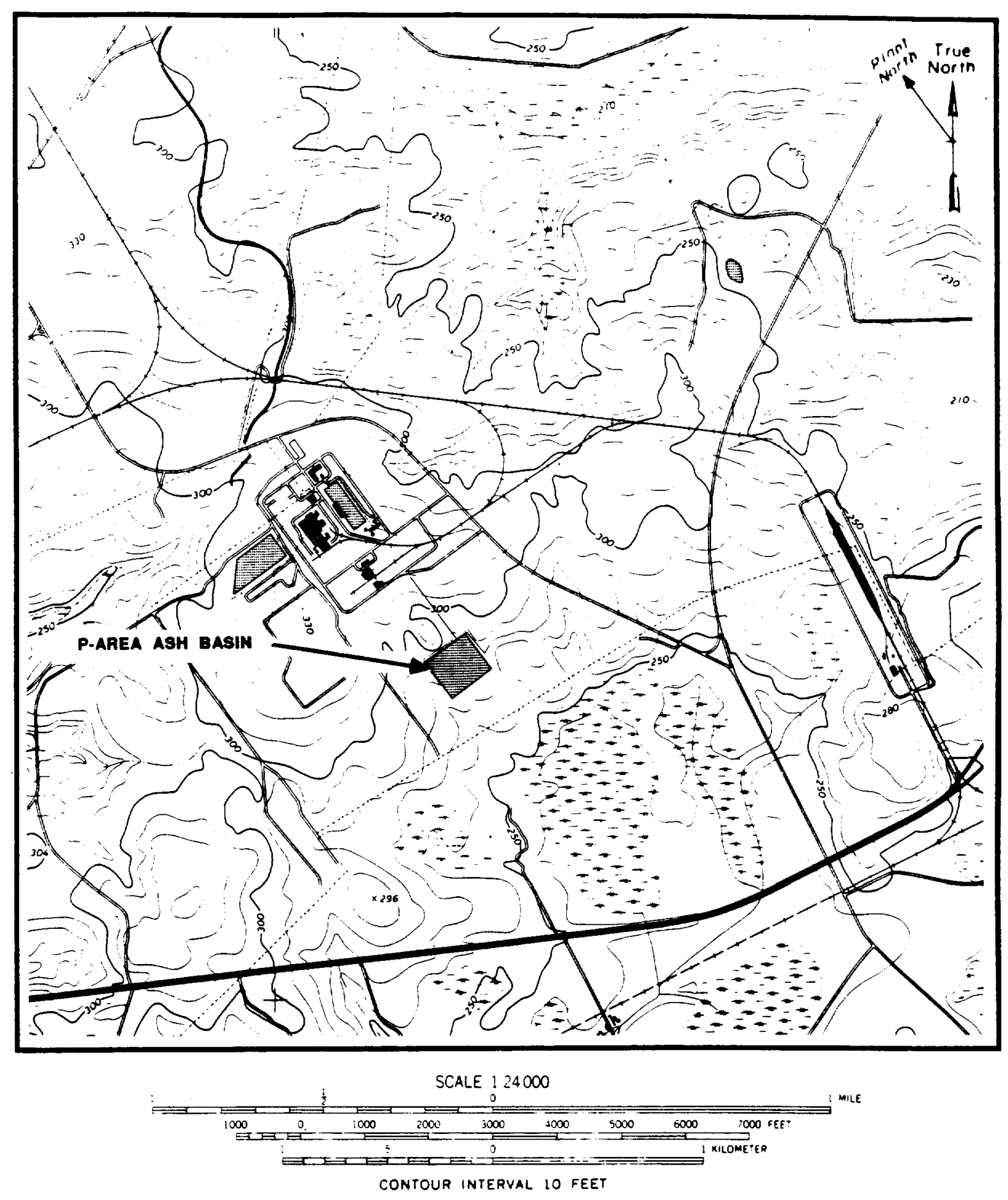

FIGURE C.11. Location of the P-Area Ash Basin on Girard NE quadrangle 7.5 Minute Series Topographic Map 
Review of Available Data

No groundwater, soil, or sludge data have been collected at this site.

\section{Characterization Recommendations}

Samp1ing

Three soil cores taken to a depth of $6 \mathrm{~m}$ are recommended for the site (Figure C.12). These cores should be used to determine the vertical extent of the contamination, if any. Soils should be sampled for chemical analyses according to the parameters given in Appendix Table 1. Splits of soil samples should be archived at SRP.

Installation of three groundwater monitoring wells is also recommended (Figure C.12). One of the monitoring wells should be cored continuously. The cores should be described geologically and archived. All monitoring wells should be logged geophysically for gamma, resistivity, porosity, and caliper.

Chemical and Physical Analyses

Soils should be analyzed according to the parameters outlined in Appendix Table 1. Specific analytes are metals (Appendix Table 2) and radioactivity (Appendix Table 4). Groundwater should be analyzed according to the parameters listed in Appendix Table 6.

\section{R-Area Ash Basin}

\section{Site Description}

The R-Area Ash Basin is located south of the R-Area perimeter fence (Figure C.13). The nearest plant boundary is located approximately $8 \mathrm{~km}$ to the east. The area covered by the basin is approximately $45,000 \mathrm{~m}^{2}$. Depth of the basin is approximately $4.5 \mathrm{~m}$.

The R-Area Ash Basin received ash sluice water from 1951 until 1964. The basin is currently open and inactive.

The R-Area Ash Basin is located on the Aiken Plateau at an elevation of approximately $90 \mathrm{~m}(295 \mathrm{ft})$. Surface drainage is to the south-southwest toward the headwaters of Steel Creek or a small canal that flows into Par Pond. 


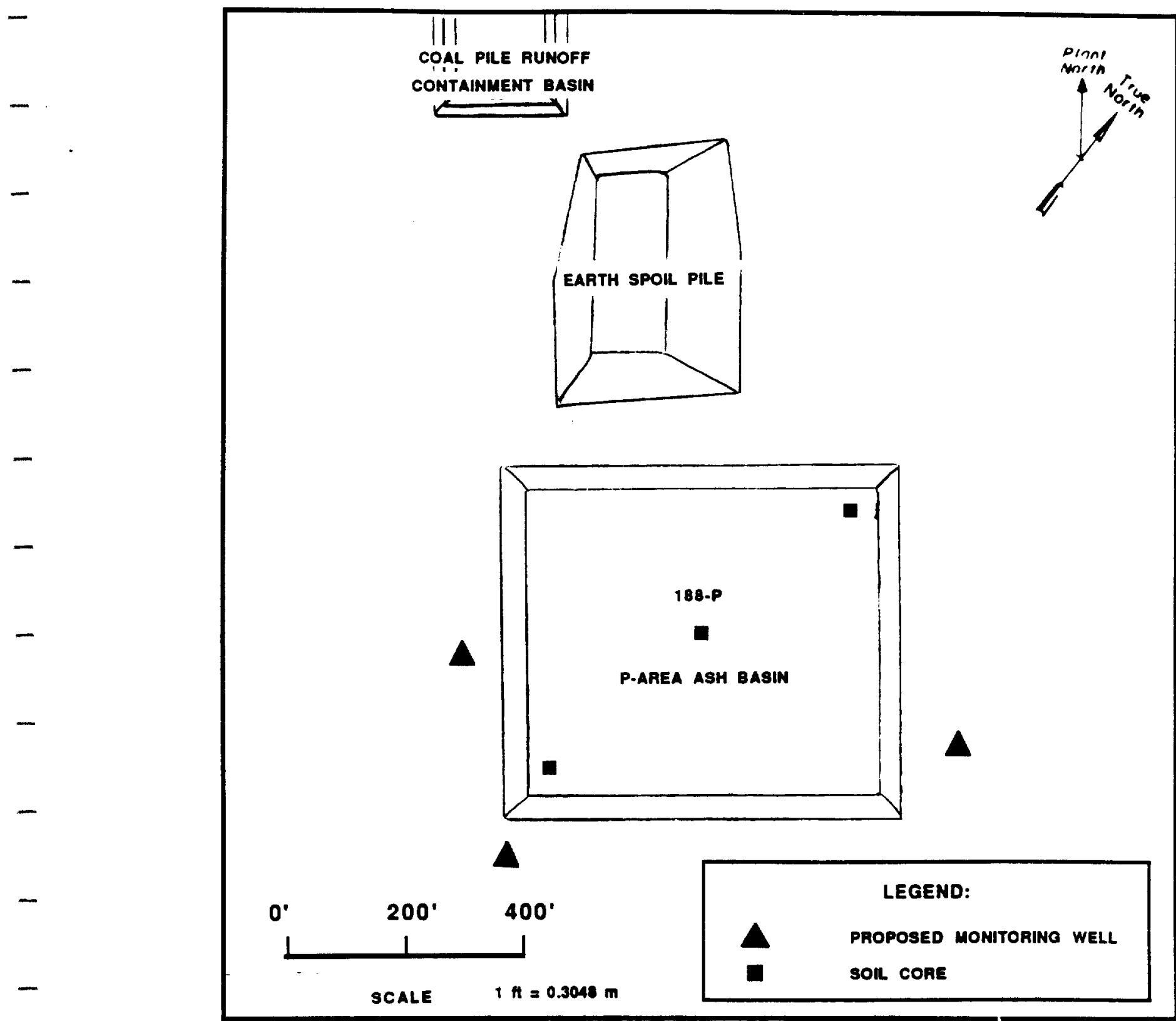

FIGURE C.12. Proposed Monitoring Well and Sampling Locations at the P-Area Ash Basin 


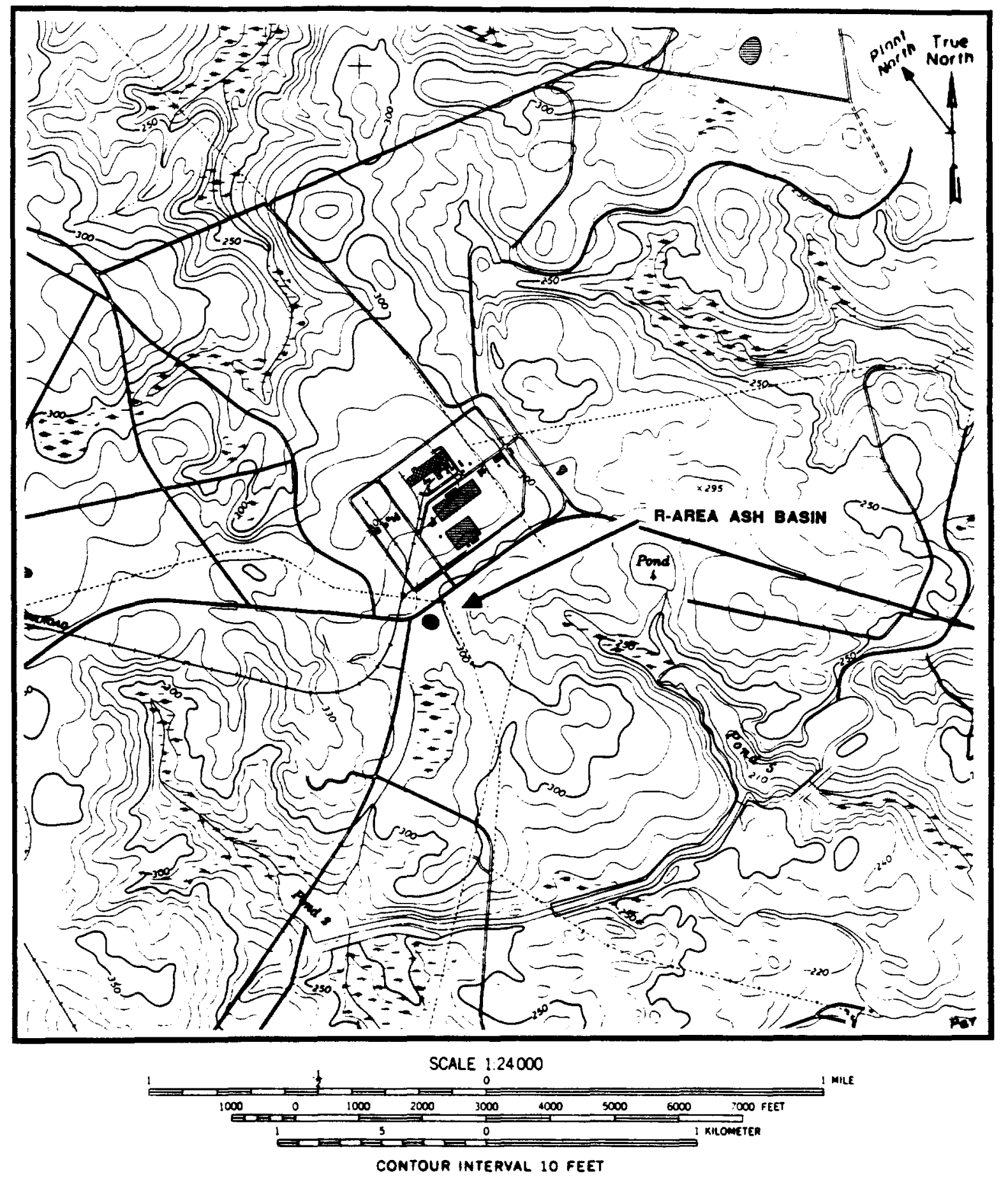

FIGURE C.13. Location of the R-Area Ash Basin on New Ellenton SE quadrangle 7.5 Minute Series Topographic Map 
Although there are no groundwater monitoring wells at this site, groundwater hydrology can be extrapolated from nearby wells located at the R-Area Acid/Caustic Basin and the R-Area Burning/Rubble Pit. Groundwater flow is believed to be to the south-southeast. Depth to the water table is approximately 2 to $3 \mathrm{~m}$ (1986 data) at the nearby Acid/Caustic Basin.

Review of Available Data

No groundwater, soil, or sludge data have been collected at this site.

\section{Characterization Recommendations}

Sampling

Three soil cores taken to immediately above the water table are recommended for the site (Figure C.14). These cores should be used to determine the vertical extent of the contamination, if any. Soils should be sampled for chemical analyses according to the parameters outlined in Appendix Table 1. Splits of soil samples should be archived at SRP.

Installation of three groundwater monitoring wells is also recommended (Figure C.14). One of the monitoring wells should be cored continuously. The cores should be described geologically and archived. All monitoring wells should be logged goephysically for gamma, resistivity, porosity, and caliper.

Chemical and Physical Analyses

Soils should be analyzed according to the parameters given in Appendix Table 1. Specific analytes are metals (Appendix Table 2) and radioactivity (Appendix Table 4). Groundwater should be analyzed according to the parameters given in Appendix Table 6. 


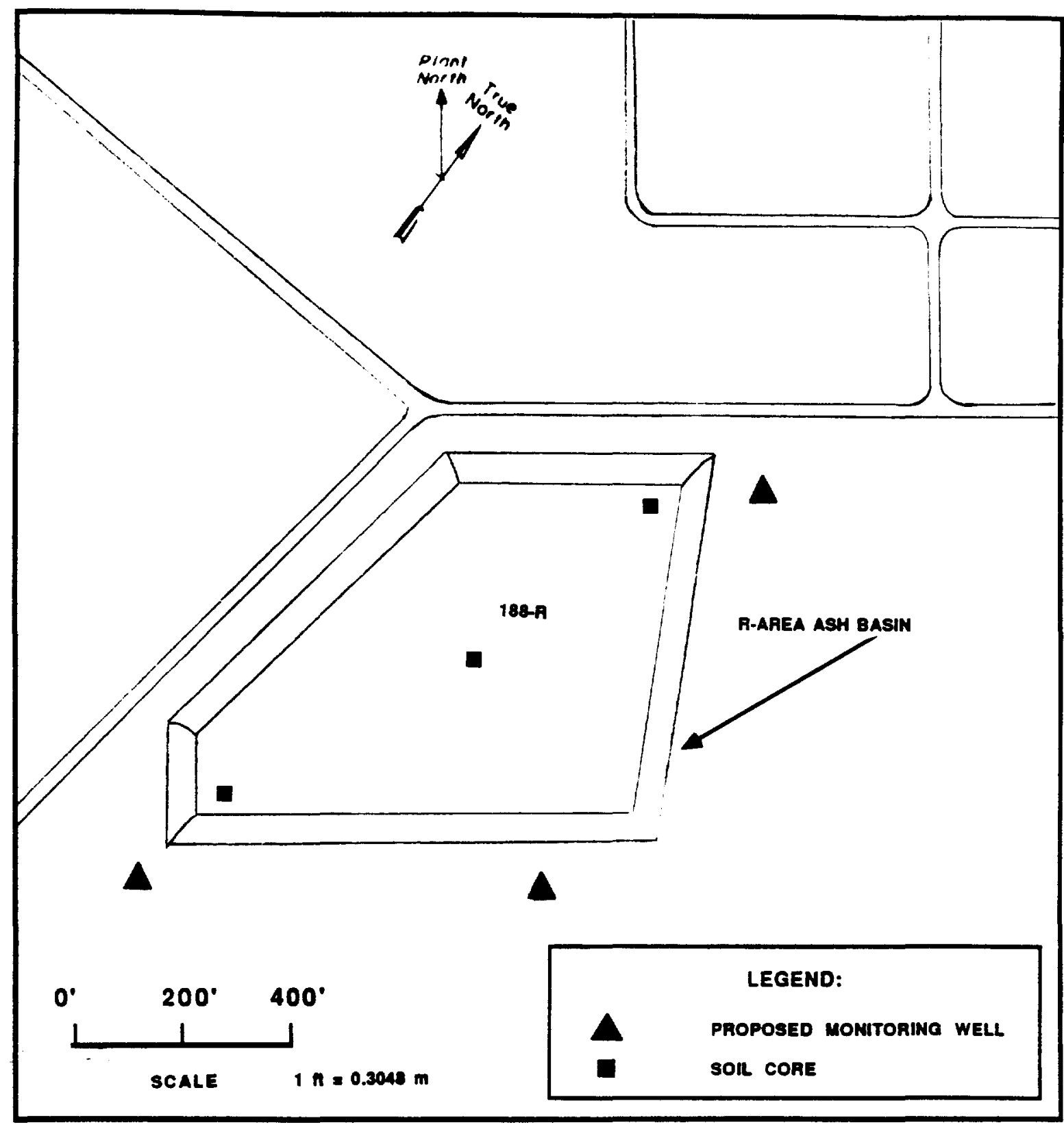

FIGURE C.14. Proposed Monitoring Well and Sampling Locations at the R-Area Ash Basin

$$
\text { C }-24
$$




\section{Background}

\section{Site History}

Powerhouse ash from $\mathrm{A}$ and $\mathrm{C}$ areas is disposed of in dry ash piles. Five ash piles have been used; two are currently active and three are inactive. The inactive piles have been seeded with grass to prevent erosion. Two of the inactive piles were merged when they were stabilized. The two active piles have been surrounded by containment dikes. Information on site histories and descriptions were obtained from Christensen and Gordon (1983) and Heffner et al. (in press).

Two ash piles (Buildings 788-A and 788-2A) are located in A Area. Building 788-2A is active and receives approximately $3,800 \mathrm{~m}^{3}$ of ash per year. Building 788-A is presently on standby. Building 788-2A was constructed on top of the pre-existing A-Area Rubble Pit (Building 731-2A) (Ross \& Green, 1983). Three ash piles (Buildings 188-C, 188-1C, and 188-2C) are located in C Area. These ash piles are presently inactive. Each of the piles received approximately $1,500 \mathrm{~m}^{3}$ of ash per year until 1984.

\section{Site Description}

A-Area Ash Piles

The two A-Area Ash Piles are located southeast of the A-Area perimeter fence east of Road D (Figure D.1). SRP coordinates for the northeast corner of Building 788-A are N 100761, E 50622 and for the northeast corner of Building 788-2A are $\mathrm{N} \mathrm{98733,E} \mathrm{44478.} \mathrm{The} \mathrm{piles} \mathrm{cover} \mathrm{areas} \mathrm{of}$ approximately 14,000 and $5,000 \mathrm{~m}^{2}$, respectively, and are approximately 3 to $4 \mathrm{~m}$ high.

The A-Area Ash Piles are on the Aiken Plateau at an elevation of approximately $104 \mathrm{~m}(340 \mathrm{ft})$. Surface drainage is to the east toward Tims Branch.

Four groundwater monitoring wells (ARP series) have been installed at the A-Area Burning/Rubble Pits, the same site as A-Area Ash Pile 788-2A. Groundwater flow in the area is toward the west-northwest. Because there are no groundwater monitoring wells near Building 788-A, no detailed information is available on flow direction in the immediate vicinity of this site. General A/M-Area data from 1986 indicate that the depth to the water table is approximately $30 \mathrm{~m}$. 

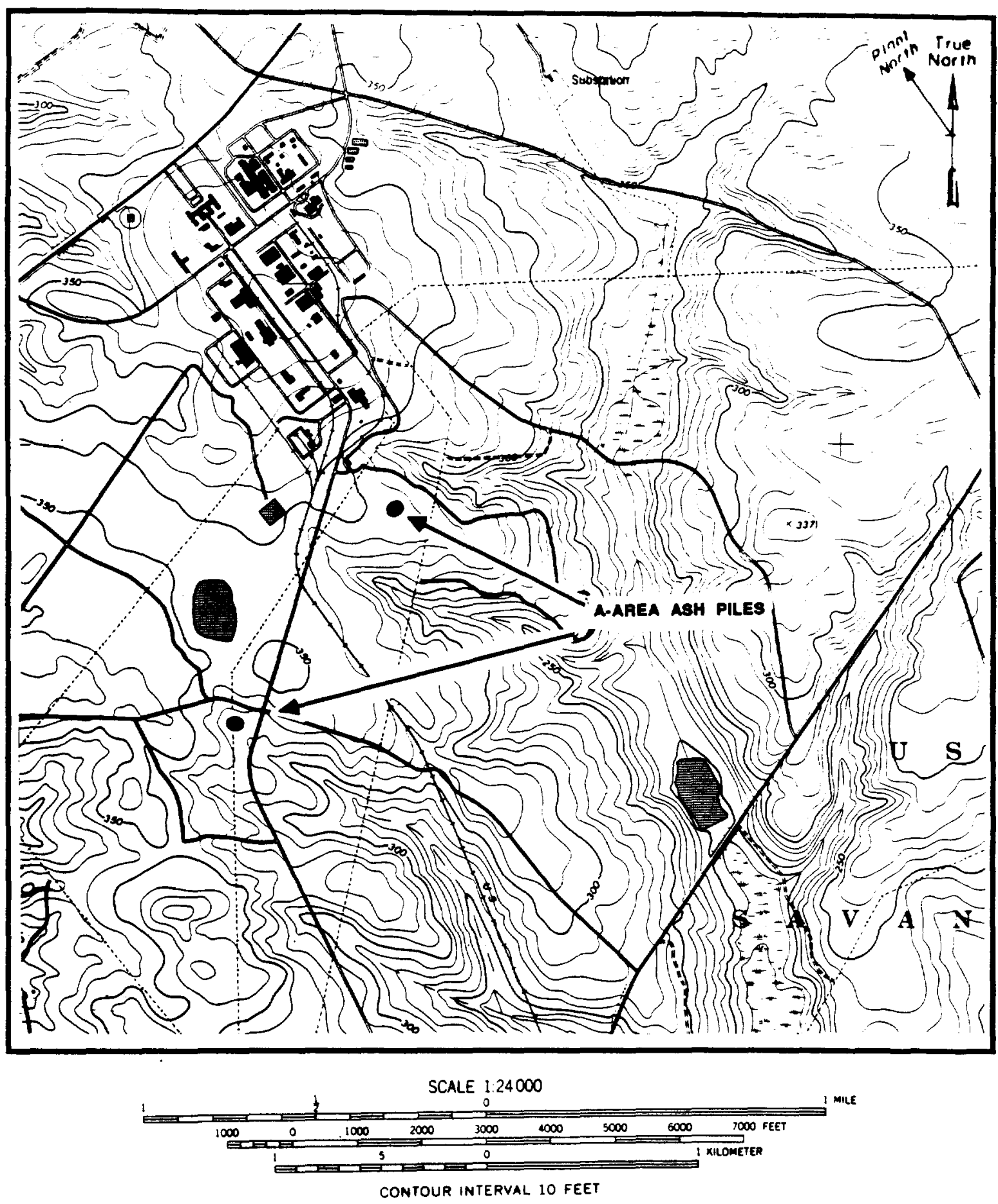

FIGURE D.1. Location of the A-Area Ash Piles on New Ellenton SW quadrangle 7.5 Minute Series Topographic Map 
C-Area Ash Piles

The three C-Area Ash Piles are located outside the C-Area perimeter fence to the north and west (Figure D.2). The piles are located on either side of Road A-7. SRP coordinates for the northeast corner of Building 188-C are N 69027, E 45748; for the northeast corner of Building 188-1C coordinates are N 69027, E 45748; and for the northeast corner of Building 188-2C coordinates are $\mathrm{N}$ 68343, E 47437. Buildings 188-1C and 188-C were merged into one pile when the piles were stabilized. The two stabilized piles cover areas of approximately 5,000 and $11,000 \mathrm{~m}^{2}$, respectively. Heights of the two stabilized piles are 3.7 and $1.2 \mathrm{~m}$, respectively.

The C-Area Ash Piles are located on the Aiken Plateau at an elevation of approximately $88 \mathrm{~m}(290 \mathrm{ft})$. Surface drainage is to the west toward a tributary of Four Mile Creek.

Although there are no groundwater monitoring wells at these sites, data from nearby wells suggest that groundwater flow is to the west toward a tributary of Four Mile Creek. Depth to the water table is approximately 10 to $20 \mathrm{~m}$ (1986 data) at the nearby C-Area Burning/Rubble Pits.

Review of Available Data

No soil, groundwater, or waste material data have been obtained from any of the ash pile sites.

\section{Characterization Recomnendations}

\section{Sampling}

Four soil cores are recommended for the ash piles: three cores to a depth of $4 \mathrm{~m}$ from ground surface and one to the water table as a model for a11 ash piles (Figures D.3 through D.6). These cores should be used to determine the vertical extent of any contamination if any. Soils should be sampled for chemical analyses according to the parameters given in Appendix Table 1. Splits of soil samples should be archived at SRP.

Installation of three groundwater monitoring wells is recommended at each of the piles except for 788-2A, which already has wells installed (Figures D.4 through D.6). One of the monitoring wells at each pile should be cored continuously, and the cores described geologically and archived. All of the monitoring wells should be logged geophysically for gamma, resistivity, porosity, and caliper. 


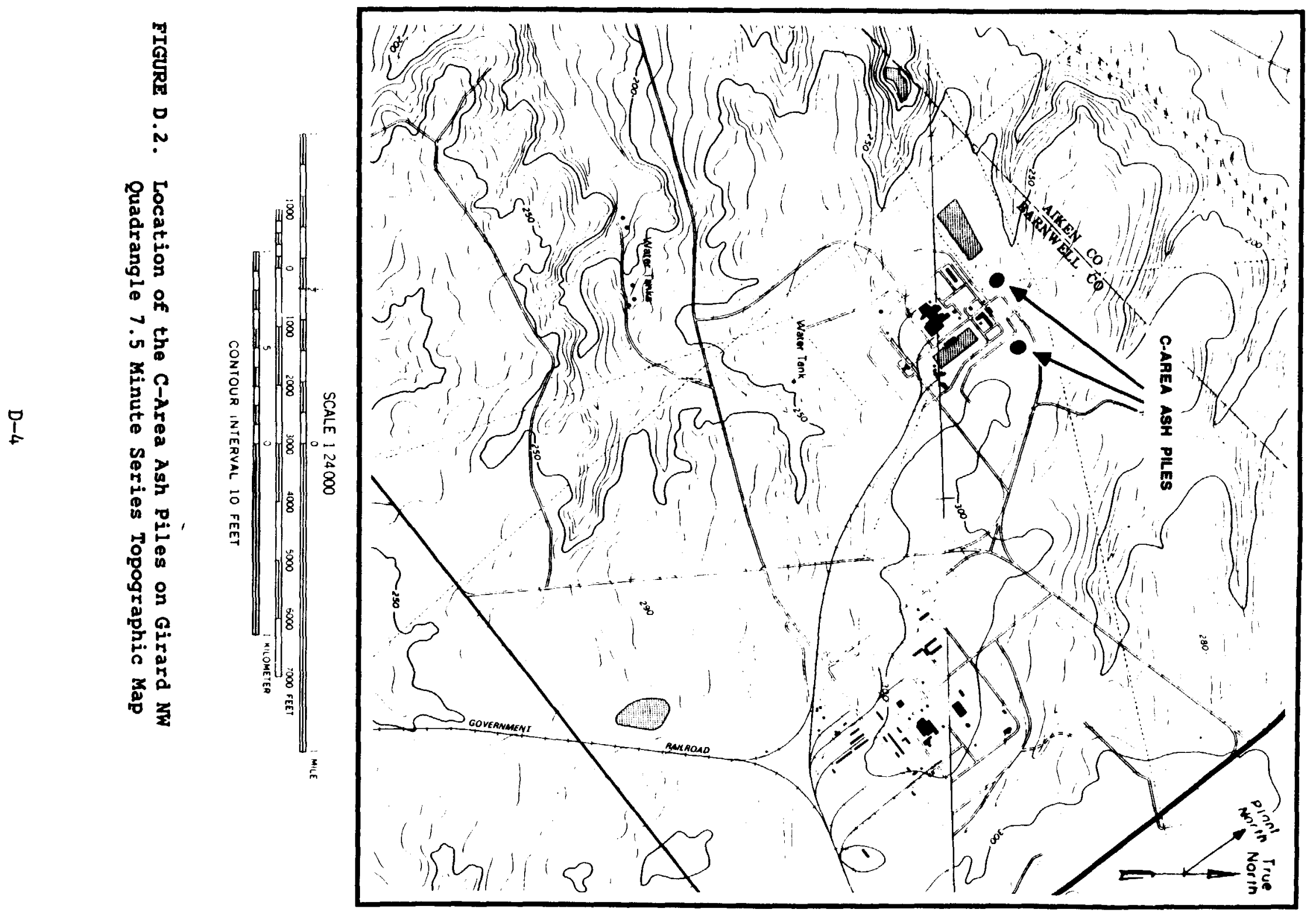




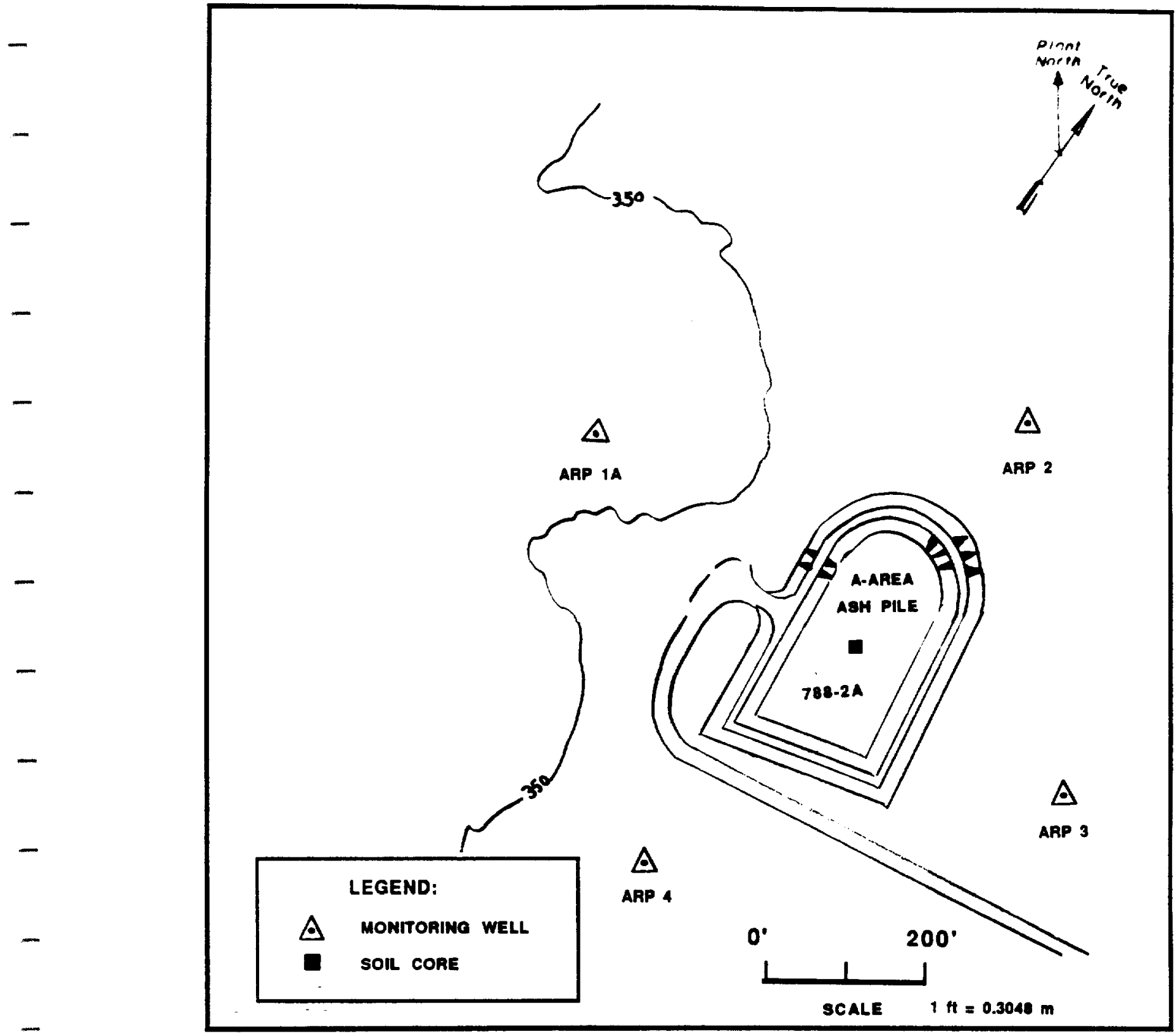

FIGURE D.3. Proposed Sampling Locations at A-Area Ash Pile 788-2A 


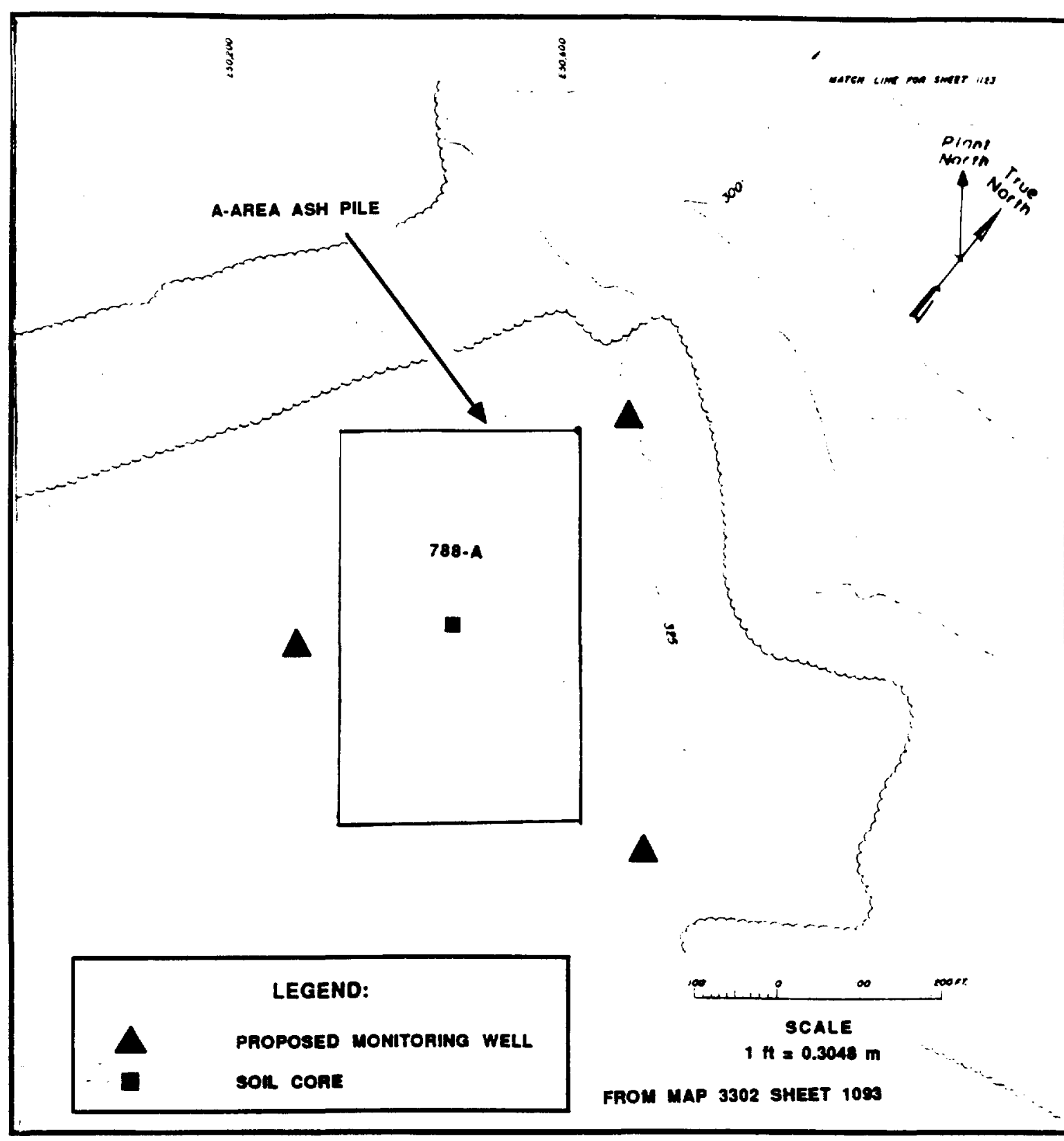

FIGURE D.4. Proposed Monitoring Well and Sampling Locations at A-Area Ash Pile 788-A 


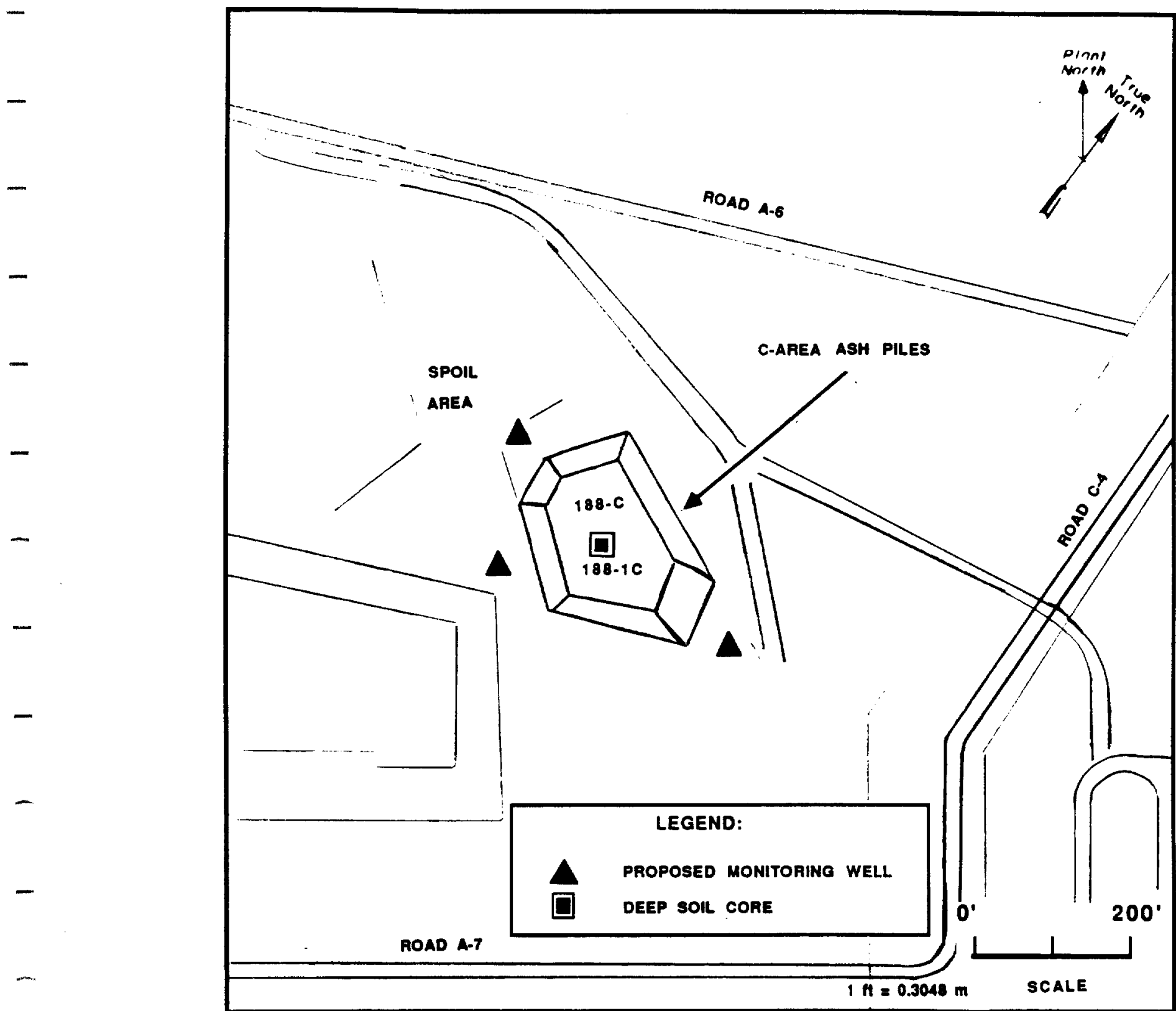

FIGURE D.5. Proposed Monitoring Well and Sampling Locations at C-Area Ash Piles $188-C$ and 188-1C 


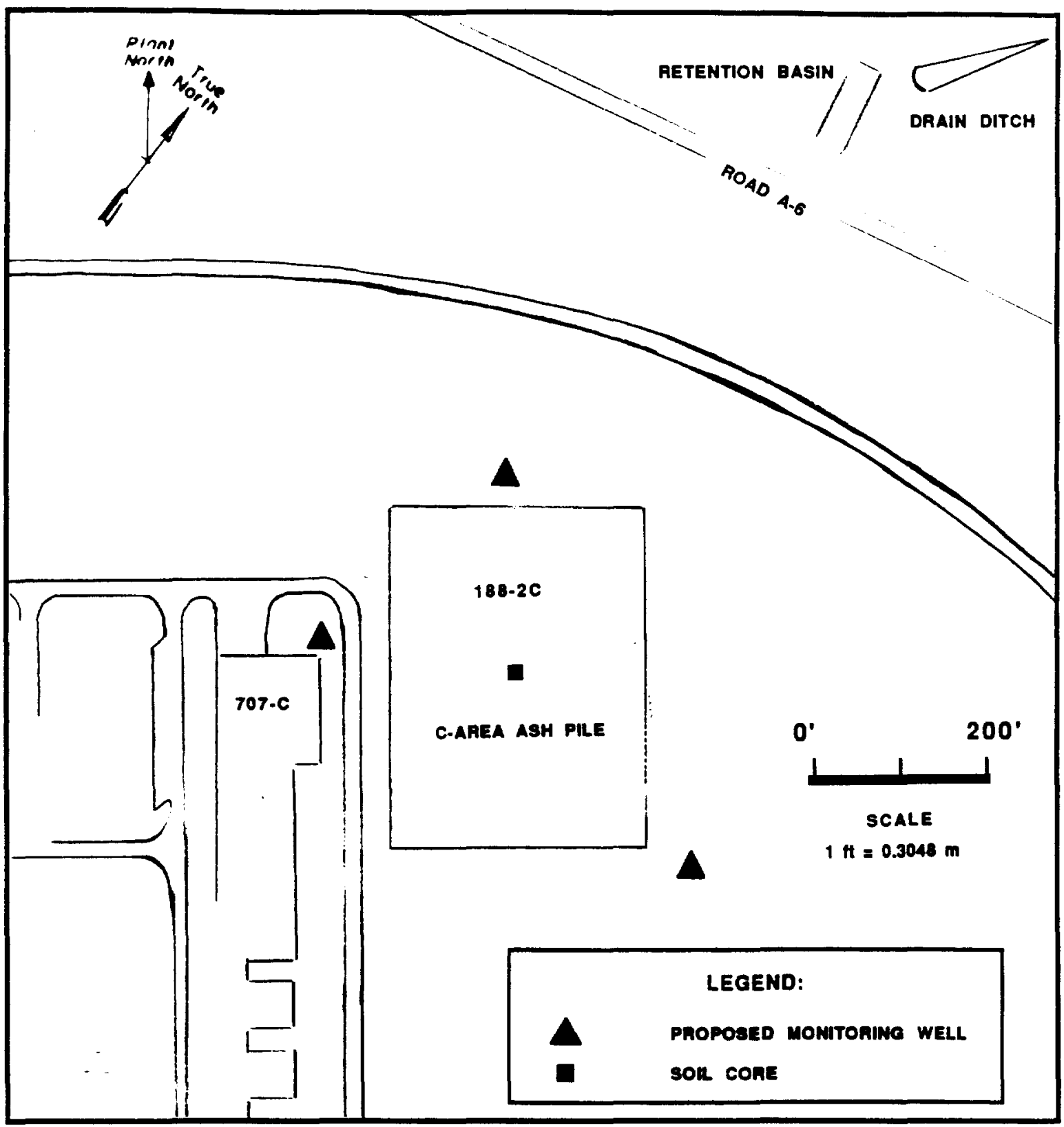

FIGURE D.6. Proposed Monitoring Well and Sampling Locations at C-Area Ash Pile 188-2C 


\section{Analyses}

Soils should be analyzed according to the parameters listed in Appendix Table 1. Specific analytes are metals (Appendix Table 2), volatile organics (Appendix Table 3), and radioactivity (Appendix Table 4). Groundwater should be analyzed according to the parameters given in Appendix Table 6 . 


\section{Background}

\section{Site History}

In 1957 and 1958 the SRP reactors underwent major modifications to their primary and secondary cooling water systems. The reactor shutdowns necessitated by these upgrade activities became known as the Bingham Pump Outages (Pekkala et a1., 1987c). C Reactor was the first to be modified, and all radioactive refuse generated during that outage was sent to the Radioactive Solid Waste Burial Grounds. Low-level radioactive refuse generated during pump outages at the $K, L, P$, and $R$ reactors, however, was disposed of in pits excavated in each of the respective areas.

Waste materials deposited in these pits include pipes, cables, ladders, drums, wooden boxes, and miscellaneous hardware. The radiation level of this material was less than $25 \mathrm{mRad} / \mathrm{hr}$ at $7.6 \mathrm{~cm}$ when buried, with no detectable alpha activity. A total of approximately $1 \mathrm{Ci}$ of activity (primarily ${ }^{137} \mathrm{Cs}$ and $90_{\mathrm{Sr}}$ ) is estimated to remain at the seven sites. Following completion of construction activities, the outage pits were closed by backfilling with clean soil over the deposited waste materials.

\section{Site Description}

The Bingham Pump Outage Pits are unlined pits excavated below grade. These pits are located in the $K, L, P$, and $R$ areas of the plant, approximately 7.2 to $9.8 \mathrm{~km}$ from the nearest plant boundaries (Figures E. 1 through E.4). The building numbers, physical dimensions, and SRP coordinates for these waste sites are as follows:

\begin{tabular}{|c|c|c|c|c|c|c|c|}
\hline $\begin{array}{l}\text { Reactor } \\
\text { Area } \\
\end{array}$ & $\begin{array}{l}\text { Pit } \\
\text { No. }\end{array}$ & $\begin{array}{l}\text { Bldg. } \\
\text { No. }\end{array}$ & $\begin{array}{l}\text { Dimensions } \\
\underline{L} \times W \times D(m)\end{array}$ & $\begin{array}{l}\text { Surface } \\
\text { Area }\left(\mathrm{m}^{2}\right)\end{array}$ & $\begin{array}{l}\text { Volume } \\
\text { Capacity }\left(\mathrm{m}^{3}\right)\end{array}$ & $\begin{array}{l}\text { SRP Coord } \\
\text { (NE Corne }\end{array}$ & nates \\
\hline K & 1 & $643-1 G$ & $122 \times 18 \times 4$ & 2,196 & 8, & N 52 & E 4 \\
\hline$L$ & 1 & $643-2 G$ & $130 \times 9 \times 4$ & & & N 48 & $\mathrm{E}$ \\
\hline $\mathbf{L}$ & 2 & $643-3 G$ & $144 \times 8 \times 4$ & & 4, & N 48945 & $E$ \\
\hline $\mathbf{P}$ & 1 & $643-4 G$ & $144 \times 8 \times 4$ & 1,152 & & N 45706 & $E$ \\
\hline $\mathbf{R}$ & 1 & & $76 \times 6 \times 4$ & 456 & 1,824 & N 56959 & $E$ \\
\hline $\mathbf{R}$ & 2 & 64 & $76 \times 5 \times 4$ & 380 & 1,520 & N 56959 & E 7 \\
\hline $\mathbf{R}$ & 3 & $643-10 G$ & $159 \times 8 \times 4$ & 1,272 & 5,088 & N 57224 & E 774 \\
\hline
\end{tabular}

The outage pit in $K$ Area is located at an elevation of $79 \mathrm{~m}(260 \mathrm{ft})$. Surface drainage and shallow groundwater flow are to the southwest toward a tributary of Indian Grave Branch, which is approximately $290 \mathrm{~m}$ away. Depth to the water table from the bottom of the pit is approximately 


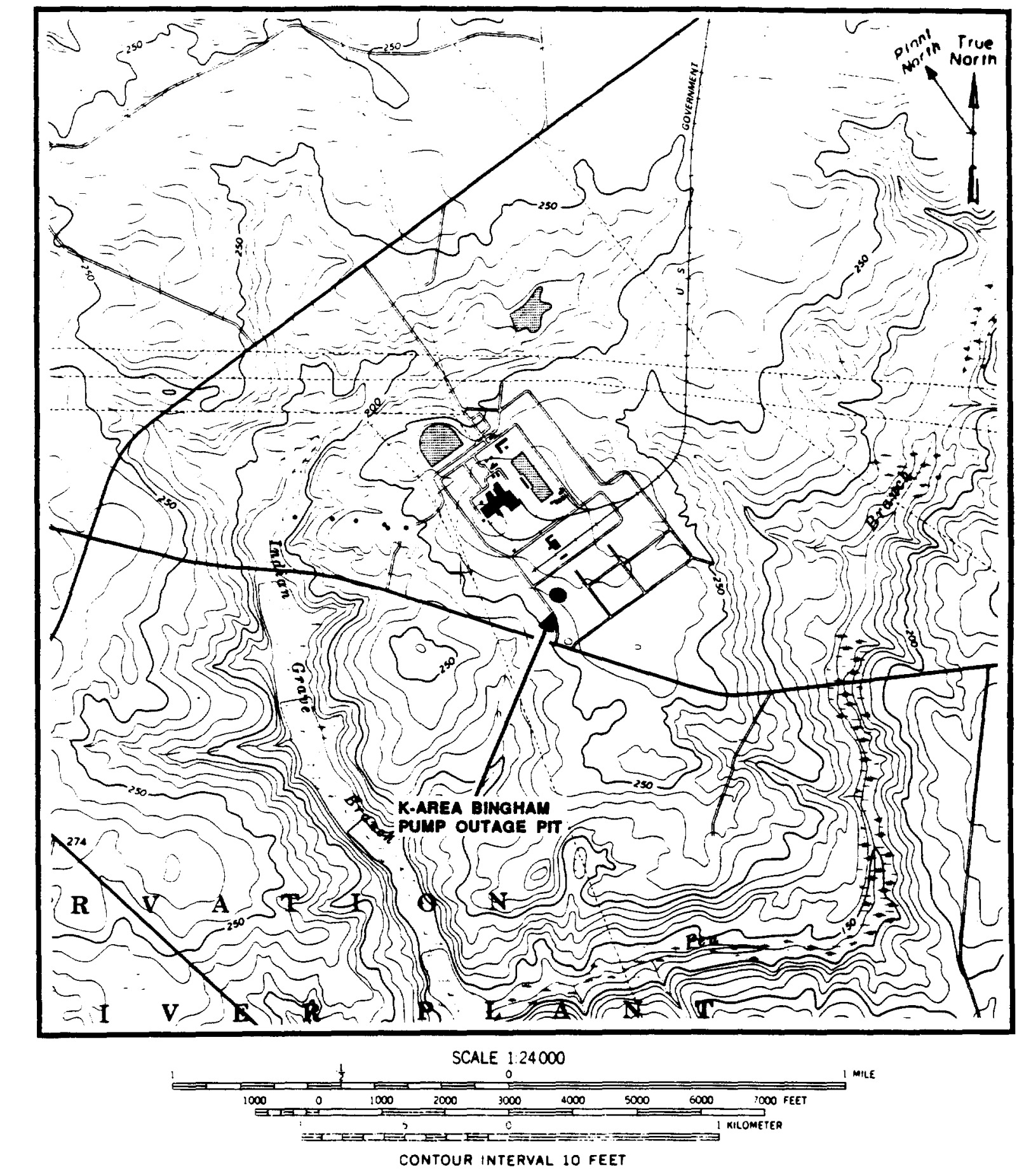

FIGURE E.1. Location of the K-Area Binghan Punp Outage Pit
on Girard Nw Quadrangle 7.5 Minute Series
Topographic Map

E-2 

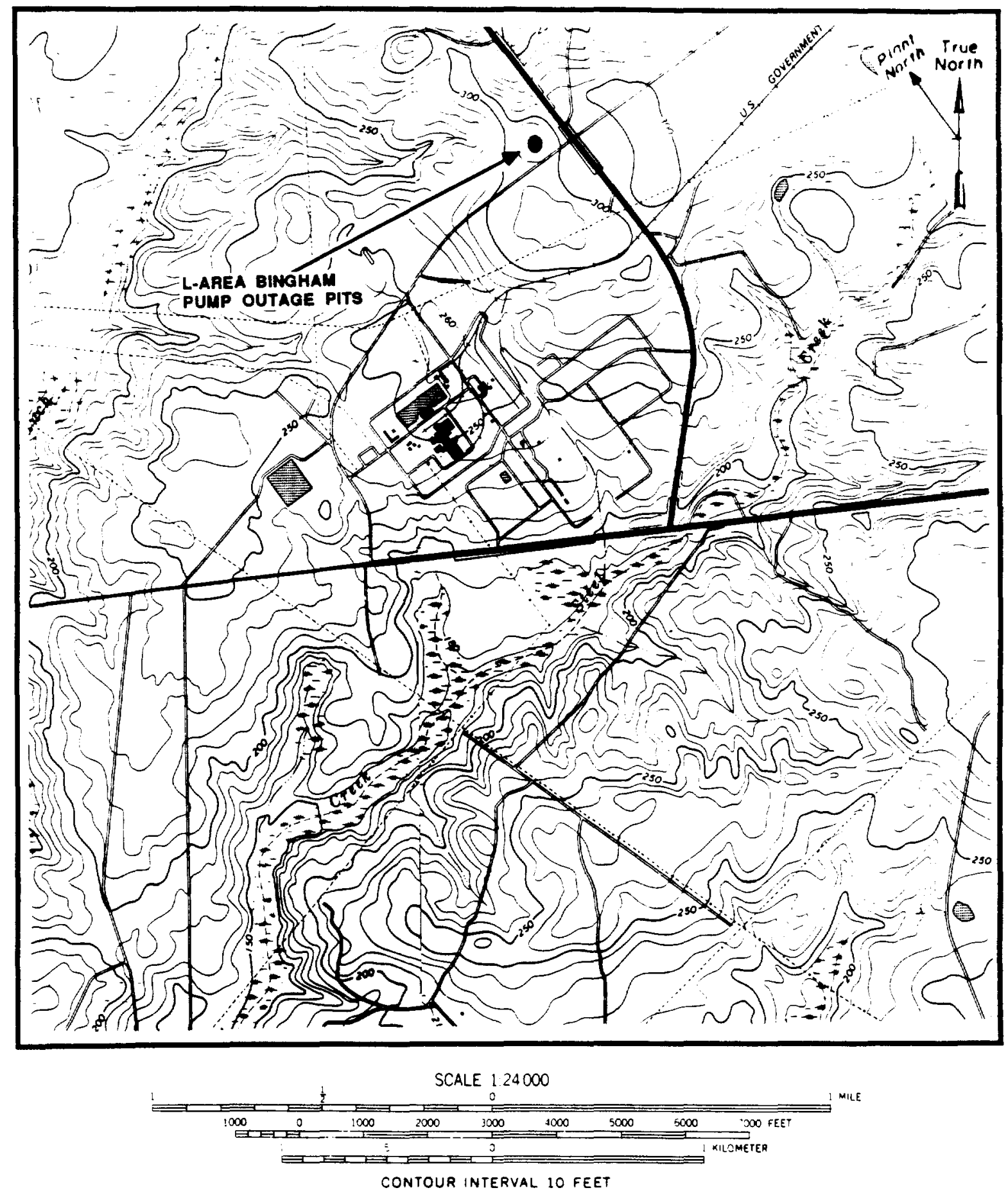

FIGURE E.2. Location of the L-Area Bingham Pump Outage Pits on Girard NW Quadrangle and Girard NE Quadrangle 7.5 Minute Series Topographic Maps 

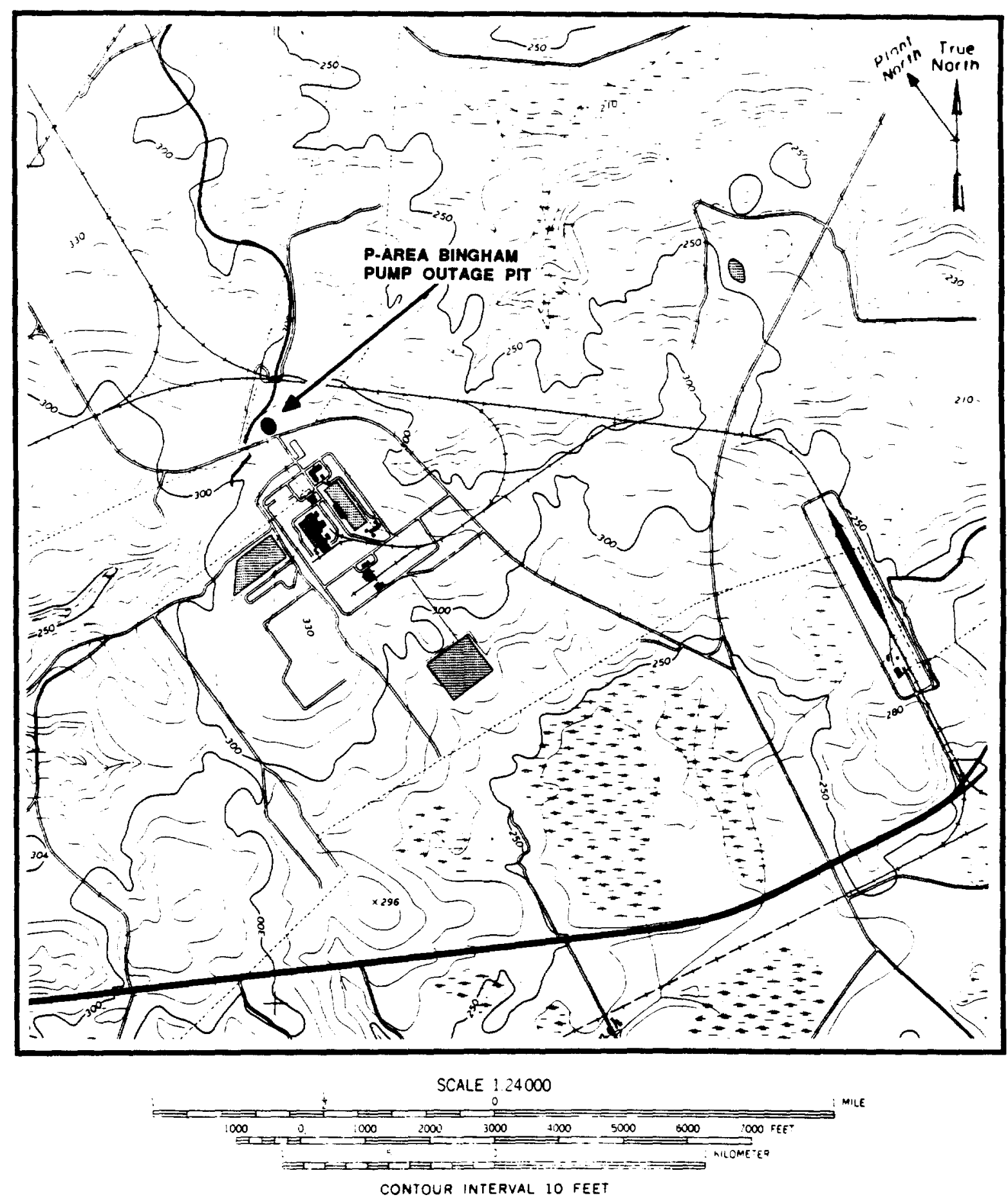

\section{FIGURE E.3. Location of the P-Area Binghan Punp Outage Pit on Girard ve Quadrangle 7.5 Minute Series Topographic Map}



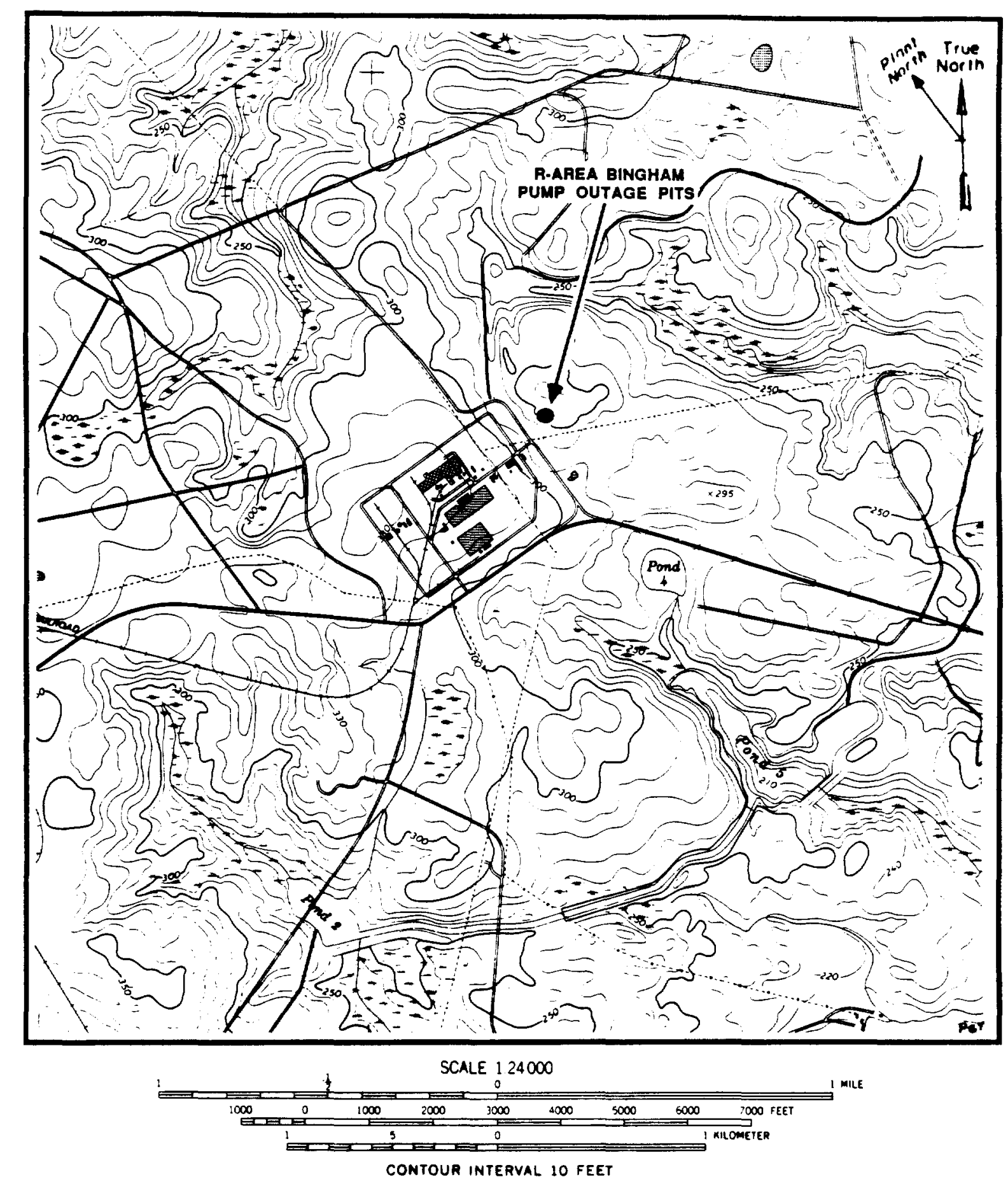

\section{FIGURE E.4. Location of the R-Area Binghan Pump Outage Pits on New Ellenton SE Quadrangle 7.5 Minute Series Topographic Map}


$11 \mathrm{~m}$. Surface elevation of the two L-Area outage pits ranges from 88 to $91 \mathrm{~m}$ (290 to $300 \mathrm{ft}$ ). Surface drainage and shallow groundwater flow is west toward a tributary of Pen Branch ( $360 \mathrm{~m}$ distant). Depth to the water table is approximately $2 \mathrm{~m}$ below grade. The P-Area Bingham Pump Outage Pit is located just east of the divide between Stee1 Creek and Par Pond at an elevation of approximately $97 \mathrm{~m}(320 \mathrm{ft})$. Surface drainage and shallow groundwater flow is north toward an unnamed stream that drains to Par Pond. Depth to the water table is approximately $2 \mathrm{~m}$ below grade. The three outage pits in $\mathrm{R}$-Area are located at elevations ranging from 91 to $94 \mathrm{~m}$ ( 300 to $310 \mathrm{ft}$ ). Surface drainage and shallow groundwater flow are to the northeast towards Joyce Branch (570 $\mathrm{m}$ distant), which drains into an arm (Pond C) of Par Pond. Depth to the water table is approximately $16 \mathrm{~m}$. Thick vegetation is present at all sites. There are no groundwater monitoring wells located around any of the Bingham Pump Outage Pits.

\section{Review of Available Data}

There are no groundwater or soil core data available for any of the Bingham Pump Outage Pits. In 1970, a comparative study of radiation levels in vegetation taken from the surfaces of the outage pits and from various locations around the plant's perimeter was conducted. The radioactivity in vegetation taken from the waste sites was found to be only slightly elevated over that detected in vegetation from the perimeter areas (Fenimore \& Horton, 1974).

\section{Characterization Recommendations}

\section{Sampling}

The potential exists for minor radioactive contamination of the soil underlying the pits (Looney et al., 1987). It is recommended that GPR surveys be conducted at each waste site to define pit boundaries and to identify possible sampling locations where solid debris will not interfere with coring operations. Proposed GPR transect patterns for each waste site are shown in Figures E.5 through E.8. In $L$ and $R$ areas, where multiple pits are present, one pit should be designated for characterization.

Three 6-m deep boreholes should be cored beneath the bottom of each pit (Figures E.5 through E.8). Recommended sampling intervals for these boreholes are described in Appendix Table 1. A composite sample of waste material deposited in each pit should also be taken for chemical and radiological analyses.

Coring operations should use a mobile drill rig equipped with a wireline coring device. The boreholes should be cored through the center of the site. If buried debris hinders coring operations or the pit surface conditions are unsuitable to support the weight of the drill rig, 


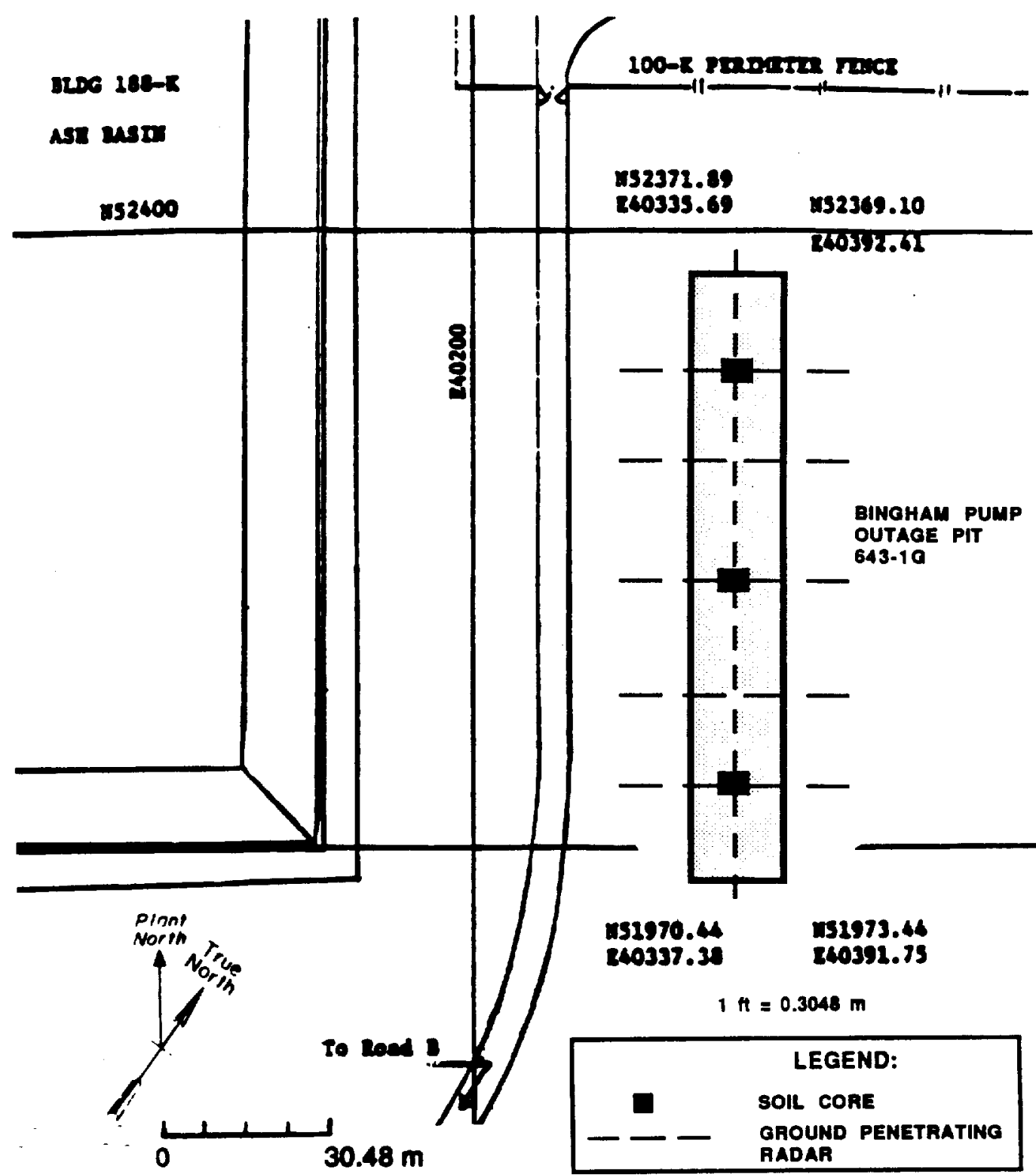

FIGURE E.5. Proposed Sampling Locations at the K-Area Bingham Punp Outage Pit 


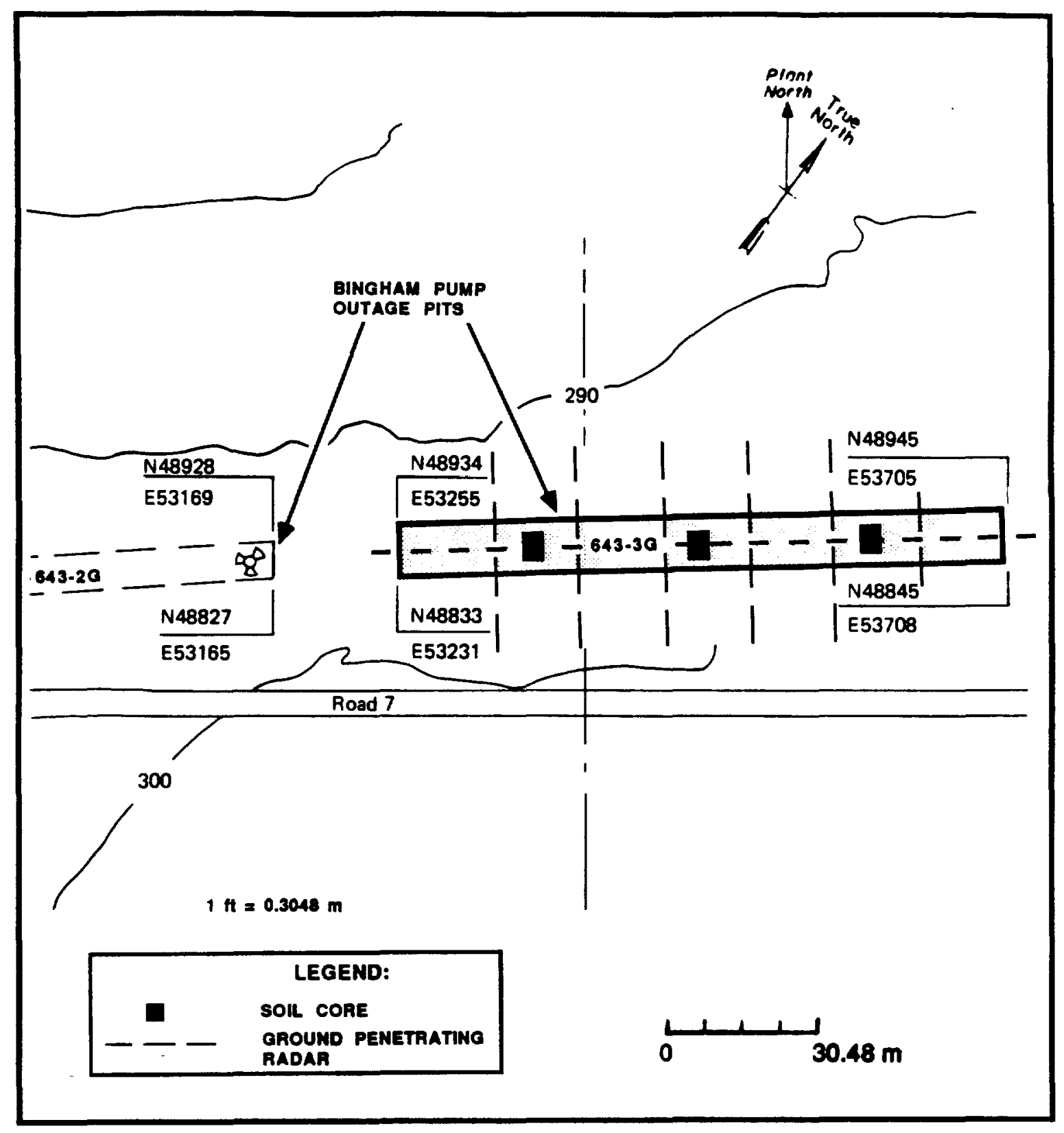

FIGURE E.6. Proposed Sampling Locations at the L-Area Bingham Punp Outage Pits 


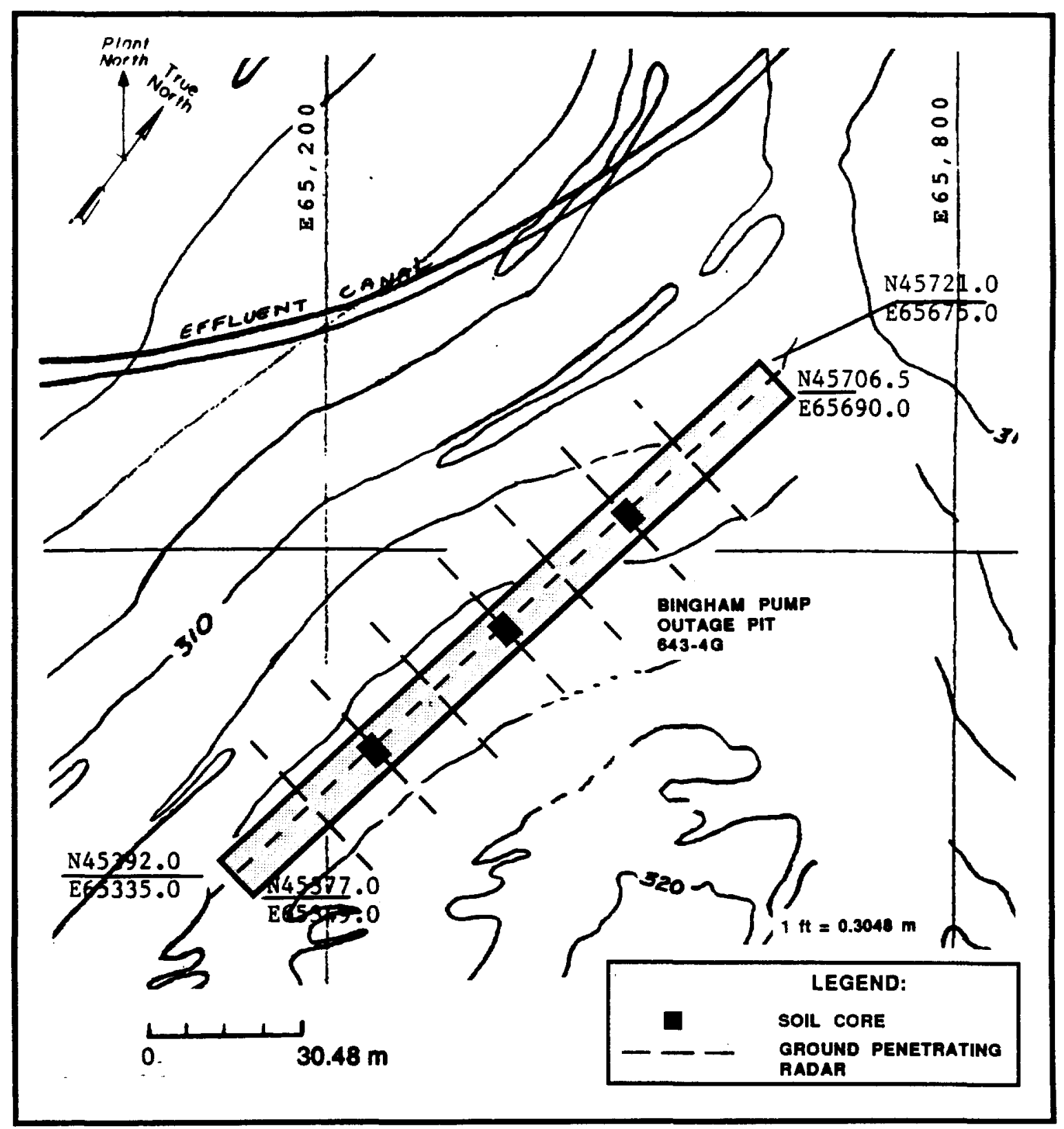

FIGURE E.7. Proposed Sampling Locations at the P-Area Bingham Pung Outage Pit 


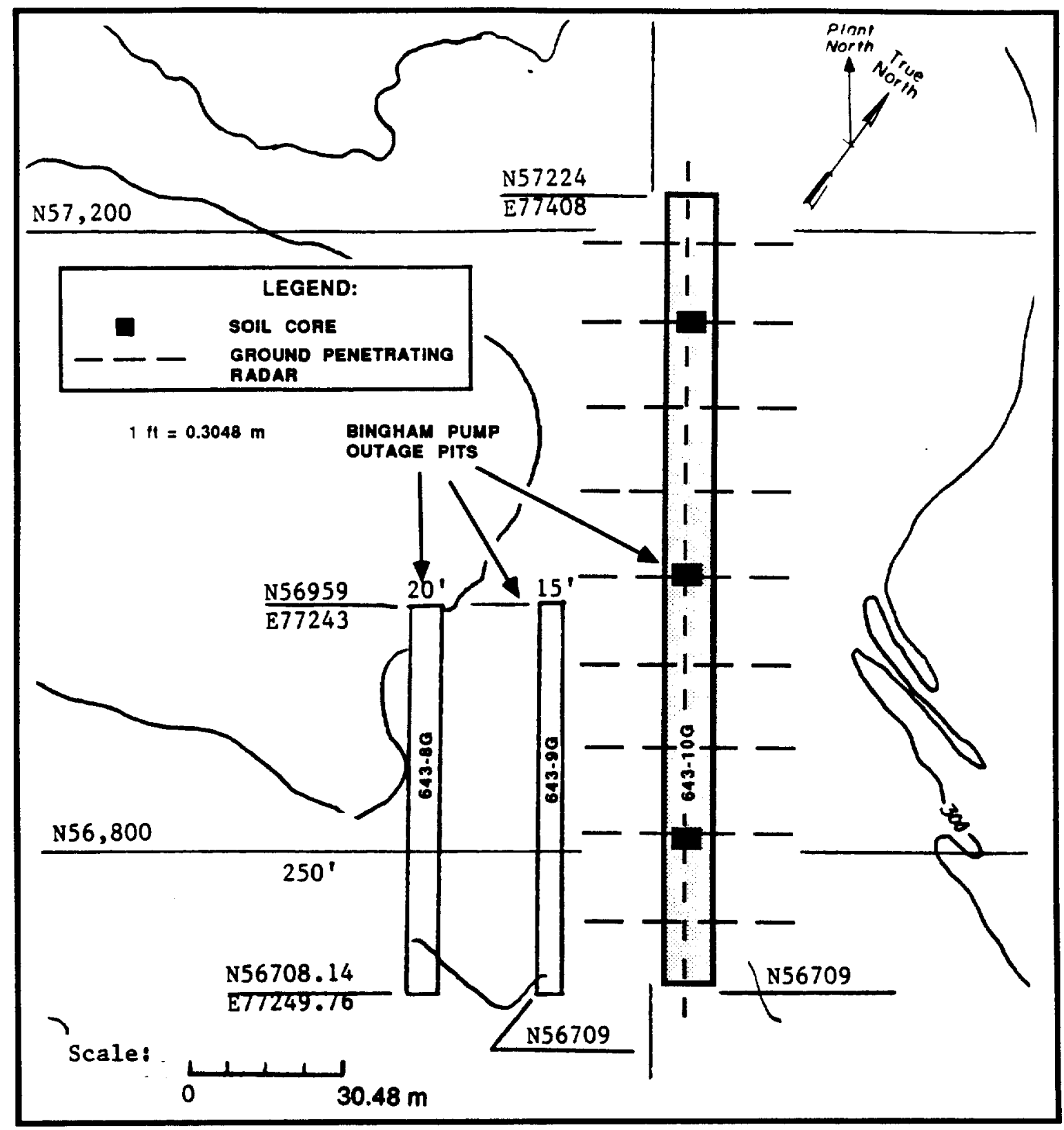

FIGURE E.8. Proposed Sampling Locations at the R-Area Bingham Punp Outage Pits 
then cuts should be excavated into the fill material to provide rig access to the pit's bottom. Immediately following completion of sampling operations, excavated materials should be reburied and disturbed surface areas graded and seeded to prevent erosion.

\section{Chemical and Physical Analyses}

Analytical requirements (Classes 1, 2, and 3) for the soil cores are described in Appendix Table 1. Additional analytical requirements for these soil cores are as follows:

\section{Interval (m)}

$0.00-0.25$

$0.25-0.50$

$0.50-1.00$

$1.00-1.50$

$1.50-2.00$

$2.00-2.50$

$2.50-3.00$

$3.00-4.00$

$4.00-5.00$

$5.00-6.00$

\section{Recommended Analyses}

expanded rad; Ludlum counts

gamma scan; $90 \mathrm{Sr}$; Ludlum counts

gamma scan; $90 \mathrm{Sr}$; Ludlum counts

expanded rad; Lud1um counts

Ludlum counts

Ludlum counts

Ludlum counts

Lud 1 um counts

expanded rad; Ludlum counts

Ludlum counts

Note: For expanded rad and gamma scan see Appendix Table 5; Ludlum counts are field gross alpha, gross beta, and gross gamma counts performed on a Ludlum Meter. 


\section{Background}

\section{Site History}

Fifteen Burning Pits were constructed at SRP in 1951 and were backfilled for use as rubble pits in 1973. Table F.1 lists the Burning/Rubble Pits, their building numbers, SRP coordinates, and dimensions. During the operation of the pits, spent organic solvents, waste oils, paper, plastics, and rubber were disposed of in the pits and burned periodically. The chemical composition and volume of the disposed waste are unknown. The use of the pits for disposal of burnable wastes was discontinued in 1973 when the pits were converted to rubble pits. When a pit became full of rubble, backfill was placed over the rubble, and the pit was closed (Huber et al., 1987c). The Burning/Rubble Pits are located in A, C, Central Shops, D, F, L, P, and $R$ areas. The pits are discussed separately because they have different site characteristics (i.e., hydrogeology, surface topography, etc.). Site specific charterization plans were developed for each of the Burning/Rubble Pit locations which resulted in slight variations of sampling patterns and methods.

\section{A-Area Burning/Rubble Pits}

\section{Site Description}

The two A-Area Burning/Rubble Pits are located $2.4 \mathrm{~km}$ south of M Area just west of Roads $D$ and $C-1$ (Figure F.1). The elevation of the site is $105 \mathrm{~m}(345 \mathrm{ft})$. Surface drainage is to the east toward Tims Branch, a tributary of Upper Three Runs Creek. First quarter 1987 water-1eve1 data from the four monitoring wells at the site indicate that the depth to the water table is $38.6 \mathrm{~m}$ and that groundwater flow is to the west. Groundwater flow is believed to be influenced by the M-Area groundwater withdrawal and treatment program. A hydrologic boundary exists at Upper Three Runs Creek, which is located $5.6 \mathrm{~km}$ south-southeast of the site.

\section{Review of Available Data}

First quarter 1987 groundwater monitoring data show trichloroethylene to be present in three monitoring wells in concentrations ranging from $1.15 \mu \mathrm{g} / \mathrm{L}$ to $148 \mu \mathrm{g} / \mathrm{L}$ (Mikol et al., in press). The trichloroethylene concentration in well ARP 3 has increased from $14 \mu \mathrm{g} / \mathrm{L}$ in November 1985 to $248 \mu \mathrm{g} / \mathrm{L}$ in June 1987 (Zeigler et al., 1987). The concentration of trichloroethylene has decreased in wells ARP $1 A$ and ARP 2 and has only slightly increased in well ARP 4 over the same time period. 
TABLE F.1

Burning/Rubble Pit Locations, Building Numbers, SRP Coordinates (Northeast Corner), and Dimensions

Location

A Area

C Area

Central Shops

D Area

F Area

$\mathrm{K}$ Area

L Area

P Area

R Area
B1dg. No.

731-A

731-1A

$131-C$

631-1G

631-5G

631-6G

431-D

431-1D

231-F

231-1F

$131-K$

131-L

131-P

131-R

131-1R
SRP Coordinates

N 98929 E 44801

N 99130 E 44672

N 68694 E 44041

N 65600 E 52797

N 64365 E 52912

N 60365 E 52912

N 66693 E 18370

N 66751 E 18430

N 79647 E 50880

N 79619 E 50717

N 54354 E 42726

N 48282 E 49141

N 45306 E 63294

N 54371 E 75851

N 54534 E 75685
Dimensions (m)

$54.6 \times 100 \times 3.1$

$9.4 \times 173.4 \times 3.1$

$7.6 \times 106.7 \times 3.1$

$9.1 \times 61.0 \times 3.1$ $10.7 \times 117.3 \times 3.1$

$9.1 \times 88.4 \times 3.1$

$15.2 \times 82.9 \times 3.1$ $11.6 \times 73.8 \times 3.1$

$18.9 \times 83.8 \times 3.1$ $26.8 \times 99.1 \times 3.1$

$9.1 \times 70.1 \times 3.1$

$8.8 \times 70.1 \times 3.1$

$18.3 \times 64 \times 3.1$

$6.4 \times 72.5 \times 3.1$ $10 \times 71.9 \times 3.1$ 

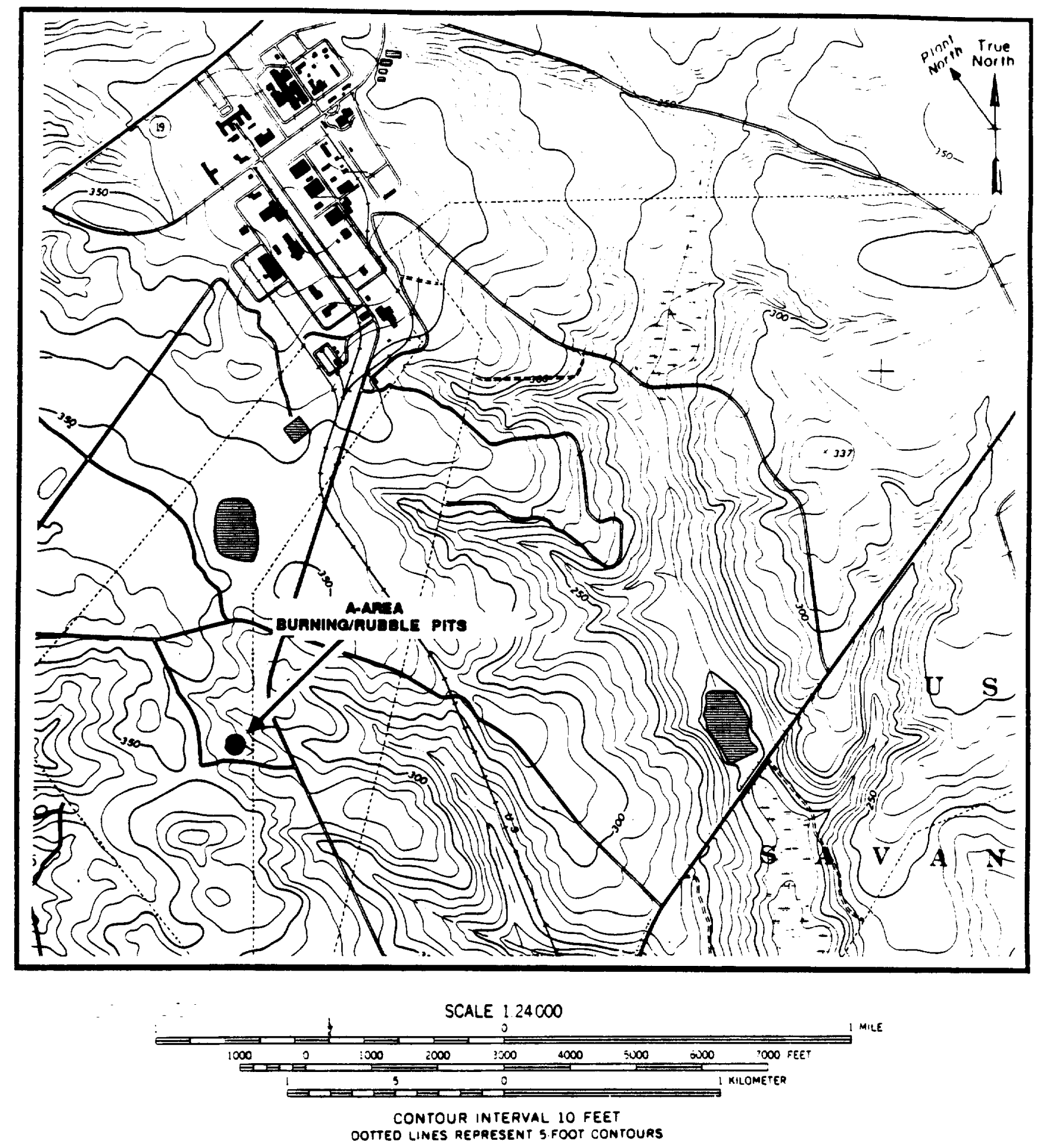

FIGURE F.1. Location of the A-Area Burning/Rubble Pits on New Ellenton SW Quadrangle 7.5 Minute Series Topographic Map 
Characterization Recommendations

Sampling

A soil gas survey is recommended for the site and will be used to map the horizontal extent of any volatile organic migration in the unsaturated zone. The resulting data will also help to define soil sampling locations. Figure F.2 shows the proposed locations for soil gas samples.

The size and shape of the pits can be determined using GPR. Two survey lines should be run across the width of each pit, and one 1 ine should be run the length of each pit (Figure F.2).

A shallow soil coring program is recommended to characterize the soils in and around the pit. Nine $6-\mathrm{m}$ deep soil cores should be taken and analyzed at the intervals given in Appendix Table 1. Figure F.2 shows the proposed coring locations. This shallow coring program and the soil gas survey are designed to determine the horizontal extent of any surface and shallow soil contamination that may be present.

Additional monitoring wells should be installed to determine the vertical extent of any groundwater contamination that may have occurred. The new wells should be constructed close to the downgradient water-table well to form a cluster. The number of wells and the placement of screens will be determined using any existing geologic data and the results of the core from the deepest well (to be drilled first). The number of new wells required to complete the cluster is not expected to exceed two. Figure F.2 shows the general location of the well cluster. Specific placement of the monitoring wells for delineating vertical groundwater contamination will be determined using the data generated by the previously mentioned characterization methods. Undisturbed samples should be collected from each well to determine the permeability and porosity (total and effective) of the underlying hydrogeologic units.

Chemical and Physical Analyses

Samples from the soil gas sampling survey should be analyzed for vOC as listed in Appendix Table 3.

To characterize the source and extent of contamination in the unsaturated zone, the 6-m deep soil samples should be analyzed for selected parameters at the intervals 1isted in Appendix Table 1. Specific analytes should include those 1 isted in Appendix Tables 2 (metals) and 3 (volatile organics).

Groundwater samples should be analyzed for the parameters given in Appendix Table 6 . Undisturbed samples collected during the drilling of cluster wells should be analyzed for vertical and horizontal permeability, porosity, relative permeabilty, bulk density, and grain size. 


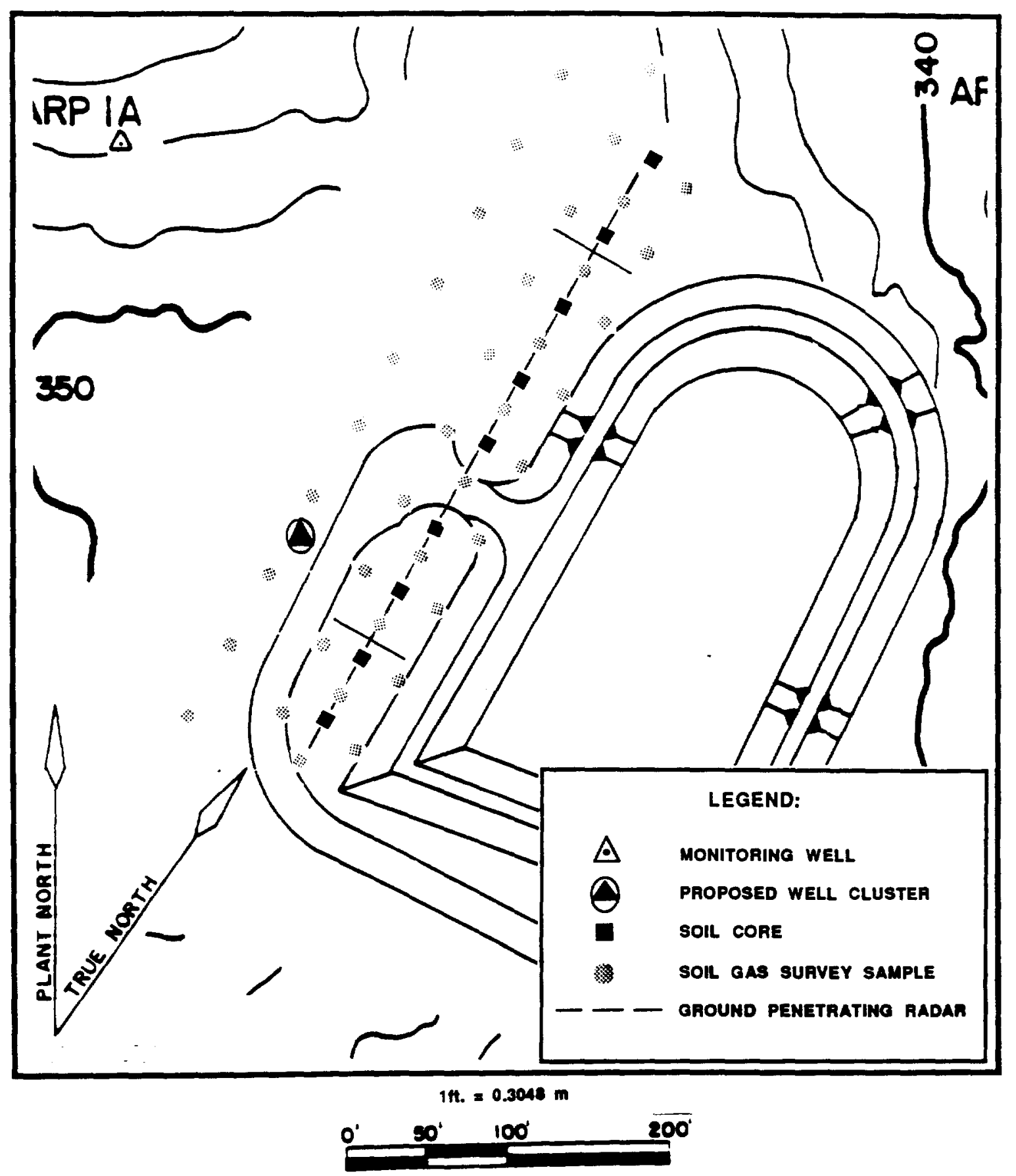

FIGURE F.2. Proposed Cluster Well and Sampling Locations for the A-Area Burning/Rubble Pits 
C-Area Burning/Rubble Pit

\section{Site Description}

The C-Area Burning/Rubble Pit is located west of $\mathrm{C}$ Area and north of Road A-7 on a ridge between two tributaries of Four Mile Creek (Figure F.3). The elevation of the site is $82.4 \mathrm{~m}(270 \mathrm{ft})$. Surface drainage is to the southwest toward a stream feeding two ponds that drain into Four Mile Creek (Figure F.3). First quarter 1987 water-level data (Mikol et al., in press) from the four monitoring wells at the site indicate that the depth to the watertable is $18.1 \mathrm{~m}$ and that groundwater flow is to the west. A hydrologic boundary exists at Upper Three Runs Creek, which is located $610 \mathrm{~m}$ west-northwest of the site.

\section{Review of Available Data}

Two monitoring wells at the site have shown elevated concentrations of TOH. TOH concentrations in wells CRP 1 and CRP 3 have ranged from 461 to $3,549 \mu \mathrm{g} / \mathrm{L}$ (Heffner et al., in press). On several occasions a more detailed chemical analysis has identified the major contributor of TOH to be trichloroethylene, present in the groundwater at levels up to 3,670 $\mu \mathrm{g} / \mathrm{L}$. A review of the groundwater data shows the levels of $\mathrm{TOH}$ and trichloroethylene to be decreasing in wel1 CPR 1 and increasing in CRP 3 (Zeigler et al., 1987). When this trend is compared with the direction of groundwater flow, it appears that the plume is moving from east-southeast to west-northwest.

A soil gas survey was completed at the site in January 1986. Twenty-nine soil gas samples were collected and analyzed for volatile organic constituents. trans-1,2-Dichloroethylene, trichloromethane, 1,1,1-trichloroethane, trichloroethylene, and tetrachloroethylene were found to be present in the soil gas, suggesting that there may be some biological degradation of the tetrachloroethylene and trichloroethylene taking place.

A GPR demonstration was conducted at the site. The results from this survey clearly outline the horizontal extent of the pit and a nearby water line. In addition, there are radar anomalies in the results that may indicate buried objects. It may be beneficial to try to excavate these anomalies in order to verify the GPR results.

A detailed hydrogeologic survey is currently being conducted at well cluster $P 18$, which is located east of C Area, approximately $1.6 \mathrm{~km}$ from the site. This study will provide detailed information on the geology of the area as well as information on the physical characteristics of the site 1ithology. 

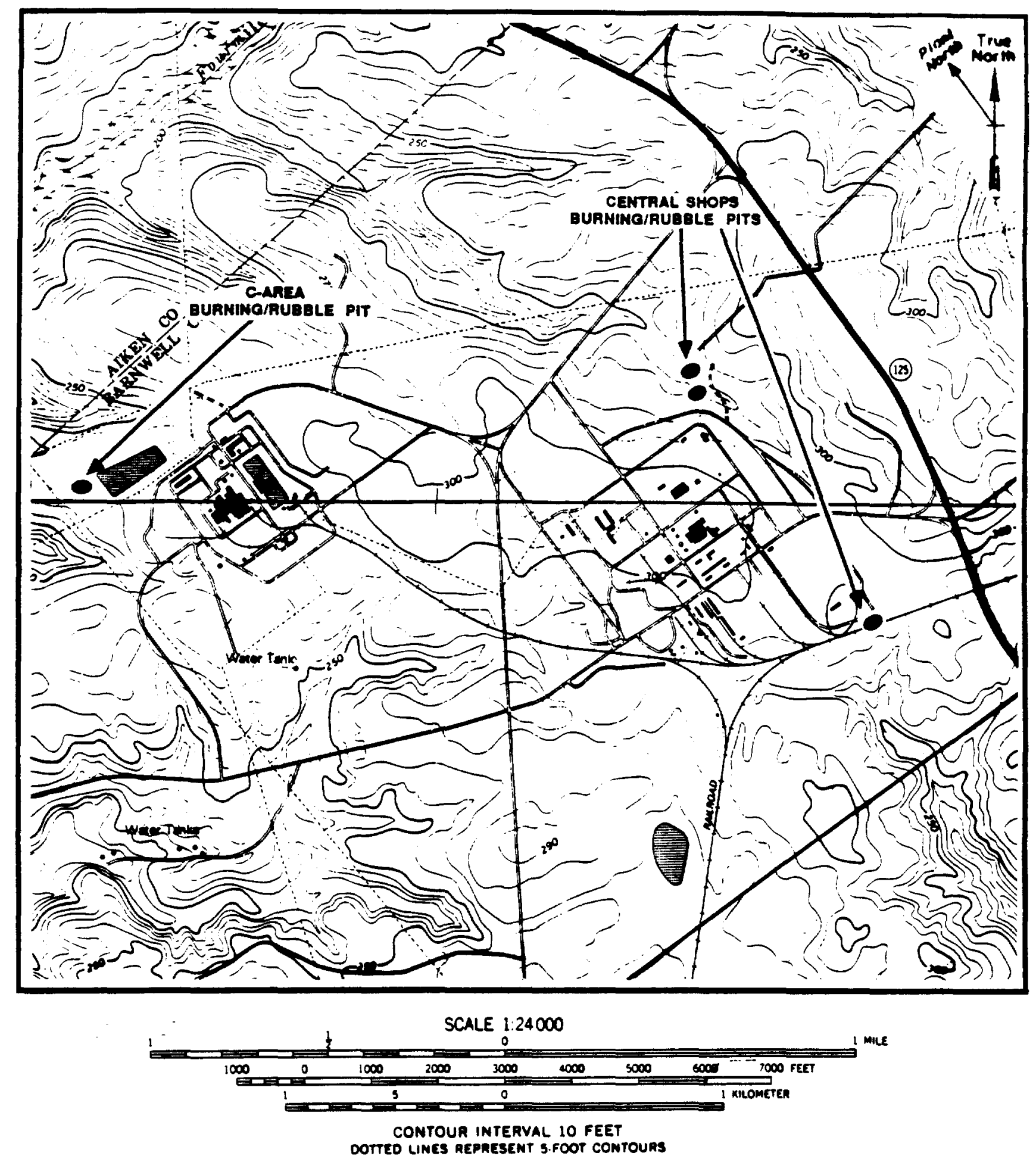

FIGURE F.3. Locations of the C-Area and Central Shops Area Burning/Rubble Pits on Girard NW Quadrangle 7.5 Minute Series Topographic Map 


\section{Characterization Recommendations}

Sampling

A shallow soil coring program is recommended for the characterization of soils in and around the pit. Nine 6-m deep soil cores should be taken and analyzed at the intervals given in Appendix Table 1. Figure F.4 shows the proposed sampling locations. This shallow coring program and the existing soil gas data should be used to determine the horizontal extent of any surface and shallow soil contamination that may have occurred.

In addition to the shallow cores, a deep core is recommended for the site. This core should be drilled in the pit and should reach total depth at the regional water table below the site. Samples for chemical analysis should be collected at several intervals based on lithology changes in an effort to determine the vertical extent of soil contamination and the contaminant attenuation potential of the various lithologic sections above the water table. The deep core should also provide information on the stratigraphy and lithology of the underlying sediments. Some of the GPR amonalies should be excavated to determine if they are drums or other potentially hazardous objects.

Additional monitoring wells should be installed to determine the vertical extent of any groundwater contamination that may have occurred. The new wells should be constructed close to the downgradient water-table well to form a cluster. The number of wells and the placement of screens will be determined using any existing geologic data and the results of the core from the deepest well (to be drilled first). The number of new wells required to complete the cluster is not expected to exceed two. Figure F.4 shows the general location of the well cluster. Specific placement of the monitoring wells for delineating horizontal groundwater contamination should be determined using the data generated by the previously mentioned characterization methods. Undisturbed samples should be collected from each well to determine the permeability and porosity (total and effective) of the underlying hydrogeologic units.

\section{Chemical and Physical Analyses}

In an attempt to characterize the source and extent of contamination in the unsaturated zone, the 6-m deep soil cores should be analyzed for selected parameters at the intervals listed in Appendix Table 1. Specific analytes should include those 1 isted in Appendix Tables 2 (metals) and 3 (volatile organics). Sample specimens from the deep boring should be selected in the field based on a visual interpretation of 1ithologic changes by a qualified field geologist and analyzed for the parameters 1isted in Appendix Tables 1 (Classes 2 and 3 ), 2, and 3. 


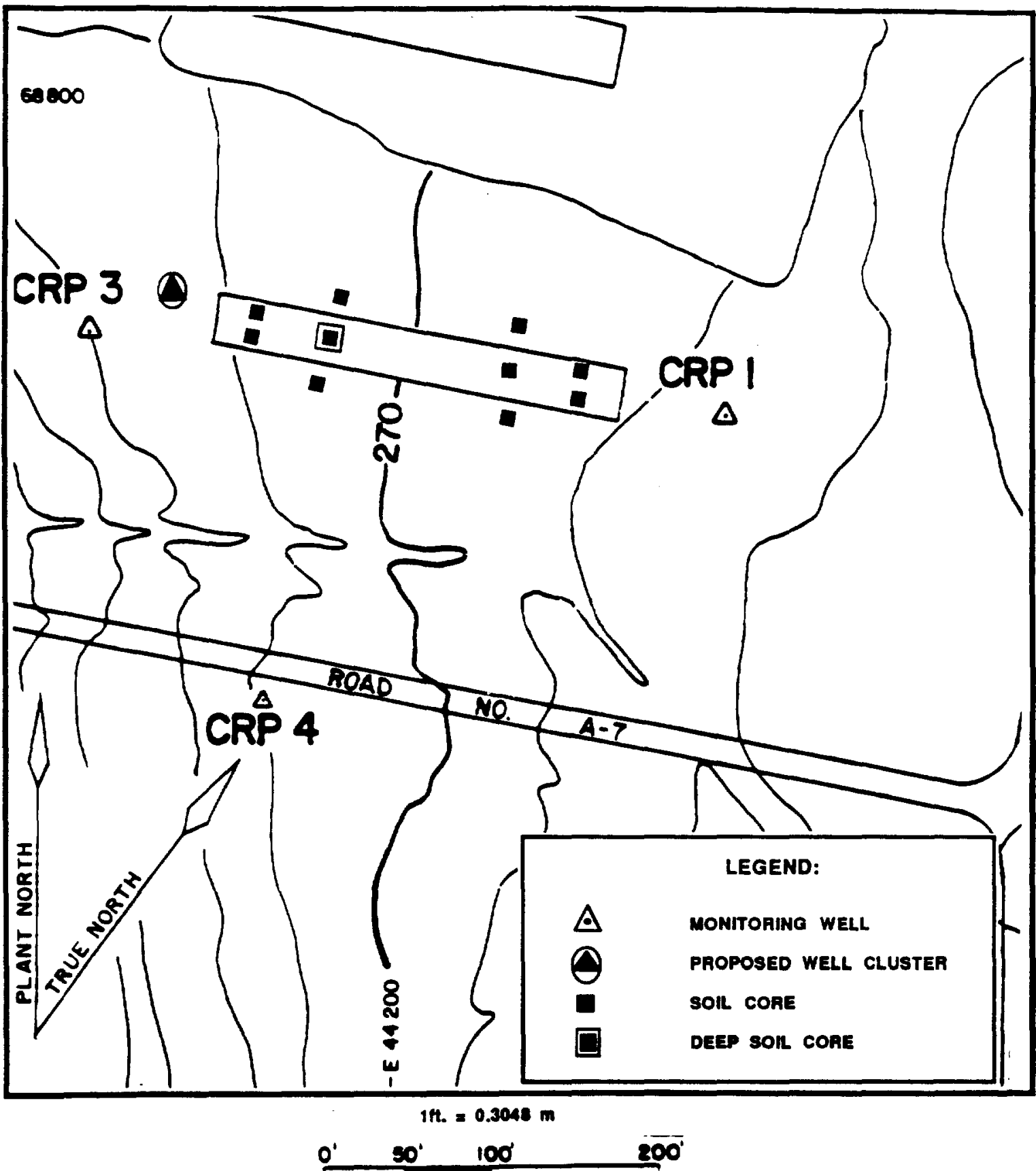

FIGURE F.4. Proposed Cluster Well and Sampling Locations for the C-Area Burning/Rubble Pit 
Groundwater samples should be analyzed for the parameters 1 isted in Appendix Table 6. Undisturbed samples collected during the drilling of cluster wells should be analyzed for vertical and horizontal permeability, porosity, storage coefficient, relative permeability, bulk density, and grain size.

\section{Central Shops Burning/Rubble Pits}

\section{Site Description}

Two of the Central Shops Burning/Rubble Pits (Buildings $631-1 \mathrm{G}$ and 631-5G) are located north of the Central Shops Area just outside of the perimeter fence; Building $631-6 \mathrm{G}$ is located southeast of the Central Shops Area, north of the C-Line railroad (Figure F.3). Buildings 631-1G and $631-5 \mathrm{G}$ are at an elevation of $82.3 \mathrm{~m}$ ( $270 \mathrm{ft}$ ), and Building $631-6 \mathrm{G}$ is at an elevation of $88.4 \mathrm{~m}(290 \mathrm{ft})$. First quarter 1987 water-level data from the four monitoring wells at Buildings $631-1 \mathrm{G}$ and $631-5 \mathrm{G}$ indicate that the depth to the water table is $7.8 \mathrm{~m}$ and that groundwater flow is to the west (Mikol et al., in press). There are no monitoring wells installed at Building $631-6 \mathrm{G}$, but groundwater maps of the area suggest that the groundwater flow at this site is to the southwest.

\section{Review of Available Data}

The four monitoring wells around Buildings $631-\mathrm{K}$ and $631-5 \mathrm{G}$ are located upgradient of the site and, therefore, do not serve as detection wells and cannot be used to assess groundwater contamination.

\section{Characterization Recommendations}

Samp1ing

A soil gas survey is recommended for both locations and will be used to map the horizontal extent of any volatile organic constituent migration in the unsaturated zone. The resulting data will help define soil core locations. Figure F.5 shows the proposed locations for soil gas samples.

The size and shape of the pits at each site should be determined using GPR. Two survey lines should be run across the width of each pit, one line should be run the length of the pit $631-6 \mathrm{G}$ and two lines should be run the length of pits $631-1 \mathrm{G}$ and $631-5 \mathrm{G}$. Figure F.5 shows the proposed survey lines.

A shallow-soil coring program is recommended for the characterization of soils in and around the pits. Nine 6-m deep soil cores should be taken and analyzed at the intervals 1 isted in Appendix Table 1. Figure F.5 


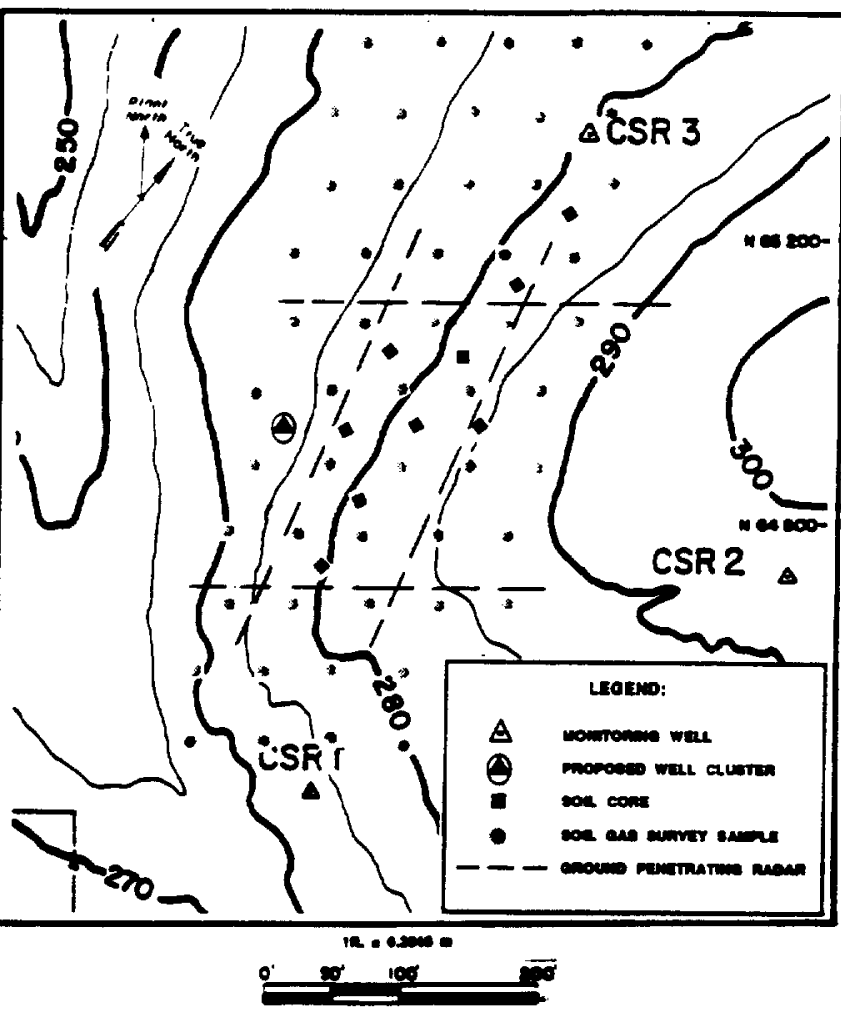

FIGURE F.5. Proposed Cluster Well and Sampling Locations for the Central Shops Area Burning/Rubble Pits 
shows the proposed sampling locations. This shallow coring program and the soil gas survey are designed to determine the horizontal extent of surface and shallow soil contamination.

Three monitoring wells should be installed at each site to determine the vertical extent of any groundwater contamination that may have occurred. The monitoring wells should be installed in a cluster with screens in the Barnwell, McBean, and Congaree formations. Figure F.5 shows the location of the well clusters. Specific placement of the monitoring wells for delineating horizontal groundwater contamination should be determined using the data generated by the previously mentioned characterization methods. In addition to the cluster well at 631-6G, three water-table wells should be installed to determine the water-table configuration of the site and serve as monitoring wells since there are no wells at this site currently. Undisturbed samples should be collected from each well to determine the permeability and porosity (total and effective) of the underlying hydrogeologic units.

Chemical and Physical Analyses

Samples from the soil gas sampling survey should be analyzed for VOCs as 1 isted in Appendix Table 3.

To characterize the source and extent of contamination in the unsaturated zone, the 6-m deep soil cores should be analyzed for selected parameters at the intervals listed in Appendix Table 1. Specific analytes should include those given in Appendix Tables 2 (metals) and 3 (volatile organics).

Groundwater samples should be analyzed for the parameters 1 isted in Appendix Table 6 . Undisturbed samples collected during the drilling of cluster wells should be analyzed for vertical and horizontal permeability, porosity, relative permeability, bulk density, and grain size.

\section{D-Area Burning/Rubble Pits}

\section{Site Description}

The D-Area Burning/Rubble Pits are located $0.4 \mathrm{~km}$ west of $D$ Area near a swampy area adjacent to an unnamed stream (Figure F.6). The elevation of the site is $39.6 \mathrm{~m}(130 \mathrm{ft})$. Surface drainage is to the west-southwest toward a small tributary of the Savannah River. First quarter 1987 water-level data from the four monitoring wells at the site indicate that the depth to the water table is $3.8 \mathrm{~m}$ and that groundwater flow is to the south-southeast (Mikol et al., in press). 

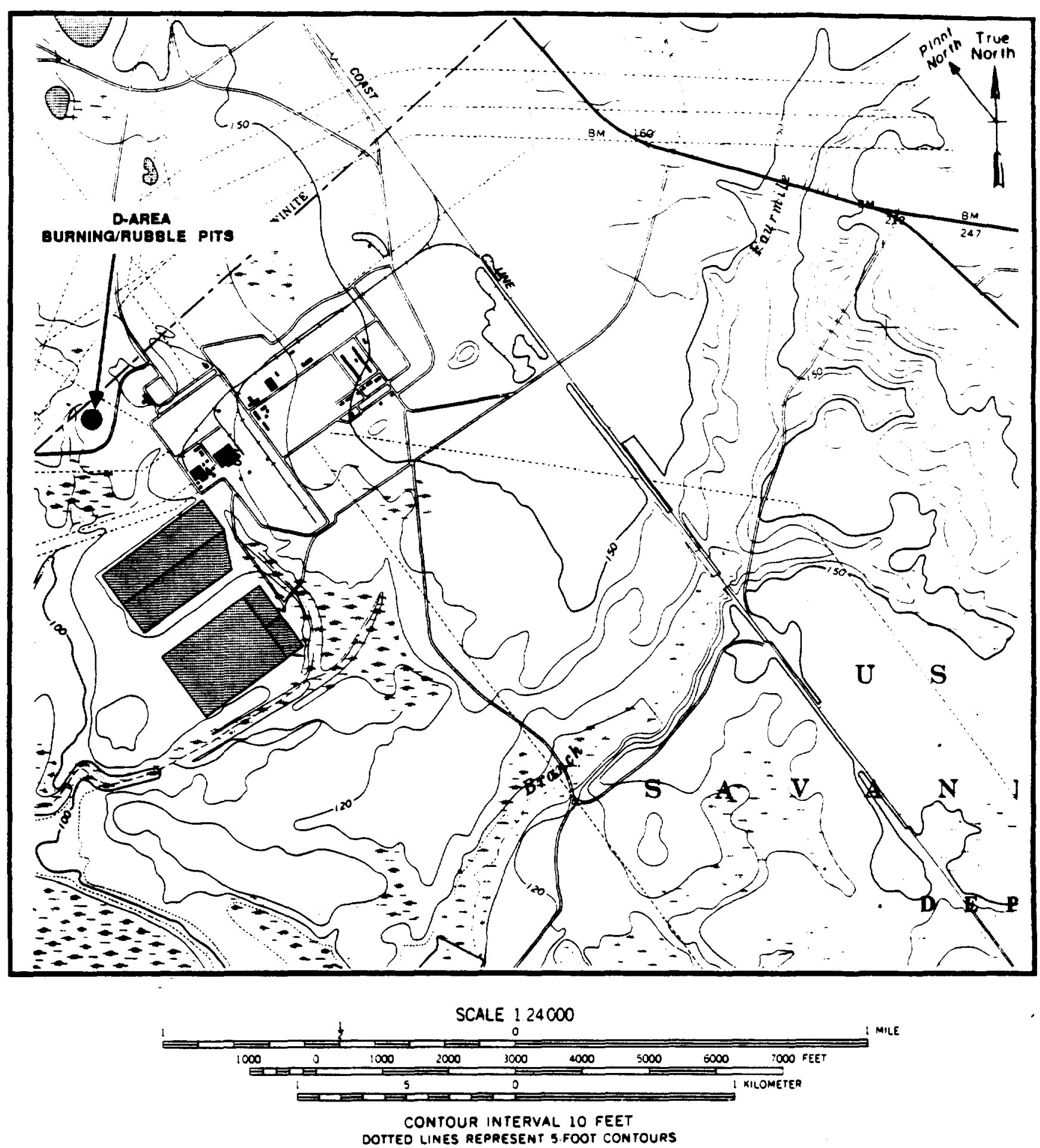

FIGURE F.6. Location of the D-Area Burning/Rubble Pits on Girard NW Quadrangle 7.5 Kinute Series Topographic Map 
Review of Available Data

Groundwater monitoring data show that small amounts of tetrachloroethylene $(20 \mu \mathrm{g} / \mathrm{L})$ are present in well DBP 1 . Concentrations are less than $3.0 \mathrm{\mu g} / \mathrm{L}$ in the other monitoring wells (Heffner et al., in press). Al1 other measured constituents are within drinking water standards. Hydrographs from the monitoring wells show a seasonal fluctuation of $1.22 \mathrm{~m}$ in the water-table elevation, indicating that the bottom of the pit is seasonally below the water table.

\section{Characterization Recommendations}

\section{Sampling}

A soil gas survey is recommended for the site and will be used to map the horizontal extent of VOC migration in the unsaturated zone. These data will also help define soil core locations. Figure F.7 shows the proposed locations for soil gas samples.

The size and shape of the pit can be determined using GPR. Two survey lines should be run across the width of the pit, and one line should be run the length of the pit. Figure F.7 shows the proposed survey lines.

A shallow soil coring program is recommended for the characterization of soils in and around the pit. Nine $6-\mathrm{m}$ deep soil cores should be taken and analyzed at the intervals 1 isted in Appendix Table 1. Figure F.7 shows the proposed sampling locations. This shallow coring program and the soil gas survey are designed to determine the horizontal extent of any surface and shallow soil contamination that may have occurred.

Additional monitoring wells should be installed to determine the vertical extent of any groundwater contamination that may have occurred. The new wells should be constructed close to the downgradient water-table well to form a cluster. The number of wells and the placement of screens will be determined using any existing geologic data and the results of the core from the deepest well (to be drilled first). The number of new wells required to complete the cluster is not expected to exceed two. Figure F.7 shows the general location of the well cluster. Specific placement of the monitoring wells for delineating vertical groundwater contamination will be determined using the data generated by the previously mentioned characterization methods. Undisturbed samples should be collected from each well to determine the permeability and porosity (total and effective) of the underlying hydrogeologic units.

\section{Chemical and Physical Analyses}

Samples from the soil gas sampling survey should be analyzed for VOCs as listed in Appendix Table 3. 


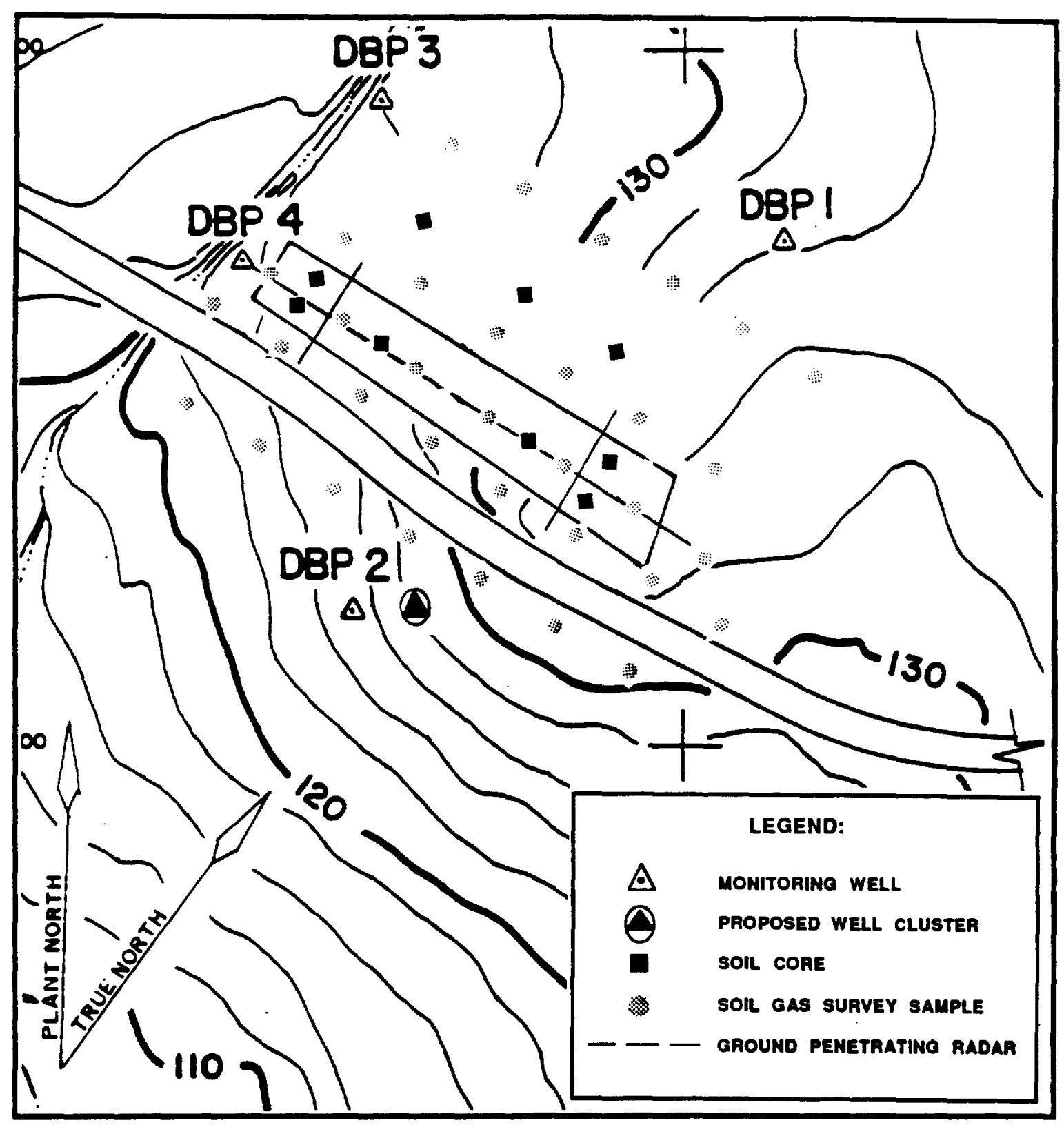

1ft. $=0.3098 \mathrm{~m}$ 
In an attempt to characterize the source and extent of contamination in the unsaturated zone, the $6-\mathrm{m}$ deep soil cores should be analyzed for selected parameters at the intervals listed in Appendix Table 1 . Specific analytes should include those listed in Appendix Tables 2 (metals) and 3 (volatile organics).

Groundwater samples should be analyzed for the parameters given in Appendix Table 6 . Undisturbed samples collected during the drilling of cluster wells should be analyzed for vertical and horizontal permeability, porosity, relative permeability, bulk density, and grain size.

\section{F-Area Burning/Rubble Pits}

\section{Site Description}

The F-Area Burning/Rubble Pits are located $1 \mathrm{~km}$ west of $F$ Area on a ridge between two tributaries of Upper Three Runs Creek east of Road $C$ (Figure F.8). The elevation of the site is $90 \mathrm{~m}(295 \mathrm{ft})$. The site lies on a surface drainage divide with drainage both to the southwest and the northeast. Water-level data from four monitoring wells at the site indicate that the site is located on a groundwater divide and has two predominant flow directions (west-southwest and west-northwest). First quarter 1987 water-level data from wells indicate that the depth to the water table is $29.9 \mathrm{~m}$ (Mikol et a1., in press).

\section{Review of Available Data}

The primary contaminants found in groundwater at the site are nonvolatile beta, nitrate (as N), and trichloroethylene. In 1986, wel1 FBP $1 \mathrm{~A}$ had an average nonvolatile beta count of $173 \mathrm{pCi} / \mathrm{L}$ and a nitrate (as $\mathrm{N}$ ) concentration of $23.4 \mathrm{mg} / \mathrm{L}$. Trichloroethylene concentrations in well FBP $2 \mathrm{~A}$ steadily decreased during $1986 \mathrm{from} 105 \mu \mathrm{g} / \mathrm{L}$ to $25 \mu \mathrm{g} / \mathrm{L}$ (Zeigler et al., 1987). A review of hydrologic studies of $F$ and $H$ areas indicates that a potential source of nonvolatile beta and nitrate may be groundwater migrating from either of the process sewer lines in the area.

\section{Characterization Recommendations}

\section{Sampling}

A soil gas survey is recommended for the site and should be used to map the horizontal extent of any VOC migration in the unsaturated zone. These data should also help define soil sampling locations. Figure F.9 shows the proposed locations for soil gas samples. 

New Ellenton NW quadrangle 7.5 Minute Series Topographic Map 


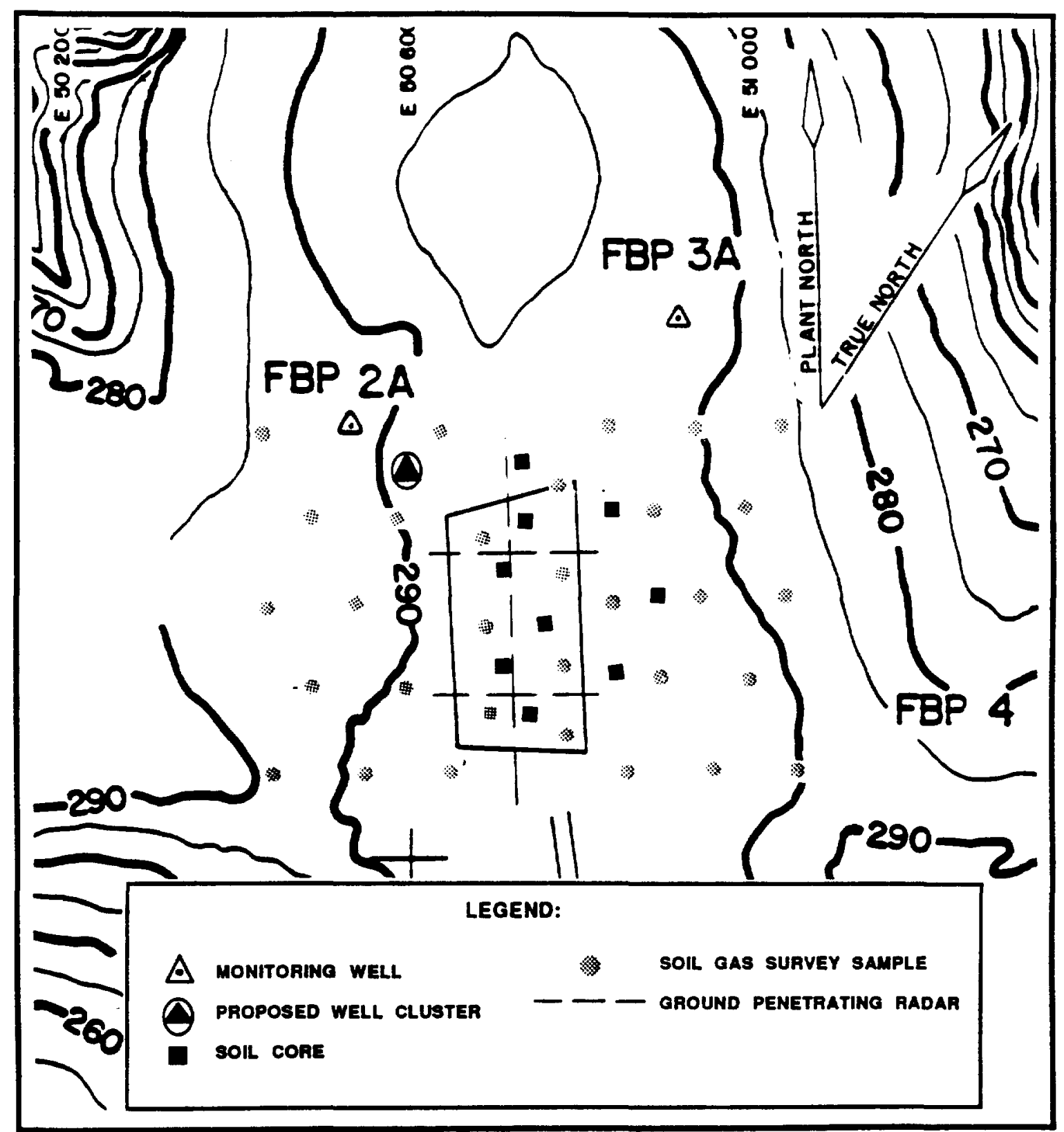

1tt. $=0.3048 \mathrm{~m}$

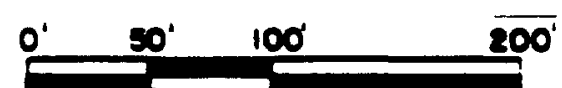

FIGURE F.9. Proposed Cluster Well and Sampling Locations for the F-Area Burning/Rubble Pitg 
The size and shape of the pit can be determined using GPR. Two survey lines should be run across the width of the pit, and one line should be run the length of the pit. Figure F.9 shows the proposed survey lines.

A shallow soil coring program is recommended for the characterization of soils in and around the pit. Nine 6-m deep soil cores should be taken and analyzed at the intervals 1 isted in Appendix Table 1. Figure F.9 shows the proposed sampling locations. This shallow coring program and the soil gas survey are designed to determine the horizontal extent of surface and shallow soil contamination that may have occurred.

Additional monitoring wells should be installed to determine the vertical extent of any groundwater contamination that may have occurred. The new wells should be constructed close to the downgradient water-table well to form a cluster. The number of wells and the placement of screens will be determined using any existing geologic data and the results of the core from the deepest well (to be drilled first). The number of new wells required to complete the cluster is not expected to exceed two. Figure F.9 shows the general location of the well cluster. Specific placement of the monitoring wells for delineating vertical groundwater contamination will be determined using the data generated by the previously mentioned characterization methods. Undisturbed samples should be collected from each well to determine the permeability and porosity (total and effective) of the underlying hydrogeologic units.

\section{Chemical and Physical Analyses}

Samples from the soil gas sampling survey should be analyzed for VOC as 1 isted in Appendix Table 3.

In an attempt to characterize the source and extent of contamination in the unsaturated zone, the $6-\mathrm{m}$ deep soil cores should be analyzed for selected parameters at the intervals 1 isted Appendix in Table 1 . Specific analytes should include those 1isted in Appendix Tables 2 (metals) and 3 (volatile organics).

Groundwater samples should be analyzed for the parameters 1 isted in Appendix Table 6 . Undisturbed samples collected during the drilling of cluster wells should be analyzed for vertical and horizontal permeability, porosity, relative permeability, bulk density, and grain size. 


\section{K-Area Burning/Rubble Pit}

\section{Site Description}

The K-Area Burning/Rubble Pit is located $0.6 \mathrm{~km}$ northeast of $\mathrm{K}$ Area on a ridge between Indian Grave Branch and Pen Branch and south of Road 6.4.2 (Figure F.10). The elevation of the site is $77.7 \mathrm{~m}(255 \mathrm{ft})$. The site lies in the surface drainage basin of Pen Branch with drainage to the east. First quarter 1987 water-level data (Mikol et al., in press) from the four monitoring wells at the site indicate that the depth to the water table is $14 \mathrm{~m}$ and that the site is above a depression in the water table with groundwater flow to the north. The general groundwater flow is controlled by the swamp and streams that surround the site.

\section{Review of Available Data}

Groundwater monitoring data from the site wells indicate elevated levels of lead, trichlororethylene, and tetrachloroethylene. The concentration of lead in groundwater from wells KRP 1, KRP 2, and KRP 3 has steadily increased since January 1986. Tetrachloroethylene and trichloroethylene concentrations were $69 \mu \mathrm{g} / \mathrm{L}$ and $25 \mu \mathrm{g} / \mathrm{L}$, respectively, at well KRP 4 in August 1986, which represents a slight decrease from 79 and $39 \mu \mathrm{g} / \mathrm{L}$ in March 1986 (Zeigler et al., 1987).

A detailed hydrogeologic survey is currently being conducted at a well cluster southeast of $\mathrm{K}$ Area, approximately $0.8 \mathrm{~km}$ from the site. This study will provide detailed information on the geology of the area as well as information on the physical characteristics of the site 1ithology.

\section{Characterization Recommendations}

Sampling

A soil gas survey is recommended for the site and will be used to map the horizontal extent of any VOC migration in the unsaturated zone. These data should also help define soil sampling locations. Figure F.11 shows the proposed locations for soil gas samples.

The size and shape of the pit can be determined using GPR. Two survey lines should be run across the width of the pit, and one line should be run the length of the pit. Figure F.11 shows the proposed survey lines.

A shallow soil coring program is recommended for the characterization of soils in and around the pit. Nine 6-m deep soil cores should be taken and analyzed at the intervals 1 isted in Appendix Table 1. Figure F.11 shows the proposed sampling locations. This shallow coring program and the soil gas survey are designed to determine the horizontal extent of any surface and shallow soil contamination that may have occurred. 

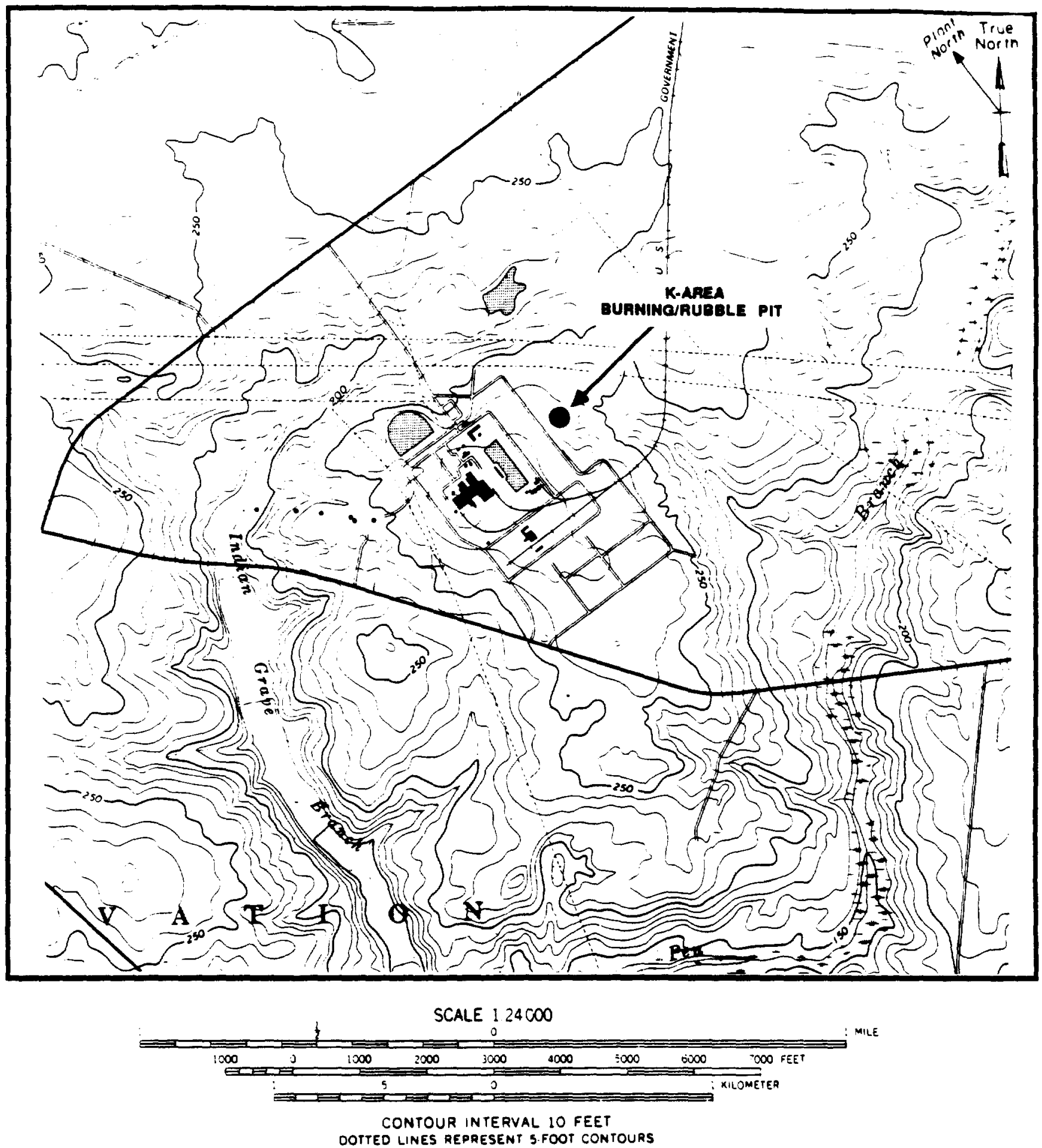

FIGURE F.10. Location of the K-Area Burning/Rubble Pit on Girard NW Quadrangle 7.5 Minute Series Topographic Map 


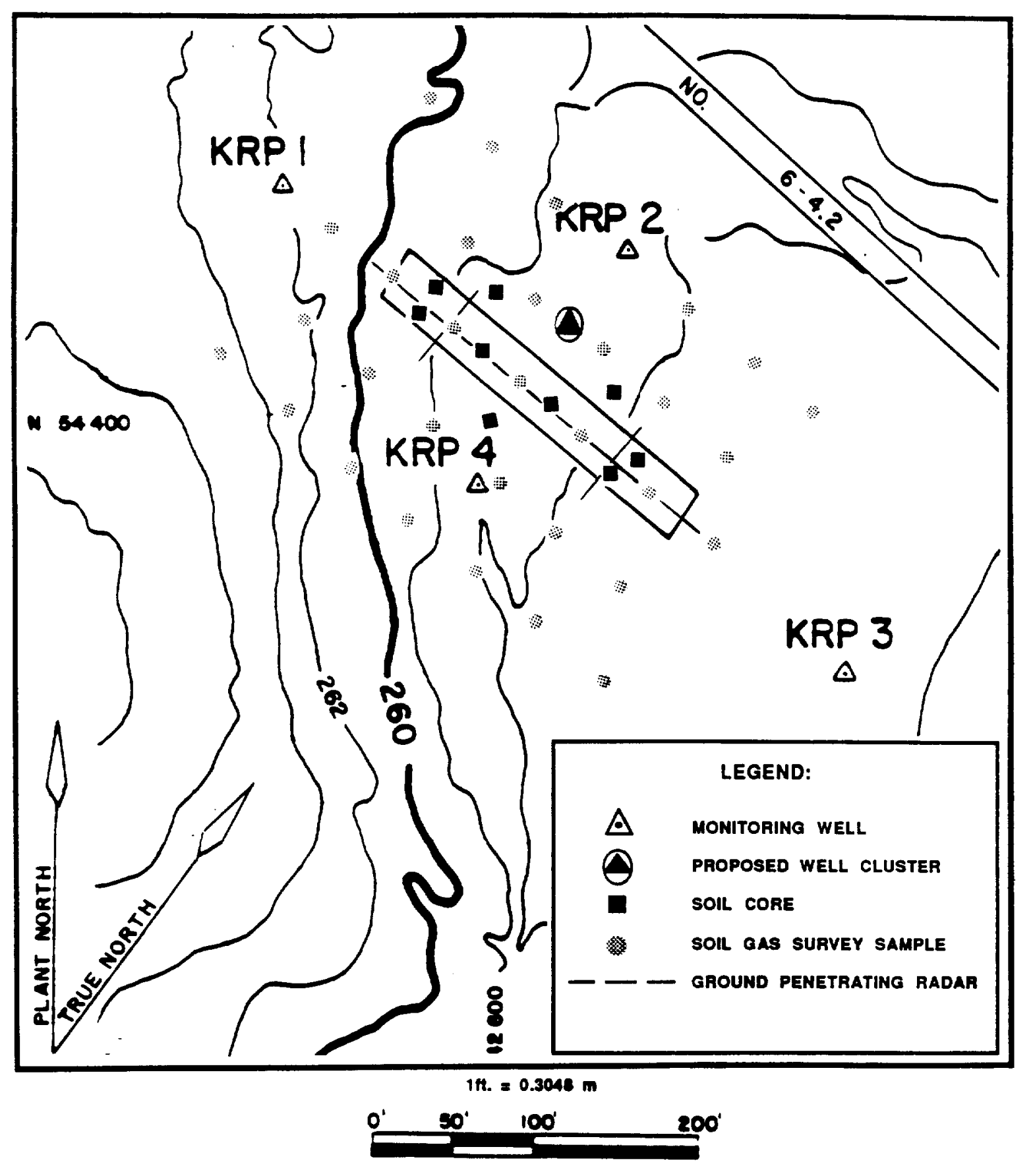

FIGURE F.11. Proposed Cluster Well and Sampling Locations for the K-Area Burning/Rubble Pit 
Two monitoring wells should be installed to determine the vertical extent of any groundwater contamination that may have occurred. The monitoring wells should be installed in a cluster with screens in the Barnwe11, McBean, and Congaree formations. Figure F.11 shows the general location of the well ciuster. Specific placement of the monitoring wells for delineating vertical groundwater contamination should be determined using the data generated by the previously mentioned characterization methods. Undisturbed samples should be collected from each well to determine the permeability and porosity (total and effective) of the underlying hydrogeologic units.

Chemical and Physical Analyses

Samples from the soil gas sampling survey should be analyzed for VOCs as listed in Appendix Table 3.

In an attempt to characterize the source and extent of contamination in the unsaturated zone, the 6-m deep soil cores should be analyzed for selected parameters at the intervals listed in Table 1 of the Appendix. Specific analytes should include those given in Appendix Tables 2 (metals) and 3 (volatile organics).

Groundwater samples should be analyzed for the parameters 1 isted in Appendix Table 6 . Undisturbed samples collected during the drilling of cluster wells should be analyzed for vertical and horizontal permeability, porosity, relative permeability, bulk density, and grain size.

\section{L-Area Burning/Rubble Pit}

\section{Site Description}

The L-Area Burning/Rubble Pit is located $0.4 \mathrm{~km}$ northwest of $\mathrm{L}$ Area off Road 7 (Figure F.12). The elevation of the site is $76.25 \mathrm{~m}(250 \mathrm{ft})$, and surface drainage is to the north toward an intermittent tributary of Pen Branch. First quarter 1987 water-level data (Mikol et a1., in press) from the four monitoring wells at the site indicate that the depth to the water table is $15 \mathrm{~m}$ and that groundwater flow is to the west.

\section{Review of Available Data}

Groundwater monitoring data from 1986 do not show elevated levels of any of the parameters analyzed (Zeigler et al., 1987). 

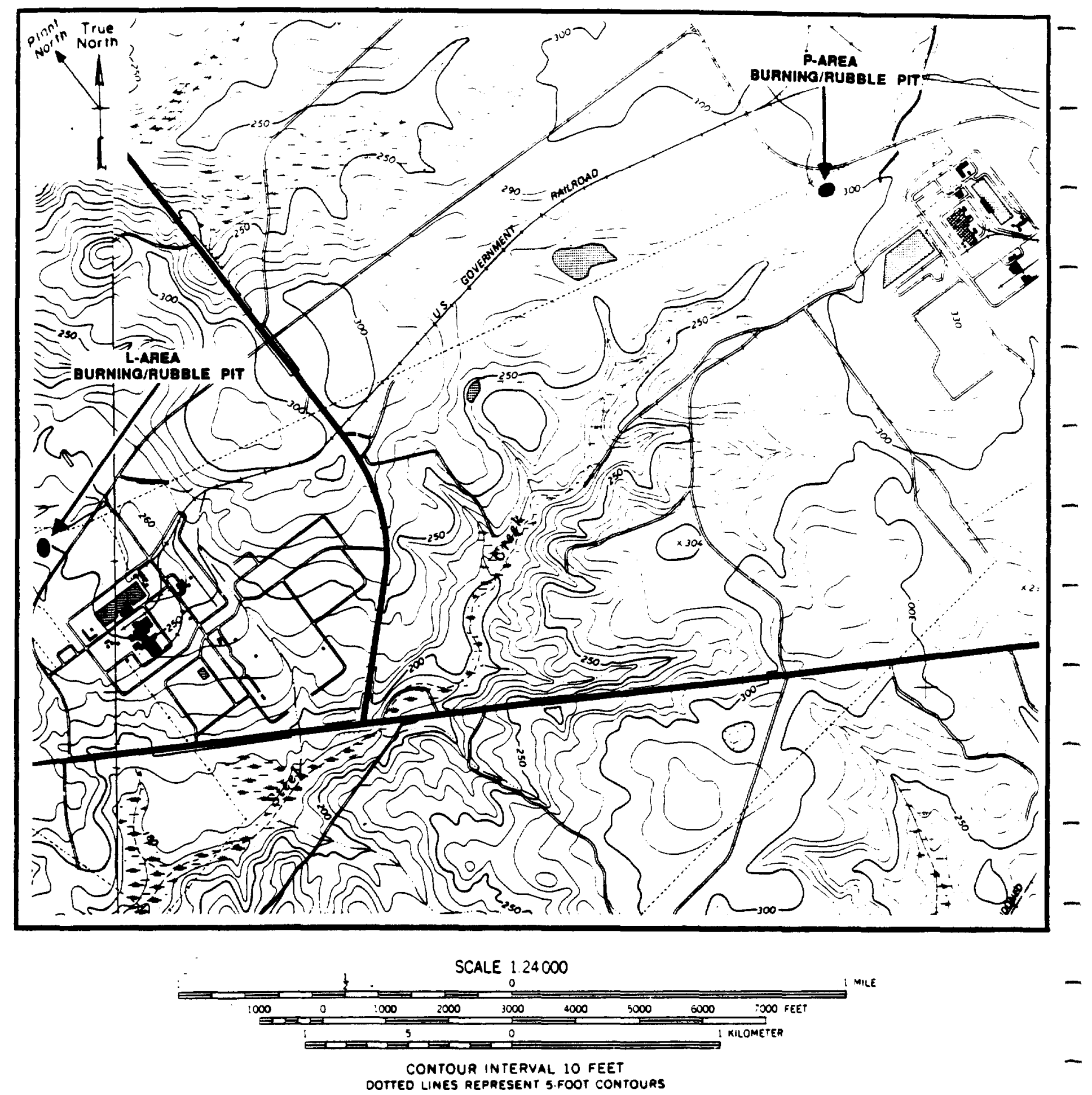

FIGURE F.12. Locations of the L-Area and P-Area Burning/Rubble Pits on Girard $\sqrt{2}$ Quadrangle 7.5 Minute Series Topographic Map 
Characterization Recommendations

Sampling

A soil gas survey is recommended for the site and should be used to map the horizontal extent of any VOC migration in the unsaturated zone. These data will also help define soil sampling locations. Figure F.13 shows the proposed locations for soil gas samples.

The size and shape of the pit can be determined using GPR. Two survey lines should be run across the width of the pit, and one line should be run the length of the pit. Figure F.13 shows the proposed survey lines.

A shallow soil coring program is recommended for the characterization of soils in and around the pit. Seven 6-m deep soil cores should be taken and analyzed at the intervals listed in Table 1 of the Appendix. Figure F.13 shows the proposed sampling locations. This shallow coring program and the soil gas survey are designed to determine the horizontal extent of any surface and shallow soil contamination that may have occurred.

Additional monitoring wells should be installed to determine the vertical extent of any groundwater contamination that may have occurred. The new wells should be constructed close to the downgradient water-table well to form a cluster. The number of wells and the placement of screens will be determined using any existing geologic data and the results of the core from the deepest well (to be drilled first). The number of new wells required to complete the cluster is not expected to exceed two. Figure F.13 shows the general location of the well cluster. Specific placement of the monitoring wells for delineating vertical groundwater contamination should be determined using the data generated by the previously mentioned characterization methods. Undisturbed samples should be collected from each well to determine the permeability and porosity (total and effective) of the underlying hydrogeologic units.

Chemical and Physical Analyses

Samples from the soil gas sampling survey should be analyzed for VOCs as 1 isted in Appendix Table 3.

To characterize the source and extent of contamination in the unsaturated zone, the 6-m deep soil cores should be analyzed for selected parameters at the intervals listed in Appendix Table 1. Specific analytes should include those listed in Appendix Tables 2 (metals) and 3 (volatile organics).

Groundwater samples should be analyzed for the parameters given in Table 6 of the Appendix. Undisturbed samples collected during the drilling of cluster wells should be analyzed for vertical and horizontal permeability, porosity, relative permeability, bulk density, and grain size. 


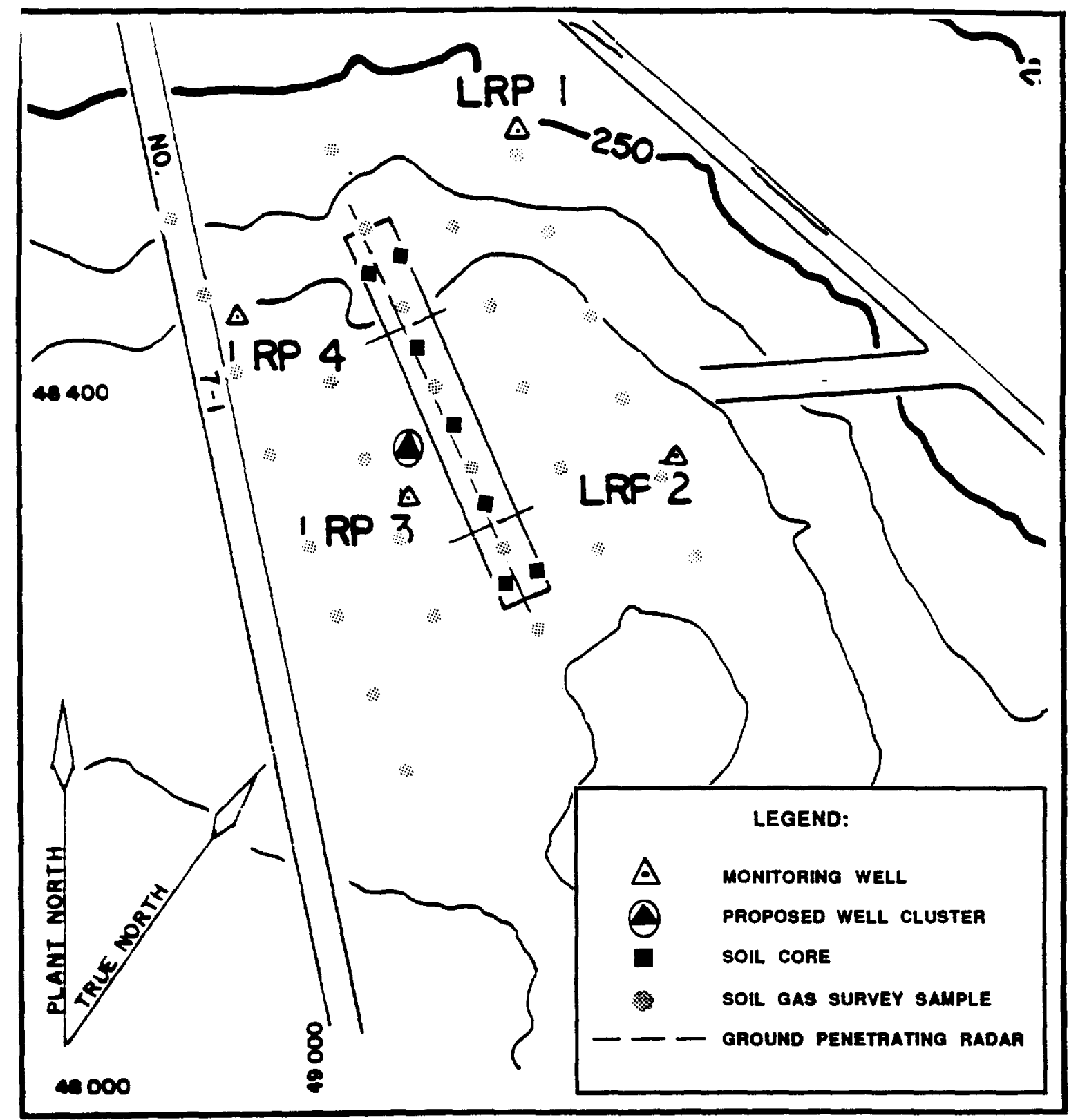

If. $=0.3048 \mathrm{~m}$

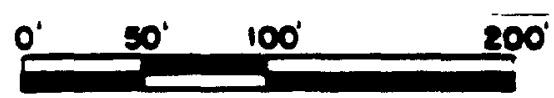

FIGURE F.13. Proposed Cluster Well and Sampling Locations for the L-Area Burning/Rubble Pit 


\section{P-Area Burning/Rubble Pit}

\section{Site Description}

The P-Area Burning/Rubble Pit is located $0.6 \mathrm{~km}$ west of $P$ Area just south of Road F (Figure F.12). The elevation of the site is $86 \mathrm{~m}$ (282 feet), and surface drainage is to the south-southwest toward steel Creek. First quarter 1987 water-level data (Mikol et al,, in press) from the four monitoring wells at the site indicate that the depth to the water table is $7.2 \mathrm{~m}$ and that groundwater flow is to the southwest toward Steel Creek.

\section{Review of Available Data}

Groundwater monitoring data for the site show organic and radioactive groundwater contamination. First quarter 1987 monitoring data report tetrachloroethylene, trichlorolethylene, and 1,1,1-trichloroethane present in concentrations of 39.4 and $43.0,41.9$ and 113 , and 290 and $332 \mu \mathrm{g} / \mathrm{L}$, respectively, in well PRP 3 (Mikol et al., in press). Data from November 1985 to the present show that these contaminants are routinely found in this area in concentrations above SRP concentration guidelines established in the groundwater quality review criteria in Appendix Table 10. Tritium contamination has been reported in wells PRP 1A, PRP 2, and PRP 3 . PRP 1A has the highest concentration at $82.9 \mathrm{pCi} / \mathrm{mL}$, and we11s PRP 2 and PRP 3 have concentrations in the $12-20 \mathrm{pCi} / \mathrm{mL}$ range (Mikol et al., in press). It should be noted that these concentrations were first reported in the first quarter of 1987 and that these are the only tritium data available to date (Mikol et a1., in press).

A soil gas survey was completed at the site in April 1986. Twenty-four soil gas samples were collected and analyzed for VOCs. trans-1,2-Dichloroethylene, trichlorome thane, 1,1,1-trichloroe thane, trichloroethylene, and tetrachloroethylene were found in the soil gas, suggesting that migration and degradation of volatilized organics may be taking place.

\section{Characterization Recommendations}

Sampling

The size and shape of the pit can be determined using GPR. Two survey lines should be run across the width of the pit, and one line should be run the length of the pit. Figure F.14 shows the proposed survey lines.

A shallow soil coring program is recommended for the characterization of soils in and around the pit. Nine 6-m deep soil cores should be taken and analyzed at the intervals 1isted in Appendix Table 1. Figure F.14 shows the proposed sampling locations. This shallow coring program and the soil gas survey are designed to determine the horizontal extent of any surface and shallow soil contamination that may have occurred. 


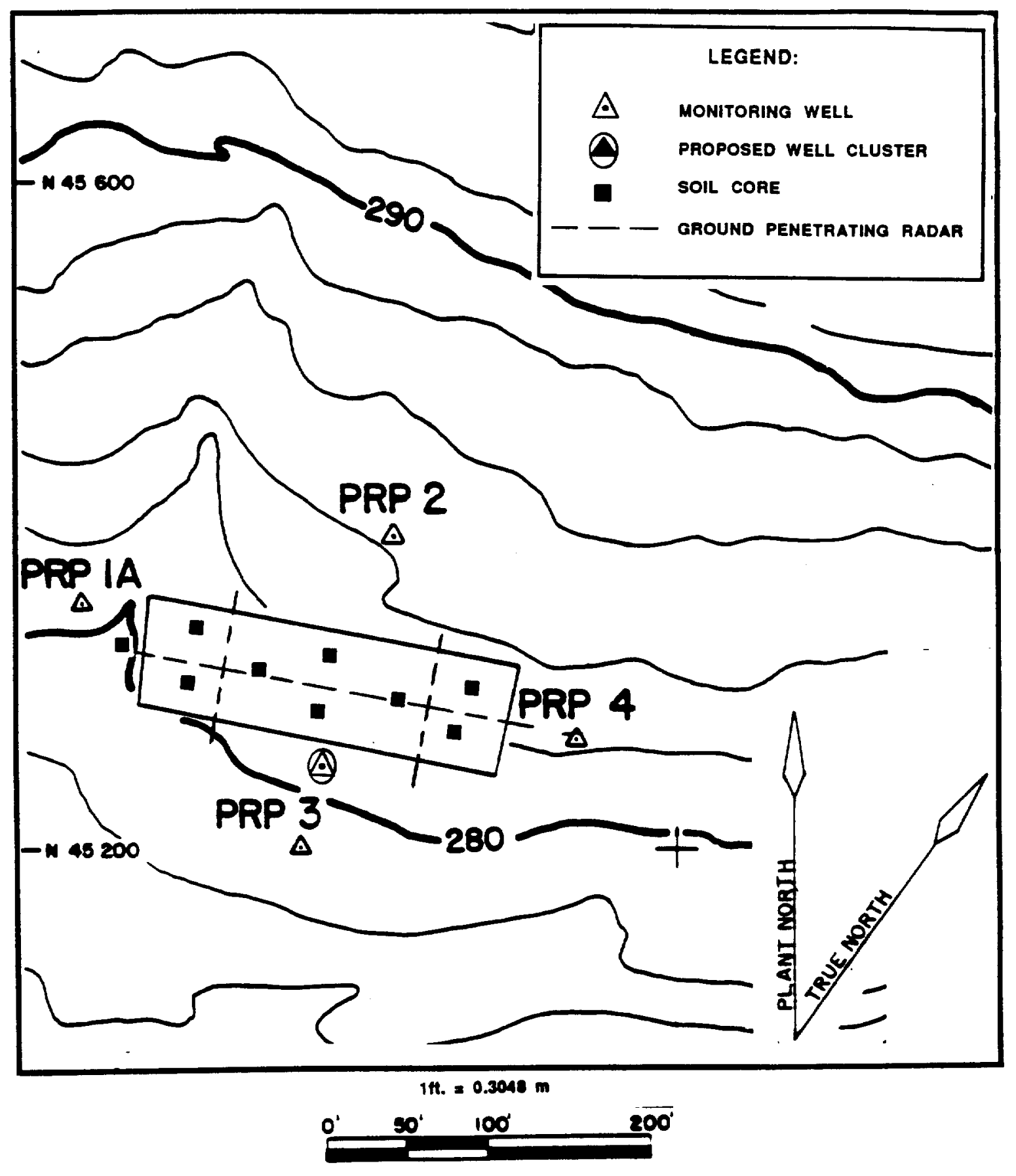

FIGURE F.14. Proposed Cluster Well and Sampling Locations for the P-Area Burning/Rubble Pit 
Additional monitoring wells should be installed to determine the vertical extent of any groundwater contamination that may have occurred. The new wells should be constructed close to the downgradient water-table well to form a cluster. The number of wells and the placement of screens wili be determined using any existing geologic data and the results of the core from the deepest well (to be drilled first) The number of new wells required to complete the cluster is not expected to exceed two. Figure F.14 shows the general location of the well cluster. Specific placement of the monitoring wells for delineating vertical groundwater contamination will be determined using the data generated by the previously mentioned characterization methods. Undisturbed samples should be collected from each well to determine the permeability and porosity (total and effective) of the underlying hydrogeologic units.

Chemical and Physical Analyses

Samples from the soil gas sampling survey will be analyzed for VOCs as 1isted in Appendix Table 3.

In an attempt to characterize the source and extent of contamination in the unsaturated zone, the $6-\mathrm{m}$ deep soil cores should be analyzed for selected parameters at the intervals 1 isted in Appendix Table 1 . Specific analytes should include those 1isted in Appendix Tables 2 (metals) and 3 (volatile organics).

Groundwater samples should be analyzed for the parameters given in Appendix Table 6 . Undisturbed samples collected during the drilling of cluster wells should be analyzed for vertical and horizontal permeability, porosity, relative permeability, bulk density, and grain size.

\section{R-Area Burning/Rubble Pits}

\section{Site Description}

The R-Area Burning/Rubble Pits are located southeast of $\mathrm{R}$ Area south of the junction of Road G and Road G-1 on a small ridge above Pond 4 (Figure F.15). The elevation of the site is $85.9 \mathrm{~m}(282 \mathrm{ft})$. Surface drainage is to the southeast toward Pond 4. First quarter 1987 water-level data (Mikol et al., in press) from the four monitoring wells at the site indicate that the depth to the watertable is $4.6 \mathrm{~m}$ and that groundwater flow is to the south.

\section{Review of Available Data}

Groundwater monitoring data from 1986 do not show elevated levels of any of the parameters analyzed (Zeigler et al., 1987). 

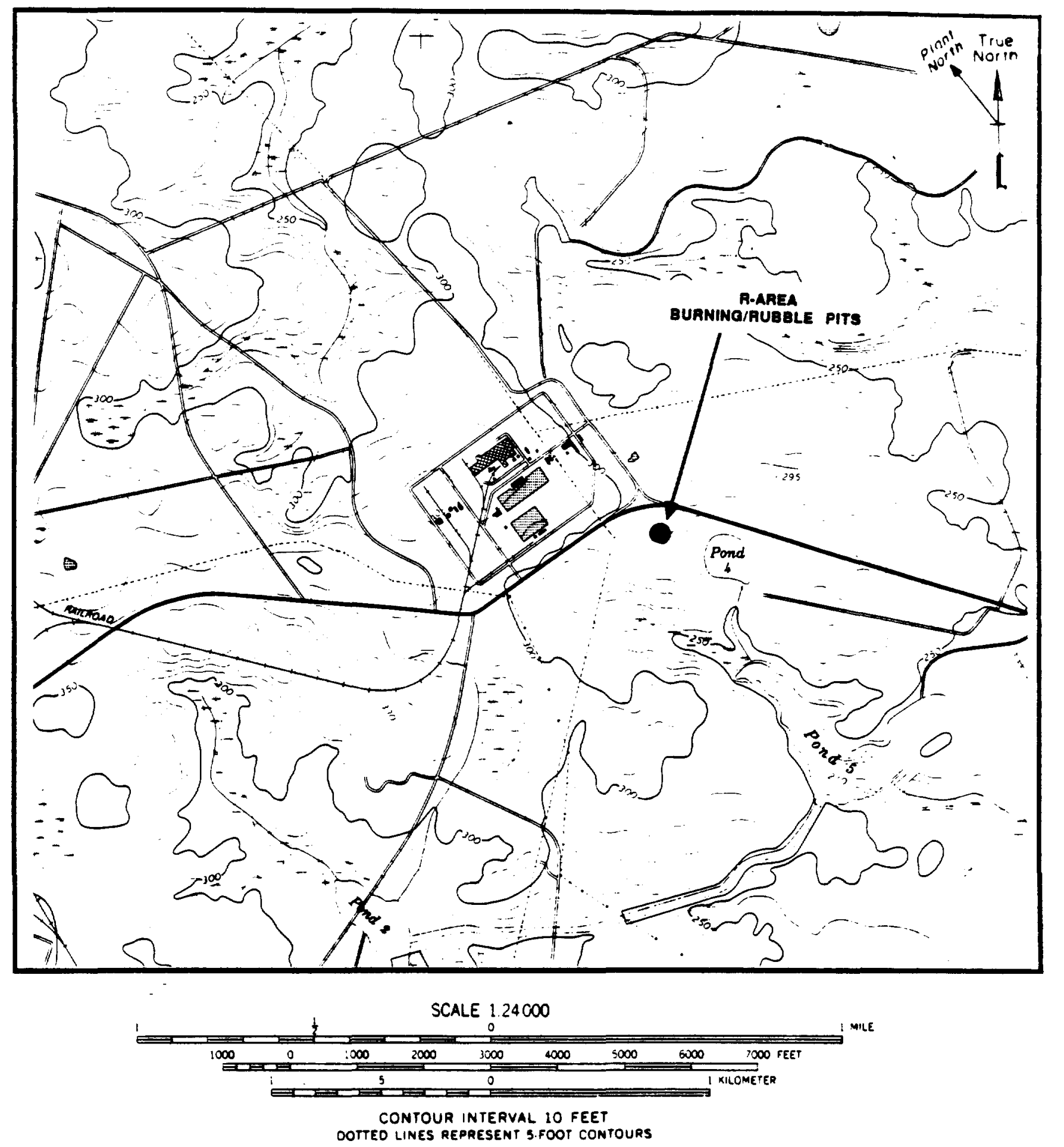

FIGURE F.15. Location of the R-Area Burning/Rubble Pits on New Ellenton SE Quadrangle 7.5 Minute Series Topographic Map 


\section{Characterization Recommendations}

Sampling

A soil gas survey is recommended for the site and should be used to map the horizontal extent of any VOC migration in the unsaturated zone. These data will help define soil sampling locations. Figure F.16 shows the proposed locations for soil gas samples.

The size and shape of the pit can be determined using GPR. Two survey lines should be run across the width of each pit, and one line should be run the length of each pit. Figure F.16 shows the proposed survey lines.

A shallow soil coring program is recommended for the characterization of soils in and around the pits. Nine 6-m deep soil cores should be taken and analyzed at the intervals listed in Appendix Table 1. Figure F.16 shows the proposed sampling locations. This shallow coring program and the soil gas survey are designed to determine the horizontal extent of any surface and shallow soil contamination that may have occurred.

Three monitoring wells should be installed to determine the vertical extent of any groundwater contamination that may have occurred. The monitoring wells should be installed in a cluster with screens in the Barnwel1, McBean, and Congaree formations. Figure F.16 shows the general location of the well cluster. Specific placement of the monitoring wells for delineating vertical groundwater contamination will be determined using the data generated by the previously mentioned characterization methods. Undisturbed samples should be collected from each well to determine the permeability and porosity (total and effective) of the underlying hydrogeologic units.

\section{Chemical and Physical Analyses}

Samples from the soil gas sampling survey should be analyzed for VoCs as 1 isted in Appendix Table 3.

In an attempt to characterize the source and extent of contamination in the unsaturated zone, the $6-\mathrm{m}$ deep soil cores should be analyzed for selected parameters at the intervals 1isted in Appendix Table 1. Specific analytes should include those listed in Appendix Tables 2 (metals) and 3 (volatile organics).

Groundwater samples should be analyzed for the parameters given in Appendix Table 6. Undisturbed samples collected during the drilling of cluster wells should be analyzed for vertical and horizontal permeability, porosity, relative permeability, bulk density, and grain size. 


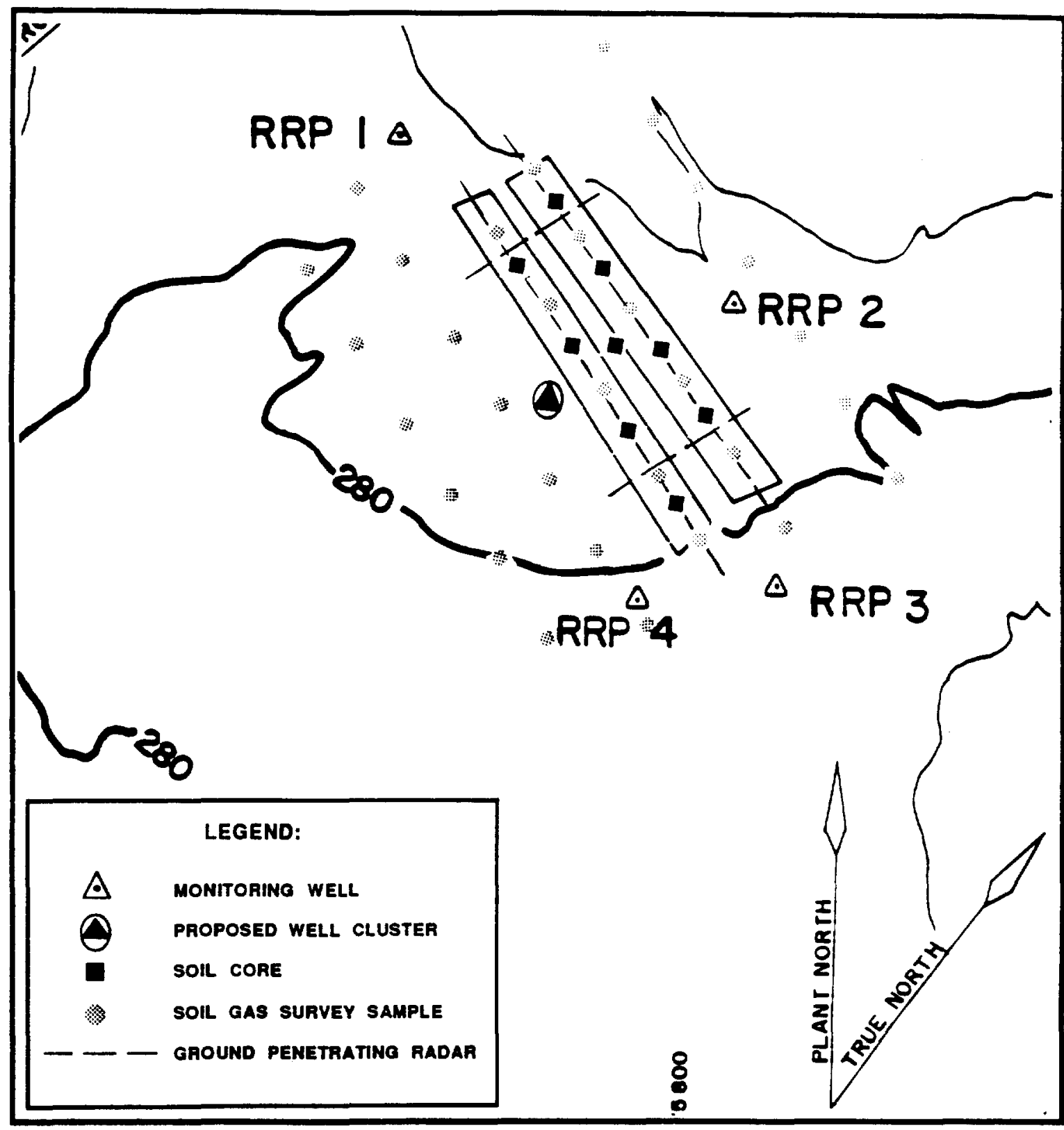

1ft. $=0.3048 \mathrm{~m}$

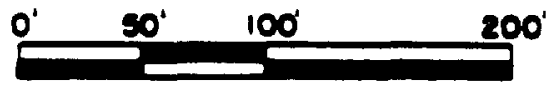

FIGURE F.16. Proposed Cluster Well and Sampling Locations for the R-Area Burning/Rubble Pits 


\section{Background}

\section{Site History}

The Chemicals, Meta1s, and Pesticides (CMP) Pits were unlined pits used for the disposal of a variety of nonradioactive chemical wastes. Hazardous waste was disposed of in these pits from 1971 through 1979. Typical waste consisted of drums of solvents (trichloroethylene and tetrachloroethylene) and other liquids (Freono, oil, paint thinner, and acid). Beryllium, titanium, calcium, and cadmium metals were disposed of in a separate metals pit. Odd-shaped items such as spray cans and gas cylinders were placed in the pits in various size containers. Detailed inventories of types and amounts of wastes disposed in each of the pits are not available.

The waste in the pits was excavated in 1984 and now is being stored. Plans call for incineration of the waste. The pits were backfilled and capped, and new monitoring wells were installed. A leach field for flushing the unsaturated zone beneath the pits was installed prior to backfilling the pits. The leach field would be put into operation if necessary (Scott et al., 1987c).

\section{Site Description}

The seven CMP Pits are located near the center of SRP approximately $900 \mathrm{~m}$ northwest of the intersection of SRP Road C and SRP Road 7. The site is situated at the top of a hill near the head of Pen Branch (Figure G.1), approximately $11 \mathrm{~km}$ to the west of the nearest plant boundary. The SRP coordinates for the northeast corners of the pits are given in Table G.1. Each pit was 3 to $5 \mathrm{~m}$ wide, 3 to $5 \mathrm{~m}$ deep, and 15 to $23 \mathrm{~m}$ long. The pits were arranged in two 1 inear rows with approximately 3 to $7 \mathrm{~m}$ between the ends of the adjacent pits (Figure G.2).

The CMP Pits are located on the Aiken Plateau at an elevation of approximately $95 \mathrm{~m}(312 \mathrm{ft})$. The pits were constructed on the crest of a hill that is bounded by Pen Branch to the north and west and by anephemeral tributary to Pen Branch on the south. High ground extends to the southeast. Surface drainage is in all other directions.

Three series of groundwater monitoring wells were installed at the site. Wells CMP 1 through 7 were water-table wells installed prior to 1980. They were grouted and abandoned when the pits were excavated in 1984. Wells CMP 8 through 13 were installed as water-table we11s in 1982 . CMP 8 through 13 were then modified to clusters in 1984, and three additional clusters (14 through 16 ) were also added. A map of existing groundwater monitoring wells is shown in Figure G.2. 

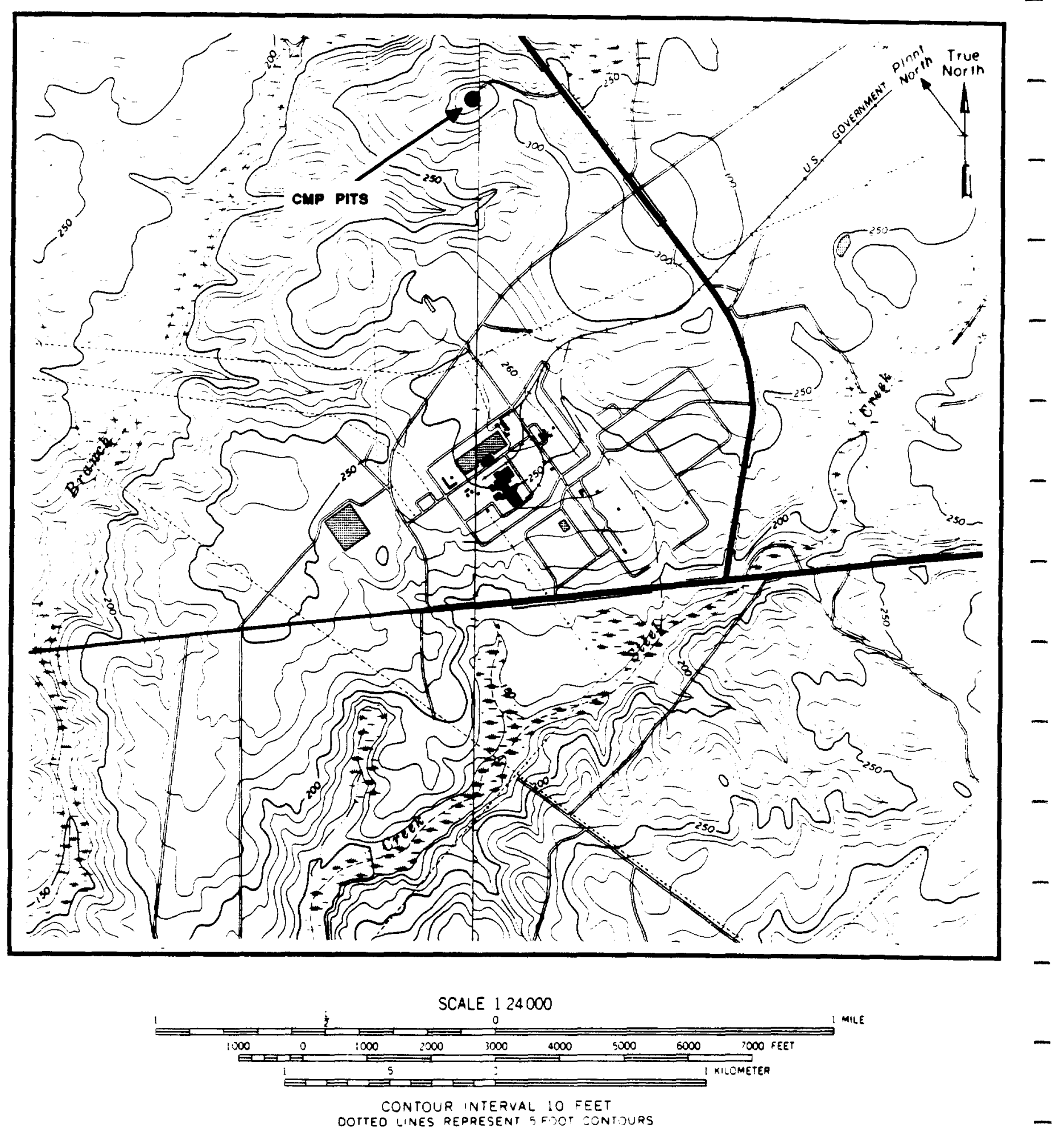

FIGURE G.1. Location of the CMP Pits on Girard NW Quadrangle 7.5 Minute Series Topographic Map 
TABLE G.1

Building Numbers and SRP Coordinates for the CMP Pits

Bldg. No.

080-17G

$080-17.1 \mathrm{G}$

080-18G

$080-18.1 \mathrm{G}$

$080-18.2 \mathrm{G}$

$080-18.3 G$

080-19G
SRP Coordinates

$\begin{array}{llll}\text { N } & 51600 & \text { E } & 53904 \\ \text { N } & 51541 & \text { E } & 53861 \\ \text { N } & 51547 & \text { E } & 53958 \\ \text { N } & 51589 & \text { E } & 53817 \\ \text { N } & 51635 & \text { E } & 53772 \\ \text { N } & 51650 & \text { E } & 53853 \\ \text { N } & 51504 & \text { E } & 53896\end{array}$




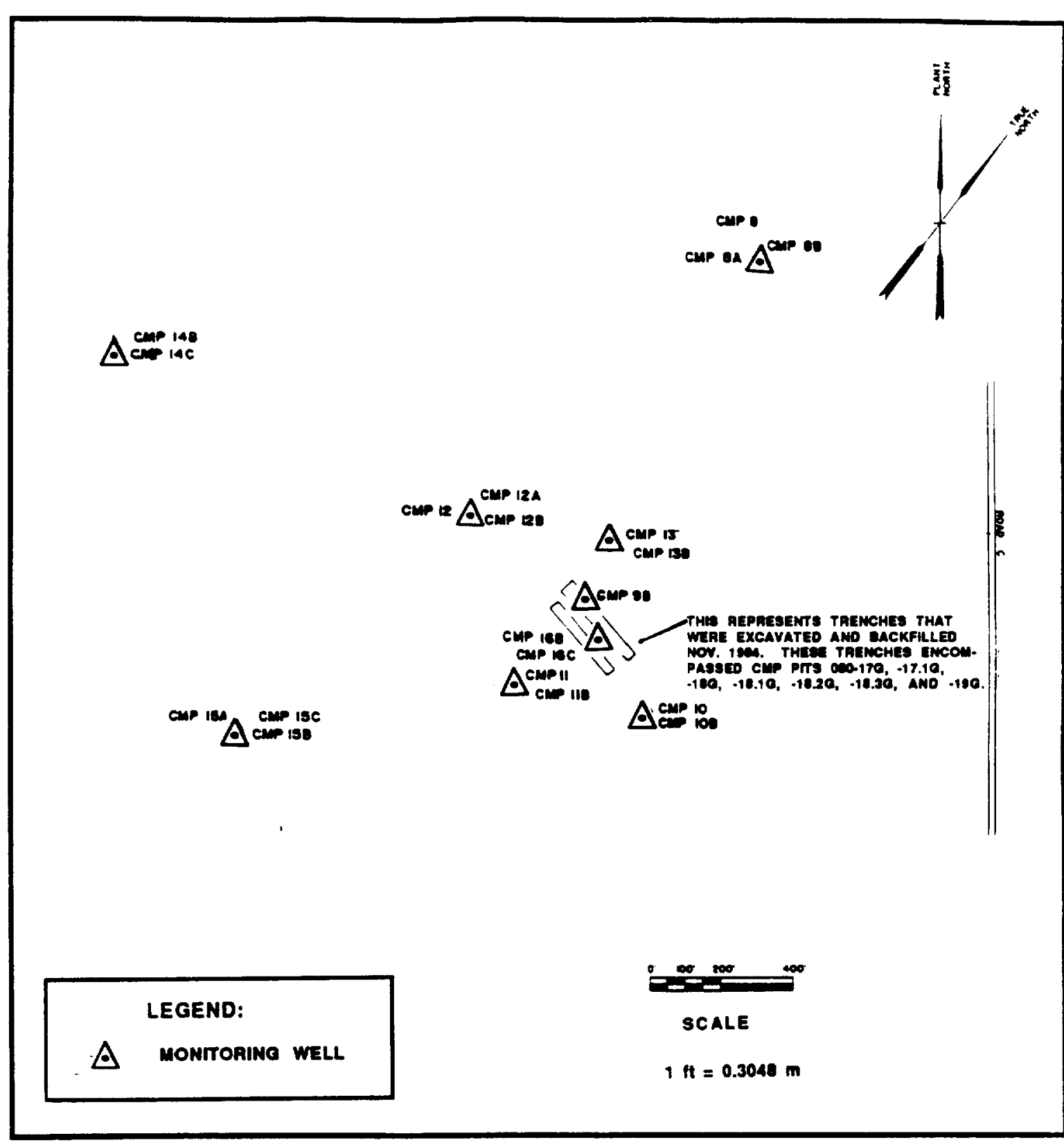

FIGURE G.2. Monitoring Well Locations at the CMP Pits

$$
\text { G-4 }
$$


Hydrologically, the site is very complex. Groundwater flow is believed to be generally to the north-northeast. Data from 1986 indicate that the depth to the water table averages $30 \mathrm{~m}$.

\section{Review of Available Data}

Two trenches, one along each of the axes of the pits, were dug, and the waste was removed in 1984. One hundred eighty-three soil samples were then collected from the trench floors after excavation of the waste materials. After chemical analyses of these samples were completed, 20 soil cores were collected at the sites of highest contamination. Soil cores ranged in length from 3.3 to $23.5 \mathrm{~m}$. Due to elevated levels (up to $7,000 \mu \mathrm{g} / \mathrm{g}$ total volatile organics) of contaminants, further excavation of soil/waste materials took place. The amount of contaminants removed from the site is estimated to be over $11,000 \mathrm{~kg}$ of organics. It is estimated that approximately $500 \mathrm{~kg}$ of contaminants remain in the soil beneath the site. A maximum concentration of $10 \mu \mathrm{g} / \mathrm{g}$ total volatile organics was used to delineate the extent of the excavation.

Groundwater from wells CMP 1 through 7 contained up to 5,000 $\mu \mathrm{g} / \mathrm{L}$ TOH, but generally averaged less than $50 \mu \mathrm{g} / \mathrm{L}$. Concentrations of pesticides were generally below detection. In 1985 groundwater from the nine cluster wells (CMP 8 through 16) was analyzed for the full set of EPA Priority Pollutants (Scott et a1., 1987c). These analyses indicate levels of volatile organic halogens and benzene above groundwater quality review criteria (Appendix Table 6) and elevated (but below drinking water standards) levels of lead, zinc, chromium, toluene, and base neutrals (phthalates). Recent quarterly monitoring data show elevated levels of zinc and lead that are still below drinking water standards (Appendix Table 6). There are no elevated concentrations of chromium in the groundwater. TOH levels are elevated in two of the monitoring wells. Trichloroethylene is elevated above groundwater quality review criteria (Appendix Table 10) in one of the wells. The other well has elevated levels of TOH, but trichloroethylene, tetrachloroethylene, carbon tetrachloride, chloroform, and 1,1,1-trichloroethane are below detection.

\section{Characterization Recommendations}

Sampling

A soil gas survey, consisting of a grid of approximately 150 surface samples across the area of the site (one sample per $10 \mathrm{~m}$ ) is recommended. This survey will highlight areas of highest VOC contamination, if any, and provide information on the source term (Figure G.3). If the soil gas survey shows extensive plume migration past the survey guide, additional monitoring wells are recommended. 
Geohydrological information will be extrapolated from the nearby regional geohydrological well cluster $\mathrm{P} 15$.

\section{Chemical and Physical Analyses}

Only soil gas analyses for volatile organics (Appendix Table 3) will be recommended at this time. 


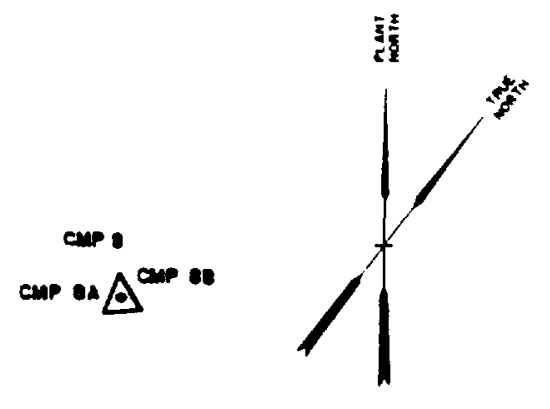

$\Delta$ emp iac

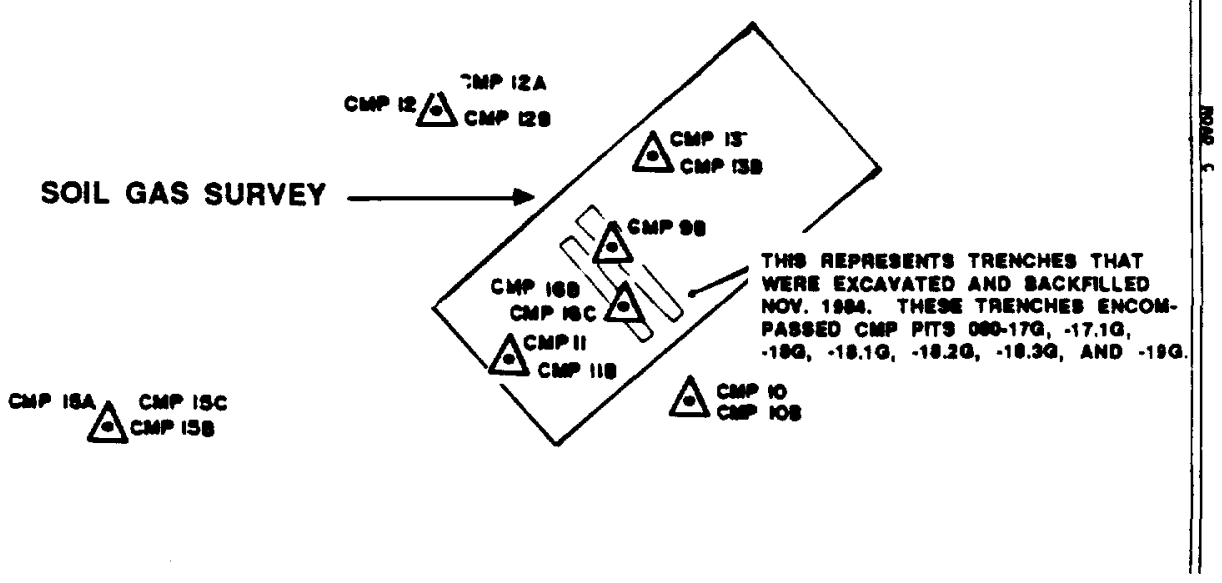

\begin{tabular}{|l|}
\hline LEGEND: \\
$\triangle$ MONITORINO WELL \\
$\square$ OUTLINE OF SOIL GAS \\
SURVEY
\end{tabular}

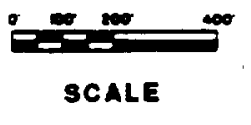

$1 \mathrm{t}=0.3046 \mathrm{~m}$

\section{FIGURE G.3. Proposed Soil Gas Survey at the CXP Pits}




\section{Background}

\section{Site History}

Steam and electricity at SRP are generated by burning coal. The coal is stored in open piles at seven locations at SRP. The rainfall runoff from the coal piles was allowed to flow to surface streams until 1977 . At that time SRP obtained an NPDES permit that required all discharges to fall between $\mathrm{pH} 6$ and 9 . Because the runoff from the coal piles did not meet this requirement, containment basins were constructed at the sites of the coal piles. The containment basins were constructed between 1978 and 1981. All of the basins are currently in use except for those in C and F areas. The C- and F-Area coal piles were removed in late 1985, and their CPRBs have been inactive since that time. Information on site history, descriptions, and existing data were obtained from Heffner et a1. (1987) and Christensen and Gordon (1983).

The Coal Pile Runoff Containment Basins (CPRB) are located in A, D, C, $K, P, F$, and $H$ areas. These areas differ widely in surface topography and groundwater hydrology. Hence, each of the basins will be discussed separately. SRP coordinates for the northeast corner of each basin are given in Table H.1.

\section{A-Area Coal Pile Runoff Containment Basin}

\section{Site Description}

The A-Area Coal Pile Runoff Containment Basin is located east-southeast of Building 716-A, outside the perimeter fence (Figure H.1). The nearest plant boundary is about $1.5 \mathrm{~km}$ to the northwest. The A-Area Coal Pile Runoff Containment Basin is approximately $4,000 \mathrm{~m}^{2}$ and $1 \mathrm{~m}$ deep.

The A-Area Coal Pile Runoff Containment Basin is located on the Aiken Plateau at an elevation of approximately $110 \mathrm{~m}(360 \mathrm{ft})$. Surface drainage is to the east toward Tims Branch.

Four groundwater monitoring wells were installed in 1980 and 1981. Because the original wells were cased with steel, they were replaced with PVC-cased wells in 1984 (Figure H.2). The water table in the area has an extremely low gradient. Hence, groundwater flow direction can be quite variable. Recent data suggest a groundwater flow direction to the north. However, the regional gradient is to the east-southeast. Data from 1986 indicate that the water table is located at a depth of approximately $30 \mathrm{~m}$. 
TABLE H.I

SRP Coordinates for the Coal Pile Runoff Containment Basins

$\underline{\text { Site }}$

A Area

C Area

D Area

F Area

H Area

K Area

P Area
B1dg. No.

$788-3 A$

$189-C$

489-D

$289-F$

289-H

$189-\mathrm{K}$

189-P
SRP Coordinates

N 102190 E 51530 *

N 65400 E 47087

N 63200 E 20500

N 76769 E 54988

N 71155 E 64013

N 53300

E 39491

N 42106

E 65112

* Coordinates for this basin are for the southeast corner. A11 other coordinates are for the northeast corner of the basin. 

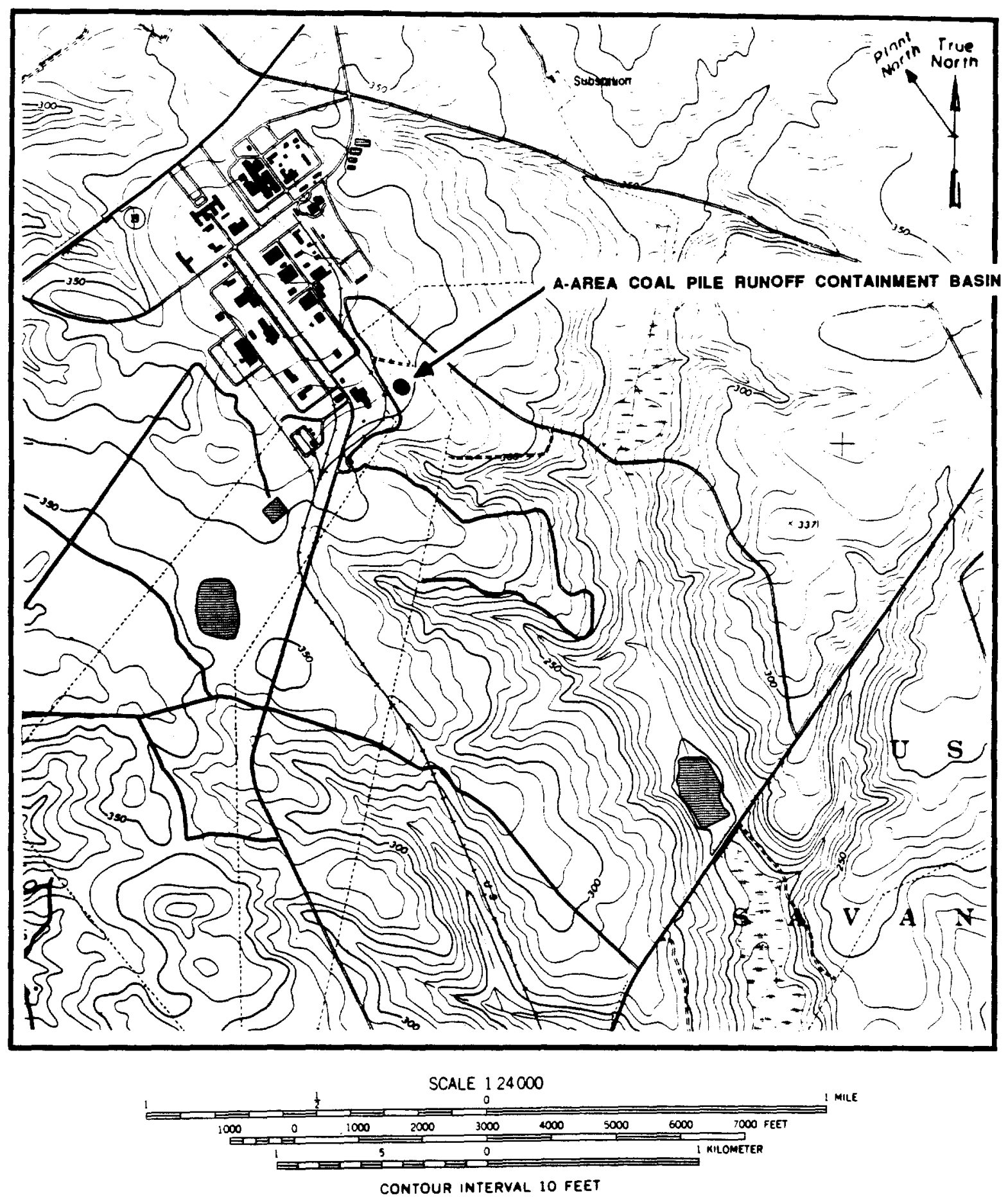

FIGURE H.1. Location of the A-Area Coal Pile Runoff Containment Basin on New Ellenton $S W$ Quadrangle 7.5 Minute Series Topographic Map 


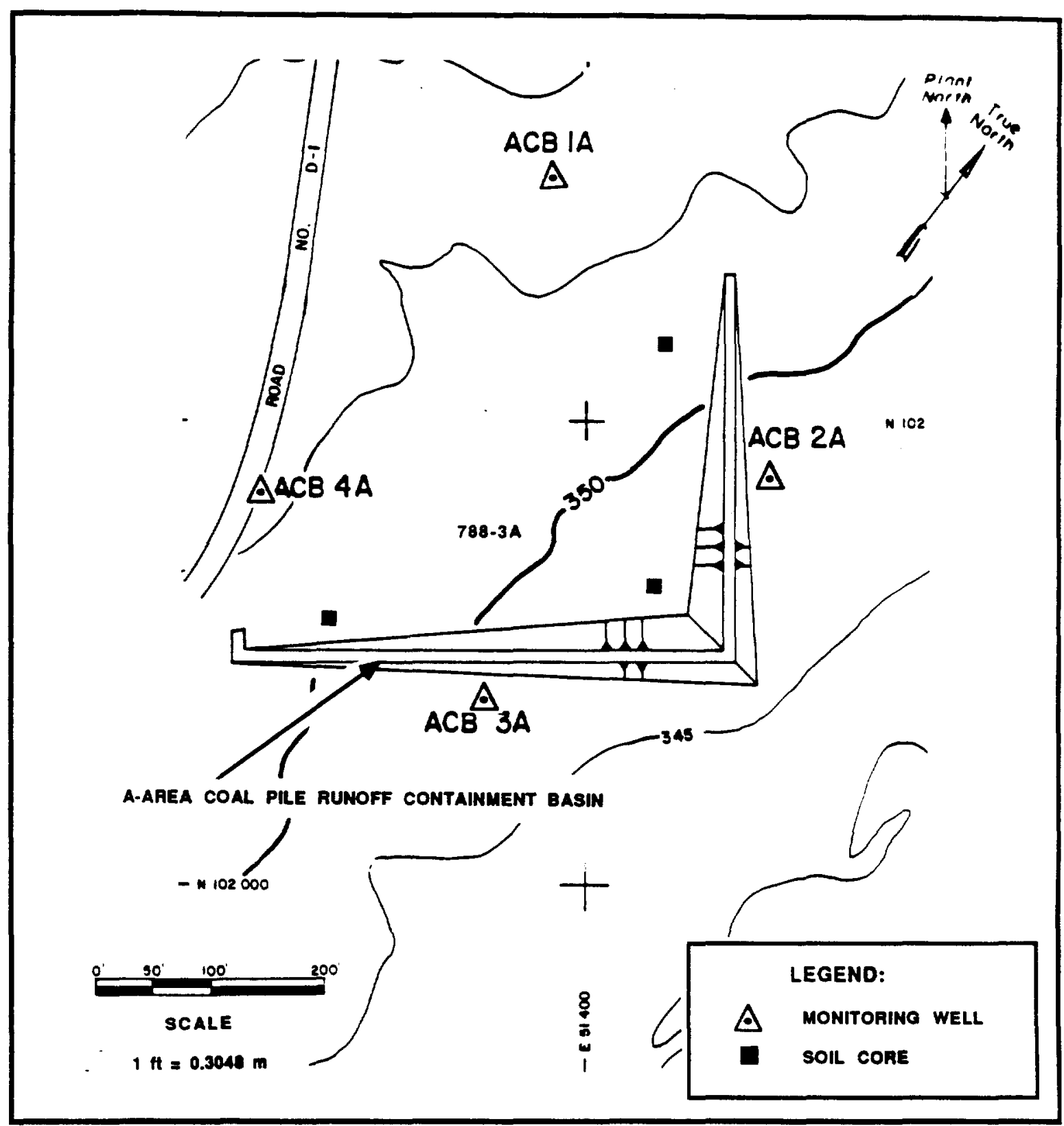

FIGURE H.2. Existing Monitoring Wells and Proposed Sampling Locations at the A-Area Coal Pile Runoff Containment Basin 


\section{Review of Available Data}

Groundwater at this site contains slightly elevated levels of TDS, which are predominantly sodium, sulfate, and chloride (Mikol et al., in press; Zeigler et al., 1987). The effect of the basin on groundwater quality is minimal. All groundwater components are present in concentrations below groundwater quality review criteria (Appendix Table 10).

\section{Characterization Recommendations}

Sampling

Three soil cores taken to a depth of $6 \mathrm{~m}$ are recommended to determine the vertical extent of the contamination if any and to better calculate a source term (Figure H.2). Samples for chemical analyses should be collected according to the intervals given in Appendix Table 1 . Splits of the soil samples should be archived at SRP.

\section{Chemical and Physical Analyses}

The soil cores should be analyzed according to the parameters given in Appendix Table 1. Specific analytes are metals (Appendix Table 2). The five shallowest samples for each core should also be analyzed for radioactivity (Appendix Table 4) and for VOCs (Appendix Table 3). Groundwater analyses from existing monitoring wells should follow Appendix Table 6 .

\section{C-Area Coal Pile Runoff Containment Basin}

\section{Site Description}

The C-Area Coal Pile Runoff Containment Basin is located south of Building No. 100-C opposite the southeast corner of the perimeter fence (Figure H.3). The nearest plant boundary is approximately $9 \mathrm{~km}$ to the west. The basin is $1,500 \mathrm{~m}^{2}$ and $2.3 \mathrm{~m}$ deep.

The C-Area Coal Pile Runoff Containment Basin is located on the Aiken Plateau at an elevation of approximately $85 \mathrm{~m}(280 \mathrm{ft})$. Surface drainage is to the southeast toward a small tributary of Four Mile Creek.

Four groundwater monitoring wells with PVC casings were installed in 1981 (Figure H.4). Groundwater flow is southwest toward Four Mile Creek. Data from 1986 indicate that the depth to the water table is $17 \mathrm{~m}$ (Zeigler et al., 1987). 

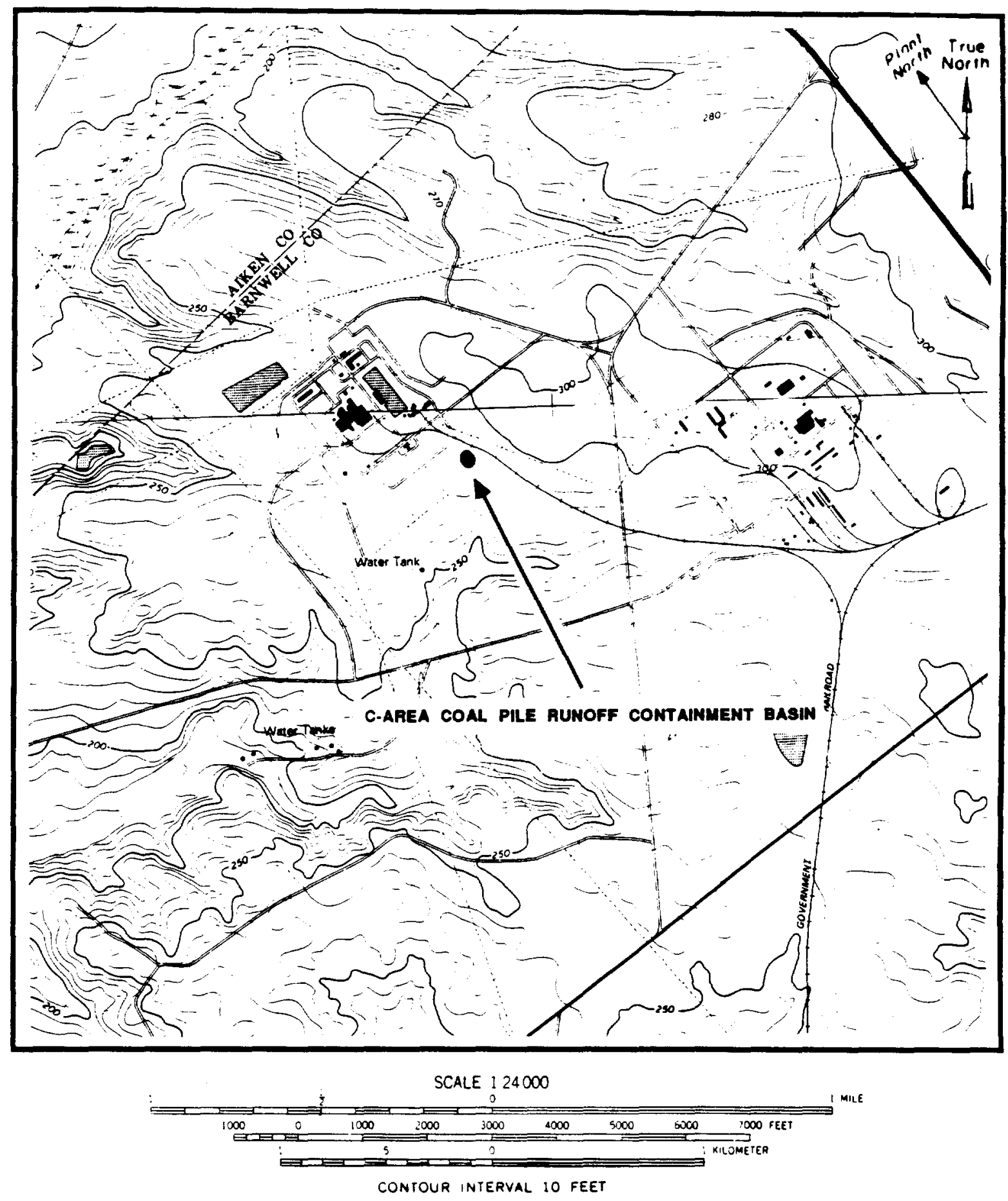

FIGURE H.3. Location of the C-Area Coal Pile Runoff Containment Basin on Girard NW Quadrangle 7.5 Minute Series Topographic Map 


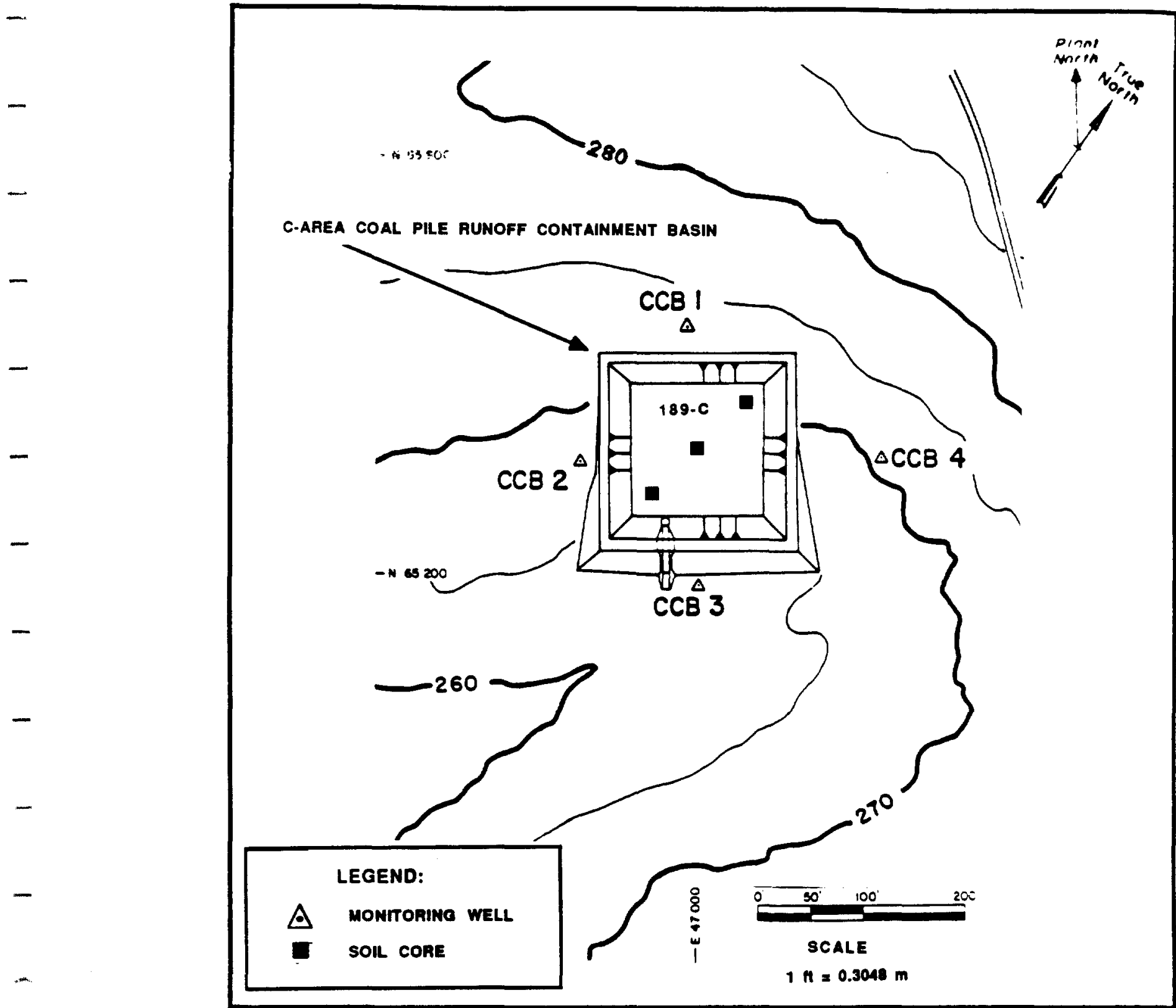

FIGURE H.4. Existing Monitoring Wells and Proposed Sampling Locations at the C-Area Coal Pile Runoff Containment Basin 


\section{Review of Available Data}

Groundwater data at this site show no evidence of a contaminant plume. TDS levels at all wells range from 18 to $28 \mathrm{mg} / \mathrm{L}$, which is typical of uncontaminated groundwater in this area (Zeigler et al., 1987). Levels of metals are all well below groundwater quality review criteria (Appendix Table 10).

\section{Characterization Recommendations}

\section{Sampling}

Three soil cores taken to a depth of $6 \mathrm{~m}$ are recommended to determine the vertical extent of the contamination, if any (Figure H.4). Samples should be collected for chemical analysis according to the parameters given in Appendix Table 1. Splits of all soil sample should be archived at SRP.

\section{Chemical and Physical Analyses}

The soil cores should be analyzed according to the parameters given in Appendix Table 1. Specific analytes are metals (Appendix Table 2). The five shallowest samples from each core should also be analyzed for radioactivity (Appendix Table 4 ) and volatile organics (Appendix Table 3). Groundwater analyses should follow the parameters given in Appendix Table 6 .

\section{D-Area Coal Pile Runoff Containment Basin}

\section{Site Description}

The D-Area Coal Pile Runoff Containment Basin is located outside the perimeter fence at the southwest corner of Building 4p0-D (Figure H.5). The nearest plant boundary is the Savannah River, about $1.8 \mathrm{~km}$ to the west. The area covered by this basin is approximately $50,600 \mathrm{~m}^{2}$. The basin is approximately $1.4 \mathrm{~m}$ deep.

The D-Area Coal Pile Runoff Containment Basin is located on a Savannah River terrace at an elevation of about $40 \mathrm{~m}(130 \mathrm{ft})$. The unconsolidated terrace material consists of sand, silt, and clay. Surface drainage is to the southwest toward a small tributary that flows into the Savannah River swamp, which occurs at an elevation of $27 \mathrm{~m}$ in this area. 

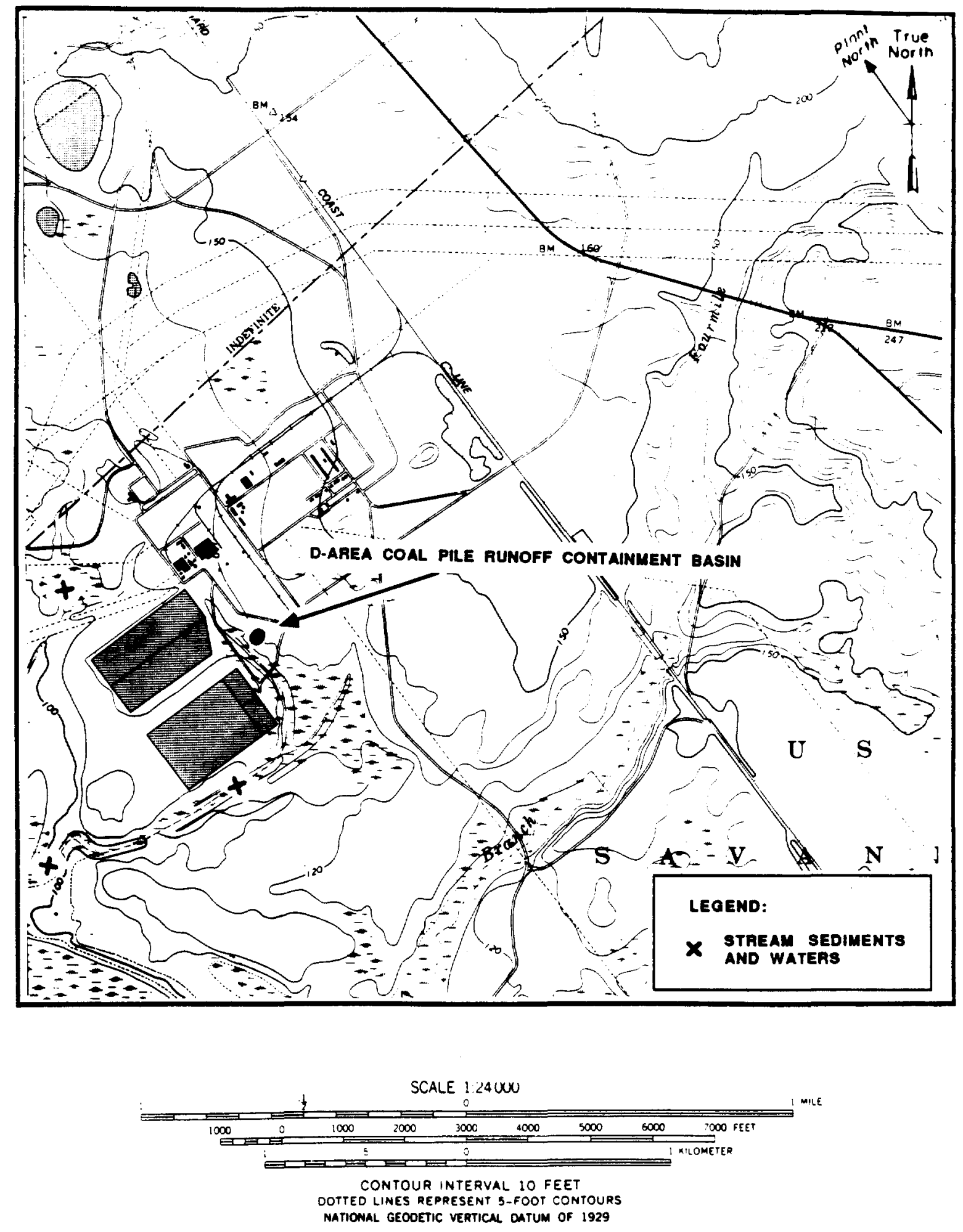

FIGURE H.5. Location of the D-Area Coal Pile Runoff Containment Basin on Girard NW Quadrangle 7.5 Minute Series Topographic Map 
Five groundwater monitoring wells were installed in 1981. Because the original wells were cased with steel, they were replaced with five PVC-cased wells in 1984 (Figure H.6). Seven additional monitoring wells have recently been installed by SREL near this basin and the nearby D-Area Ash Basin. Five of these wells are located close to the D-Area Coal Pile Runoff Containment Basin (Figure H.6). Water-table elevation data from DCB $1 \mathrm{~A}$ through $5 \mathrm{~A}$ show that the site is located on a groundwater nose, with flow direction ranging from southwest to west. We11s DCB 1A, DCB 5A, and DCB 4A are downgradient from the basin. Data from 1986 indicate that the depth to the water table is about $2 \mathrm{~m}$. The area represents a site of groundwater discharge, with a vertical gradient upward. Hence, there is little likelihood for downward migration of contaminants below the water-table aquifer.

\section{Review of Available Data}

Groundwater at this site contains levels of organic halogens (trichloroethylene), metals (chromium, cadmium, zinc, selenium, copper), radioactivity (gross alpha, beta, and radium), fluoride, and sulfate above groundwater review criteria (Appendix Table 10). Elevated concentrations of iron and manganese are also present. The $\mathrm{pH}$ of the groundwater is very low, less than 3 in DCB 1A. Levels of TDS are elevated in all of the site wells. The highest concentrations were detected in well DCB 1A. Elevated levels of some of the contaminants were also present in wel1 DCB 5A (Heffner et al., in press). No groundwater data are available yet from the five new monitoring wells installed by SREL. Other research at this site has been conducted by SREL. See Section C for a list of references.

\section{Characterization Recommendations}

Sampling

Four shallow soil cores from within the confines of the basin are recommended to determine the vertical extent of contamination if any (Figure H.6). Due to the shallow nature of the water table, all cores should be taken to the water table. Soils should be sampled for chemical analyses according to the parameters in Appendix Table 1. One undisturbed soil core should be collected from outside the basin. This core should be described geologically and used for physical measurements (Appendix Table 1, Class 3 plus porosity and permeability). This deeper core will be used to describe the physical parameters of the hydrogeological units at all D-Area waste sites. Because of the shallow nature of the water table in D-Area there is a greater potential for contamination of the 
water-table aquifer. The physical parameters will be helpful for hydrological modeling at the D-Area waste sites. Splits of the soils will be archived at SRP in case more analyses are required (Figure H.6). The deep borehole should be geophysically logged.

Due to the shallow nature of the water table and the high concentrations of TDS in the groundwater, a terrain conductivity survey is recommended to determine the extent of the elevated TDS level plume.

Stream water and sediment samples are recommended upgradient and downgradient of the site (Figure H.5).

Chemical and Physical Analyses

Soil samples will be analyzed according to the parameters given in Appendix Table 1. Specific analytes are metals (Appendix Table 2), radioactivity (Appendix Table 4), and volatile organics (Appendix Table 3). Groundwater analyses will include the parameters in Appendix Table 6. If radioactivity levels are elevated above drinking water standards, a more comprehensive analysis of individual radionuclides (Appendix Table 5) will be required.

\section{F-Area Coal Pile Runoff Containment Basin}

\section{Site Description}

The F-Area Coal Pile Runoff Containment Basin is located east of Building 200-F and north of the railroad track into the area (Figure H.7). The nearest Plant boundary is approximately $10 \mathrm{~km}$ to the west. The basin is $4,500 \mathrm{~m}^{2}$, and the depth of the basin is $2.4 \mathrm{~m}$.

The F-Area Coal Pile Runoff Containment Basin is located on the Aiken Plateau at an elevation of approximately $98 \mathrm{~m}(320 \mathrm{ft})$. Surface drainage is to the south toward an unnamed tributary of Four Mile Creek.

Four monitoring wells with PVC casings were installed at the site in 1981 (Figure H.8). Regional groundwater data suggest that $f$ low is to the south-southwest (Zeigler et al., 1987). The data from 1986 indicate that the depth to the water table is approximately $24 \mathrm{~m}$. 


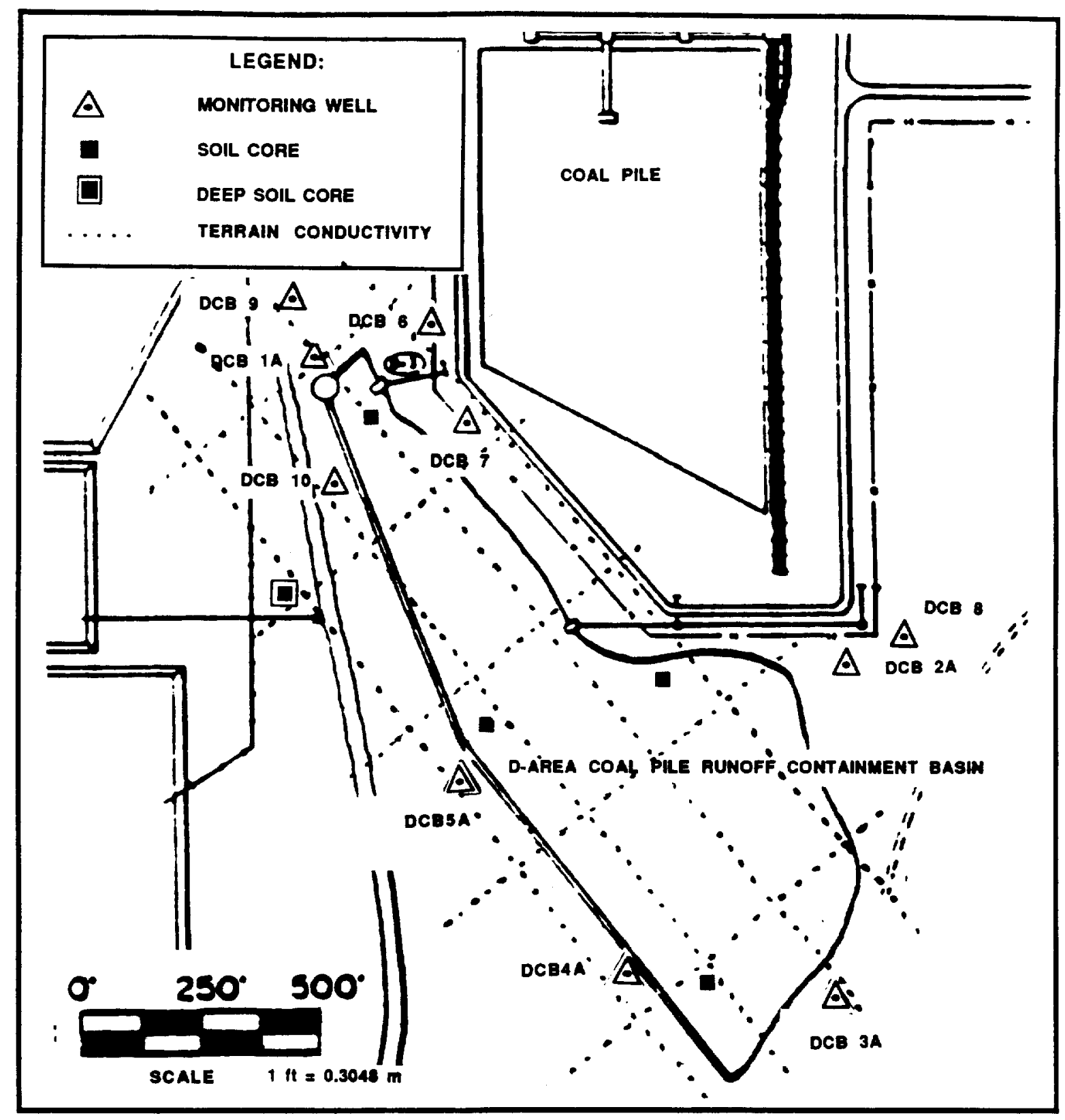

FIGURE H.6. Existing Monitoring Wells and Proposed Sampling Locations at the D-Area Coal Pile Runoff Containment Basin 


\section{Review of Available Data}

Groundwater data from monitoring well FCB 1, the upgradient well, is invalid because the well has become contaminated with grout. Groundwater data from the other three monitoring wells suggest that there has been relatively little influence on groundwater quality. In the first quarter of 1987 groundwater from well FCB 3 had slightly elevated TDS levels, but levels were still far below groundwater quality review criteria (Appendix Table 10). The dissolved solids that were slightly elevated in this water were calcium and sulfate. No trace metals were elevated. In early 1986 groundwater in we11 FCB 3 contained levels of radioactivity above groundwater quality review criteria (Appendix Table 10). More recent data (Mikol et al., in press) show levels of radioactivity below groundwater quality review criteria (Appendix Table 10 ).

\section{Characterization Recommendations}

\section{Sampling}

Three soil cores taken to a depth of $6 \mathrm{~m}$ are recommended to determine the vertical extent of any potential contamination (Figure H.8). Samples for chemical analyses should be collected according to the parameters in Appendix Table 1. Splits of all soil samples should be archived at SRP.

Monitoring well FCB 1 should be plugged and a new well (FCB5) installed to replace it. The monitoring well should be cored continuously, and the core described geologically and archived. The monitoring well borehole should be logged geophysically for gamma, resistivity, porosity, and caliper.

Chemical and Physical Analyses

The soil cores should be analyzed according to the parameters in Appendix Table 1 . Specific analytes are radioactivity (Appendix Table 4) and metals (Appendix Table 2). Groundwater should be analyzed according to the parameters given in Appendix Table 6 . 

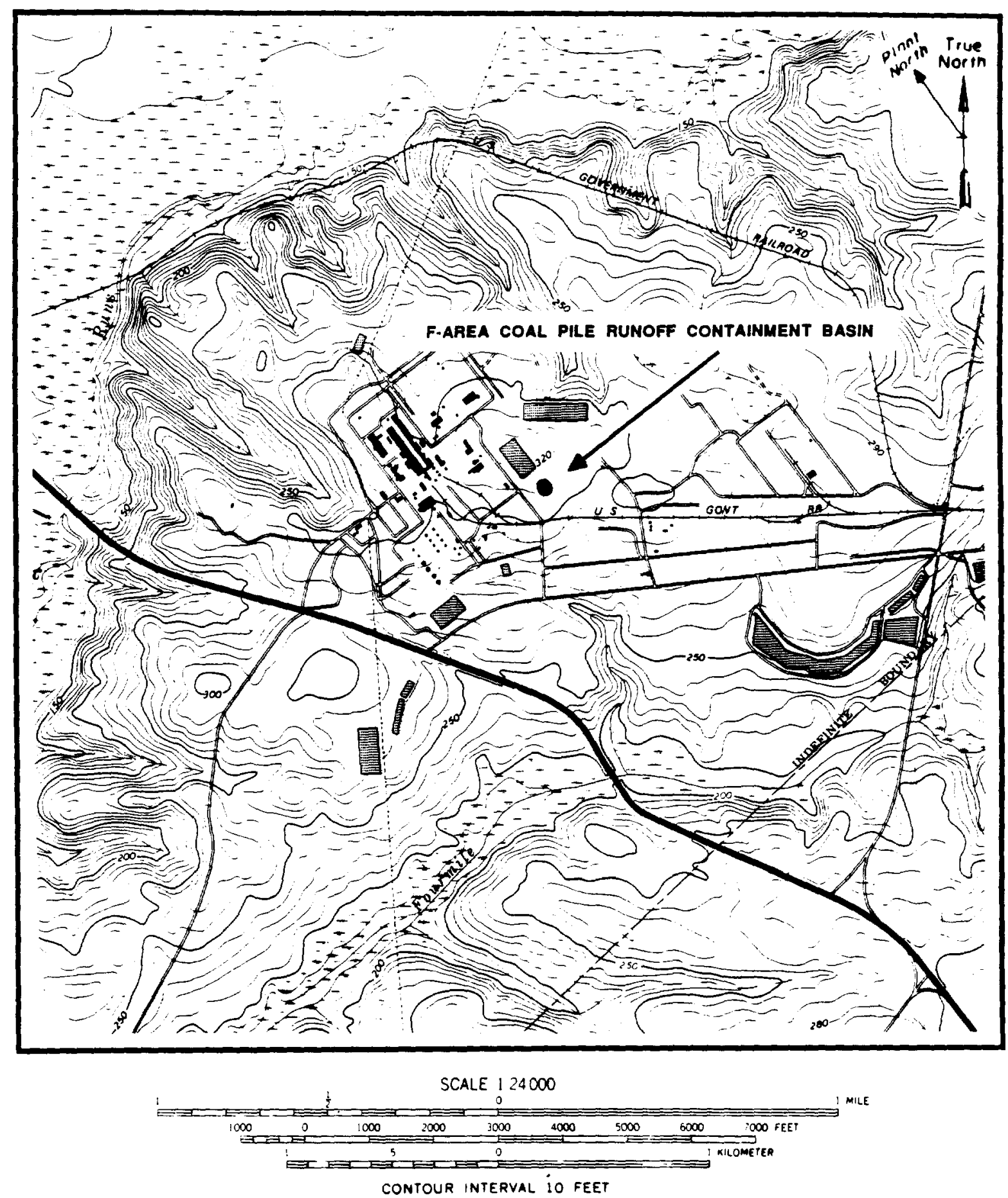

FIGURE H.7. Location of the F-Area Coal Pile Runoff Containment Basin on New Ellenton SW quadrangle 7.5 kinute Series Topographic Map 


\section{H-Area Coal Pile Runoff Containment Basin}

\section{Site Description}

The H-Area Coal Pile Runoff Containment Basin is located east of Building 200-H and north of Road E (Figure H.9). The nearest Plant boundary is approximately $12 \mathrm{~km}$ to the west. The area covered by the basin is approximately $4,600 \mathrm{~m}^{2}$, and the depth of the basin is approximately $2 \mathrm{~m}$.

The H-Area Coal Pile Runoff Containment Basin is located on the Aiken Plateau at an elevation of approximately $84 \mathrm{~m}(275 \mathrm{ft})$. Surface drainage is to the northeast toward an unnamed tributary of Upper Three Runs Creek.

Four groundwater monitoring wells were installed in 1981 using PVC casings (Figure H.10). Groundwater flow is to the north-northeast. Data from 1986 indicate that the depth to the water table is approximately $4.5 \mathrm{~m}$ (Zeigler et al., 1987).

\section{Review of Available Data}

Groundwater data from this site show elevated TDS levels in groundwater from wel1 HCB 2, one of the upgradient wells (Miko1 et al., in press; Zeigler et al., 1987). It appears that these elevated levels may be directly attributed to the coal storage pile. Groundwater in the other wells at this site contains background levels of all components. Groundwater in well $\mathrm{HCB} 2$ has elevated concentrations of calcium and sulfate, but concentrations are not above groundwater quality review criteria (Appendix Table 10). 


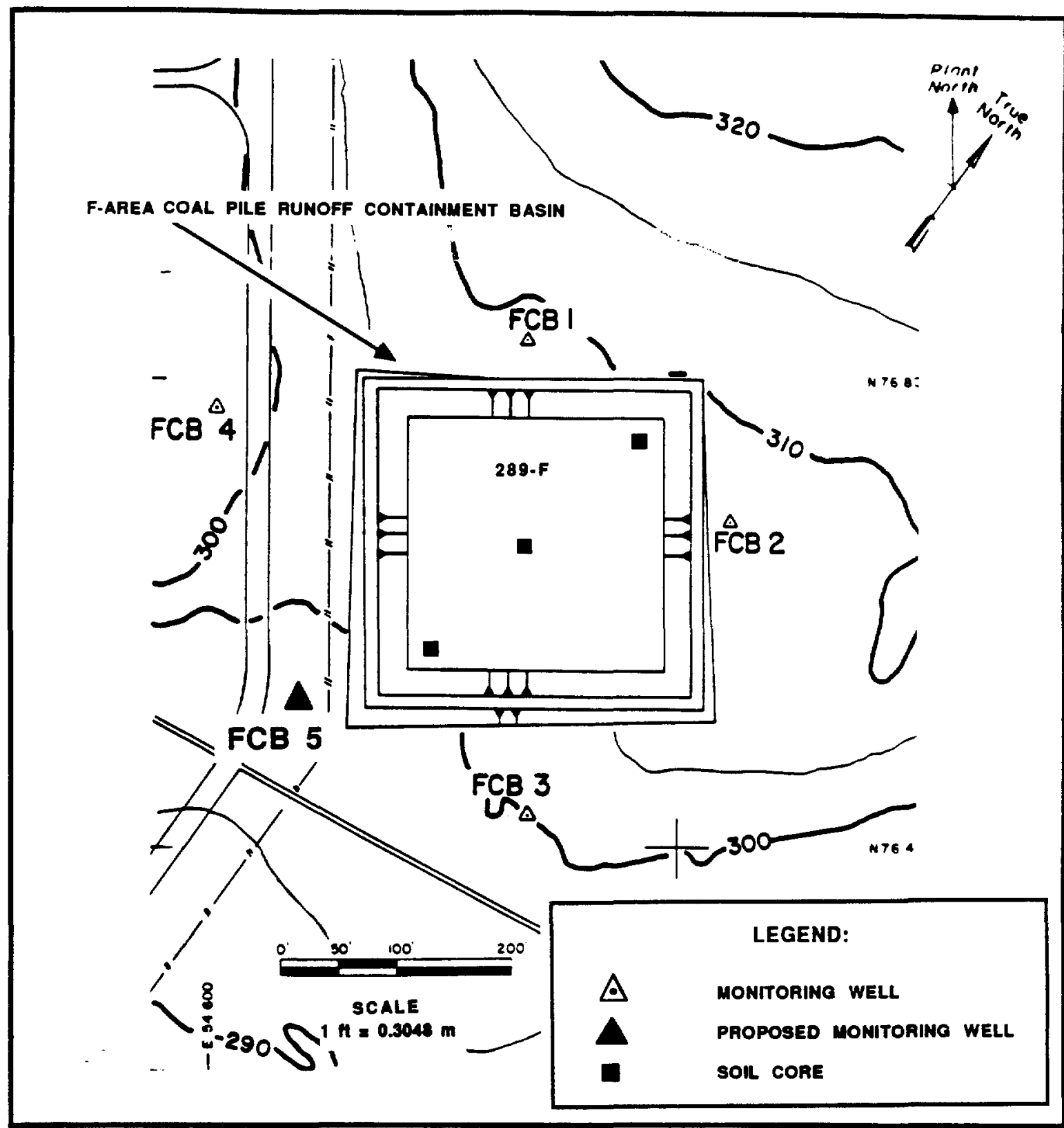

FIGURE H.8. Existing Konitoring Wells and Proposed Sampling Locations at the F-Area Coal Pile Runoff Containment Basin 


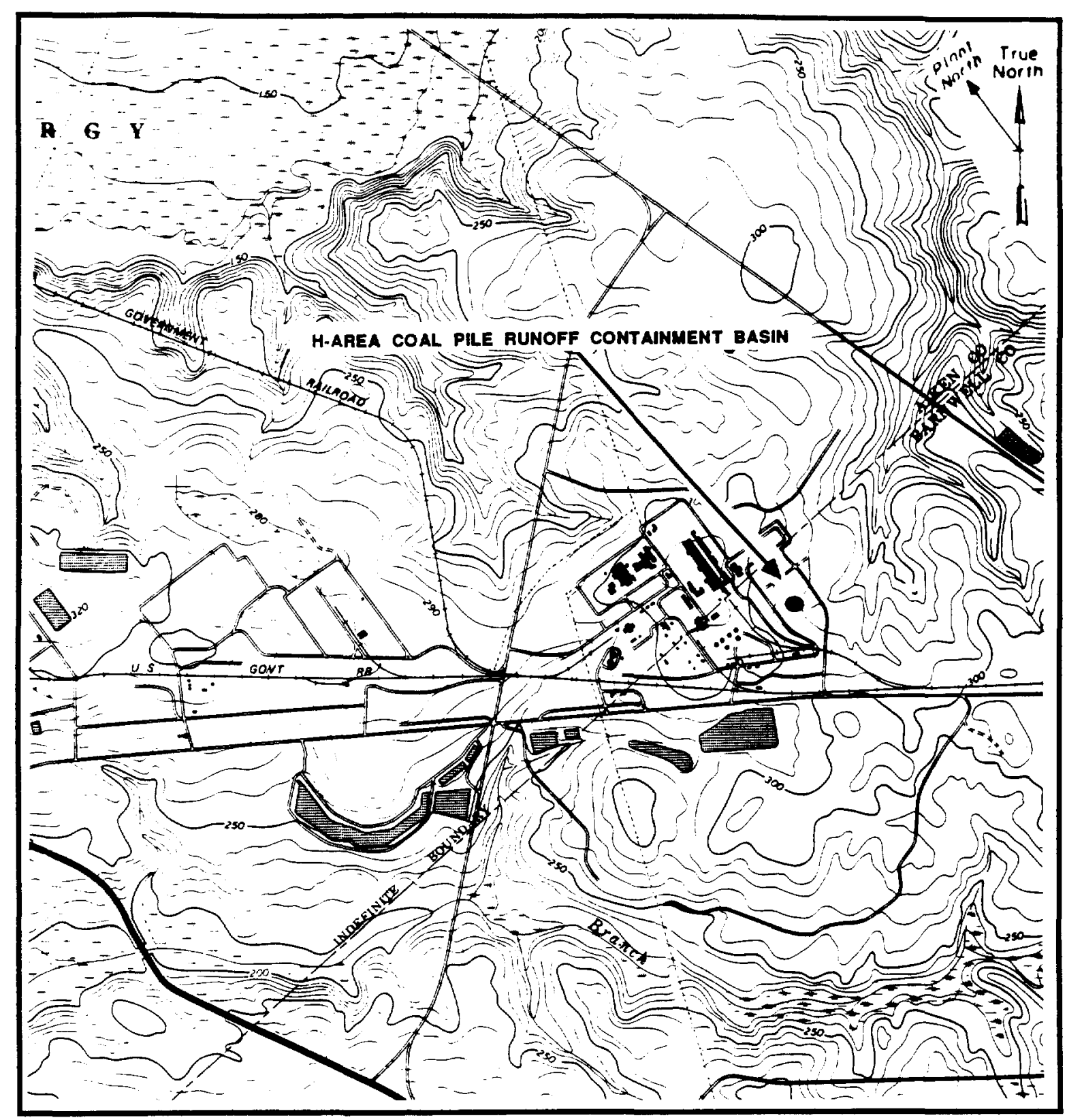

SCALE: 24000

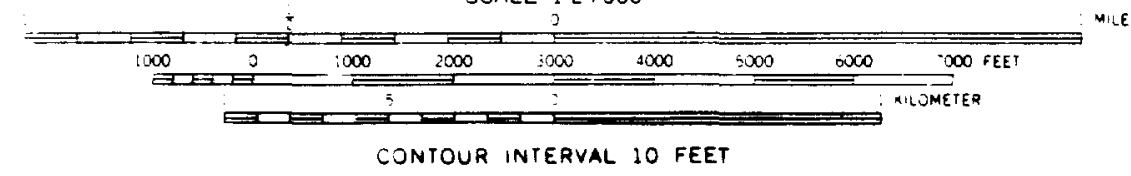

FIGURE H.9. Location of the B-Area Coal Pile Runoff Containment Basin on New Ellenton SW quadrangle 7.5 Minute Series Topographic Map 


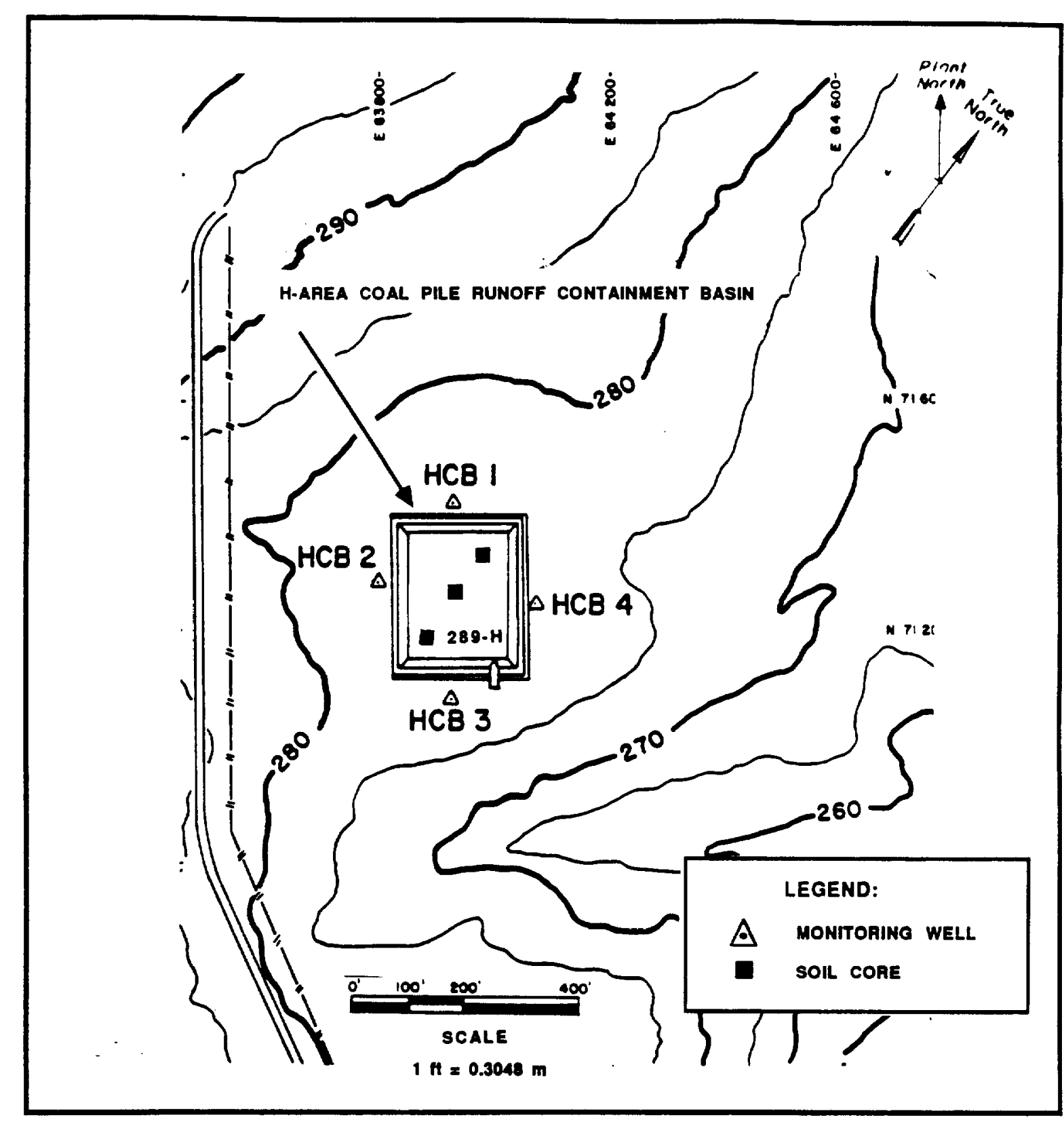

FIGURE H.10. Existing Konitoring Wells and Proposed Sanpling Locations at the B-Area Coal Pile Runoff Containment Basin 


\section{Characterization Recommendations}

Sampling

Three soil cores are recommended to determine the vertical extent of any potential contamination (Figure H.10). The cores should be taken to immediately above the water table. Samples for chemical analyses should be taken according to the parameters in Appendix Table 1. Splits of all soil samples should be archived at SRP.

Chemical and Physical Analyses

The soil cores should be analyzed according to the parameters given in Appendix Table 1. Specific analytes are metals (Appendix Table 2) and radioactivity (Appendix Table 4). Groundwater should be analyzed according to the parameters in Appendix Table 6.

\section{K-Area Coal Pile Runoff Containment Basin}

\section{Site Description}

The K-Area Coal Pile Runoff Containment Basin is located between Road $\mathrm{B}-3$ and the west side of Building $100-\mathrm{K}$, outside the perimeter fence (Figure H.11). The nearest plant boundary is over $9 \mathrm{~km}$ to the west. The area of the basin is $6,000 \mathrm{~m}^{2}$, and the depth of the basin is approximately $2 \mathrm{~m}$.

The K-Area Coal Pile Runoff Containment Basin is located on the Aiken Plateau at an elevation of approximately $80 \mathrm{~m}(260 \mathrm{ft})$. Surface drainage is to the south-southwest toward a small tributary of Indian Grave Branch.

Four groundwater monitoring wells with PVC casings were installed in 1981 (Figure H.12). Direction of groundwater flow is toward the west. Wells KCB 2 and 3 are located downgradient of the basin. However, a well located between them would better demonstrate downgradient groundwater conditions. Data from 1986 indicate that the water table is at a depth of approximately $15 \mathrm{~m}$ (Zeigler et al., 1987). 


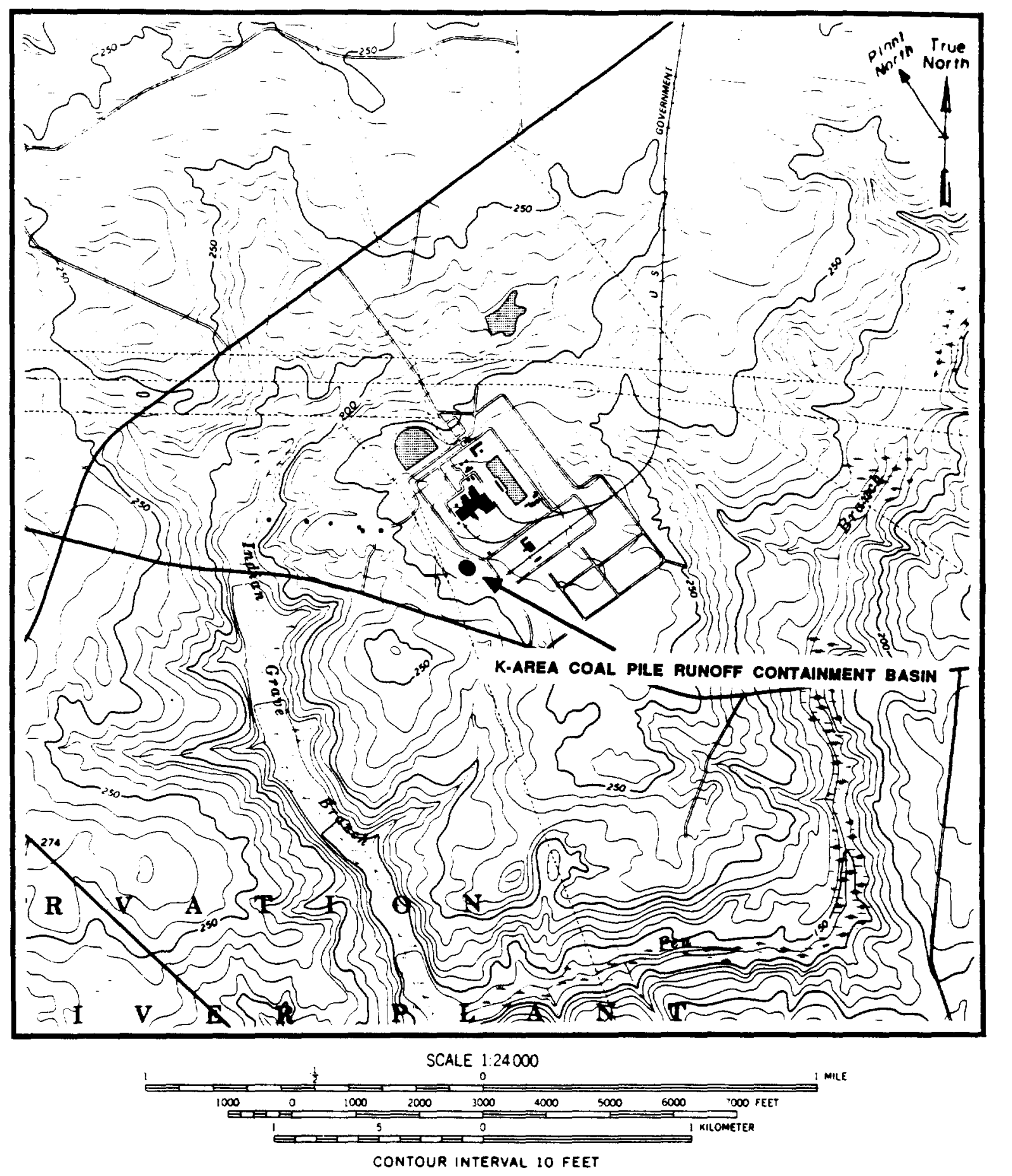

FIGURE H.11. Location of the K-Area Coal Pile Runoff Containment Basin on Girard NW Quadrangle 7.5 Minute Series Topographic Map 


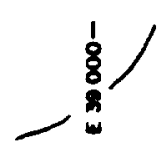

- in steoo

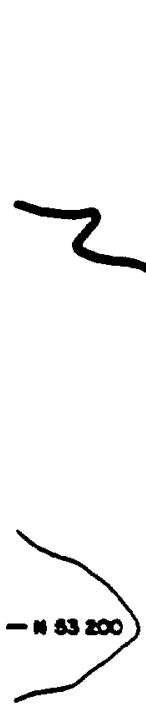

K-AAEA COAL PILE RUNOFF CONTAIMMENT BASIN
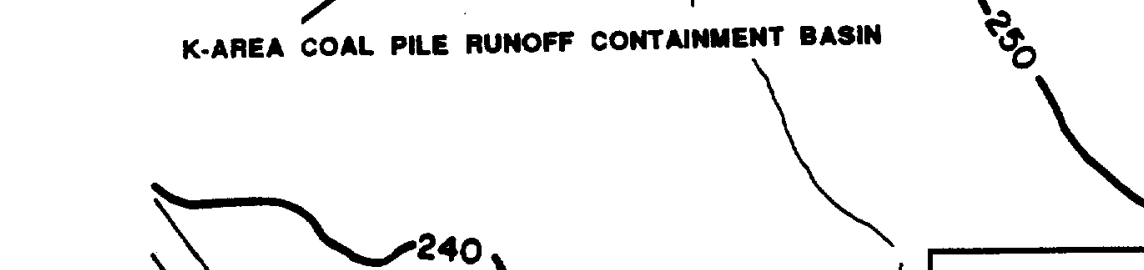

KCB 2

$\triangle$

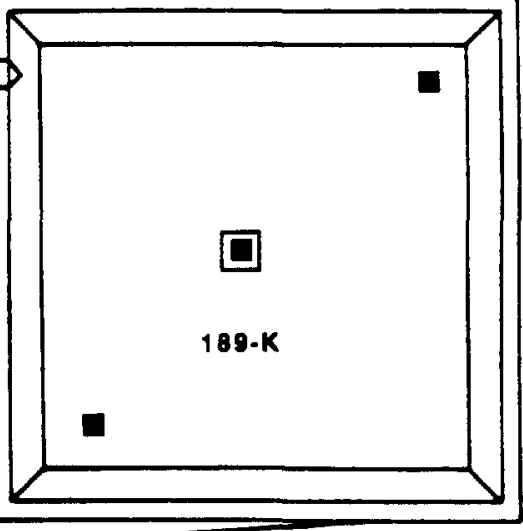

Kes

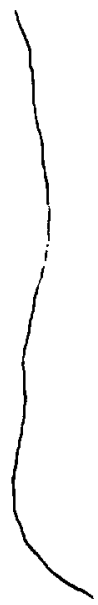

$\stackrel{8}{8} 4$

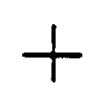

$+$

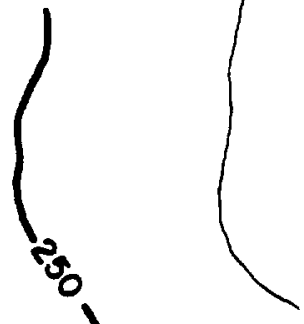

$o^{\prime}$

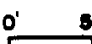

$0^{\prime} \quad 100$

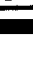

SCALE $1 n=0.3040 \mathrm{~m}$
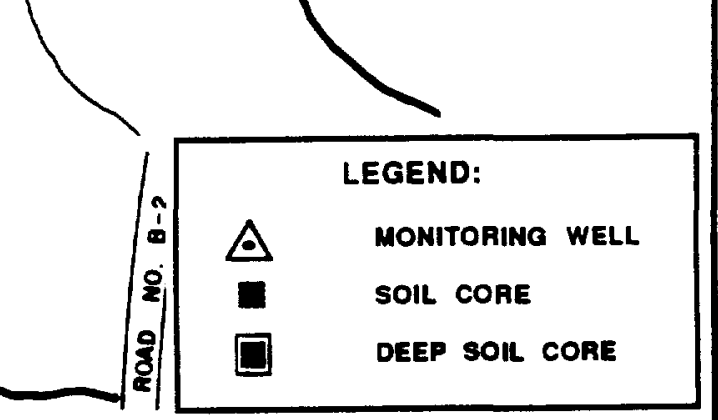

FIGURE H.12. Existing Monitoring Wells and Proposed Sampling Locations at the K-Area Coal Pile Runoff Containment Basin 


\section{Review of Available Data}

Groundwater data from this site show elevated TDS levels, although the values are still below groundwater quality review criteria (Appendix Table 10). The high TDS waters contain elevated concentrations of the major cations (calcium, magnesium, potassium, and sodium), sulfate, lead, and manganese (Mikol et al., in press; Zeigler et a1., 1987). The following radioactive parameters are present at levels above groundwater quality review criteria: gross alpha, radium, nonvolatile beta, and tritium (Appendix Table 10).

\section{Characterization Recommendations}

\section{Sampling}

Three soil cores, two taken to a depth of $6 \mathrm{~m}$ and one to immediately above the water table, are recommended to determine the vertical extent of the contamination, if any (Figure H.12). Samples for chemical analyses should be collected according to the parameters given in Appendix Table 1. Splits of all soil samples should be archived at SRP.

Chemical and Physical Analyses

The soil cores should be analyzed according to the parameters given in Appendix Table 1. Specific analytes are metals (Appendix Table 2) and radioactivity (Appendix Table 4). Groundwater should be analyzed according to the parameters listed in Appendix Table 6.

\section{P-Area Coal Pile Runoff Containment Basin}

\section{Site Description}

The P-Area Coal Pile Runoff Containment Basin is located opposite Building 185-P, outside the south end of the 100-P perimeter fence (Figure H.13). The nearest plant boundary is approximately $8.3 \mathrm{~km}$ to the east. The P-Area Coal Pile Runoff Containment Basin covers an area of approximately $9,000 \mathrm{~m}^{2}$ and is approximately $2 \mathrm{~m}$ deep.

The P-Area Coal Pile Runoff Containment Basin is located on the Aiken Plateau at an elevation of approximately $98 \mathrm{~m}(320 \mathrm{ft})$. Surface drainage is to the southeast toward a swamp at the headwaters of Meyers Branch. 


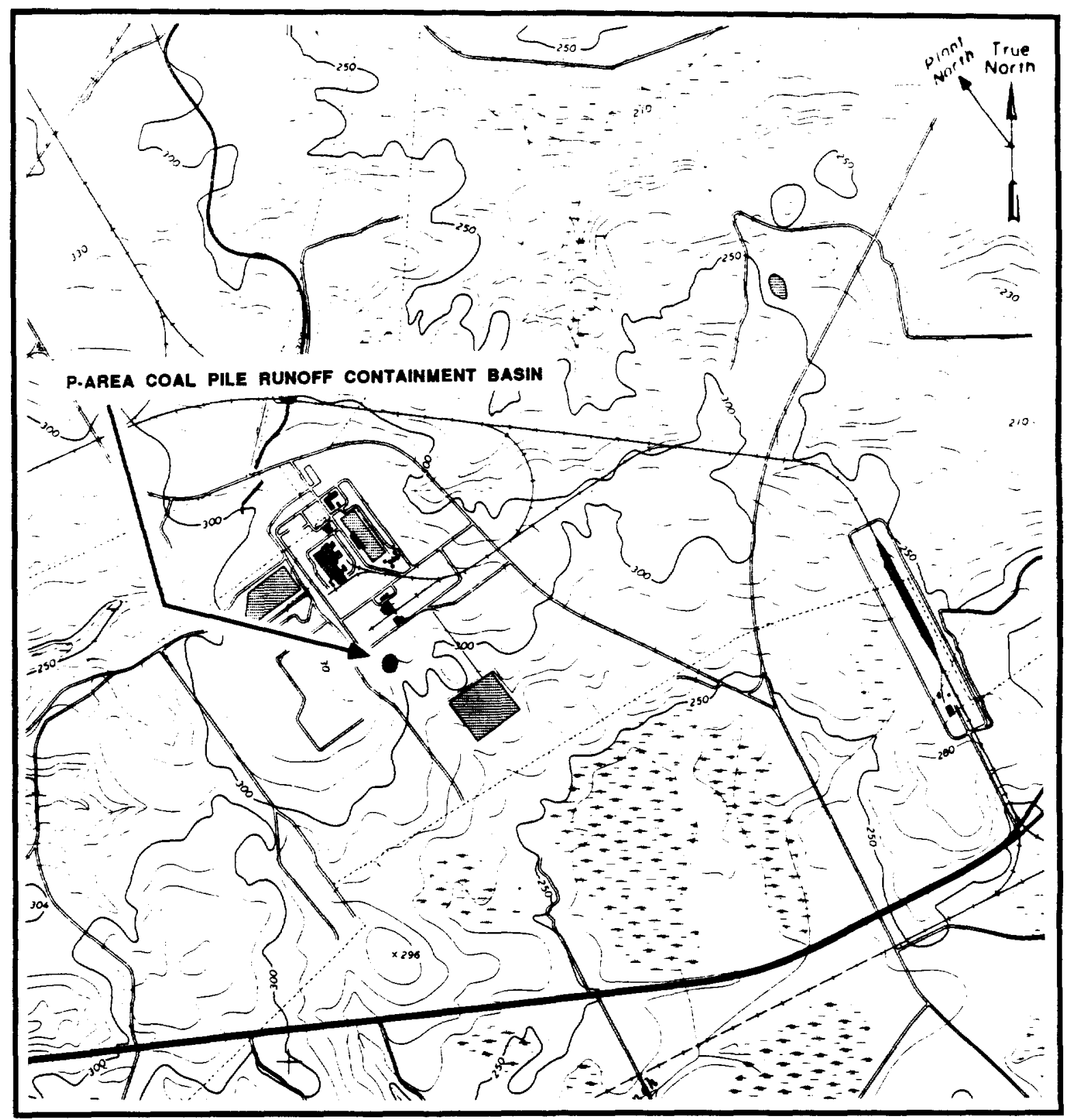

$$
\text { SCALE } 124000
$$

FIGURE H.13. Location of the P-Area Coal Pile Runoff Containment Basin on Girard NE Quadrangle 7.5 Minute Series Topographic Map 
Four groundwater monitoring wells were installed in 1980 . Because the wells were originally cased with steel, four replacement monitoring wells with PVC casings were installed in late 1983 and 1984 (Figure H.14). Groundwater flow is believed to be to the south. However, water-table elevations from the monitoring wells do not show a clear gradient in any one direction. It is likely that there is mounding of the water table beneath the basin. Data from 1986 indicate that the depth to the water table is approximately 6 to $9 \mathrm{~m}$ (Zeigler et al., 1987).

\section{Review of Available Data}

Groundwater at this site contains elevated TDS levels (Mikol et al., in press; Zeigler et a1., 1987). At we11 PCB 3A, the TDS level was 1,200 $\mathrm{mg} / \mathrm{L}$ for the first quarter of 1987. This level is well above groundwater quality review criteria (Appendix Table 10). The major cations (calcium, sodium, magnesium, potassium), sulfate, and some trace metals (cadmium, chromium, copper, iron, manganese, nickel, and selenium) are present at elevated levels in the groundwater. Elements present in concentrations above groundwater quality review criteria (Appendix Table 10) are copper, nickel, selenium, and sulfate.

\section{Characterization Requirements}

\section{Samp1ing}

Three soil cores to a depth of $6 \mathrm{~m}$ are recommended to determine the vertical extent of the contamination if any (Figure H.14). Samples for chemical analyses should be collected according to the parameters given in Appendix Table 1. Splits of all soil samples should be archived at SRP.

Due to the shallow depth to the water table and to the high conductivity of the groundwater within the plume, a terrain conductivity survey is recommended to determine the extent of the plume.

Chemical and Physical Analyses

The soil cores should be analyzed according to the parameters presented in Appendix Table 1. Specific analytes are metals (Appendix Table 2). Groundwater should be analyzed according to the parameters given in Appendix Table 6. 


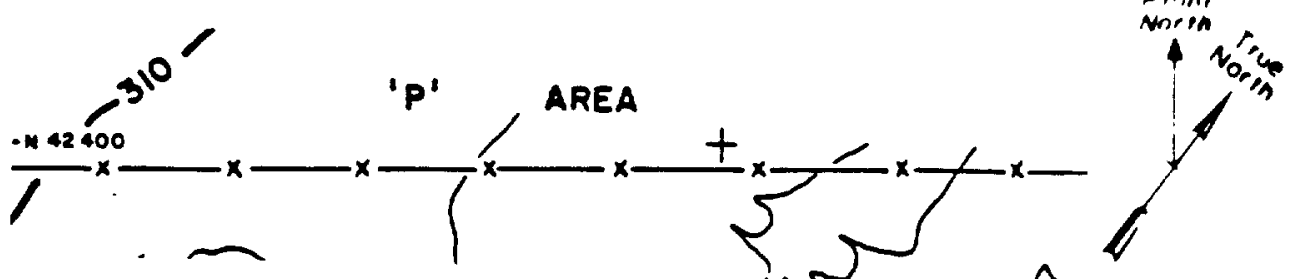

P.AREA COAL PLLE RUNOFF CONTAIMMENT BASIN
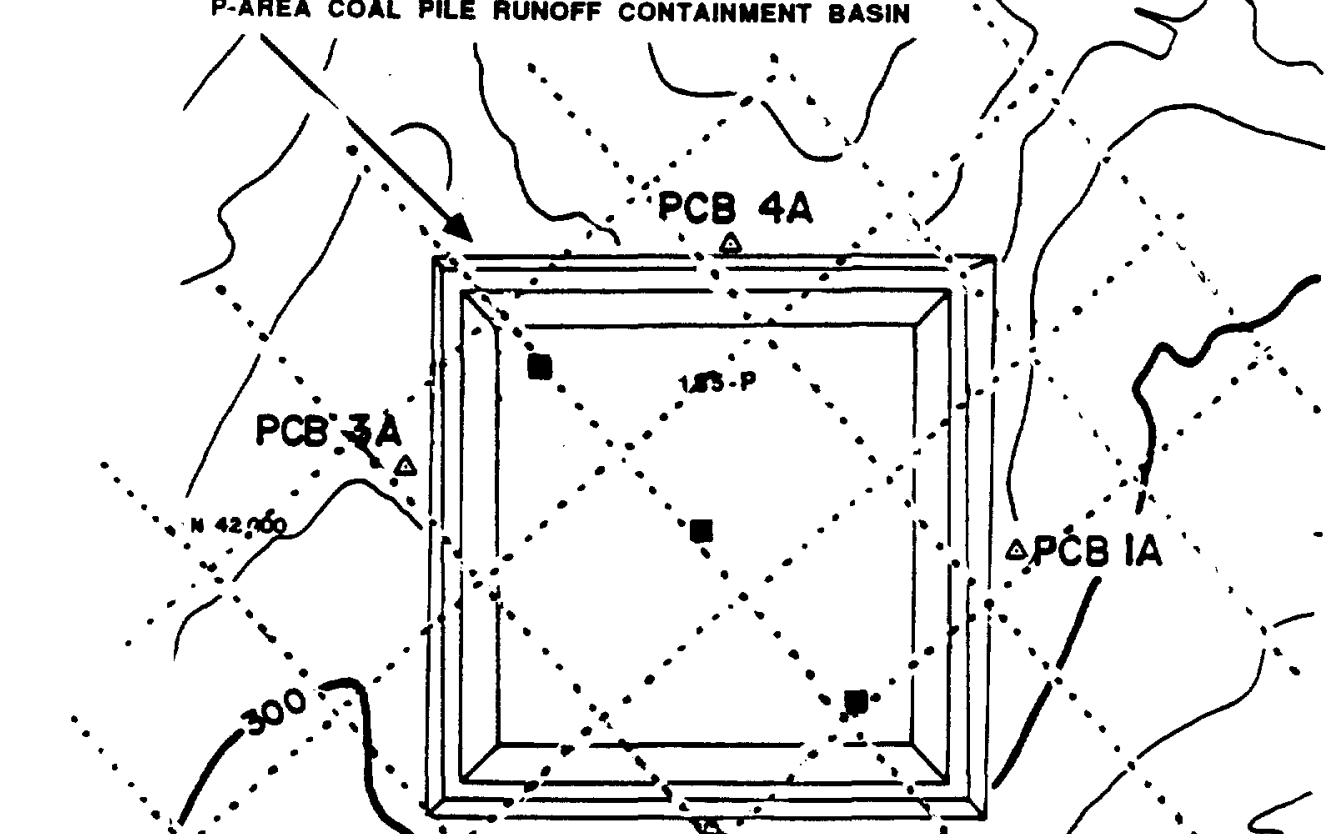


\section{Background}

\section{Site History}

Earthen Basins were constructed adjacent to the fuel unloading facilities (108 Buildings) in $\mathrm{C}, \mathrm{K}, \mathrm{L}, \mathrm{P}$, and $\mathrm{R}$ areas to contain overflow oil and water from the fuel oil loading pads and tanks. The only basin to ever receive any oil was the basin in $\mathrm{R}$-Area. There are no records of the volume of oil disposed in the R-Area Basin. To date, only the P-Area basin has been closed.

\section{Site Description}

C Area

The C-Area Earthen Basin is located south of the C-Area reactor at an elevation of $88.5 \mathrm{~m}(290 \mathrm{ft}$ ) (Figure I.1). The basin was constructed by placing an asphalt berm around an aboveground oil tank.

$\mathrm{K}$ Area

The $\mathrm{K}$-Area Earthen Basin is located south of the $\mathrm{K}$-Area reactor at an elevation of $83.8 \mathrm{~m}(275 \mathrm{ft}$ ) (Figure I.2). The basin was constructed by placing an asphalt berm around an aboveground oil tank.

L Area

The L-Area Earthen Basin is located east of the L-Area reactor at an elevation of $75.6 \mathrm{~m}(278 \mathrm{ft}$ ) (Figure $\mathrm{I} .3$ ). The basin was constructed by placing an asphalt berm around an aboveground oil tank.

P Area

The P-Area Earthen Basin is located southeast of the P-Area reactor at an elevation of $100.7 \mathrm{~m}$ (330 ft) (Figure 1.4$)$. The basin was constructed adjacent to an underground storage tank. The basin has been backfilled and closed.

\section{R Area}

The R-Area Earthen Basin is located southwest of the $\mathrm{R}$-Area reactor at an elevation of $100 \mathrm{~m}$ (328 ft) (Figure $\mathrm{I} .5$ ). The basin was constructed near the R-Area storage tank and is reported to have received some oil. Currently there are freestanding liquids in the basin. 


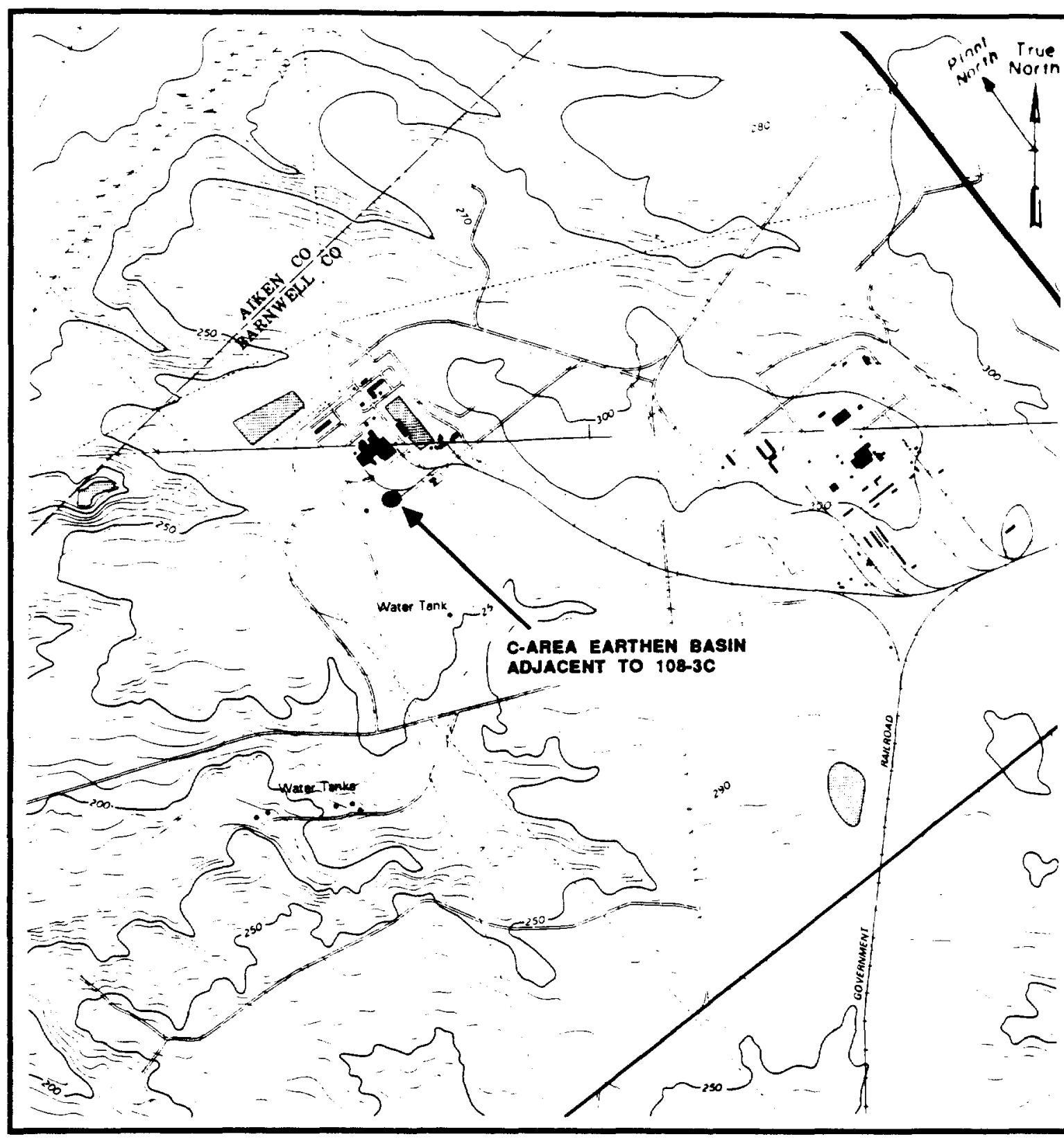

SCALE : 24000

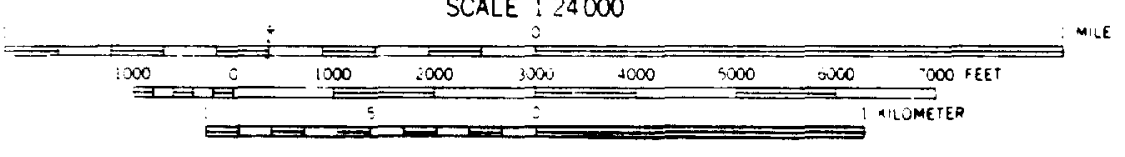

CONTOUR INTERVAL 10 FEET

FIGURE I.1. Location of the C-Area Earthen Basin on New Ellenton SW and Girard NW Quadrangle 7.5 Minute Series Topographic Maps 


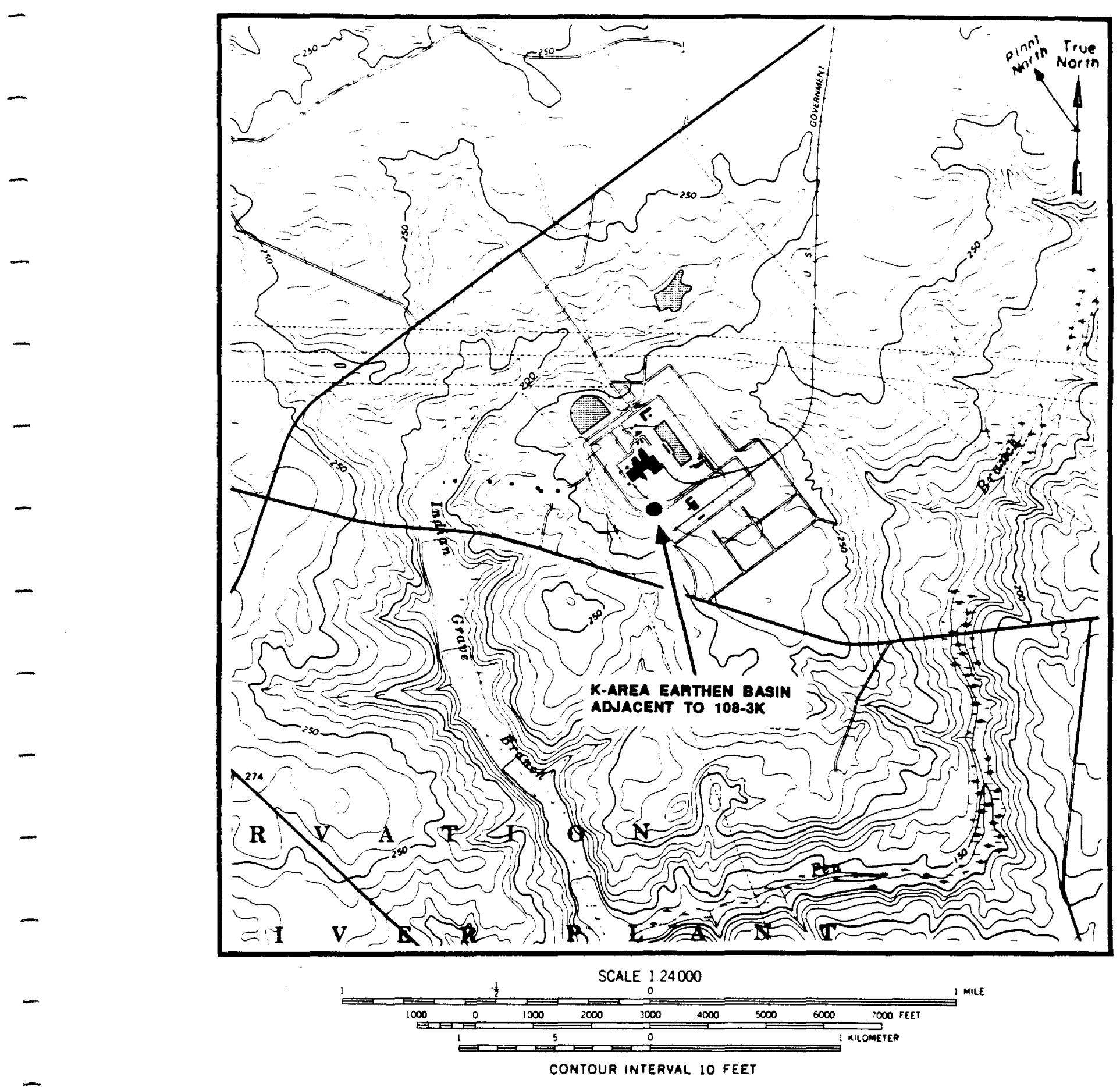

FIGURE I.2. Location of the K-Area Earthen Basin on Girard NW
Quadrangle 7.5 Minute Series Topographic Map 

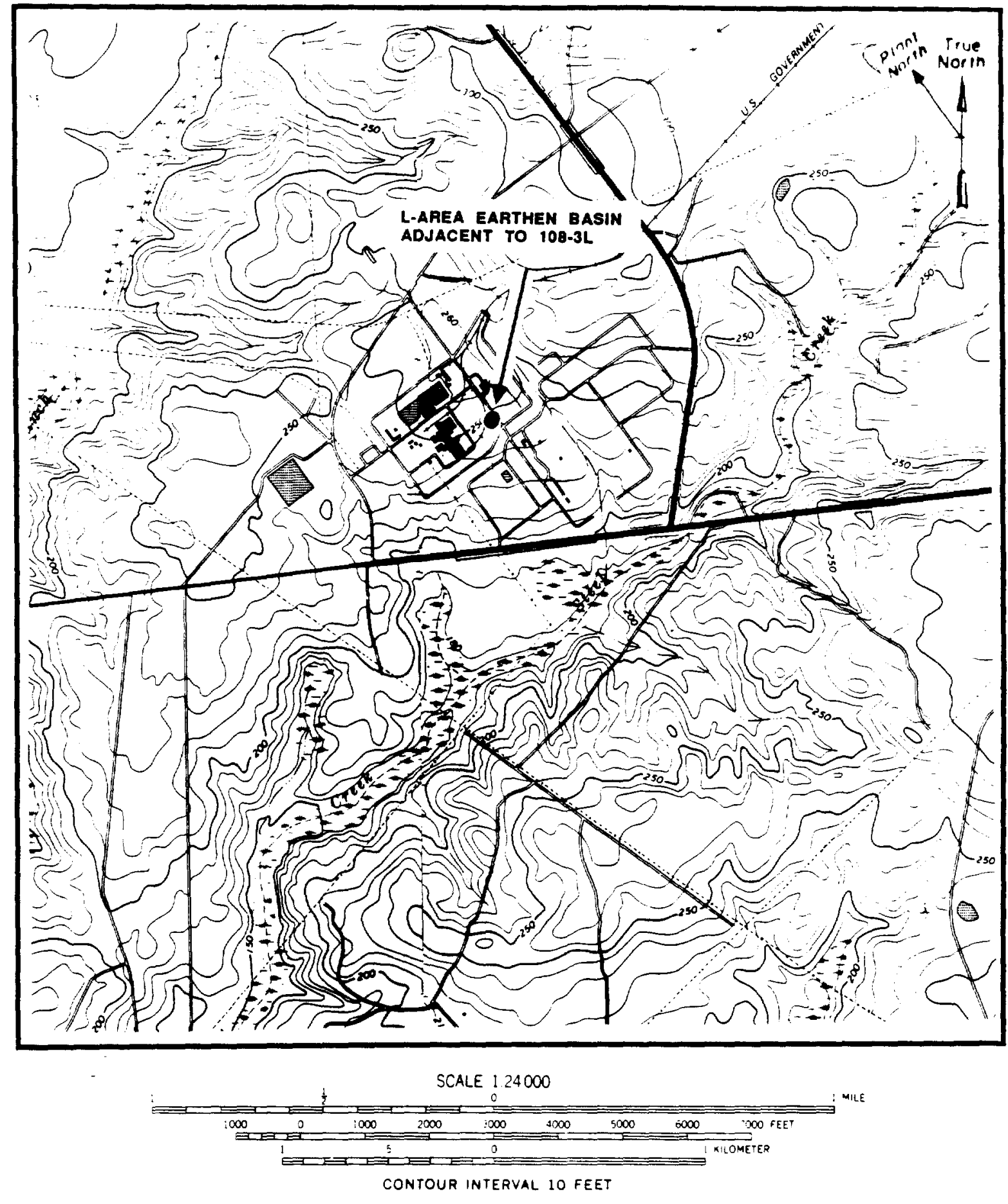
FIGURE I.3. Location of the L-Area Earthen Basin on Girard NW
Quadrangle and Girard NE Quadrangle 7.5 Minute Series
Topographic Maps 

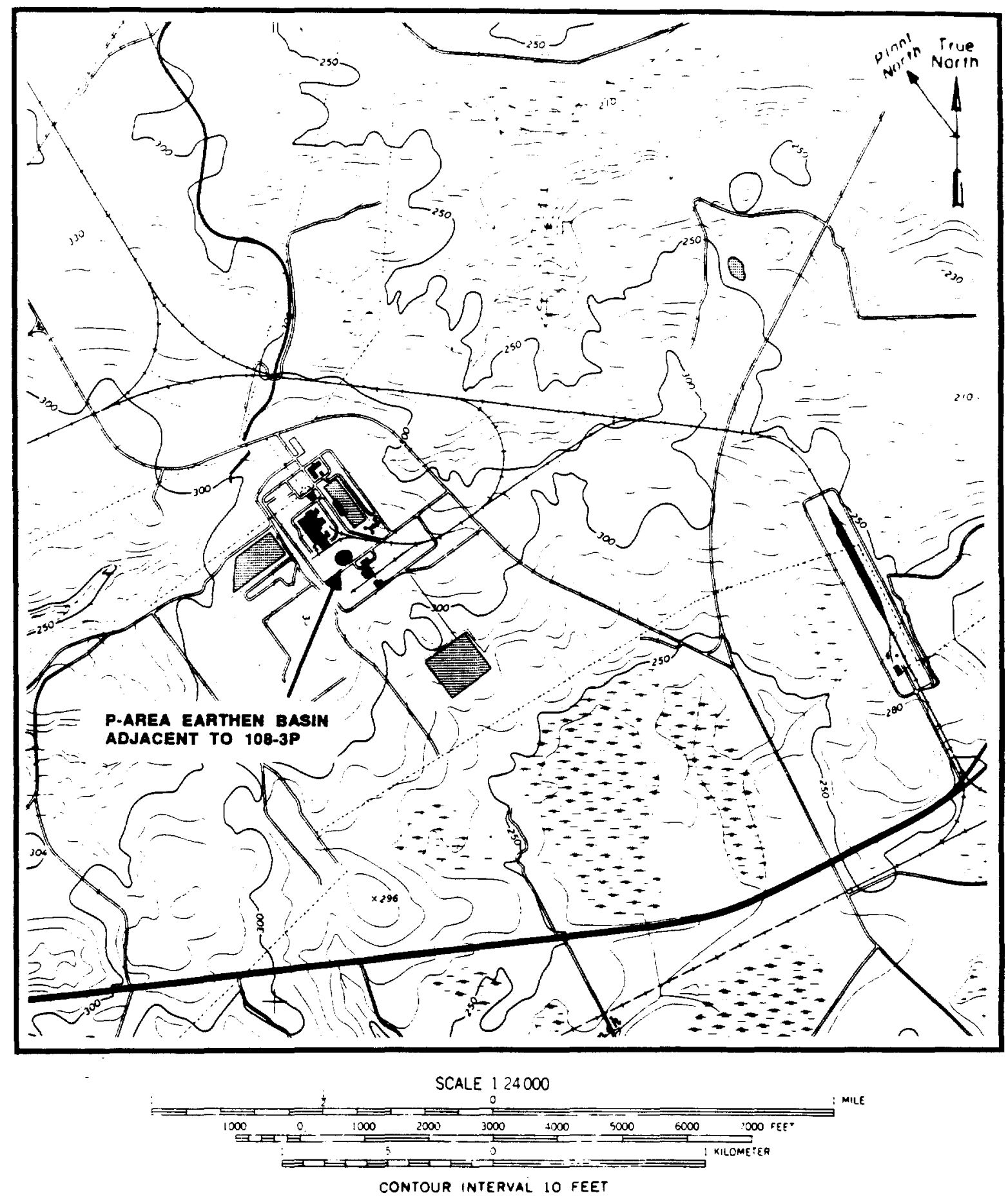

FIGURE I.4. Location of the P-Area Earthen Basin on Girard NE Quadrangle 7.5 minute Series Topographic Map 


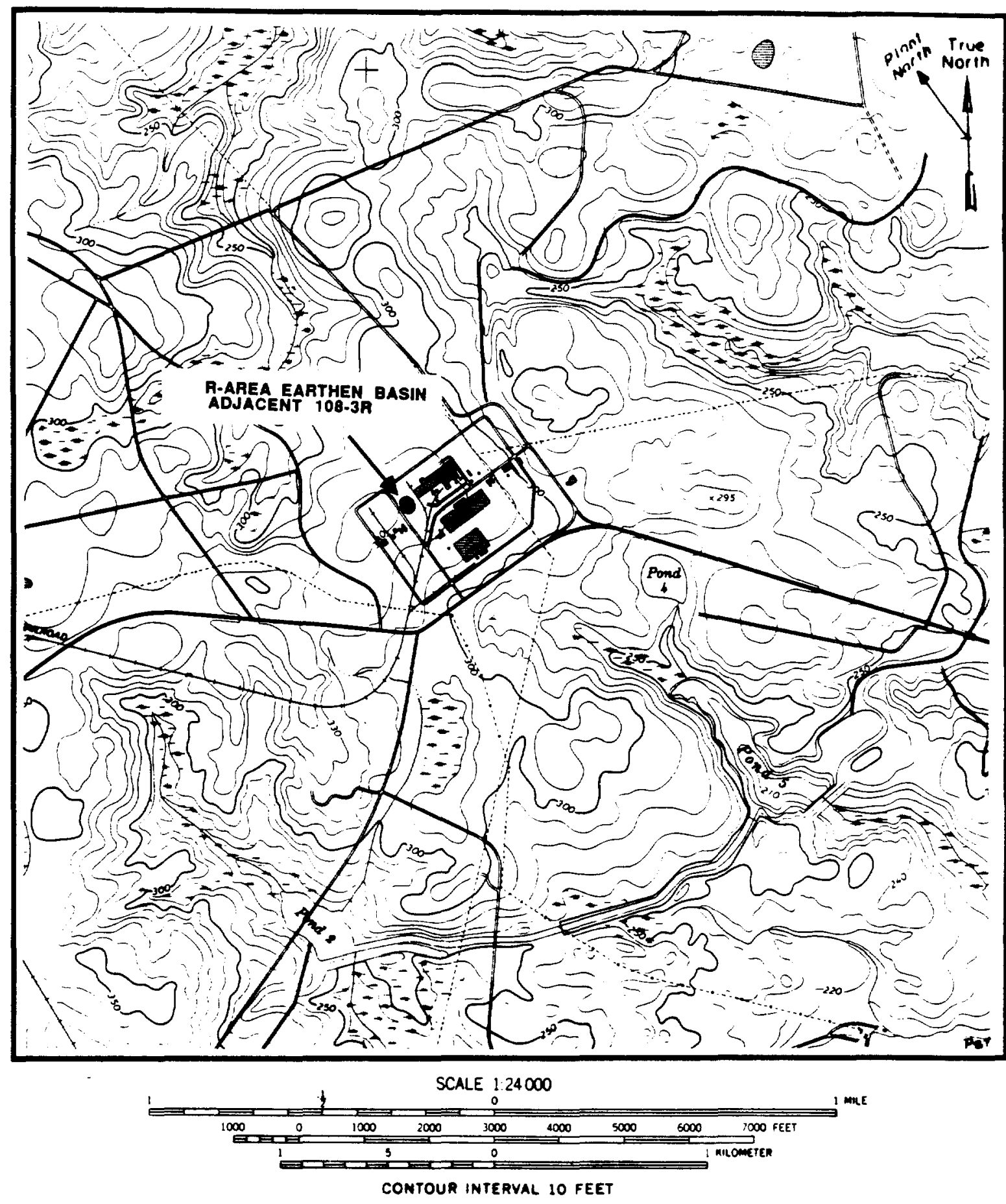

FIGURE I.5. Location of the R-Area Earthen Basin on New Ellenton SE quadrangle 7.5 Minute Series Topographic Map 
Review of Available Data

Currently there are no data available on any of these sites.

Characterization Recommendations

Sampling

No characterization is required for the $\mathrm{C}-, \mathrm{K}-, \mathrm{L}-$, and $\mathrm{P}-\mathrm{Area}$ earthen basins. Two 4-m deep soil cores and two samples of liquid should be taken in the R-Area Earthen Basin to verify the absence or presence of any remaining oil. Soil sampling intervals are those 1 isted in Appendix Table 1 .

\section{Chemical and Physical Analyses}

The soil sample analysis should include the parameters 1 isted in Appendix Table 1, with specific analytes to include Total Recoverable 0i1 and Grease as defined in EPA Test Method 9070. Liquid samples should be analyzed for $\mathrm{pH}$ and Total Recoverable $0 \mathrm{il}$ and Grease as defined in EPA Test Method 9070 . 


\section{Background}

\section{Site History}

The Erosion Control Sites are locations where inert materials such as waste concrete, asphalt, bricks, roofing materials, and stumps were used for slope stabilization and erosion control (Christensen and Gordon, 1983). The sites are currently active and continued use is planned. Table J.1 lists the Erosion Control Sites and their building numbers and SRP coordinates.

\section{Site Description}

C Area

The C-Area Erosion Control Site is located on the west side of the 100-C effluent canal, directly south of the C-Area perimeter fence (Figure J.1). The site has an elevation of $86.9 \mathrm{~m}(285 \mathrm{ft})$ and dimensions of 7.6 by 305 by $1.5 \mathrm{~m}$. The surface area is $2,318 \mathrm{~m}^{2}$. Surface drainage is to the southeast toward a tributary of Four Mile Creek.

\section{F Area}

The F-Area Erosion Control Site is located approximately $1,220 \mathrm{~m}$ west of the F-Area perimeter fence on the south side of SRP Road C (Figure J.2). The site has an elevation of $65.6 \mathrm{~m}(215 \mathrm{ft})$ and covers $8,090 \mathrm{~m}^{2}$. Surface drainage is to the west toward a tributary of Four Mile Creek.

\section{H Area}

The H-Area Erosion Control Site is located south of Road 4 and west of Road E-1, approximately $610 \mathrm{~m}$ southwest of the H-Area perimeter fence (Figure $\mathrm{J} .3)$. The site has an elevation of $82.4 \mathrm{~m}(270 \mathrm{ft})$ and covers $60,700 \mathrm{~m}^{2}$. Surface drainage is to the west toward a tributary of Four Mile Creek.

L Area

The L-Area Erosion Control Site is located approximately $915 \mathrm{~m}$ northeast of the L-Area perimeter fence (Figure J.4). The site has an elevation of $70 \mathrm{~m}$ $(230 \mathrm{ft})$ and covers $24,200 \mathrm{~m}^{2}$. Surface drainage is to the west-southwest toward a tributary of Pen Branch. 
TABLE J.1

Erosion Control Site Building Numbers and SRP Coordinates (Center)

Erosion Control Site

C Area

F Area

H Area

I Area

P Area

Substation 51

3G Pumphouse

S Area

D-F Steamline
B1dg No.

131-1C

080-28G

080-25G

080-26G

131-1P

$080-27 G$

631-8G

NA

NA
SRP Coordinates

N 46350 E 52630

N 79900 E 48750

N 71000 E 60000

N 50500 E 49000

N 45135 E 64060

N 76000 E 33000

N 67500 E 17100

N 72550 E 66250

N 66770 E 29340

Note: $\mathrm{NA}=$ not applicable. 


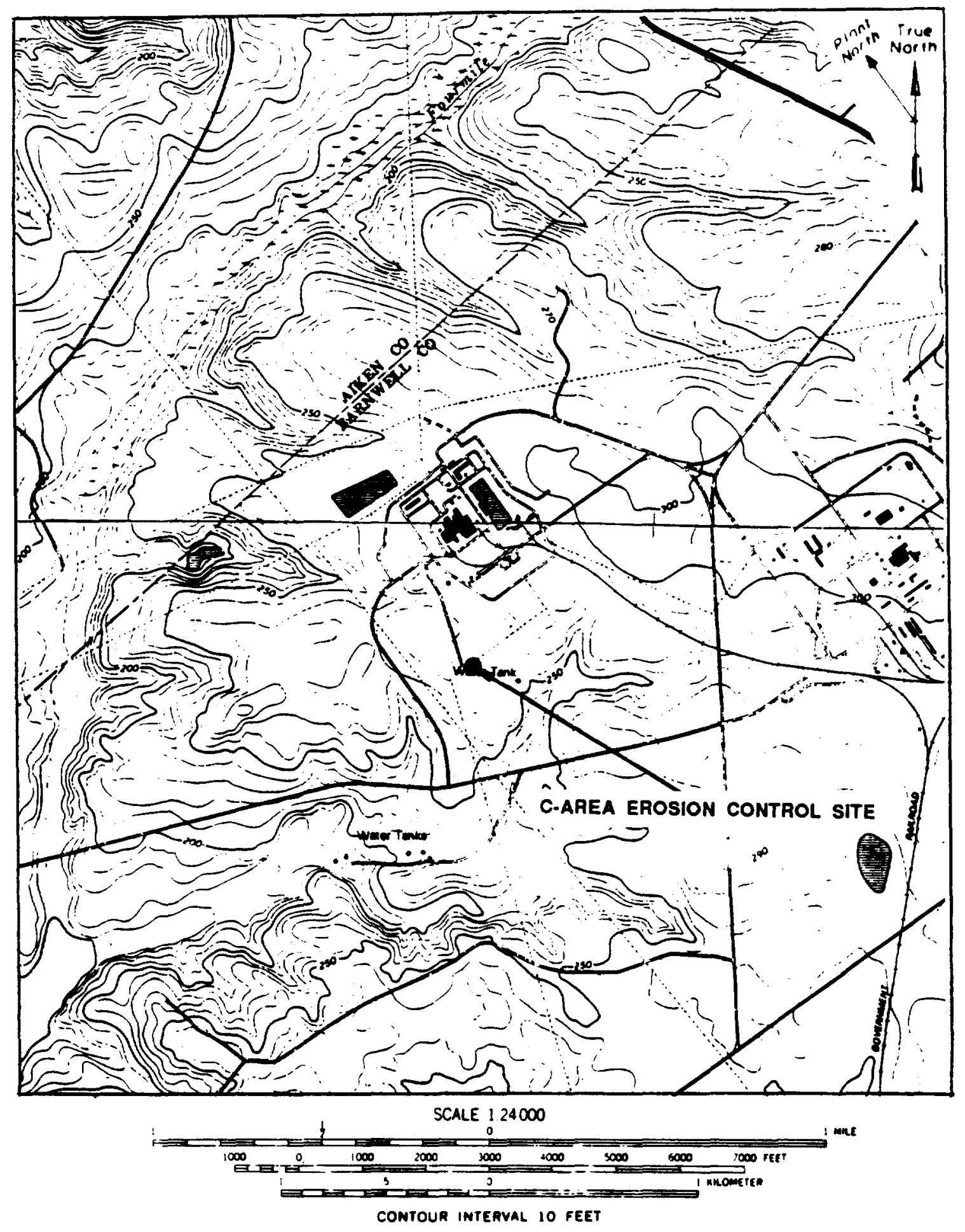

FIGURE J.1. Location of the C-Area Erosion Control Site on Girard
NW and New Ellenton SW Quadrangle 7.5 Minute Series
Topographic Maps 


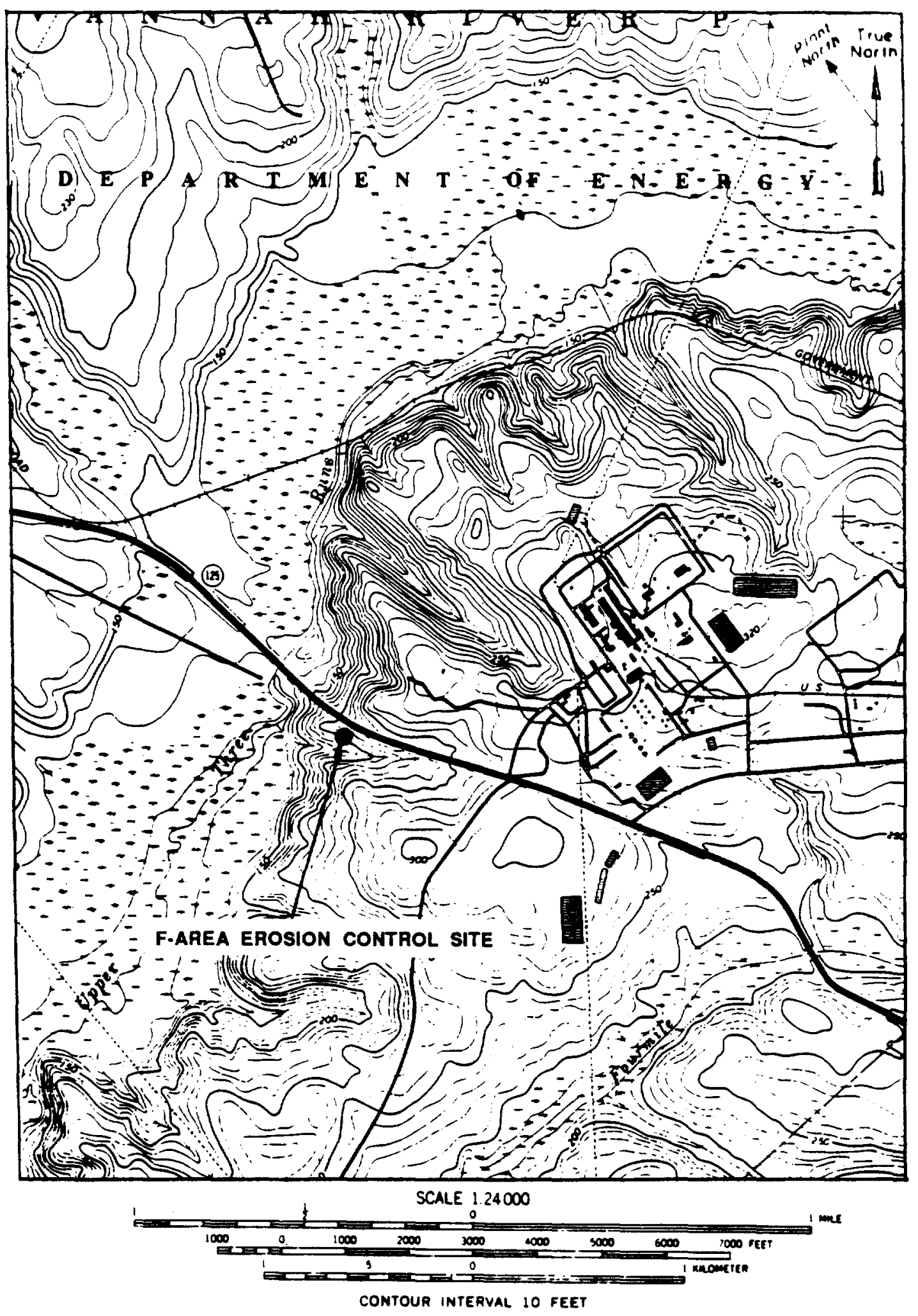

FIGURE J.2. Location of the F-Area Erosion Control site on New Ellenton NW Quadrangle 7.5 Minute Series Topographic Map 

Ellenton NW Quadrangle 7.5 Minute Series Topographic Map 


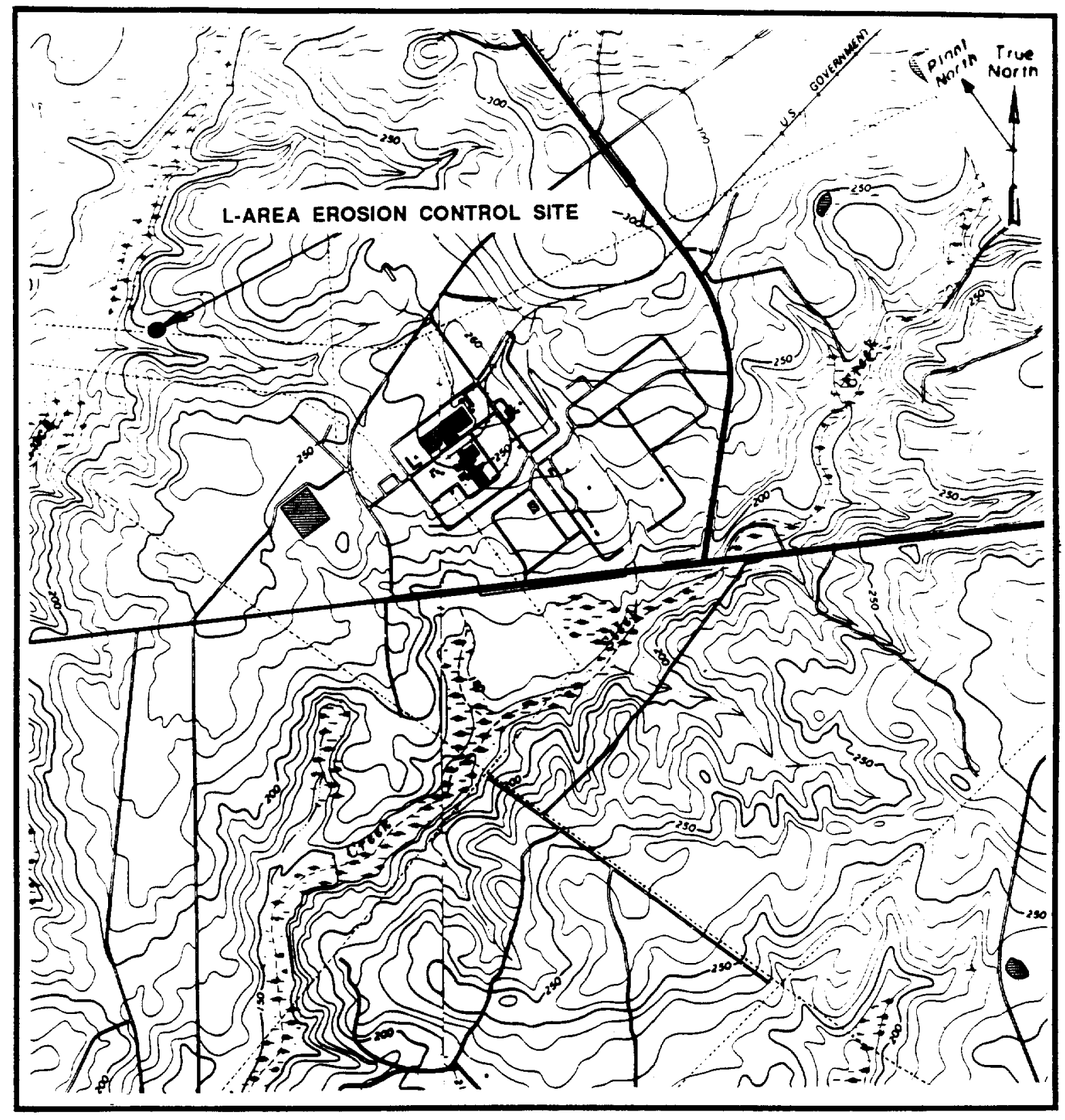

SCALE 124000

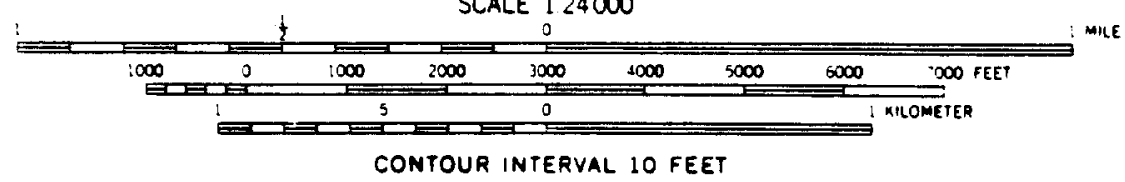

FIGURE J.4. Location of the L-Area Erosion Control Site on New Ellenton NW Quadrangle 7.5 Minute Series Topographic Map 


\section{Substation 51}

The Substation 51 Erosion Control Site is located north of Substation 51 approximately $3.37 \mathrm{~km}$ north-northeast of the D-Area perimeter fence (Figure $\mathrm{J} .5)$. The site has an elevation of $73.2 \mathrm{~m}(240 \mathrm{ft})$ and covers $371.6 \mathrm{~m}^{2}$. Surface drainage is to the southwest toward the Savannah River.

\section{G Pumphouse}

The 3G-Pumphouse Erosion Control Site is located $915 \mathrm{~m}$ west of $D$ Area at a water intake from the Savannah River (Figure J.6). The site has an elevation of $33.5 \mathrm{~m}$ (110 ft) and covers approximately 43,000 $\mathrm{m}^{2}$. Surface drainage is northwest into a tributary of the intake canal.

P Area

The P-Area Erosion Control Site is located $1.5 \mathrm{~km}$ northwest of P Area on the bank of Steel Creek (Figure J.7). The site has an elevation of $88.4 \mathrm{~m}$ $(290 \mathrm{ft})$, and surface drainage is to the northwest.

\section{S Area}

The proposed S-Area Erosion Control Site is located $850 \mathrm{~m}$ northeast of $\mathrm{H}$ Area on the bank of an intermittent stream at the Road F crossing (Figure $\mathrm{J.8})$. The site has an elevation of $65.5 \mathrm{~m}(215 \mathrm{ft})$, and surface drainage is to the north-northeast. This site was never officially established and never received any fill material.

\section{D-F Steamline}

The D-F Steaml ine Erosion Control Site is located 3,355 m northeast of D Area between Road 3 and Highway 125 (Figure J.9). The site has an elevation of $64 \mathrm{~m} \mathrm{(210} \mathrm{feet),} \mathrm{and} \mathrm{surface} \mathrm{drainage} \mathrm{is} \mathrm{to} \mathrm{the} \mathrm{southeast} \mathrm{toward} \mathrm{Four} \mathrm{Mile}$ Creek. This site has been officially established but has not received fill material to date.

Review of Available Data Sites.

Currently there are no analytical data for any of the Erosion Control

\section{Characterization Recommendations}

Because there were no hazardous or radioactive materials used to construct the Erosion Control Sites, they do not pose a threat to the environment and require no further characterization effort. 


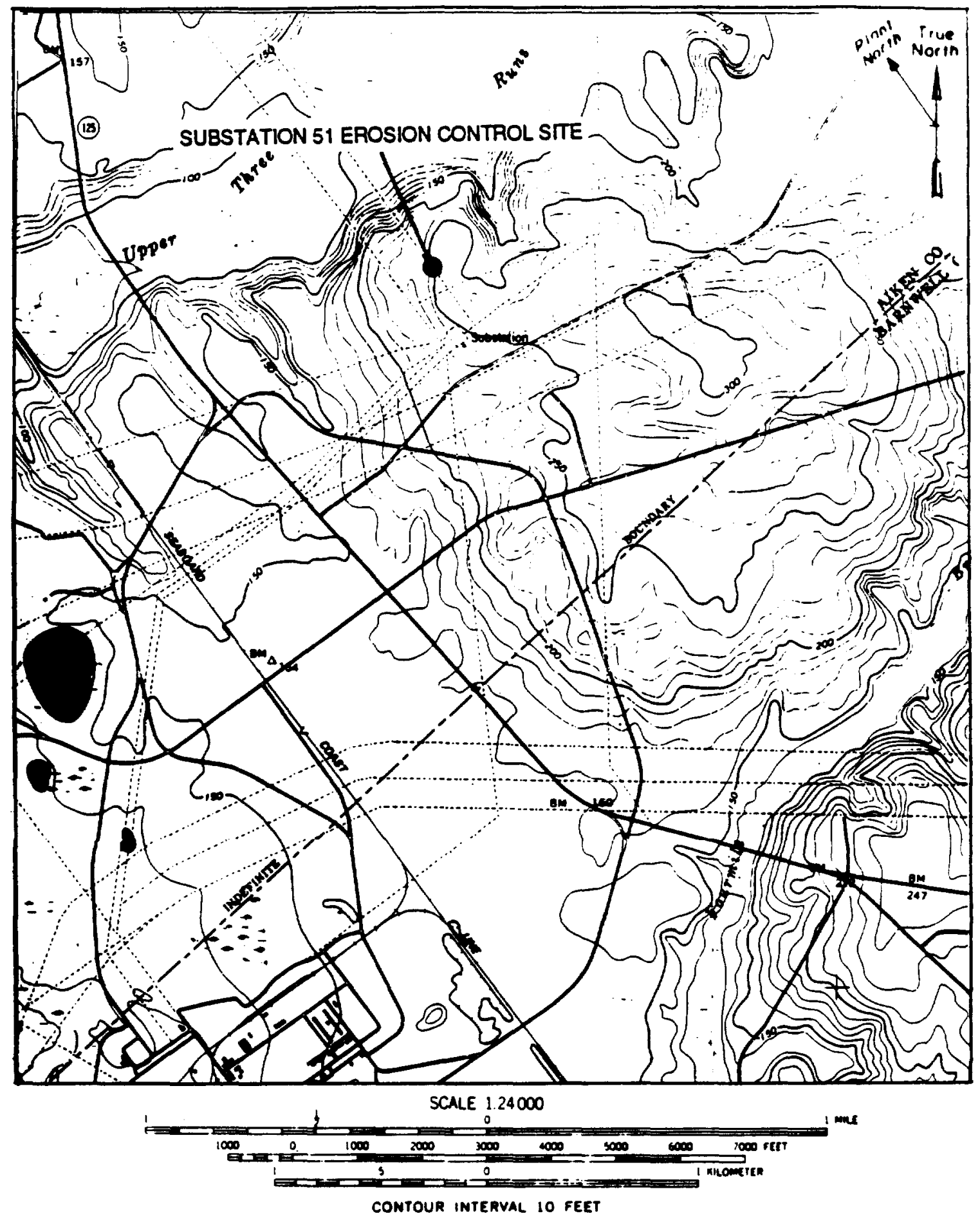

FIGURE J.5. Location of the Substation 51 Erosion Control Site on New Ellenton NW Quadrangle 7.5 Minute Series Topographic Map 


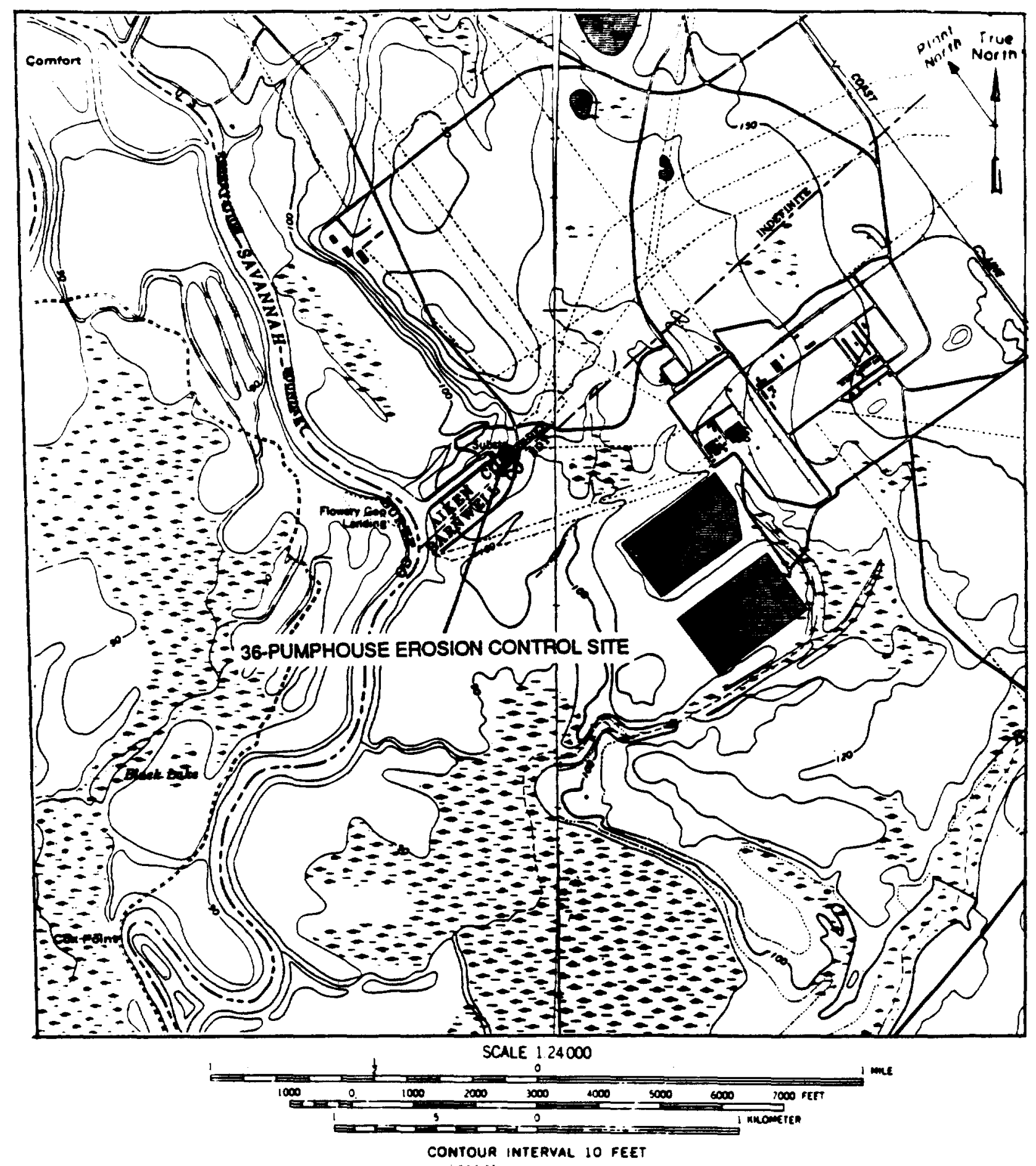

FIGURE J.6. Location of the 3G-Pumphouse Erosion Control Site on New Ellenton NW Quadrangle 7.5 Minute Series Topographic Map 

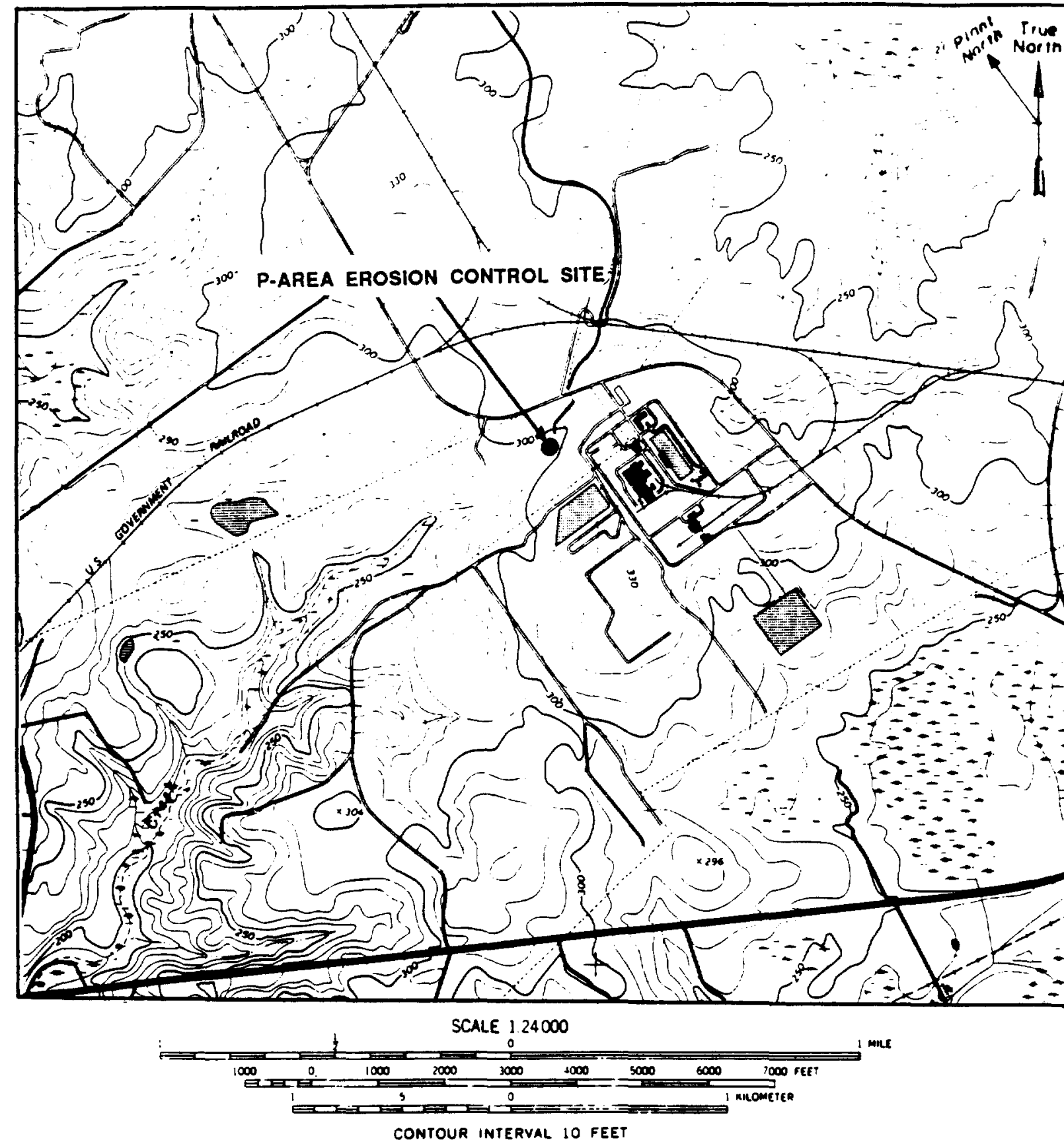

FIGURE J.7. Location of the P-Area Erosion Control Site on Girard NW Quadrangle 7.5 Minute Series Topographic Map 


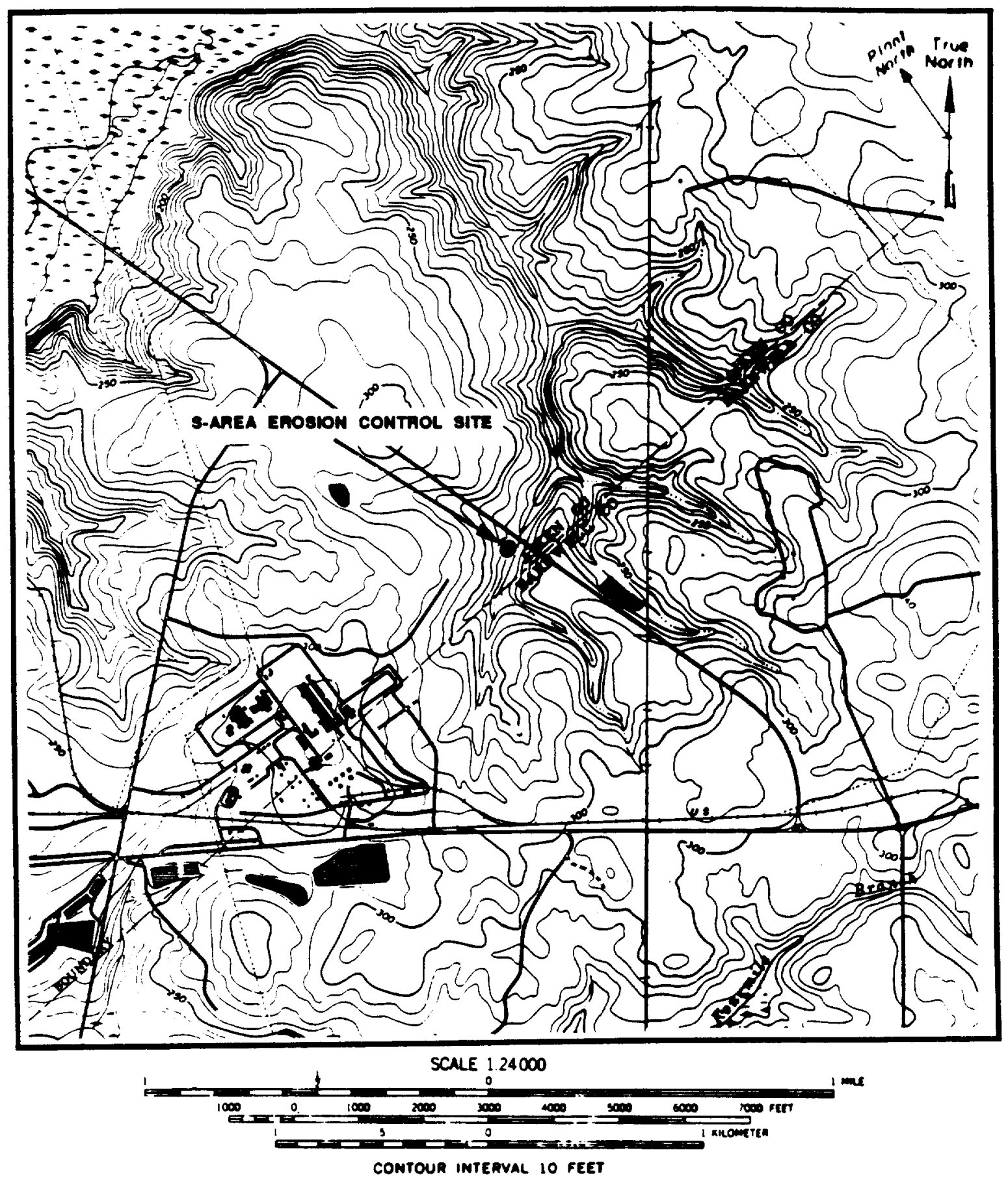

FIGURE J.8. Location of the S-Area Erosion Control Site on New Ellenton SW Quadrangle 7.5 Minute Series Topographic Map 

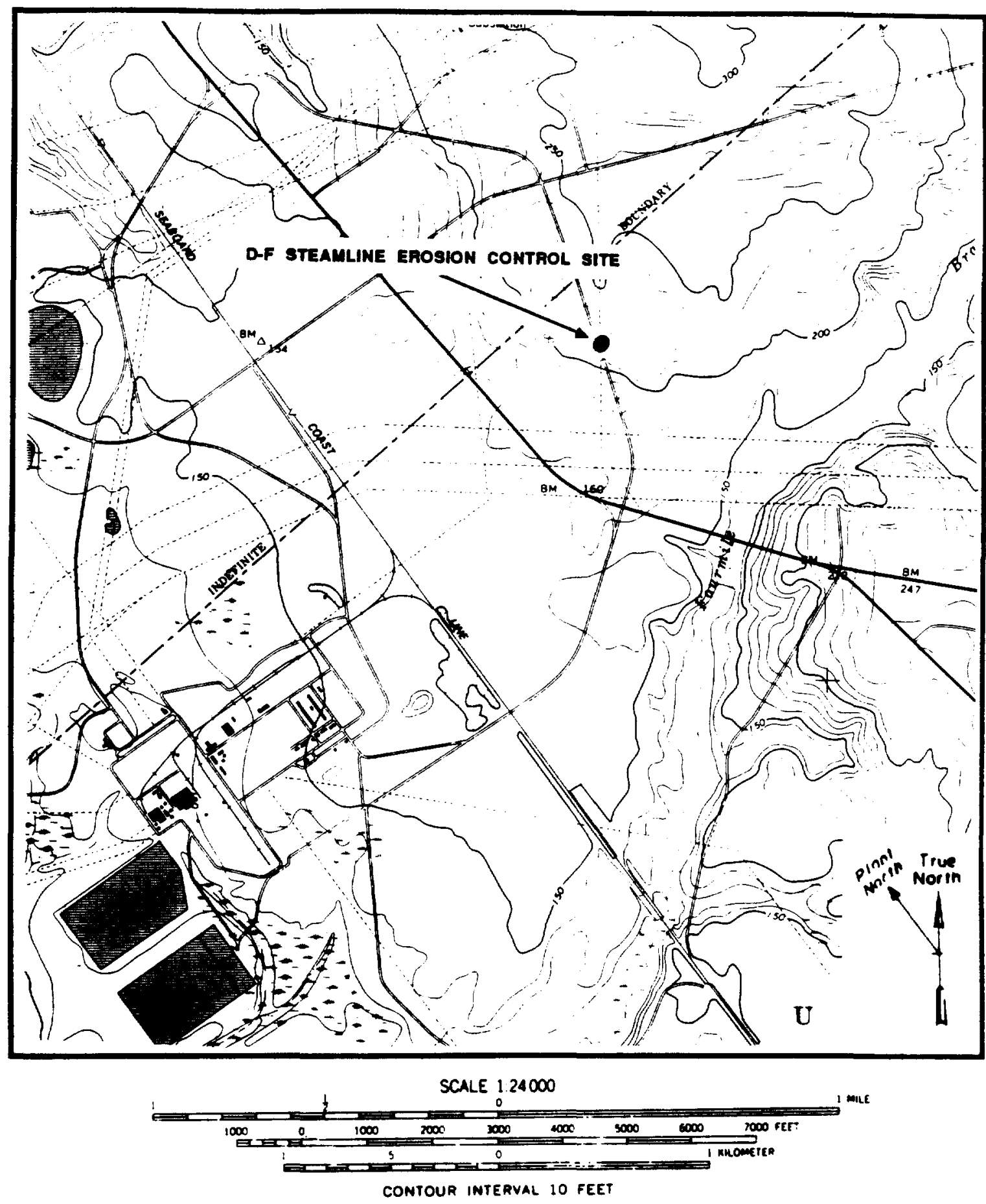

FIGURE J.9. Location of the D-F Steamline Erosion Control Site on Girard NW quadrangle 7.5 Minute Series Topographic Map 


\section{Background}

Site History

The F-Area Seepage Basins (Buildings 904-41G, 904-42G, and 904-43G) were placed in service in 1955 to replace the 01d F-Area Seepage Basin. These seepage basins routinely receive evaporator overhead containing low-leve 1 radioactivity and chemicals from the F-Area separations facilities. This wastewater typically contains significant amounts of nitrate, sodium, and tritium (Christensen \& Gordon, 1983; Killian et al., 1987a). Primary sources of this wastewater include the nitric acid recovery unit overheads, the general purpose evaporatory overhead, the two waste tank farm evaporatory overheads, and overheads from several other process evaporators. Retention basin transfers are another source of influent to the basins. Discharge from the basins has been restricted to seepage of effluent into the underlying water-table aquifer. The F-Area Seepage Basins are currently operating under a RCRA interim status permit and are expected to remain in service until the Separations Area Effluent Treatment Facility begins operation in 1988 (Killian et al., 1987a).

\section{Site Description}

The F-Area Seepage Basins are located near the center of SRP, approximately $9.1 \mathrm{~km}$ west of the nearest plant boundary (Figure K.1). This wastewater treatment facility consists of three unlined basins connected by subterranean pipelines. The dimensions and SRP coordinates for each basin are as follows:

\begin{tabular}{|c|c|c|c|}
\hline Basin & $\begin{array}{l}\text { Dimensions } \\
\mathrm{L} \times \mathrm{W} \times \mathrm{D}(\mathrm{m})\end{array}$ & Volume $\left(\mathrm{m}^{3}\right)$ & $\begin{array}{l}\text { SRP Coordinates } \\
\text { (NE Corner) }\end{array}$ \\
\hline 1 & $27 \times 84 \times 4$ & $8.9 E+03$ & N 75779 \\
\hline 2 & $27 \times 161 \times 4$ & $1.7 \mathrm{E}+04$ & N 75640 E 51188 \\
\hline 2 & $94 \times 219 \times 4$ & $8.3 E+04$ & N 75485 E 50663 \\
\hline
\end{tabular}

The combined surface areas of the three seepage basins encompass approximately $27,200 \mathrm{~m}^{2}$. Maximum storage capacity for all three basins is approximately $109,000 \mathrm{~m}^{3}$. Average daily flow into the basins during 1985 was $411 \mathrm{~m}^{3} /$ day. Surface elevations around the basins range from 83 to $87 \mathrm{~m}$ (272 to $285 \mathrm{ft}$ ). Depth to the water table in the area of the basins is approximately $18 \mathrm{~m}$ below grade. The water-table divide between the drainage to Upper Three Runs Creek and Four Mile Creek is north of the F-Area Seepage Basins. There are 17 RCRA (three cluster and one water-table we11) and 13 radioactive monitoring wells located around the F-Area Seepage Basins. 

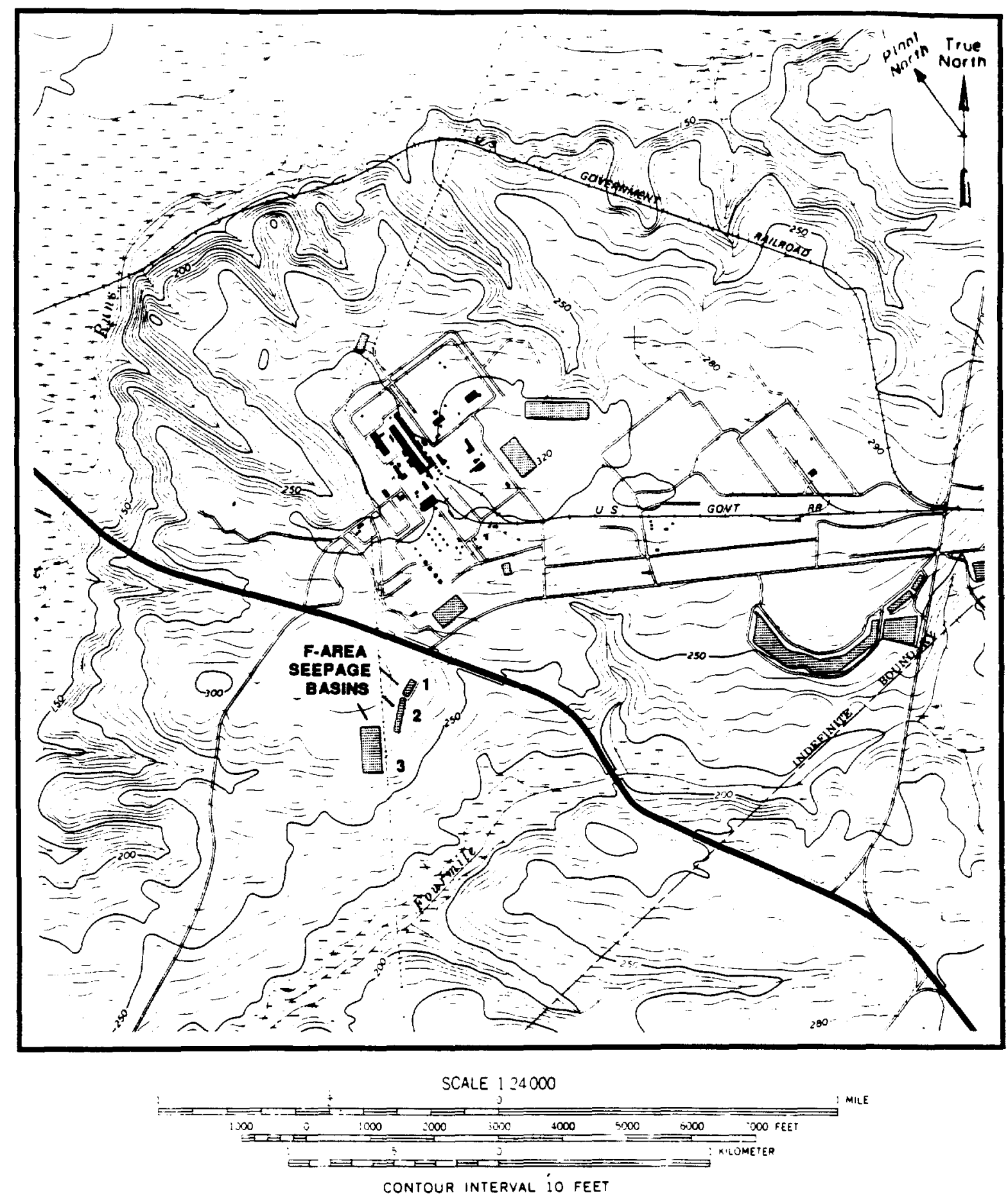

FIGURE K.1. Location of the F-Area Seepage Basins on New Ellenton SW quadrangle 7.5 Minute Series Topographic Map 
Additiona11y, 32 RCRA point-of-compliance wells and 12 plume-assessment wells are being installed around these basins in the fourth quarter of 1987.

Surface drainage and shallow groundwater flow is to the south toward an unnamed tributary of Four Mile Creek. Lateral flows in the underlying McBean and Congaree formations are toward Four Mile Creek and Upper Three Runs Creek, respectively. The basins currently contain process effluent and accumulated rainwater.

$\underline{\text { Review of Available Data }}$

Several environmental studies to characterize the influent and soils at this waste site have been conducted. A review of data from an influent characterization study performed in 1983 indicates that the average values or activities for iron, lead, mercury, nitrate, sodium, gross alpha, gross beta, and tritium exceeded groundwater quality review criteria in Appendix Table 10 (Killian et al., 1987a; Ryan, 1984).

Two soil characterization studies have been performed at the F-Area Seepage Basins. In 1971 soil cores ranging in length from 2.6 to $5.5 \mathrm{~m}$ were taken from the bottom of Basin 3. Both cesium and plutonium were detected. Although cesium was present throughout the deep $(5.5 \mathrm{~m})$ core, concentrations in the top half of the core were almost 4 times greater than in the lower half. Plutonium was found to be much less mobile than the cesium, with over $99 \%$ of this radionuclide being retained in the top $20 \mathrm{~cm}$ of the soil cores. In November and December of 1984, 1-m deep soil cores were taken from 2 to 3 locations within each seepage basin. Approximately $90 \%$ of the chemical constituents analyzed for were contained within the top $30 \mathrm{~cm}$ of the soil colum (Corbo et a1., 1985). Concentrations of the following constituents were greater than SRP background levels or DOE soil guidelines for radioactive constituents: arsenic, chromium, copper, mercury, nickel, nitrate, sodium, tin, zinc, $241_{\mathrm{Am}},{ }^{137} \mathrm{Cs},{ }^{60} \mathrm{Co},{ }^{129} \mathrm{I},{ }^{5} \mathrm{Nb}, 238_{\mathrm{Pu}}, 240_{\mathrm{Pu}}, 90 \mathrm{Sr}, 235_{\mathrm{U}}$, and $238 \mathrm{U}$ (Looney et al., 1987). EP toxicity tests (metals only) performed on selected soil samples were within RCRA criteria.

A review of groundwater data from the RCRA monitoring wells for 1986 and the first quarter of 1987 indicates that the F-Area Seepage Basins have significantly affected groundwater quality within the water-table and McBean aquifers, but not within the upper and lower Congaree aquifers. Chemical constituents that routinely exceeded drinking water standards were cadmium, chromium, iron, lead, manganese, nitrate, TDS, gross alpha, total radium, and tritium. Elevated levels of nonvolatile beta were also found. The indicator parameters nitrate and sodium were highest in the water-table wells and decreased with depth at all well sites with the exception of FSB 79 , where the $C$ well (McBean Formation) showed higher concentrations than the water-table wel1 (Mikol et a1., in press; Zeigler et al., 1987). The most contaminated downgradient water-table well is FSB 78. Low levels of tritium have been detected in the Congaree Formation at wel1 clusters FSB 78, 79, and 87 . This may be due to recharge of the aquifer through the Green Clay in the vicinity of the F-Area Seepage Basins (Killian et al., 1987a). A review of radioactive groundwater monitoring data indicates that only tritium, ${ }^{90} \mathrm{Sr}$, and uranium have been routinely detected in concentrations significantly greater than background values (Stone \& Christensen, 1983). 


\section{Characterization Recommendations}

\section{Sampling}

No further environmental sampling of the F-Area Seepage Basins is proposed. However, additional characterization work in the area of the basins has been conducted or is being planned. Thirty-two RCRA point-of-compliance wells were recently completed in the vicinity of the basins. Ten of these wells, which were completed in the Congaree Formation, were cored, geophysically logged, and archived. Proposed work includes characterizing the abandoned F-Area process sewer line and mapping and sampling the groundwater outcrop areas located between the basins and Four Mile Creek. Data from this additional work will assist in defining the basins environmental setting and characterizing the degree and extent of contamination.

\section{Chemica1 and Physical Analyses}

The archived Congaree well cores should be retrieved and physical analyses (classes 2 and 3 of Appendix Table 1 ) conducted on representative samples from each hyrogeologic unit within the core. Routine monitoring of the F-Area Seepage Basin RCRA and radioactive wells should be expanded to include the radioactivity analyses described in Appendix Table 5. This expanded monitoring program should continue for one year. 


\section{Background}

\section{Site History}

The Fire Department Training Facility (Building 904-113G, sometimes referred to as the Central Shops 0il Basin, was used from 1979 to 1982 by the SRP Fire Department for the purpose of training personnel to fight waste oil fires (Heffner et al., in press). Burnable oil was poured into the basin, ignited, and then extinguished by fire department personnel.

\section{Site Description}

The training facility consists of a shallow pit surrounded by a $46-\mathrm{cm}$ high asphalt dike. Burnable oil was poured into the pit and ignited, and the resulting fire was then extinguished by the fire department.

The Fire Department Training Facility is located adjacent to the Ford Building Seepage Basin. It is at a surface elevation of approximately $88 \mathrm{~m}(290 \mathrm{ft})$ and occupies an area of approximately $457 \mathrm{~m}^{2}$. The facility is located on a northern slope, where surface drainage is toward an unnamed tributary of Four Mile Creek (Figure L.1). The training facility is approximately $8.9 \mathrm{~km}$ from the nearest plant boundary.

Two monitoring wells (CSO 1 and CSO 2) were installed to characterize the geologic and hydrogeologic conditions and to monitor the water-table elevation and groundwater quality beneath the facility. Monitoring wells CSO 1 and CSO 2 were installed in the third quarter of 1983 and second quarter of 1984 , respective1y. The depth to the water table is $15.2 \mathrm{~m}$ below the ground surface, and the flow is to the north (Heffner et al., in press).

\section{Review of Available Data}

The sediment beneath the training facility has not been sampled and characterized. A soil gas survey at the training facility was conducted in the fourth quarter of 1986. Results from this survey indicate some elevated levels of hydrocarbon compounds. Concentrations of $>1,000 \mu \mathrm{g} / \mathrm{g}$ of total hydrocarbons were found at five sample locations in the immediate area of the facility. All dissolved chemical constituent and radioactivity levels in groundwater samples from wells CSO 1 and cSO 2 have been below the values listed in Appendix Table 10. Conductivity levels in wells CSO 1 (26.0 to 45.0 umhos $/ \mathrm{cm})$ and CSO 2 (27.0 to 42.0 umhos $/ \mathrm{cm}$ ) were less than the SRP background value of 50 umhos $/ \mathrm{cm}$. TOC levels in both sites wells have been less than $6.0 \mathrm{mg} / \mathrm{L}$ except for a single excursion of $9.69 \mathrm{mg} / \mathrm{L}$ in well cSO 2 in February 1985. TOH levels have consistently been below $0.046 \mathrm{mg} / \mathrm{L}$ in both monitoring wells. The $\mathrm{pH}$ in both site wells has ranged between 4.0 and 5.3 , which is consistent with $\mathrm{pH}$ values reported as naturally occurring in Barnwell Formation groundwater. 


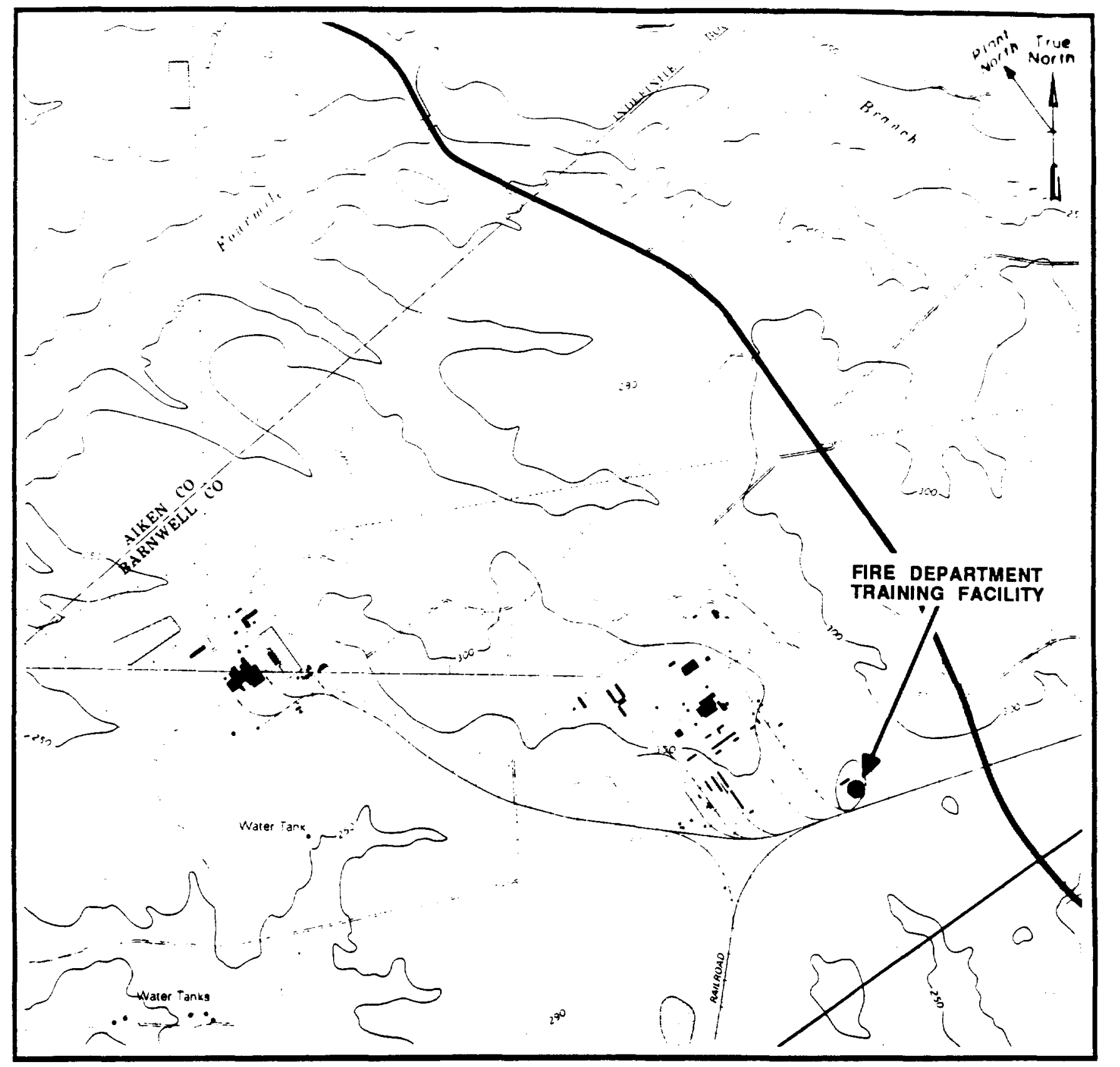

SCALE 1.24000

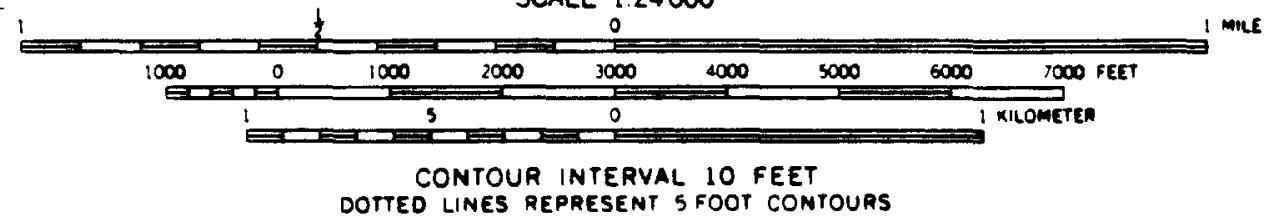

FIGURE L.1. Location of the Fire Department Training Facility on New Ellenton $S W$ and Girard NW quadrangle 7.5 Minute Series Topographic Maps 


\section{Characterization Recommendations}

\section{Sampling}

Three 3-m deep sediment cores should be taken inside the training facility (Figure L.2). The core should be subdivided into the sampling intervals given in Appendix Table 1.

\section{Chemical and Physical Analyses}

The sediment cores from the facility should be measured for the inorganic ions and metals given in Appendix Table 2. In addition to these analyses, the 0.00 to $0.25-\mathrm{m}$ and the $1-\mathrm{m}, 2-\mathrm{m}$, and $3-\mathrm{m}$ intervals should be analyzed for the volatile organics listed in Appendix Table 3. The 0.00 to $0.25 \mathrm{~m}$ interval should be analyzed for EP toxicity and EPA Appendix IX parameters listed in Appendix Table 7. In addition, the top layer of sediment should be sampled for petroleum hydrocarbons. 


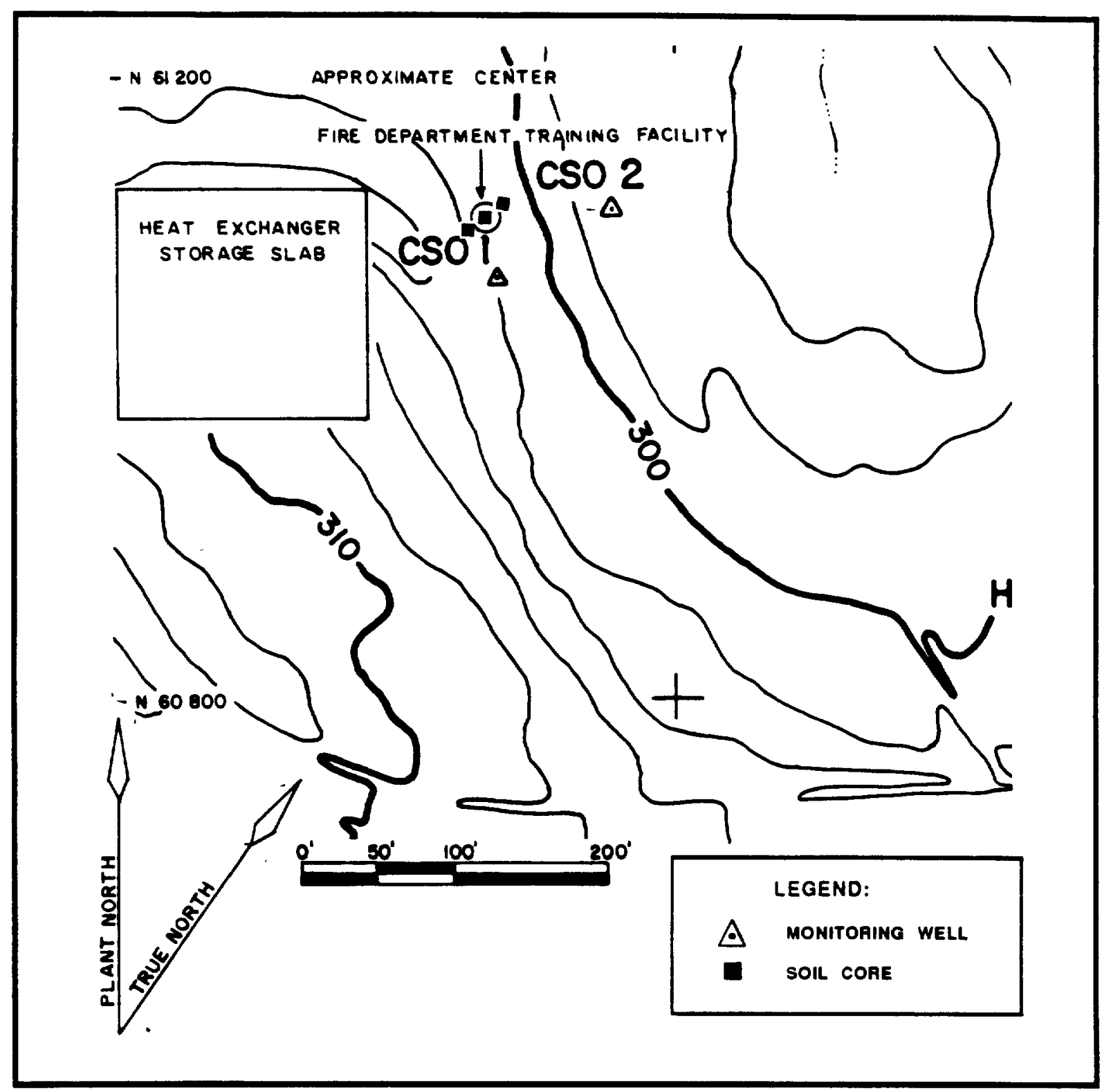

FIGURE L.2. Proposed Sampling and Monitoring Well Locations at the Fire Department Training Facility 


\section{Background}

\section{Site History}

The Ford Building Seepage Basin (Building 904-91G) received wastewater from the repair of slightly contaminated process equipment received from throughout the plant. Highly contaminated equipment requiring repair is first decontaminated by the individual custodial area before being transported to the Ford Building. Wastewater generated at the Ford Building during equipment repair work has been found to contain low levels of contamination. Previously, the wastewater was drained to a 6,000-gal retention tank located adjacent to the Ford Building, analyzed for radionuclides, and then released to the seepage basin or sent to Waste Management Operations (WMO) for concentration and disposal. The use of the retention tank and basin was halted in January 1984. Wastewater from the Ford Building is now sent to WMO for disposal.

The retention tank and its piping from the Ford Building and to the seepage basin are underground. During the late 1960s, an extensive program for repair of process water heat exchangers for the reactor areas was initiated. The decontamination was done in $\mathrm{C}$ Area, and the repair was conducted in the Ford Building. The largest loading of wastewater to the basin occurred during 1965. An inventory of the radionuclides released to the basin from 1965 to 1984 with decay corrections through 1985 is presented in Pekkala et al. (1987d). In addition to radionuclides, trace amounts of surfactants, soils, grease, and other chemicals may have been in the wastewater. Through the end of 1984 , the basin received a total of $1,440 \mathrm{~m}^{3}$ of wastewater. The basin was retired in 1984 and is now dry except for occasionally impounded rainwater.

\section{Site Description}

The Ford Building Seepage Basin is located in the Central Shops Area in the central part of SRP as shown in Figure M.1. The basin is approximately $30 \mathrm{~m}$ from the Ford Building and $8.9 \mathrm{~km}$ east of the nearest plant boundary. The approximate coordinates for the basin's northeast corner are $\mathrm{N} 60685$, E 52560. The basin is rectangular and was constructed by excavating below grade a nominal $3 \mathrm{~m}$ and then backfilling around the basin sides at grade level to form earthen dike walls. Originally, the basin had bottom dimensions of 8 $\mathrm{m}$ by $6 \mathrm{~m}$ and ground-leve 1 dimensions of $24 \mathrm{~m}$ by $12 \mathrm{~m}$, giving an approximate volume capacity of $600 \mathrm{~m}^{3}$. 


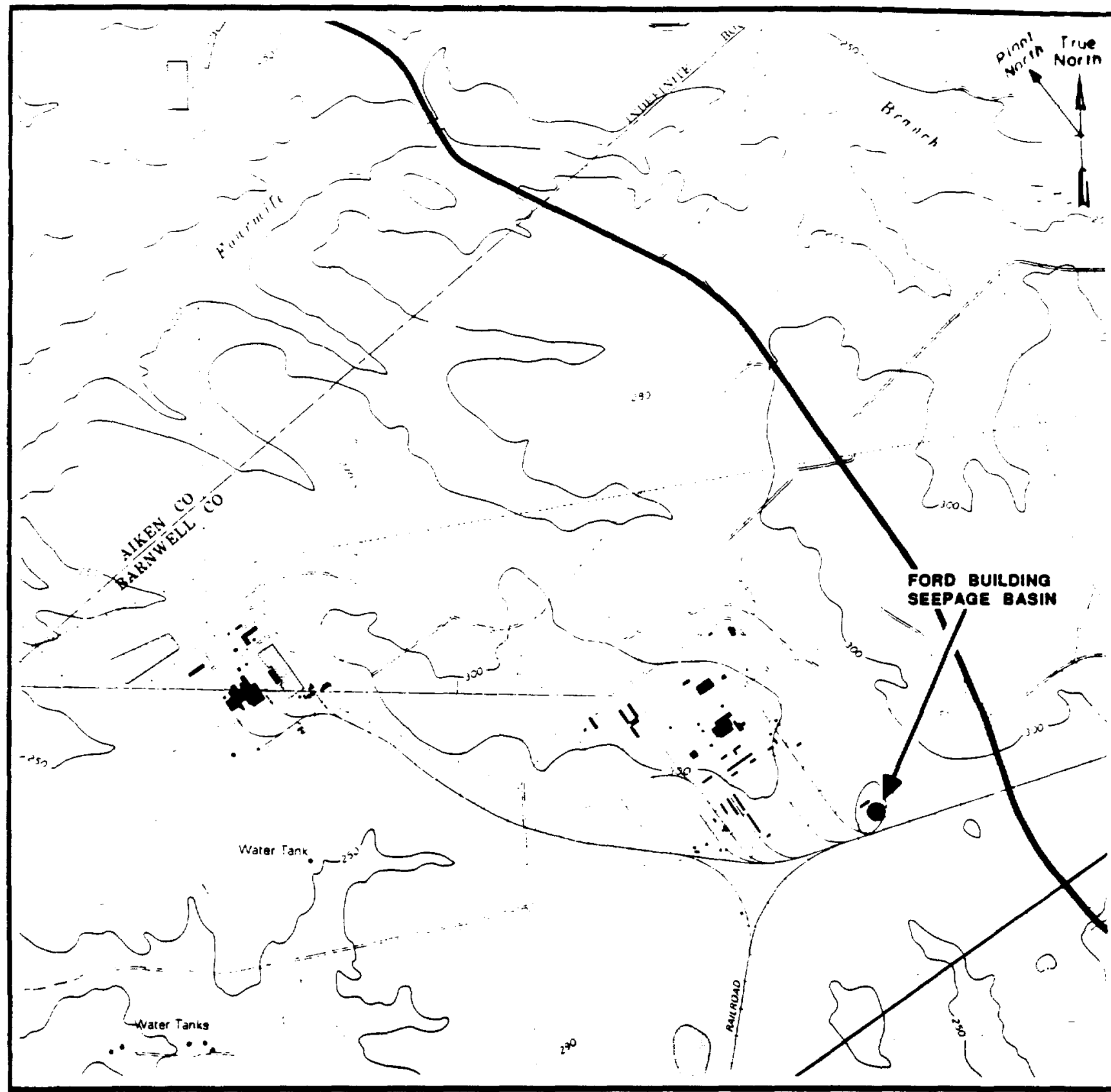

SCALE 1.24000

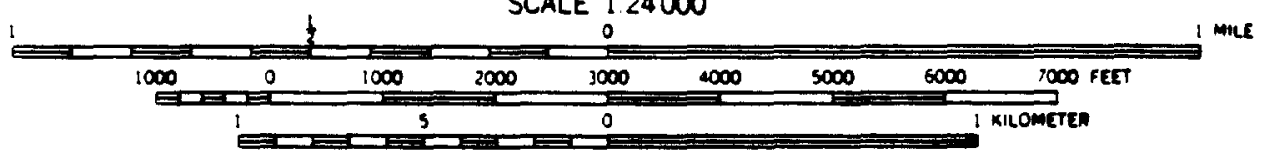

CONTOUR INTERVAL 10 FEET

DOTTED LINES REPRESENT S FOOT CONTOURS

FIGURE M.1. Location of the Ford Building Seepage Basin on New Ellenton SW and Girard NW Quadrangle 7.5 Minute Series Topographic Maps 
Three groundwater monitoring wells are located in the vicinity of the basin. HXB 1 through HXB 3 (Figure M.2) monitor the groundwater in the local flow path from the basin. The Ford Building Seepage Basin is located at an elevation of $91 \mathrm{~m}$, and the depth to the groundwater table is $15 \mathrm{~m}$. Water-1evel elevation measurements from the basin monitoring wells indicate that the water-table elevation has been consistently declining since the second quarter of 1984. The groundwater flow direction in the vicinity of the basin is to the southeast, consistent with local topography. Given this flow direction, wells HXB 1 and HXB 3 would be located downgradient of the basin, and an upgradient well would not exist for this site. Well HXB 2, located on the opposite side of a small topographic divide, may monitor the water table to the north.

\section{Review of Available Data}

In 1985, a comprehensive program of soil sampling and analysis was performed to characterize sediment from the basin floor and walls and from beneath the underground pipeline leading from the retention tank to the basin. For this study, a total of 11 sampling sites were established (Figure M.2). Inside the basin, three $1.5-\mathrm{m}$ holes were cored perpendicular to the floor of the basin, and six $15-\mathrm{cm}$ holes were cored horizontal to the north and east walls of the basin. In addition, a $1.5-\mathrm{cm}$ hole was cored perpendicular to grade in a nearby pristine area for soil background concentrations.

In the basin soils, concentrations of ${ }^{137} \mathrm{Cs},{ }^{60} \mathrm{Co}$, and ${ }^{90} \mathrm{Sr}$ are significantly above background, and concentrations of ${ }^{155} \mathrm{Eu}$ are slightly elevated (Pekkala et al., 1987). The concentration profiles for ${ }^{13} \mathrm{Cs}$ and 60 Co peak in the top layers of basin sediment, implying less mobility for these radionuclides than for ${ }^{90} \mathrm{Sr}$ and ${ }^{155} \mathrm{Eu}$ for which no clear profile could be discerned. Beneath the pipeline, only ${ }^{90} \mathrm{Sr}$ shows elevated concentration levels. In the basin walls, none of the radionuclides show elevated concentration levels.

The concentration profiles for the majority of metals in the basin floor drop rapidly to background within the first $0.6 \mathrm{~m}$ of soil depth. The metals with elevated concentration levels in the top $8 \mathrm{~cm}$ of basin soil are aluminum, arsenic, cadmium, chromium, copper, iron, mercury, nicke1, selenium, and zinc. In the soil beneath the pipeline, aluminum, arsenic, cadmium, chromium, and iron have elevated concentrations.

In the basin floor, the concentration profiles for the majority of the inorganic ions are typical of those observed for the metals. The inorganic ions with elevated concentration levels in the top $8 \mathrm{~cm}$ of basin soil are ammonia, nitrogen, fluoride, sulfate, and total phosphate. Under the pipeline, only total phosphate levels are elevated. Along the basin walls, none of the inorganic ions show elevated levels. No significant concentration of organics were detected in the basin floor, basin walls, or beneath the pipeline. 


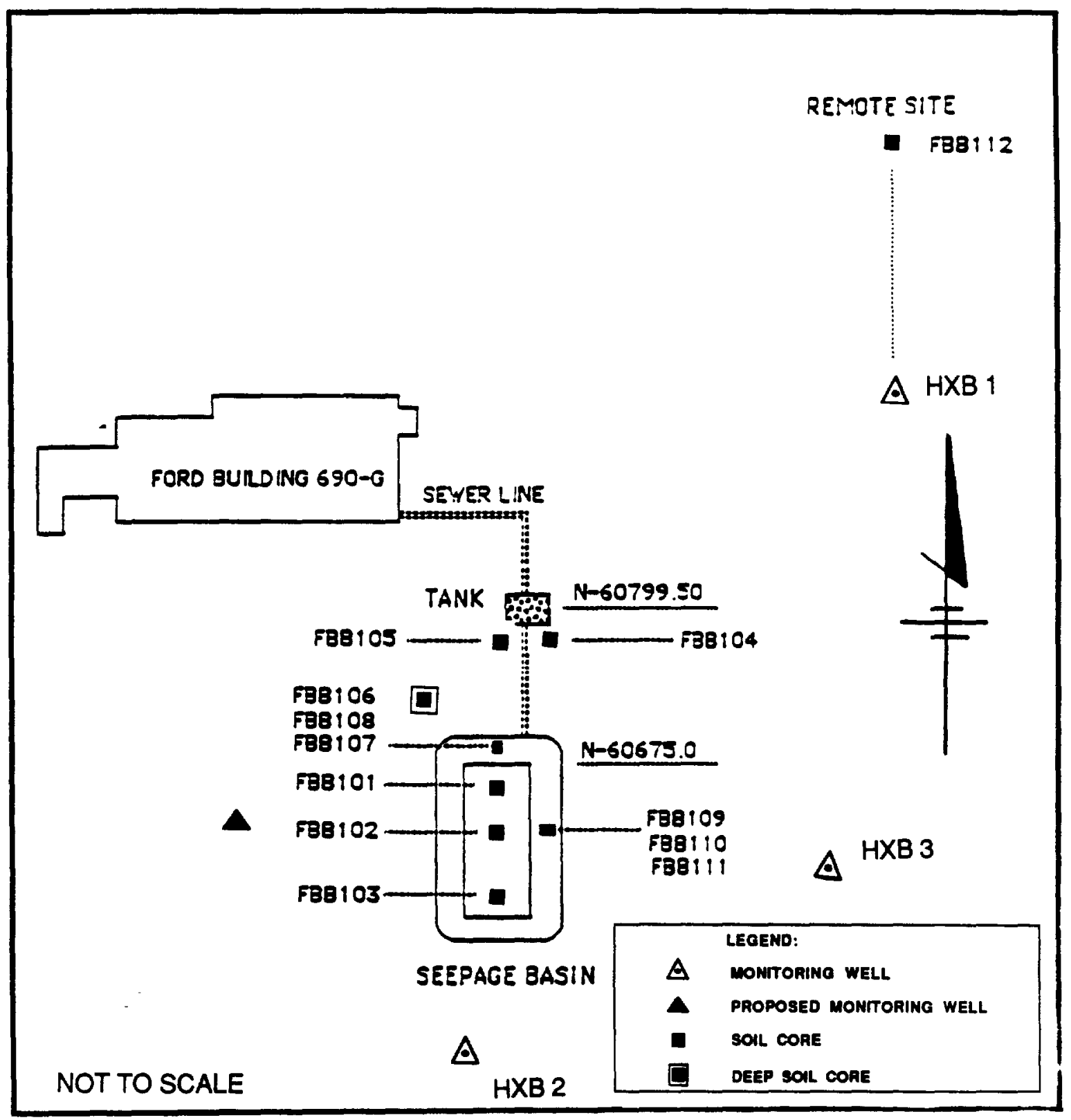

FIGURE M.2. Proposed Sampling Locations at the Ford Building Seepage Basin 
The groundwater monitoring data from the Ford Building Seepage Basin indicate that the groundwater quality has not been significantly affected by the operation of the basin (Heffner et al., in press). The groundwater at this basin is characterized bylow dissolved chemical constituent and radionuclide levels as compared to the groundwater quality comparison criteria reported in Appendix Table 10. Conductivity levels (19 to $45 \mu \mathrm{mhos} / \mathrm{cm}$ ) reported for the site wells were less than the SRP background level of 50 $\mu$ mhos/cm (Heffner et al., in press). Inorganic, organic, and radioactive chemical constituent levels found in the groundwater were less than half of their respective drinking water standards over the monitoring period (Appendix Table 10).

\section{Characterization Recommendations}

Sampling

One additional water table is recommended downgradient from the basin. Existing wells are either upgradient or sidegradient and are insufficient detection wells. The well should be cored and geophysically logged to provide specific geologic and hydrogeologic information. The location of the recommended well is shown in Figure M.2.

\section{Chemical and Physical Analysis}

Groundwater samples collected from the new well should be analyzed for parameters 1isted in Tables 5 and 6 in the appendix. A sample of the material in the saturated zone should be analyzed for Class 2 and 3 parameters of Table 1 in the appendix.

The approximate location of the new monitoring well should be geophysically logged. In addition, gamma logs should be taken at each well to better define the sediments beneath the basin. The wells should be sampled quarterly as part of the Health Protection Department groundwater monitoring program. The groundwater samples should be analyzed for the parameters listed in Appendix Table 6. In addition, all wells at the Ford Building Seepage Basin should be analyzed for the radionuclides 1isted in Appendix Table 5. 


\section{Background}

\section{Site History}

There are no records of waste disposal for the Ford Building Waste Site (Building 643-11G). Objects identified on the surface of the site include shoe covers, step-off pads, coveralls, and rubber gloves. There are two signs marking the site: one reads "Clean Pans On1y," and the other is a regulated sign (Huber et al., 1987a). The signs and materials indicate that regulated work may have been performed here. In addition to the wastes already discussed, an unknown volume of waste from a ruptured oil line was discharged into this area during the 1970 s. The site has not been used for many years.

\section{Site Description}

The site is located northwest of the Ford Building Seepage Basin in the southeast corner of the Central Shops Area on a ridge between two tributaries: one flows to Pen Branch, and the other flows to Four Mile Creek (Figure N.1). The northeast corner of the site has SRP coordinates of $\mathrm{N} 61328$, E 52132. The site has dimensions of $6.7 \mathrm{~m}$ by $51.5 \mathrm{~m}$ and a surface elevation of $90 \mathrm{~m}(295 \mathrm{ft})$. Currently there are no monitoring wells at the site; however, monitoring wells CSO 1 and CSO 2 for the nearby Fire Department Training Facility indicate that the depth to the water table is approximately $16.6 \mathrm{~m}$.

\section{Review of Available Data}

Currently there are no data available for this site.

\section{Characterization Recommendations}

\section{Sampling}

A soil gas survey is recommended for the site and will be used to map the horizontal extent of any VOC migration that may have occured in the unsaturated zone. The resulting data will help define soil sampling locations. Figure N.2 show the proposed locations for soil gas samples.

The size and shape of the site can be determined using GPR. Two survey lines should be run across with width of the site, and one line should be run the length of the site (Figure N.2). 


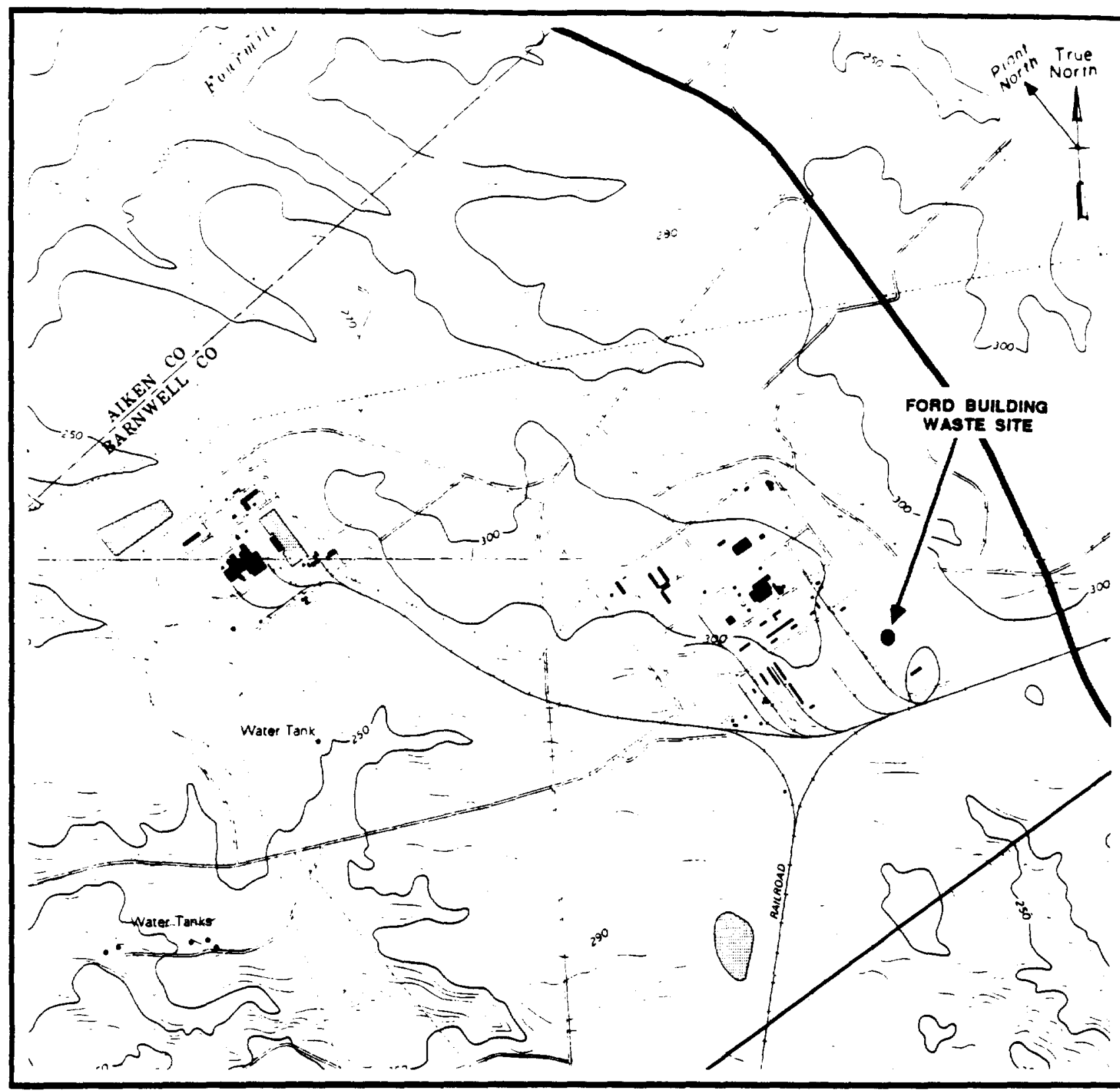

SCALE 1.24000

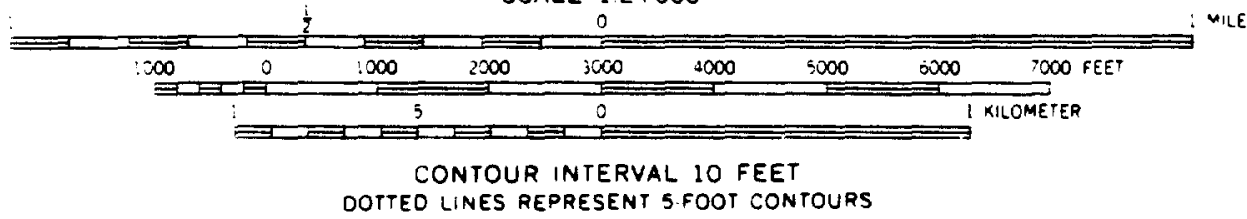

FIGURE N.1. Location of the Ford Building Waste Site on New E1lenton SW and Girard NW Quadrangle 7.5 Minute Series Topographic Maps 


\section{LEGEND:}

SOIL CORE

ry soll gas sufVEy sAMPLE

- - - Ground penetratimo radar
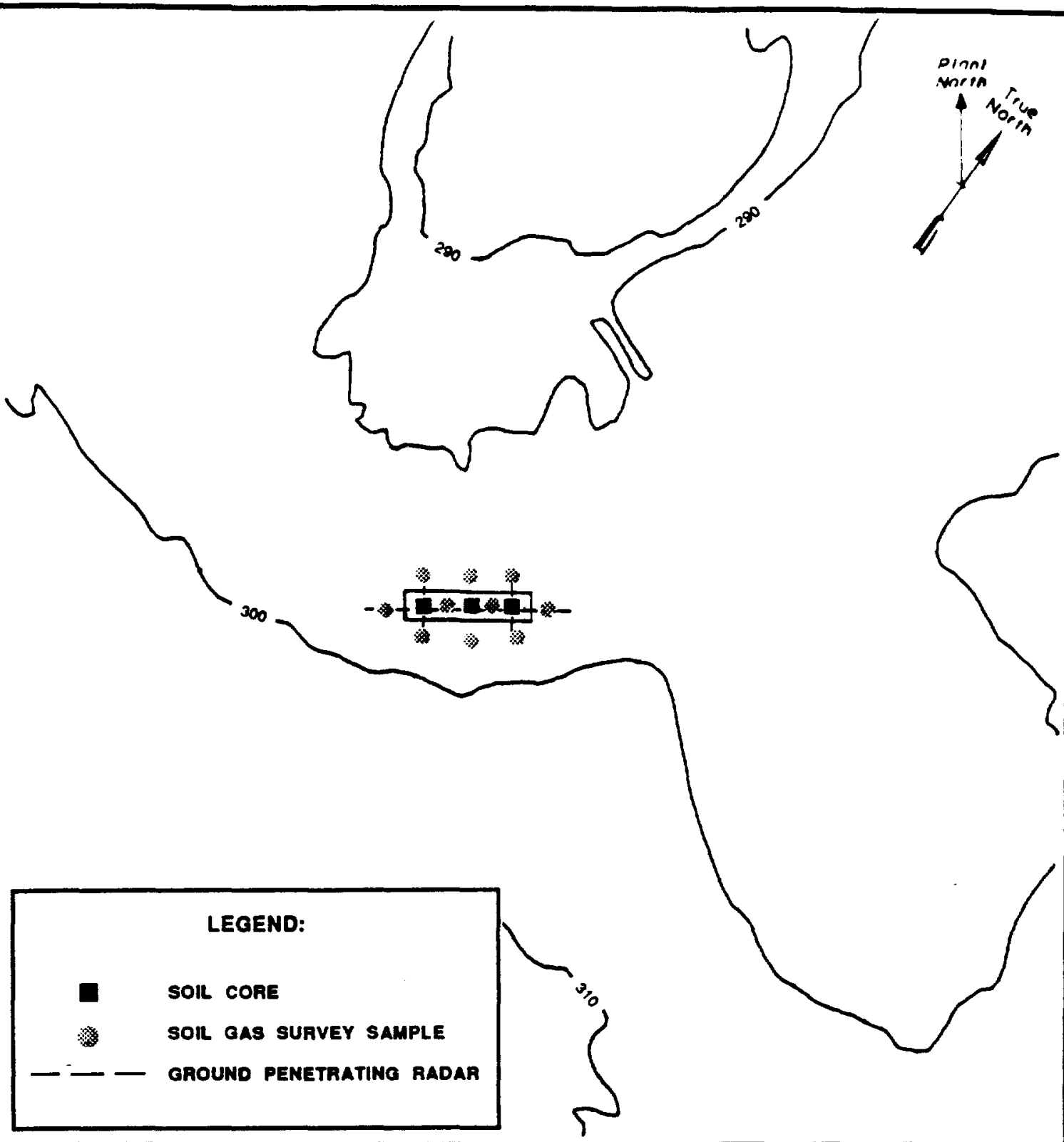

1ft. $=0.3048 \mathrm{~m}$

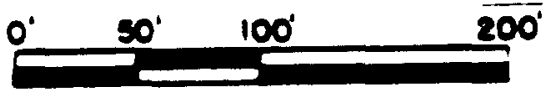

FIGURE N.2. Proposed Sampling Locations for the Ford Building Waste Site 
A shallow soil coring program is recommended for the characterization of soils in and around the site. Three 3-m deep soil cores should be taken and analyzed at the intervals given in Appendix Table 1 . Figure N.2 shows the proposed sampling locations. This shallow coring program and the soil gas survey are designed to determine the horizontal extent of any surface and shallow soil contamination that may have occurred.

Chemical and Physical Analyses

Samples from the soil gas sampling survey should be analyzed for VOCs as listed in Appendix Table 3.

In an attempt to characterize the source and extent of contamination in the unsaturated zone, the 3-m deep soil cores should be analyzed for selected parameters at the intervals listed in Appendix Table 1. Specific analytes should include the parameters given in Appendix Tables 2 (Metals) and 3 (VOCs). 


\section{Background}

Site History

The Gas Cylinder Disposal Facility (Building 131-2L) is located in $L$ Area. Partially full cylinders were placed in the ground, fastened by concrete, the tops removed, and the gas was vented to the atmosphere. Once emptied, the cylinders were covered with concrete and backfilled with dirt (Heffner et al., in press). The last date of waste receipt was 1982. The site is currently inactive. The SRP coordinates for the facility are as follows:
N 48459
E 49004
N 48451
E 48980
N 48461
E 48977
N 48470
E 49000

\section{Site Description}

The site currently houses 28 empty cylinders that contained the following gases:
Gas
No. of Cylinders
HF
2
F
$\mathrm{HBr}$
2
2
1
1
1
4
1
5
2
1
2
$\mathrm{BrF}_{5}$
$\mathrm{C}_{1} \mathrm{~F}_{3}$
$\mathrm{NH}_{4}$
HCL
$\mathrm{BrF}_{3}$
$\mathrm{C}_{2}$
$\mathrm{NO}_{2}$
$\mathrm{H}_{2} \mathrm{~S}$
$\mathrm{SO}_{2}$
Acetylene, $\mathrm{O}_{2}$,
$\mathrm{H}_{2} \mathrm{O}$, Argon
Unknown
The facility covers approximately $35 \mathrm{~m}^{2}$ and is located near the L-Area Burning/Rubble Pit. There are no groundwater monitoring wells at this facility. The depth to the water table is believed to be $15 \mathrm{~m}$ below the ground surface, and the flow is thought to be to the northwest (Figure 0.1 ). 

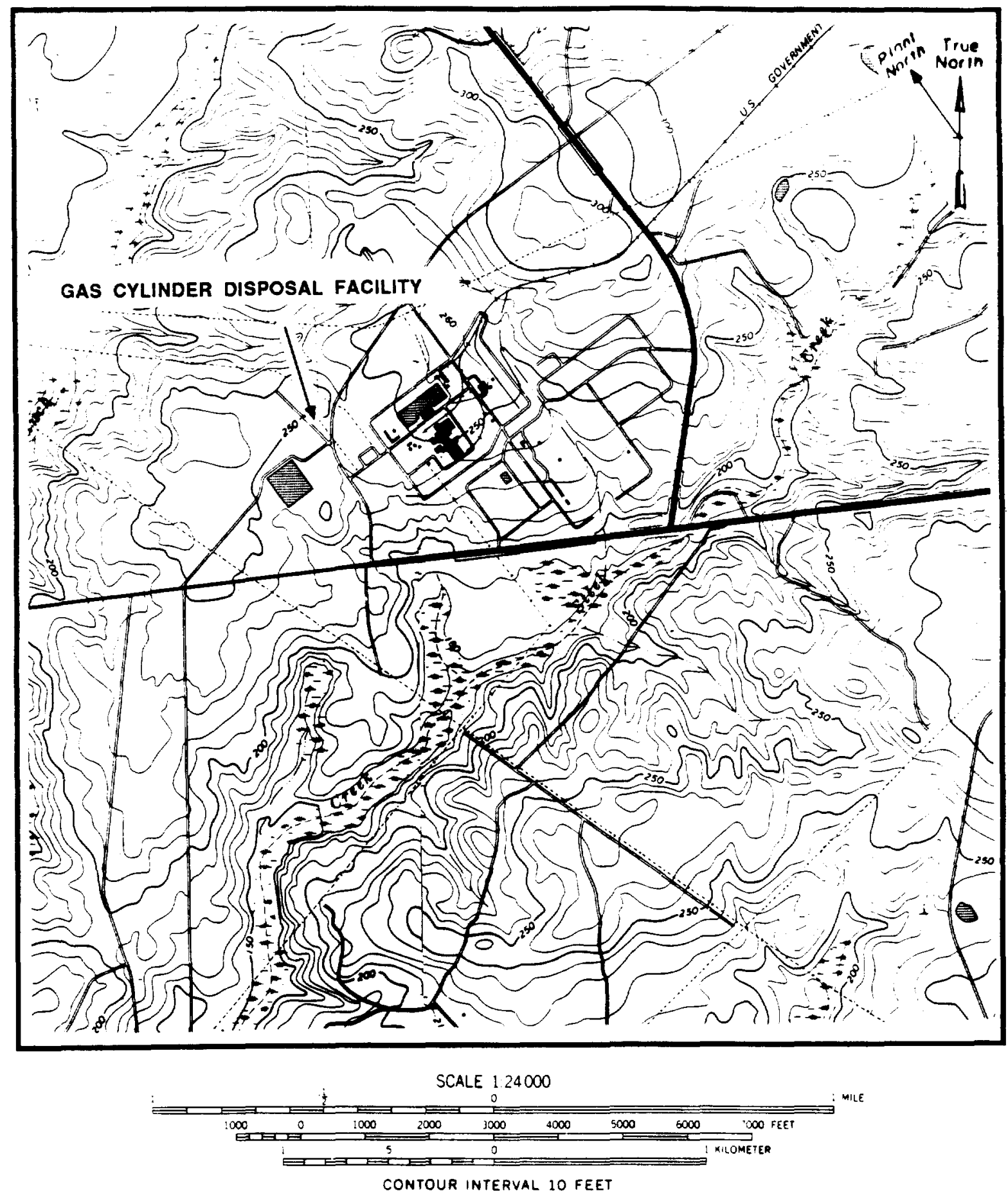

FIGURE 0.1. Location of the Gas Cylinder Disposal Area on Girard NE quadrangle 7.5 kinute Series Topographic Map 
Review of Available Data

The sediment beneath the Gas Cylinder Disposal Facility has not been sampled and characterized.

\section{Characterization Recommendations}

Sampling

No sampling is recommended at this site. 


\section{Background}

\section{Site History}

The disposal history for the Gunsite 720 Rubble Pit (Building 631-16G) is unknown. Eight corroded drums of unknown origin have been reported at the site (Huber \& Bledsoe, 1987a). In July 1987 the drums were removed and analyzed for volatile organics. The drums were found to be empty, and results of the VOC analysis indicate that present concentration levels are below detectable limits.

\section{Site Description}

The site is located $170 \mathrm{~m}$ north of Road $\mathrm{A}-2$. The site has an elevation of $45.7 \mathrm{~m}(150 \mathrm{ft})$. The center of the site has SRP coordinates of N 80000, E 27350 (Figure P.1). Surface drainage is to the west-southwest.

\section{Characterization Recommendations}

Sampling

A soil gas survey is recommended for the site and should be used to map the horizontal extent of any VOC migration that may have occurred in the unsaturated zone. The resulting data should help define soil sampling locations. Figure P.2 shows the proposed locations for soil gas samples.

A deep core, taken into the water table, should be drilled at this site. This core should be drilled in the pit and should reach total depth at the regional water table below the site. Samples for chemical analysis should be collected at several intervals based on lithology changes in an effort to determine the vertical extent of soil contamination and the contaminant attenuation potential of the various 1 ithologic sections above the water table. Once the core is completed, a casing should be installed and the boring completed as a well.

\section{Chemical and Physical Analyses}

Samples from the soil gas sampling survey should be analyzed for VOCs as listed in Appendix Table 3 . 

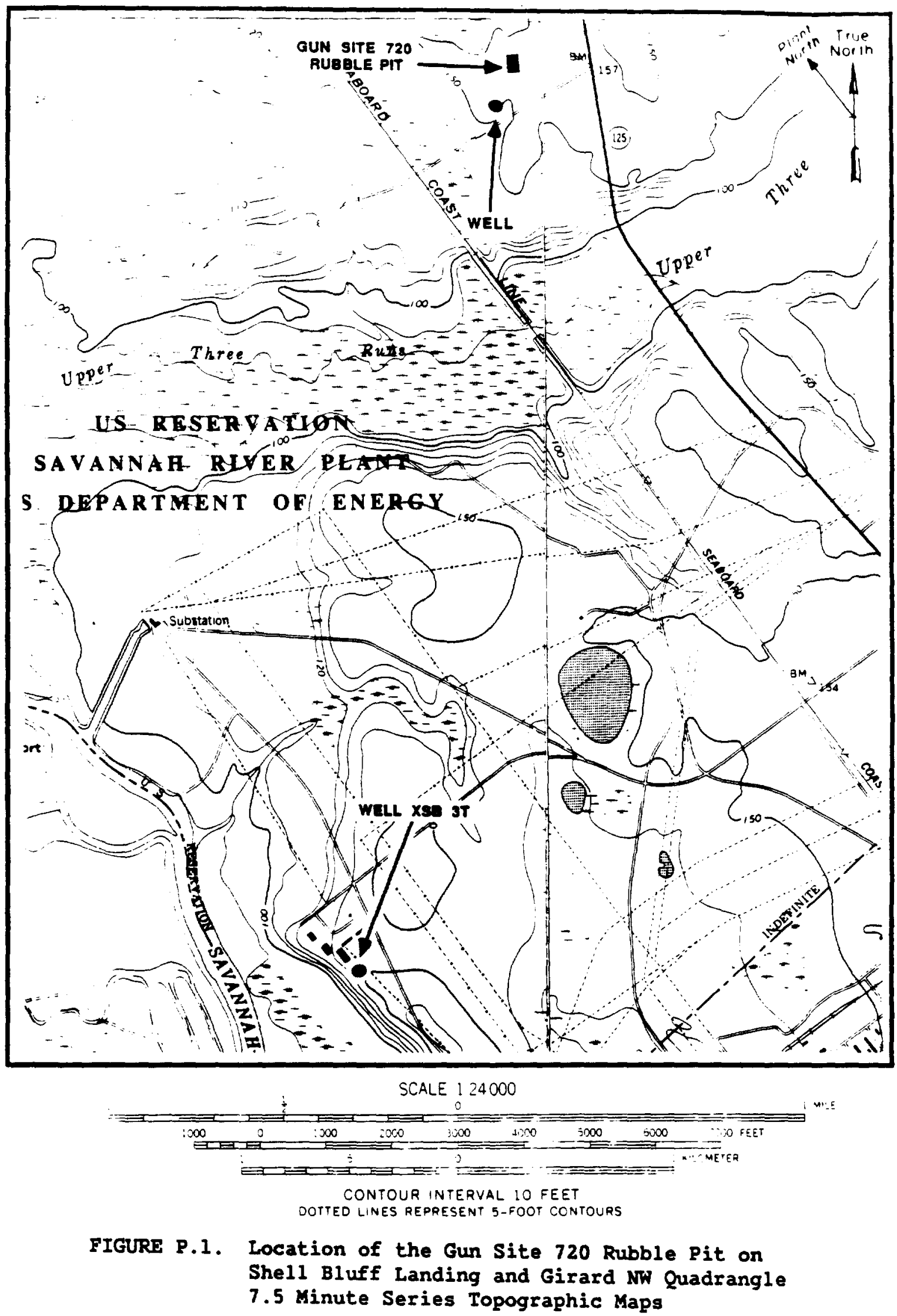
Q

EXCAVATED BAARELS ON PAD
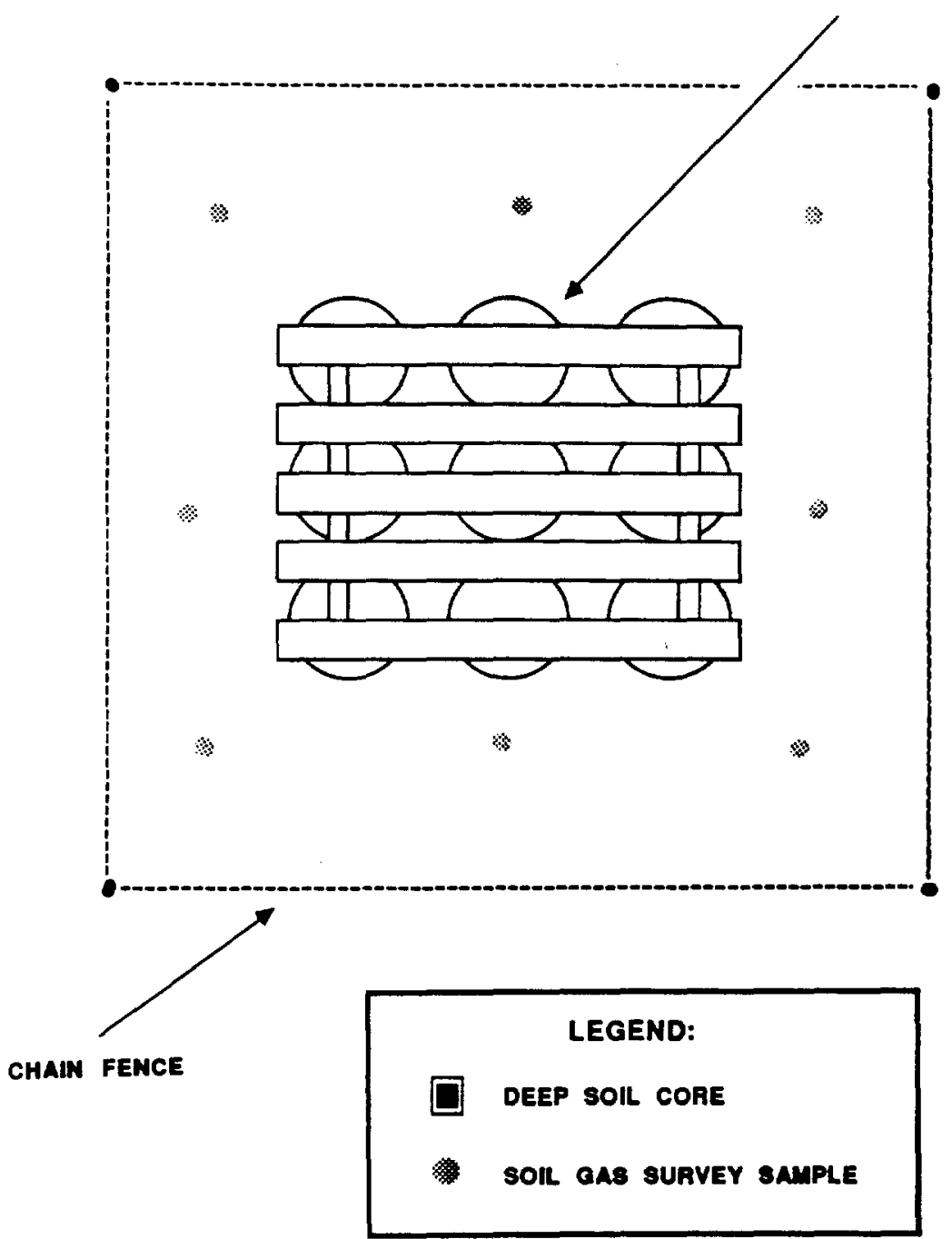

NOT TO SCALE

FIGURE P.2. Proposed Sampling Locations at the Gunsite 720 Rubble Pit

$$
\text { P-3 }
$$


Sample specimens from the deep core should be selected in the field based on a visual interpretation of lithologic changes and analyzed for the parameters 1isted in Appendix Tables 1 (Classes 2 and 3), 2 (Metals) and 3 (VOCs).

Groundwater samples should be analyzed for the parameters given in Table 6 of the Appendix. Undisturbed samples collected during the drilling of the deep core should be analyzed for vertical and horizontal permeability, porosity, relative permeability, bulk density, and grain size. 


\section{Background}

\section{Site History}

From 1955 to 1957, three 75- and 90-mm military anti-aircraft gun emplacements were in operation at SRP. Table Q.1 1ists the gunsites and their SRP coordinates. These facilities also housed troops, military staff, a motor pool, and support equipment. The gun emplacements and support facilities were dismantled and abandoned in 1961 (Christensen \& Gordon, 1983). The materials in these rubble piles include concrete, brick, lumber, metal, glass, empty drums, and asbestos.

\section{Site Description}

\section{Gunsite 51}

Gunsite 51 is located $3.9 \mathrm{~km}$ south of $\mathrm{K}$ Area and northeast of SRP Road $A$ on a ridge between Pen Branch and Steel Creek (Figure Q.1). The site has an elevation of $77.7 \mathrm{~m}(255 \mathrm{ft})$. Surface drainage from the site is to the west toward Pen Branch. The rubble from this site has been removed, and all that remains from the rubble pile are concrete pads. Currently, the remaining buildings at the site are being used to store geologic cores.

Gunsite 72

Gunsite 72 is located $4.3 \mathrm{~km}$ northwest of $\mathrm{D}$ Area at the end of SRP Road A-2 on a point north of Upper Three Runs Creek (Figure Q.2). The site has an elevation of $39.6 \mathrm{~m}(130 \mathrm{ft})$. Surface drainage from the site is to the south toward Upper Three Runs Creek. The rubble from this site has been removed, and all that remains from the rubble pile is a concrete pad. Some of the area was revegetated to provide landcover.

Gunsite 102

Gunsite 102 is located $6 \mathrm{~km}$ north of $\mathrm{R}$ Area and south of SRP Road 2-1 on a ridge between Reedy Branch and Mill Creek (Figure Q.3). The site has an elevation of $94.5 \mathrm{~m}(310 \mathrm{ft})$. Surface drainage is either north toward Reedy Branch or south toward Mill Creek.

Gunsite 113

Gunsite 113 is located just inside the northeast plant boundary east of SRP Road 8 (Figure Q.4). The site has an elevation of $99 \mathrm{~m}$ ( $325 \mathrm{ft}$ ). This site has relatively flat topography, and, therefore, the surface drainage direction is undefined. 
TABLE 9.1

Gunsite Rubble Pile Building Numbers and SRP Coordinates

\begin{tabular}{lllll} 
Site & B1dg. No. & & \multicolumn{2}{c}{ SRP Coordinates } \\
Gunsite 51 & $080-29 G$ & N 41600 & E 55200 \\
Gunsite 72 & 080-31G & N 80400 & E 22600 \\
Gunsite 102 & O80-30G & N 74800 & E 84900 \\
Gunsite 113 & None Assigned & N 64750 & E 115400
\end{tabular}




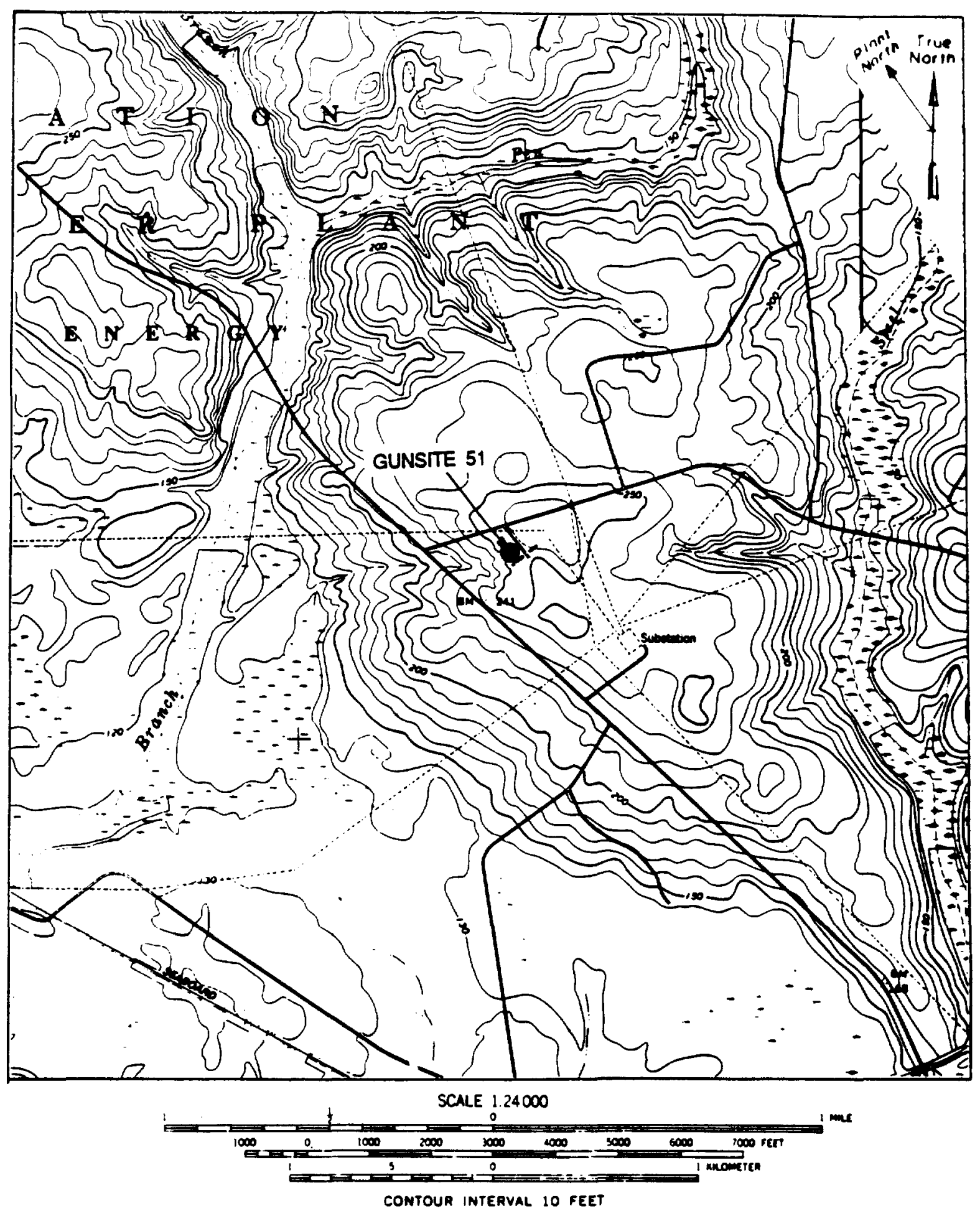

FIGURE Q.1. Location of the Gunsite 51 Rubble Pile on Girard NW Quadrangle 7.5 Minute Series Topographic Map 


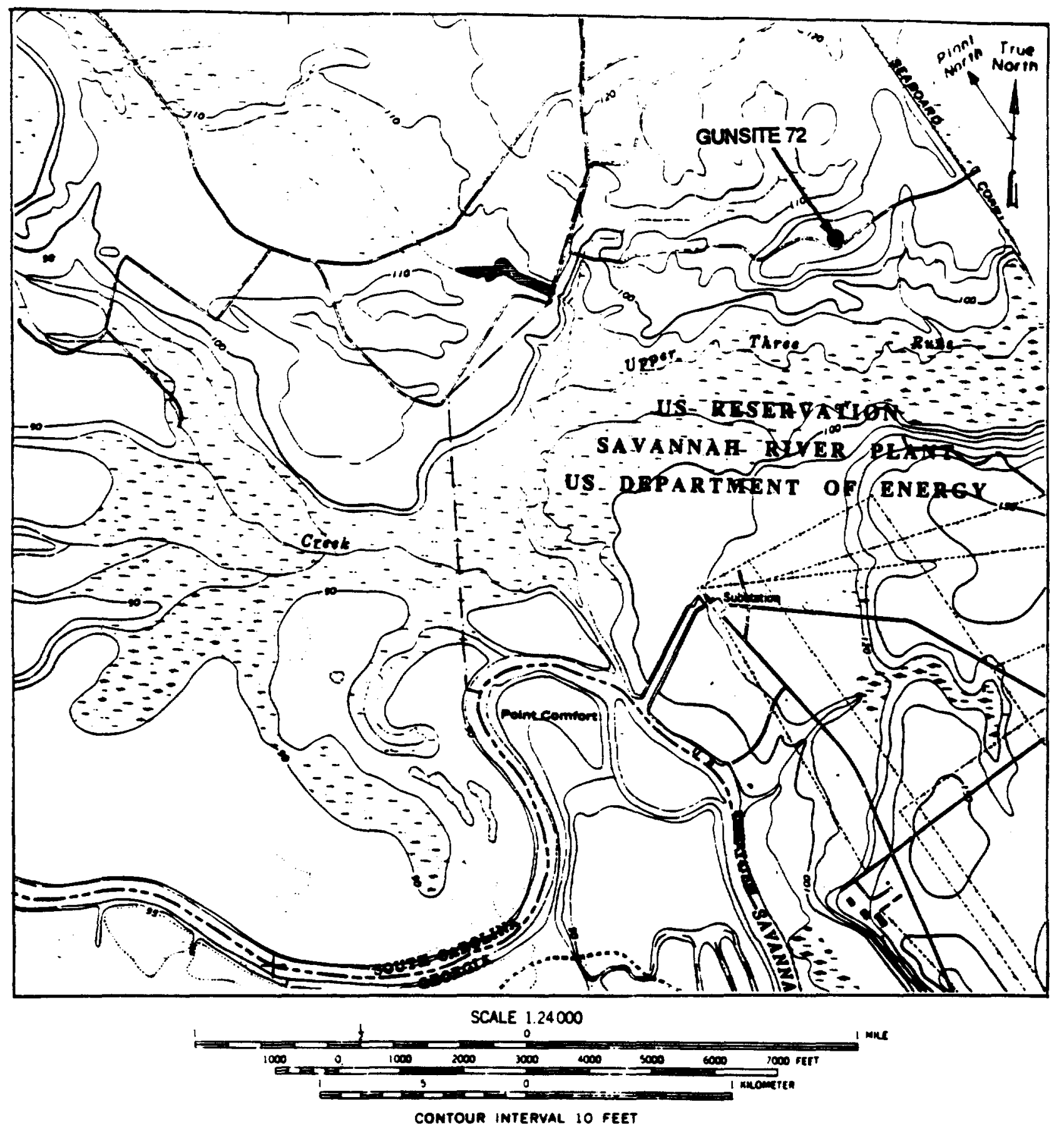

FIGURE Q.2. Location of the Gunsite 72 Rubble Pile on Shell Bluff Landing Quadrangle 7.5 Minute Series Topographic Map 


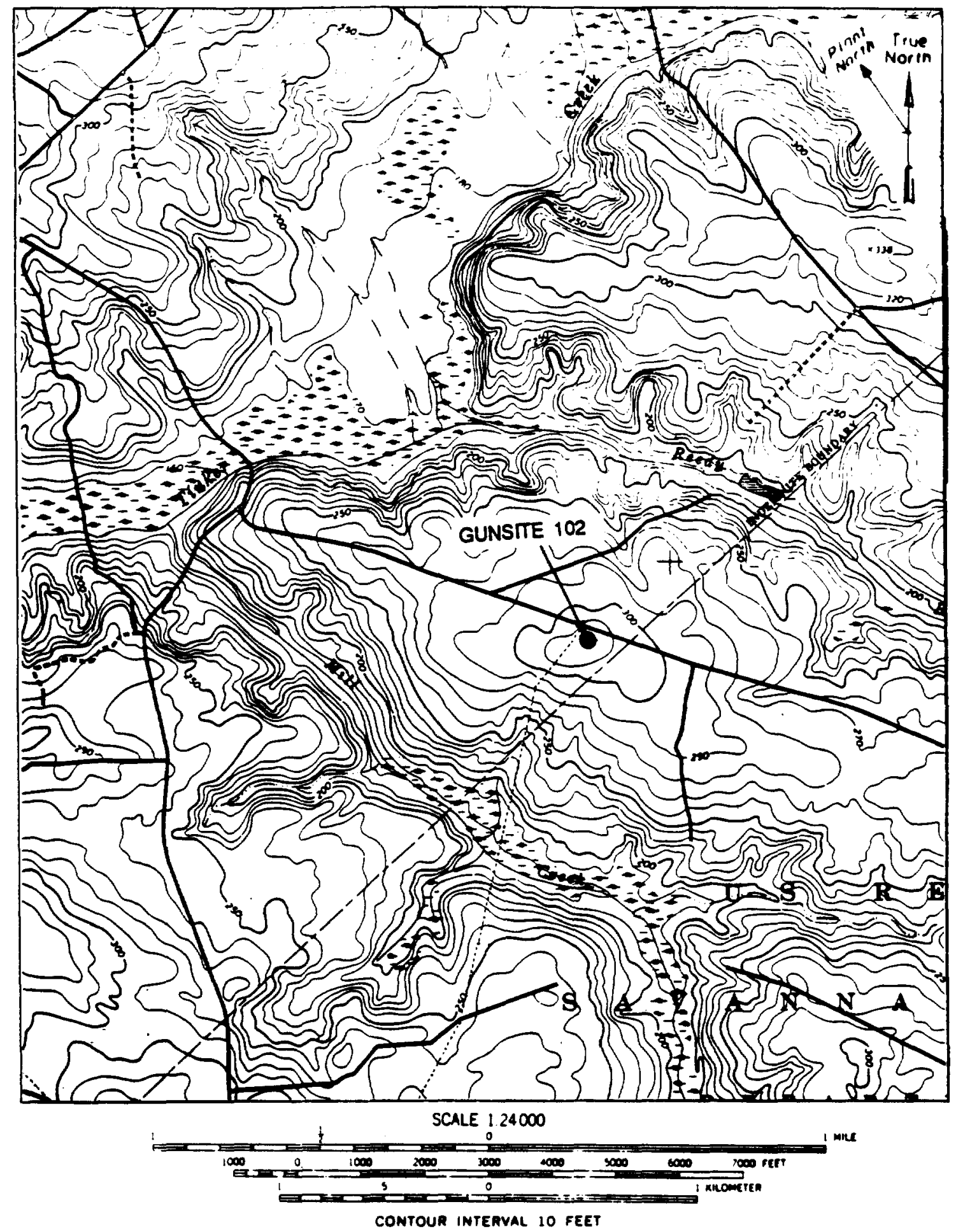

FIGURE Q.3. Location of the Gunsite 102 Rubble Pile on New Ellenton SE Quadrangle 7.5 Minute Series Topographic Map 


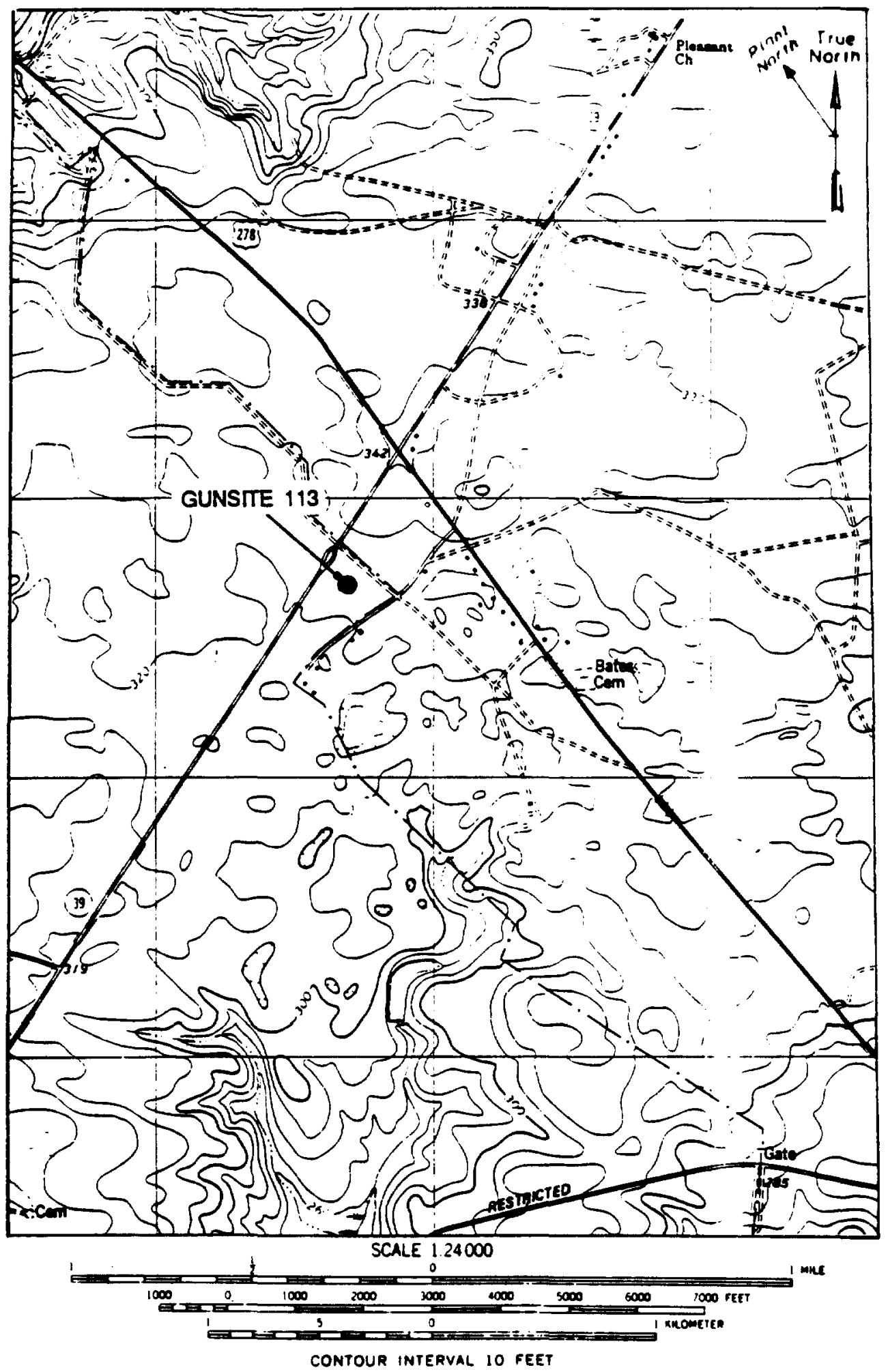

FIGURE Q.4. Location of the Gunsite 113 Rubble Pile on Long Branch Quadrangle 7.5 Minute Series Topographic Map 


\section{Characterization Recomendations}

Gunsites 51 and 72 should require no further action because they have already had their waste material removed. No characterization of the remaining rubble at Gunsites 102 and 113 is required because the wastes at these sites are inert building materials. However, if potentially hazardous wastes are discovered during closure of these sites, some characterization may be required to identify the wastes. 


\section{Background}

\section{Site History}

The H-Area Seepage Basins (Buildings 904-44G, 904-45G, 904-46G, and 904-56G) were placed in service in 1955 to treat chemically contaminated and radioactive wastewater from the H-Area separations facilities. Sources of wastewater to the seepage basins include the nitric acid recovery unit overheads, the general purpose evaporator overheads, overheads from the two waste tank farm evaporators, cooling water from the tritium facilities, and retention basin transfers (Christensen \& Gordon, 1983). This wastewater typically contains significant amounts of nitrate, sodium, and tritium (Christensen \& Gordon, 1983; Killian et a1., 1987b). Discharge from the basin has been restricted to seepage of effluent into the underlying water-table aquifer. In 1962, Basin 3 (Building 904-46G) was taken off line due to clogged bottom sediments. The H-Area Seepage Basins (Basins 1, 2, and 4) are currently operating under a RCRA interim status permit and will remain in service until the Separations Area Effluent Treatment Facility begins operation in 1988 (Killian et a1., 1987b).

\section{Site Description}

The H-Area Seepage Basins are located in the central part of SRP, approximately $10 \mathrm{~km}$ west of the nearest plant boundary (Figure R.1). This wastewater treatment facility consists of four unlined earthen basins connected by subterranean pipelines. Basins 1, 2, and 4 are current1y open, active, and contain process effluent and accumulated rainfall. Basin 3, which was taken of 1 ine in 1962, is open and contains rainwater. The dimensions and SRP coordinates for the northeast corner of each basin are as follows:

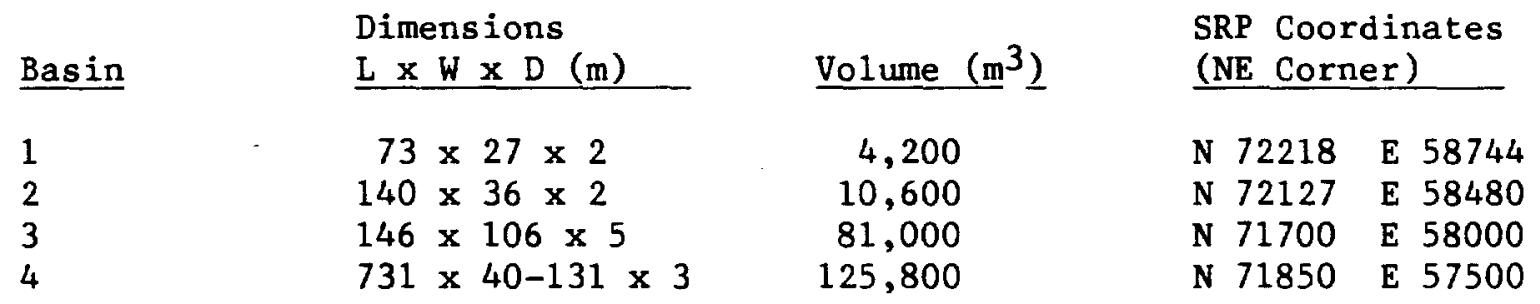

Note: Basin 4 is arc shaped.

The combined surface areas of the four seepage basins encompass approximately $61,933 \mathrm{~m}^{2}$. Maximum storage capacity for all four basins is approximately $221,600 \mathrm{~m}^{3}$. The average daily flow into the basins during 1985 was $577 \mathrm{~m}^{3} /$ day. The H-Area Seepage Basins have an approximate surface elevation of $79 \mathrm{~m}(260 \mathrm{ft})$ and are located about $152 \mathrm{~m}$ north of Four Mile Creek and $2,740 \mathrm{~m}$ south of Upper Three Runs Creek. The 

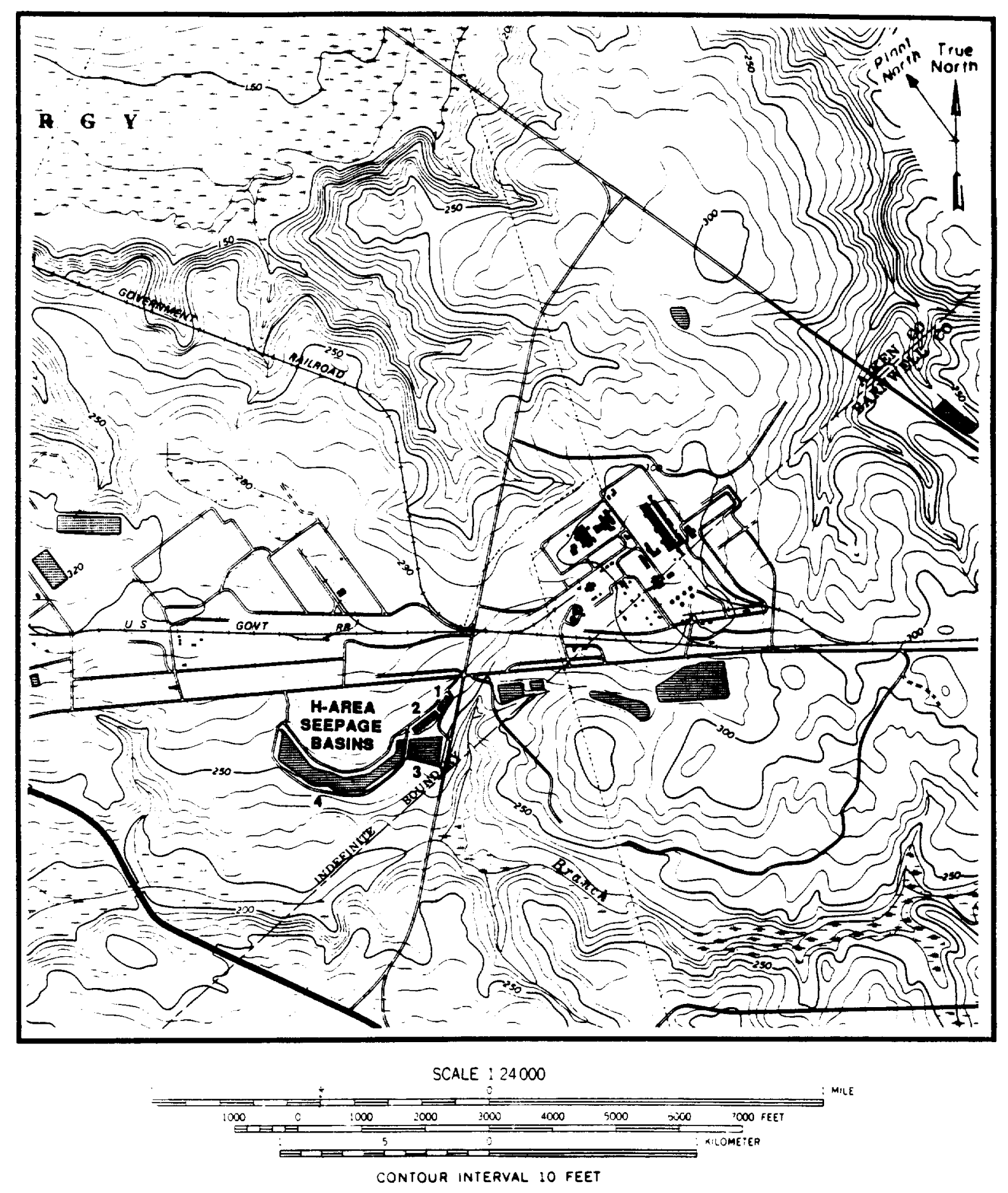

FIGURE R.1. Location of the H-Area Seepage Basins on New Ellenton SW Quadrangle 7.5 Minute Series Topographic Map 
water-table divide between the drainage to these two major creeks is located north of the H-Area Seepage Basins. The regional water table in the area of the seepage basins is 4.6 to $7.6 \mathrm{~m}$ below grade. There are 28 RCRA ( 6 cluster and 5 water-table) and 16 radioactive groundwater monitoring wells located around the four H-Area Seepage Basins. Additionally, 43 RCRA point-of-compliance wells and 16 plume-assessment wel1s are presently being installed in the area of these basins. Surface drainage and shallow groundwater flow is to the south-southwest toward Four Mile Creek. Lateral flow in the upper (sandy) portion of the McBean Formation is also toward Four Mile Creek. Deep groundwater flow in the Congaree Formation is to the northwest toward Upper Three Runs Creek.

\section{Review of Available Data}

A review of selected data from analyses of seepage basin influent indicates that the average concentrations for chromium $(0.072 \mathrm{mg} / \mathrm{L})$, iron $(5.1 \mathrm{mg} / \mathrm{L})$, manganese $(0.56 \mathrm{mg} / \mathrm{L})$, mercury $(0.043 \mathrm{mg} / \mathrm{L})$, nitrate (538 mg/L), pH (2.37), gross alpha, gross beta, and tritium exceeded groundwater quality review criteria (Heffner et al., in press).

In December 1984 , a soil characterization study was conducted at the H-Area Seepage Basins. One-meter deep soil cores were taken from two to five locations within each bas in and subdivided into $15-\mathrm{cm}$ intervals for analysis. Approximately $90 \%$ of the chemical constituents analyzed for (excluding tritium and nitrate, which were highly mobile) were contained within the top $0.30 \mathrm{~m}$ of the soil column (Corbo et al., 1985). Concentrations of the following constituents exceeded SRP background levels or DOE soil guidelines for radioactive constituents: silver, arsenic, cyanide, chromium, copper, iron, mercury, manganese, sodium, nickel, nitrates, lead, selenium, tin, zinc, $241 \mathrm{Am}, 243,244 \mathrm{Cm},{ }^{60} \mathrm{Co}$ ${ }^{137} \mathrm{Cs},{ }^{3} \mathrm{H},{ }^{129} \mathrm{I}, 238_{\mathrm{Pu}}, 239,240 \mathrm{Pu},{ }^{\circ} \mathrm{Sr},{ }^{99} \mathrm{Tc}, 233,234_{\mathrm{U}}, 235_{\mathrm{U}}$, and $238_{\mathrm{U}}$ (Looney et al., 1987). EP toxicity tests (metals only) performed on selected soil samples were within RCRA criteria.

A review of groundwater data from the RCRA monitoring we1ls for 1986 and the first quarter of 1987 indicates that the H-Area Seepage Basins have significantly affected groundwater quality within the underlying water-table and McBean aquifers. Chemical constituents that routinely exceeded groundwater quality review criteria are lead, manganese, mercury, nitrate, gross alpha, gross beta, total radium, and tritium. The indicator parameters nitrate and sodium were highest in the water-table wells and decreased with depth at all well sites with the exception of well cluster HSB 86, where the $C$ well (McBean Formation) showed higher concentrations of nitrate than the water-table well (Mikol et al., in press; Zeigler et a1., 1987). The most contaminated downgradient water-table well appears to be HSB 68 , which is adjacent to the southern perimeter of Basin 4. 


\section{Characterization Recommendations}

\section{Sampling}

No further environmental sampling of the H-Area Seepage Basins is proposed. However, additional characterization work in the area of the basins has been conducted or is being planned. Forty-three RCRA

point-of-compliance wells are currently being installed in the vicinity of the basins. Sixteen of these wells (eight each in the McBean and Congaree formations) will be cored, geophysically logged, and archived. Proposed work includes characterizing the abandoned H-Area process sewer 1 ine and mapping and sampling the groundwater outcrop areas located between the basins and Four Mile Creek. Data from this additional work will assist in defining the basins environmental setting and characterizing the degree and extent of contamination.

\section{Chemical and Physical Analyses}

The archived Congaree and McBean well cores should be retrieved and physical analyses (Class 2 and 3 of Appendix Table 1) conducted on representative samples from each hydrogeologic unit within the cores. Routine monitoring of the H-Area Seepage Basin RCRA and radioactive wells should be expanded to include the radioactivity analyses described in Appendix Table 5. This expanded monitoring program should continue for one year. 


\section{Background}

\section{Site History}

The history of the Hydrofluoric Acid Spil1 Area (Building 631-4G) is unknown. The only documentation on the site is a sign at the site that reads "CONTAMINATED AREA HYDROFLUORIC ACID BURIED 6 FT DO NOT DIG 15 FT EACH SIDE OF POST" (Huber \& Bledsoe, 1987b).

\section{Site Description}

The site is located in the southwest part of the Central Shops Area south of Road 3 between two intermittent tributary streams to Four Mile Creek (Figure S.1). The northeast corner of the site has SRP coordinates

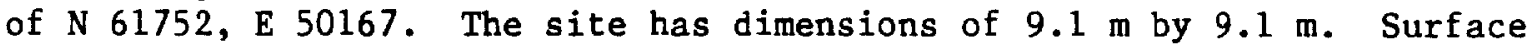
drainage is to a swampy area south of the site that drains northwest into Four Mile Creek. The site elevation is $88.45 \mathrm{~m}(290 \mathrm{ft})$. Four monitoring wells at the site indicate that the depth to the water table at the site is approximately $13.7 \mathrm{~m}$ and that groundwater flow is to the west-southwest.

\section{Review of Available Data}

Existing groundwater data from 1985 through first quarter 1987 indicate that there has been no effect on groundwater quality from the site (Mikol et al., in press; Zeigler et al., 1987). Fluoride, pH, and conductivity measurements have been stable and are consistent with SRP background concentrations. In addition, periodic metal analyses have indicated that there is no metals contamination in groundwater at the site.

A GPR demonstration was conducted at the site. This survey shows some radar anomolies in the vicinity of the pit that may indicate buried objects (steel drums). It may be beneficial to try to excavate these anomalies to verify the GPR methods.

\section{Characterization Recommendations}

\section{Samp1ing}

A shallow soil coring program is planned for the characterization of soils in and around the site. Three 3-m deep soil cores should be taken and analyzed at the intervals given in Table 1 of the Appendix. Figure S.2 shows the proposed sampling locations. This shallow coring program is designed to determine the horizontal extent of any surface and shallow soil contamination that may have occurred. 

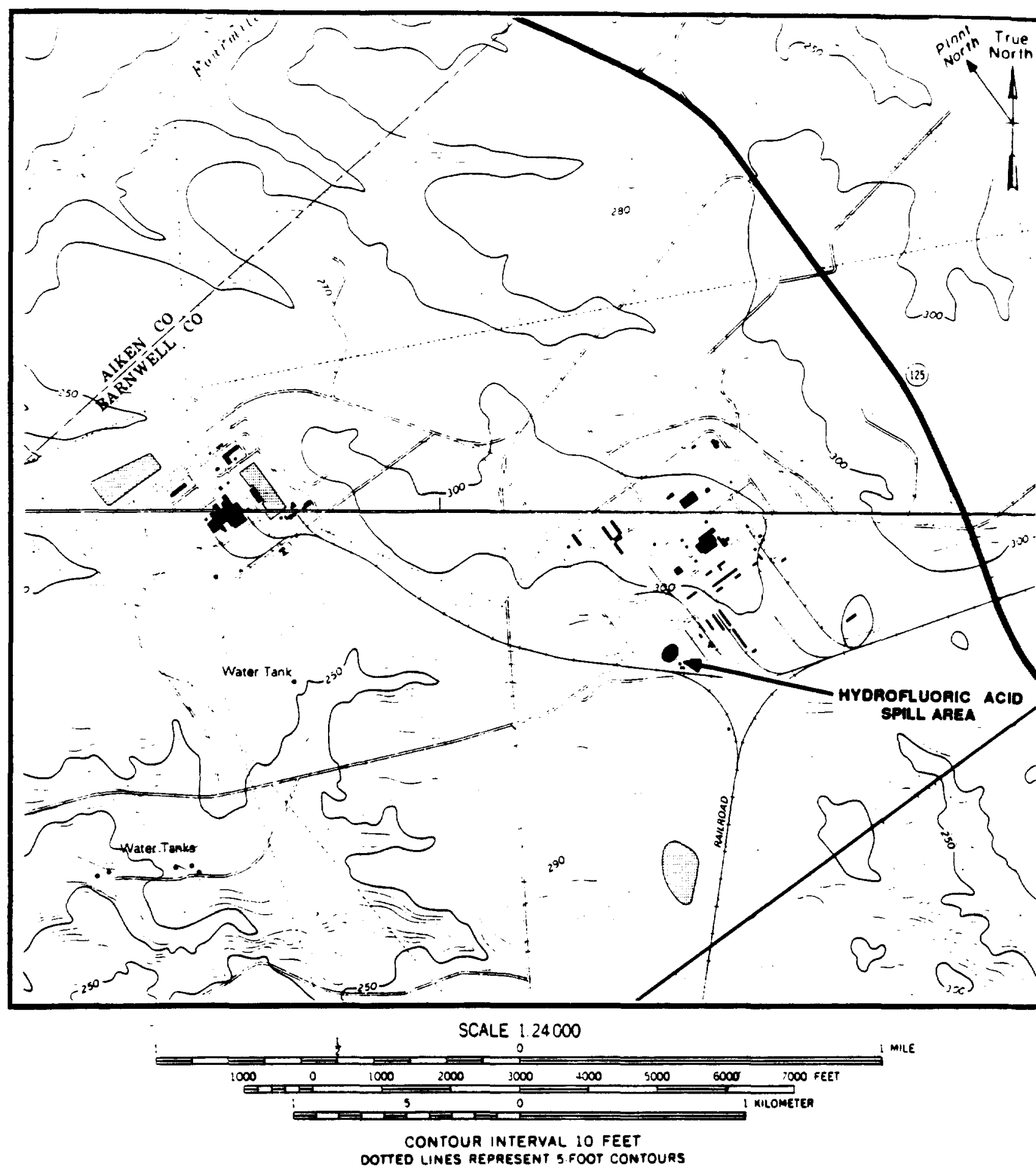

FIGURE S.1. Location of the Hydrofluoric Acid Spill Area on New Ellenton SW and Girard NW quadrangle 7.5 Minute Series Topographic Maps 


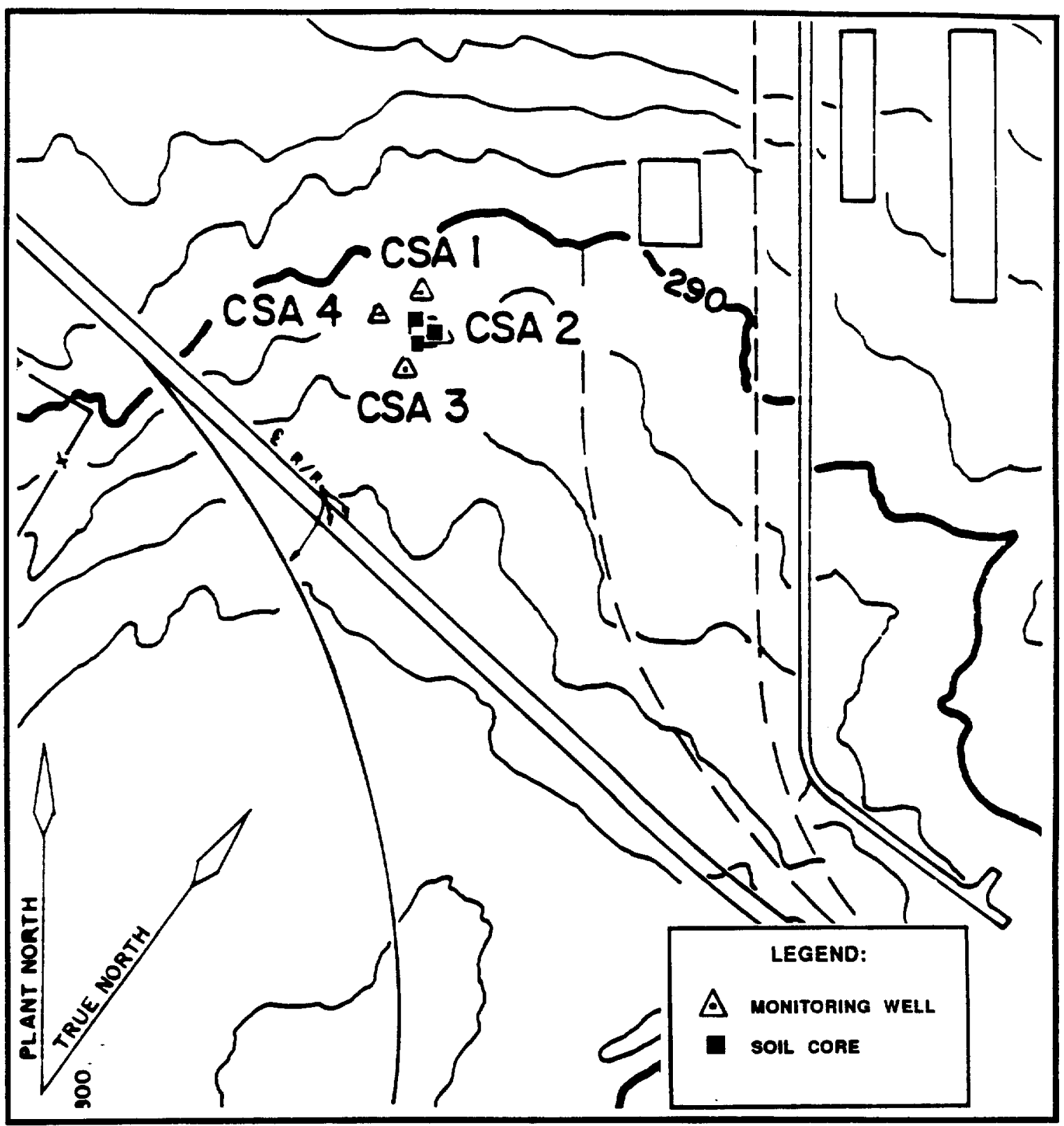

1ft. $=0.3040 \mathrm{~m}$

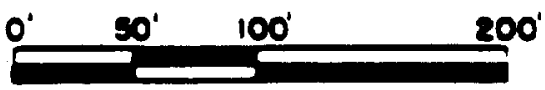

FIGURE S.2. Proposed Sampling Locations for the Hydrofluoric Acid Spill Area 
If the shallow cores indicate that there is soil contamination, a deep core should be drilled to assess the extent of vertical contamination. This core should reach total depth at the regional water table below the site. Samples for chemical analysis should be collected at several intervals based on lithology changes in an effort to determine the vertical extent of soil contamination and the contaminant attenuation potential of the various lithologic sections above the water table. The deep core should also provide information on the stratigraphy and lithology of the underlying sediments.

Some of the GPR anomalies should be excavated to determine if they are drums or other potentially hazardous objects.

Chemical and Physical Analyses

The 3-m deep cores should be analyzed for selected parameters at the intervals 1 isted in Appendix Table 1. Specific analytes should include the parameters 1 isted in Appendix Table 2. Sample specimens from the deep borings should be selected in the field based on a visual interpretation of lithologic changes by a qualified field geologist and analyzed for parameters 1isted in Appendix Tables 1 (Classes 2 and 3 ) and 2 (meta1s). 


\section{Background}

\section{Site History}

The K-Area Retention Basin (Building 904-88G) has received low-level radioactive purge water from the $\mathrm{K}$-Area Reactor Disassembly Basins since 1965. During the purging operations, water from the disassembly basins is passed through two mixed bed deionizers to remove radionuclides from the wastewater before it is released to the basin. Effluents from the deionizers are monitored during the purge. A review of the radioactive releases to the $\mathrm{K}$-Area Retention Basin shows that, although many radionuclides have been discharged to the basin, almost all of the radioactivity is due to ${ }^{3} \mathrm{H},{ }^{90} \mathrm{Sr},{ }^{37} \mathrm{Cs}$, and ${ }^{60} \mathrm{Co}$. In addition to radionuclides, trace quantities of aluminum, iron, sodium, chloride, carbonate, nitrate, phosphate, sulfate, sulfite, oil, and grease have been discharged to the basin (Heffner et a1., in press). The K-Area Retention Basin is currently active and receiving purge water.

\section{Site Description}

The K-Area Retention Basin was constructed in 1963 on a northwesttrending, gently sloping region in the northwest portion of $K$ Area (Figure T.1). The surface elevation near the basin is about $79 \mathrm{~m}$ (260 ft) and decreases to Indian Grave Branch, located approximately $335 \mathrm{~m}$ from the site. The basin is semicircular and approximately $130 \mathrm{~m}$ wide. The containment volume of the $\mathrm{K}$-Area Retention Basin is approximately $1.89 \mathrm{E}+08 \mathrm{~L}$. The $\mathrm{K}$-Area Retention Basin is approximately $9.2 \mathrm{~km}$ from the nearest plant boundary.

Five monitoring wells were installed around the $\mathrm{K}$-Area Retention Basin to characterize the geologic and hydrogeologic conditions and to monitor the water-table elevation and groundwater quality. (Figure T.2). Monitoring we11s KRB 1 and KRB 8 were installed when the basin was constructed in 1963, and three additional wells (KRB 13, KRB 14, and KRB $15)$ were installed in 1966. The depth to the water table is $16.8 \mathrm{~m}$ below ground level, and groundwater flows generally to the northwest, consistent with the local topography.

\section{Review of Available Data}

The sediment beneath and the contents of the K-Area Retention Basin have not been sampled and characterized. The nonradioactive monitoring data from the wells at the basin indicate that the constituents in the groundwater in the vicinity of upgradient wells KRB 1 and KRB 8, sidegradient well KRB 13, and downgradient wells KRB 14 and KRB 15 have been below the levels given in Appendix Table 10 except for cadmium in well 


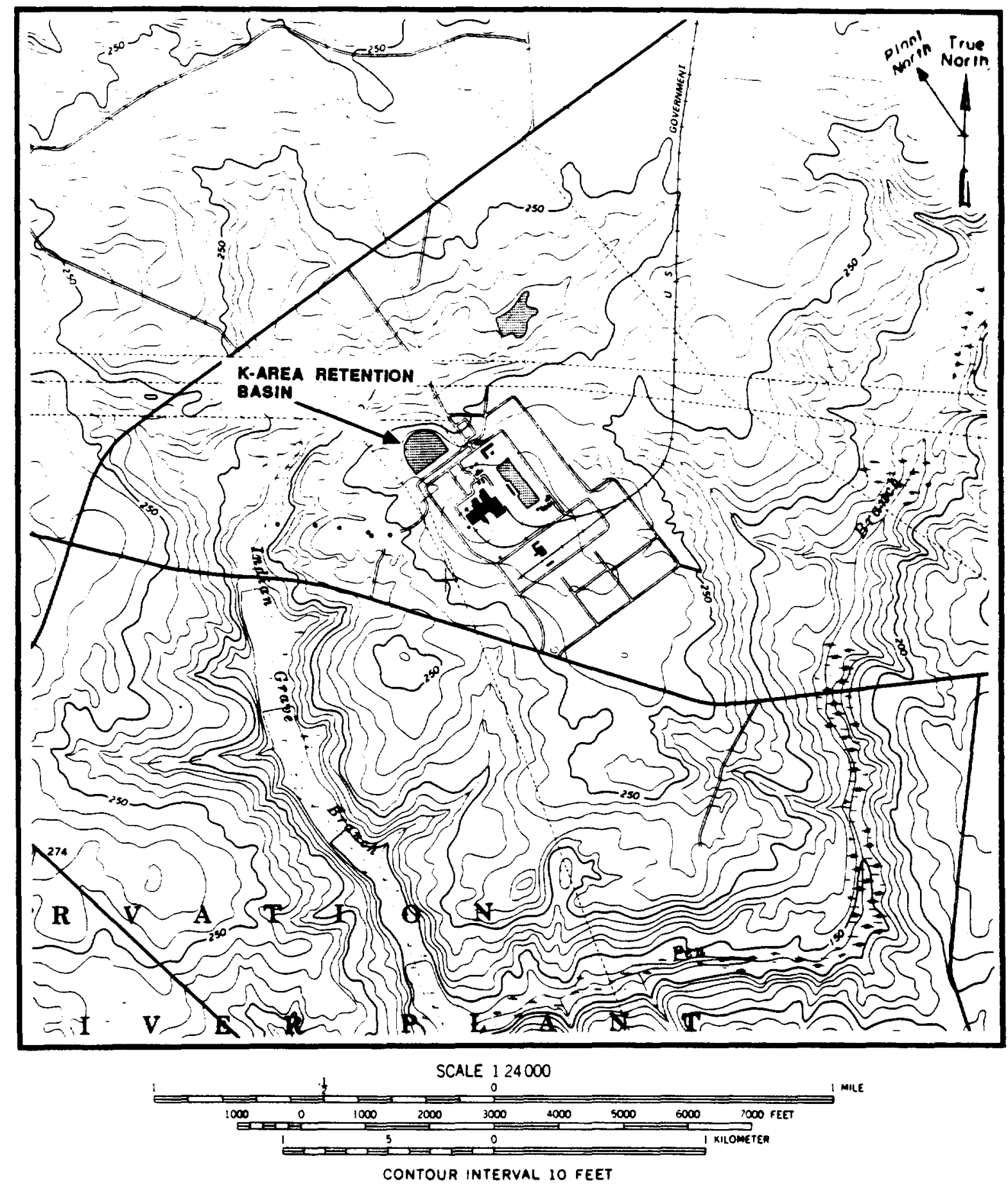

FIGURE T.1. Location of the K-Area Retention Basin on Girard NW Quadrangle 7.5 Minute Series Topographic Map 


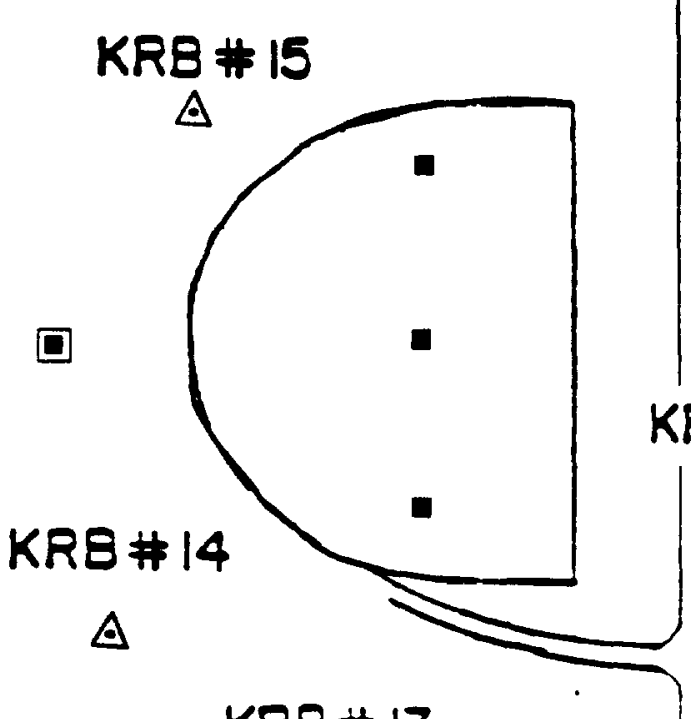

KRB \#13 $\Delta$ KRB $\neq 1$ LEGEND:

NOT TO SCALE

$$
\Delta \cdot \begin{array}{ll}
\Delta & \text { MONITORING WELL } \\
\square & \text { SOIL CORE } \\
\square & \text { DEEP SOIL CORE }
\end{array}
$$

FIGURE T.2. Proposed Sampling Locations at the $\mathrm{K}$-Area Retention Basin 
KRB 14; manganese in wells KRB 8 and KRB 14; lead in wells KRB 1, KRB 8, and KRB 13; and iron in well KRB 13 (Heffner et al., in press).

The basin wells have had higher concentrations of these materials than the levels indicated for the basin influent (Heffner et a1., in press). Cadmium concentrations in we11 KRB $14(0.002$ to $0.012 \mathrm{mg} / \mathrm{L})$ slightly exceeded the groundwater quality review criteria in Appendix Table 10 of $0.010 \mathrm{mg} / \mathrm{L}$ on one occasion. Manganese levels in wel1 KRB $8(0.035$ to $0.051 \mathrm{mg} / \mathrm{L})$ and well KRB $14(0.024$ to $0.434 \mathrm{mg} / \mathrm{L})$ were above the groundwater quality review criteria in Appendix Table 10 of $0.05 \mathrm{mg} / \mathrm{L}$ on a number of occasions. Lead concentrations in well KRB $1(0.004$ to $0.255 \mathrm{mg} / \mathrm{L})$, KRB $8(0.005$ to $0.124 \mathrm{mg} / \mathrm{L})$, and $\mathrm{KRB} 13(0.005$ to $0.239 \mathrm{mg} / \mathrm{L})$ exceeded the groundwater quality review criteria in Appendix Table 10 of $0.050 \mathrm{mg} / \mathrm{L}$ on a few occasions. The iron concentrations in wel1 KRB 13 , ranging from 0.007 to $0.464 \mathrm{mg} / \mathrm{L}$, exceeded the drinking water standard of $0.300 \mathrm{mg} / \mathrm{L}$ on one occasion. Iron concentrations of $0.464 \mathrm{mg} / \mathrm{L}$ are consistent with levels reported as naturally occurring in Barnwell Formation groundwater. Manganese and lead concentrations were above the groundwater quality review criteria in Appendix Table 10 in the upgradient well as well as some of the downgradient wells.

The radioactive monitoring data indicate that tritium levels were above the groundwater quality review criteria in Appendix Table 10 of $20 \mathrm{pCi} / \mathrm{mL}$ in all of the K-Area Retention Basin monitoring wells (Heffner et al., in press). The highest tritium values were found in we $11 \mathrm{KRB} 8$, ranging from 275,000 to $289,000 \mathrm{pCi} / \mathrm{mL}$. Reported total radium levels in the retention basin wells were consistently less than the levels in Table 10 of the Appendix of $5 \mathrm{pCi} / \mathrm{L}$, except for one isolated case in well $\mathrm{KRB} 15$ $(5.2 \mathrm{pCi} / \mathrm{L})$. Reported nonvolatile beta and gross alpha levels remained under $10 \mathrm{pCi} / \mathrm{L}$ and $5 \mathrm{pCi} / \mathrm{L}$, respectively, in all of the basin wells except we11 KRB 15. Nonvolatile beta levels ranging from 32.73 to $38.61 \mathrm{pCi} / \mathrm{L}$ were reported for well KRB 15 .

\section{Characterization Recommendations}

\section{Sampling}

Three sediment cores should be taken inside the $\mathrm{K}$-Area Retention Basin (Figure T.2). A11 cores should be $6 \mathrm{~m}$ in length extending from the bottom of the original basin. The cores should be subdivided into the sampling intervals listed in Appendix Table 1. In addition, a composite basin water sample should be taken.

One deep borehole should be made to better determine the vertical extent of contamination, if any, and to fully characterize the hydrogeologic units beneath the site. The borehole should be cored to the first major aquitard below the water table. The borehole should be located adjacent to the site near the inlet of the basin. This borehole should have surface casing to prevent the infiltration of basin constituents into the underlying aquifer. A continuous core, should be 
taken for the first $6 \mathrm{~m}$ from the bottom of the basin for the purpose of chemical analysis according to Appendix Table 1. Below this leve1, 0.3-m sample cores should be taken every $1.5 \mathrm{~m}$ within each saturated zone and from each 1ithological boundary present. Additionally, one undisturbed sample for physical testing should be collected from each clay-rich interval and saturated zone below the water table (Figure T.2).

In addition, water samples should be taken from the adjacent Indian Grave Branch.

\section{Chemical and Physical Analyses}

The sediment cores from the basin should be measured for the inorganic ions and metals 1 isted in Appendix Table 2. The sediment cores should also be analyzed for radioactive constituents listed in Appendix Table 4. In addition, the top interval of each core should be tested for the 1 ist of EP toxicity and Appendix IX constituents given in Appendix Tables 7 and 8 .

Analyses for the borehole samples will include metals and ions ( $A 1$, $\left.\mathrm{Fe}, \mathrm{Na}, \mathrm{Cl}, \mathrm{CO}_{3}, \mathrm{NO}_{3}, \mathrm{SO}_{3}, \mathrm{SO}_{4}\right)$ and radionuclides $\left({ }^{3} \mathrm{H},{ }^{90} \mathrm{Sr},{ }^{13} 7_{\mathrm{Cs}}\right.$, and ${ }^{60} \mathrm{Co}$ ), soil $\mathrm{pH}$, conductivity, moisture content, cation exchange capacity, TOH, and TOC. Physical testing for soil samples should include stratification characteristics, grain size, porosity and permeability (horizontal and vertical), and hydraulic conductivity.

A11 groundwater wells in the vicinity of the basin should be analyzed for the expanded radioactivity constituents listed in Appendix Table 5 . The surface water samples from Indian Grave Branch should be analyzed for inorganic ions, metals, and radionuclides listed in Appendix Tables 2 and 5 . 


\section{Background}

\section{Site History}

The L-Area Oil and Chemical Basin (Building 904-83G) was used for the disposal of low-level radioactive oil and chemical liquid wastes from 1961 to 1979. These wastes came from production and research areas throughout the plant and contained tritium, activation products, mixed fission products, decontamination wastewater, and spent degreasing solvents. Wastes were transported to the basin by tank truck, metal drums, and other containers. Chemical analyses were not made, but all wastes were radiochemically analyzed before disposal in the basin. Major radionuclides discharged to the basin were ${ }^{60} \mathrm{Co},{ }^{137} \mathrm{Cs},{ }^{3} \mathrm{H},{ }^{90} \mathrm{Sr}$, and unidentified alpha and beta-gamma emitters. This facility received approximately $90 \mathrm{~m}^{3}$ of waste annually, with a total volume of $4,730 \mathrm{~m}^{3}$ through 1979. Discharge from the basin has been restricted to the seepage of effluent into the underlying water-table aquifer (Pekkala et al., 1987b).

\section{Site Description}

The L-Area 0il and Chemical Basin is an unlined basin located approximately $9.8 \mathrm{~km}$ to the northwest of the nearest plant boundary (Figure U.1). The basin was constructed by excavating below grade and backfilling around the sides to form earthen dike walls. Surface elevation of the basin is $72 \mathrm{~m}(235 \mathrm{ft})$. Basin dimensions are $36 \mathrm{~m}$ long by $24 \mathrm{~m}$ wide by $3.4 \mathrm{~m}$ deep, with a volume capacity of approximately 2,937 $\mathrm{m}^{3}$. The facility has a surface area of approximately $864 \mathrm{~m}^{2}$. The northeast corner of the basin is located at SRP coordinates $N 45203$, E 51113. Rainfall has kept some water in the basin at all times since deactivation in 1979. It is believed that seepage through the basin's floor has been reduced due to sealing of bottom sediments by oil and chemical wastes. There are four groundwater monitoring wells (LCO 1 through 4) located around the perimeter of the seepage basin. Additiona11y, there are two seven-well clusters (P15 and LAW 1) and two three-well clusters (LAW 2 and LAW 3) located in the general vicinity of the basin. Depth to the water table at the basin site is approximately $7 \mathrm{~m}$ below grade. Groundwater flow and surface drainage in the area of the basin is to the south toward Steel Creek (L Lake).

\section{Review of Available Data}

In April 1984, a composite surface water sample was taken from the basin to characterize the chemical constituents within the water column. Results of this study indicated that no parameters exceeded applicable drinking water standards with the exception of iron $(1.04 \mathrm{mg} / \mathrm{L})$. 

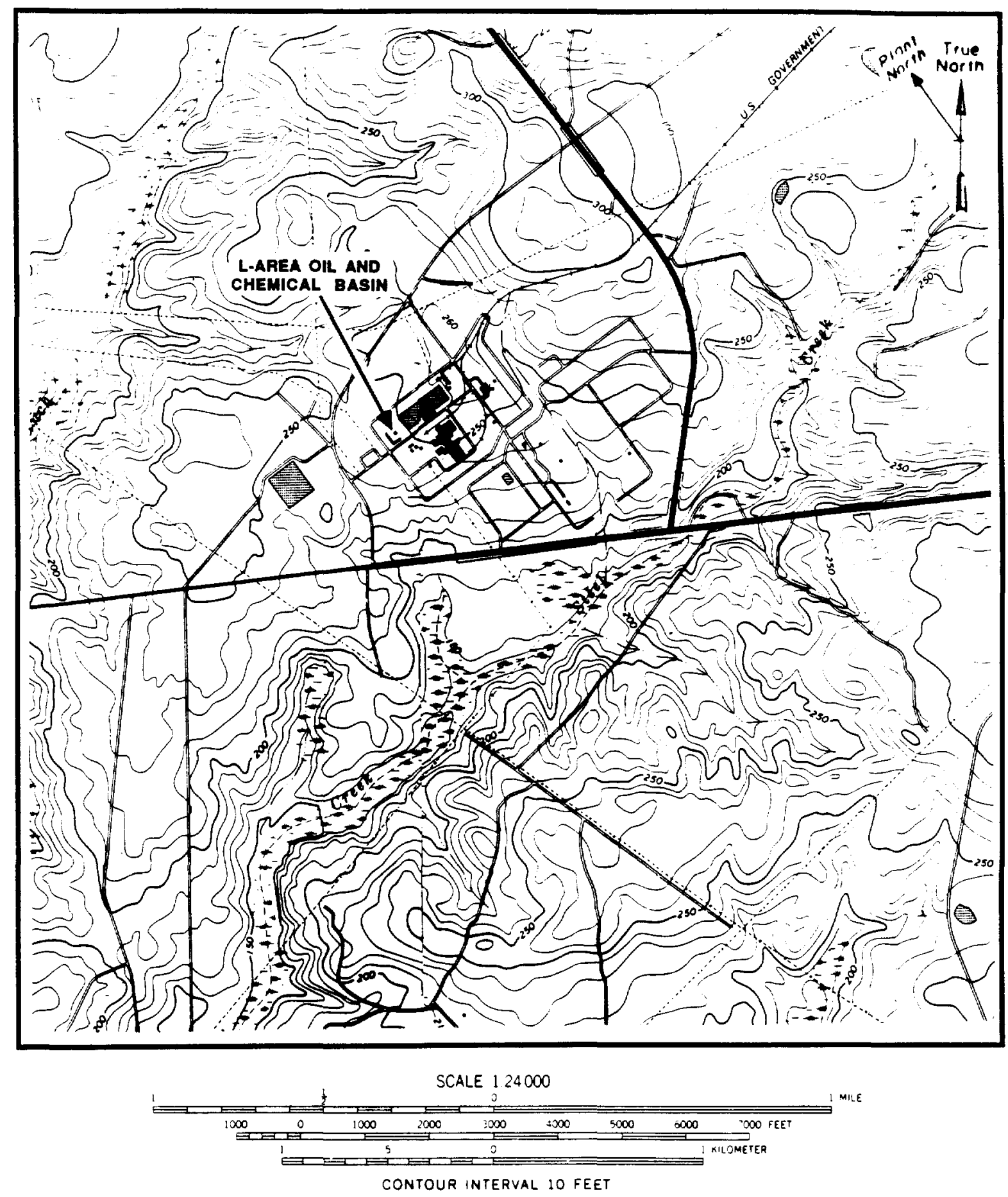

FIGURE U.1. Location of the L-Area Oil and Chemical Basin on Girard NW and Girard NE Quadrangle 7.5 Minute Series Topographic Maps 
The basin's bottom sediments have been sampled on two occasions. In January 1984, four grab samples were taken from the upper sediment layer and analyzed for the radioisotopes of cobalt, cesium, and europium. Significant amounts of ${ }^{60} \mathrm{Co}$ and ${ }^{137} \mathrm{Cs}$ were detected (Price et al., in press). In 1985, a more extensive characterization study was conducted when nine cores ranging in depth from 79 to $188 \mathrm{~cm}$ were taken from the basin's bottom (Figure U.2). A composite of two cores (LBC-5 and LBC-6) was analyzed, and elevated levels of arsenic, cadmium, chromium, lead, mercury, magnesium, manganese, nickel, sodium, selenium, uranium, zinc, ${ }^{60} \mathrm{Co}, 137 \mathrm{Cs}$, gross alpha, and gross beta were detected. Maximum concentrations for all chemicals occurred within the top $76 \mathrm{~cm}$ of the core. No samples exceeded EP toxicity test criteria. The highest levels of ${ }^{60} \mathrm{Co}$ and ${ }^{137} \mathrm{Cs}$ were found at depths of 15 to $38 \mathrm{~cm}$. No significant levels of petroleum hydrocarbons were detected (Pekkala et a1., 1987b).

A review of groundwater monitoring data for the period encompassing 1986 through the first quarter of 1987 indicates that the L-Area Oil and Chemical Basin has had an effect on groundwater quality. Chemical constituents that exceeded groundwater quality review criteria were lead, manganese, mercury, nitrate, sulfate, nonvolatile beta, total radium, and tritium. Elevated levels of $T O C$ and $T O H$ were also noted (Mikol et al., in press; Ziegler et al., 1987).

\section{Characterization Recommendations}

\section{Sampling}

No further sample acquisition is recommended.

\section{Chemical and Physical Analyses}

At least two of the archived sample cores should be retrieved and analyzed for the radionuclides listed in Appendix Table 5. 


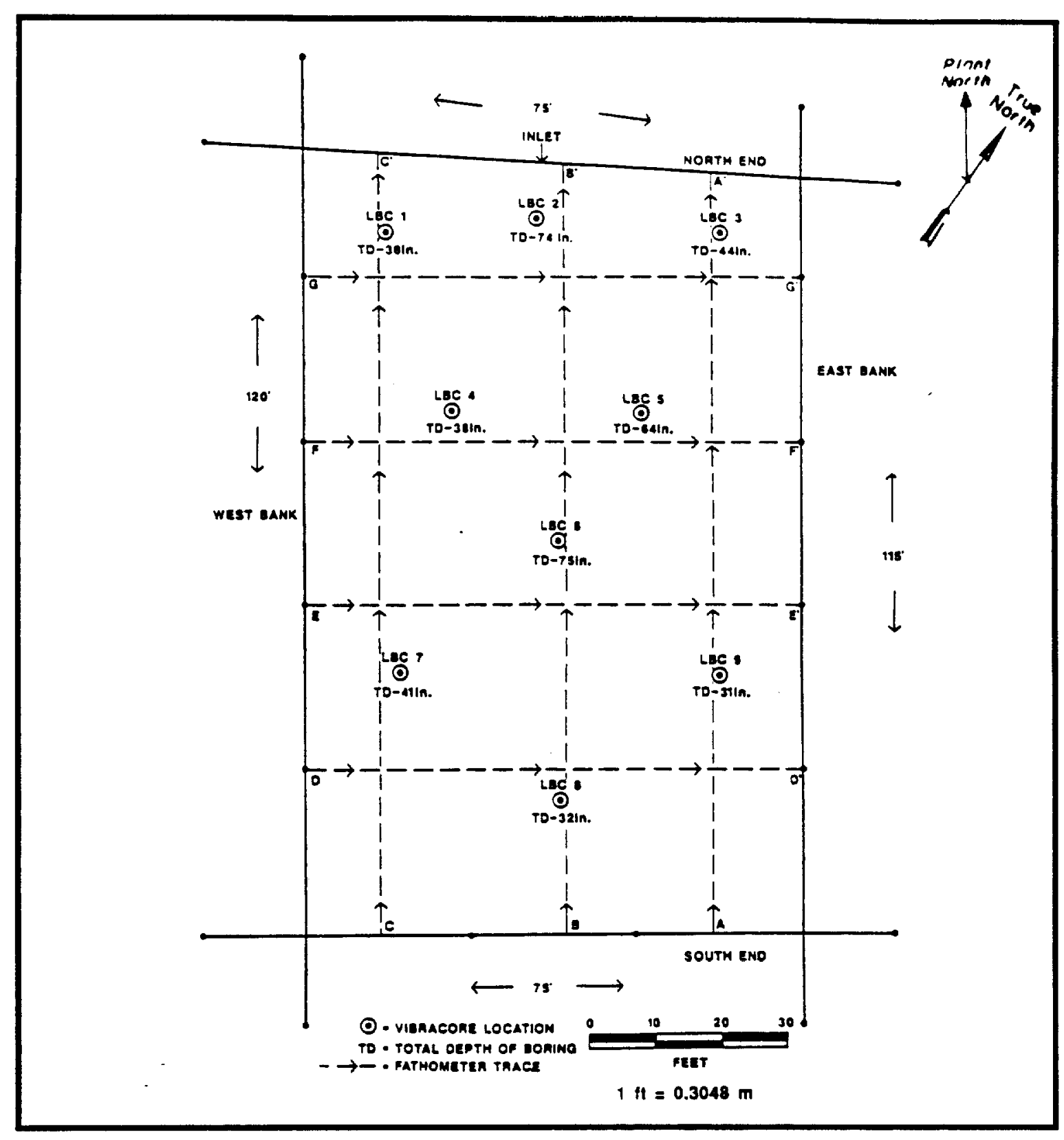

FIGURE U.2. Sampling Locations within the L-Area Oil and Chemical Basin 


\section{Background}

\section{Site History}

The Central Shops and F-Area lumber piles were established in 1975 for the periodic burning of scrap lumber. Each site receives approximately 25 $\mathrm{m}^{3}$ of scrap lumber per month. Waste material collected for incineration at these sites includes poles, crates, pallets, and unsalvageable wooden furniture. No radioactive or hazardous chemical constituents are believed to have been disposed of at these sites (Heffner et a1., in press). The Central Shops and F-Area Scrap lumber piles are currently active, and their continued use is planned.

\section{Site Description}

The Lumber Piles are centrally located in SRP near the Central Shops (CS) and $F$ areas of the plant. Specifically, the Central Shops Lumber Pile is located north of the Central Shops perimeter fence and south of SRP Road C-5 (Figure V.1) immediately adjacent to Centra1 Shops Burning/Rubble Pit 631-1G. The F-Area Lumber Pile is located west of the F-Area perimeter fence and north of SRP Road C (Figure V.2) at the same site as the F-Area Burning/Rubble pits. The dimensions and SRP coordinates of these waste sites are as follows:

$\begin{array}{lllll}\text { Location } & \text { B1dg. No. } & & \begin{array}{l}\text { SRP Coordinates } \\ \text { (Estimated Center) }\end{array} & \text { Dimension } \\ \text { CS Area } & 631-2 G & \text { N } 65000 \text { E } 52800 & 91 \times 91 \\ \text { F Area } & 231-3 F & \text { N } 79400 \text { E } 50700 & 61 \times 122\end{array}$

Surface elevation at both sites is approximately $85 \mathrm{~m}(280 \mathrm{ft})$. There are no groundwater monitoring wells located in the immediate vicinity of either the Central Shops or F-Area lumber piles. Therefore, site-specific hydrogeologic information is not available. Surface drainage and shallow groundwater flow in the area of the Central Shops Lumber Pile is to the west-northwest toward Four Mile Creek. The water-table elevation in nearby monitoring wells located around the Central Shops Burning/Rubble Pits averages $6 \mathrm{~m}$ below grade. Surface drainage and shallow groundwater flow in the area of the F-Area Lumber Pile is to the west toward Upper Three Runs Creek. The water-table elevation in monitoring wells located around the nearby F-Area Burning/Rubble Pits averages $26 \mathrm{~m}$ below grade.

\section{Review of Available Data}

No soil core data are available for either the Central Shops or the F-Area lumber piles. Although there are no groundwater data available for 

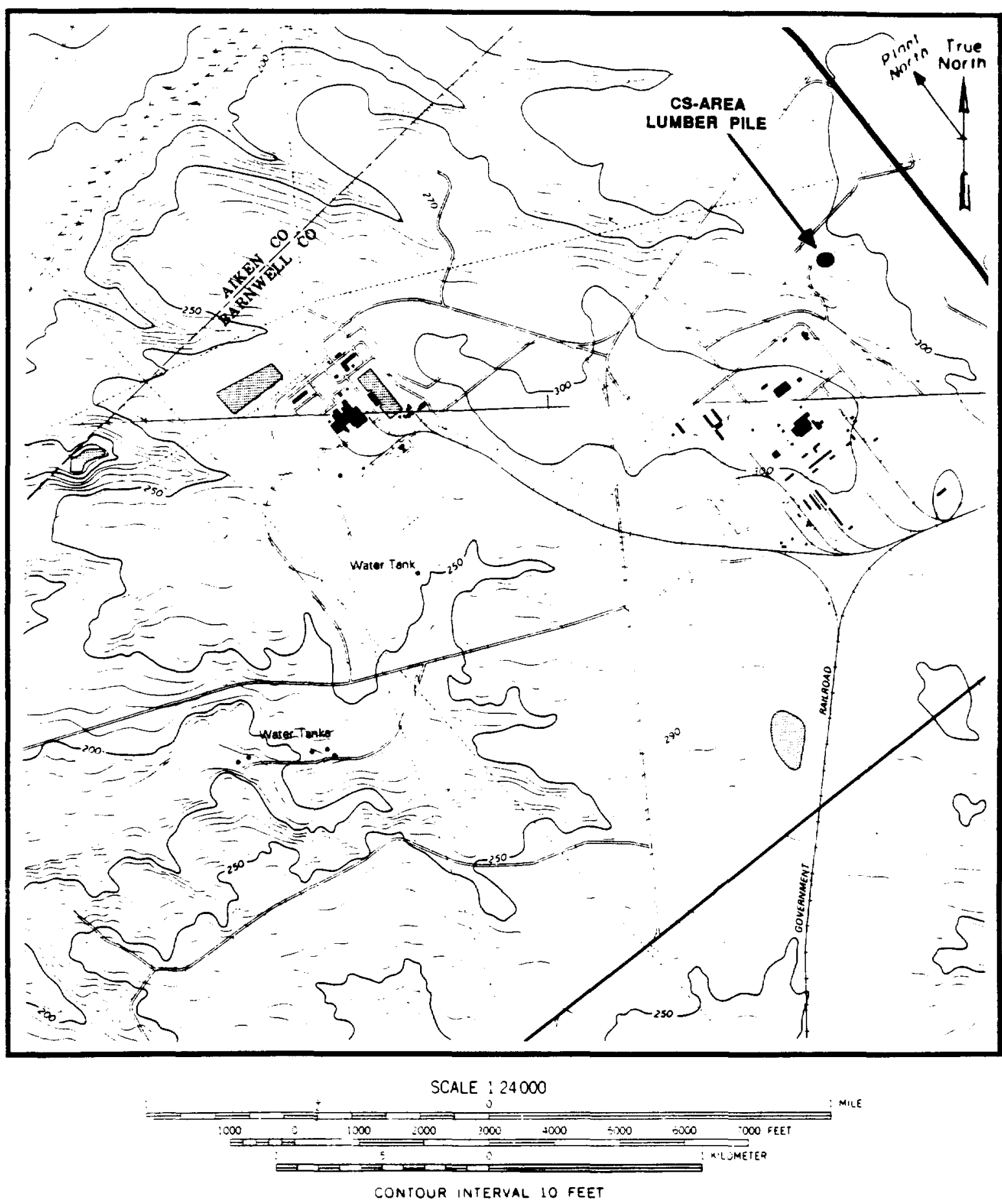

\section{FIGURE V.1. Location of the Central Shops Lumber Pile on New Ellenton Sw and Girard NW quadrangle 7.5 Minute Series Topographic Maps}



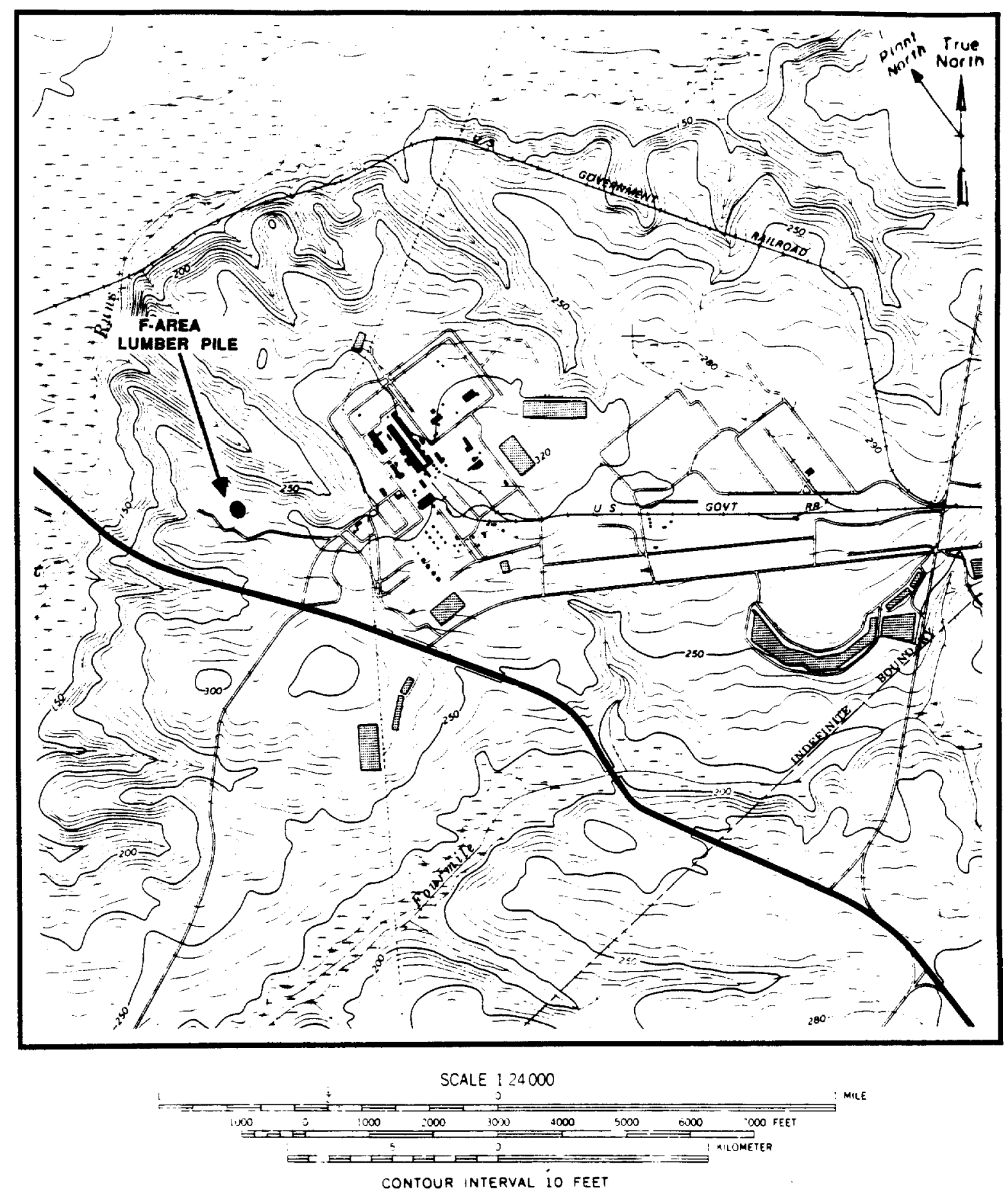

FIGURE V.2. Location of the F-Area Lumber Pile on New Ellenton SW
Quadrangle 7.5 Minute Series Topographic Map 
the Central Shops Lumber Pile, data from the F-Area Burning/Rubble pit wells are applicable to the F-Area Lumber Pile. Review of these data for 1986 and the first quarter of 1987 indicates elevated levels of nonvolatile beta, nitrate (as $\mathrm{N}$ ), and trichloroethylene (Mikol et al., in press; Zeigler et al., 1986). A potential source of these constituents may be groundwater migrating from the process sewer lines located east of the lumber pile site.

\section{Characterization Recommendations}

\section{Sampling}

Due to the close proximity of the CS and F-Area lumber piles to the CS and F-Area burning/rubble pits, sampling of these piles should be performed as part of the burning/rubble pit sampling program. (See sampling requirements for the Central Shops and F-Area burning/rubble pits.)

\section{Chemical and Physical Analyses}

The analytical requirements should be those given for the Central Shops and F-Area burning/rubble pits. 


\section{Background}

\section{Site History}

The M-Area Settling Basin (Building 904-51G) and associated areas received process effluent from the M-Area fue1- and target-fabrication facilities from 1958 until 1985. Waste effluents can be generally characterized as electroplating waste from aluminum forming and metal finishing processes. The waste effluent was highly variable but usually contained metal-rich solutions (aluminum, uranium, nickel, lead, mercury, copper) with high concentrations of nitrate, phosphate, sulfate, and metal degreasers. The $\mathrm{pH}$ of the influent was highly variable due to the use of both acids and caustics in the various processes.

Total uranium discharged to the basin between 1974 and 1984 was 1,100 $\mathrm{mCi}$. No data are available before 1974. Approximately $3.5 \mathrm{E}+06 \mathrm{~kg}$ of volatile organic solvents were discharged to the process sewer, with $2.0 \mathrm{E}+06 \mathrm{~kg}$ going to the seepage basin and the remainder released directly to Tims Branch, a nearby stream.

Discharges flowed to the settling basin via a $76.2-\mathrm{cm}$ diameter underground vitrified-clay process sewer line approximately $715 \mathrm{~m}$ long. Many cracks and misalignments in the pipe were discovered in 1981. In 1983 the sewer was 1 ined with a $0.30-m$ PVC 1 iner. An estimated $50 \%$ of all 1iquids that overflowed from the basin seeped into the ground in a natural seepage area above Lost Lake.

Flow was stopped to the settling basin in July 1985. However, greater than $80 \%$ of the normal volume of liquid is still present in the basin. Water levels in Lost Lake varied widely from 1958 to 1985 as a result of increases in process discharge and rainfall. Since flow to the settling basin was discontinued in 1985, the overflow area and Lost Lake have dried out. However, it is anticipated that Lost Lake will alternate between dry and wet periods depending on the amount of precipitation.

The M-Area Settling Basin is permitted by SCDHEC in compliance with the Interim Status Standards. A proposed plan to close the M-Area HWMF in place as a landfil1 has been approved by SCDHEC and EPA (Region IV). A groundwater remediation program was implemented in April 1985.

Information describing site location, history, and existing data has been obtained from Pickett et al. (1987a), from the closure plan (Colven et al., 1985), from the extended characterization study (Pickett, 1985), and from the supplemental technical data summary on the groundwater (Marine \& Bledsoe, 1985). 


\section{Site Description}

The M-Area Settling Basin and associated areas are located in the northwestern portion of SRP in the 300 Area (Figure W.1). The site is approximately $1,800 \mathrm{~m}$ southeast of the nearest plant boundary. The M-Area HWMF encompasses (1) the settling basin, (2) the overflow ditch, (3) a natural seepage area, (4) a Carolina bay known as Lost Lake, and (5) the inlet process sewer 1 ine (Figure W.1). SRP coordinates for the northeast corner of the M-Area Settling Basin are N 102151, E 48684 and for the northeast corner of Lost Lake are N 102000, E 47800.

The settling basin is a rectangular basin with an unlined floor approximately $85 \mathrm{~m}$ by $70 \mathrm{~m}$ and a depth of approximately $5.2 \mathrm{~m}$. Original liquid capacity for the basin was $30,000 \mathrm{~m}^{3}$. The basin is classified as a settling basin instead of a seepage basin because there has been surface water discharged from the basin. The inlet process sewer line, carrying the 1 iquid waste from $M$ Area to the settling basin, entered the settling basin on the north side (Figure W.1). The overflow ditch, located on the west side of the basin, received liquids from the basin and transported them to a seepage area immediately above Lost Lake (Figure W.1). The seepage area covers approximately 3 acres. Lost Lake, located southwest of the seepage area, is a natural Carolina bay of approximately 10 to 25 acres (Figure W.1). Lost Lake has no outlet.

The M-Area Settling Basin and vicinity is located at an elevation of approximately $107 \mathrm{~m}(350 \mathrm{ft})$ on the Aiken Plateau. Topography at the waste site is fairly level. Surface drainage is generally to the southeast toward Tims Branch.

Approximately 100 groundwater monitoring wells have been installed as part of the M-Area groundwater investigation. Eleven groundwater wells are being pumped as recovery wells. The recovered groundwater is fed to an air-stripping column that removes essentially $100 \%$ of the chlorocarbons from the influent stream.

Groundwater hydrology of the M-Area Settling Basin and environs has been well delineated by information collected as a result of the insta1lation of the numerous monitoring wells. A water-table high exists northeast of the settling basin. The settling basin and Lost Lake are close to a water-table divide. Groundwater flow, based on groundwater chemistry, is believed to be generally to the south from M-Area toward the intersection of Upper Three Runs Creek and the Savannah River (Colven et al., 1985). The water table is present at a depth of approximately 35 to $40 \mathrm{~m}$. 

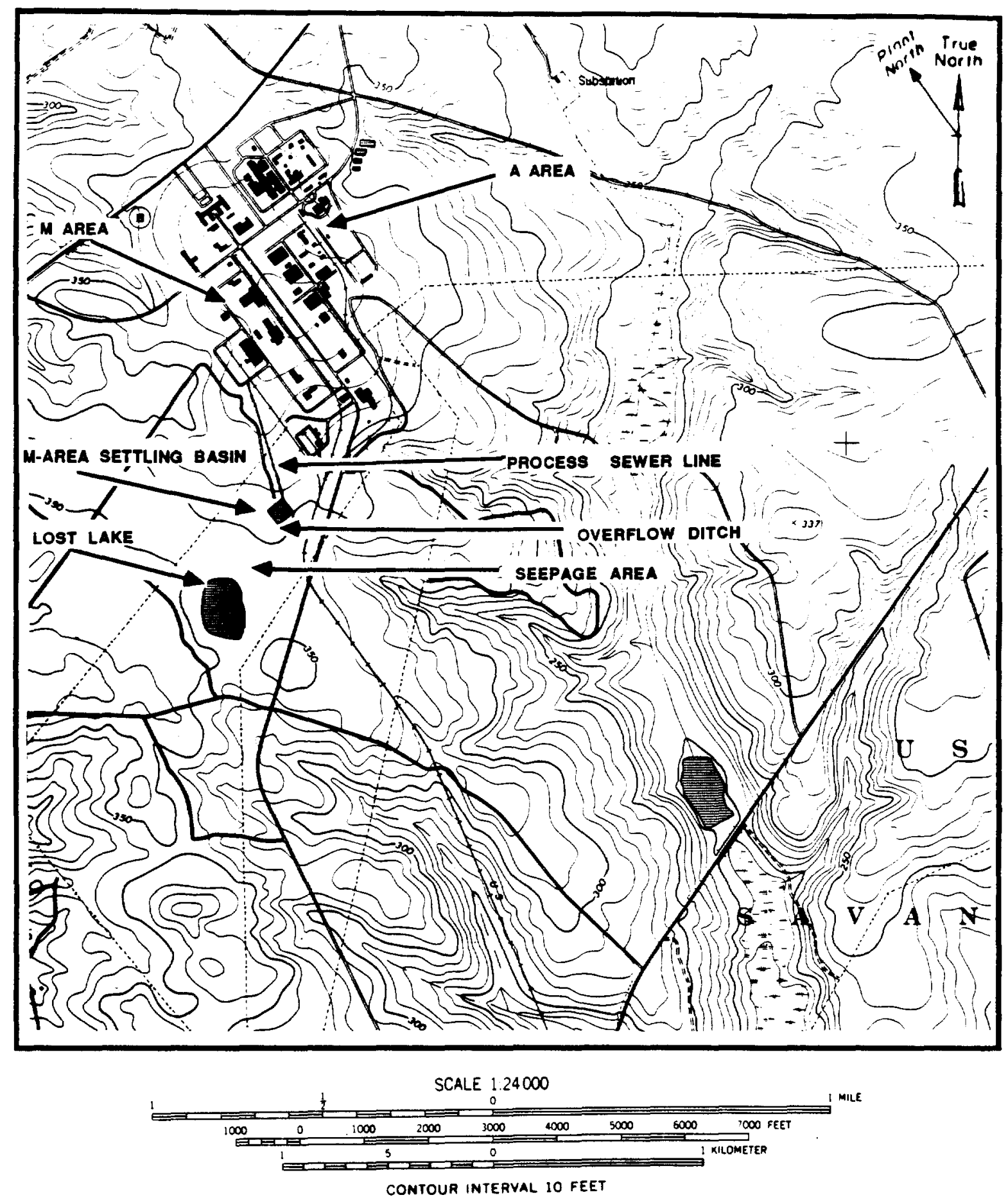

FIGURE w.1. Location of the M-Area Settling Basin and Vicinity on New Ellenton SW quadrangle 7.5 Minute Series Topographic Map 
The liquid in the settling basin has been found to be vertically stratified into two layers. Significant differences in density, conductivity, dissolved oxygen, sodium, and nitrate exist between the two layers. Sixteen samples were collected from each layer. The water was found to be alkaline and highly conductive. Cadmium and lead are the only metals that exceed EPA primary drinking water standards (Appendix Table 10). However, elevated levels of uranium, nickel, aluminum, and nitrate also exist. Four chlorinated hydrocarbons were detected in the water at levels above groundwater quality review criteria (Appendix Table 10).

The sludge in the bottom of the settling basin consists primarily of aluminum hydroxide, with smaller amounts of organic carbon and metal phosphates. The sludge contains the major inventories of iron, nickel, chromium, and uranium in the basin. A number of organic compounds are also present in significant amounts.

Seventy-three soil cores have been analyzed in order to characterize the M-Area Settling Basin and vicinity. Four soil cores were collected to be used as M-Area reference samples. In 1981 two surficial (0-15 cm) soil samples were collected from the bottom of the M-Area Settling Basin. Five 4.5-m deep soil cores were taken in 1982. The extended characterization study included four additional 1.8-m deep soil cores collected in 1985 . In both the 1982 and 1985 samples, metals (with the exception of uranium) were found to reach background levels within the upper $0.6 \mathrm{~m}$ of the surface. Elevated levels of chlorinated hydrocarbons (up to $50 \mu \mathrm{g} / \mathrm{L}$ ) were detected at depths of $4.5 \mathrm{~m}$ in 1982 and up to $2,000 \mu \mathrm{g} / \mathrm{L}$ were found in the upper $1 \mathrm{~m}$. In 1985, elevated levels of chlorinated hydrocarbons (up to 24 $\mu \mathrm{g} / \mathrm{L}$ ) were detected on $1 \mathrm{y}$ in the upper $0.6 \mathrm{~m}$ of soil. From 0.6 to $1.8 \mathrm{~m}$, no chlorinated hydrocarbons were detected. It is possible that the more mobile organic constituents migrated toward the water table between 1982 and 1985 (Colven et al., 1985).

Four soil cores immediately adjacent to the basin were collected to a depth of $4.5 \mathrm{~m}$. There is no evidence of any horizontal migration of inorganics or organics in the soil samples.

Twelve soil cores (1.0-m deep) have been collected and analyzed along the entire length of and adjacent to the overflow ditch. The cores collected along the ditch contained a sludge sample at the surface. The composition of the sludge in the overflow ditch is very similar to that of the sludge in the settling basin, but levels of metals and organics are generally lower. Soils in the overflow ditch contain elevated levels of metals. Nickel and uranium are the most mobile and are present at elevated levels at the 1.0-m depth. The other metals are most concentrated in the top $15 \mathrm{~cm}$ of the soil. Low levels of organic contamination were found in the top $15 \mathrm{~cm}$ of the soils along the overflow ditch. 
Eighteen soil cores were collected in the natural seepage area. These samples contained sludge at the surface and were taken to a depth of approximately $0.3 \mathrm{~m}$. Two $1.8-\mathrm{m}$ soil cores were also collected. The sludge in the seepage area was similar in composition to the sludge in the settling basin and the overflow ditch. The soils underlying the seepage area contain levels of metals that are higher than the M-Area reference samples. Nickel and uranium, the most mobile metals, were at background levels within $1 \mathrm{~m}$ of the surface. Volatile organic concentrations were below detection in all but one sample, which contained only $19 \mathrm{ng} / \mathrm{g}$ tetrachloroethylene.

Soil samples, to a depth of $45 \mathrm{~cm}$, were collected on a grid pattern in and around Lost Lake. Slightly elevated concentrations of metals occur in the surficial soils below the normal water line at Lost Lake. Below $15 \mathrm{~cm}$, most soils contain background levels of metals. Contamination by organic compounds appears to be quite minor, with only one sample containing tetrachloroethylene and one sample containing phthalates.

Elevated concentrations of chlorinated organic compounds have been detected in the groundwater in a number of the monitoring wells. The elevated VOCs present the major contamination problem for the groundwater in $M$ Area. The process sewer line and the settling basin are believed to be the major source of groundwater contamination.

Radioactivity, gross alpha and gross beta, exceeds groundwater quality review criteria (Appendix Table 10) in only three of the M-Area monitoring wells; all three are located near the settling basin. In the immediate area of the settling basin, elevated levels of aluminum, antimony, chloride, chlorobenzene, conductivity, manganese, nicke1, nitrate, sodium, strontium, uranium, and zinc are present in the groundwater. Levels of nitrate that exceed the groundwater quality review criterion (Appendix Table 10) are also present in some of the monitoring wells.

\section{Characterization Recommendations}

An extended characterization of the M-Area Settling Basin and vicinity has been completed (Pickett, 1985). As previously mentioned, a closure plan has been submitted and approved by South Carolina and EPA (Region IV) (Colven et al., 1985). Additional sampling and analysis are not recommended at this time. 


\section{Background}

\section{Site History}

The Metallurgical Laboratory Basin (Building 904-110G) has received wastewater effluent from the Equipment Engineering Division metallurgical laboratory in Building 723-A since 1956. The wastewater flowed from Building 723-A to the basin via an underground process sewer pipeline. The historic wastewater discharge rate to the basin was estimated to be $3.8 \mathrm{~m}^{3} /$ day.

Although specific discharges to the basin have varied during facility operation, effluents have always consisted of small quantities of laboratory wastes from metallographic sample preparation (degreasing, cleaning, and etching) and corrosion testing of stainless steels and nickel-based alloys (Michael et a1., 1987).

Chemicals used over the history of the basin for degreasing operations include solvents such as acetone, 1,1,1-trichloroethane, trichloroethylene, and tetrachloromethane. This process involves immersing metal parts in the solvent to remove dirt and grease. These solvents were released in $1-L$ quantities intermittently during the years they were used. Chemicals such as potassium and sodium cyanide, hydrofluoric acid, and other acids were used as etchants for preparing samples for metallographic evaluation. In addition, small amounts of cyanide were also released to the basin in the form of depleted plating solutions at a rate of $1 \mathrm{~L}$ per discharge over the first 20 years of basin operation. Wastes from the cleaning of stainless steel fill and capillary tubing were discharged to the basin at a rate of $0.5 \mathrm{~L}$ intermittently over the basin's operational history. These wastes contained hydrofluoric acid and fluoride salts.

Nitric acid, at $65 \%$ concentration, was used in the corrosion testing of stainless steels and was discharged to the basin at a rate of approximately $12 \mathrm{~L}$ at a time, 7 times per month. Noncontact cooling water, also used in corrosion testing, was discharged to the basin at a rate of about 3,700 L/day for virtually the entire history of the basin. Other water discharges included rinsewater from various laboratory operations at a rate of about $100 \mathrm{~L}$ /day. During periods of heavy rain, basin liquids overflowed through a drainage canal to an adjacent Carolina bay. The quantities of materials that may have been deposited in this depression from runoff and/or discharge are unknown. No radioactive materials were ever discharged to the basin. Effluent flow to the basin was terminated on November 8, 1985. The current water level in the basin is approximately $1.2 \mathrm{~m}$. The sloping banks of the basin are covered with small bushes, weeds, and grass. 


\section{Site Description}

The Metallurgical Laboratory Basin is located on the Aiken Plateau in A Area of SRP in the southeast section as shown in Figure X.1. Coordinates of the northeast corner of the basin are $\mathrm{N} 104114, \mathrm{E}{ }^{\circ} 51556$. The basin is approximately $2.3 \mathrm{~km}$ from the nearest plant boundary. The dimensions of the basin are approximately $31 \mathrm{~m} 10 \mathrm{ng}$ by $12 \mathrm{~m}$ wide by $1.5 \mathrm{~m}$ deep. The volume capacity of the basin is approximately $550 \mathrm{~m}^{3}$.

Ground surface elevations are approximately $113 \mathrm{~m}$ (370 ft) and slope generally to the east in the direction of Tims Branch, the closest natural surface water drainage, located approximately 1,220 $\mathrm{m}$ from the basin. The depth to the water table is approximately $40 \mathrm{~m}$ below ground surface, and the groundwater flow is to the west. Geologically, the basin is constructed within the undifferentiated Tertiary age sediments (i.e., Barnwe11, McBean, and Congaree formations). Regional1y, these formations dip to the southeast at a rate of about $2 \mathrm{~m} / \mathrm{km}$.

Three groundwater monitoring wells (AMB 1, 2, and 3) were installed around the basin in June 1983. We11s AMB 1 and 3, however, went dry, were grouted up, and new wells (AMB $1 A$ and $3 A$ ) were installed in April 1984. The well casings are constructed of PVC. Pumps were not installed in AMB $1 \mathrm{~A}$ and $3 \mathrm{~A}$ until the fourth quarter of 1984. The wells are sampled quarterly as part of the Health Protection Department groundwater monitoring program.

\section{Review of Available Data}

A characterization program for the Metallurgical Laboratory Basin, conducted from September 1984 to January 1985, consisted of the sampling and analysis of basin sediment, basin water, and groundwater. The objective of the characterization program was to determine whether contaminants were present in the basin and whether they have migrated into the sediments beneath the basin or have moved laterally away from the basin. Therefore, the characterization program consisted of the collection of samples from beneath and around the basin (Figure X.2). Basin sediments and underlying soil to $6.1 \mathrm{~m}$ deep were taken from three locations within the basin. Soils outside the basin were obtained to a depth of $7.6 \mathrm{~m}$ at four sites around the basin. The possibility existed that leakage had occurred along the process sewer pipeline that leads to the basin. If leakage had occurred, it would most likely have occurred at a joint. Therefore, a section of the pipeline, approximately $10.7 \mathrm{~m}$ from the basin, was uncovered, and samples were collected from sediments beneath each of the three joints (Figure X.3). An additional sediment sample was collected from a location approximately $1.2 \mathrm{~m}$ from the pipeline to furnish background comparisons.

The results of the soil core analyses are presented in Johnson et al. (1987a). These results indicate that no significant organic contamination 


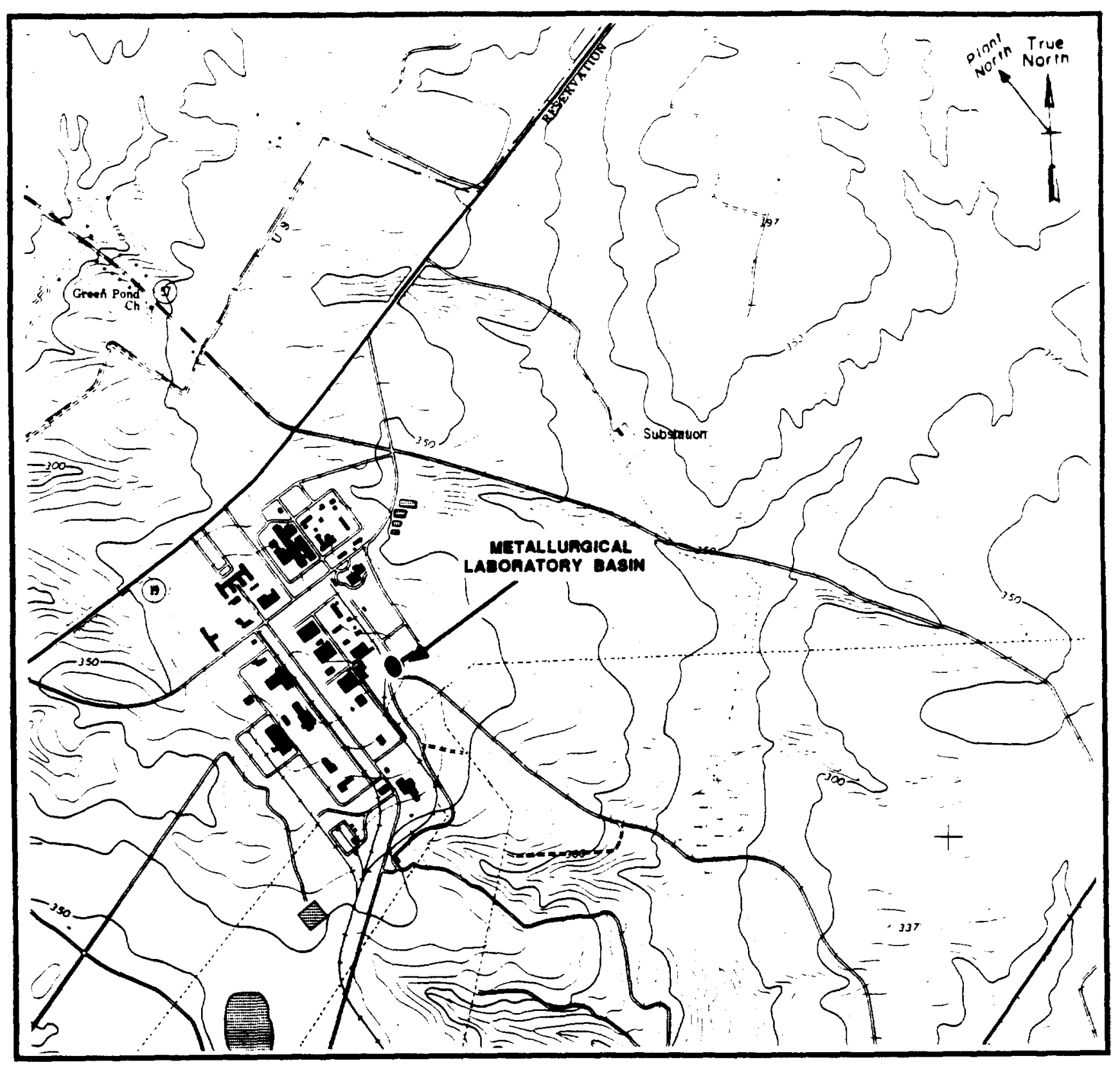

SCALE 124000

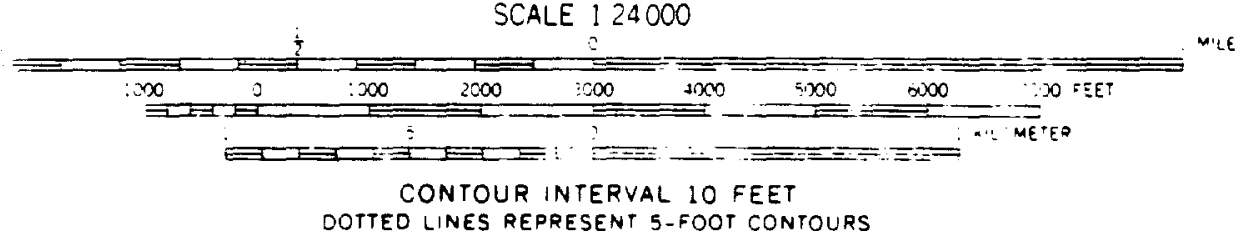

FIGURE X.1. Location of the Metallurgical Laboratory Basin on New Ellenton SW Quadrangle 7.5 Minute Series Topographic Map 

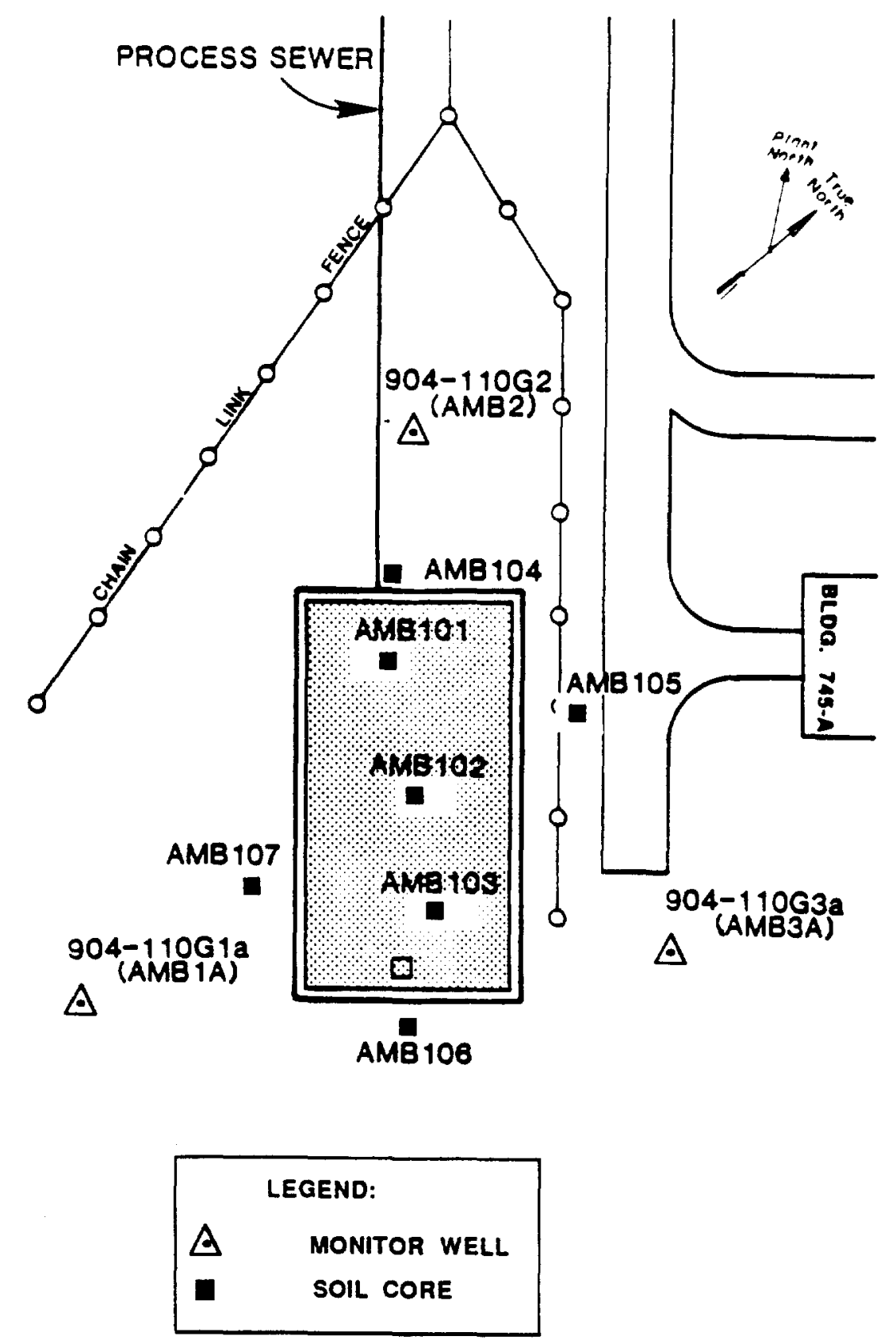

NOT TO SCALE

FIGURE X.2. Metallurgical Laboratory Basin Sampling Locations 


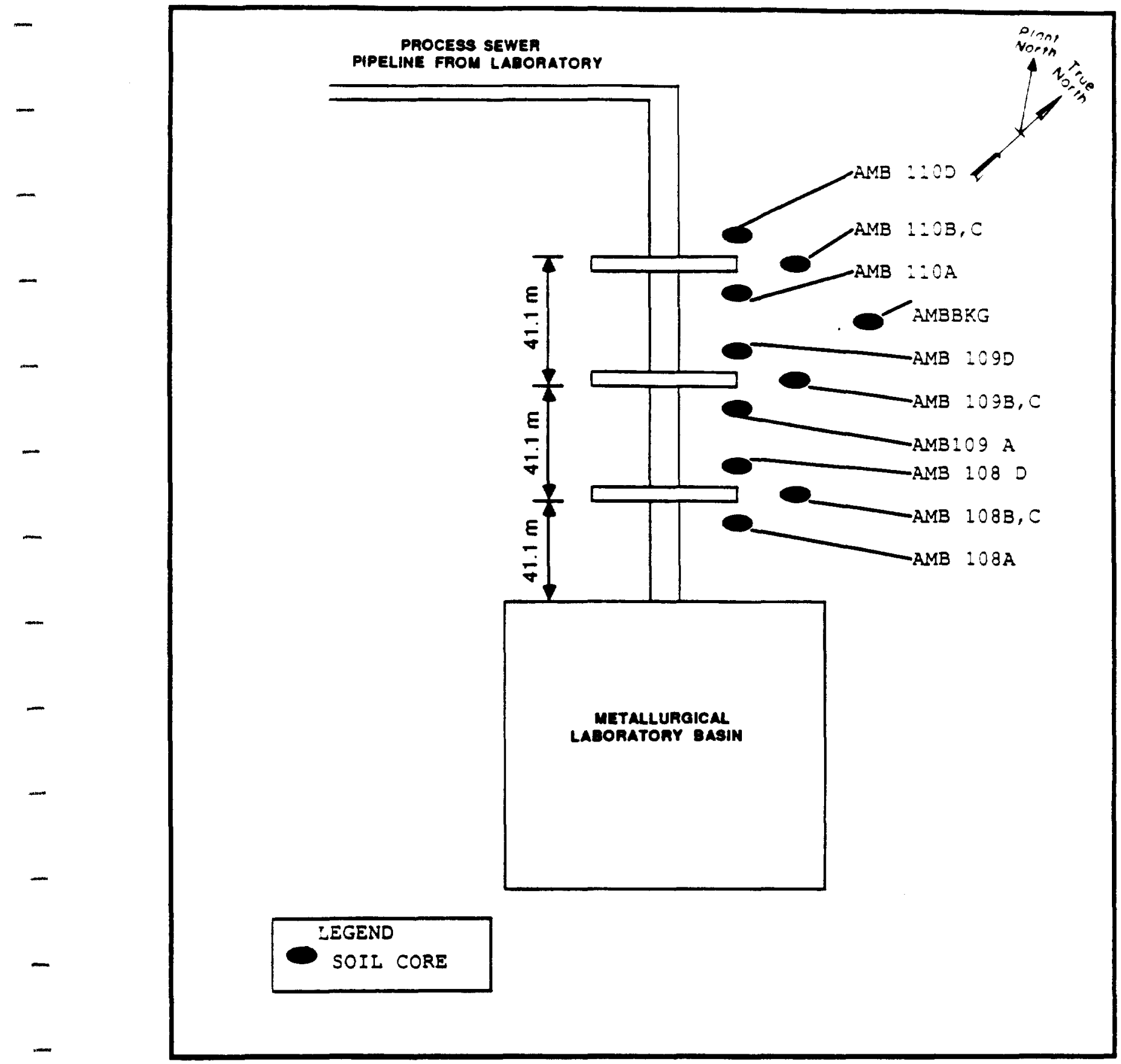

FIGURE X.3. Process Sewer Line Sampling Locations

$$
x-5
$$


exists in any of the sediments sampled. Of the organic chemicals analyzed, only bis-2-ethyl phthalate and di-n-butyl phthalate were detected in the top layer of sediments in the basin and in the bottom layer of sediments outside the basin. The organics detected in the basin were also detected in the pipeline sediments. In addition to these organics, dichloromethane was also detected in the pipeline sediment samples. All organics were detected in concentrations of less than $1 \mathrm{mg} / \mathrm{L}$ and were only slightly elevated above the background samples.

A review of the chemical analysis data for the eight layers of sediment cores within and around the basin indicates elevated concentrations of aluminum and iron in the top layer, with the concentrations progressively decreasing with soil depth. The other chemical parameters that progressively decrease with depth from the top to the bottom layer are lead, zinc, and chromium. The maximum lead, zinc, chromium, and mercury concentrations in the basin sediments are 137, 37, 148 , and $1.6 \mathrm{ug} / \mathrm{g}$, respectively. The analytical data for the top 0 to $0.076-\mathrm{m}$ layer of sediments along the pipeline indicate elevated concentrations of aluminum, iron, mercury, chromium, and lead. Concentrations of aluminum, iron, and mercury in the pipeline sediments were found to be higher than in the basin sediments.

EP toxicity tests conducted on sediment core samples in and around the basin and along the basin process sewer pipeline indicate that the concentrations of each of the metals analyzed for are below $1 \%$ of the guideline concentrations provided by EPA. The analytical results for the inorganic ions indicate elevated concentration levels of sulfate and nitrate in the 1.5 to $2.4-\mathrm{m}$ samples taken beneath the basin. Cyanide is detected only in the top layer of the basin sediments at concentrations only slightly above background and at elevated concentrations along the process sewer pipeline.

A composite basin water sample collected from each of the four corners of the basin was analyzed. Of note is the fact that the basin water $\mathrm{pH}$ is 3.8 (Johnson et a1., 1987a). In addition, results from groundwater monitoring analyses of the three wells at the basin indicate low levels of most of the constituents analyzed. Elevated levels of TOH were found in a11 three wells at the basin. The presence of these organic constituents is probably part of the contaminant plume in A/M Area and most likely is not due to the discharge of waste effluent to the basin because only small amounts of organic materials were discharged to the basin.

In addition to the characterization efforts at the basin, a characterization program was initiated to determine the extent of chemical contamination in the overflow Carolina bay area near the basin. A total of seven sediment sampling sites were established in the discharge area of the basin: four effluent channel sites and three sites in the adjacent Carolina bay (Figure X.4). Sediment cores were taken to a depth of $76 \mathrm{~cm}$ and were analyzed for a number of constituents. A review of the chemical 


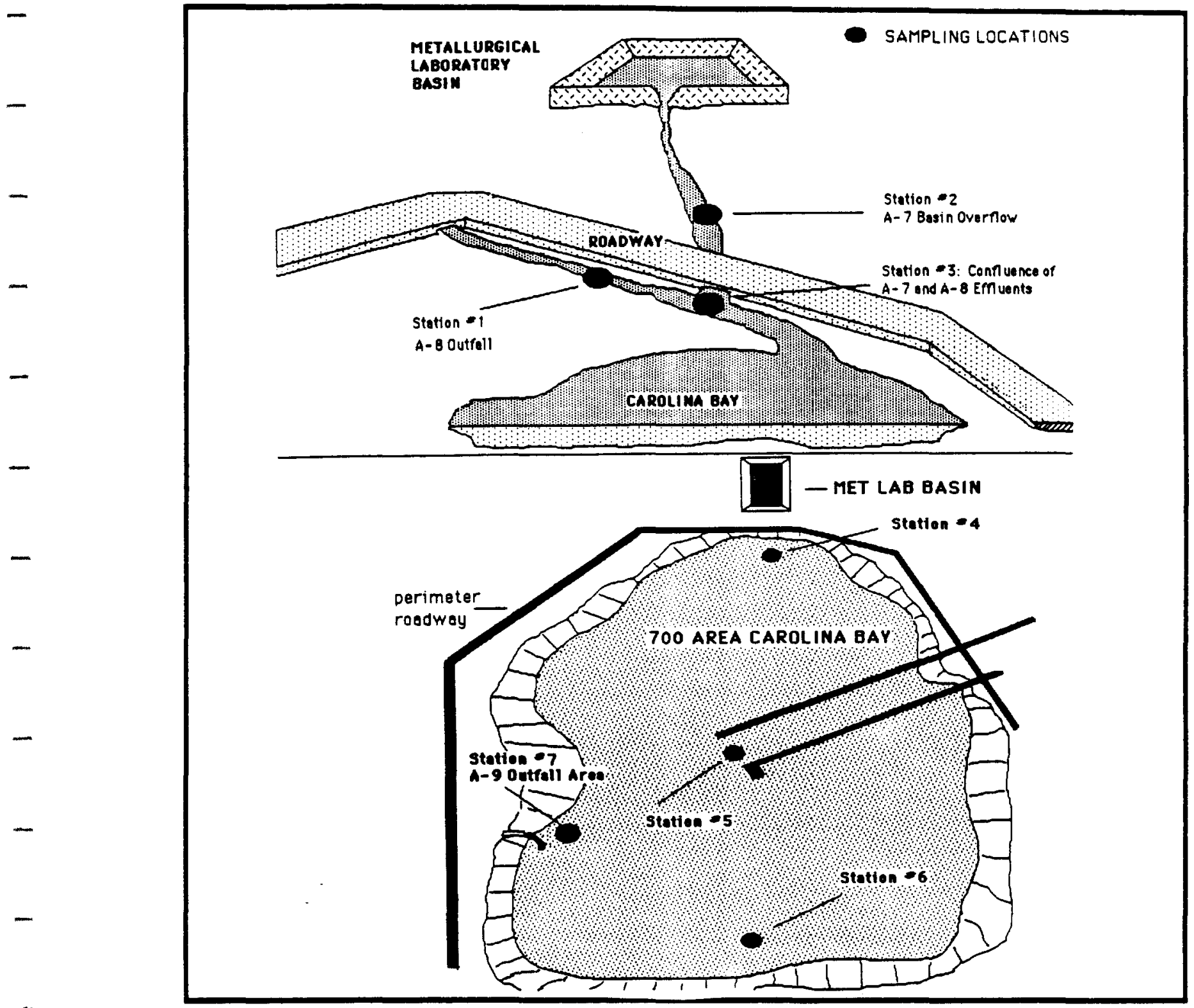

FIGURE X.4. Carolina Bay Sampling Locations 
analysis data from the overflow Carolina bay area indicates elevated levels of lead, mercury, arsenic, chromium, and copper. The highest concentrations of contaminants were found in sediment cores closest to the A-8 outfall, which is the discharge from the A-Area powerhouse.

The groundwater data from the Metallurgical Laboratory Basin indicate that the basin has had no significant effect on local groundwater quality. Groundwater quality in the vicinity of the basin has been characterized by low dissolved chemical constituent levels as compared to the criteria in Appendix Table 10 with the exception of trichloroethylene in all three site wells. Trichloroethylene is not related to past site activities given that only an estimated $1.5 \mathrm{~L}$ of trichloroethylene were discharged to the basin over its 30-year operational history (Michael et al., 1987). Average conductivity levels in the three site wells (37.7 to 57.1 umhos $/ \mathrm{cm}$ ) were consistent with the SRP background value of 50 umhos/cm. Gross alpha (up to $138 \mathrm{pCi} / \mathrm{L}$ ) and total radium (up to $16 \mathrm{pCi} / \mathrm{L}$ ) levels in wells $A M B$ IA and $A M B$ BA were over the groundwater quality review criteria reported in Appendix Table 10 in September and November 1984

(Heffner et a1., in press). Radioactivity levels in the site wells since November 1984 have consistently been below the groundwater quality review criteria reported in Appendix Table 10. Radioactivity is not related to past Metallurgical Laboratory Basin site activities.

\section{Characterization Recommendations}

\section{Sampling}

After a review of the current data from this site, no additional characterization effort is recommended. The basin is currently under litigation for compliance with the RCRA. In addition, because of the close proximity of the groundwater monitoring wells to the site, it is extremely hard to accurately determine the appropriate upgradient and downgradient wells. It is recommended, therefore, that four additional wells be drilled to the water table to adequately define groundwater flow and direction and the effects of the basin's operation on groundwater quality. The approximate location of the four new monitoring wells is indicated in Figure X.5.

\section{Chemical and Physical Analyses}

Geophysical gamma logs should be taken at each of the new monitoring wells to define the sediments beneath the basin. The wells should be sampled quarterly as part of the Health Protection Department groundwater monitoring program. The groundwater samples should be analyzed for the parameters 1 isted in Appendix Table 6. 


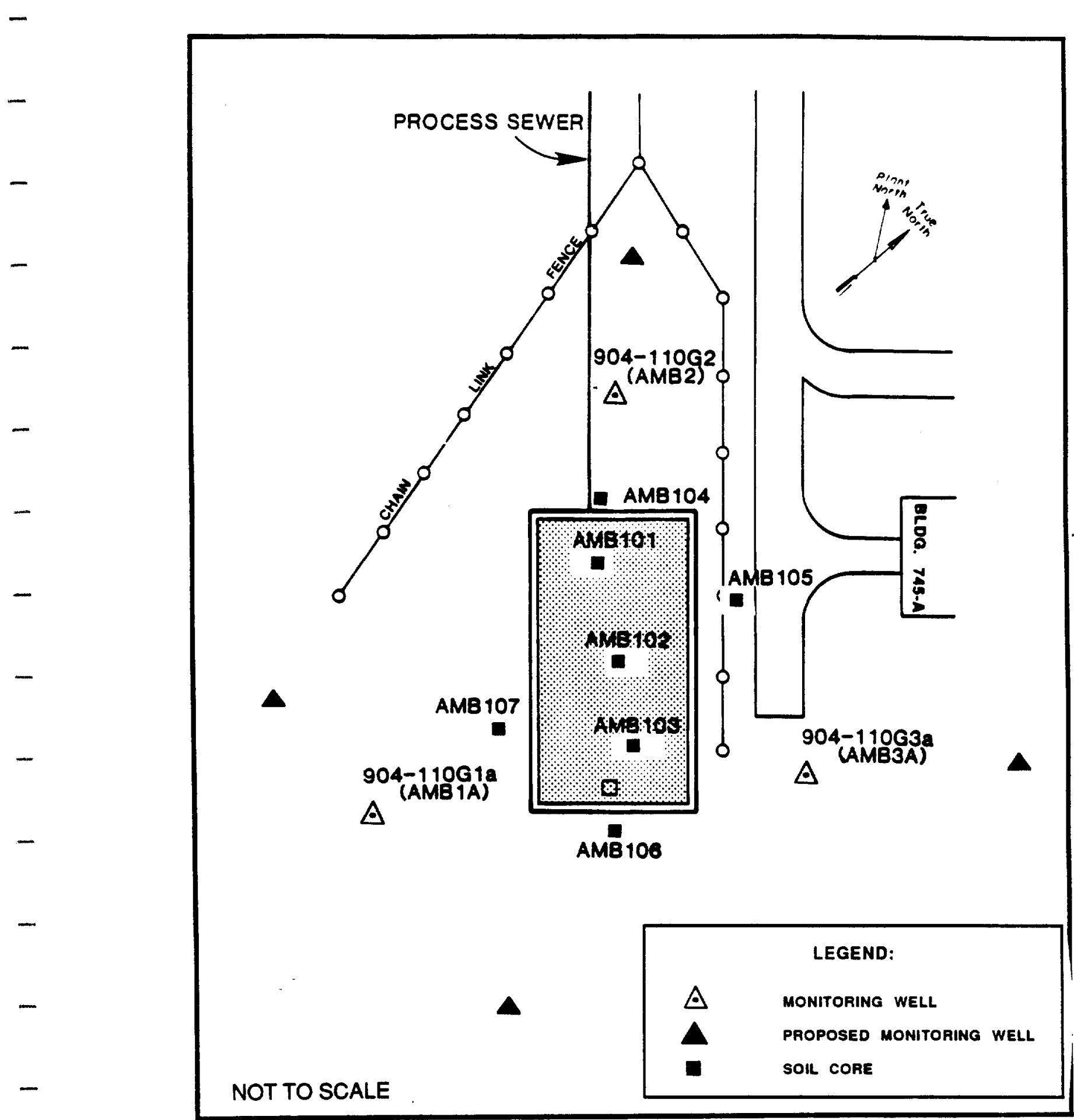

$-$

FIGURE X.5. Proposed Monitoring Well Locations at the Metallurgical Laboratory Basin 


\section{Background}

\section{Site History}

The Metals burning Pit (Building 731-4A) was used to dispose of 1ithium-aluminum a1loy and other waste metals generated by M-Area operations until 1974. Photographs of the site taken in late 1973 and early 1974 show metal scraps, drums, and plastic pipe. Piles of ash pictured are evidence of the burning operation. In 1974 the site was regraded and covered with soil (Pickett et al., 1987c).

\section{Site Description}

The Metals Burning Pit is located on the west side of Road $\mathrm{C}-1$, an unimproved dirt road that follows an overhead transmission line in the northwest portion of SRP (Figure Y.1).

The site is approximately 2,130 m south of the M-Area Sett1ing Basin and $3,350 \mathrm{~m}$ from the closest plant boundary. SRP coordinates for the northeastern corner of the Metals Burning Pit are N 97694, E 44565. The pit was irregular in shape with dimensions of approximately $120 \mathrm{~m}$ by $120 \mathrm{~m}$ (Figure Y.2). The waste material ranged from 1 to $2 \mathrm{~m}$ in height.

The Metals Burning Pit is located on the Aiken Plateau at an elevation of approximately $108 \mathrm{~m}(355 \mathrm{ft})$. Surface drainage is east toward a tributary of Tims Branch, which drains into Upper Three Runs Creek.

Four groundwater wells were installed at the Metals Burning Pit in 1983 and 1984 (Figure Y.2). We1ls ABP 1 and 2 were abandoned in 1984 and replaced by $A B P 1 A$ and $2 A$, which had lower screen settings. Groundwater flow is from northeast to southwest across the site. Data from 1986 indicate that the depth to the water table is approximately 40 to $45 \mathrm{~m}$ (Zeigler et al., 1987).

\section{Review of Available Data}

No soil cores or surface samples have been collected at the Metals Burning Pit.

Groundwater in wells $A B P 2 A$ and $A B P 3$ contains levels of trichloroethylene, up to $47 \mu \mathrm{g} / \mathrm{L}$, that are elevated above the groundwater quality review criteria standards (Appendix Table 10). There is no evidence of inorganic or radioactive contamination of the groundwater at this site (Mikol et al., in press; Zeigler et a1., 1987). 

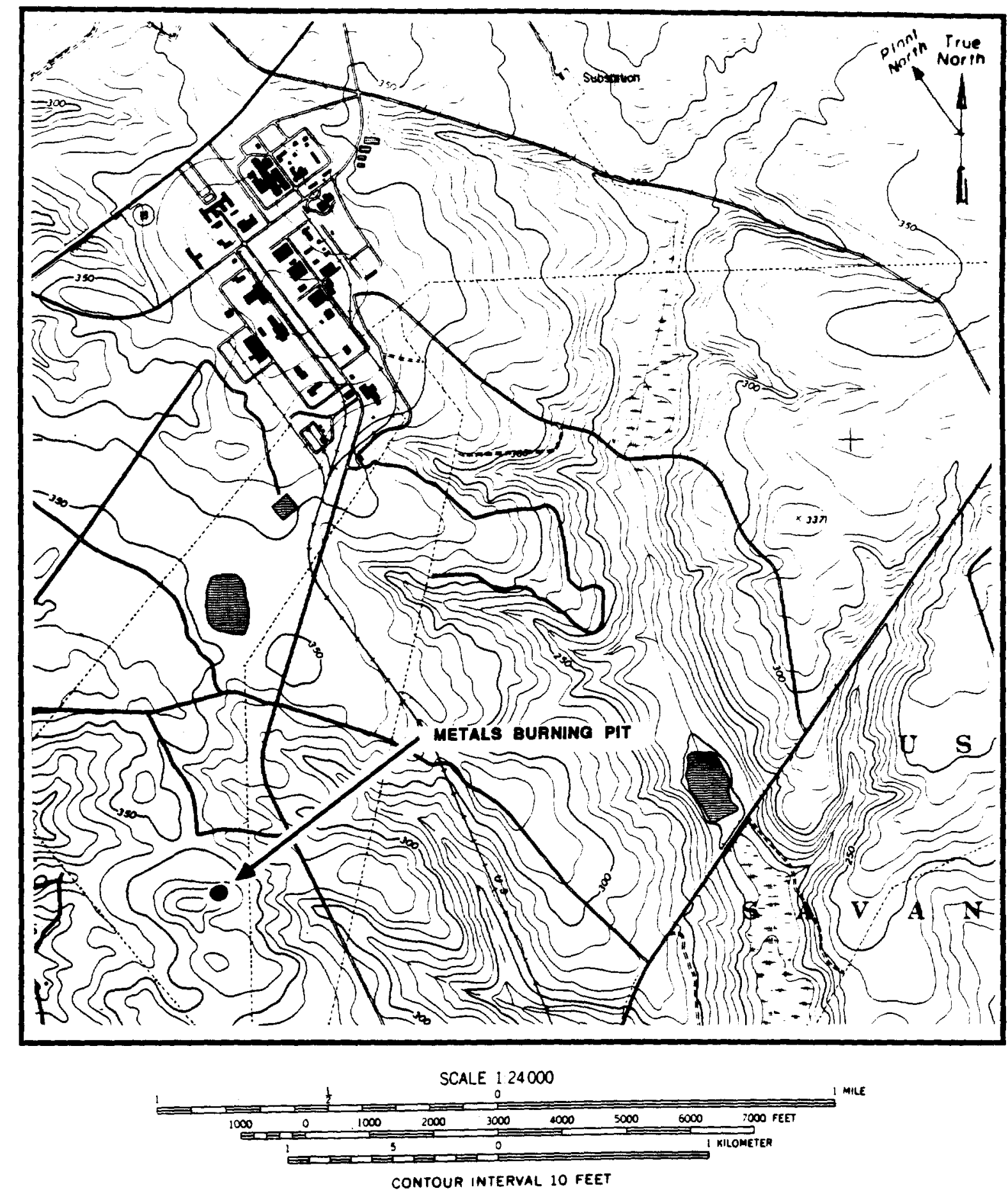

FIGURE Y.1. Location of the Metals Burning Pit on New Ellenton SW Quadrangle 7.5 Minute Series Topographic Map 

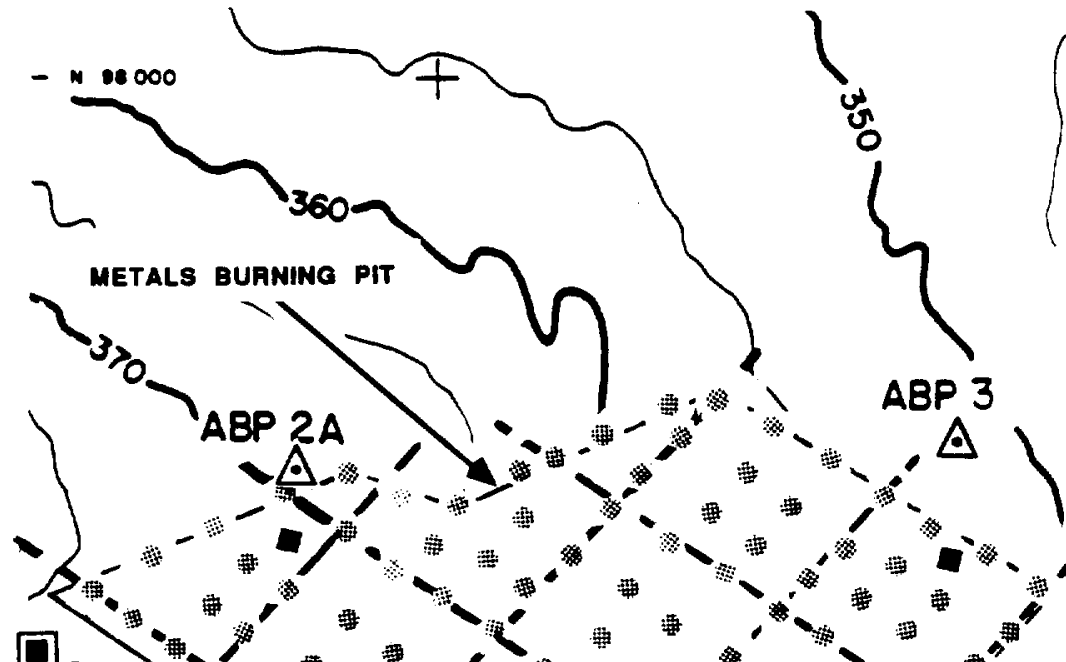
a
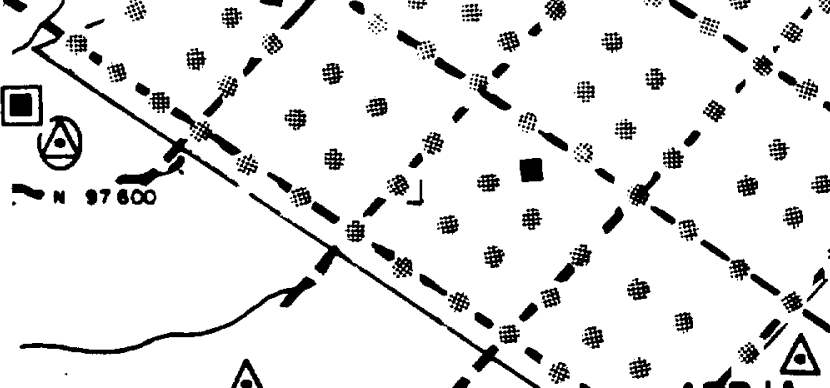

$A B P 4$
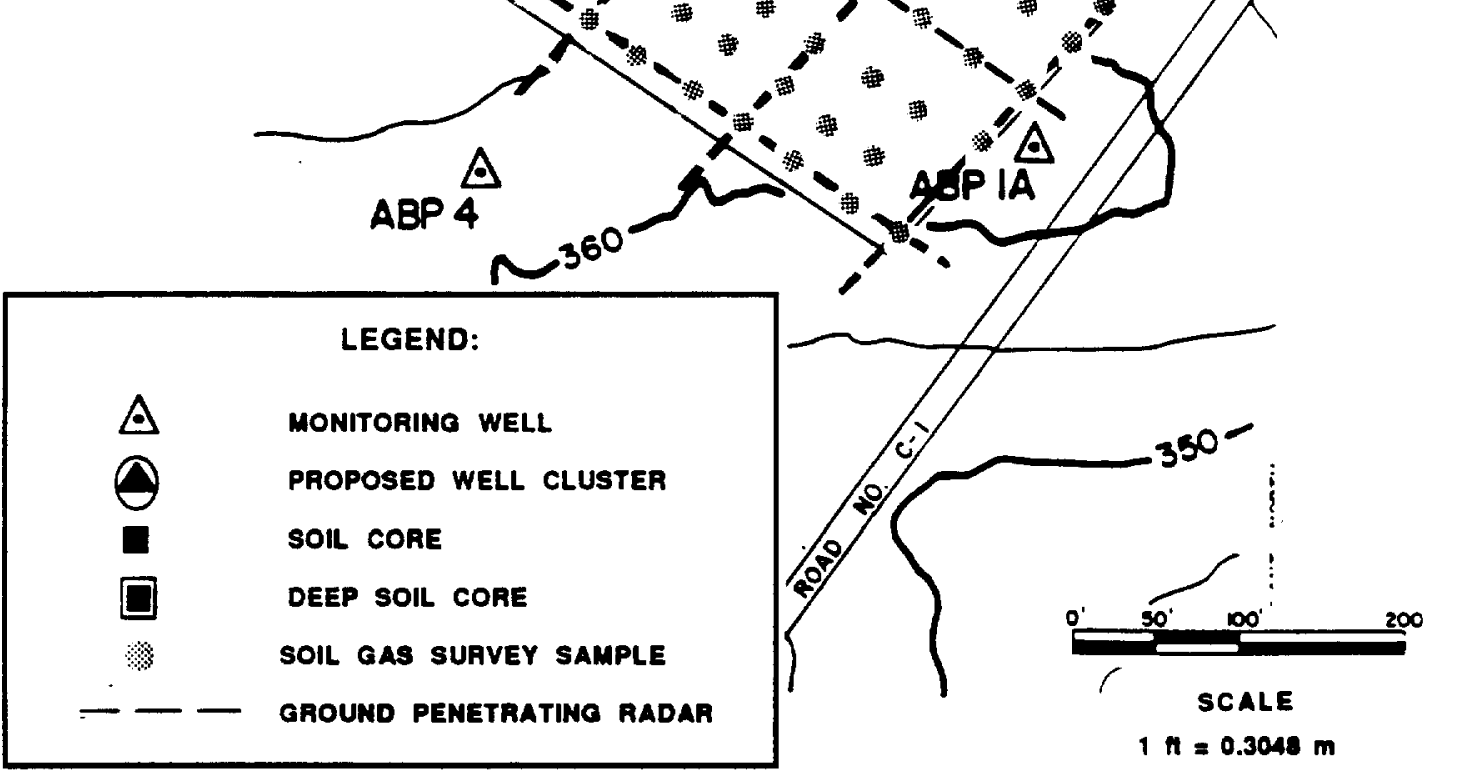

FIGURE Y.2. Location of Existing and Proposed Monitoring Well and Sampling Sites at the Metals Burning Pit 


\section{Characterization Recommendations}

Samp1ing

Because much of the material placed in the Metals Burning Pit was miscellaneous solid wastes that probably included barrels containing potentially hazardous wastes, a GPR survey is recommended to delineate the outlines of the pit and the location of the barrels. A schematic showing the recommended lines (one per $30 \mathrm{~m}$ ) for the GPR survey is presented in Figure Y.2.

A soil gas survey, consisting of a grid of approximately 144 surface samples across the area of the pit ( 1 sample per $10 \mathrm{~m}$ ), is recommended. This survey will highlight areas of highest contamination (Figure Y.2).

From the soil gas data, locations can be selected for shallow soil cores. The shallow soil cores within the confines of the pit are needed to better delineate the vertical extent of the organic contamination detected in the nearby monitoring wells. Three soil cores to a depth of $6 \mathrm{~m}$ are recommended. Soil samples for chemical analysis should be collected according to the parameters given in Appendix Table 1.

One deep boring to the first major aquitard below the water table (the first clay in the Lower Ellenton) is needed. Justification for the deep boring from the surface to the first clay in the Lower Ellenton is twofold: (1) this interval has been designated as the upper aquifer for modeling purposes, and (2) vertical movement of VOC contaminated groundwater has been demonstrated at other locations within M Area. Groundwater at the site contains elevated levels of volatile organics, which are known to migrate easily and quite likely have migrated vertically at both sites. The deep boring will be used to determine if this migration has occurred and to characterize the aquifers and aquitards for modeling purposes. The deep boring will be approximately $100 \mathrm{~m}$ deep and be geophysically logged for gamma, resistivity, porosity, and caliper.

A continuous core needs to be taken from the deep boring. Chemical samples from the first $6 \mathrm{~m}$ should be collected according to the parameters 1isted in Appendix Table 1. Deeper samples should be collected for chemical analysis at $300-\mathrm{cm}$ intervals. Samples for physical analysis should be collected at lithological boundaries. Undisturbed samples of a11 aquitards and aquifers are needed for porosity and permeability analyses. Splits of all soil/sediment samples will be archived at SRP.

The deep boring should be completed as a monitoring well, which would be part of a three well cluster, with screened zones in the Congaree Formation, the McBean Formation, and at the water table. A map of the proposed sampling scheme is shown in Figure Y.2. 


\section{Chemical and Physical Analyses}

Soil samples should be analyzed according to the parameters 1 isted in Appendix Table 1. Specific analytes are VOCs (Appendix Table 3). Groundwater should be analyzed according to the parameters given in Appendix Tables 3 and 6 .

The deep core should be described geologically for stratification and analyzed for grain size and sorting (sieve analysis), mineral content (x-ray diffraction for bulk mineralogy and clay type), bulk density, porosity, permeability (both horizontal and vertical), and hydraulic conductivity for samples of all aquitards and aquifers. 


\section{Background}

\section{Site History}

The Miscellaneous Chemical Basin (Building 731-5A), located in an old borrow pit, is believed to have been used to dispose of waste solvents and used oil. The site was in use from as early as 1956 until 1974. In 1974 the site, including a surrounding field, was regraded (Pickett et al., 1987 c).

\section{Site Description}

The Miscellaneous Chemical Basin is located approximately $150 \mathrm{~m}$ east of Road $\mathrm{C}-1$, an unimproved dirt road that follows an overhead transmission line in the northwestern part of SRP (Figure Z.1). The site is approximately $2,130 \mathrm{~m}$ south of the M-Area Settling Basin and 3,350 m east of the closest plant boundary. SRP coordinates for the center of the Miscellaneous Chemical Basin are N 97284, E 44846. The Miscellaneous Chemical Basin was approximately $6 \mathrm{~m}$ by $6 \mathrm{~m}$ and about $0.3 \mathrm{~m}$ deep.

The Miscellaneous Chemical Basin is located at an elevation of $102 \mathrm{~m}$ $(335 \mathrm{ft})$. Surface drainage is to the east toward a tributary of Tims Branch, which drains into Upper Three Runs Creek.

Four groundwater monitoring wells were installed at the Miscellaneous Chemical Basin in 1987 (Figure Z.2). One more well is scheduled to be installed within the next 6 months. Data from the first three wells at the Miscellaneous Chemical Basin in combination with data from the Metals Burning Pit wells suggest that the Miscellaneous Chemical Basin is located on a groundwater nose. It is believed that groundwater is flowing to the south at the Miscellaneous Chemical Basin. Data from the newly installed monitoring wells will help to better define the groundwater flow direction. Data from 1986 show the depth to the water table to be approximately 30 to $40 \mathrm{~m}$ (Zeigler et al., 1987).

\section{$\underline{\text { Review of Available Data }}$}

Numerous surface soil samples at the Miscellaneous Chemical Basin have been collected and analyzed for volatile organics. High concentrations of tetrachloroethylene and trichloroethylene have been detected in surface soils (up to $6,000 \mathrm{ng} / \mathrm{g}$ ). Trichloromethane (up to $19 \mathrm{ng} / \mathrm{g}$ ) and trans-1,2-dichloroethylene (up to $48 \mathrm{ng} / \mathrm{g}$ ) were also present in concentrations above background. Analysis of soil cores, taken to a depth 

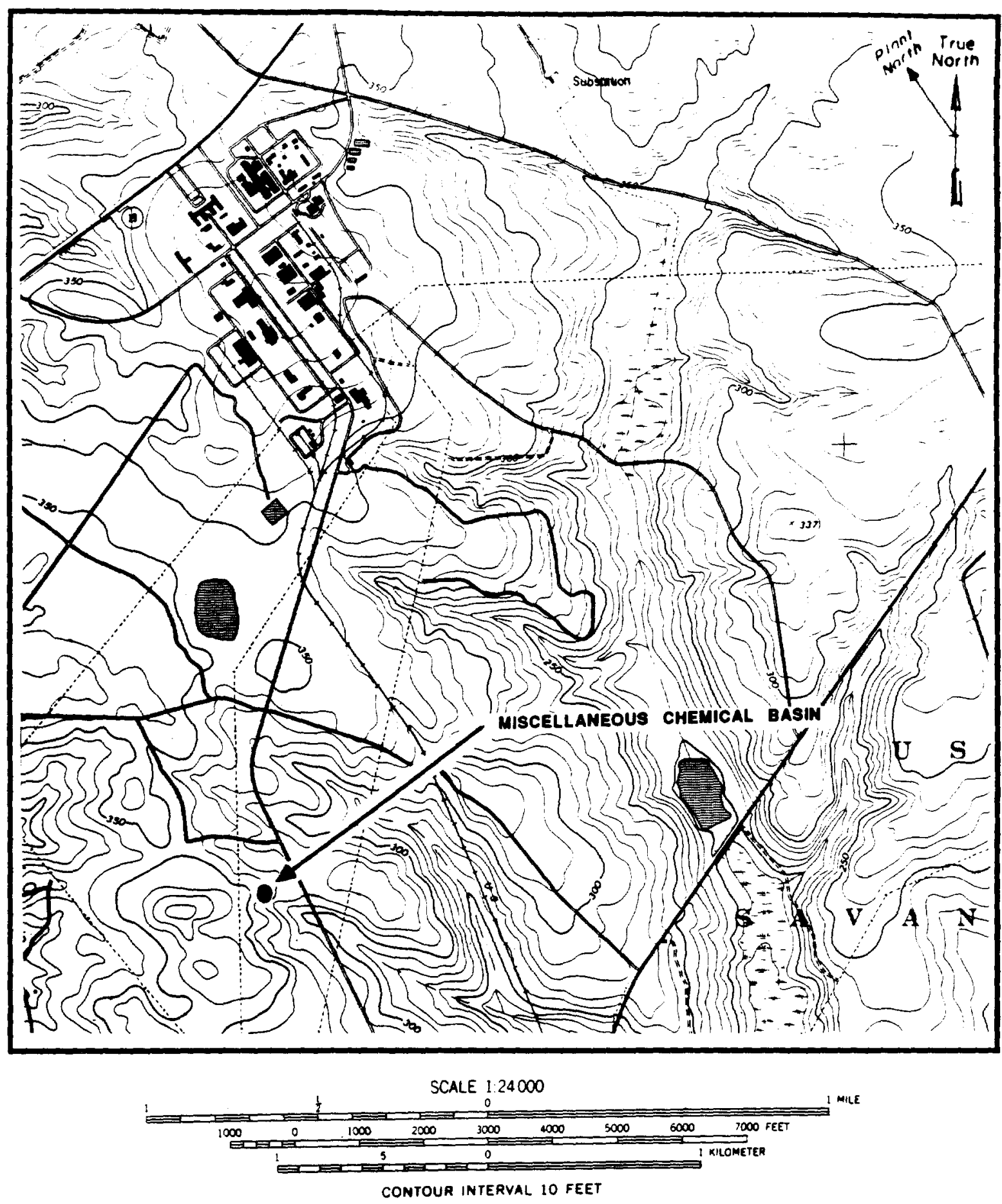

FIGURE z.1. Location of the Miscellaneous Chemical Basin on New Ellenton SW Quadrangle 7.5 Minute Series Topographic Map 


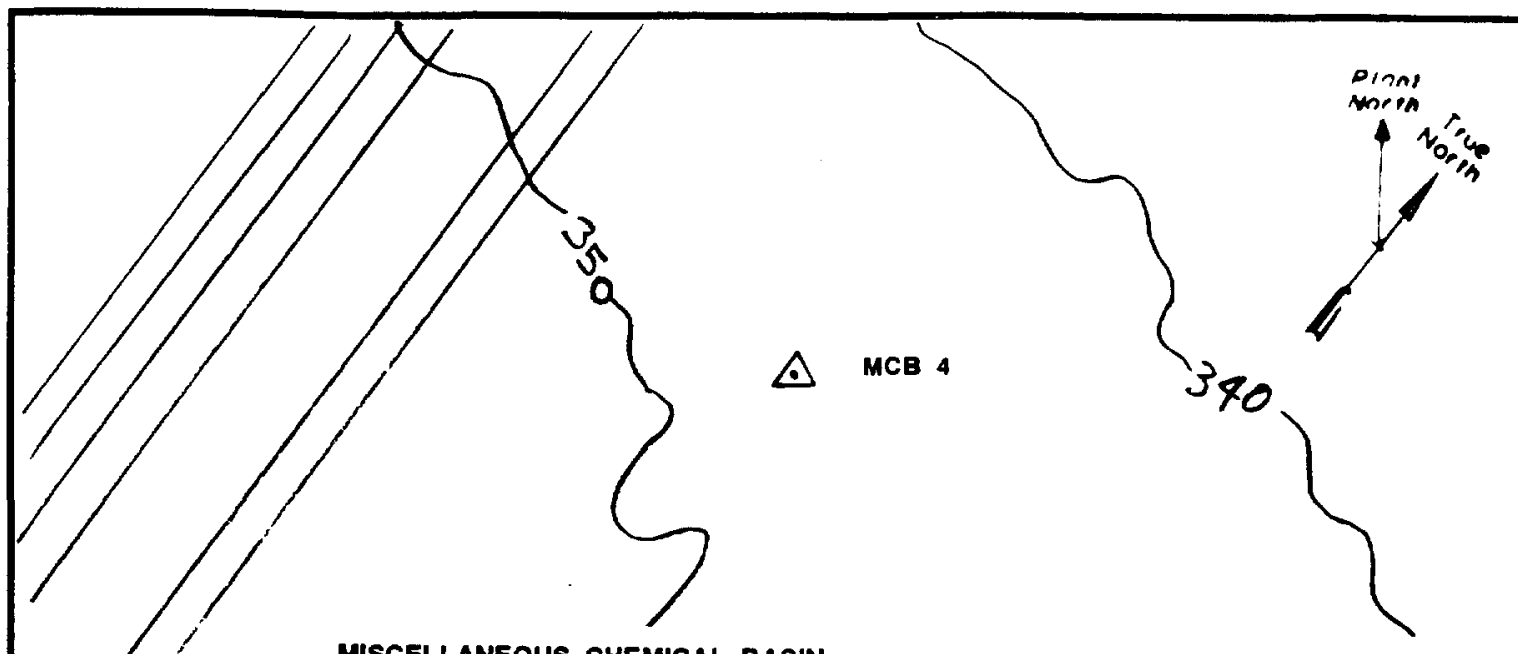

MISCELLANEOUS CHEMICAL BASIN

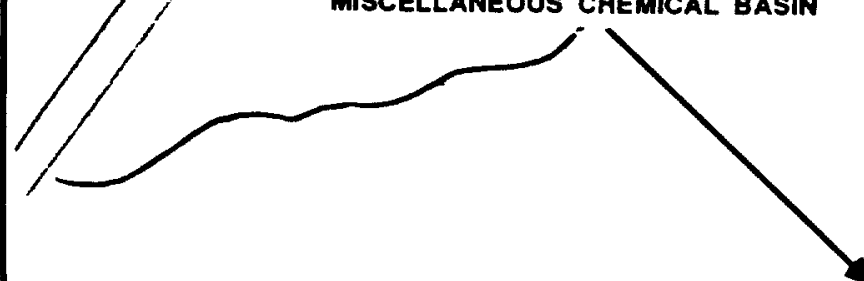

$7]^{\triangle C B 5}$

$\theta$

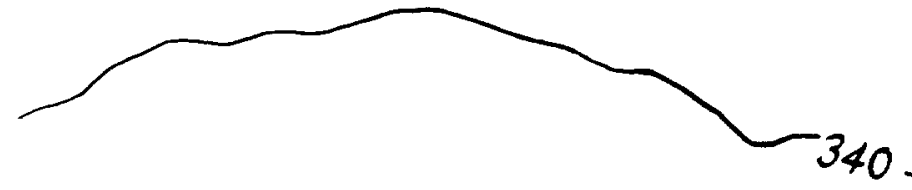

LEGEND:

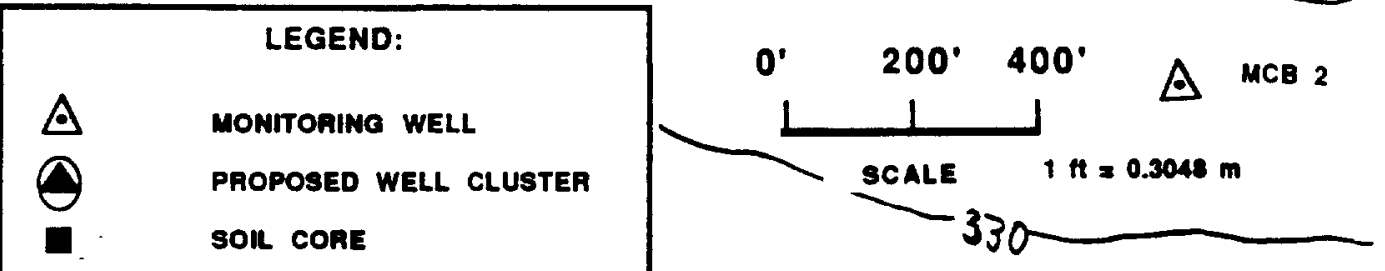
the Miscellaneous Chemical Basin 
of $69 \mathrm{~m}$ during installation of the three monitoring wells, show much lower concentrations of volatile organics, up to $22 \mathrm{ng} / \mathrm{g}$ trichloroethylene and $7 \mathrm{ng} / \mathrm{g}$ tetrachloroethylene.

Elevated levels of volatile organic halogens (up to $75 \mu \mathrm{g} / \mathrm{L}$ trichloroethylene and up to $35 \mu \mathrm{g} / \mathrm{L}$ tetrachloroethylene) have been detected in the Miscellaneous Chemical Basin wells (Mikol et al., in press). There is no evidence of inorganic or radioactive contamination of the groundwater at this site.

\section{Characterization Recommendations}

\section{Sampling}

Shallow soil cores are needed to delineate the extent of the organic contamination at the Miscellaneous Chemical Basin. Surface soil samples, analyzed during a soil gas survey, show high levels of VOCs, whereas cores from monitoring wells show low, but above background, levels. However, none of the cores were taken from within the confines of the basin itself. Three additional soil cores collected to a depth of $6 \mathrm{~m}$ within the basin itself would better delineate the vertical extent of the contamination (Figure Z.2). Existing data indicate that organic halogens, present at elevated levels, have remained at or very close to the surface at this site. This hypothesis needs to be confirmed by collection of additional data.

A three well cluster of monitoring wells should be installed downgradient of the site. These wells should be screened at the water table, in the McBean Formation, and in the Congaree Formation. Geological information should be obtained from the deep core taken at the nearby Metals Burning Pit. A map of the proposed sampling scheme is shown in Figure Z.2.

\section{Chemical and Physical Analyses}

Soil cores should be analyzed according to the parameters given in Appendix Table 1. Specific analytes are VoCs (Appendix Table 3). Groundwater should be analyzed according to the parameters 1 isted in Appendix Tables 3 and 6 . 


\section{Background}

\section{Site History}

The New TNX Seepage Basin (Building 904-102G) has been in operation since 1980 and was constructed to replace the 01d TNX Seepage Basin. The basin receives process wastewater from the TNX facility from pilot-scale tests conducted in support of the Defense Waste Processing Facility (DWPF) and plant Separations Area. Batch discharges to the basin are neutralized prior to release to the basin. The majority of the wastewater sent to the basin after 1983 contains simulated nonradioactive DWPF sludge along with other laboratory chemicals. Prior to 1983, simulated nonradioactive salt supernate was also sent to the basin.

The New TNX Seepage Basin is scheduled to remain active until the TNX Effluent Treatment Plant (ETP) begins operation. The ETP has been designed to process all of the wastewater currently being sent to the basin. Once the ETP is in operation, flow to the basin will be stopped and a basin closure plan implemented (Dunaway et al., 1987a).

\section{Site Description}

The New TNX Seepage Basin is located in the southeastern section of the TNX facility, across River Road from the TNX process area (Figure AA.1). The basin was constructed in two sections, with the smaller section 1ying immediately northwest of the larger section. The SRP coordinates for the northeastern corner of the larger section of the basin are $\mathrm{N} 71105, \mathrm{E}$ 17855. Together these two sections encompass approximately $1.63 \mathrm{~km}^{2}$ of land. The Savannah River, which is the nearest plant boundary to the basin, is approximately $620 \mathrm{~m}$ away.

The basin consists of two rectangular sections: a small inlet section and a large seepage section. The two sections are connected by an underground $20-\mathrm{cm}$ diameter vitrified pipe that runs from the southeast wall of the small section to the northwest wall of the large section. Both sections are approximately $3 \mathrm{~m}$ deep and have long axes oriented northeast by southwest. A pipe that runs through the southeast wall of the large basin section directs the basin overflow down NPDES outfall $\mathrm{X}-013 \mathrm{~A}$. This outfall eventually empties into the Savannah River. The volume capacity for the two basin sections is approximately $2,170 \mathrm{~m}^{3}$.

The basin is located at an elevation of about $43.6 \mathrm{~m}(143 \mathrm{ft}$ ) on a bluff above the Savannah River swamp that is at an elevation of 27 to $30 \mathrm{~m}$ (Figure AA.1). The water table in the vicinity of the basin is found at a depth of about $12 \mathrm{~m}$ below ground surface and flows in a westerly direction. Four groundwater monitoring wells (YSB 1 through YSB 4) were installed in the second quarter of 1980 to characterize the geologic and hydrogeologic conditions and to monitor the water-table elevation and 


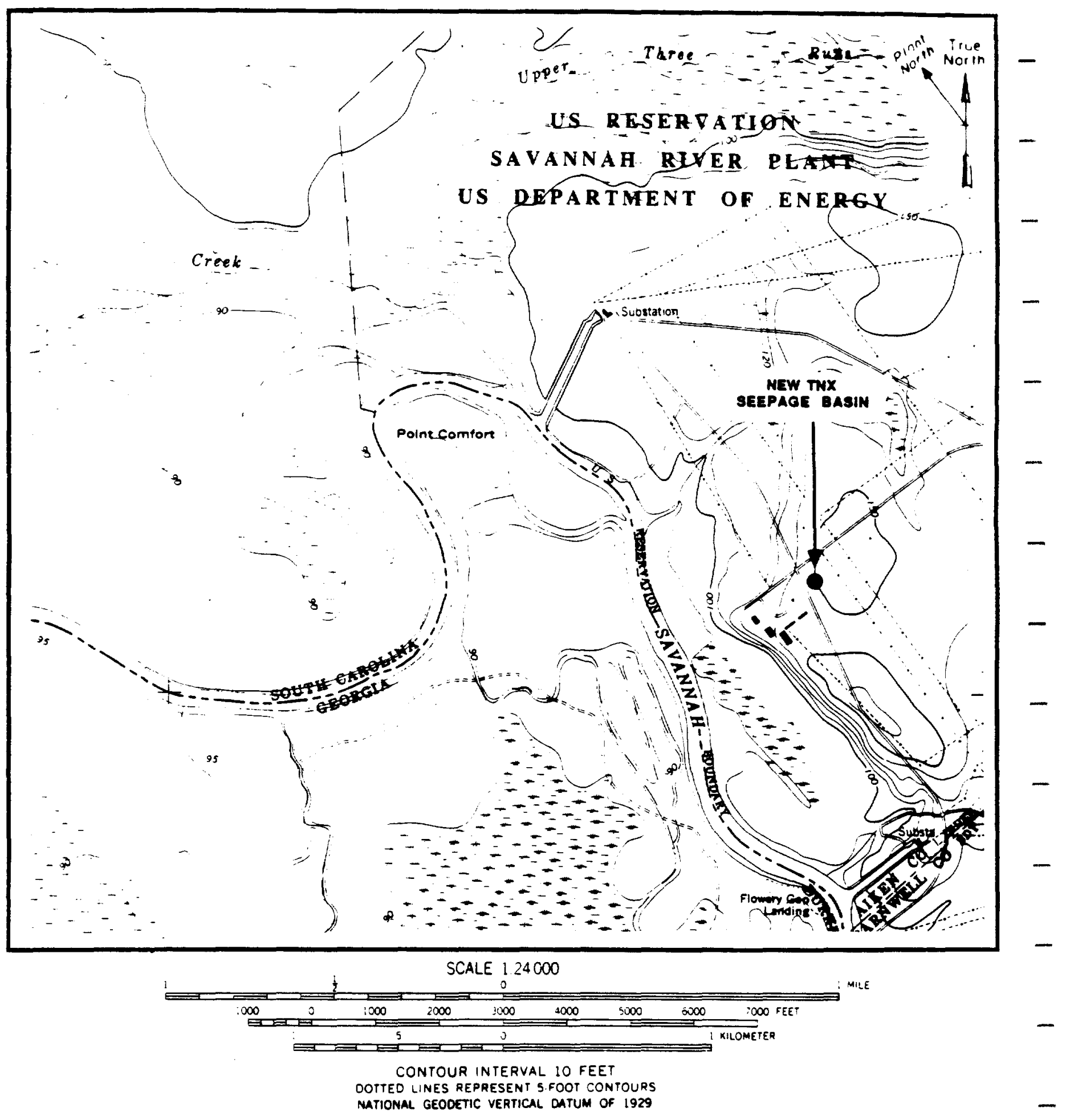

FIGURE AM.1. Location of the New TNX Seepage Basin on Shell Bluff Landing Quadrangle 7.5 Minute Series Topographic Map 
groundwater quality in the vicinity of the basin. Due to possible water-quality interferences resulting from the galvanized steel casings and screens, these wells were replaced by wells YSB 1A through YSB 4A in the fourth quarter of 1983 (Figure AA.2).

\section{Review of Available Data}

A program to define the extent of chemical contamination in the vicinity of the New TNX Seepage Basin was conducted in the fourth quarter of 1985. This program included the sampling and analysis of sediment samples from beneath and adjacent to the basin. Three sediment sampling sites were established inside the basin, with two being in the large basin section and one in the small basin section. Three sampling sites were a1so established outside the basin, with two being in the basin outfall gully and one in a pristine area. All sediment cores were taken to a depth of $1.5 \mathrm{~m}$.

Analytical results from the characterization program indicate that no significant organic contamination exists in any of the sediments sampled. Only phenol was detected at low concentrations in one layer of sediment cores outside the basin. A review of the chemical analysis data for the nine layers of sediment cores within and adjacent to the basin indicates elevated levels of barium, nickel, chromium, lead, nitrates, phosphate, and sodium in the top $0.15 \mathrm{~m}$ of sediment (Dunaway et a1., 1987a).

EP toxicity tests performed on basin sediment samples indicate concentrations of each of the metals analyzed for were below $1 \%$ of the guideline concentrations provided by EPA.

The groundwater data from monitoring wells at the New TNX Seepage Basin indicate that the basin has influenced groundwater quality in the vicinity of downgradient wells YSB $3 A$ and YSB 4A (Heffner et al., in press). This is indicated by the elevated levels of conductivity, sodium, and nitrate reported for these wells compared to upgradient wel1 YSB 2A. Groundwater quality in the vicinity of upgradient well YSB $2 \mathrm{~A}$ and downgradient YSB $1 \mathrm{~A}$ has been characterized by low dissolved chemical constituents and radioactivity levels compared to groundwater quality criteria reported in Appendix Table 10 except for a single excursion for iron and gross alpha in well YSB 1A. The average conductivity values for wells YSB 2A $(42.1 \mu \mathrm{mhos} / \mathrm{cm})$ and YSB $1 \mathrm{~A}(28.1 \mu \mathrm{mhos} / \mathrm{cm})$ were less than the SRP background value of $50 \mu \mathrm{mhos} / \mathrm{cm}$. Sodium levels in both of these wells remained less than $5.6 \mathrm{mg} / \mathrm{L}$ over the monitoring period. Nitrate levels in wells YSB 2A $(0.75$ to $1.70 \mathrm{mg} / \mathrm{L})$ and YSB $1 \mathrm{~A}(0.93$ to $1.30 \mathrm{mg} / \mathrm{L})$ remained well below the groundwater quality review criterion reported in Appendix Table 10. Iron in wel1 YSB $1 \mathrm{~A}(0.018$ to $1.040 \mathrm{mg} / \mathrm{L})$ was over the groundwater quality review criterion reported in Appendix Table 10 in a single excursion. Iron at $1.040 \mathrm{mg} / \mathrm{L}$ is consistent with iron levels reported as naturally occurring in Barnwell Formation groundwater. Gross alpha in well YSB $1 \mathrm{~A}(2.0$ to $17.0 \mathrm{pCi} / \mathrm{L})$ was over the drinking water standard of $15.0 \mathrm{pCi} / \mathrm{L}$ in a single excursion (Heffner et al., in press). 


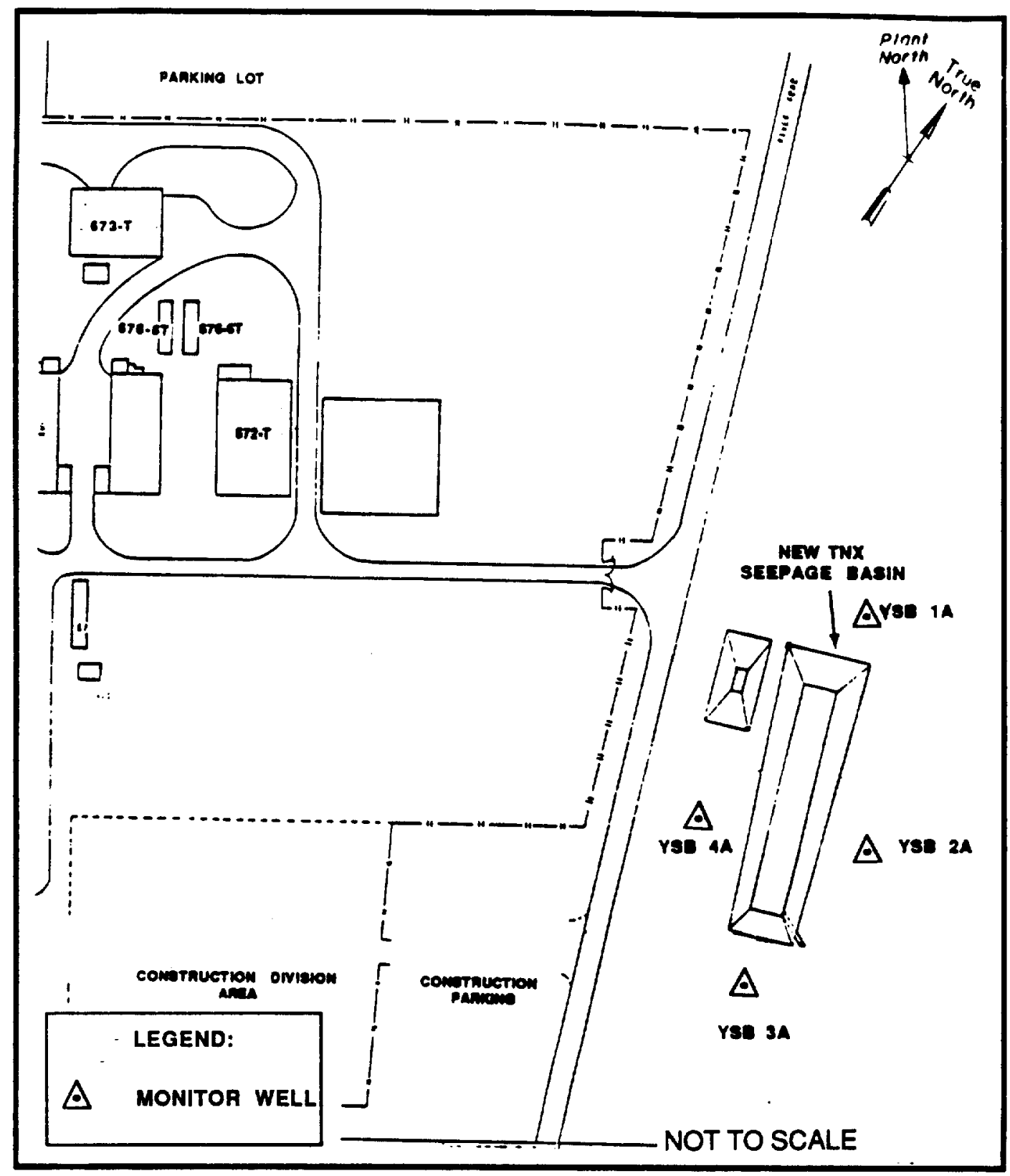

FIGURE AA.2. Location of Monitoring Wells at the New TNX Seepage Basin 
The average conductivity levels in wells YSB $3 A(240.05 \mu \mathrm{mhos} / \mathrm{cm})$ and YSB 4A ( 74.69 umhos $/ \mathrm{cm})$ were elevated compared to the average value for upgradient wel1 YSB $2 A$ and the SRP background value of 50.0 umhos $/ \mathrm{cm}$. Groundwater samples from wells YSB 4A and YSB 3A were below the groundwater quality review criteria reported in Appendix Table 10 except for nitrate in well YSB $3 \mathrm{~A}$ and iron in well YSB 4A. Groundwater pH ranged between 4.5 and 6.3 in all four site wells. This $\mathrm{pH}$ range is consistent with $\mathrm{pH}$ values reported as naturally occurring in the Barnwell Formation (Heffner et al., in press).

\section{Characterization Recommendations}

Sampling

After a review of the current data from this site, no additional characterization effort is recommended. A geologic core should be taken at the nearby D-Area Coal Pile Runoff Containment Basin to better define the hydrogeologic units in this vicinity. The closure of this basin is currently under litigation for compliance with RCRA. 


\section{Background}

Site History

The 01d F-Area Seepage Basin (Building 904-49G) was constructed as a test facility for the disposal of wastewaters generated by the processing of radioactive fuels. This basin received waste streams from a variety of sources within the F-Area separations facilities including evaporator overheads, laundromats, general purpose laboratories, acid recovery unit overheads, chemical drain systems, A-Line sumps, and pad drainage. It is estimated that between 35 and 52 million $L$ of wastewater were discharged to the basin during its use between November 1954 and May 1955. In 1955 three new seepage basins were constructed in F Area to handle the increased waste flows from the separations facilities, and routine use of the old basin ceased. The basin has since been used intermittently to divert rainfall runoff and process effluents from NPDES Outfall F-2 (Odum et al., 1987).

\section{Site Description}

The 01d F-Area Seepage Basin is an unlined basin located just northwest of the F-Area perimeter fence, approximately $10 \mathrm{~km}$ to the west of the nearest plant boundary (Figure BB.1). Site elevation is approximately $85 \mathrm{~m}(280 \mathrm{ft})$. The basin has a surface area of approximately $5,370 \mathrm{~m}^{2}$ and is divided into two cells. The first cell is $15 \mathrm{~m}$ by $91 \mathrm{~m}$ and has a surface area of $1,365 \mathrm{~m}^{2}$. A 3-m-high berm, which is $12 \mathrm{~m}$ wide at its base and $1.5 \mathrm{~m}$ wide at its top, separates the two basin cells. Flow between the two cells is provided by a spillway cut into the separating berm at the northeast end of the basin. The facility's inlet and outlet are located at the southeast (N 80202, E 53502) and southwest (N 80363, E 53965) corners of the basin, respectively. Currently, the basin has an accumulation of rainwater estimated to be less than $45 \mathrm{~cm}$ deep. Water level within the basin fluctuates depending upon rates of seepage, evaporation, and rainfall (Odum et al., 1987).

There are four groundwater monitoring wells located around the seepage basin. Depth to the water table at the site is approximately $21 \mathrm{~m}$ below grade. Surface drainage and groundwater flow in the area is northward toward Upper Three Runs Creek. The basin is located adjacent to a storm and process water outfall (NPDES F-2) that becomes an unnamed tributary to Upper Three Runs Creek.

\section{Review of Available Data}

In early 1985 surface water samples were collected from the inlet and outlet sections of the basin. No constituents within the outlet sample 

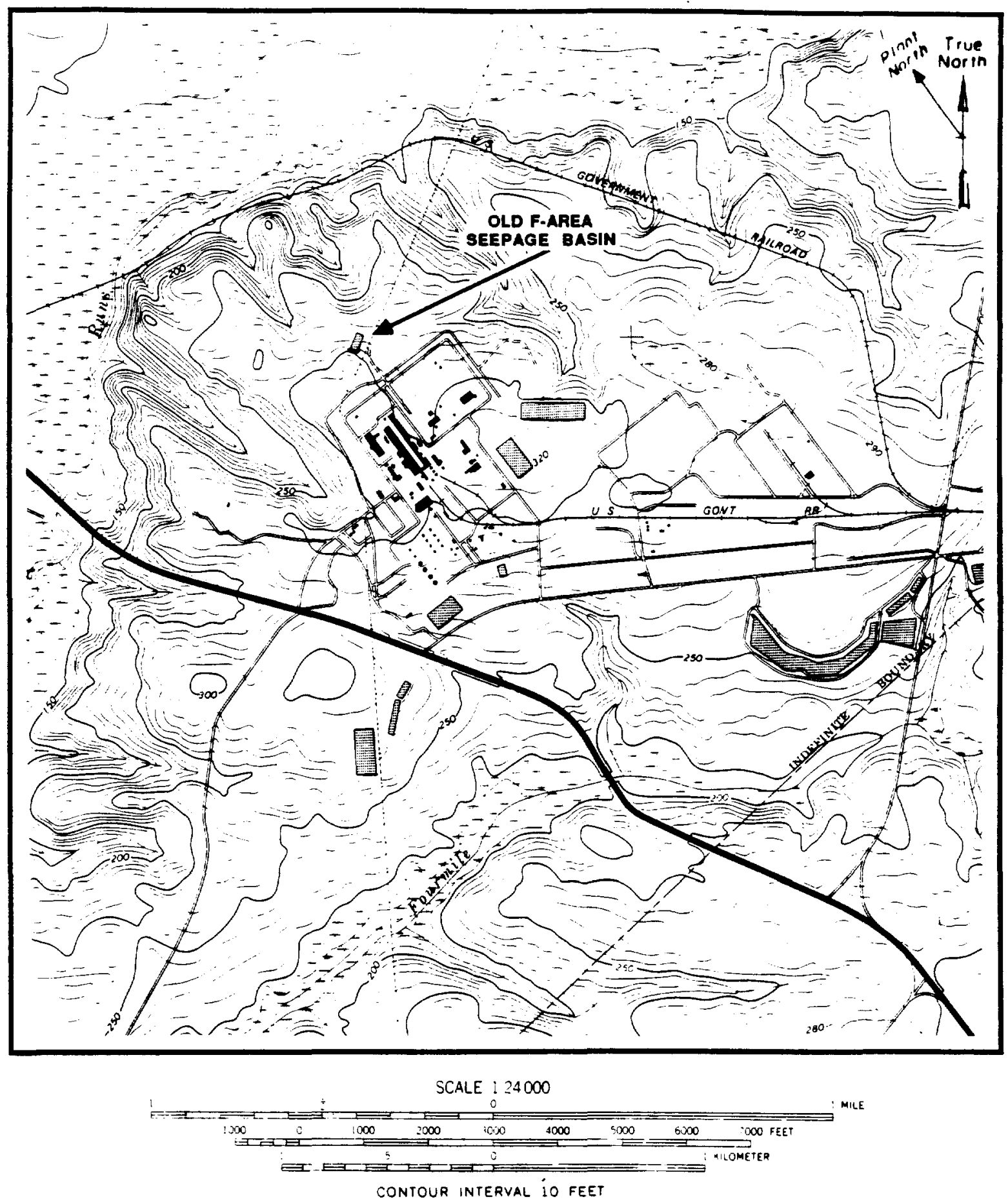

FIGURE BB.1. Location of the Old F-Area Seepage Basin on New Ellenton SW Quadrangle 7.5 Minute Series Topographic Map 
exceeded drinking water standards with the exception of iron at $0.31 \mathrm{mg} / \mathrm{L}$ (Odum et al., 1987). In 1986 soil cores $4.2 \mathrm{~m}(14 \mathrm{ft}$ ) deep were taken from four locations within the basin. Data from these cores indicate elevated levels of mercury, sulfate, uranium, ${ }^{337} \mathrm{Cs}, 3_{\mathrm{H},}{ }^{2}{ }^{2} \mathrm{I}, 239,240_{\mathrm{Pu}}$, and $238 \mathrm{U}$. The area of greatest concentration for many of these constituents was borehole FNB-103, which was located in the northeast corner of the basin. At this site uranium and ${ }^{3} \mathrm{H}$ concentrations increased with depth, indicating contamination below the total depth $(4.2 \mathrm{~m})$ of borehole penetration (Shedrow, 1986).

A review of groundwater monitoring data indicates elevated levels of conductivity, barium, manganese, nitrate, sodium, TOH, lead, gross alpha, gross beta, and total radium in groundwater downgradient from the site (Odum et al., 1987; Zeigler et a1., 1987).

\section{Characterization Recommendations}

\section{Sampling}

Two boreholes should be cored within the basin adjacent to original sampling sites FNB-102 and FNB-103 (Figure BB.2). These boreholes should be sampled continuously to just above the water table (approximately $17 \mathrm{~m}$ total depth).

\section{Chemical and Physical Analyses}

Recommended analyses for the two basin cores are as follows:

\begin{tabular}{|c|c|}
\hline Interval (m) & ecommended A \\
\hline $\begin{array}{l}0-3 \\
3-3.75 \\
3.75-4.50 \\
4.50-5.25 \\
5.25-6.00 \\
6.00-6.75 \\
6.75-7.50 \\
7.50-8.25 \\
8.25-9.00 \\
9.00-9.75 \\
9.75-10.5 \\
10.5-11.25 \\
11.25-12.0 \\
12-12.75 \\
12.75-13.5 \\
13.5-14.25\end{array}$ & 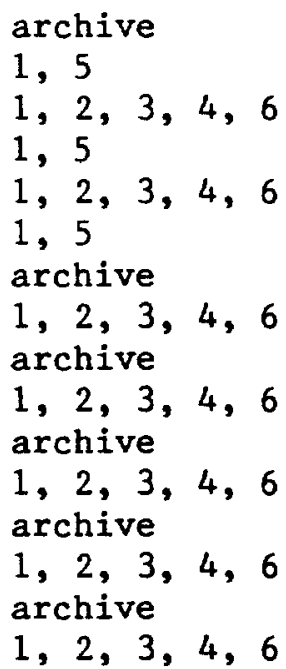 \\
\hline
\end{tabular}


Note: 1 = aluminum, ammonia (as N), barium, cadmium, chromium, iron, lead, mercury, nitrate (as $N$ ), sodium, uranium

$2=$ loss on ignition

$3=$ GCMS-VOA

4 = gross alpha, beta, gamma, gamma scan, iodine-129, p1utonium-238/239/240, strontium-90, uranium-234/235/238

5 = gross alpha, beta, gamma, gamma scan, strontium-90

6 = tritium

The recommended sampling and analytical strategies are similar to those utilized during the 1986 characterization study. 

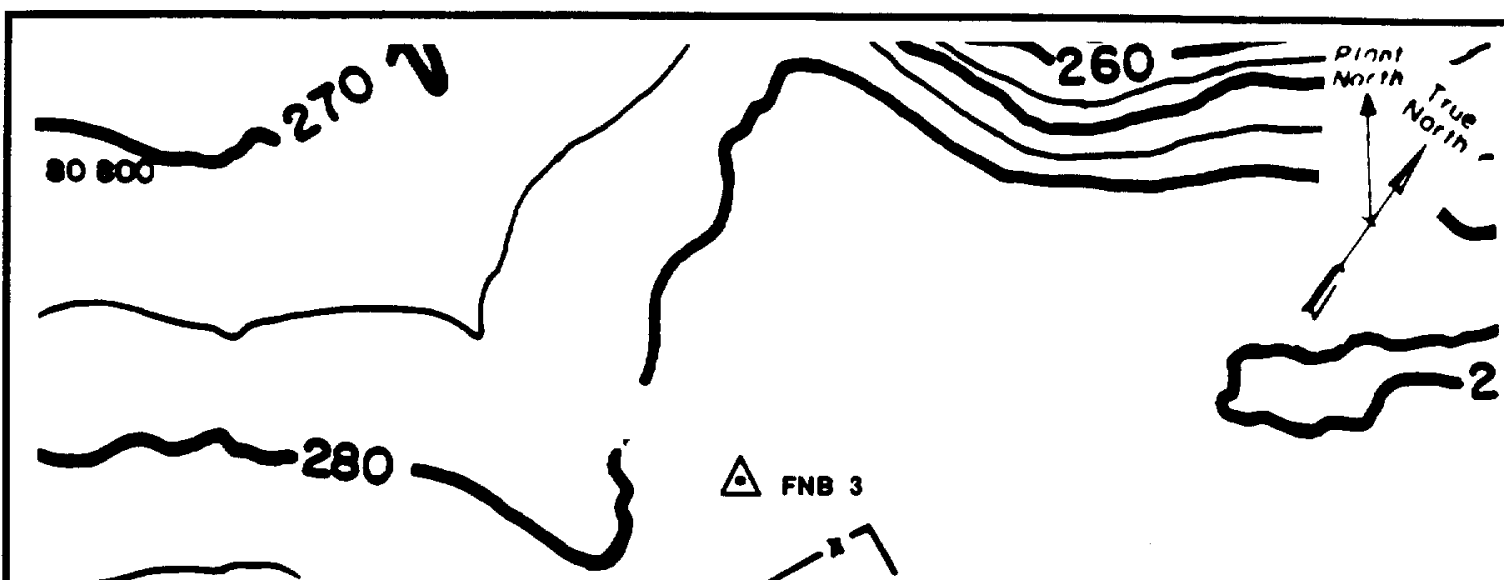

$\triangle$ FNB 3

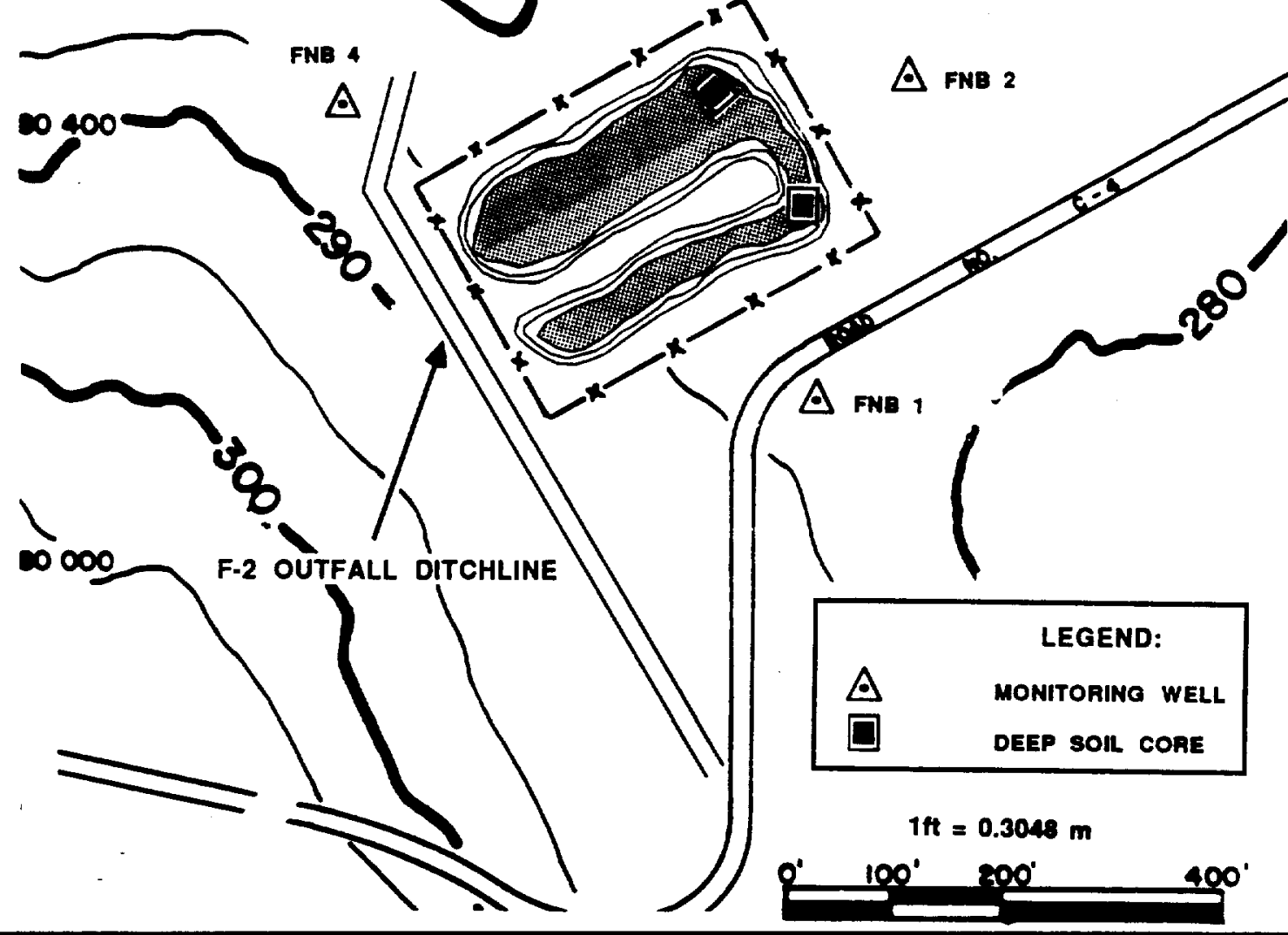

FIGURE BB.2. Proposed Sampling Locations within the Old F-Area Seepage Basin 


\section{Background}

\section{Site History}

The 01d TNX Seepage Basin (Building 904-76G) was built in 1958 to receive wastewater from pilot-scale tests conducted at TNX in support of the Defense Waste Processing Facility (DWPF), plant Separations Area, and fuel and target manufacturing areas. In the spring of 1980 , the wastewater flow was stopped to the basin, and the basin was taken out of service. Wastewater flow to the basin was then diverted to the New TNX Seepage Basin.

When in operation, process wastewater was delivered to the basin through an underground 20-cm-diameter vitrified pipeline. This pipeline entered the basin through the north wall of the settling section. A $13-\mathrm{cm}$ weir permitted effluent from the settling section to flow over into the main section. A similar-sized weir across the west wall of the main section directed the basin's overflow down into the nearby TNX swamp. During the 22-year loading history of the basin, overflow from the basin has resulted in the creation of an outfall delta approximately $30 \mathrm{~m}$ wide inside the swamp.

In 1980, the discharge of process wastewater to the basin ceased. Several retirement methods were considered for closure of the basin, but based on economic and technical considerations, the decision was made to close the basin by backfilling and clay capping. In 1981, this closure plan was implemented. The closure plan involved breaching the west wall of the basin to drain the free-standing liquids into the adjacent wetlands. Then the basin was backfilled with approximately $3 \mathrm{~m}$ of a sand and clay mixture, followed by $15 \mathrm{~cm}$ of SC-6 clay, and $50 \mathrm{~cm}$ of top soil. To divert rainwater runoff, the top of the basin was given a $1 \%$ slope, and the surface was seeded with centipede grass to minimize surface erosion. Currently, a portion of the top of the basin has been covered with asphalt. An office trailer rests on top of the payment, alongside an equipment lay-down area. Vegetation in the vicinity of the basin and outside the fence consists primarily of woods (Dunaway et a1., 1987b).

\section{Site Description}

The 01d TNX Seepage Basin is located in the southwestern section of the TNX facility. The basin was constructed in two sections: an inlet section and a large main section. Together these two sections encompassed approximately $953 \mathrm{~m}^{2}$ of TNX 1and. The SRP coordinates of the center of the basin are N 71128, E 16939. The Savannah River, the nearest plant boundary to the basin, is $305 \mathrm{~m}$ to the west. As originally built in 1958, the basin consisted of a rectangular settling section and a rectangular main section, with surface areas of approximately $82 \mathrm{~m}^{2}$ and $871 \mathrm{~m}^{2}$, respectively. The settling section lies immediately north of the main 
section, and a weir permitted flow between the two sections. Each basin section was approximately $3 \mathrm{~m}$ deep with walls that sloped outward at approximately $56^{\circ}$ angles.

The basin is located at an elevation of $45 \mathrm{~m}$ (148 ft) on a bluff above the Savannah River swamp, which is at an elevation of 27 to $30 \mathrm{~m}$ (Figure CC.1). Water-level elevation measurements from basin monitoring wells indicate that there has been a slight decline since 1980. The water table is found at a depth of approximately $30 \mathrm{~m}$ and the predominant groundwater flow direction over the monitoring period is to the west toward the Savannah River swamp. Seven monitoring wells have been installed to characterized the geologic and hydrogeologic conditions and to monitor the water-table elevation and groundwater quality near the basin (Figure CC.2). Four wells, XSB 1 through XSB 4, were installed in April 1980. Due to possible water-quality interferences, XSB 3 was abandoned and replaced with XSB $3 A$ in 1984. Three additional wells, XSB 5, XSB 5A, and $\mathrm{XSB} 3 \mathrm{~T}$, were installed near the basin to verify the upward vertical hydraulic gradients and to monitor the groundwater quality of the "Tuscaloosa" Formation.

\section{Review of Available Data}

A program to define the extent of chemical and radionuclide contamination in the vicinity of the 01d TNX Seepage Basin was begun in 1984. This program included sampling and analysis of sediment samples from beneath the basin and in the adjacent swamp area. The data obtained from this characterization study are presented in Simmons et al. (1985).

The radionuclides detected above background in the basin sediment were $243 \mathrm{Cm}, 244 \mathrm{Cm}, 23{ }^{2} \mathrm{Pu}, 238_{\mathrm{U}}, 240 \mathrm{Pu}, 228 \mathrm{Ra}, 235 \mathrm{U}$, and $228 \mathrm{Th}$. These radionuclides were limited to the northeast area of the basin in the location that had previously been the upper inlet. In addition, the levels detected above background were associated with the upper layer of basin sediment.

Metals present above SRP background levels in the basin sediments were silver, chromium, copper, mercury, nickel, and cyanide. All of these constituents are related to past disposal practices. EP toxicity tests (heavy metals only) performed on basin sediments indicate concentrations below EPA maximum contaminant limit guidelines. No organic constituents were detected above background in any of the sediment samples taken at the basin.

The groundwater data from the 01d TNX Seepage Basin indicate that there has been a significant impact on groundwater quality from the operation of the basin (Heffner et al., in press). Mercury has consistently exceeded the groundwater quality review criteria in Appendix Table 10 in upgradient wel1 XSB 2 and downgradient well XSB 4 . Nitrate 

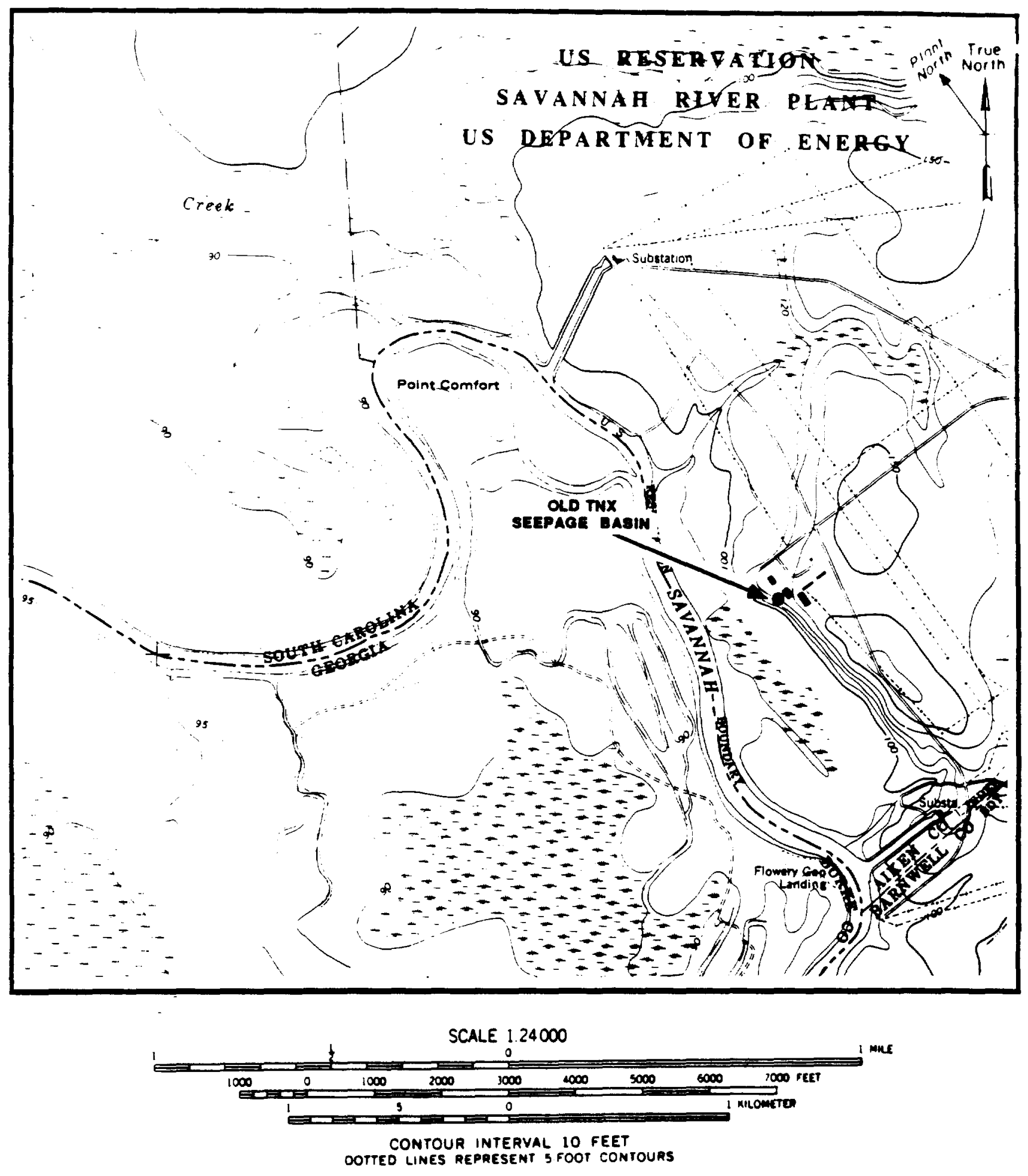

FIGURE CC.1. Location of the Old MxX Seepage Basin on Shell Bluff
Landing Quadrangle 7.5 Minute Series Topographic Map

CC -3 

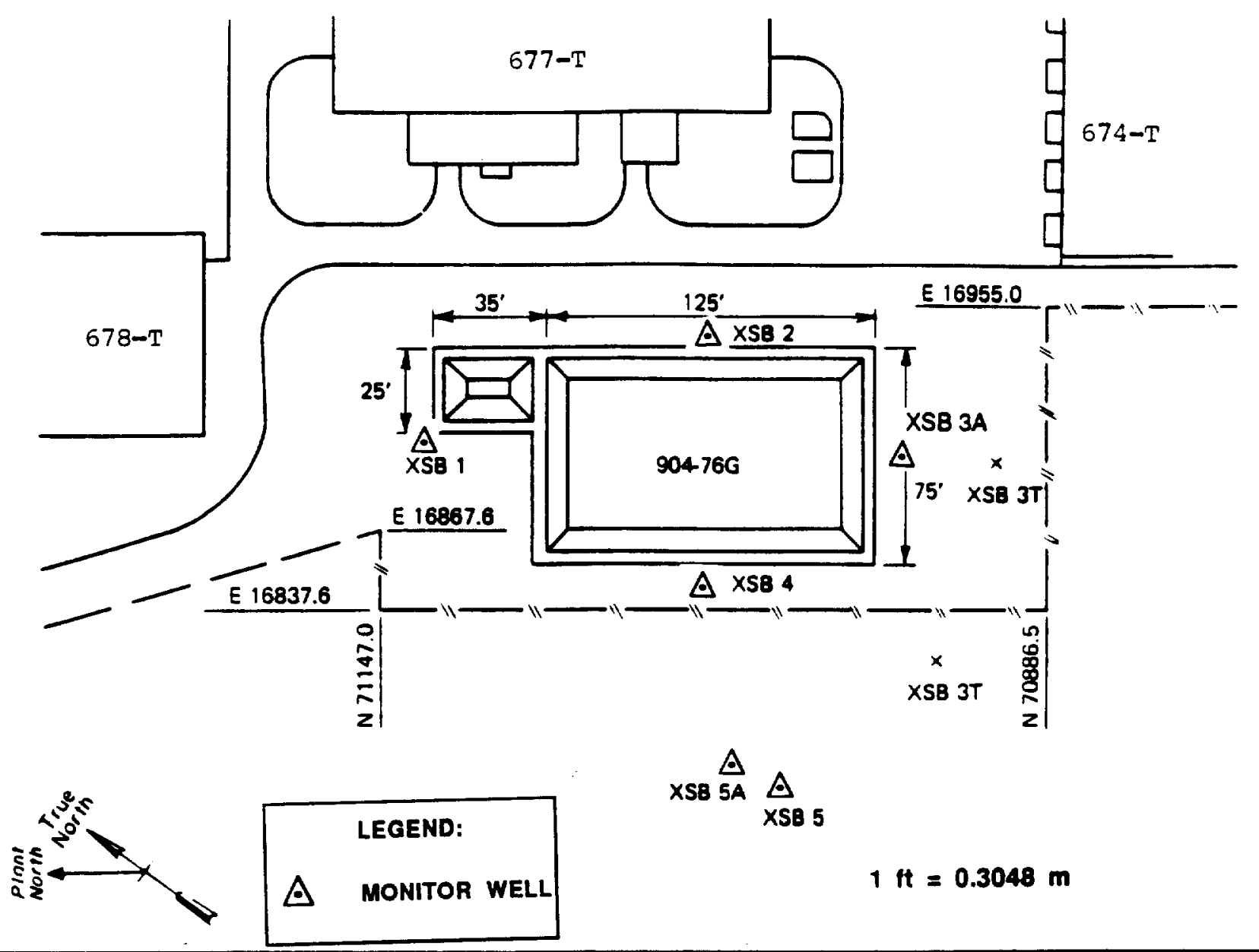

FIGURE CC.2. Monitoring Well Location Map for the Old TNX Seepage Basin 
concentrations follow a similar pattern, with values for well XSB 2 ranging from 137.0 to $200 \mathrm{mg} / \mathrm{L}$ and values for well XSB 4 ranging from 27.2 to $138.0 \mathrm{mg} / \mathrm{L}$. All four site wells have on occasion contained nitrate levels above the groundwater quality criteria in Appendix Table 10. Manganese concentrations above the groundwater quality criteria in Appendix Table 10 were detected in we11s XSB 2 through XSB 4. The highest levels were found in well XSB $2(1.72$ to $2.27 \mathrm{mg} / \mathrm{L})$. Nickel concentrations exhibited a similar trend, with the highest concentrations in wells XSB 2 and XSB 4.

Concentrations of barium, chloride, and sodium were consistently above the groundwater quality criteria in Appendix Table 10 for the four site wells. Conductivity levels in the site wells also exhibited the same pattern, with levels in wells XSB 2 (990 to $3,100 \mu \mathrm{mhos} / \mathrm{cm}$ ) and XSB 4 (260 to $1,440 \mu \mathrm{mhos} / \mathrm{cm}$ ) being higher than levels in well XSB 1 (85.0 to $220 \mu \mathrm{mhos} / \mathrm{cm})$. Groundwater $\mathrm{pH}$ in the downgradient wells and upgradient well XSB 2 ranged from 3.0 to 5.3, which is slightly lower than the $\mathrm{pH}$ range of 4.6 to 5.8 in upgradient well XSB 1 . Cadmium concentrations up to $0.038 \mathrm{mg} / \mathrm{L}$ in wells XSB 2, XSB $3 A$, and XSB 4 have exceeded the groundwater quality criteria in Appendix Table 10. Lead concentrations exceeding the groundwater quality criteria in Appendix Table 10 have been detected in all four site wells (Heffner et al., in press).

An average TOH concentration of $13 \mathrm{mg} / \mathrm{L}$ was detected in we 11 XSB $2 \mathrm{~A}$, compared to 2.3 to $6.0 \mathrm{mg} / \mathrm{L}$ for the remaining site wells. Tetrachloromethane has been detected in upgradient well XSB $2(0.027$ to $0.038 \mathrm{mg} / \mathrm{L})$ below the groundwater quality criteria in Appendix Table 10. Trichloroethylene has been detected in all wells up to $0.826 \mathrm{mg} / \mathrm{L}$. A11 we1ls except well XSB 1 contained gross alpha activity above the groundwater quality criteria in Appendix Table 10. Activities were the highest in wells XSB 2 (125 to $391 \mathrm{pCi} / \mathrm{L})$ and XSB 4 (278 to $418 \mathrm{pCi} / \mathrm{L})$. Nonvolatile beta activities exhibited the same trend. Radium levels similarly were lower in wells XSB 1 and XSB 3A, with wells XSB 2 and XSB 4 consistently exceeding the groundwater quality criteria in Appendix Table 10.

\section{Characterization Recommendations}

\section{Sampling}

No additional characterization effort is recommended for this site. A geologic core will be taken at the nearby D-Area Coal Pile Runoff Containment Basin to better define the hydrogeologic units in this area.

\section{Chemical and Physical Analyses}

It is recommended that the existing wells be sampled and analyzed for the extended list of radionuclides outlined in Appendix Table 5. 


\section{Background}

\section{Site History}

The Radioactive Waste Burial Grounds are solid waste storage/disposal facilities centrally located at SRP (Figure DD.1). These sites receive all radioactive solid waste produced at SRP, as well as periodic shipments from other DOE facilities. There are three distinct facilities: (1) Building 643-G, a 3.1E+05 $\mathrm{m}^{2}$ area used from 1952 through 1972; (2) Building $643-7 \mathrm{G}$, a $4.8 \mathrm{E}+05 \mathrm{~m}^{2}$ site contiguous with the original area that received waste beginning in 1969; and (3) a closure area (Building 643-28G) within 643-7G, defined in 1986 as a mixed waste management facility. This closure area $(643-28 \mathrm{G})$ has received materials defined as hazardous by RCRA. Figure DD.1 shows the areas within the Burial Grounds where various materials are disposed. A detailed description of the Radioactive Waste Burial Grounds is presented in Jaegge et al. (1987).

The Burial Grounds are divided into sections for accommodating disposal of various levels and types of radioactivity in waste materials: transuranic (TRU) alpha waste, low-level waste (alpha and beta-gamma), intermediate-level beta-gamma waste, and waste generated offsite. "he Burial Grounds are operated in compliance with DOE Orders regarding radioactive waste disposal; in general, lower catagories of waste are handled by shallow land disposal techniques, while higher activity waste (e.g., TRU waste) is stored or placed in a "greater confinement system." Examples of waste materials received include the following:

- Contaminated equipment--obsolete or failed tanks, pipes, jumpers, and other process equipment from the radiochemical separations areas.

- Reactor hardware and resins--fuel components and housings not containing irradiated fuel and spent deionizer resins.

- Spent 1ithium-aluminum targets--the waste target alloy after tritium has been extracted.

- $0 i 1$ from pumps in the tritium facilities and reactor areas--before bulk storage was started, the oil was placed in drums containing an absorbent material and buried.

- Mercury from gas pumps in tritium facilities--before 1968, radioactively contaminated mercury was buried in 1-L polyethylene bottles contained within a $0.02-\mathrm{m}^{3}$ steel can. Approximately 9,000 $\mathrm{kg}$ of mercury are buried in the 643-G Burial Ground. 


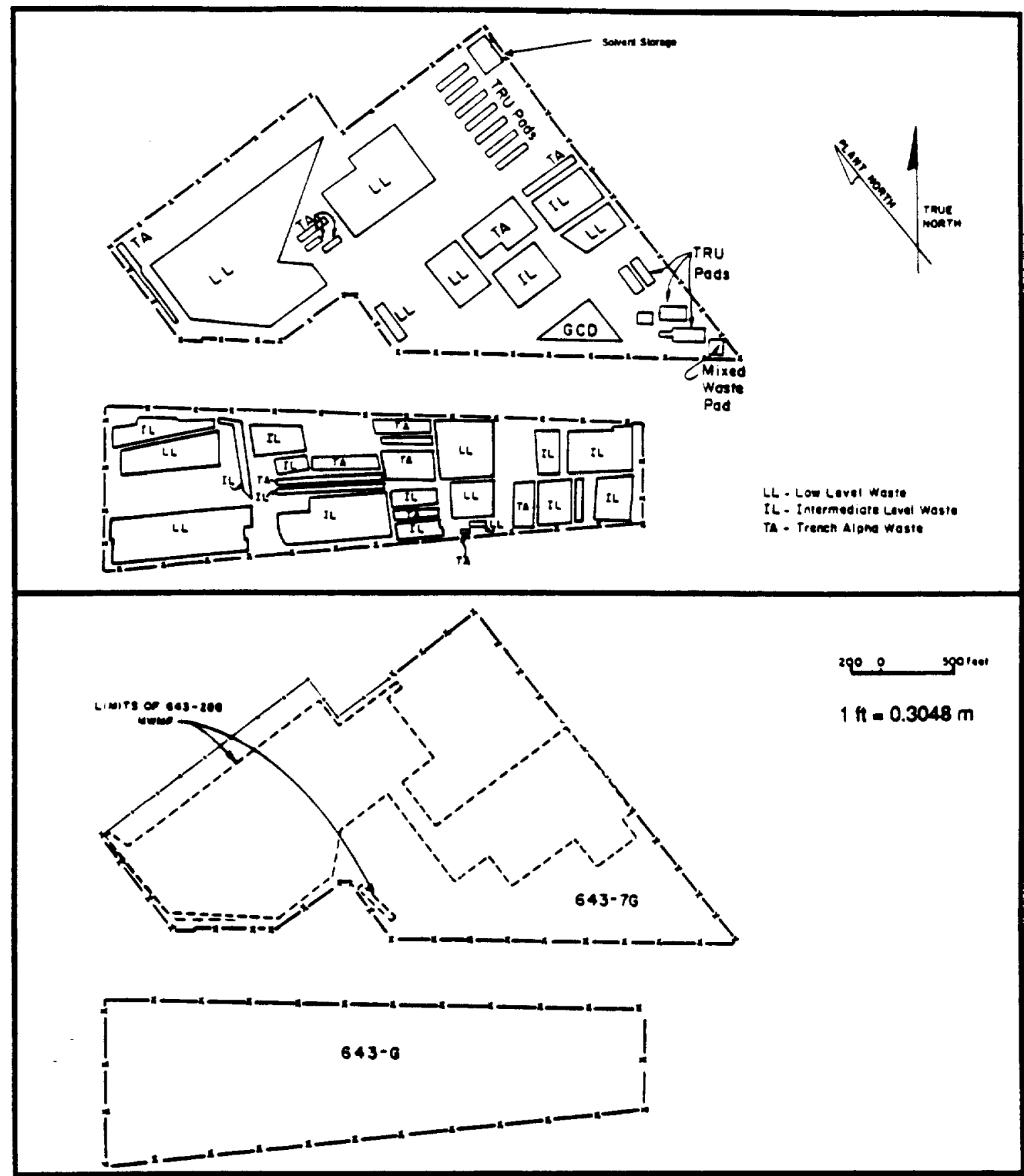

FIGURE DD.1. Burial Grounds Showing Zones of Filled Trench Alpha, Intermediate- and Low-Level Beta-Gamma Waste, and Solvent Storage and the Boundary of 643-28G MWRF 
- Incidental waste from laboratory and production operations--sma11 equipment, spent air filters, clothes, analytical waste, decontamination residues, plastic sheeting, and gloves.

- Shipments from offsite--for example, tritiated waste from Mound Laboratory, ${ }^{238} \mathrm{Pu}$ process waste from Los Alamos Scientific Laboratory and Mound Laboratory, debris from two U.S. military airplane accidents in foreign countries, and U.S. Navy submarine components.

Significant quantities of various radionuclides as well as some nonradioactive materials have been received over the years. For example, $4.1 \mathrm{E}+06 \mathrm{Ci}$ of tritium, $1.7 \mathrm{E}+04 \mathrm{Ci}$ of $90 \mathrm{Sr}, 5.3 \mathrm{E}+03 \mathrm{Ci}$ of $238 \mathrm{Pu}$, and $1.0 \mathrm{E}+05 \mathrm{~kg}$ of lead have been estimated as potential disposal activities/masses. A complete 1 ist of these materials is in Jaegge et a1. (1987).

A large amount of data is available related to the Radioactive Waste Burial Grounds. A closure plan has been submitted to SCDHEC for the Mixed Waste Management Facility (643-28G). Various site assessment reports, technical data summaries, and closure plans are in preparation for 643-G and $643-7 G$.

\section{Site Description}

The Burial Grounds occupy $7.9 E+05 \mathrm{~m}^{2}$ between the $F$ and $H$ separations areas, approximately $10 \mathrm{~km}$ east of the nearest plant boundary. The original disposal area $(643-G)$ is quadrilateral with corners at the following coordinates:

\section{SRP Coordinates}
N 75277
E 54411
N 76150
E 55081
N 73900
E 58080
N 73346
E 57586

Site $643-7 G$ is a polygonal shape with corners at the following coordinates: SRP Coordinates
N 75277
E 54411
N 76150
E 55081
N 73900
E 58080
N 73346
E 57586
N 76000
E 55876
N 76800
E 55876
N 76800
E 57600
N 76475
E 58800 


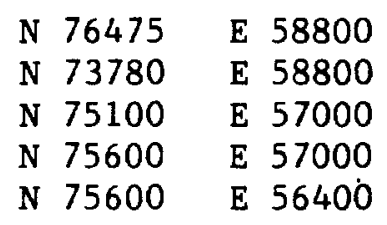

The Burial Grounds are located in an interstream area between two tributaries of the Savannah River, Upper Three Runs Creek to the north and Four Mile Creek to the south (Figure DD.2). The ground surface at the Burial Grounds is relatively flat with elevations across the site ranging approximately from $85 \mathrm{~m}$ to $98 \mathrm{~m}$ ( 280 to $320 \mathrm{ft})$. A topographic map of the Burial Grounds is shown in Figure DD.3. Precipitation that falls on the Burial Grounds is carried from the site in engineered drainages shown as arrows in Figure DD.3. These drainages vary in depth and slope. The average slope of the ground surface from the Burial Grounds to Four Mile Creek is approximately $0.07 \mathrm{~m} / \mathrm{m}$.

The Burial Grounds are located over a groundwater divide. Horizontal gradients in the water table are gentle (Figure DD.4). Horizontal groundwater flow is southeasterly (toward Four Mile Creek) from most of 643-G, while horizontal groundwater flow in the water table from the remaining Burial Grounds area is north (toward Upper Three Runs Creek). As shown in Figure DD.5, vertical gradients are relatively large, and vertical flow is expected to dominate over much of the Burial Grounds area. Water will move downward until it reaches the Congaree Formation; at this point, horizontal flow (toward Upper Three Runs Creek) dominates. There is an upward head from the Black Creek ("Tuscaloosa") through the Ellenton Formation; therefore, flow paths from the Burial Grounds do not enter the Black Creek. The $135 \mathrm{grid}$ wells in the Burial Grounds are shown in Figure DD.6. These wells were installed for radionuclide monitoring. A set of protocol monitoring wells and well clusters is currently being installed around the Burial Grounds (Figure DD.7).

\section{Review of Available Data}

The primary data collected at the Radioactive Waste Burial Grounds are groundwater activities of radionuclides (Jaegge et a1., 1987). Tritium, which moves freely in the groundwater, is the primary waste constituent in the groundwater with concentrations up to greater than $1,000 \mathrm{uCi} / \mathrm{L}$. Elevated levels of nonvolatile beta-gamma (up to $>10,000 \mathrm{pCi} / \mathrm{L}$ ) and alpha (up to $>100 \mathrm{pCi} / \mathrm{L}$ ) have also been measured. Preliminary measurements for nonradioactive constituents suggest that the groundwater has elevated lead, mercury, and cadmium concentrations. 
A $\mathbf{G}$

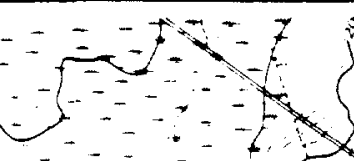

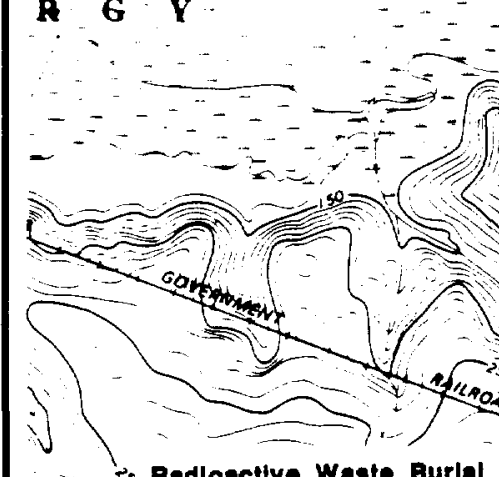

Redloactlve Waste Burlal Grounds
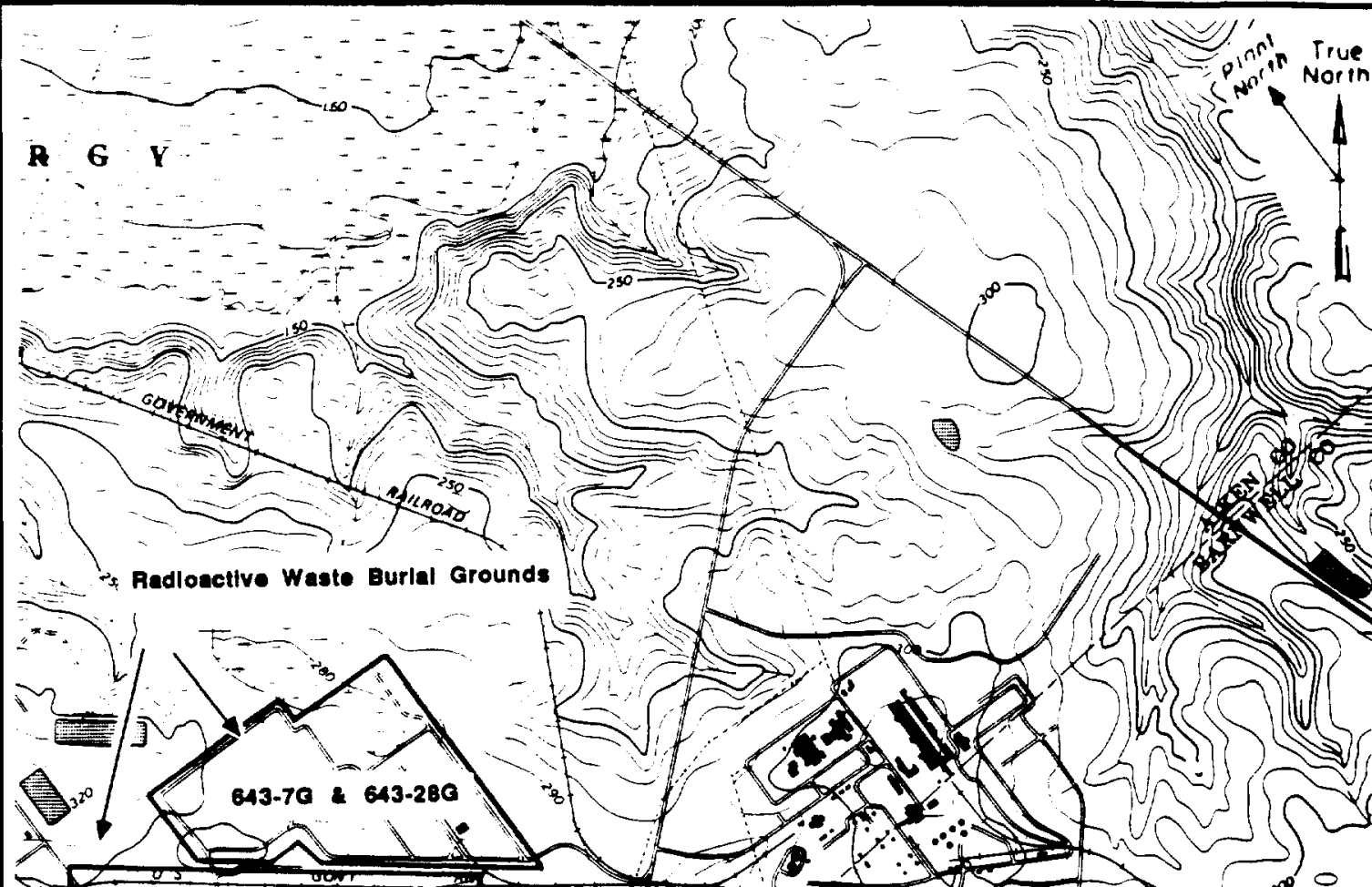


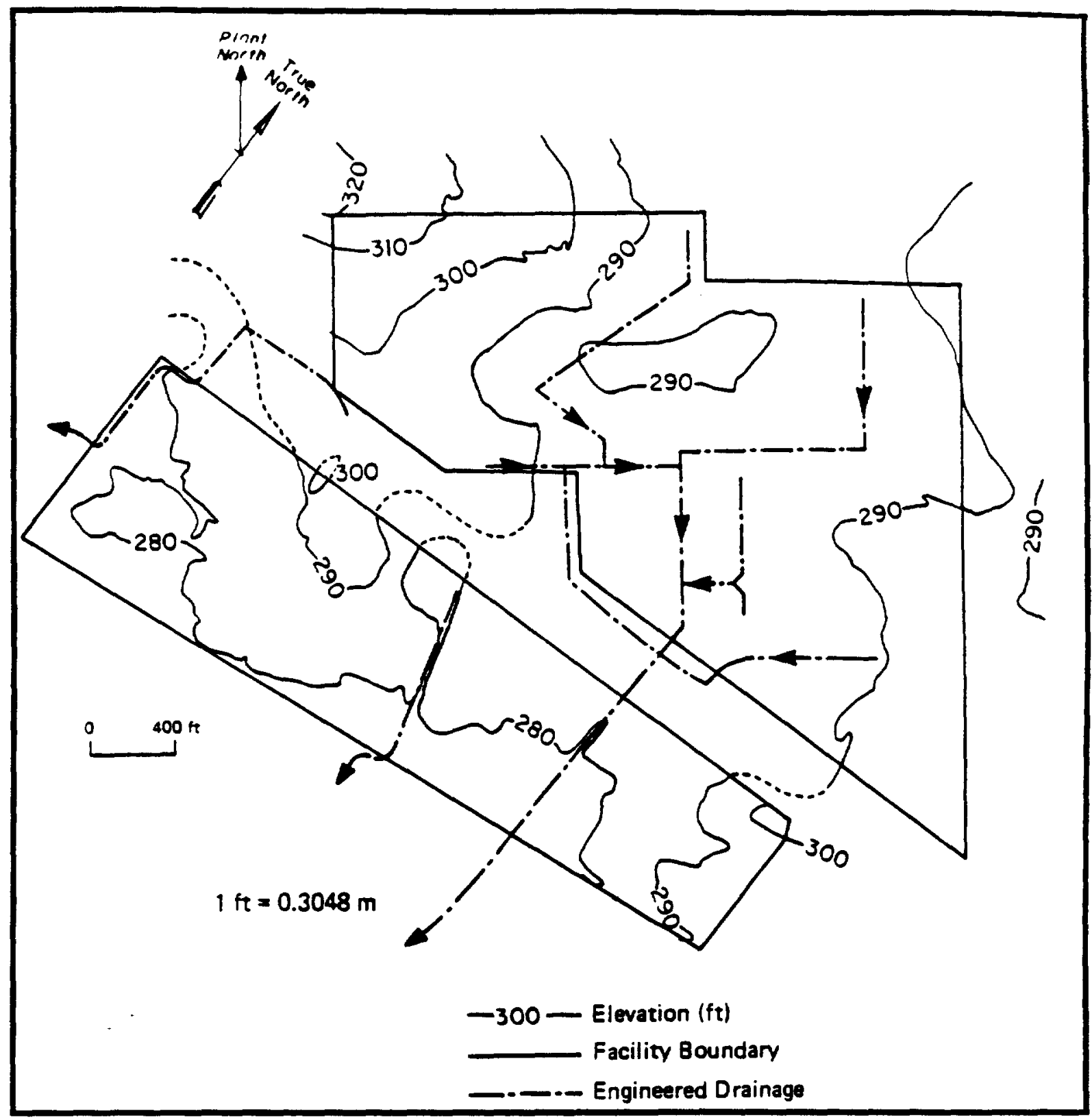

FIGURE DD.3. Topography and Drainage in the Radioactive Waste Burial Grounds 


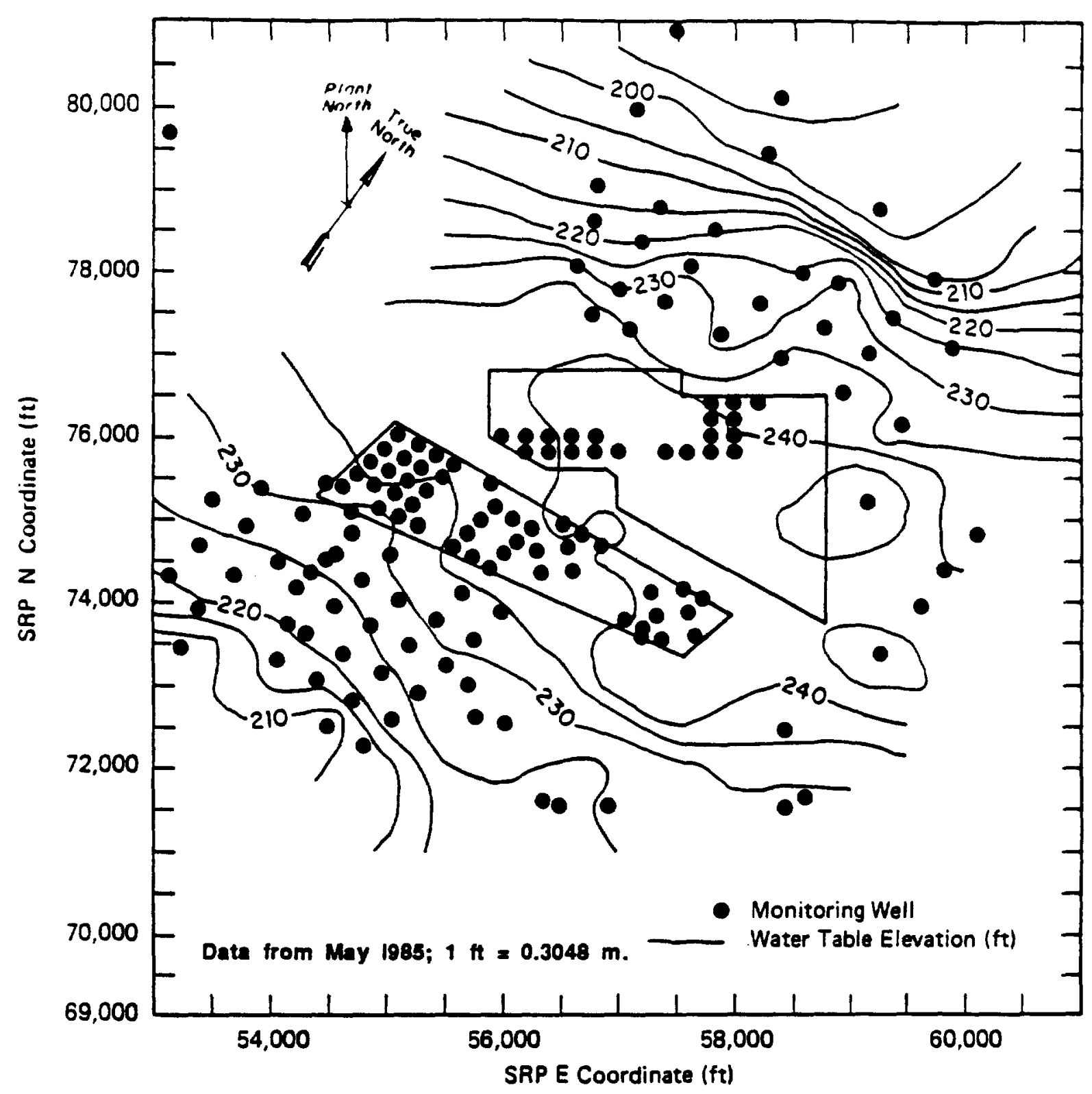

FIGURE DD.4. Water-Table Map in the Imnediate Vicinity of the Burial Grounds 


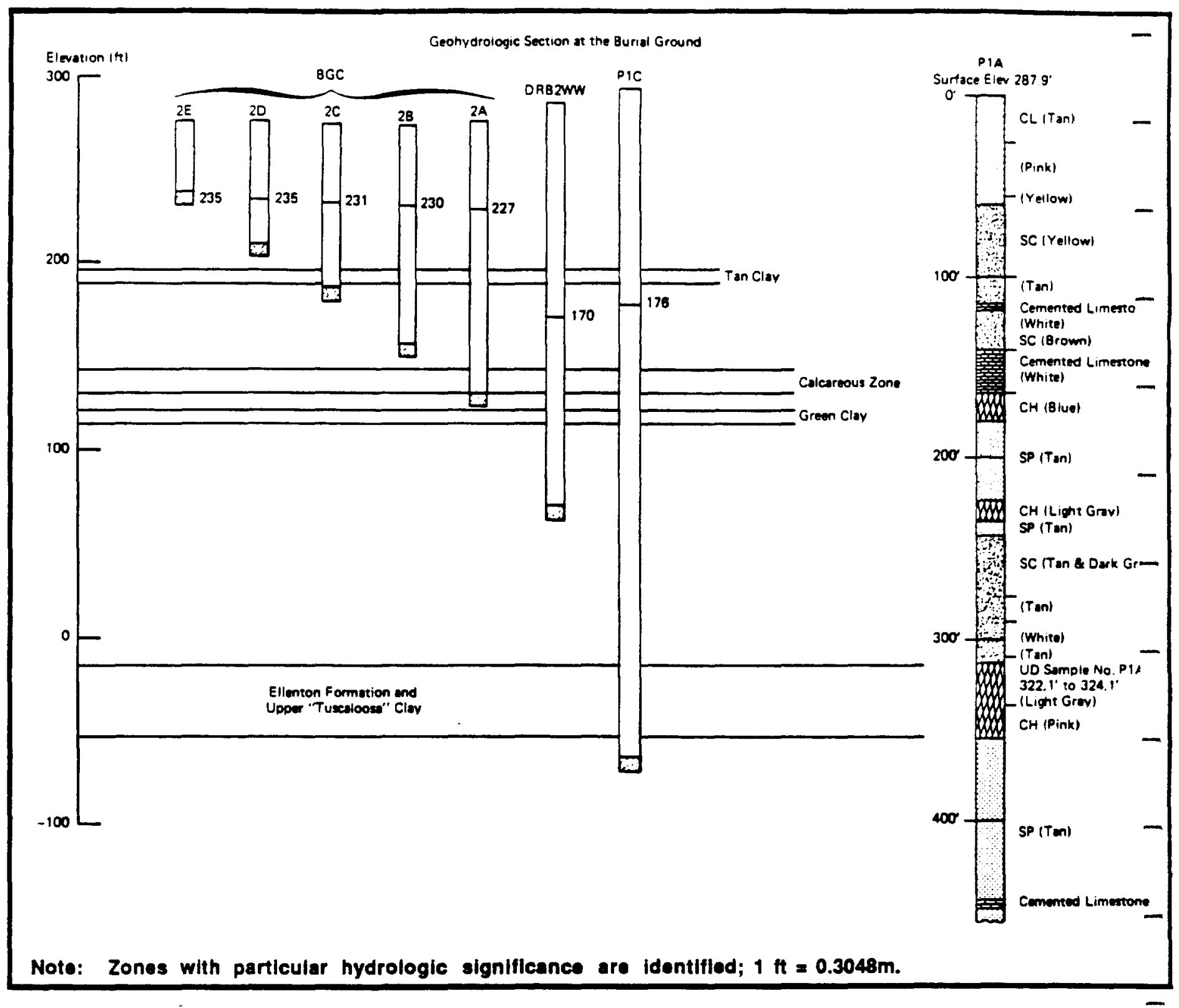

FIGURE DD.5. Vertical Head Relationships in Well Log from Burial Ground Wells 

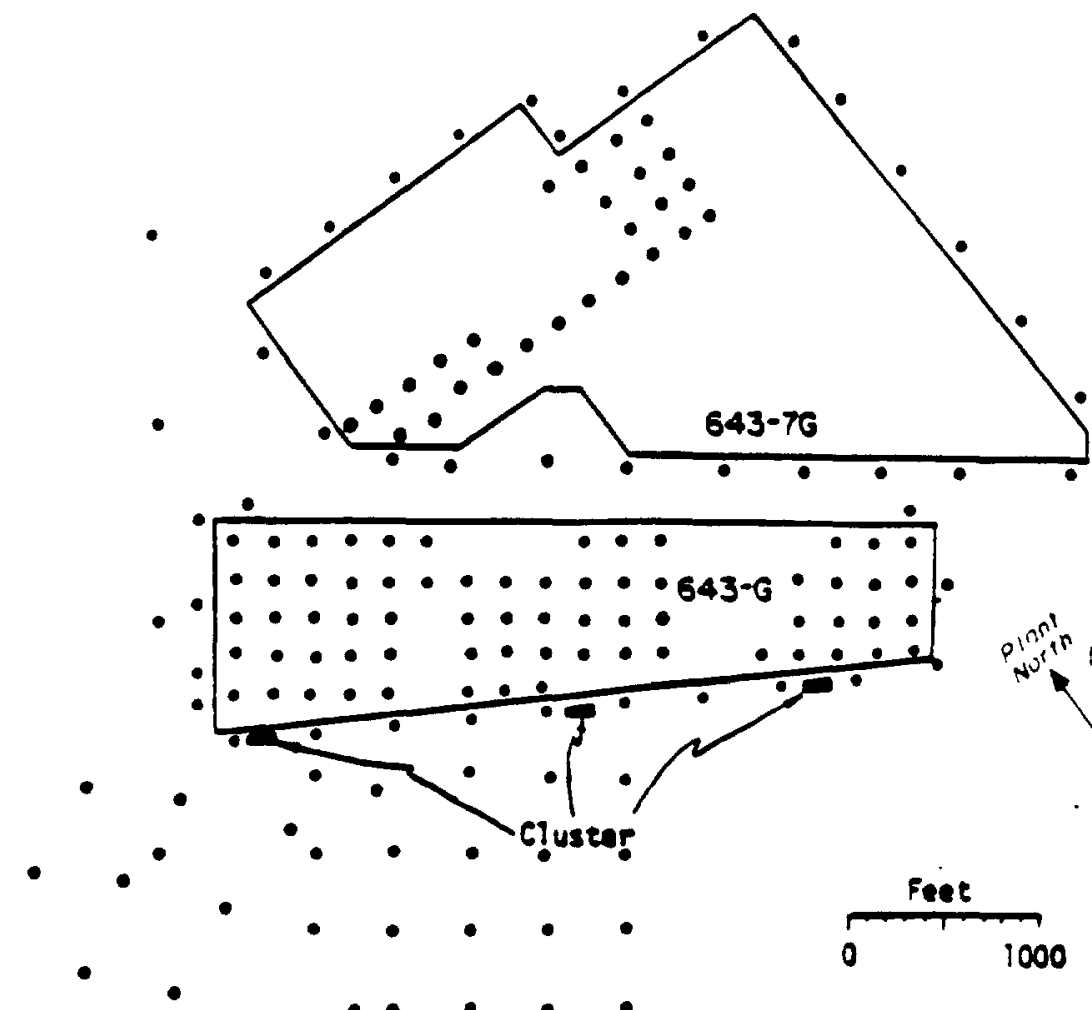

-
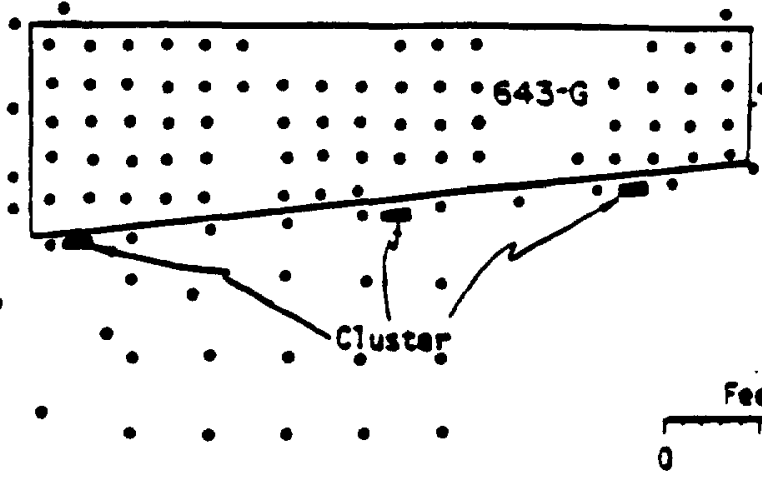


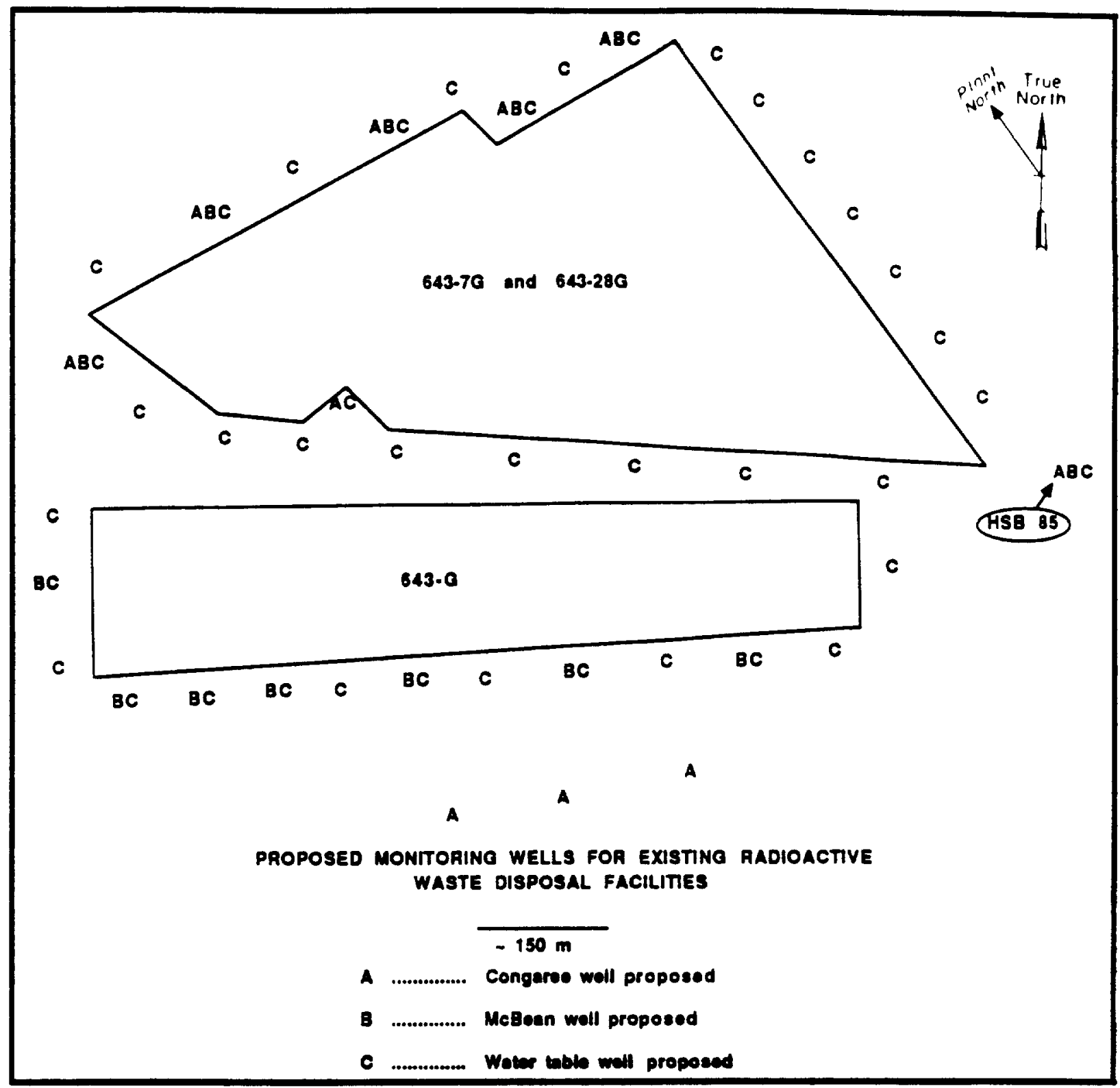

FIGURE DD.7. Protocol Monitoring Wells for the Existing and Previous Radioactive Waste Disposal Facilities 


\section{Characterization Recommendations}

\section{Sampling}

Additional samples are recommended to support the proposed closure. These samples are associated with the drilling of the protocol well clusters (Figure DD.7). Each cluster with a Congaree well should be sampled. This additional data would help assure the local continuity of the significant aquitards, provide samples of the porous medium for geochemical analysis, and provide a location for geophysical logging and sediment collection so that the site can be more adequately linked to the high quality site-wide geological programs.

\section{Chemical and Physical Analyses}

The well clusters are being drilled and screened to sample all of the significant water-bearing zones. The deepest well in each cluster should be geophysically logged. Geochemical parameters (Class 2 and Class 3 parameters from Appendix Table 1) along with the laboratory geological examination should be performed on core material from each significant water-bearing zone and aquitard. Approximately four zones from each sampled cluster well should be examined, yielding approximately 40 samples. The completed wells should be sampled for radionuclides and nonradioactive constituents (Appendix Table 6). Also, sampling for an expanded list of radionuclides (Appendix Table 5) should be performed on the water from these wells. 


\section{Background}

\section{Site History}

The five reactor areas at SRP use earthen seepage basins to dispose of low-level radioactive purge waters from the reactor disassembly basins. There are 14 reactor seepage basins sitewide of which 7 ( 6 in $R$ Area and 1 in $\mathrm{K}$ Area) are inactive (Stone \& Christensen, 1983). The K-Area Reactor Seepage Basin (Building 904-65G) has been open but inactive since 1960 . R-Area Reactor Seepage Basin 1 (Building 904-103G) was placed into service in June 1957. In November of that year, the basin received approximately $200 \mathrm{Ci}$ of ${ }^{90} \mathrm{Sr}$ and $1,000 \mathrm{Ci}$ of ${ }^{137} \mathrm{Cs}$ following the failure of an experimental fuel element during a calorimeter test in the R-Area Disassembly Basin. Basins 2 through 6 (Building 904-104G, 904-57G, 904-58G, 904-59G, and 904-60G, respectively) were placed into service shortly after this incident. Basin 1 was closed and backfilled in January 1958 because of surface outcropping and leakage of radioactive contamination into a nearby abandoned sewer 1 ine. In 1960 , Basins 2 through 5 were deactivated and backfilled. The ground surface above the five basins was treated with herbicide and covered with asphalt. In addition, a kaolinite dike was constructed down to the clay layer around Basin 1 and the northwest end of Basin 3 to contain any lateral movement of radioactive contamination. Basin 6 was last used in 1964 and was backfilled in 1977. Although many different radionuclides have been discharged to these basins, almost all of the radioactivity present is due to ${ }^{3} \mathrm{H},{ }^{90} \mathrm{Sr},{ }^{60} \mathrm{Co}$, and $137_{\mathrm{Cs}}$. No records exist of any chemical discharges to these seepage basins. Groundwater monitoring at the R- and K-Area reactor seepage basins was begun in 1958 and 1984 , respectively. Typically, groundwater has been monitored for gross alpha, gross nonvolatile beta, and tritium activity. Monitoring in $\mathrm{K}$ Area has been expanded to include nonradioactive constituents (Pekkala et al., 1987).

\section{Site Description}

The K-Area Reactor Seepage Basin is located outside and west of the $\mathrm{K}$-Area perimeter fence $8.5 \mathrm{~km}$ west of the nearest plant boundary (Figure EE.1). The six R-Area Reactor Seepage Basins are located outside and north of the R-Area perimeter fence approximately $16 \mathrm{~km}$ east of the nearest plant boundary (Figure EE.2). These basins were constructed by excavating below grade and backfilling around the sides of the cut to form earthen dike walls. The physical dimensions and SRP coordinates of the northeast corner of each basin are presented in Table EE.1. 

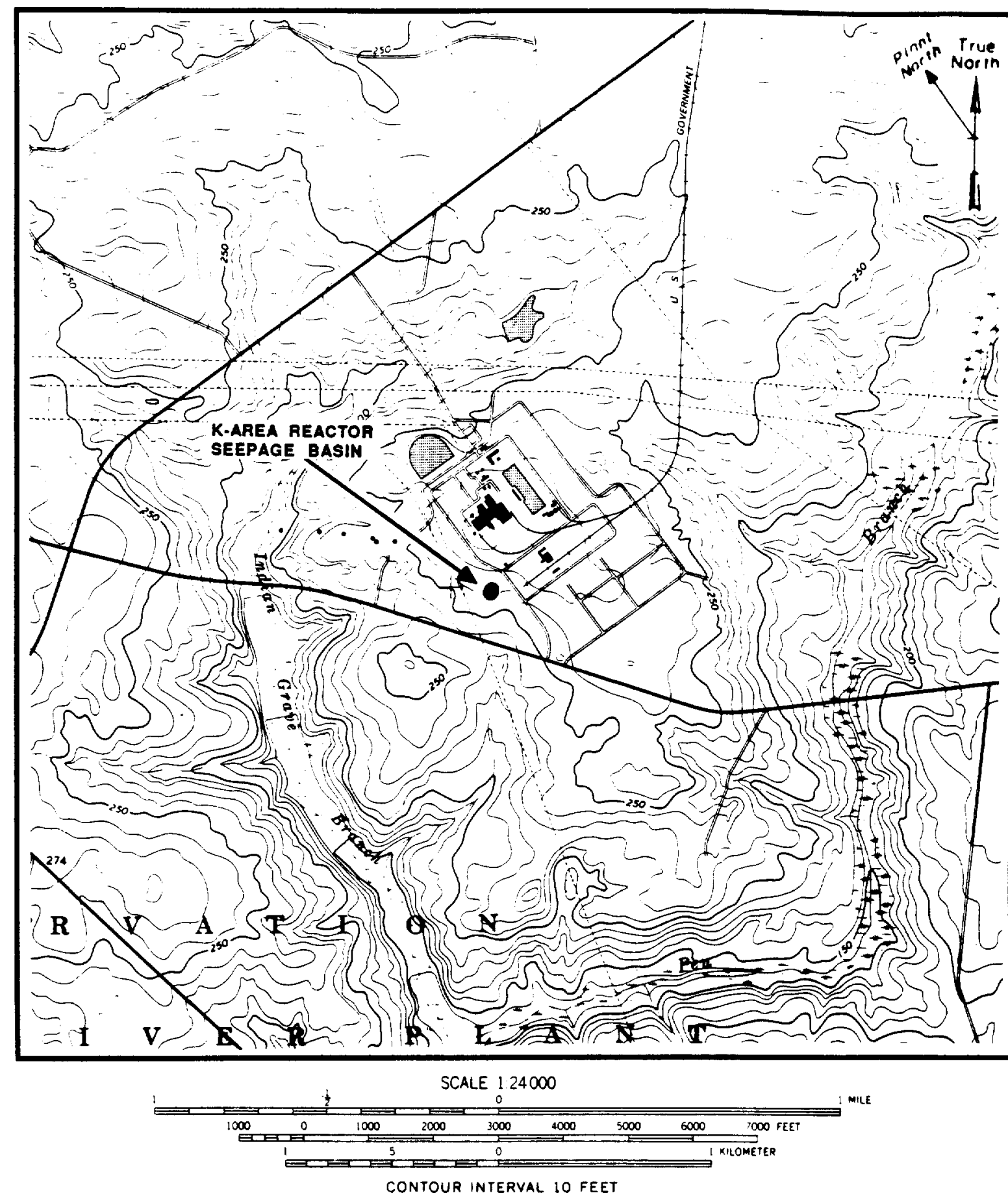

FIGURE EE.1. Location of the K-Area Reactor Seepage Basin on Girard NW Quadrangle 7.5 Minute Series Topographic Map 


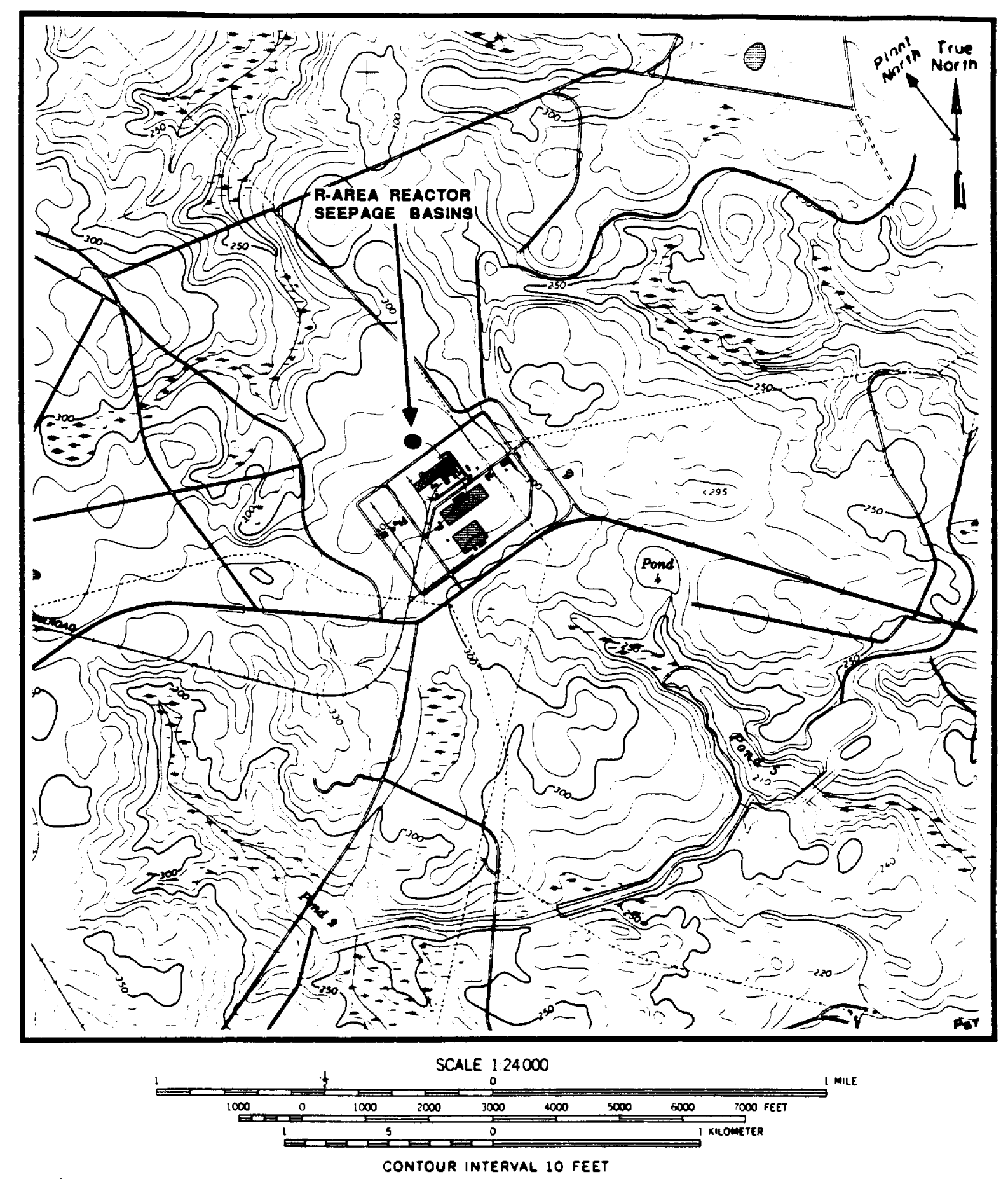

FIGURE EE.2. Location of the R-Area Reactor Seepage Basing on New Ellenton SE Quadrangle 7.5 Kinute Series Topographic Map 
TABLE EE. 1

Dimensions and SRP Coordinates of the $K$ - and R-Area Reactor Seepage Basins

\begin{tabular}{|c|c|c|c|c|c|c|}
\hline $\begin{array}{l}\text { Reactor } \\
\text { Area }\end{array}$ & $\begin{array}{l}\text { Basin } \\
\text { No. }\end{array}$ & $\begin{array}{l}\text { Dimensions } \\
\mathrm{L} \times \mathrm{W} \times \mathrm{D}(\mathrm{m})\end{array}$ & Area $\left(m^{2}\right)$ & $\begin{array}{l}\text { Volume } \\
\text { Capacity }\left(\mathrm{m}^{3}\right)\end{array}$ & \multicolumn{2}{|c|}{ SRP Coordinates } \\
\hline $\mathrm{K}$ & 1 & $41 \times 21 \times 2$ & 861 & 1,722 & N 54080 & E 39779 \\
\hline $\mathbf{R}$ & 1 & $120 \times 9 \times 3$ & 1,170 & 1,080 & N 57788 & E 74691 \\
\hline $\mathbf{R}$ & 2 & $40 \times 14 \times 3$ & 1,152 & 560 & N 58020 & E 74840 \\
\hline $\mathbf{R}$ & 3 & $90 \times 9 \times 3$ & 1,152 & 810 & N 58388 & E 74873 \\
\hline $\mathbf{R}$ & 4 & $93 \times 11 \times 2$ & 456 & 1,023 & N 58585 & E 75104 \\
\hline $\mathbf{R}$ & 5 & $90 \times 12 \times 3$ & 380 & 1,080 & N 58508 & E 75486 \\
\hline $\mathrm{R}$ & 6 & $150 \times 14 \times 5$ & 1,272 & 2,100 & N 58146 & E 75586 \\
\hline
\end{tabular}


The surface elevation of the K-Area Reactor Seepage Basin is approximately $82 \mathrm{~m}(270 \mathrm{ft})$. Water-table depth is approximately $17 \mathrm{~m}$ below grade. Surface drainage and horizontal groundwater flow are westward toward Indian Grave Branch. There are four water-table wells located around the K-Area Reactor Seepage Basin that monitor for radioactive and nonradioactive constituents. The R-Area Reactor Seepage Basins are located on a topographic divide between the headwaters of Mill Creek, a tributary of Upper Three Runs Creek (approximately $440 \mathrm{~m}$ away), and the drainage to Par Pond (about 1,140 $\mathrm{m}$ away). The surface elevations of these basins range from 94 to $97 \mathrm{~m}$ ( 310 to $318 \mathrm{ft}$ ). The water table is approximately $5 \mathrm{~m}$ below grade. Basins 1 through 4 were connected in series via overflow channels. Basin 5 received flow directly from the reactor disassembly basin. Effluent from Basins 4 and 5 was pumped to Basin 6. The surface drainage and water-table flow in the northwest part of the site is north toward Mill Creek. Surface drainage and water-table flow in the south part of the site (in the vicinity of Basins 1 and 6 ) is southeast toward Par Pond. There are 54 active radioactive monitoring wells located in the vicinity of the R-Area Reactor Seepage Basins. Discharge from the $K$ - and $R$-Area reactor seepage basins has been restricted to seepage of effluent into the underlying groundwater.

Review of Available Data

In 1978, a 6-m deep soil core was taken from the center of the K-Area Reactor Seepage Basin. Maximum concentrations of ${ }^{60} \mathrm{Co}(30 \mathrm{pCi} / \mathrm{gm}$ ) and ${ }^{137} \mathrm{Cs}(510 \mathrm{pCi} / \mathrm{gm})$ were detected in the top $15 \mathrm{~cm}$ of the soil core. The maximum concentration of ${ }^{90} \mathrm{Sr}(140 \mathrm{pCi} / \mathrm{gm})$ was found in the 15 to $30-\mathrm{cm}$ sample interval. No significant levels of radioactivity were detected below a depth of $45 \mathrm{~cm}$. A review of groundwater monitoring data for the period encompassing 1986 through the first quarter of 1987 indicates that the K-Area Reactor Seepage Basin did not affect groundwater quality (Zeigler et a1., 1987). A11 chemical constituents were within drinking water standards with the exception of tritium. The highest tritium levels were detected in upgradient well KSB 1 (Heffner et al., in press).

In 1976 , nine cores $120 \mathrm{~cm}$ in depth were taken from five of the six R-Area Reactor Seepage Basins. This characterization program was focused on Basin 1 where five cores were collected. One similar core was taken from each of Basins 2, 3, 4, and 5. The maximum radiation level in each basin was found in a narrow zone near the bottom of the backfilled basins with only minimal migration below this depth. Maximum concentrations of ${ }^{137} \mathrm{Cs}(8,000 \mathrm{nCi} / \mathrm{gm})$ and $90 \mathrm{Sr}(41 \mathrm{nCi} / \mathrm{gm})$ were detected in the inlet to Basin 1. Based on radioassay results from a limited number of soil samples, Basin 1 contains approximately $90 \%$ of the $137 \mathrm{Cs}$ and $50 \%$ of the $90 \mathrm{Sr}$ in the basin system. A review of groundwater monitoring data from 1982 through the first quarter of 1987 indicates significant nonvolatile beta contamination around Basin 1 and the northwest corner of Basin 3 . As previously noted, these areas have been sealed off by kaolinite dikes to minimize the lateral movement of radioactive contamination. Data from 
wells around Basins 2, 4, 5, and 6 indicate that these basins have had no significant affect on groundwater quality. Gross alpha levels in all site wells are within the drinking water standard (Pekkala et al., 1987;

Zeigler et al., 1987).

\section{Characterization Recommendations}

Sampling

Fourteen 3-m deep cores should be taken from the following sites around the R-Area Reactor Seepage Basins: just inside of the kaolinite dikes constructed around Basins 1 and 3, just outside of the kaolinite dikes constructed around Basins 1 and 3 , and at 10 sites bracketing the old construction sewer line (Figure EE.3). Additionally, three 1-m deep cores should be taken midline in the $\mathrm{K}$-Area Reactor Seepage Basin (Figure EE.4). Recommended sampling intervals for these boreholes are described in Appendix Table 1.

\section{Chemical and Physical Analyses}

Analytical recommendations (classes 1,2 , and 3 ) for the soil cores are described in Appendix Table 1. Additional analytical recommendations for these soil cores are as follows:

Interval (m)

$0.00-0.25$

$0.25-0.50$

$0.50-1.00$

$1.00-1.50$

$1.50-2.00$

$2.00-2.50$

$2.50-3.00$

$3.00-4.00$

$4.00-5.00$

$5.00-6.00$
Recommended Analyses

expanded radioactive; Ludlum counts

gamma scan; $90 \mathrm{Sr}$; Lud1um counts

gamma scan; $90 \mathrm{Sr}$; Ludlum counts

expanded rad; Ludlum counts

Ludlum counts

Ludlum counts

Ludlum counts

Ludlum counts

expanded radioactive; Ludlum counts

Ludlum counts

Note: expanded rad and gamma scan--see Appendix Table 5; Lud1um counts-field gross alpha, gross beta, and gross gamma counts performed on a Ludlum Meter.

Routine monitoring of wells at the R-Area Reactor Seepage Basins exhibiting elevated levels of nonvolatile beta should be expanded to include radioactivity analyses described in Appendix Table 5. This expanded monitoring program should continue for a period of one year. 


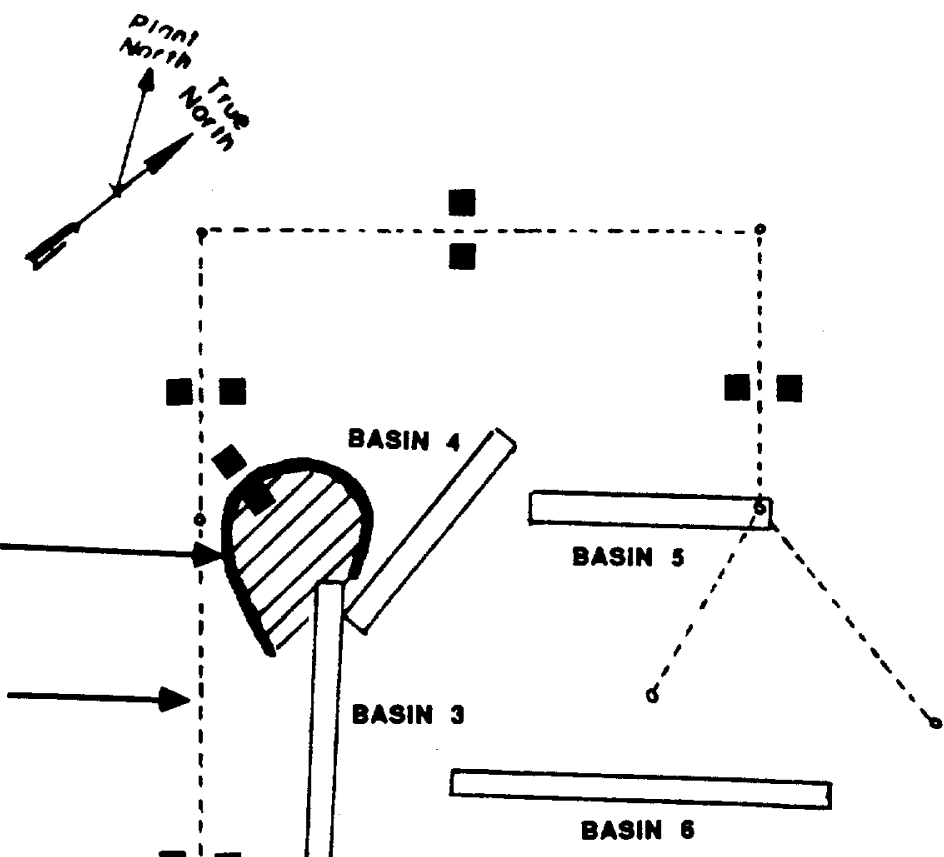

BAsIN 2
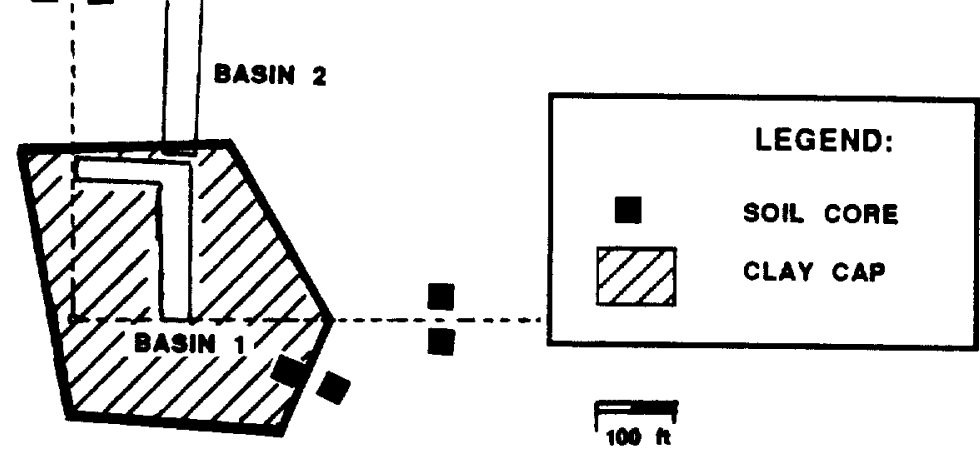

$1 \mathrm{ft}=0.3048 \mathrm{~m}$

FIGURE EE.3. Proposed Sampling Locations within the R-Area Reactor Seepage Basins 


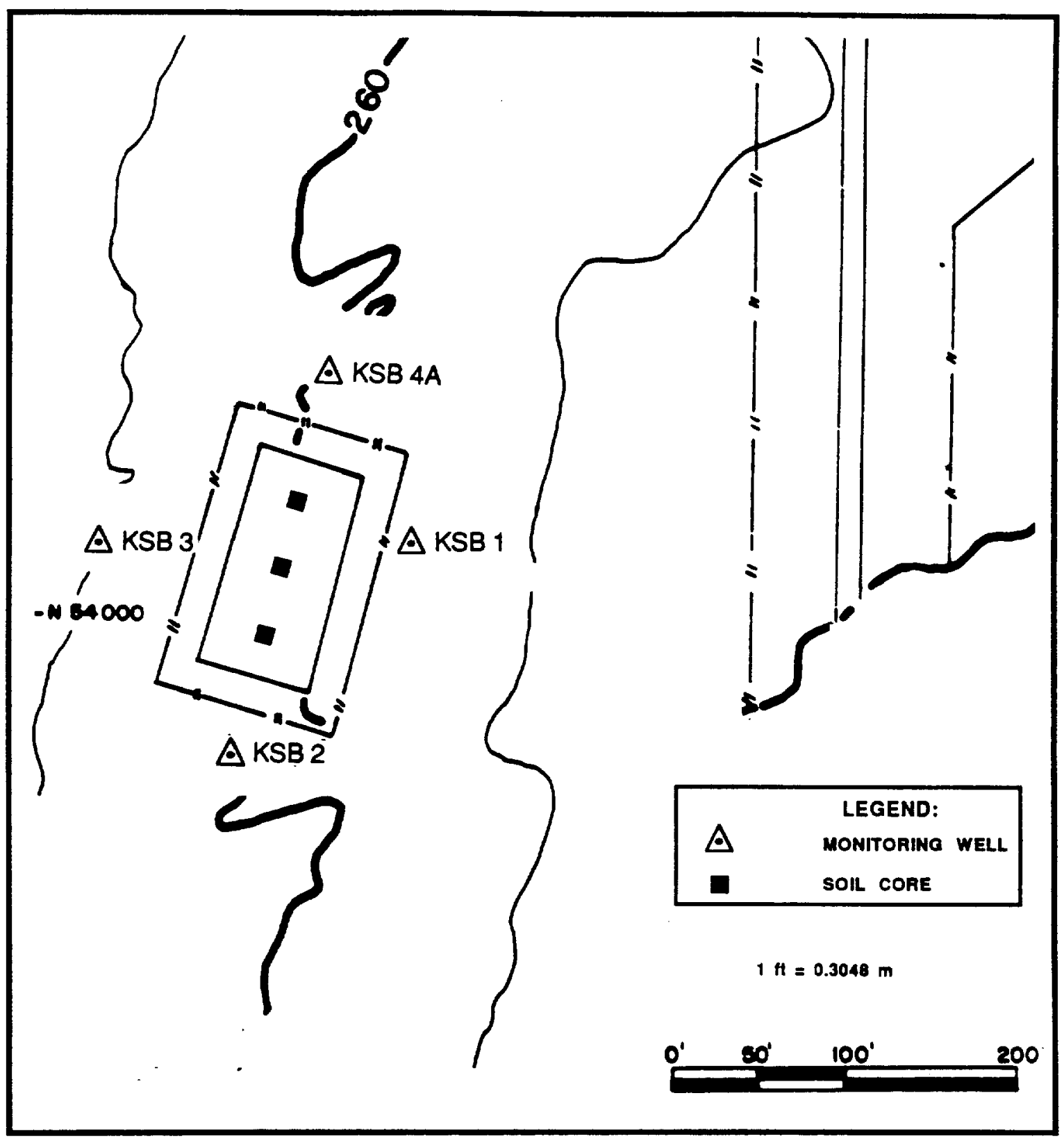

FIGURE EE.4. Proposed Sampling Locations within the K-Area Reactor Seepage Basin 


\section{Background}

\section{Site History}

The Risher Road Metal Pit (Building 631-17G) was used for disposal of scrap metal and lumber. The pit contains approximately 1.3 to $2.5 \mathrm{~m}^{3}$ of lumber and some scrap metal and is presently inactive (Heffner et al., in press).

\section{Site Description}

The Risher Road Metal Pit is located approximately $0.6 \mathrm{~km}$ west-northwest of the intersection of Road 2 and Road 2-1 (Figure FF.1). SRP coordinates for the site are N 103500, E 67000. The site is located in the northern part of SRP approximately $1.7 \mathrm{~km}$ southeast of the plant boundary. The Risher Road Metal Pit is an earthen pit covering approximately $36 \mathrm{~m}^{2}$ and is located on the Aiken Plateau at an elevation of approximately $109 \mathrm{~m}(357 \mathrm{ft})$. Surface drainage is to the west toward an unnamed tributary of Upper Three Runs Creek. No information about groundwater flow direction or depth to groundwater is available because there are no monitoring wells at this site.

Review of Available Data

No soil or water samples have been collected from the Risher Road Metal Pit.

\section{Characterization Recommendations}

\section{Sampling}

Soil cores are recommended to determine if any hazardous material has been released at the site (Figure FF.2). Because of the small size of the site and because of the relatively harmless nature of the contents of the site, three. soil cores of 3-m lengths are recommended. Soil cores should be sampled for chemical analyses according to the parameters given in Appendix Table 1. These data should be sufficient to complete an initial characterization of the site.

If significant contaminants are found in the soils, four water-table monitoring wells are recommended. One of the monitoring wells should be cored continuously. The cores should be described geologica1ly and archived at SRP for physical analyses if required at a later time. The monitoring wells should be logged geophysically for gamma, resistivity, porosity, and caliper if depth to the water-table is greater than $15 \mathrm{~m}$. 

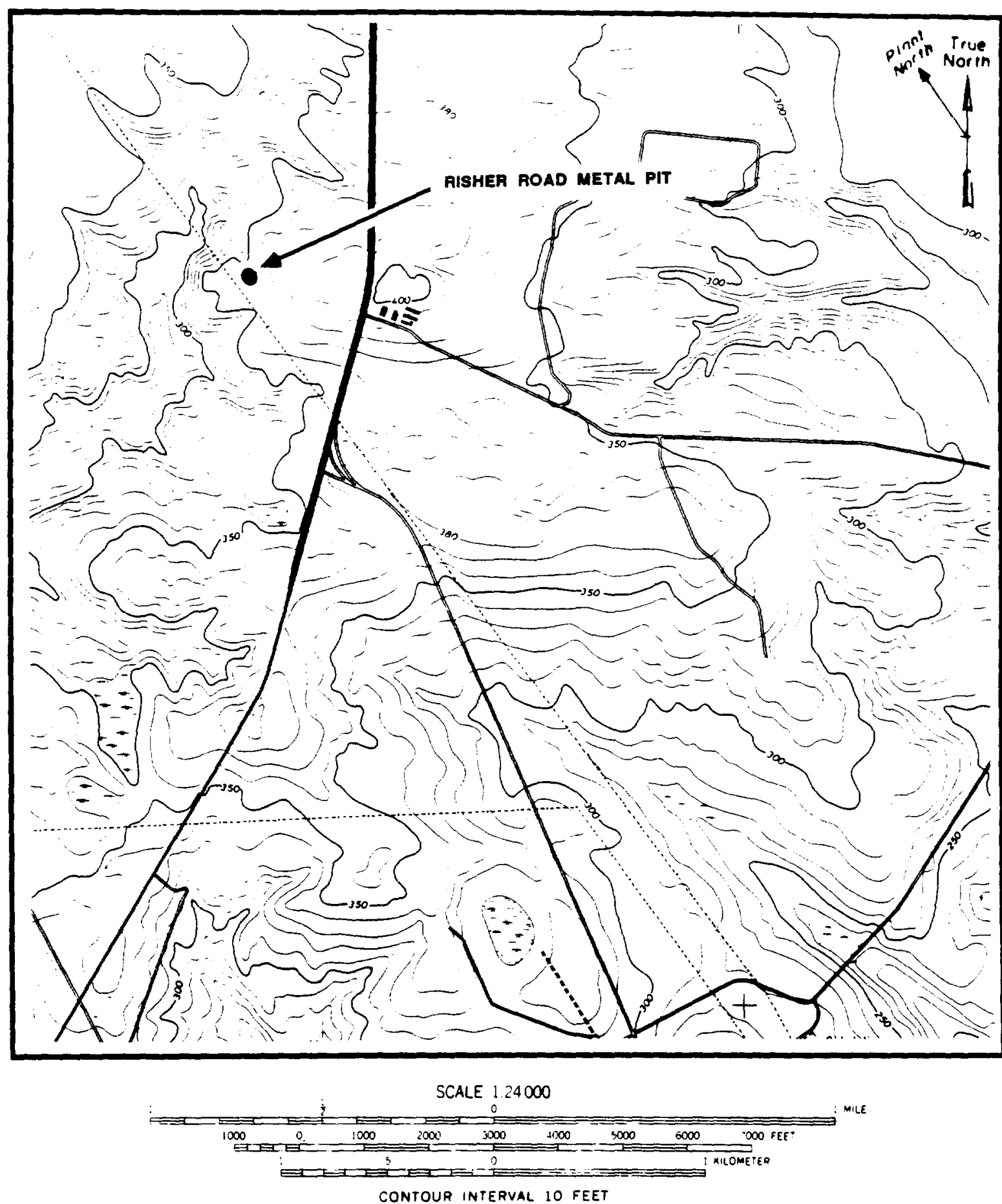

FIGURE FF.1. Location of the Risher Road Metal Pit on New Ellenton SW Quadrangle 7.5 Minute Series Topographic Map 


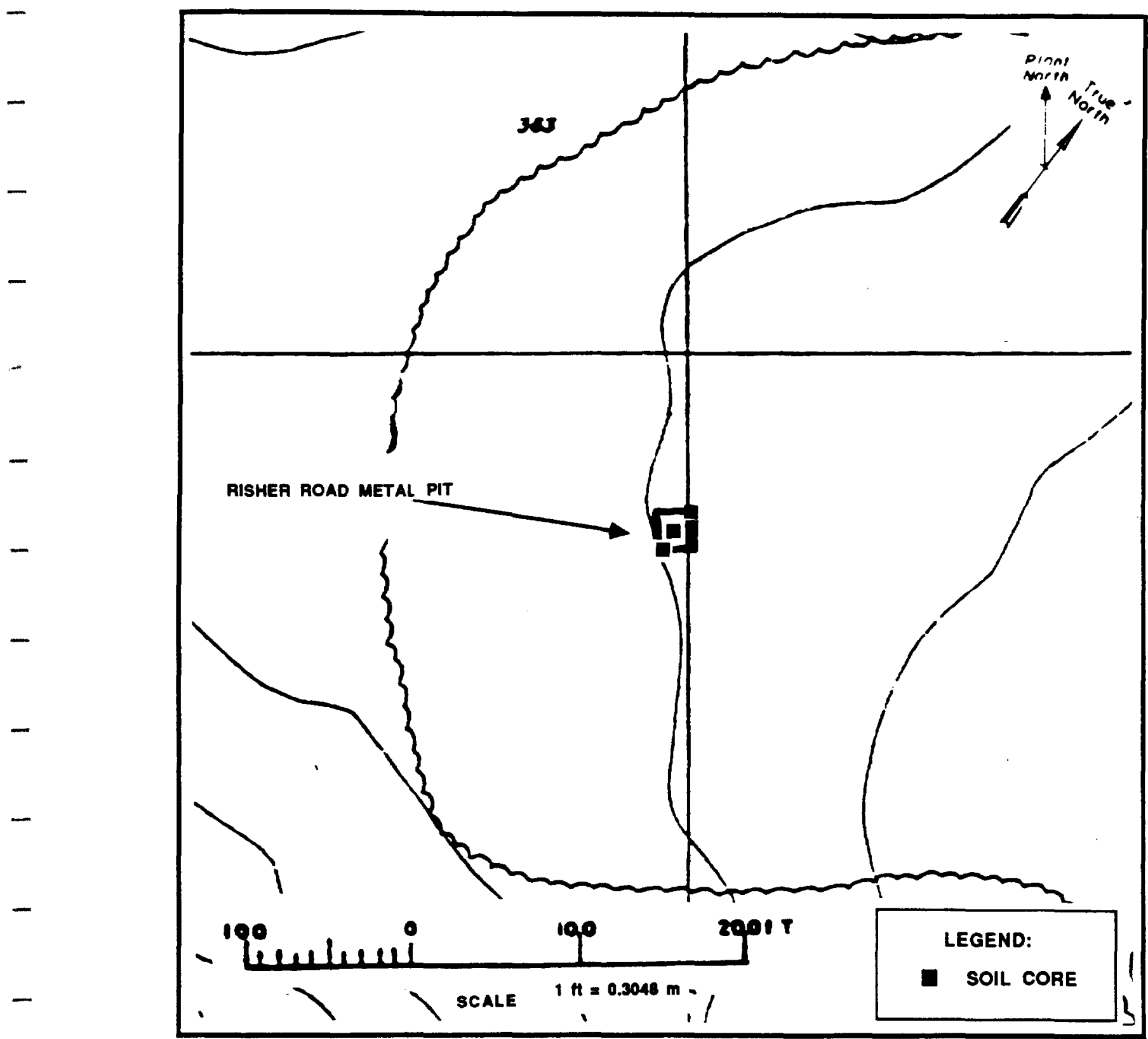

FIGURE FF.2. Proposed Sampling Locations at the Risher Road Metal Pit 
Chemical and Physical Analyses

Soil samples should be analyzed according to the parameters 1 isted in Appendix Table 1. Specific analytes are metals (Appendix Table 2) and volatile organics (Appendix Table 3 ). 


\section{Background}

\section{Site History}

The history of disposal, including the nature of the disposed materials, in the Road A Chemical Basin (Building 904-111G) is not known. A 1983 report (Ross \& Green) lists its contents as miscellaneous radioactive and chemical aqueous wastes. The site was operated until 1973, at which time it was backfilled and closed. An area significantly larger than the original basin was graded and replanted (Pickett et al., 1987b).

\section{Site Description}

The Road A Chemical Basin, also known as the Baxley Road Dump, is located approximately $800 \mathrm{~m}$ west of the intersection of SRP Road A (SC Rt. 125 ) and SRP Road 6 and approximately $3 \mathrm{~km}$ southeast of the D-Area Powerhouse (Figure GG.1). SRP coordinates for the NE corner of the site are $\mathrm{N} 55825, \mathrm{E} 29352$. The basin was originally irregular in shape, approximately $30 \mathrm{~m}$ wide, $53 \mathrm{~m}$ long, and 2.5 to $3.0 \mathrm{~m}$ deep (Figure GG.2). Total area for the original basin was approximately $1,600 \mathrm{~m}^{2}$; volume capacity was approximately $4,500 \mathrm{~m}^{3}$.

The Road A Chemical Basin is located close to the steep edge of the escarpment of the Aiken Plateau between the drainages of Four Mile Creek and Indian Grave Branch. Surface elevation is approximately $64 \mathrm{~m}$ $(210 \mathrm{ft})$. Surface drainage at the site is southwest. The site is located about $0.4 \mathrm{~km}$ from a swamp that feeds into Four Mile Creek approximately $1.8 \mathrm{~km}$ above its confluence with the Savannah River.

Four groundwater monitoring wells were installed in 1983 and 1984. Groundwater flow is toward the southwest or south-southwest (Zeigler et al., 1987). Monitoring well BRD 3 is the upgradient well (Figure GG.2). Water in well BRD 1 probably represents downgradient groundwater conditions. Data from 1986 indicate that the water table is present at a depth of 8 to $14 \mathrm{~m}$ below grade in the four monitoring wells.

\section{Review of Available Data}

No soil cores or surface samples have been collected at the Road A Chemical Basin. 


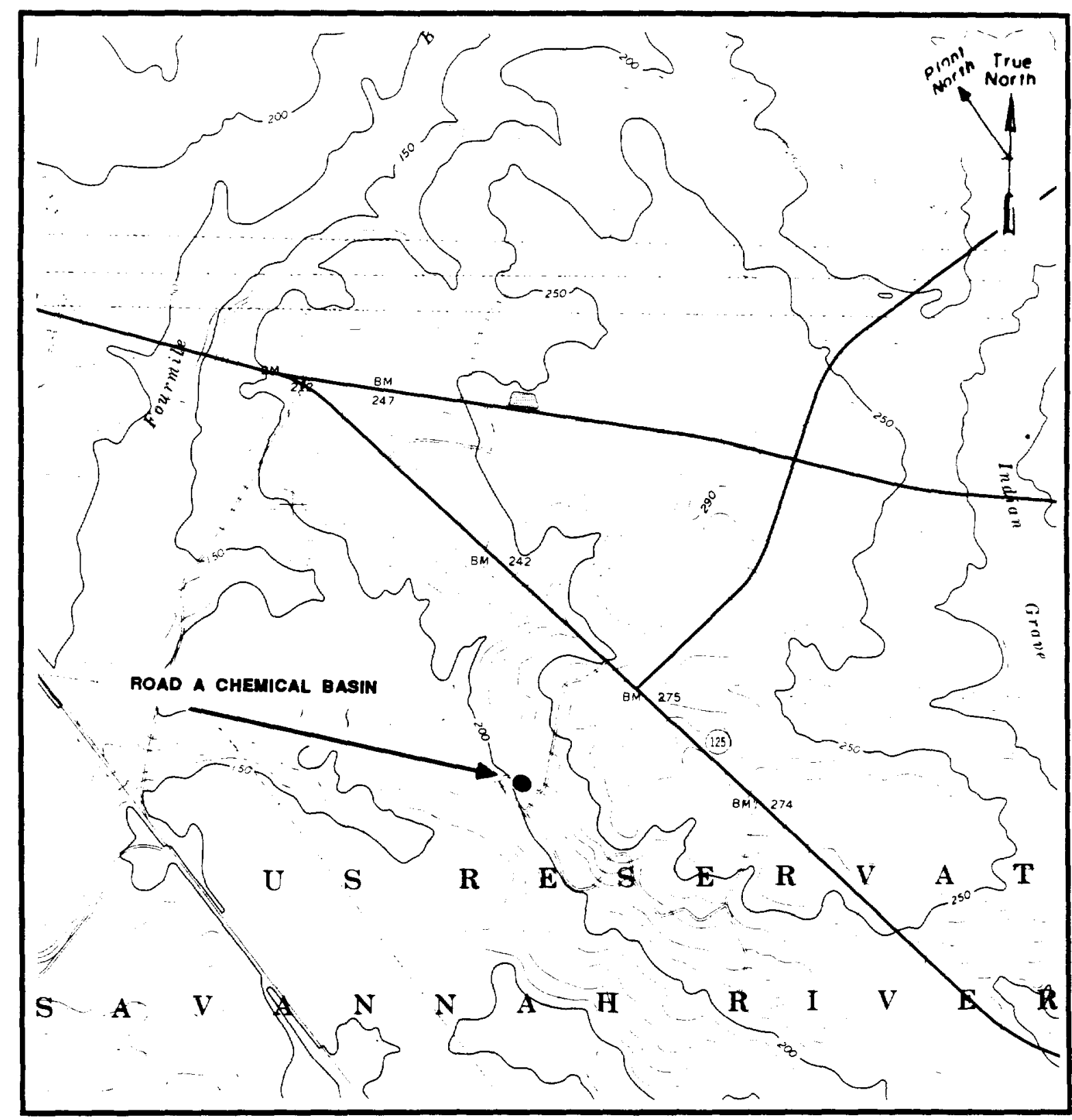

SCALE $: \because 900$

CON'OUR INTERVAL IO FEET

NATIONAL GEODETIC VERTICAL DATUM OF 1929

FIGURE GG.1. Location of the Road $\lambda$ Chemical Basin on New Ellenton Sw Quadrangle 7.5 Minute Series Topographic Map 


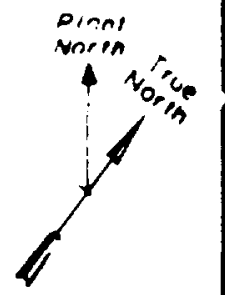<smiles></smiles>

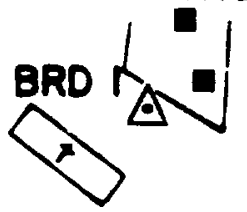

\section{$\triangle B R D^{3}$}
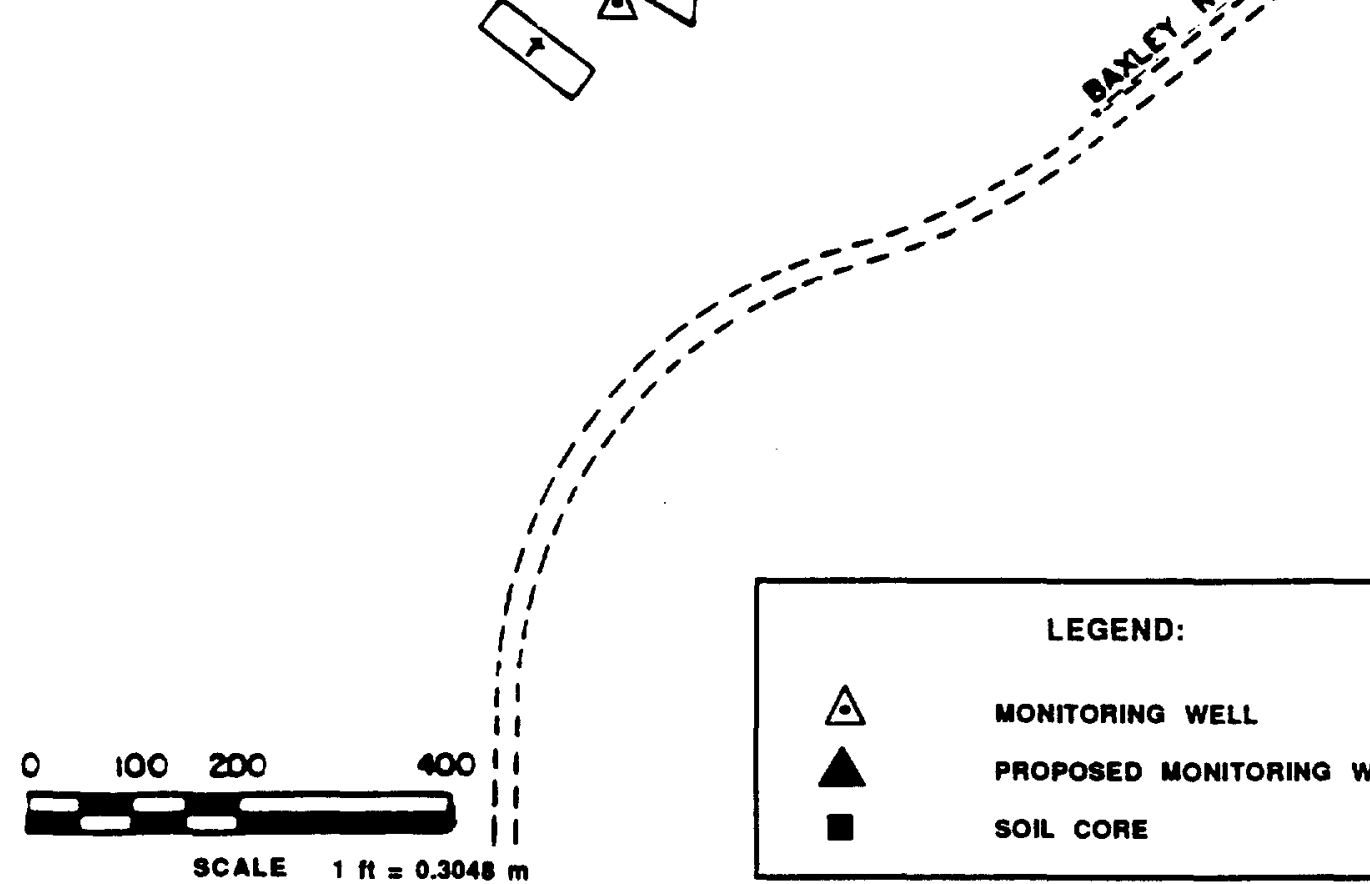

LEGEND:

$\triangle$ monitoring WeLL

PROPOSED MONITORING WELL

SOIL CORE

FIGURE GG.2. Existing Monitoring Wells and Proposed Sampling Locations for the Road A Chemical Basin

GG-3 
Statistical analysis of the upgradient versus downgradient groundwater quality shows lead to be the only constituent significantly different in a downgradient well (Pickett et a1., 1987b). In 1986 lead concentrations ranged from less than 5 to $120 \mu \mathrm{g} / \mathrm{L}$ (Zeigler et a1., 1987). In the first quarter of 1987 the highest concentration of lead was detected in the upgradient well, BRD 3 (Mikol et al., in press). The variability in the concentration of lead in the groundwater in a particular well with time suggests that some elevated levels of lead in the groundwater may be related to groundwater sampling techniques or contamination from the wel1-construction process.

In 1986 and 1987 gross alpha concentrations were all below 15 pCi/L, the EPA interim drinking water standard.

\section{Characterization Recommendations}

Sampling

Shallow soil cores are recommended to determine the vertical extent of the contamination, if any. Three $6-\mathrm{m}$ soil cores within the confines of the basin are recommended (Figure GG.2). Soil samples for chemical analysis should be collected according to the parameters given in Appendix Table 1.

Geohydrological information can be obtained from the nearby regional geohydrology well cluster $P$ 23. If signficant contamination is detected in the soils and sediments below the site, an additional downgradient monitoring well is recommended. This well should be located between BRD 1 and BRD 4, because BRD 1 and BRD 4 are not ideally located as downgradient wells. The locations of the soil cores and the proposed monitoring well are presented in Figure GG.2.

\section{Chemical and Physical Analyses}

The soil cores should be analyzed according to the parameters 1 isted in Appendix Table 1. Specific analytes are metals (Appendix Table 2) and radioactivity (Appendix Table 4). VOCs do not appear to be a problem at this site; therefore, no organic analyses are recommended.

Groundwater samples should be analyzed according to the parameters outlined in Appendix Table 6. If gross alpha or beta exceeds the groundwater quality review criteria in Appendix Table 10, a more detailed analysis of radionuclides (Appendix Table 5) may be necessary. 


\section{Background}

\section{Site History}

Rubble piles are used at SRP for disposing of industrial debris from specific areas. Rubble piles consist mostly of inert materials such as concrete, brick, tile, asphalt, hard plastics, glass, and rubble products.

\section{Site Description}

The following is a list of the known rubble piles at the site.

Bldg. No. Site Name

$\begin{array}{ll}\text { 731-6A } & \text { A-Area Rubble Pile } \\ 631-7 G & \text { Misc. (Central Shops) } \\ 631-11 G & \text { Cemetery Road (closed) } \\ 631-14 G & \text { Bragg Bray Road Rubble Pile (closed) } \\ 631-12 G & \text { Between Cemetary \& Bragg Bray Rd. } \\ 631-13 G & \text { Road 781.1 Rubble Pile (closed) } \\ 631-10 G & \text { SREL Rubble Pile (closed) } \\ 631-9 G & \text { Forestry Rubble Pile (closed) } \\ \text { NA } & \text { L-Area Rubble Pile } \\ \text { NA } & \text { R-Area Rubble Pile }\end{array}$

\section{SRP Coordinates Location}

N 102000 E 50900 Figure HH.1

N 61922 E 49372 Figure HH.2

N 101000 E 80600 Figure HH.3

N 103800 E 79300 Figure HH.3

N 101800 E 80000 Figure HH. 3

N 105800 E 78000 Figure HH.3

N 99300 E 69100 Figure HH.4

N 99300 E 70000 Figure HH.4

NA NA Figure HH.5

NA NA Figure HH.6

There are no groundwater monitoring wells at these sites.

\section{Review of Available Data}

The sediment beneath and the contents of the Rubble Piles have not been sampled and characterized.

\section{Characterization Recommendations}

\section{Sampling}

It is recommended that one sediment core be taken at each rubble pile. All cores should be $6 \mathrm{~m}$ in length, extending from the bottom of the original pile. The cores should be subdivided into the sampling intervals given in Appendix Table 1.

\section{Chemica1 and Physical Analyses}

The sediment cores from the basin should be analyzed for the inorganic ions and metals given in Appendix Table 2. The first interval should be analyzed for EPA Appendix IX and EP toxicity (Appendix Tables 7 and 8). 

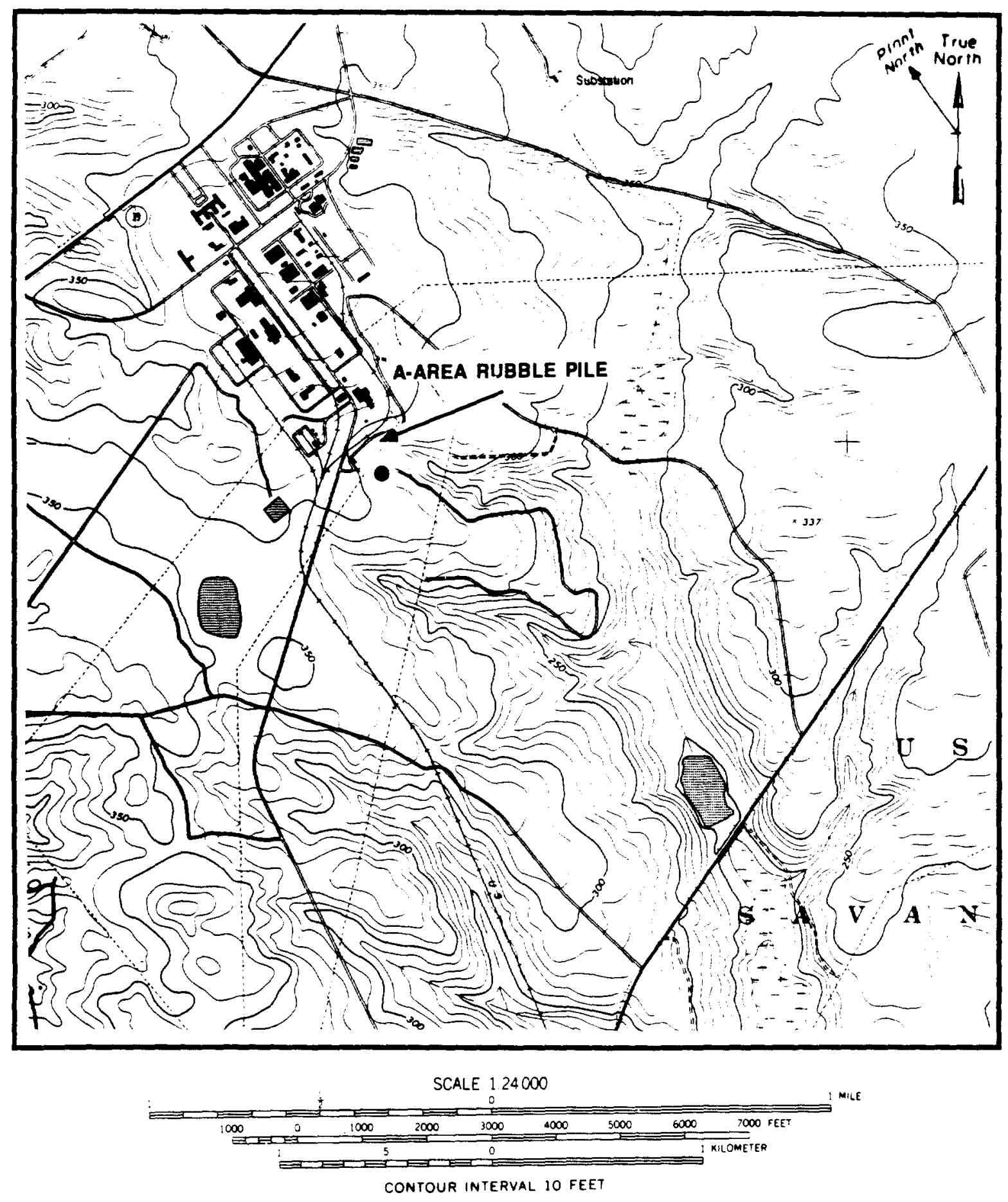

FIGURE HH.1. Location of the A-Area Rubble Pile on New Ellenton
SW Quadrangle 7.5 Minute Series Topographic Map

HH-2 


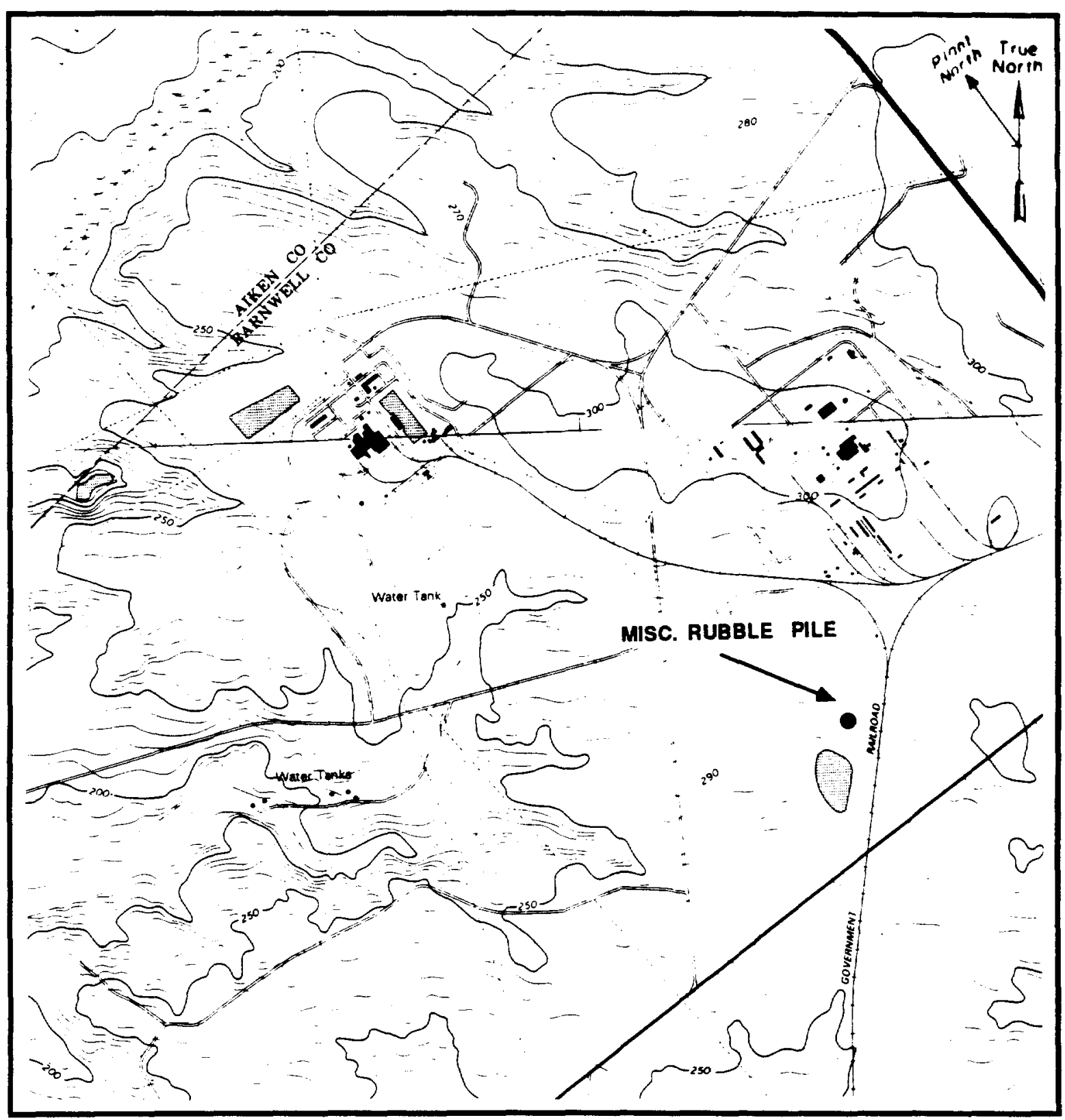

SCALE : 24000

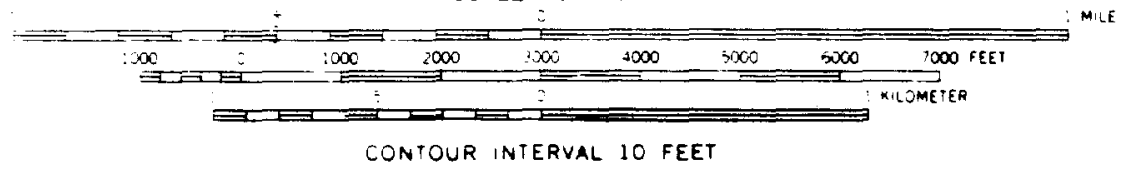

FIGURE HH.2. Location of the Miscellanous Rubble Pile on Girard NW Quadrangle 7.5 Minute Series Topographic Map 

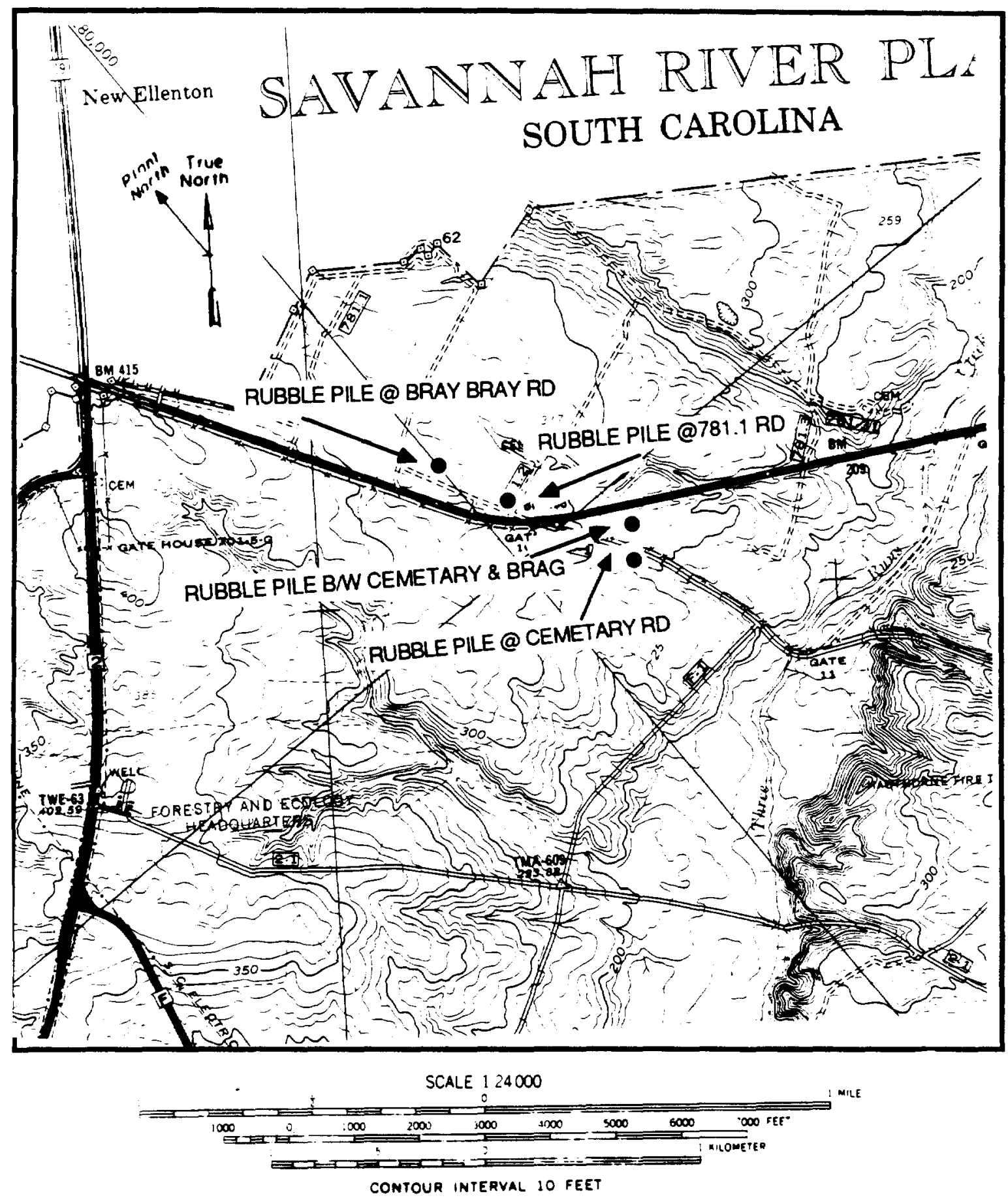

FIGURE FH.3. Location of the Rubble Pile at Cemetary Road, the Rubble Pile Between Cemetary Road and Brag Bray Road, the Rubble Pile at Road 781.1, and the Rubble Pile at Brag Bray Road 

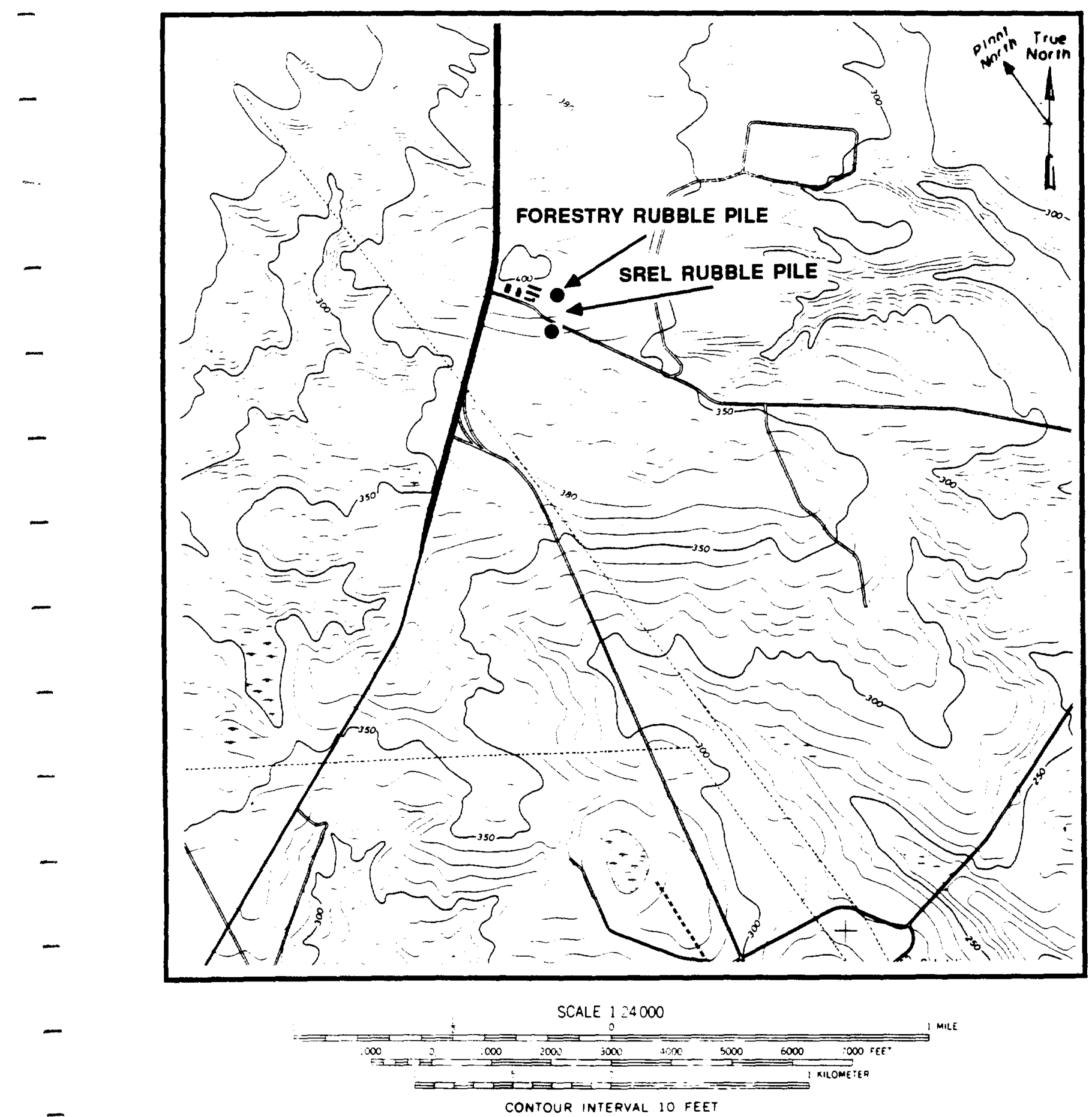

\section{FIGURE HH.4. Location of the SREL and Forestry Rubble Piles on New Ellenton SW Quadrangle 7.5 Minute Series Topographic Map}



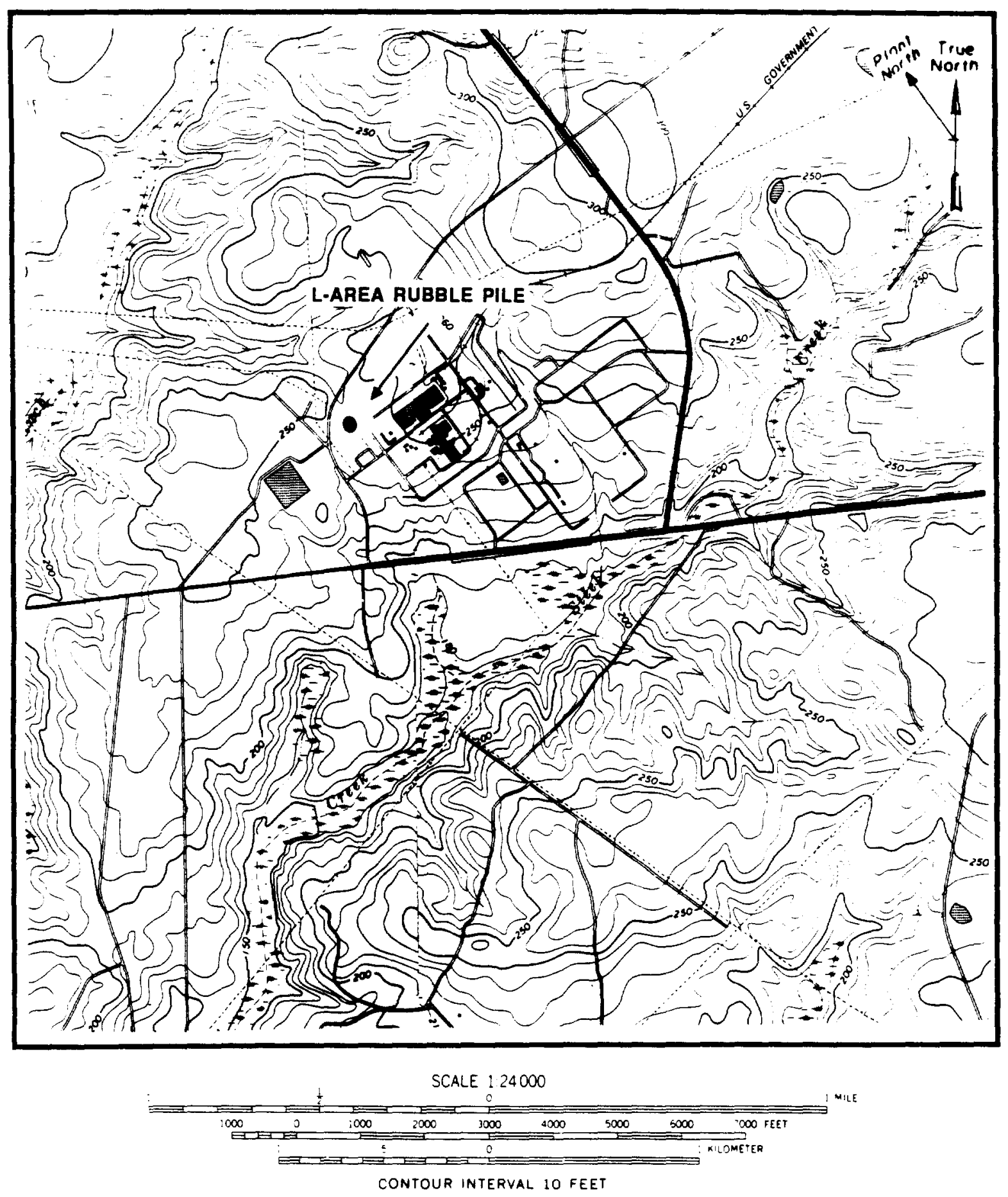

FIGURE HH.5. Location of the L-Area Rubble Pile on Girard NE
Quadrangle 7.5 Minute Series Topographic Map

HIH- 6 

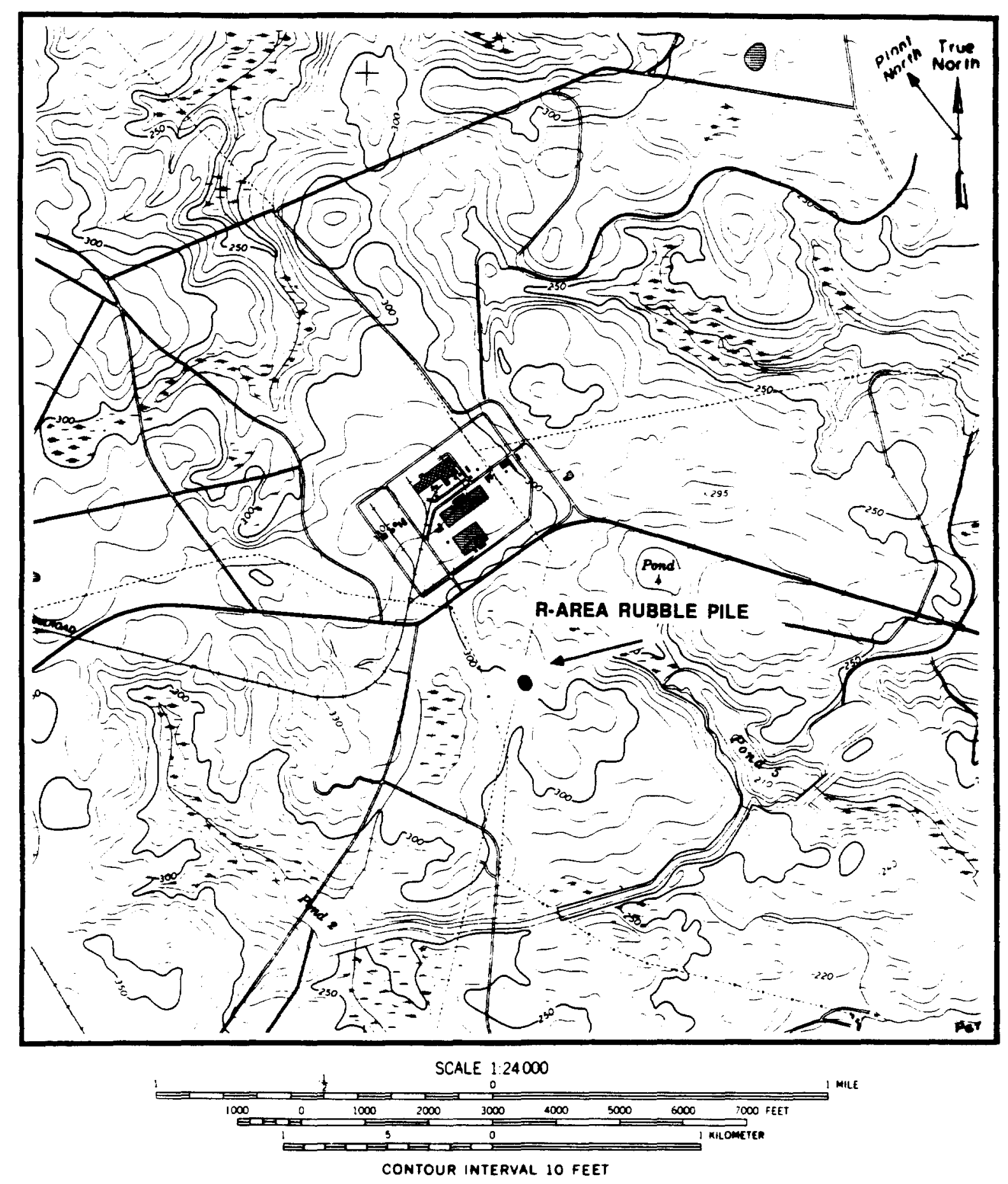

FIGURE HH.6. Location of the R-Area Rubble Pile on New Ellenton SE Quadrangle 7.5 Minute Series Topographic Map 


\section{Background}

\section{Site History}

From 1973 to 1983, unlined earthen pits were used throughout the plant for the disposal of dry, inert rubble such as concrete, brick, tile, asphalt, hard plastics, glass, rubber products, and non-returnable empty drums. No radioactive or hazardous chemical constituents are believed to have been disposed of at these sites. A detailed list of the types of materials buried in each Rubble Pit is given below.

\section{Location B1dg. No. Type of Rubble Disposed}

A Area 731-2A Paper, wooden pallets, cans, drums, glass

CS Area 631-3G Paper, cans, lumber, barrels, metal pipe and shavings, electrical switchgear

631-7G Miscellaneous materials

D Area 431-2D

Metal, concrete, lumber, poles

F Area 231-4F

Metal, concrete, lumber, poles, fluorescent 1ight fixtures, glass

231-2F Concrete, lumber, cement, fence and telephone poles, rip rap, brick, tile, wallboard, paneling, metal scrap and shavings, drums, electrical conduit, furniture, firehose

Forestry 761-9G Animal carcasses, lumber, light fixtures, concrete, metal drums, wire

L Area 131-1L Metal, lumber, poles, concrete, transite Miscellaneous rubble Concrete and mental from powerhouse stack and silo

R Area 131-2R Metal, concrete, lumber, poles

\section{Site Description}

There are 11 Rubble Pits located in the A, CS, D, F, G, L, and $R$ areas of the plant (Figures II.1 through II.7). These facilities consisted of unlined earthen pits of generally unknown depths. Available information indicates that all of these waste sites have been backfilled and seeded since they were last used in 1983. The physical dimensions and SRP coordinates for each of the Rubble Pits are as follows: 

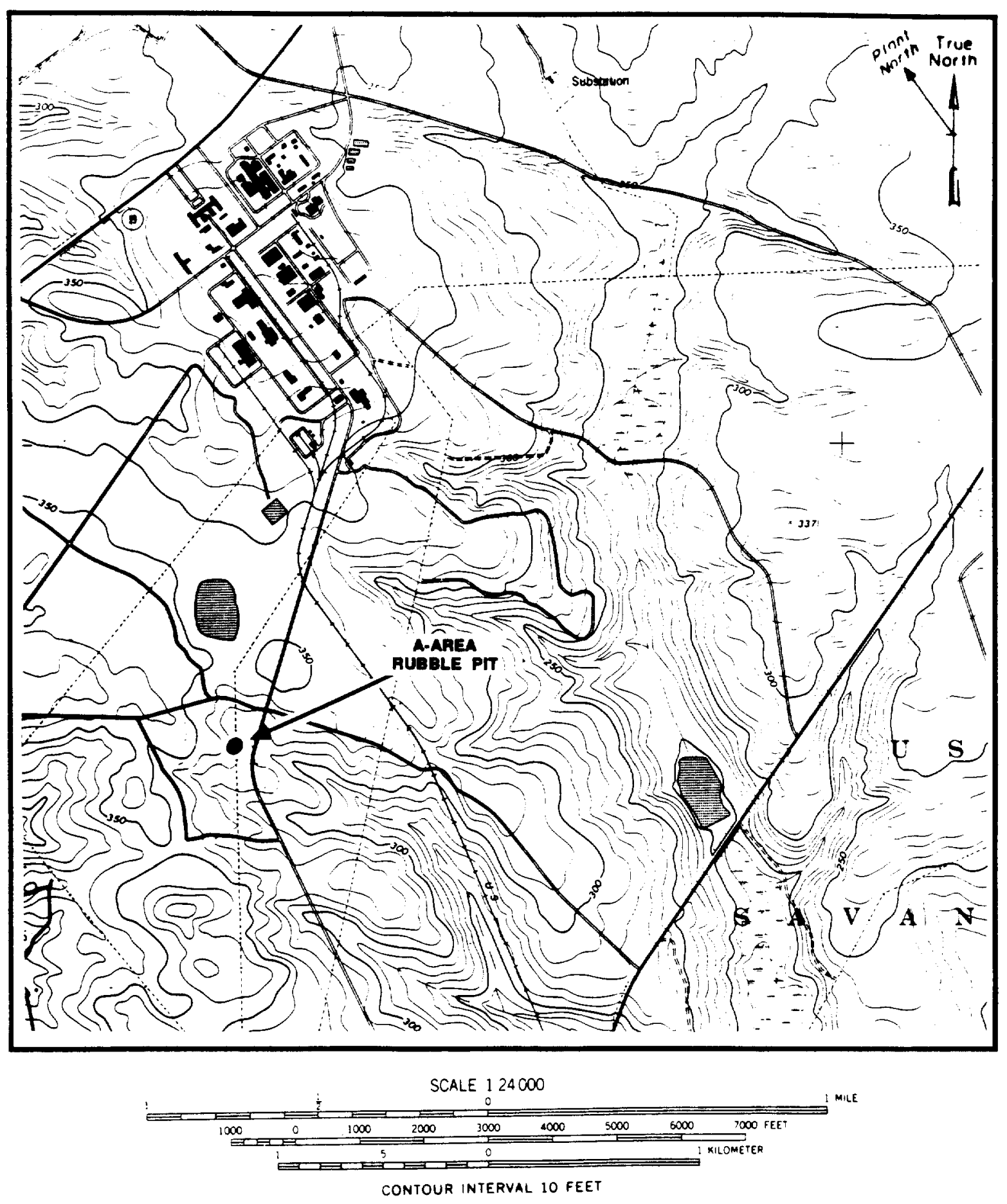

FIGURE II.1. Location of the A-Area Rubble Pit on New Ellenton SW Quadrangle 7.5 Minute Series Topographic Map 

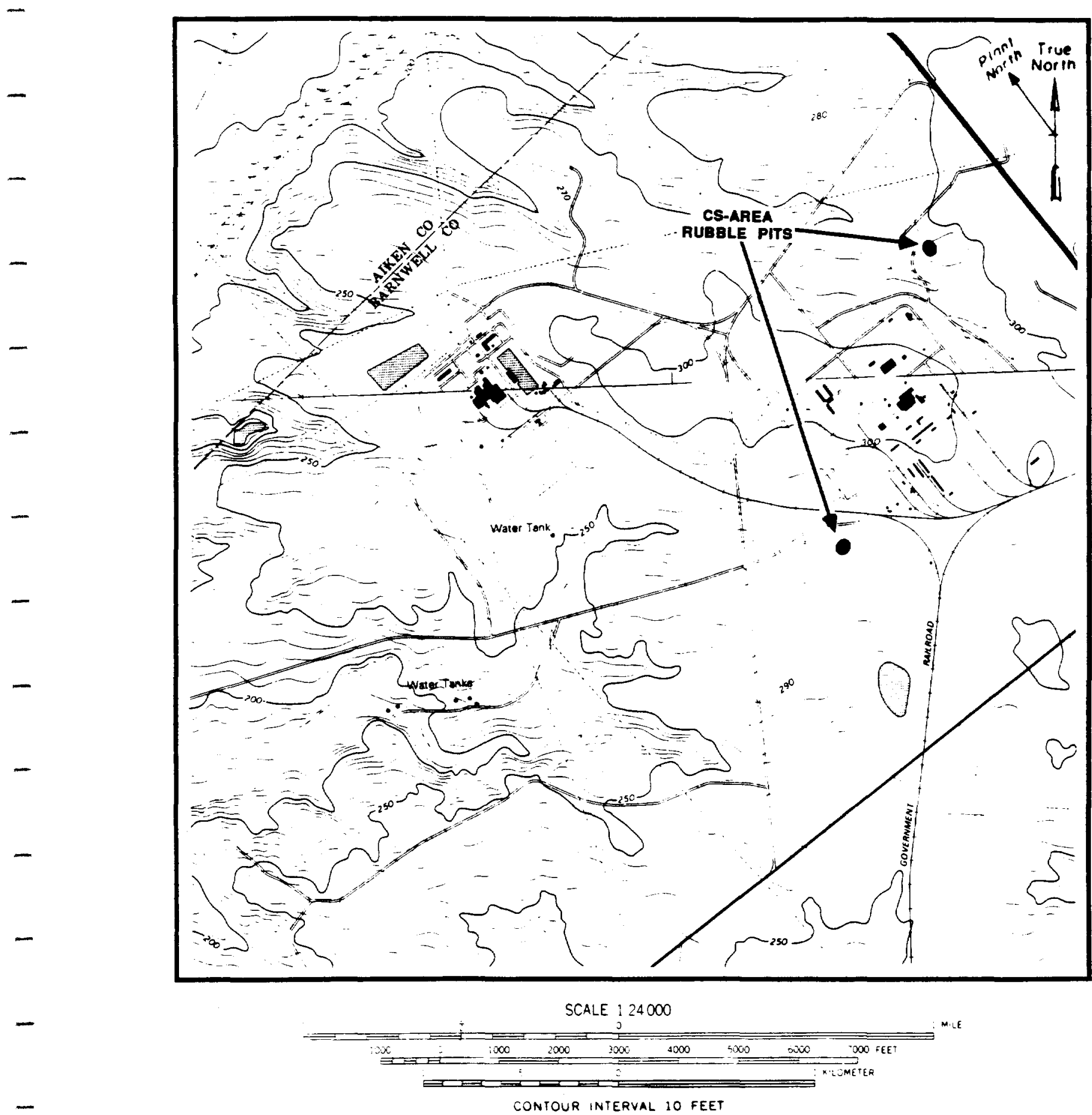

FIGURE II.2. Location of the CS-Area Rubble Pits on New Ellenton SW and Girard NW quadrangle 7.5 Minute Series Topographic Maps 

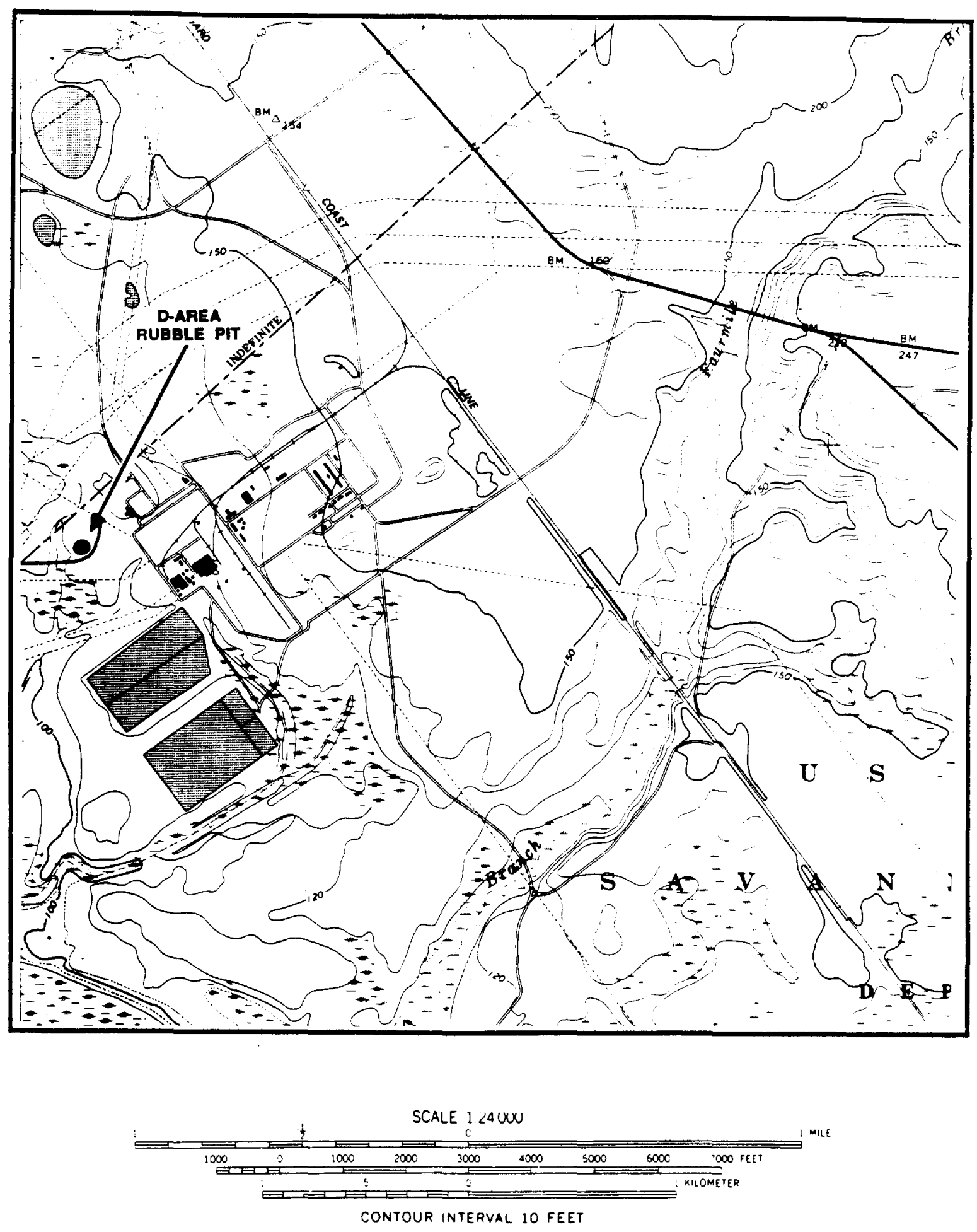

FIGURE II.3. Location of the D-Area Rubble Pit on Girard NW Quadrangle 7.5 Minute Series Topographic Map 

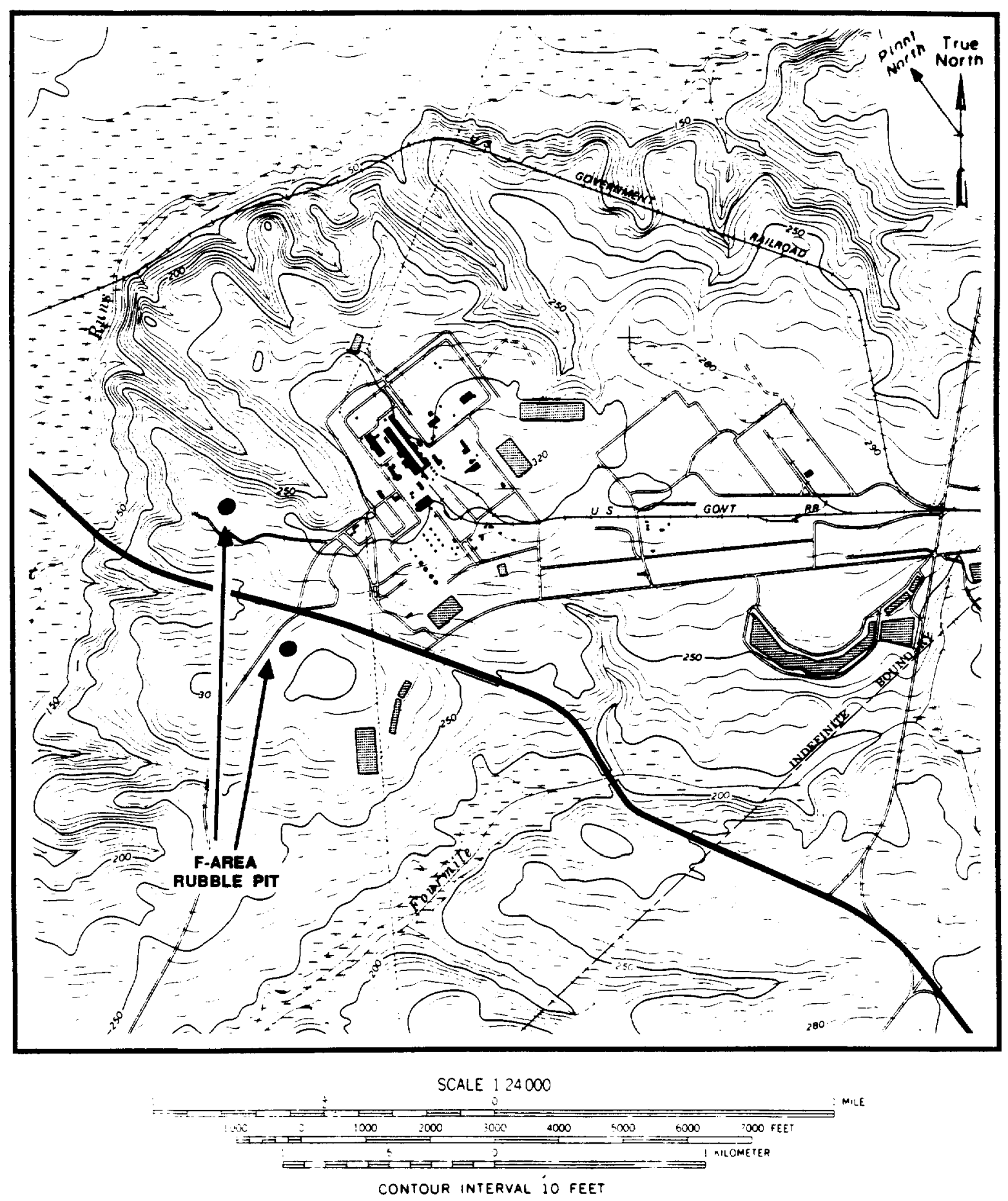

FIGURE II.4. Location of the F-Area Rubble Pits on New Ellenton Sw Quadrangle 7.5 Minute Series Topographic Map 


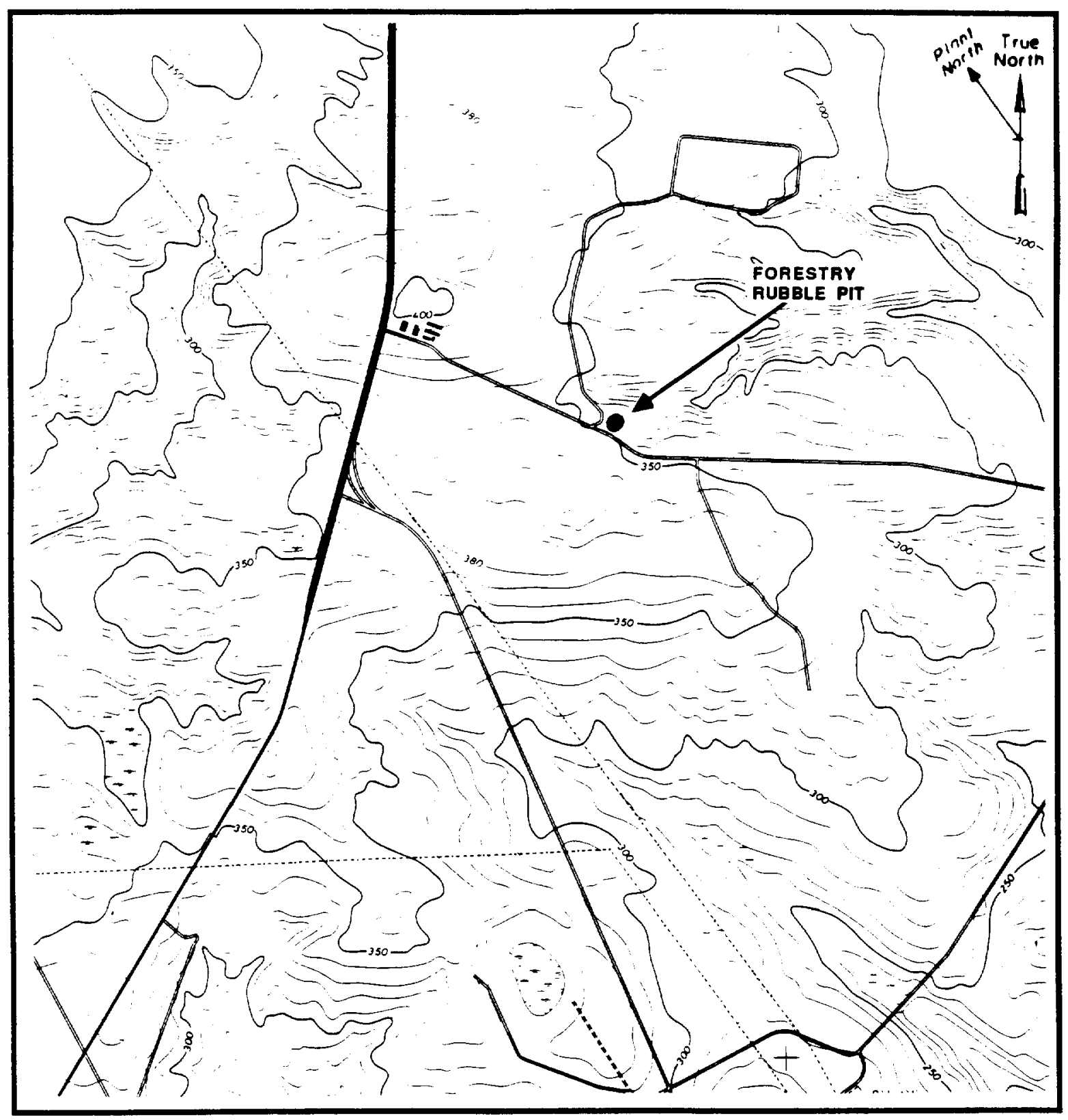

$-$

$-$

$-$

-

$-$

$-$

$-$

SCALE $: 24000$

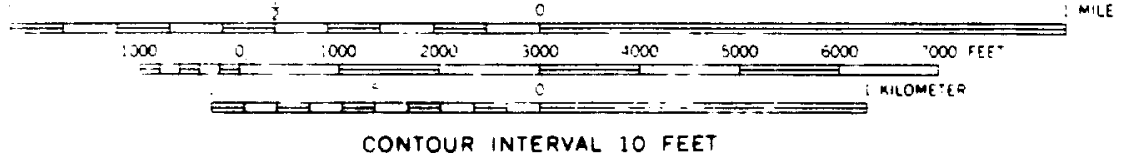

FIGURE II.5. Location of the Forestry (G-Area) Rubble Pit on New Ellenton SW Quadrangle 7.5 Minute Series Topographic Map 

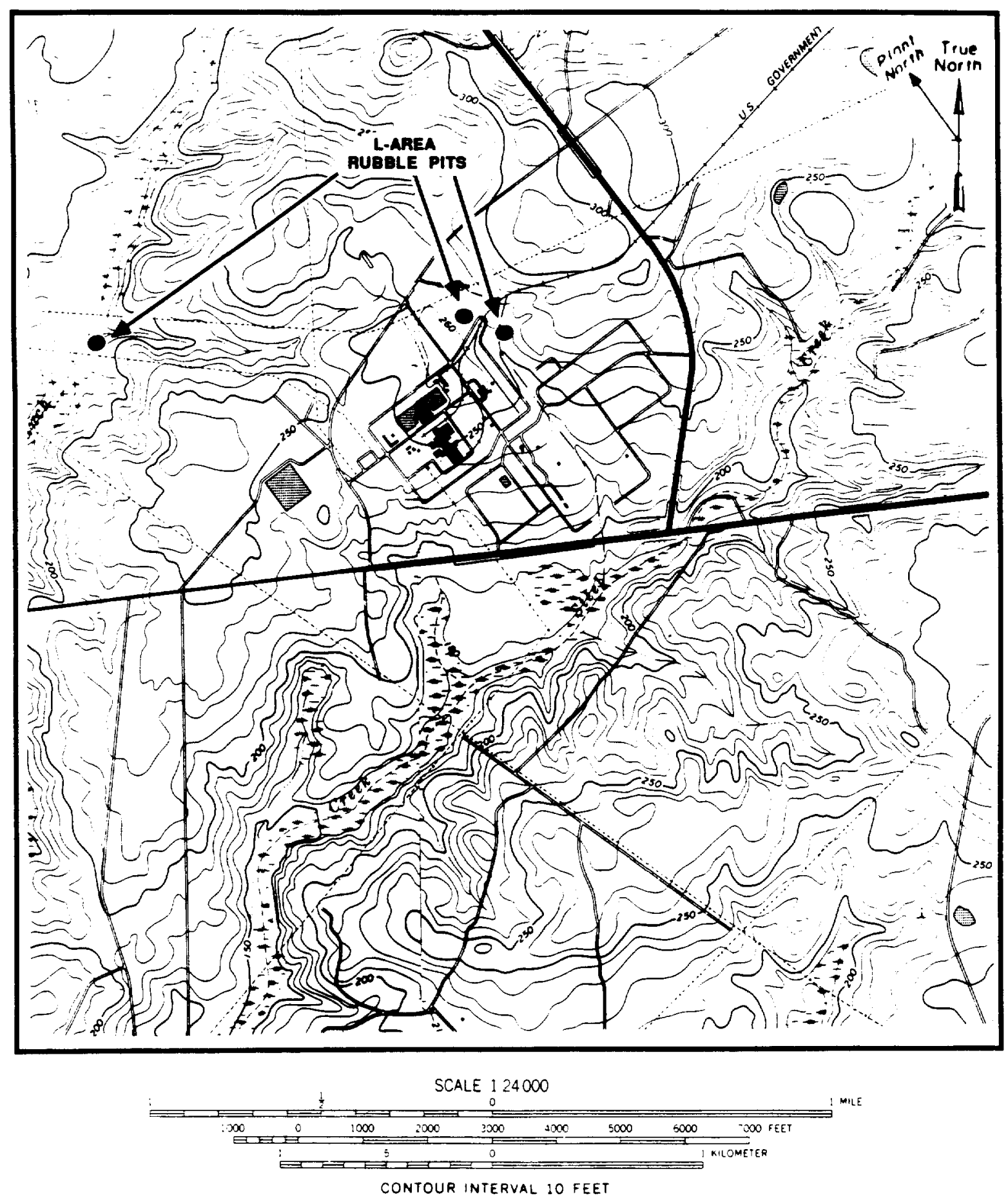

IGURE II.6. Location of the L-Area Rubble Pits on Girard NW and Girard NE Quadrangle 7.5 Minute Series Topographic Maps 


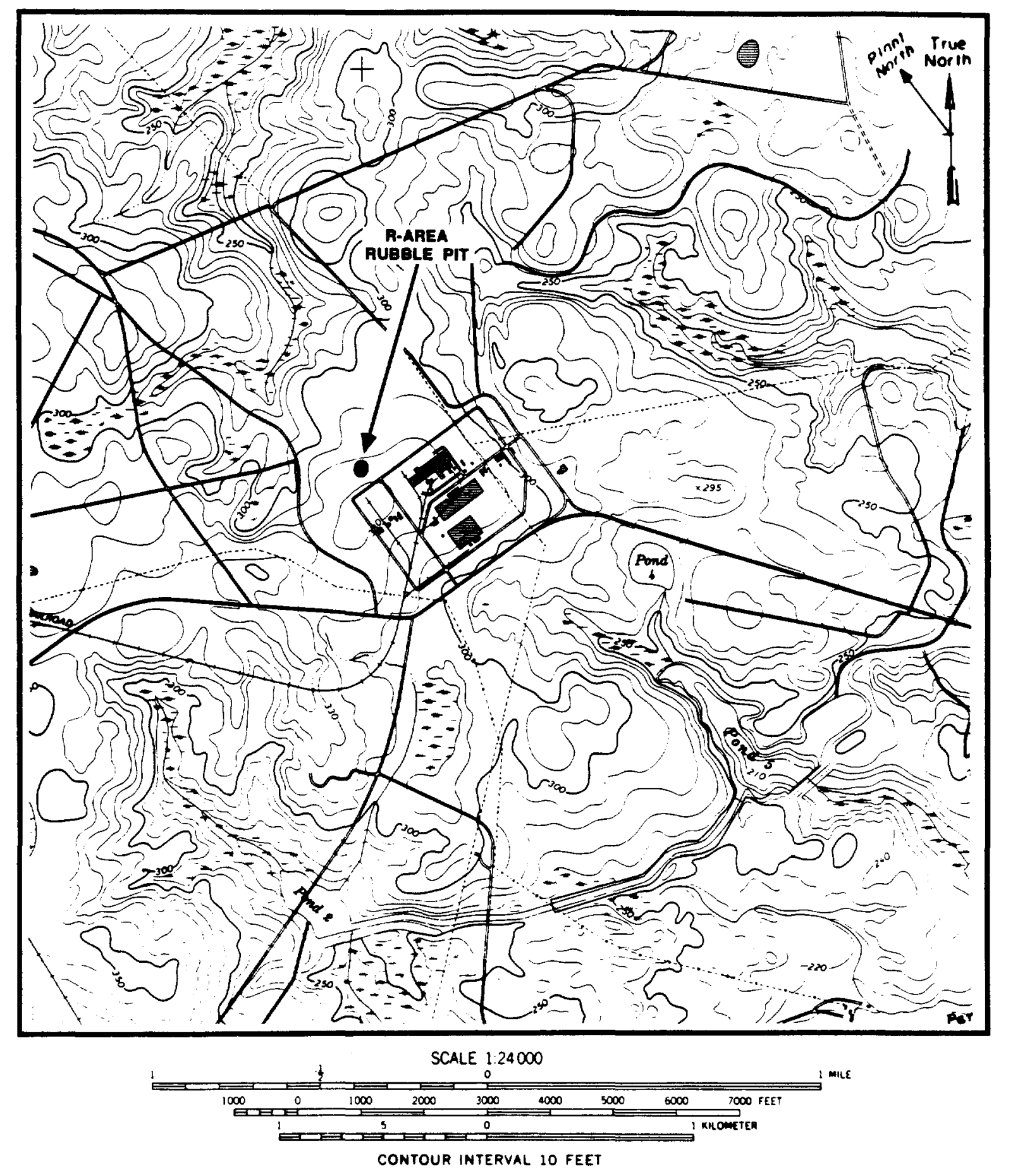

FIGURE II.7. Location of the R-Area Rubble Pit on New Ellenton SE Quadrangle 7.5 Minute Series Topographic Map 
Location

$\begin{array}{ll}\text { A Area } & 11 \times 197 \\ \text { CS Area } & 15 \times 122 \\ & 2,787 \mathrm{~m}^{2} \\ \text { D Area } & 71 \times 118 \\ \text { F Area } & 48 \times 152 \\ & 79 \times 155 \\ \text { Forestry } & 9 \times 240 \\ \text { L Area } & 15 \times 67 \\ & 43 \times 98 \\ \text { R Area } & 16 \times 17 \\ & 35 \times 56\end{array}$

SRP Coordinates

$\begin{array}{llll}N & 99100 & \text { E } & 44350 \\ N & 65095 & \text { E } & 53126 \\ N & 61922 & \text { E } & 49372 \\ N & 66393 & \text { E } & 18598 \\ N & 77376 & \text { E } & 50573 \\ N & 79122 & \text { E } & 51088 \\ N & 99300 & \text { E } & 70000 \\ N & 46350 & \text { E } & 52630 \\ N & 50766 & \text { E } & 47188 \\ N & 47612 & \text { E } & 52730 \\ N & 55742 & \text { E } & 74274\end{array}$

Little site-specific hydrogeologic information is available for the Rubble Pits due to the lack of dedicated groundwater monitoring wells. However, sufficient information does exist from monitoring wells associated with nearby waste sites to describe conditions within the general vicinity of most of the pits. The A-Area Rubble Pit is located west of Road $D$ adjacent to the A-Area Burning/Rubble Pits. The water table in the vicinity of this pit is approximately $30 \mathrm{~m}$ below grade. Surface drainage is east toward Tims Branch, a tributary of Upper Three Runs Creek. The predominant direction of water-table flow is west-northwest. The elevation of the pit is approximately $105 \mathrm{~m}$ (345 $\mathrm{ft}$ ). The A-Area Ash Pile (788-2A) is located on top of the A-Area Rubble Pit (Ross \& Green, 1983).

The two Central Shops Area Rubble Pits are approximately $9 \mathrm{~km}$ from the nearest plant boundary. One pit (Building 631-3G) is located northeast of Central Shops in the vicinity of the Central Shops Burning/Rubble Pits. Surface elevations in this area range from 80 to $83 \mathrm{~m}$ ( 262 to $272 \mathrm{ft}$ ). Depth to the water table ranges from 6 to $11 \mathrm{~m}$ below grade. Surface drainage and groundwater flow range from northwest to southwest toward Four Mile Creek. The other rubble pit (Building 631-7G) is located south of Central Shops in the same general area as the SRL Oil Test Site. No water-table monitoring wells are located in the vicinity of this pit, so hydrogeologic conditions beneath the site are undefined. Surface drainage in the area is southwest toward Four Mile Creek.

The D-Area Rubble Pit is located west of the D-Area perimeter fence and just south of the D-Area Burning/Rubble Pits, approximately $1.25 \mathrm{~km}$ east of the nearest plant boundary. Elevations in the area range from 38 to $40 \mathrm{~m}$ ( 125 to $131 \mathrm{ft}$ ). Surface drainage is west and south toward the Savannah River. Water-table elevation measurements obtained from wells around the D-Area Burning/Rubble Pits indicate that the water table is approximately $3 \mathrm{~m}$ below grade. Shallow groundwater flow is to the south.

The two F-Area Rubble Pits are located in the central part of the plant. The nearest plant boundary is approximately $8 \mathrm{~km}$ to the west. One pit is located north of Road $C$ on a topographic high of approximately $91 \mathrm{~m}$ $(300 \mathrm{ft})$. Surface drainage and shallow groundwater flow is either south toward Four Mile Creek or west toward Upper Three Runs Creek. There are 
no active groundwater monitoring wells located in the vicinity of this pit so site-specific hydrogeologic conditions are unknown. The other pit is located south of Road C, just north of the 200-F entrance road. Elevation of this pit is approximately $85 \mathrm{~m}(280 \mathrm{ft})$. Surface drainage and sha1low groundwater flow in the area of this pit is west toward Upper Three Runs Creek. Water-table elevation in monitoring wells located around the nearby F-Area Burning/Rubble Pits averages $26 \mathrm{~m}$ below grade.

The Forestry Rubble Pit (also known as the Forestry Bone Yard) is located off Road 2 near the Forestry and Ecology Headquarters Complex, approximately $2.5 \mathrm{~km}$ southeast of the nearest plant boundary. Surface elevation in this area is approximately $115 \mathrm{~m}(378 \mathrm{ft})$. There are no water-table monitoring wells located in the vicinity of this pit, so hydrogeologic conditions beneath the site are unknown.

There are three Rubble Pits located in or near L Area, approximately $9.8 \mathrm{~km}$ northwest of the nearest plant boundary. Two of these Rubble Pits (Buildings 131-1L and 131-4L) are just north of the area fence at an elevation of $79 \mathrm{~m}(260 \mathrm{ft})$. The water table in the area of both pits is approximately $6 \mathrm{~m}$ below grade. Surface drainage and groundwater flow for the pit closest to the RBOF cask storage pad (Building 131-1L) is southeast toward Stee1 Creek. Surface drainage and groundwater flow for the pit located between Road $\mathrm{C}-7$ and the railroad (Building 131-4L) are probably westward toward Pen Branch. The third L-Area Rubble Pit (131-3L), located east of the intersection of Road 7-1 and Pen Branch, lies at an elevation of approximately $58 \mathrm{~m}(190 \mathrm{ft})$. Hydrogeologic information for this pit is unavailable, but surface drainage and shallow groundwater flow in this area would probably be west to Pen Branch due to the closeness of the stream.

The R-Area Rubble Pit is located just outside the west corner of the R-Area perimeter fence, approximately $7.7 \mathrm{~km}$ from the nearest plant boundary. This pit is situated near a hydraulic divide between the headwaters of Mill Creek (a tributary of Upper Three Runs Creek) to the north and Par Pond to the east. Data obtained from wells around the nearby R-Area Reactor Seepage Basins indicates that the water table is approximately $5 \mathrm{~m}$ below grade. Elevation at this site is approximately 94 m (308 ft).

\section{Review of Available Data} Pits.

There are no soil core or groundwater data available for the Rubble 


\section{Characterization Recommendations}

\section{Sampling}

It is recommended that a GPR survey be conducted at each site to define pit boundaries and identify possible coring locations where buried debris will not interfere with sampling operations.

It is recommended that a single $6-\mathrm{m}$ deep borehole be cored beneath the bottom of each rubble pit. Recommended sampling intervals for these boreholes are described in Appendix Table 1 .

Chemical and Physical Analyses

Analytical requirements (Classes 1,2 , and 3 ) for the soil cores are described in Appendix Table 1. 


\section{Background}

\section{Site History}

The Sanitary Landfill (Building 740-G) was opened in 1973 when the practice of burning waste in open pits was discontinued. Materials such as paper, plastics, rubber, wood, cardboard, and rags are placed in trenches that are covered with soil daily. The landfill receives about 3,500 metric tons of waste per year. Other types of waste that have been placed in the landfill are pesticide bags, aerosol cans, food waste, and asbestos in bags. In July 1980, Phase I of the landfill was filled. At that time, Phase II was placed in service. Phases III and IV were placed into operation in late 1983. The landfill is operated under South Carolina Domestic Waste Permit No. 87A. The site is presently in operation. Information on site history and location was taken from Christensen and Gordon (1983). Available groundwater data were taken from Zeigler et a1. (1987) and Mikol et a1. (in press).

\section{Site Description}

The Sanitary Landfill is located west of Road C, between the intersection of SRP Roads 2 and $C$ and Upper Three Runs Creek (Figure JJ.1). SRP coordinates for the northeast corner of the site are $N 84559$, E 45231. The site covers approximately $400,000 \mathrm{~m}^{2}$. Depth of the landfill is approximately $3.7 \mathrm{~m}$.

The Sanitary Landfill is located about halfway down the slope from the Aiken Plateau to Upper Three Runs Creek at an elevation of approximately $55 \mathrm{~m}(180 \mathrm{ft})$. Surface drainage is southeast toward Upper Three Runs Creek.

There are presently 31 groundwater monitoring wells installed and sampled at the site (Figure JJ.2). Seventeen were installed in late 1986 and first sampled in 1987. Groundwater at the water table flows to the southeast toward Upper Three Runs Creek. Data from 1986 indicate that the depth to the water table at the site is approximately $9 \mathrm{~m}$ (Zeigler et al., 1987).

\section{Review of Available Data}

Groundwater data from the 31 monitoring wells have been analyzed quarterly for $\mathrm{pH}$, temperature, specific conductance, alkalinity, TOC, chloride, nitrate, TDS, and water-table depth; and annua11y for cadmium, chromium, lead, mercury, arsenic, barium, selenium, silver, fluoride, PCBs, endrin, 1indane, methoxychlor, toxaphene, 2,4-D, and 2,4,5-TP (Silvex). 


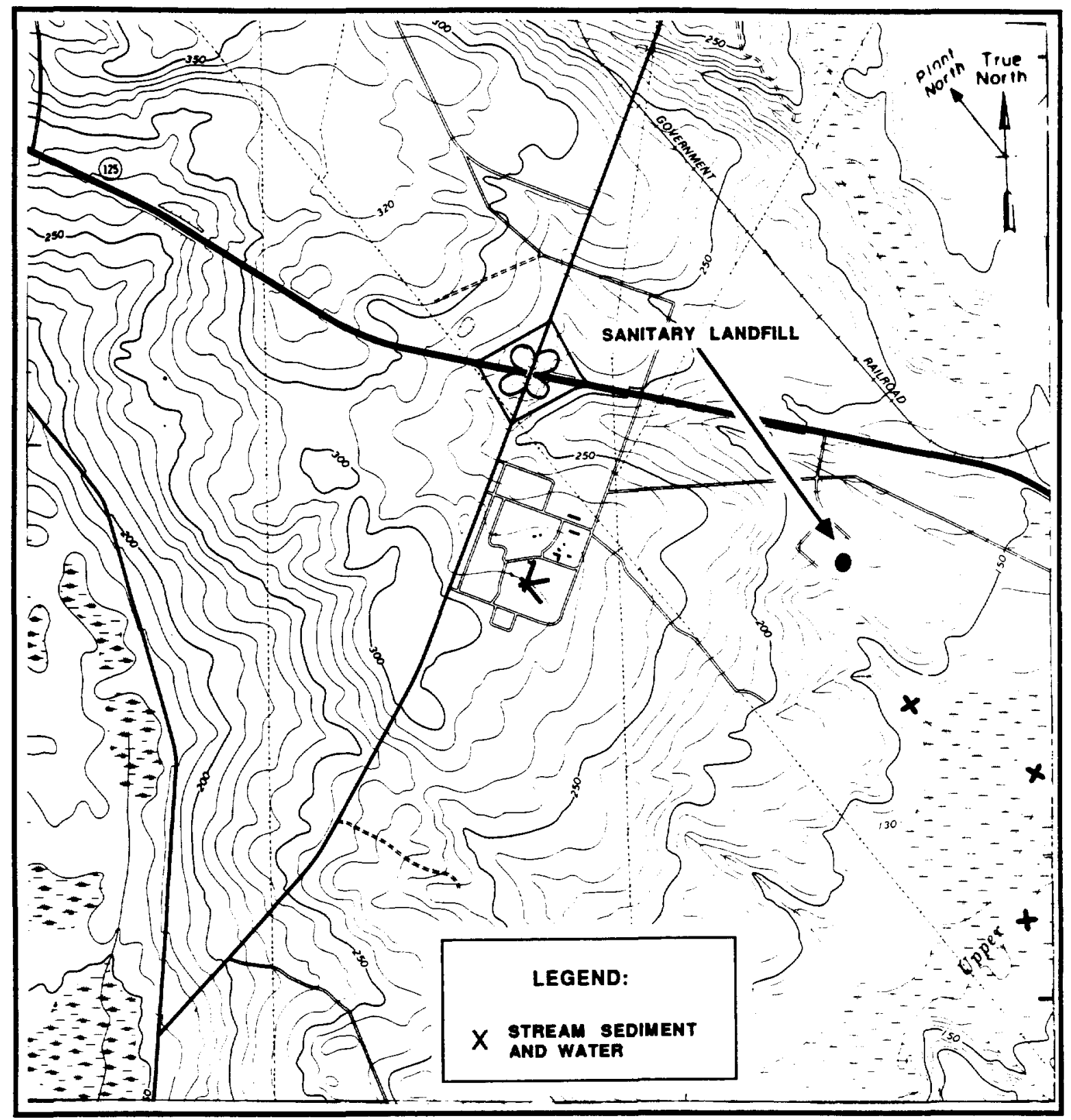

SCALE $1: 24000$

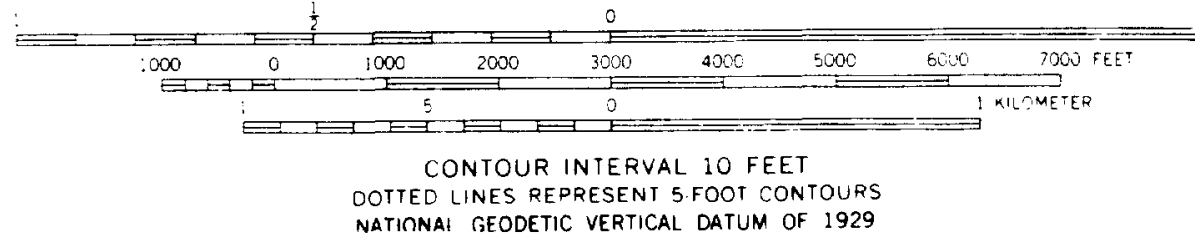

$5^{i-z}$

FIGURE JJ.1. Location of the Sanitary Landfill on New Ellenton SW Quadrangle 7.5 Minute Series Topographic Map 

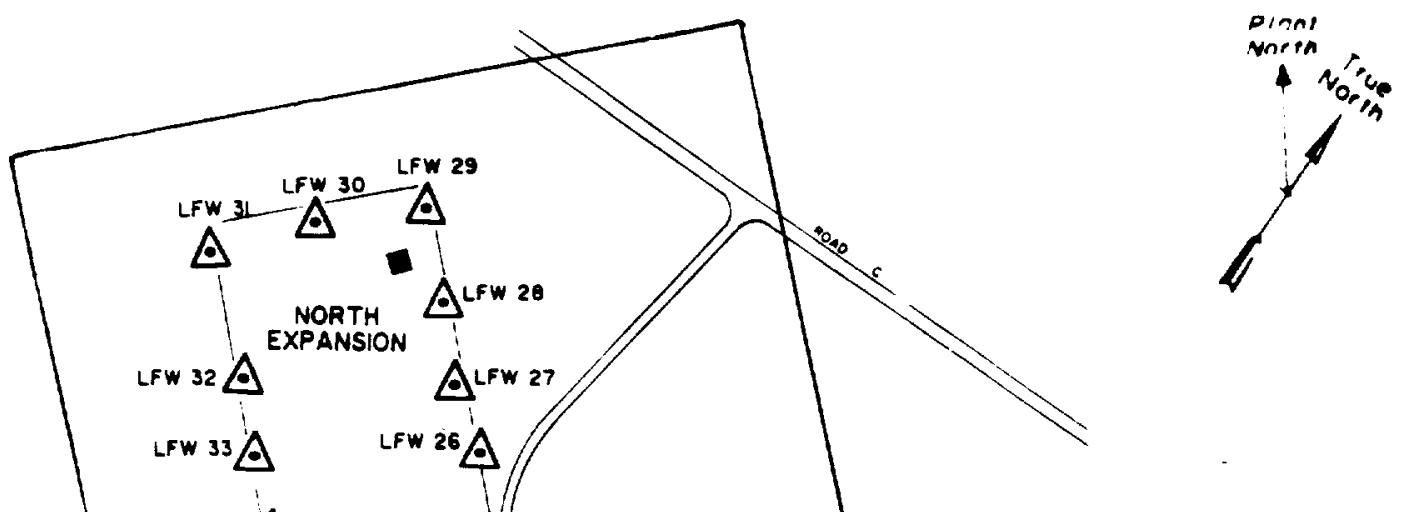

LFW $34 \Delta$
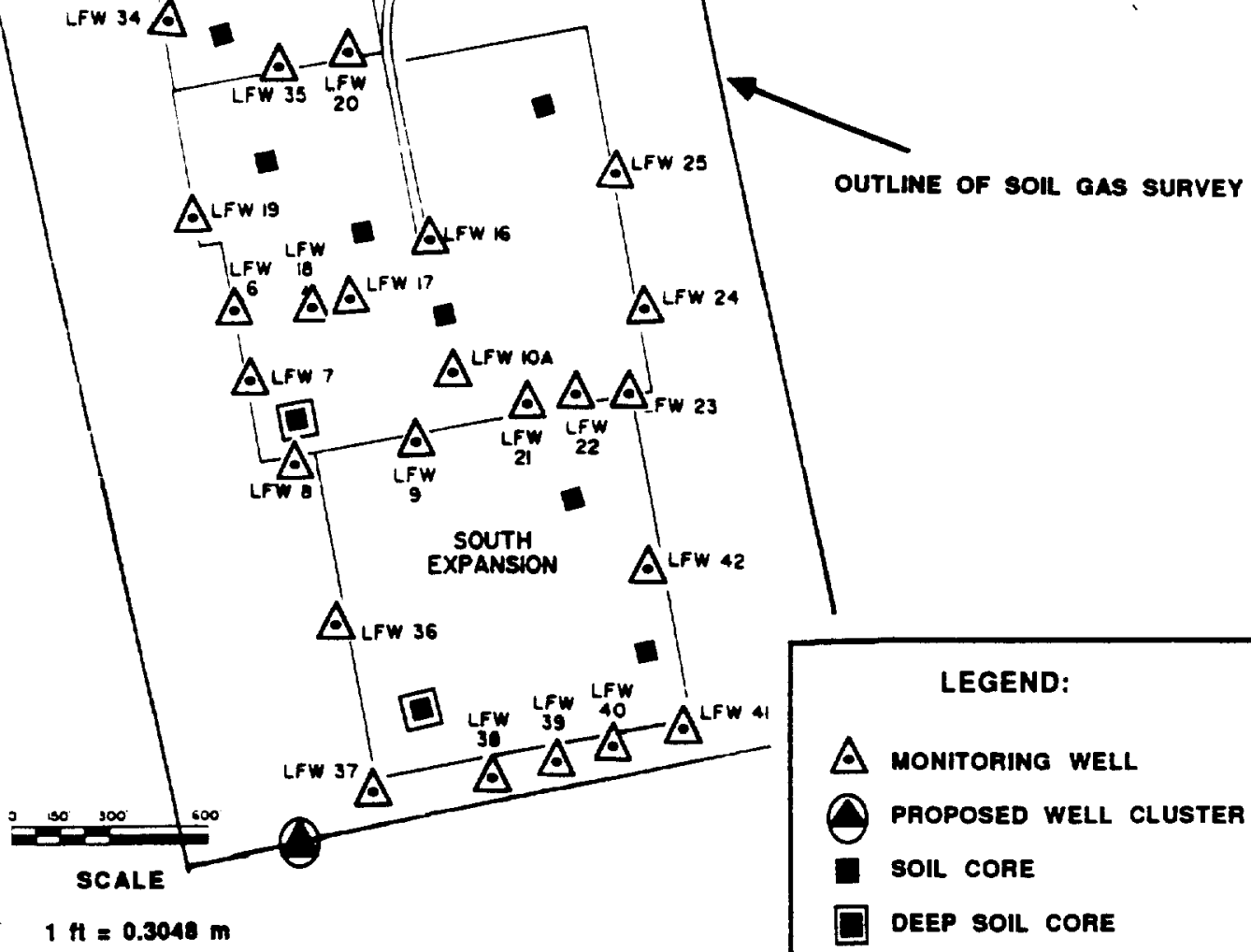

$\triangle$ monitoring Well

Q paoposed well cluster

SOIL CORE

$\square$ DEEP SOIL CORE

FIGURE JJ.2. Location Map of Existing and Proposed Sanitary Landfill Monitoring Wells and Soil Sampling Sites 
In 1986, groundwater data from the site showed elevated levels of TOH in several of the monitoring wells (Zeigler et al., 1987). The highest concentrations of $\mathrm{TOH}$ were detected in groundwater from wells located within the boundary of the waste site. TOH concentrations as high as $197 \mu \mathrm{g} / \mathrm{L}$ were found in the interior wells (LFW 17 and 18). TOH levels above groundwater quality review criteria (Appendix Table 10) were detected in five of the wells (LFW $6,7,8,9$, and 23) located immediately outside the boundary of the waste site. Elevated levels (but not above groundwater quality review criteria) of conductivity were also detected in the interior wells (LFW 17 and 18) and from four of the boundary we11s (LFW 6, 7,8 , and 9).

In 1986,17 new groundwater wells were installed, and 6 we11s were abandoned. Levels of TOH and radioactivity above groundwater quality review criteria (Appendix Table 10) have been detected in a number of the wells (Mikol et al., in press). Levels of TOH up to $403 \mu \mathrm{g} / \mathrm{L}$ were detected in wells located at the southeast boundary of the landfill (at the edge of the south expansion). Elevated levels of radioactivity (alpha, beta, and tritium) were detected in groundwater in some of the wells. Levels of gross alpha (as high as $28 \mathrm{pCi} / \mathrm{L}$ ) and tritium (as high as $97 \mathrm{pCi} / \mathrm{mL}$ ) above groundwater quality review criteria (Appendix Table 10) were detected in a few of the wells.

\section{Characterization Recommendations}

\section{Sampling}

A soil gas survey consisting of a grid spaced at 20-m intervals (due to the large size of the site) is recommended to highlight areas of highest volatile organic contamination and to better define the source term (Figure JJ.2). Shallow soil cores from within the boundary of the sanitary landfill are recommended. It is recommended that 10 soil cores, 8 of $10 \mathrm{~m}$ length and 2 to the water table, be taken. The soil samples for chemical analysis should be collected according to the parameters given in Appendix Table 1.

Hydrogeological information about the site can be extracted from the nearby regional hydrogeological well cluster $P 29$. A three-well monitoring well cluster is recommended to check for vertical migration of contaminants into the Congaree Formation. Two new additional wells should be added to the LFW 37 water-table monitoring well to form a cluster. Screens in the two additional wells should be set in the McBean Formation and in the Congaree Formation. 
Stream water and sediment samples from the outcrop area in Upper Three Runs Creek should be collected. The locations of the stream samples and the soil cores are presented in Figures JJ.1 and JJ.2, respectively.

\section{Chemical and Physical Analyses}

The soil cores should be analyzed according to the parameters given in Appendix Table 1. Specific analytes are volatile organics (Appendix Table 3), metals (Appendix Table 2), and radioactivity (Appendix Table 4).

Groundwater from the monitoring wells should be analyzed according to the parameters outlined in Appendix Tables 3 and 6 . If high levels of radioactivity are found, more detailed radionuclide analyses (Appendix Table 5) would be warranted. 


\section{Background}

\section{Site History}

The Sanitary Sewage Sludge Disposal Pit (Building 080-24G) has received all of the sanitary sewage sludge from the various sewage treatment plants at SRP since 1955. The sludge is trucked to the pit on a monthly basis. The typical loading is approximately $378,787 \mathrm{~L} / \mathrm{yr}$. In 1983 an asphalt film was reported on the pit fluid as a result of the inadvertent dumping of an asphalt solution into the pit. The pit is currently receiving sewage treatment sludge, but closure is planned in the near future.

\section{Site Description}

The Sanitary Sewage Sludge Disposal Pit is an unlined pit located south of the Central Shops complex (Figure KK.1). SRP coordinates for the northeast corner of the pit are $N$ 61440, E 49900. Approximate nominal dimensions are $12 \mathrm{~m}$ by $18 \mathrm{~m}$ by $1.5 \mathrm{~m}$ deep. The sludge column is approximately $1.5 \mathrm{~m}$ deep. No water-table monitoring wells are located in the vicinity of this pit so hydrogeologic conditions beneath the site are undefined. Surface drainage in the area is southwest toward Four Mile Creek.

\section{Review of Available Data}

There are no groundwater data available for the Sanitary Sewage Sludge Disposal Pit. Two environmental studies have been conducted at this site. In May 1980, sludge samples were taken from the pit. Concentrations of constituents analysed for were below detection limits. In November 1986, auger samples were taken from the sludge colum and underlying pit sediments at two locations within the pit. Depth of penetration into the soil column was $1.2 \mathrm{~m}$ ( $4 \mathrm{ft})$. An asphalt-1ike substance was evident in sludge samples taken from both locations. Review of soil core data from the November 1986 study indicates elevated levels of ammonia, barium, calcium, cadmium, chromium, copper, iron, lead, magnesium, manganese, mercury, nickel, nitrate, phosphorus, selenium, silver, sodium, and zinc. Contaminant concentrations tend to diminish with depth (Shedrow, 1987). 

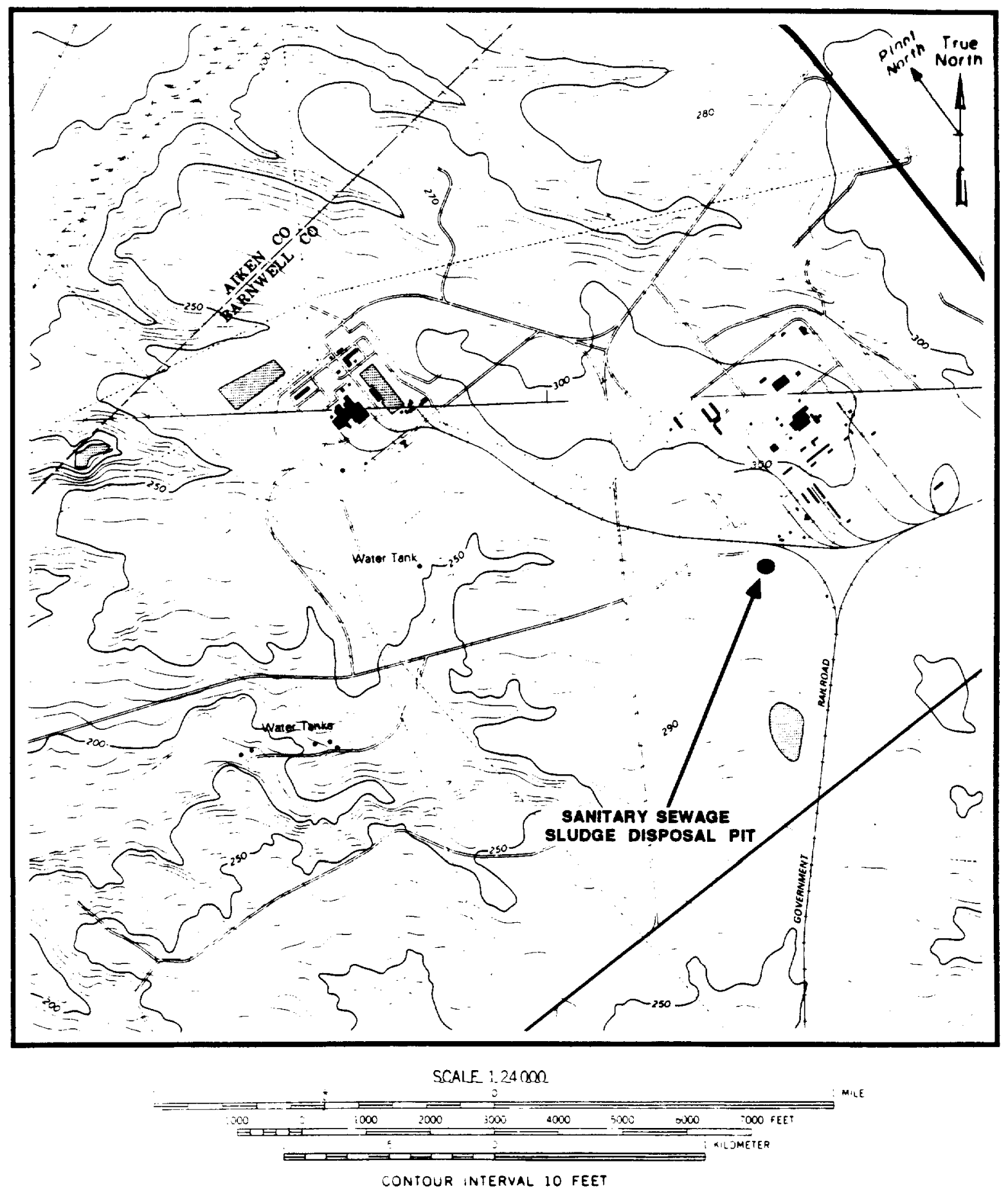

FIGURE KK.1. Location of the Sanitary Sewage Sludge Disposal Pit on New Ellenton SW and Girard NW Quadrangle 7.5 Minute Series Topographic Maps 


\section{Characterization Recommendations}

\section{Sampling}

Two 3-m deep cores should be taken: one from the bottom of the Sanitary Sewage Sludge Disposal Pit and one from the effluent ditchline into which the basin overflows. Recommended sampling intervals for these boreholes are described in Appendix Table 1.

Three water-table monitoring wells should be constructed around the pit, one upgradient and two downgradient (Figure KK.2). If organics contamination is detected in the soil samples, consideration should be given to installing cluster rather than water-table wells. These clusters should include a minimum of three wells: one screened at the water table, one in the McBean Formation, and one in Congaree Formation.

\section{Chemical and Physical Analyses}

Analytical requirements (Classes 1, 2, and 3 ) for the soil cores are described in Appendix Table 1. Additional analytical requirements for these soil cores are as follows:

\section{Interva1 (m)}

$0.00-0.25$

$0.25-0.50$

$0.50-1.00$

$1.00-1.50$

$1.50-2.00$

$2.00-2.50$

$2.50-3.00$

\section{Recommended Analysis}

inorganic ions; VOA

inorganic ions; VOA

inorganic ions; VOA

inorganic ions; VOA

inorganic ions; VOA

Note: inorganic ions--see Appendix Table 2;

VOA--see Appendix Table 3.

Groundwater monitoring we11 samples should be analyzed as described in Appendix Table 6. All wells should be sampled quarterly for a period of one year. 


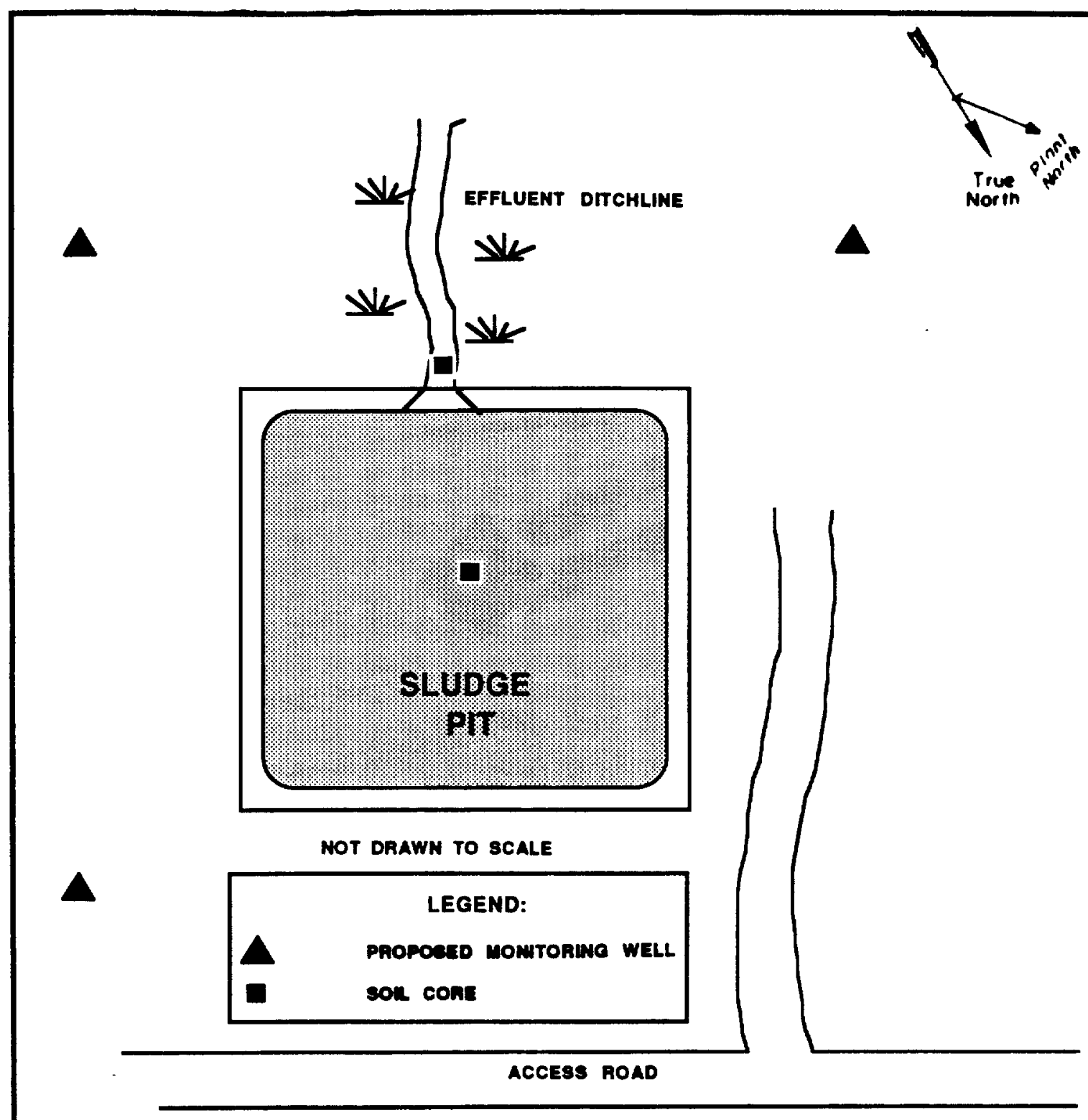

FIGURE KK.2. Location of Proposed Groundwater Monitoring Wells and Sampling Sites Around the Sanitary Sewage Sludge Disposal Pit 


\section{Background}

Site History

The Savannah River Laboratory (SRL) 0il Test Site (Building 080-16G) was used to study the biodegradation of machine cutting oil. The study involved 9,956 $\mathrm{L}$ of waste oil, which was spread over $464.5 \mathrm{~m}^{2}$. In addition to the oil application sites, two plots totaling $400 \mathrm{~m}^{2}$ were used for the application of hydraulic fluid and paint thinner. The results of the test, which was conducted from 1975 to 1980 , indicate that the waste oil had not migrated more than $30 \mathrm{~cm}$ from the ground surface and that nearly $50 \%$ of the oil was lost to volatilization and biodegradation. A more detailed account of the study can be found in Johnson et al. (1987b).

\section{Site Description}

The SRL 0i1 Test Site is located approximately $610 \mathrm{~m}$ south of the Central Shops Area and $600 \mathrm{~m}$ east of the intersection of Roads 3 and 5 on a ridge between two tributaries of Four Mile Creek (Figure LL.1). The northeast corner of the site has SRP coordinates of $N 61922, E$ 49372. The oil test plots have dimensions of 3.7 by $10.7 \mathrm{~m}$ each and the paint thinner test sites have dimensions of 3 by $70 \mathrm{~m}$ each. The surface elevation of the site is $88.4 \mathrm{~m}(290 \mathrm{ft})$. Surface drainage is to the southeast toward a tributary of Four Mile Creek. Monitoring wells for the Hydrofluoric Acid Spill Area, $305 \mathrm{~m}$ northeast of the SRL 0i1 Test site, indicate the depth to the water table in the immediate area is approximately $13.7 \mathrm{~m}$. The regional water-table map for the Central Shops Area indicates the water table flow is west-southwest.

\section{Review of Available Data}

To date, the only characterization data available for this site are for several soil parameters (Watts et al., 1982) and a soil gas survey. The soil parameters are percentage organic matter by weight, phosphorous, potassium, magnesium, calcium, $\mathrm{pH}$, and cation exchange capacity. The results show an initial increase in the amount of phosphorous, potassium, and calcium present; however, all concentrations returned to background levels one year after the oil application.

The results from the soil gas survey are being written up and will be available following completion of the report. 

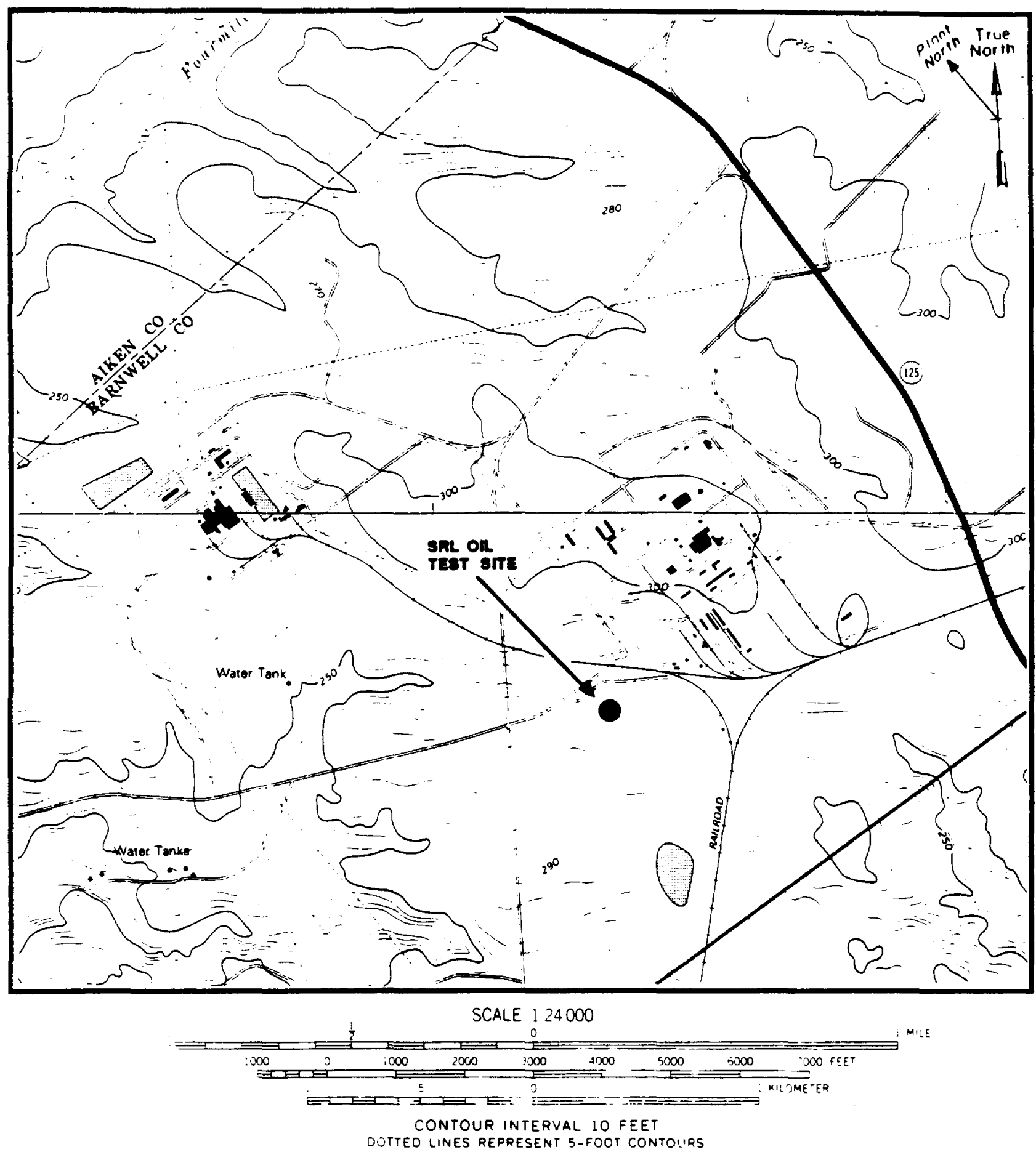

FIGURE LL.1. Location of the SRL Oil Test Site on New Ellenton SW and Girard NW Quadrangle 7.5 Minute Series Topographic Maps 


\section{Characterization Recommendations}

\section{Sampling}

A shallow soil coring program is planned to characterize the soils in and around the pit. Fourteen soil samples are recommended for this site. Three 6-m deep soil samples will be collected from each of the plots that received paint thinner; two $3-\mathrm{m}$ deep soil samples will be taken from three of the plots that received waste oils; and one 6-m deep soil sample will be taken from two different control plots. Figure LL.2 shows the recommended location of soil borings at the site. This shallow coring program and the soil gas survey are designed to determine the horizontal extent of surface and shallow soil contamination (Figure LL.2).

Four groundwater monitorings wells should be installed at the site. Placement of the wells should be such that one well is upgradient and three are downgradient (Figure LL.2).

\section{Chemical and Physical Analyses}

Samples from the soil gas sampling survey should be analyzed for VOCs as listed in Appendix Table 3.

Al1 the soil cores should be analyzed according to the scheme listed in Appendix Table 1 with specific analytes to include those 1 isted in Appendix Table 3 and Total Recoverable 0il and Grease EPA Test Method 9070.

Groundwater samples should be analyzed for the parameters given in Appendix Table 6 . Undisturbed samples collected during the drilling of monitoring wells should be analyzed for horizontal and vertical permeability, porosity, relative permeability, bulk density, and grain size. 
SRLOIL TEST SIIE SCHEMATIC

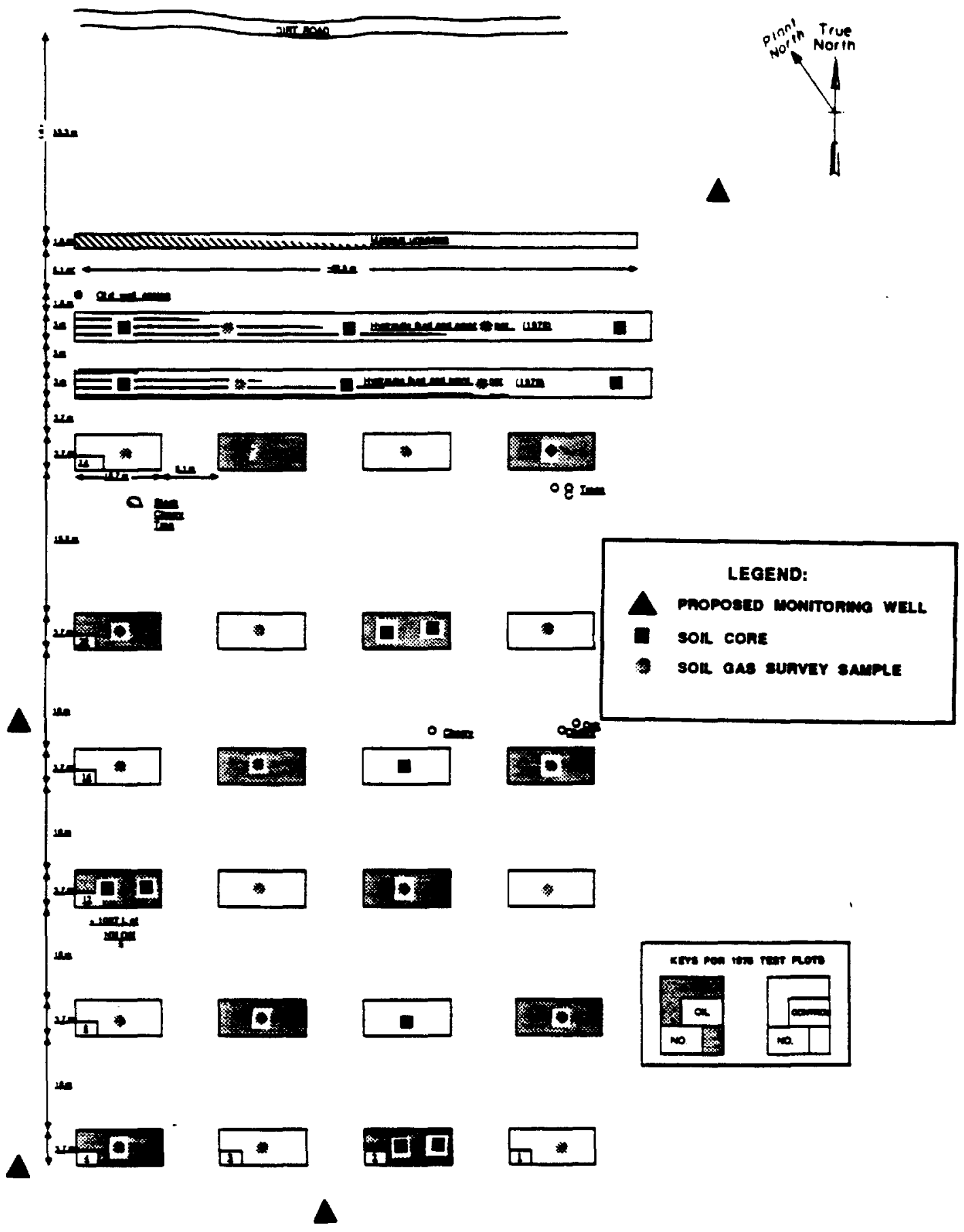

FIGURE LL.2. Proposed Sampling Locations at the SRL Oil Test Site 


\section{Background}

\section{Site History}

The Savannah River Laboratory (SRL) Seepage Basins received wastewater containing low levels of radioactivity $(<100 \mathrm{~d} / \mathrm{m} / \mathrm{ml}$ alpha and $<50 \mathrm{~d} / \mathrm{m} / \mathrm{ml}$ beta-gamma) from 1954 until October 1982. The low-1evel waste was generated in Buildings 773-A and 735-A. A detailed discussion of the SRL Seepage Basins is presented in Fowler et al. (1987).

The first two basins (Building 904-53G) were placed in operation in 1954; Basin 3 (Building 904-54G) and Basin 4 (Building 904-55G) were added in 1958 and 1960, respectively. The four basins are connected sequentially via overflow channels. The final basin, however, has no overflow. Fluid losses from the Basins were predominantly from seepage through the bottoms of Basins 1 through 3 . Wastewater seldom entered Basin 4 because seepage in the first three basins was approximately equal to input volume.

During the 28-year loading history, approximately $130,000 \mathrm{~m}^{3}$ of water were discharged to the basins. The primary waste constituents were radionuclides. The most significant of these were tritium (105 Ci), ${ }^{137} \mathrm{Cs}$ $(4.7 \mathrm{Ci}),{ }^{60} \mathrm{Co}(0.1 \mathrm{Ci}),{ }^{238 \mathrm{U}}(0.022 \mathrm{Ci}), 238_{\mathrm{Pu}}(0.009 \mathrm{Ci})$, and $239_{\mathrm{Pu}}$ $(0.003 \mathrm{Ci})$. The wastewater also contained low concentrations of nonradioactive constituents (e.g., mercury, lead, chromium, sodium, and nitrate). Wastewater samples taken in 1979, during operation of the basins, were analyzed for metals; the concentrations in these samples were below the EP toxicity test guidelines. A review of applicable waste handling procedures, along with interviews of SRL staff persons, was conducted to determine if chlorinated organic solvents were released to the SRL Seepage Basins. These studies indicate that there was no significant source of organics to the wastewater entering the basins (i.e., no sources were identified, alternate waste handing procedures were in place for chlorinated solvents, and the fabrication laboratory, the primary location where these solvents were used, was not physically connected to the drain system feeding the basins).

The basins were taken out of service in 0ctober 1982. The basins are enclosed by a 2-m-high fence that is approximately $8 \mathrm{~m}$ from the edge of the basins. Currently, the basins contain rainwater that collects during storms and then evaporates or seeps into the ground. The level varies from a few inches to several feet of water. Concentrations of dissolved constituents in the standing water are relatively low.

A large amount of data is available for the SRL Seepage Basins. A Technical Data Summary (Bransford et a1., 1984) has been written. A site assessment report and a closure plan are in preparation. 


\section{Site Description}

The four SRL Seepage Basins are located south of Road A-1 and west of Road D-1 (Figures MM.1 and MM.2). This location is in the northwest section of the Savannah River Plant and is about 1,000 m southeast of the nearest plant boundary. Approximate SRP grid coordinates, dimensions, and volume capacities for each basin are 1 isted below.

Building No. SRP Coordinates Dimensions (m) Volume Capacity (m ${ }^{3}$ )

904-53G

Basin 1
N 105605 E 52590
N 105645
E 52634
N 105550 E 52730
N 105510 E 52687

$40 \times 19 \times 2.0$

1,520

Basin 2
N 105647
N 105740
E 52637
E 52741
N 105645 E 52838
N 105552 E 52734

904-54G

Basin 3
N 105756
N 105840
E 52755
E 52853
N 105710 E 52985
N 105626 E 52887

$53 \times 38 \times 2.7 \quad 5,440$

$904-55 G$

Basin 4
N 105856
E 52871
N 105959 E 52983
N 105734 E 53209
N 105635 E 53775

$94 \times 46 \times 3.4$

14,700

The basins are rectangular and were constructed by excavation and filling to the existing topography. 

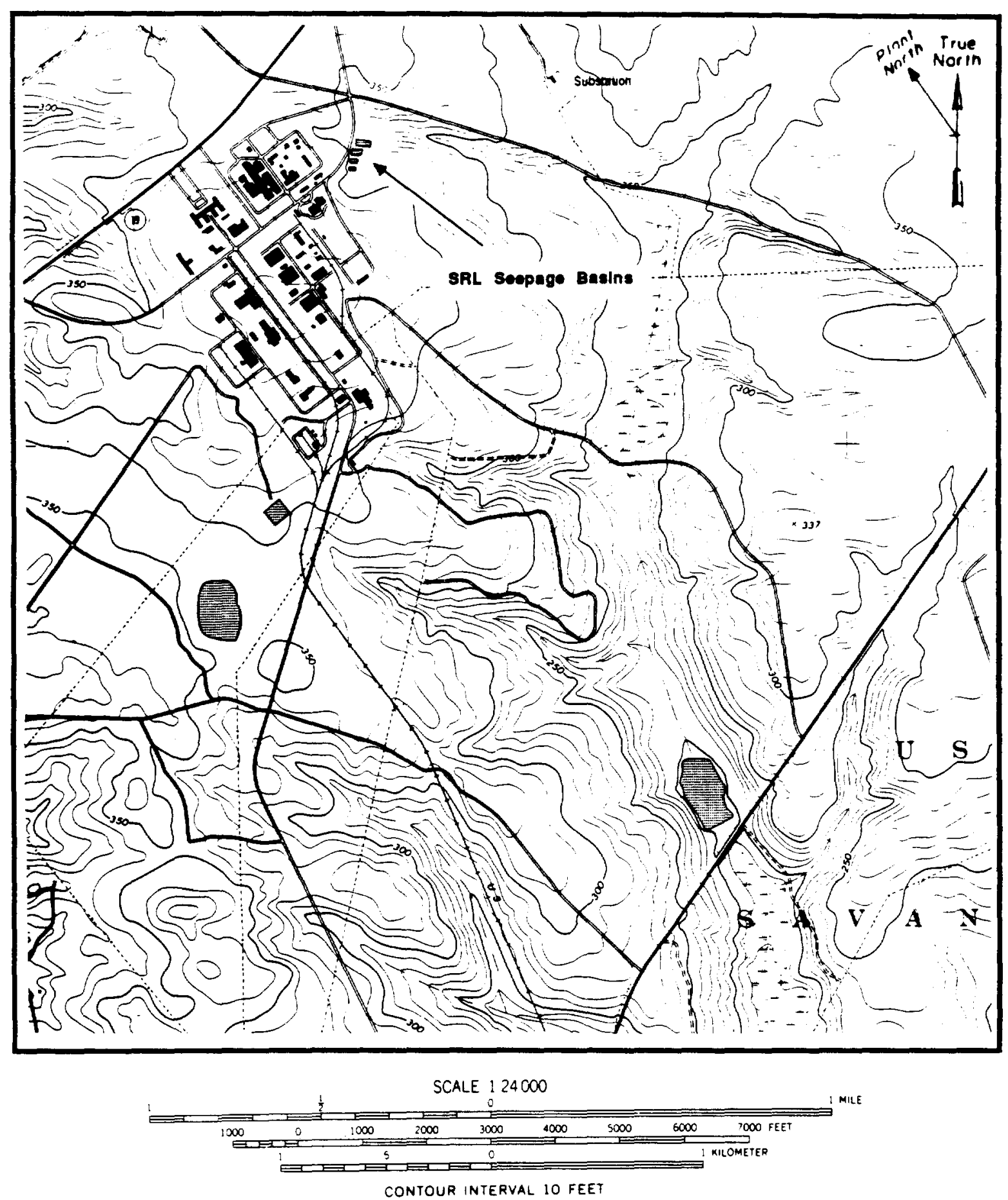

FIGURE M.1. Location of the SRL Seepage Basins on New Ellenton Sw Quadrangle 7.5 Minute Series Topographic Map 


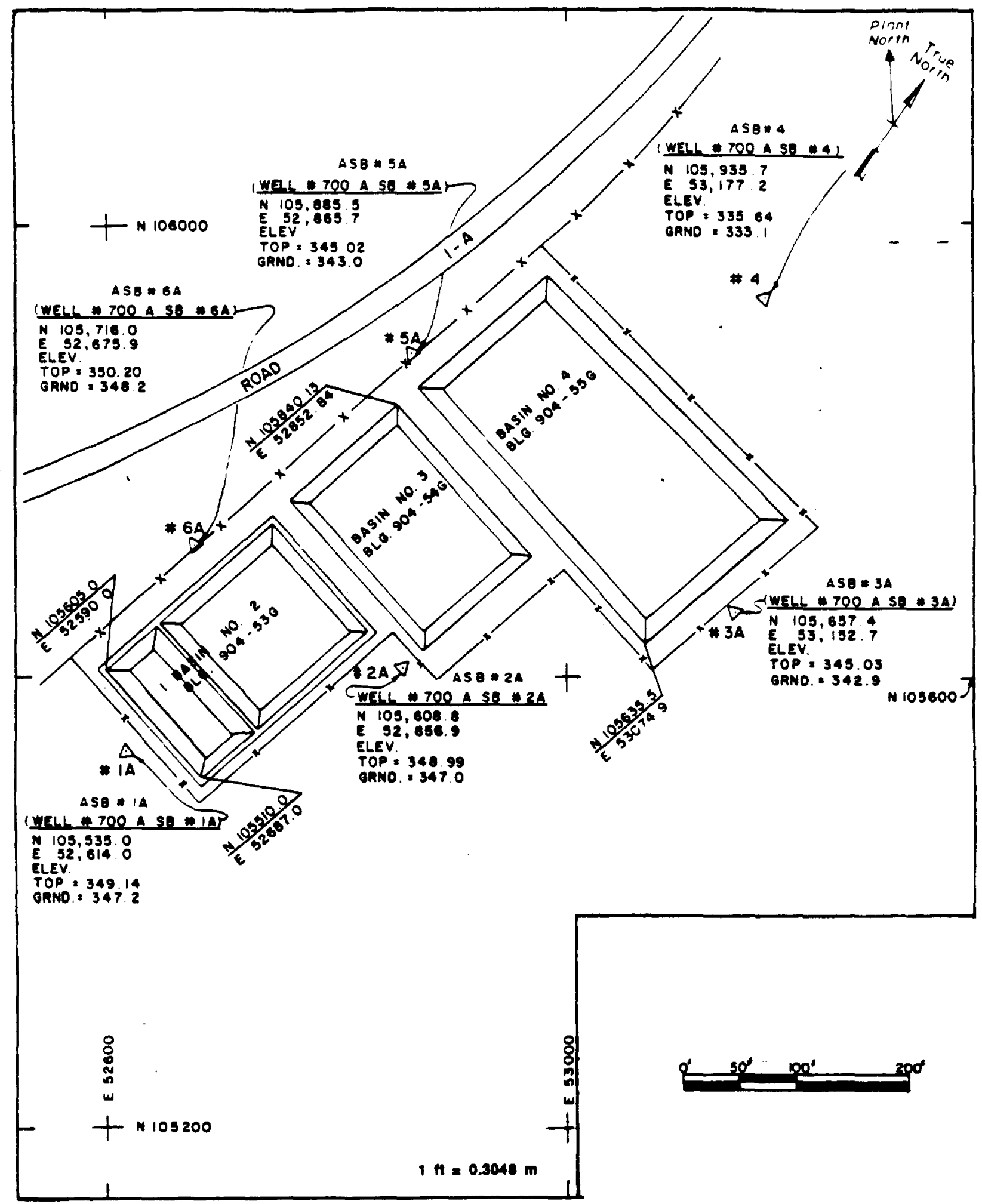

FIGURE MAS.2. SRL Seepage Basins Blueprint 
Ground surface elevations in the area of the basins approach $110 \mathrm{~m}$ $(360 \mathrm{ft})$ and slope southeasterly. Surface water in the vicinity of the basins consists of two intermittent streams: Tims Branch and an unnamed tributary to Tims Branch. The confluence of these streams is approximately $60 \mathrm{~m}$ northeast of Basin 4. The combined streams flow to the south to Upper Three Runs Creek, which is about $6 \mathrm{~km}$ away. During the time the basins were used, the two streams were predominantly fed by discharges from the SRL and Savannah River Ecology Laboratory (SREL) storm/process water outfalls. (These are currently NPDES permitted outfalls.) The stream to the north of the basins also receives overflow water from the SREL greenhouses, duck ponds, and alligator ponds.

A total of nine wells were installed to characterize the SRL Seepage Basins. Six water-quality monitoring wells (ASB 1 through 6) immediately adjacent to the basins were drilled in 1981. Three additional water-table wells (ASB 7 through 9) were installed as part of the basin characterization program in 1983 (Bransford et al., 1984). The locations of these wells is shown in Figure MM.3. Subsequent to the basin characterization program, wells ASB 1, 2, 5, and 6 were replaced by protocol wells constructed with PVC casings (A series).

Located near a groundwater divide, the horizontal groundwater gradients in the vicinity of the basins are shown in Figure MM.3. Note that the horizontal gradient of the water table in this area is very gentle, suggesting that horizontal flow is relatively slow. Vertical gradients dominate the flow paths and velocities from this site until the water reaches deeper water-bearing layers such as the Congaree Formation.

In addition to the nine wells drilled to support the characterization of the SRL Seepage Basins, there are over 50 well/well-cluster locations in the general. A/M Area of SRP where detailed, high quality lithologic and/or geophysical data are available. These data are presented in Fallaw and Sargent (1986). There are four locations close to the SRL Seepage Basins: ASB 8, MSB 42, MSB 37, and MSB 34. Al1 of these cores contain several clay-silt layers as well as a clay-rich zone identified as the Ellenton Formation, which is a relatively good aquitard in this area. There are several subzones in the groundwater in this area; flow directions and velocities in and between these subzones is governed by the interaction of the geologic framework and the hydrologic boundaries. The vertical gradients in the area, combined with the nature of the aquitards, suggest that water moves down from the water table to deeper formations. Once water enters the Congaree sands, horizontal flow is relatively fast toward outcrops in Upper Three Runs Creek. A small amount of flow is expected to continue downward into the Black Creek ("Tuscaloosa") sands; this flow results from a downward head through the relatively thick group of clays that minimize flow. 


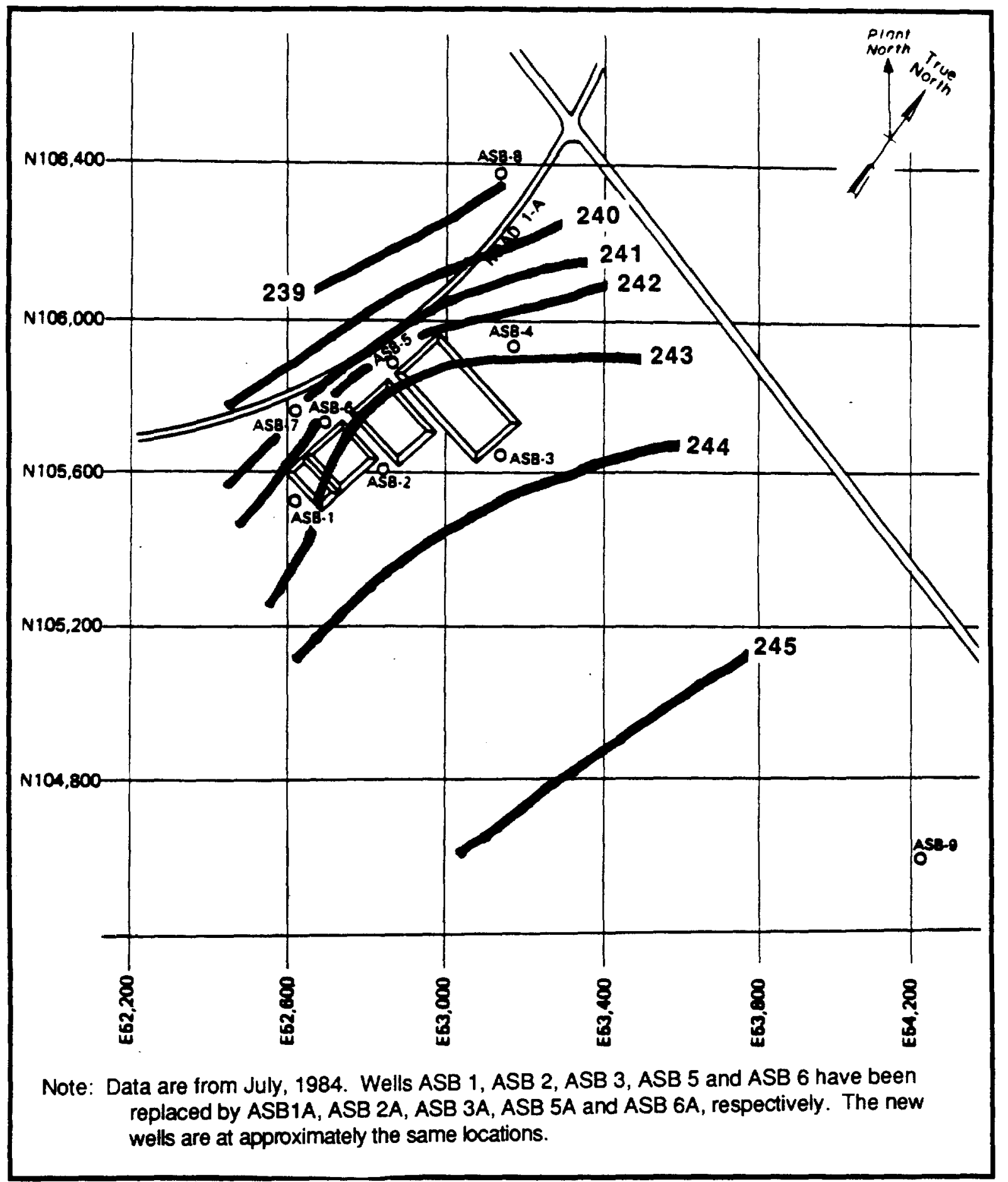

FIGURE MM.3. Monitoring Well Location Map and Water Table Elevation Map for the SRL Seepage Basins 
Review of Available Data

After the seepage basins were taken out of service, a soil samp1ing program was planned and implemented. The characterization program included analyses of basin sediment samples and groundwater samples. The objective of the program was to determine the condition of the site and to evaluate the mobility of the waste constituents. Five cores, $6.1 \mathrm{~m}$ in length, were taken in each basin. These cores were segmented and analyzed for a wide range of radioactive and nonradioactive constituents. Typical vertical concentration profiles for inorganics and radionuclides suggest that almost all of these materials were sequestered in a shallow zone beneath the site. Tritium was an important exception to this behavior. There were no significant organic constituents detected in the sediments. EP toxicity tests of the most concentrated ( 0 to $7.6-\mathrm{cm}$ ) segments were performed as part of the 1983 characterization study. All concentrations were well below the EP toxicity concentration guidelines. A summary of the soil analysis results is presented in Fowler et al. (1987) and the complete data set is in Bransford et al. (1984).

A soil gas sampling grid near the SRL Seepage Basins indicates that the streams on both sides of the basins possibly received chlorinated organics in the past. The compounds were not elevated in samples taken from around the basins' fence (Price et al., 1987).

The protocol groundwater quality data from wells ASB 1A, ASB 2A, ASB 3A, ASB 4, ASB 5A, and ASB 6A are presented in Fowler et al. (1987), Zeigler et al. (1987), and Mikol et al. (in press). All of the constituents except TOH are below the groundwater quality review criteria (Appendix Table 10). As discussed above, there are many sources of TOH (chlorinated solvents) in this area, and it is unlikely that the basins contributed significant quantities of these materials to the groundwater. A separate effort is underway to remediate the organic plume beneath the A/M Area. 


\section{Characterization Recommendations}

\section{Sampling}

Additional samples are recommended to support the proposed closure. These samples are additional samples of the standing water in the basin, completion of one well cluster at ASB 2 (two wells required) down to the Upper Congaree sands, and analyzing the groundwater for radionuclides. The first item is currently in progress. The additional well cluster will provide samples of the porous medium for geochemical analysis and provide a location for geophysical logging and sediment collection so that the site can be more adequately linked to the high quality site-wide geological programs. The radionuclide analyses will provide additional data related to the primary constituents sent to the basins.

\section{Chemical and Physical Analyses}

The sample of basin water should be analyzed for inorganics (Appendix Table 2), radionuclides (Appendix Table 4), and organics (TOH and Appendix Table 3). The well cluster should be drilled and screened similar to the A/M-Area plume definition wells. The deepest well should be geophysically logged, and undisturbed core material from representative clay and sand zones should be collected for porosity and permeability tests. Geochemical parameters (Class 2 and 3 in Appendix Table 1) along with the normal onsite geological examination should be performed on core material. The wells should be sampled along with the other SRL Seepage Basins monitoring wells. Other upgradient facilities should be identified when interpreting the data. Finally, all of the basins monitoring wells should be sampled for an expanded lists of radionuclides (Appendix Table $5)$. 


\section{Background}

\section{Site History}

The Scrap Metal Pile (Building 631-18G) was used for disposal of scrap metal. The Scrap Metal Pile contains three car bodies and miscellaneous scrap metal and is presently inactive (Heffner et al., in press).

\section{Site Description}

The Scrap Metal Pile is located northwest of the intersection of Roads A-18 and 9, approximately $2.7 \mathrm{~km}$ from Road A (Figure NN.1). SRP coordinates for this site are $\mathrm{N} 24000$, E 42700. The Scrap Metal Pile covers an area of approximately $42 \mathrm{~m}^{2}$ and is located on the southern edge of the Aiken Plateau immediately above the swampy headwaters of a smal1 tributary of Steel Creek. Elevation at the site is approximately $67 \mathrm{~m}$ $(220 \mathrm{ft})$. The small tributary extends for approximately $3 \mathrm{~km}$ where it then enters Steel Creek, about $2.5 \mathrm{~km}$ above the Savannah River swamp. Surface drainage is to the southwest toward the Steel Creek tributary. No information about groundwater flow direction and depth to groundwater is available because there are no monitoring wells at this site. However, available data suggest a very shallow depth to the water table and a groundwater flow direction to the south-southwest.

\section{Review of Available Data}

No soil or water samples have been collected from the Scrap Metal Pile.

\section{Characterization Recommendations}

\section{Sampling}

Soil cores are recommended to determine if any hazardous material has been released at the site (Figure NN.2). Because of the small size of the site and because of the relatively harmless nature of the contents of the site, three soil cores to a depth of $3 \mathrm{~m}$ (or to the water table if less) are recommended. Soil cores should be sampled for chemical analyses according to the parameters given in Appendix Table 1. These data should be sufficient to complete an initial characterization of the site. 


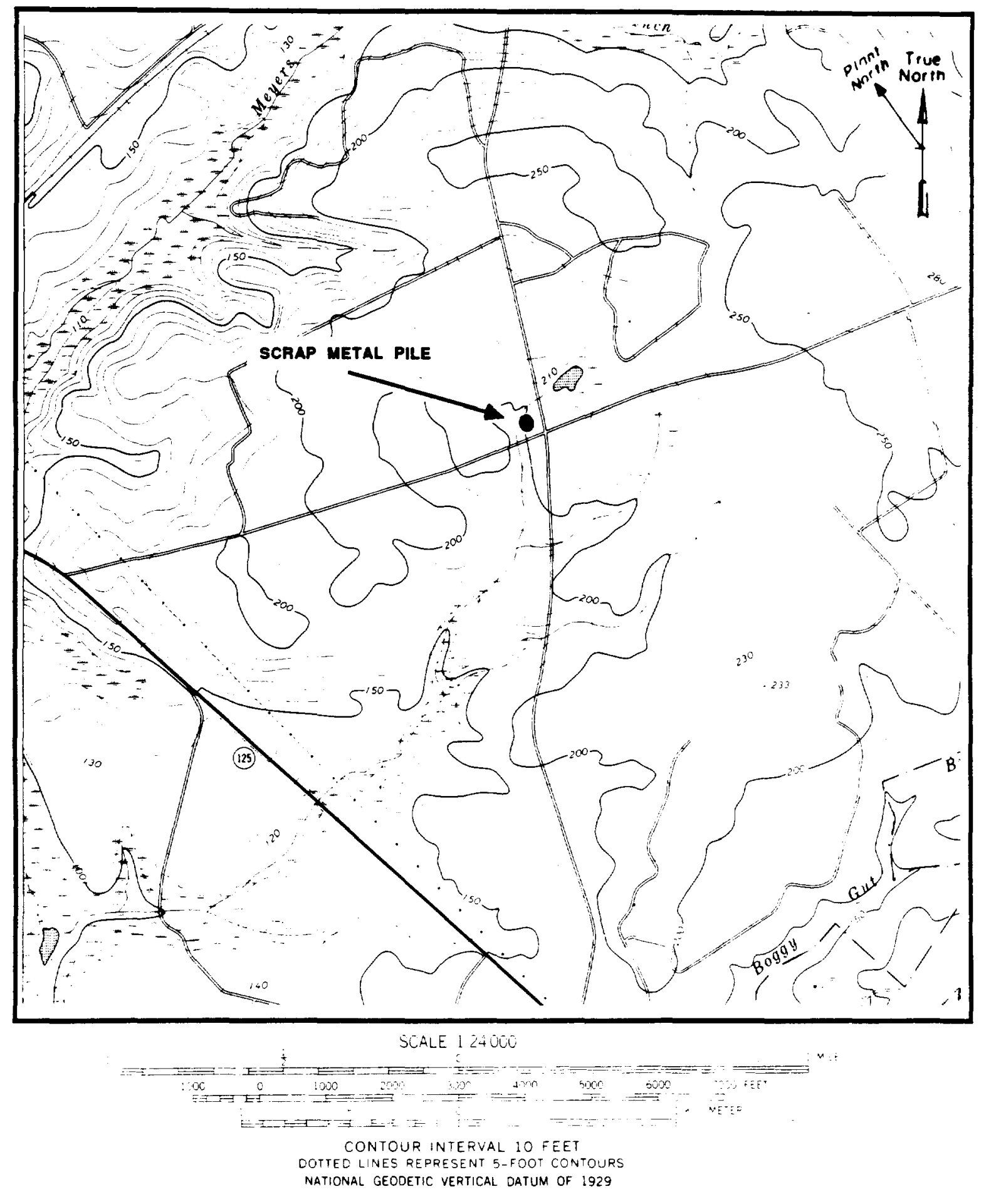

FIGURE MN.1. Location of the Scrap Metal Pile on Girard NE Quadrangle 7.5 Minute Series Topographic Map 

If significant contamination is found in the soils at the site, four monitoring wells are recommended. One of the monitoring wells should be cored continuously to obtain hydrogeologic information about the site. The cores should be described geologically and archived at SRP for possible physical analyses if required at a later time. All monitoring wells should be logged geophysically for gamma, resistivity, porosity, and caliper.

\section{Chemical and Physical Analyses}

Soil samples should be analyzed according to the parameters outlined in Appendix Table 1. Specific analytes are metals (Appendix Table 2) and VoCs (Appendix Table 3). 


\section{Background}

\section{Site History}

The Separations Area Retention Basins in $\mathrm{F}$ and $\mathrm{H}$ areas (Buildings 281-3F and 281-3H) were used from 1955 until 1973. These unlined basins provided temporary emergency storage for potentially contaminated cooling water from the chemical separations processes. When radioactivity was detected in the cooling water, immediate action was taken to divert the water from surface drainage streams to the retention basins. During the holding period, some of the contaminated water seeped into the ground through the floor of the basins. If the radioactivity of the wastewater was above stream release limits, the wastewater was processed by deionization to reduce the contamination to permit release. The quantity of material released to the retention basins is unknown.

In 1978 a characterization study of the floor of the F-Area Retention Basin was completed. As a result, $0.6 \mathrm{~m}$ of sediment was removed from the floor of the basin in 1979; the basin was then backfilled and planted. The H-Area Retention Basin was not reclaimed in any manner, and it now contains water (Scott et al., 1987b).

\section{Site Description}

Both retention basins are located in the central area of SRP. The F-Area Retention Basin is located outside and south of the F-Area perimeter fence and east of Building 281-8F (Figure 00.1). The H-Area Retention Basin is located just outside the southwest corner of the H-Area perimeter fence (Figure 00.1). The nearest plant boundary is approximately 8 to $10 \mathrm{~km}$ west of the basins. SRP coordinates for the northeast corner of the F-Area Retention Basin are N 76325, E 53709 and for the H-Area Retention Basin are N 71595, E 59948. Both basins were rectangular in shape with dimensions of $36.6 \mathrm{~m}$ wide by $61 \mathrm{~m} 1$ ong by $2.1 \mathrm{~m}$ deep. Volume capacity of each basin was approximately $4,700 \mathrm{~m}^{3}$.

The F-Area Retention Basin is located in an area of fairly level topography on the Aiken Plateau immediately above a small tributary of Four Mile Creek. The basin is located at an elevation of $82.3 \mathrm{~m}(270 \mathrm{ft})$. Surface drainage is toward the tributary of Four Mile Creek. The H-Area Retention Basin, at an elevation of $82 \mathrm{~m}(270 \mathrm{ft})$, is located immediately above another small tributary to Four Mile Creek, about $2.5 \mathrm{~km}$ east of the F-Area Retention Basin. Surface drainage is toward the small tributary of Four Mile Creek. 


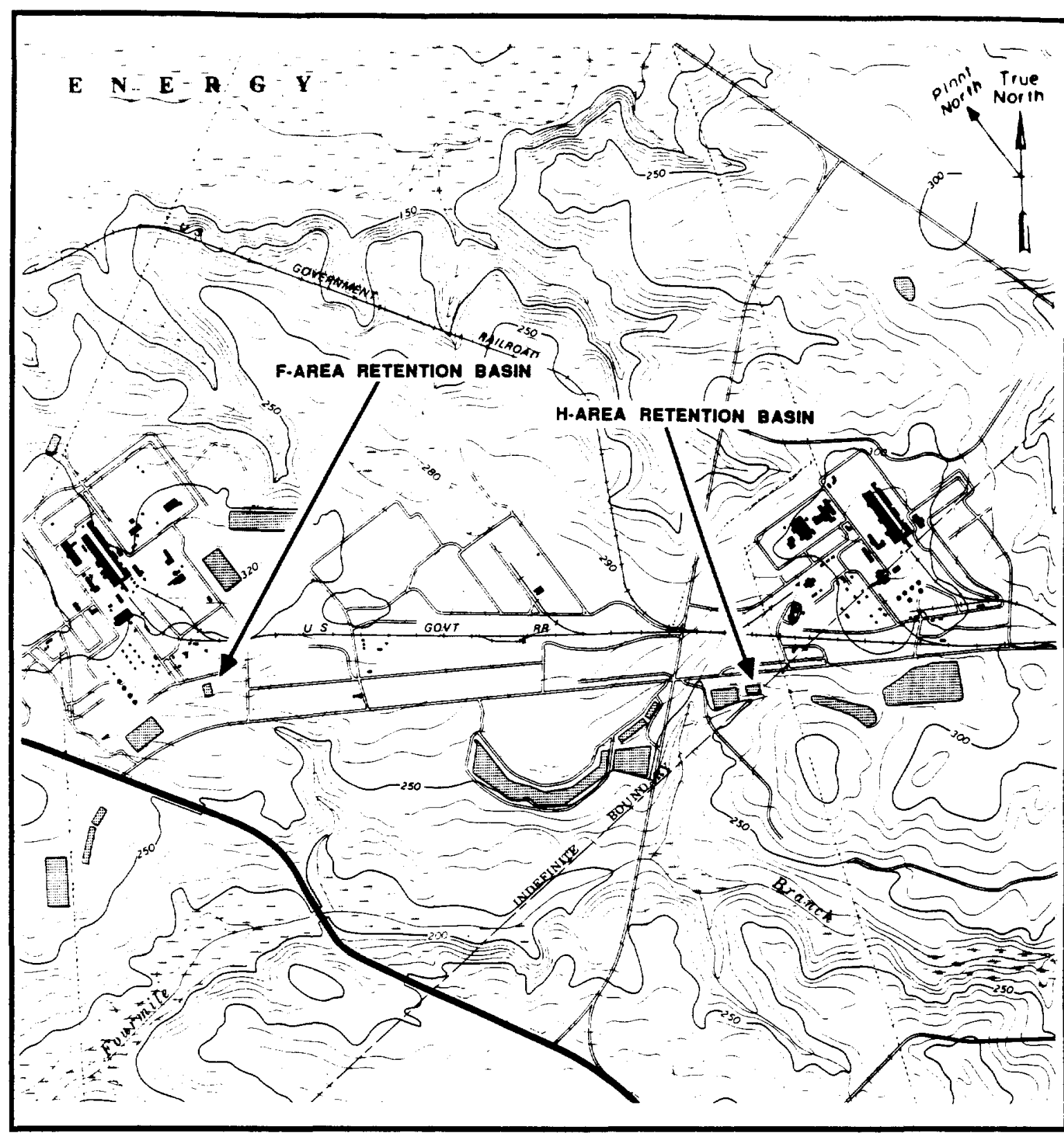

$$
\begin{gathered}
\text { SCALE ! } 24000 \\
\text { NATIONAL GEODETIC VERTICAL DATUM OF } 1929 \\
\text { CONTOUR INTERVAL IO FEET }
\end{gathered}
$$

\section{FIGURE 0.1 . Location of the Separations Area Retention Basins on New Ellenton SW quadrangle 7.5 Minute Series Topographic Map}


No groundwater monitoring wells have been installed near the F-Area Retention Basin. Two monitoring wells were installed at the H-Area Retention Basin in 1984. Regional monitoring wells indicate that groundwater flow at the F-Area Retention Basin is to the south-southwest (Scott et al., 1987b). According to regional groundwater flow models, groundwater is flowing steeply to the southwest, toward Four Mile Creek, at the H-Area Retention Basin (Scott et al., 1987b). However, data from the two monitoring wells at the H-Area Retention Basin and the four monitoring wells at the nearby active H-Area Retention Basin (281-8H) indicate that groundwater flow is to the west-southwest. Data from 1986 indicate that the depth to the water table in both areas is approximately 3 to $6 \mathrm{~m}$ (Zeigler et a1., 1987).

\section{Review of Available Data}

Four 3.6-m deep soil cores were collected from the bottom of the F-Area Retention Basin in 1978. The primary radionuclides present in the soil were ${ }^{137} \mathrm{Cs}$ and $89,90 \mathrm{Sr}$. Most of the cesium was present in the top $0.5 \mathrm{~m}$, whereas the strontium was located in the top $1.8 \mathrm{~m}$. In 1978 and $1979,970 \mathrm{~m}^{3}$ of soil were excavated. Fifty-three additional soil cores were then collected to a maximum depth of $5.5 \mathrm{~m}$. Remaining inventory for the basin is calculated as $34 \mathrm{mCi}$ of $137 \mathrm{Cs}$ and $390 \mathrm{mCi}$ of $89,90 \mathrm{Sr}$ at a depth of $45 \mathrm{~cm}$ and $20 \mathrm{mCi}$ of $137 \mathrm{Cs}$ and $140 \mathrm{mCi}$ of $89,90 \mathrm{Sr}$ at a depth of $12.5 \mathrm{~cm}$.

In 1973 soil cores were collected from the H-Area Retention Basin. The inventory for radionuclides was conservatively estimated to be $0.50 \mathrm{Ci}$ for ${ }^{238} \mathrm{Pu}, 10 \mathrm{Ci}$ for ${ }^{137} \mathrm{Cs}$, and $3.5 \mathrm{Ci}$ for $89,90 \mathrm{Sr}$. In 1977 , radiological surveys of surface soil, vegetation, and sediments adjacent to the retention basin showed elevated levels of radioactivity. In 1979, soil from the basin floor was moved to the sides of the basin. This soil contained $6,700 \mathrm{pCi} / \mathrm{g}$ of alpha and $54,000 \mathrm{pCi} / \mathrm{g}$ of beta. Water removed from the basin contained $0.8 \mathrm{pCi} / \mathrm{mL}$ of alpha and $120 \mathrm{pCi} / \mathrm{mL}$ of $137 \mathrm{Cs}$.

Very low levels, below groundwater quality review criteria (Appendix Table 10), of gross alpha, nonvolatile beta, and tritium have been detected in the groundwater at the H-Area Retention Basin. In 1986 and 1987, gross alpha ranged from 1 to less than $3 \mathrm{pCi} / \mathrm{L}$ and nonvolatile beta ranged from 1.8 to $10.0 \mathrm{pCi} / \mathrm{L}$ (Mikol et al., in press; Zeigler et al. 1987). In 1987 tritium measured in the groundwater ranged from 26.6 to $43.3 \mathrm{pCi} / \mathrm{mL}$. However, both we1ls are located upgradient of the basin. 


\section{Characterization Recommendations}

\section{Sampling}

No additional shallow soil cores from within the boundary of the F-Area Retention Basin are recommended. Three soil cores of 6-m lengths are recommended at the H-Area Retention Basin. Samples for chemical analysis should be collected according to the parameters 1 isted in Appendix Table 1 .

Four groundwater monitoring wells at the F-Area Retention Basin and two additional groundwater monitoring wells at the H-Area Retention Basin are recommended in order to determine the exact direction of groundwater flow. The two additional H-Area monitoring wells would allow comparisons of groundwater chemistry between upgradient and downgradient wells. It is difficult to find a good location for the downgradient monitoring well because of the proximity of this site to the active H-Area Retention Basin $(281-8 \mathrm{H})$. One of the monitoring wells should be cored continuously to characterize the hydrolprology of the waste site. The core should be described geologically and archived for possible additional analyses.

Deep monitoring wells are not required at these two sites because of the shallow depth to the water table and the close proximity of surface streams where the groundwater outcrops. Groundwater flow in this area will be predominantly in a horizontal direction to the nearby streams.

Samples of stream water and stream sediments both above and below the retention basins are also recommended because of the close proximity of the basins to surface streams and the shallow nature of the water table. The proposed sampling locations are shown in Figures 00.2 and 00.3 .

\section{Chemical and Physical Analyses}

The groundwater and surface water samples should be analyzed for according to the parameters given in Appendix Tables 5 and 6 . The stream sediment and soil samples should be analyzed for radioactivity (Appendix Table 5). 


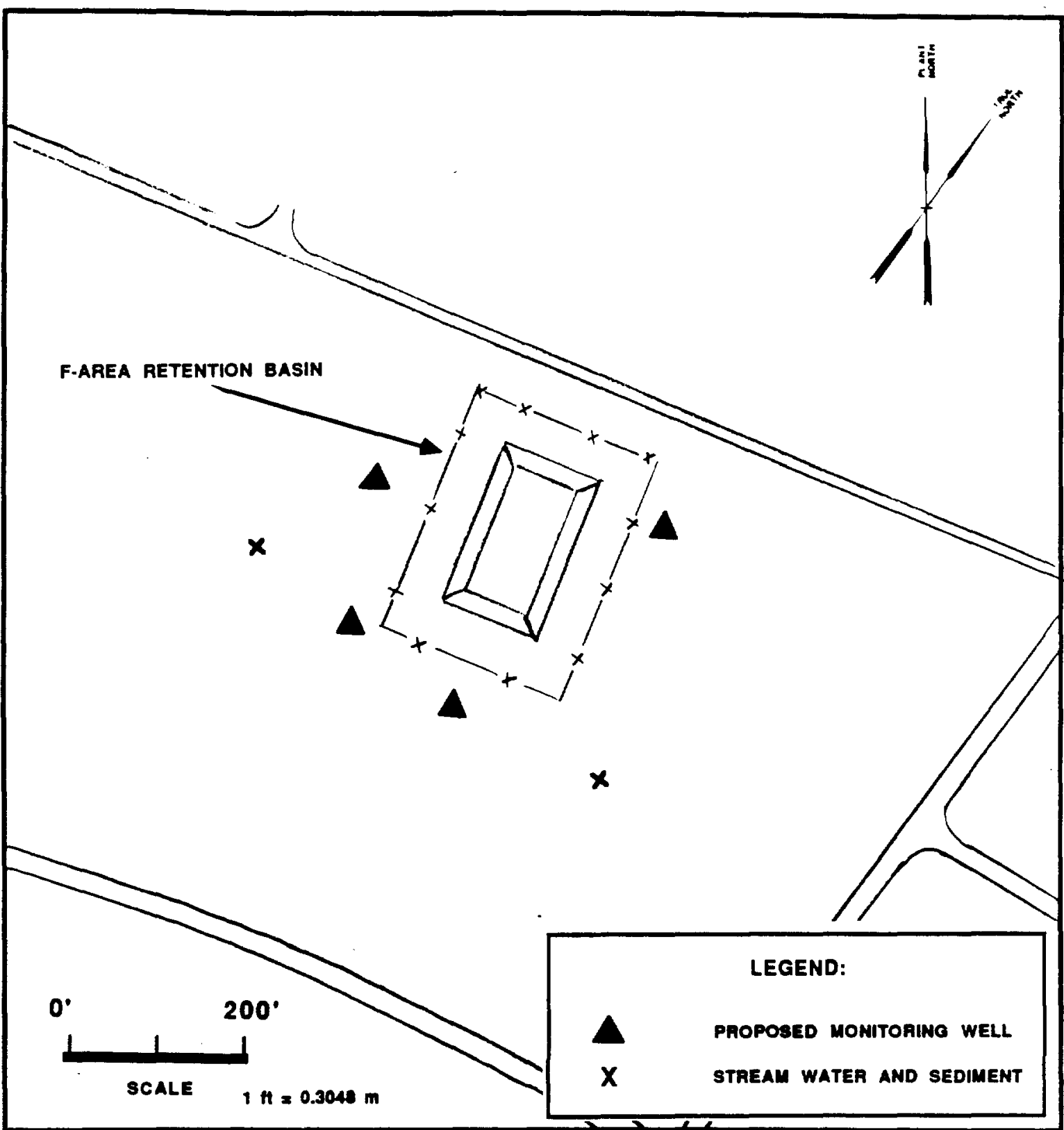

FIGURE 0.2 . Proposed Monitoring Well and Sampling Locations at the F-Area Retention Basin 


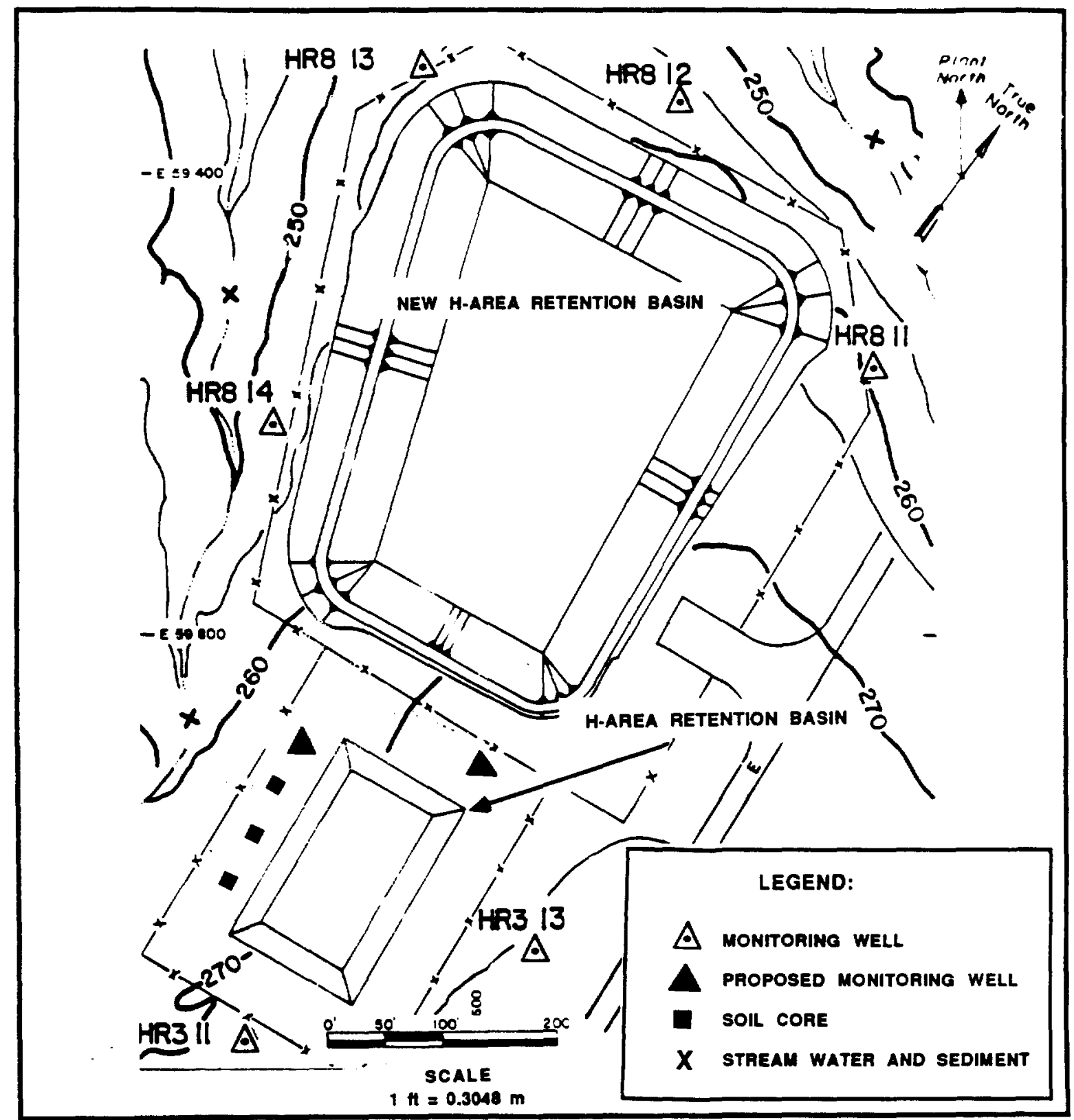

FIGURE $\infty .3$. Proposed Sampling Locations at H-Area Retention Basin 


\section{Background}

\section{Site History}

Under the DOE Biomass Fuels Program, sewage sludge supplied from two offsite sources was applied to soils in 1980 and 1981 at nine experimental pine forests and borrow pits at SRP (Figure PP.1). A total of 1,800,000 gal of liquid sludge and 500 tons of solid sludge were applied on 46 acres of loblolly pine forest plots and 75 acres of borrow pits.

Liquid sludge from the Wastewater Treatment Plant in Augusta, GA, was injected about 13 to $20 \mathrm{~cm}$ below the surface of the 40-Acre Hardwood Site (Building 761-G) at a rate of up to $50,000 \mathrm{gal} / \mathrm{acre}$, which is equivalent to approximately $800 \mathrm{lb}$ of nitrogen per acre. Five species of hardwood trees were then planted in February 1981 to identify the amount of wood biomass that could be produced under coppice growth using sewage sludge as a fertilizer and soil conditioner.

In December 1980, 350,000 gal of 1iquid sludge from Augusta, GA, were injected about 13 to $20 \mathrm{~cm}$ below the surface of the K-Area Borrow Pit (Building 761-4G) at a rate of up to $17,500 \mathrm{gal} / \mathrm{acre}$, which is equivalent to $280 \mathrm{lb}$ of nitrogen per acre. Ten species of hardwood trees and loblolly pines were then planted in February 1981 to identify the amount of wood biomass that could be produced under coppice growth using sewage sludge as a fertilizer and soil conditioner.

The sewage sludge applied to the Lucy Site (Building 751-3G) came from both the Horse Creek Pollution Control Facility located in North Augusta, SC, and the Augusta Wastewater Treatment Plant. The Horse Creek sludge was applied to the Lucy Site in July 1981 with a manure spreader at a rate of up to 80 tons (wet) per acre, which is equivalent to approximately 800 1b of nitrogen per acre. The Augusta Plant liquid sludge was either disked or sprayed on the Lucy Site in April 1981 at a rate of up to 37,500 gal/acre, which is equivalent to approximately $600 \mathrm{lb}$ of nitrogen per acre.

The Horse Creek sludge was applied to the Orangeburg Site (Building 761-2G) in June 1981 with a manure spreader at a rate of 40 tons (wet) per acre, which is equivalent to approximately $800 \mathrm{lb}$ of nitrogen per acre. The Augusta Plant liquid sludge was either disked or sprayed on the Orangeburg site at a rate of up to $50,000 \mathrm{gal} / \mathrm{acre}$, which is equivalent to approximately $8001 \mathrm{~b}$ of nitrogen per acre.

Three hundred tons of Horse Creek sludge were applied to the Kato Road Site (Building 761-6G) in February and March 1981 with a manure spreader at a rate of up to $800 \mathrm{lb}$ of nitrogen per acre. Approximately $300,000 \mathrm{gal}$ of liquid sludge were either disked or sprayed on the Kato Road Site at a rate of $800 \mathrm{lb} / \mathrm{acre}$. 


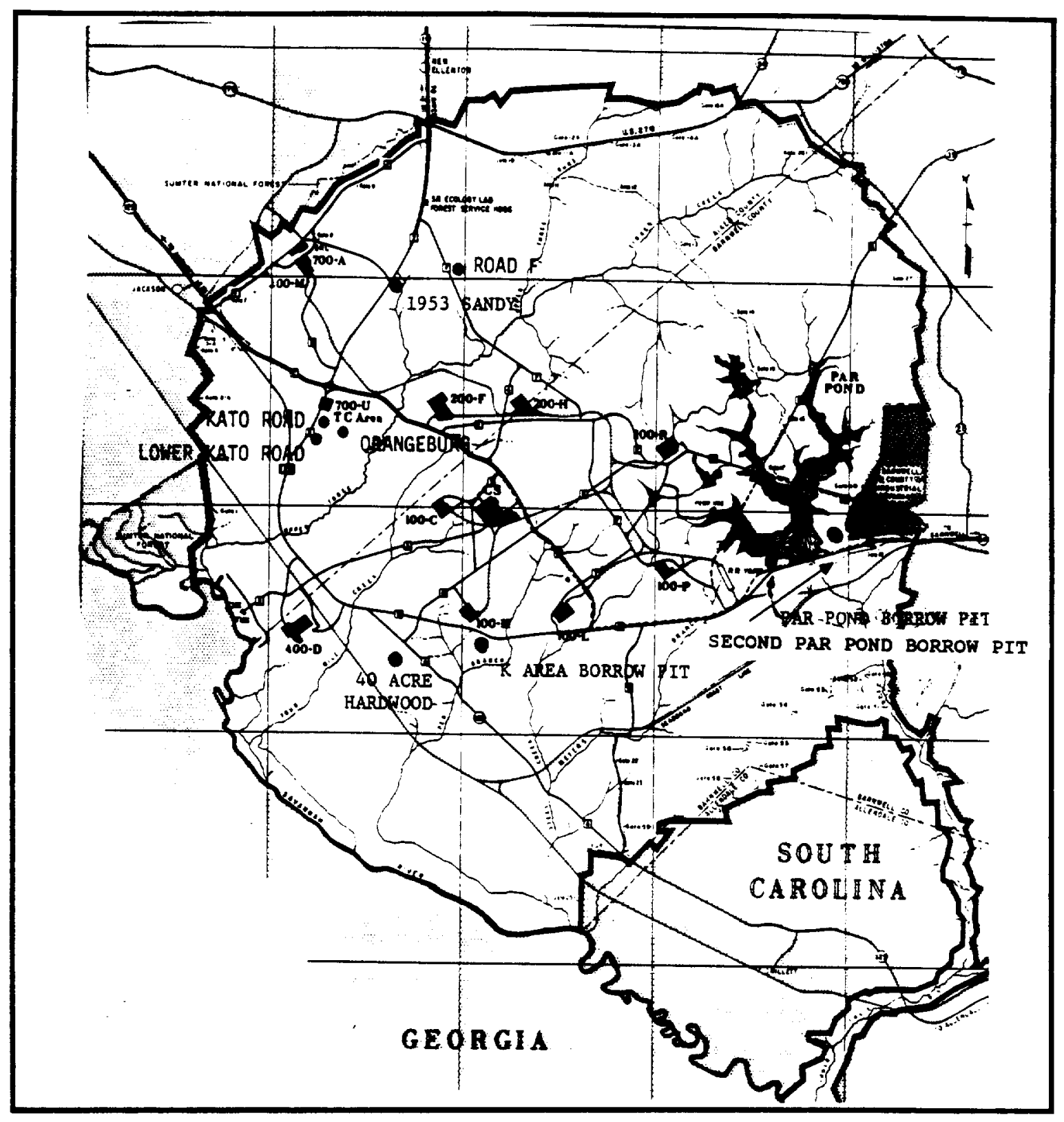

FIGURE PP.1. Location of the Sewage Sludge Application Sites 
The sewage sludge applied to the Lower Kato Road Site (Building 761-1G) came from both the Horse Creek Pollution Control Facility and the Augusta Wastewater Treatment Plant. The Horse Creek sludge was applied to the site in April 1981 with a manure spreader at a rate of 40 tons (wet) per acre. The liquid sludge from the Augusta Plant was either disked or sprayed on the site at a rate of $25,000 \mathrm{gal} / \mathrm{acre}$, which is also equivalent to $400 \mathrm{lb}$ of nitrogen per acre.

In December 1980, approximately 300,000 gal of liquid sludge from Augusta, $\mathrm{GA}$, were injected about 13 to $20 \mathrm{~cm}$ below the surface of the Par Pond Borrow $P$ it at a rate of up to $15,000 \mathrm{gal} / \mathrm{acre}$, which is equivalent to $120 \mathrm{lb}$ of nitrogen per acre. Ten species of hardwood trees and loblolly pines were planted to identify the amount of wood biomass that could be produced under coppice growth using sewage sludge as fertilizer and soil conditioner.

Liquid sludge from Augusta, GA, was either disked or sprayed on the Road $F$ Site (Building 761-7G) in the fall of 1981 at a rate of up to $50,000 \mathrm{gal} / \mathrm{acre}$, which is equivalent to $800 \mathrm{lb}$ of nitrogen per acre.

Liquid sludge from Augusta, GA, was disked on the Second Par Pond Barrow Pit (Building 761-8G) in the fall of 1981. Approximately 300,000 gal of liquid sludge were injected about 13 to $20 \mathrm{~cm}$ below the surface at a rate of up to 15,000 gal/acre, which is equivalent to $120 \mathrm{lb}$ of nitrogen per acre. A number of hardwood trees and loblolly pines were planted to identify the amount of wood biomass that could be produced under coppice growth using sewage sludge as fertilizer and soil conditioner.

\section{Site Description}

The 40-Acre Hardwood Site is located approximately $915 \mathrm{~m}$ southeast of the intersection of SRP Road 6 and Road A. Surface elevations in the vicinity of the site range from approximately 49 to $59 \mathrm{~m}$ (160 to $195 \mathrm{ft}$ ) (Figure PP.2). Three monitoring wells were installed at the site to characterize the geologic and hydrogeologic conditions and to monitor the groundwater. Monitoring wells SSS 1 through SSS 3 were installed prior to any sludge application as required by SCDHEC as part of Industrial Waste Permit No. IWP-175 (July 2, 1980). Water-table elevations obtained from the site monitoring wells since the fourth quarter of 1980 indicate that the depth to the water table has ranged from approximately 3.4 to $7.9 \mathrm{~m}$ across the area. The groundwater flow direction is to the south. The site is located at SRP coordinates N 51500, E 29000 .

The K-Area Borrow Pit covers 20 acres and is located south of SRP Road B and northeast of the Indian Grave and Pen Branch confluence (Figure PP.2). Surface elevations in the vicinity of the site range from approximately 55 to $70 \mathrm{~m}$ (180 to $230 \mathrm{ft}$ ). Three monitoring wells were installed at the K-Area Borrow Pit to characterize the geologic and hydrogeologic conditions and to monitor the groundwater. Monitoring wells SSS 13 through SSS 15 were installed prior to any sludge application as required by SCDHEC as part of 


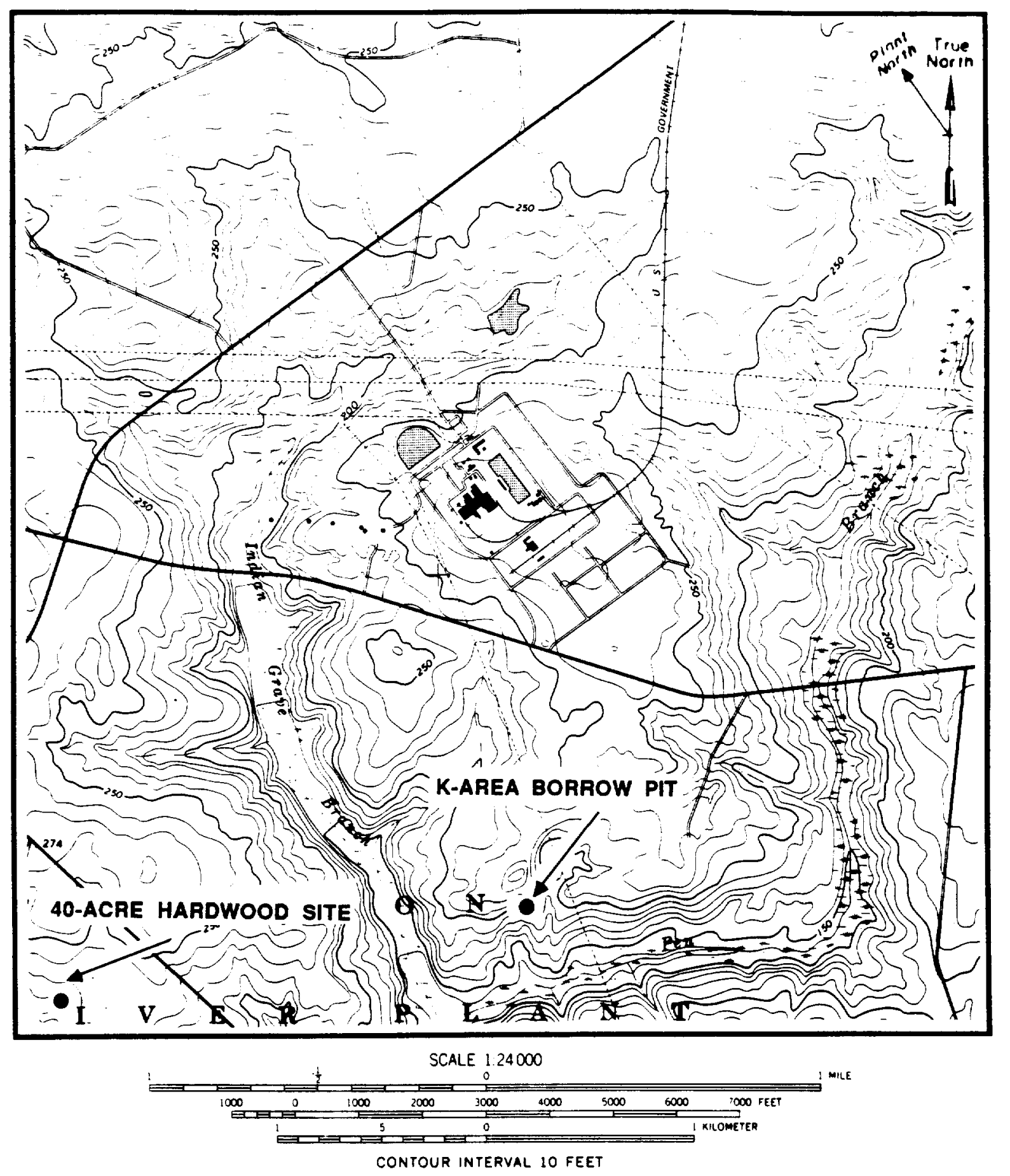

FIGURE PP.2. Location of the 40-Acre Hardwood and K-Area Borrow Pit Sludge Application Site on Girard NW Quadrangle 7.5 Minute Series Topographic Map 
Industrial Waste Permit No. IWP-175 (July 2, 1980). Water-table elevations from the K-Area Borrow Pit monitoring wells since the fourth quarter of 1980 indicate that the depth to the water table has ranged from approximately 5.5 to $16.8 \mathrm{~m}$ across the pit area. The groundwater flow direction is to the south-southeast. The site is located at SRP coordinates N 47000, E 40000 .

The Lucy Site is a 32-year-old stand of 1ob1olly pine trees planted in predominantly sandy soil. The site is located about $305 \mathrm{~m}$ east of SRP Road 2 and approximately $3.2 \mathrm{~km}$ south of the intersection of SRP Roads 2 and F (Figure PP.3). Three monitoring wells were installed at the Lucy site to characterize the geologic and hydrogeologic conditions and to monitor the water table. Monitoring wells SSS 10 through SSS 12 were installed prior to any sludge application as required by SCDHEC as part of Industrial Waste Permit No. IWP-175 (July 2, 1980). Water-table elevations from the Lucy Site monitoring wells since the fourth quarter of 1984 indicate that the depth to the water table has ranged from approximately 20.4 to $21.9 \mathrm{~m}$ across the application area. The flow direction of the water table is to the southwest. The site is located at SRP coordinates N 94800 , E 58200.

The Kato Road Site is a 35-acre area of loblolly pine trees. The site is located directly east of SRP Road 2 and approximately $1.6 \mathrm{~km}$ south of the intersection of SRP Roads C and 2 (Figure PP.4). Surface elevations in the vicinity of the site range from approximately 69 to $89 \mathrm{~m}$ (225 to $285 \mathrm{ft}$ ). Three monitoring wells were installed at the Kato Road site to characterize the geologic and hydrogeologic conditions and to monitor the groundwater. Monitoring wells SSS 19 through SSS 21 were installed prior to any sludge application as required by SCDHEC as part of Industrial Waste Permit No. IWP-175 (July 2, 1980). Water-table elevations from the Kato Road Site monitoring wells since the fourth quarter of 1980 indicate that the depth to the water table has ranged from approximately 13.4 to $32.3 \mathrm{~m}$ across the application area. The groundwater flow direction is to the south. The site is located at SRP coordinates N 84000, E 40500.

The Lower Kato Road Site is a 50-acre area of loblolly pine trees planted in 1978. The site is located east of SRP Road 2 and approximately $2.1 \mathrm{~km}$ south of the intersection of SRP Roads 2 and C (Figure PP.4). Surface elevations in the vicinity of the site range from approximately 64 to $82 \mathrm{~m}$ $(210$ to $270 \mathrm{ft}$ ). The groundwater wells were installed at the Lower Kato Road site to characterize the geologic and hydrogeologic conditions and to monitor the groundwater. Monitoring wells SSS 4 through SSS 6 were installed prior to any sludge application as required by SCDHEC as part of the Industrial Waste Permit No. IWP-175 (July 2, 1980). Water-table elevations from the Lower Kato Road Site monitoring wells since the fourth quarter of 1980 indicate that the depth to the water table has ranged from approximately 9.8 to $20.1 \mathrm{~m}$ across the application area. The groundwater flow is to the northeast. The site is located at SRP coordinates N 83800 , E 40000 . 

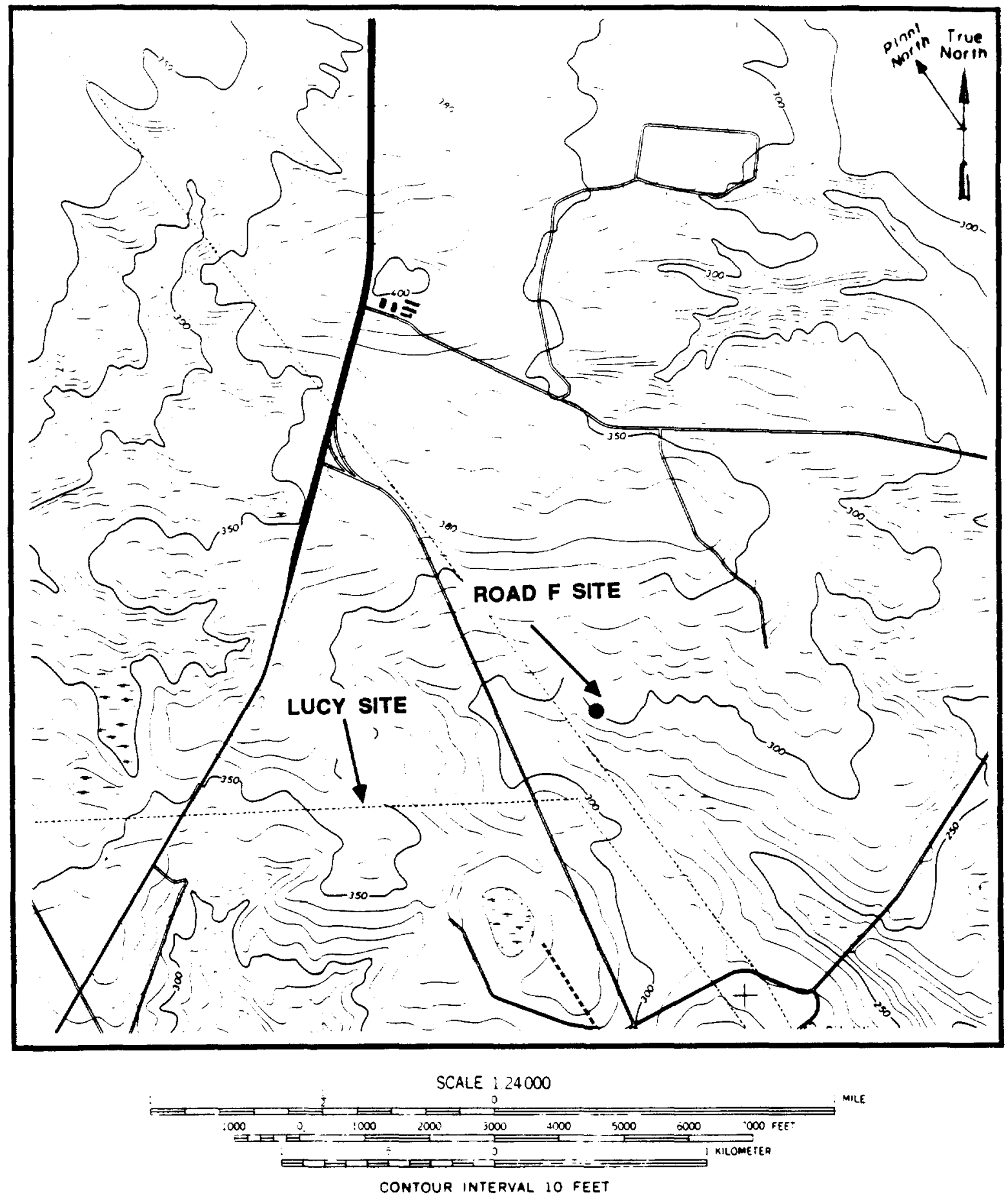

FIGURE PP.3. Location of the Road F and Lucy Sludge Application Sites on New Ellenton SW Quandrangle 7.5 Minute Series Topographic Map 

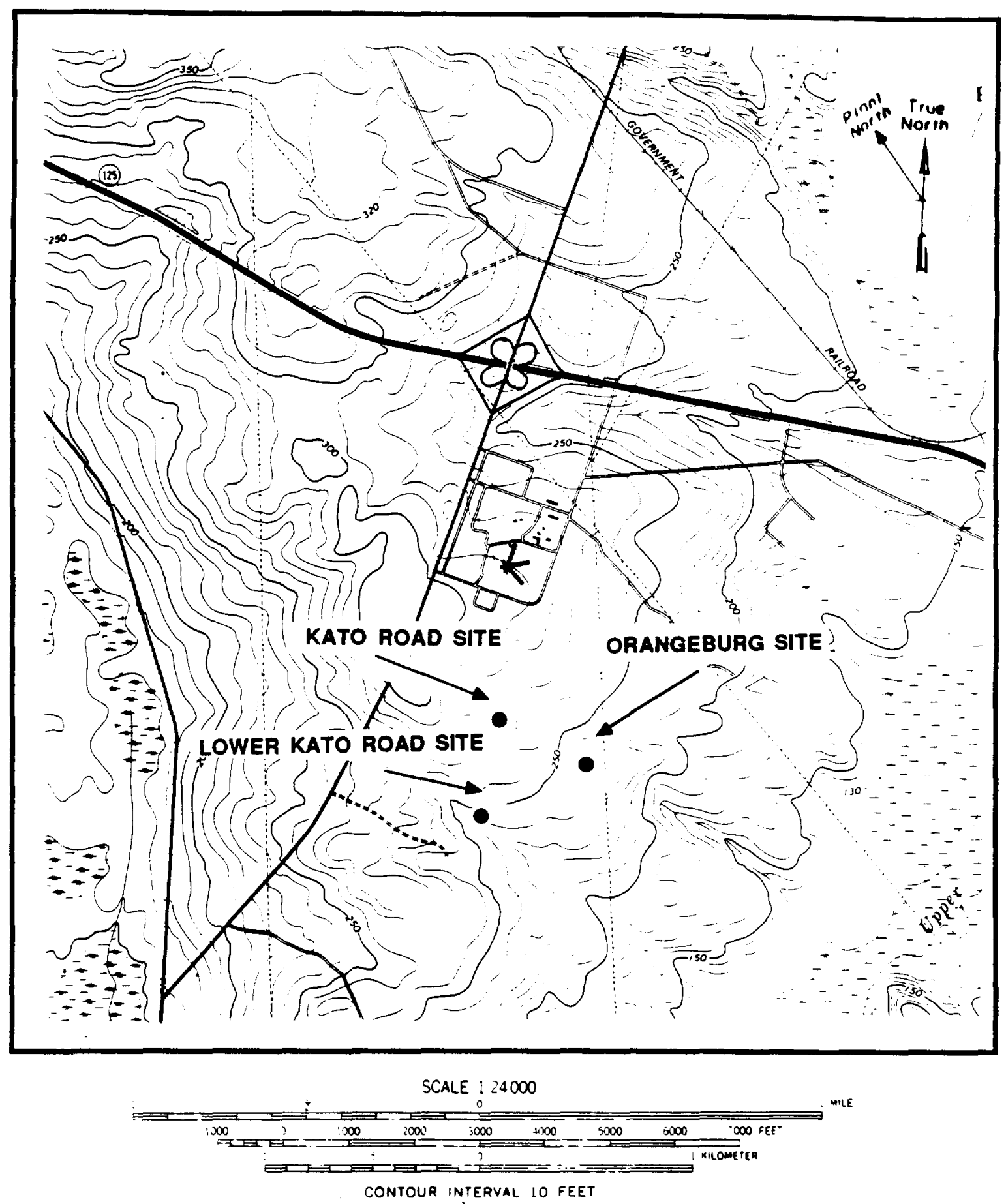

FIGURE PP.4. Location of the Kato Road, Lower Kato Road, and Orangeburg Sludge Application Sites on New Ellenton SW Quandrangle 7.5 kinute Series Topographic Map 
The Orangeburg Site is a 32-year-old stand of loblolly pine trees in a clayey-sand soil located approximately $610 \mathrm{~m}$ southeast of SRP Road 2 and approximately $1.6 \mathrm{~km}$ south of the intersection of SRP Roads 2 and $\mathrm{C}$ (Figure PP.4). Surface elevations in the vicinity of the site range from approximate 1 y 61 to $70 \mathrm{~m}$ (200 to $230 \mathrm{ft})$. Three monitoring wells were installed at the Orangeburg Site to characterize the geologic and hydrogeologic conditions and to monitor the groundwater. Monitoring wells SSS 7 through SSS 9 were installed prior to any sludge application as required by SCDHEC as part of the Industrial Waste Permit No. IWP-175 (July 2, 1980). Water-table elevations from the Orangeburg Site monitoring wells since the fourth quarter of 1980 indicate that the depth to the water table has ranged from approximately 13.4 to $20.1 \mathrm{~m}$. The groundwater flow direction is to the east. The site is located at SRP coordinates N 94800, E 58200.

The Par Pond Borrow Pit is located south of Par Pond and approximately 2.1 $\mathrm{km}$ north-northeast of the intersection of SRP Roads B and F (Figure PP.5). Surface elevations in the vicinity of the site range from approximately 66 to $70 \mathrm{~m}$ (215 to $230 \mathrm{ft}$ ). Three monitoring wells were installed at the Par Pond Borrow Pit to characterize the geologic and hydrogeologic conditions and to monitor the groundwater. Monitoring wells SSS 16 through SSS 18 were installed prior to any sludge application as required by SCDHEC as part of Industrial Waste Permit No. IWP-175 (July 2, 1980). Water-table elevations from the Par Pond Borrow Pit monitoring wells since the second quarter of 1980 indicate that the depth to the water table has ranged from approximately 1.5 to $3.0 \mathrm{~m}$. Groundwater flow is to the south-southwest.

The Road F Site is a 10-acre area of 1oblolly pine trees. The site is located directly east of SRP Road $F$ and approximately $1 \mathrm{~km}$ northeast of the intersection of SRP Roads F and F-2 (Figure PP.3). Surface elevations in the vicinity of the site range from approximately 88 to $96 \mathrm{~m}$ ( 290 to $315 \mathrm{ft}$ ). Three monitoring wells were installed at the Road F Site to characterize the geologic and hydrogeologic conditions and to monitor the groundwater. Monitoring wells SSS 22 through SSS 24 were installed prior to any sludge application as required by SCDHEC as part of Industrial Waste Permit No. IWP-175 (July 2, 1980). Water-table elevations from the Road F Site monitoring wells since the fourth quarter of 1980 indicate that the depth to the water table has ranged from approximately 13.4 to $18.3 \mathrm{~m}$ across the application area. The groundwater flow is to the northwest.

The Second Par Pond Borrow Pit is located southeast of Par Pond and just north of SRP Road B (Figure PP.5). Surface elevations in the vicinity of the site range from approximately 66 to $70 \mathrm{~m}(215$ to $230 \mathrm{ft})$. Three monitoring wells were installed at the Second Par Pond Borrow Pit to characterize the geologic and hydrogeologic conditions and to monitor the groundwater. Monitoring wells SSS 25 through SSS 27 were installed prior to any sludge application as required by SCDHEC as part of Industrial Waste Permit No. IWP-175 (July 2, 1980). Water-table elevations from the Second Par Pond Borrow Pit monitoring wells since the second quarter of 1984 indicate that the depth to the water table has ranged from approximately 1.5 to $15.2 \mathrm{~m}$ in the application area. The groundwater flow is to the southwest. 

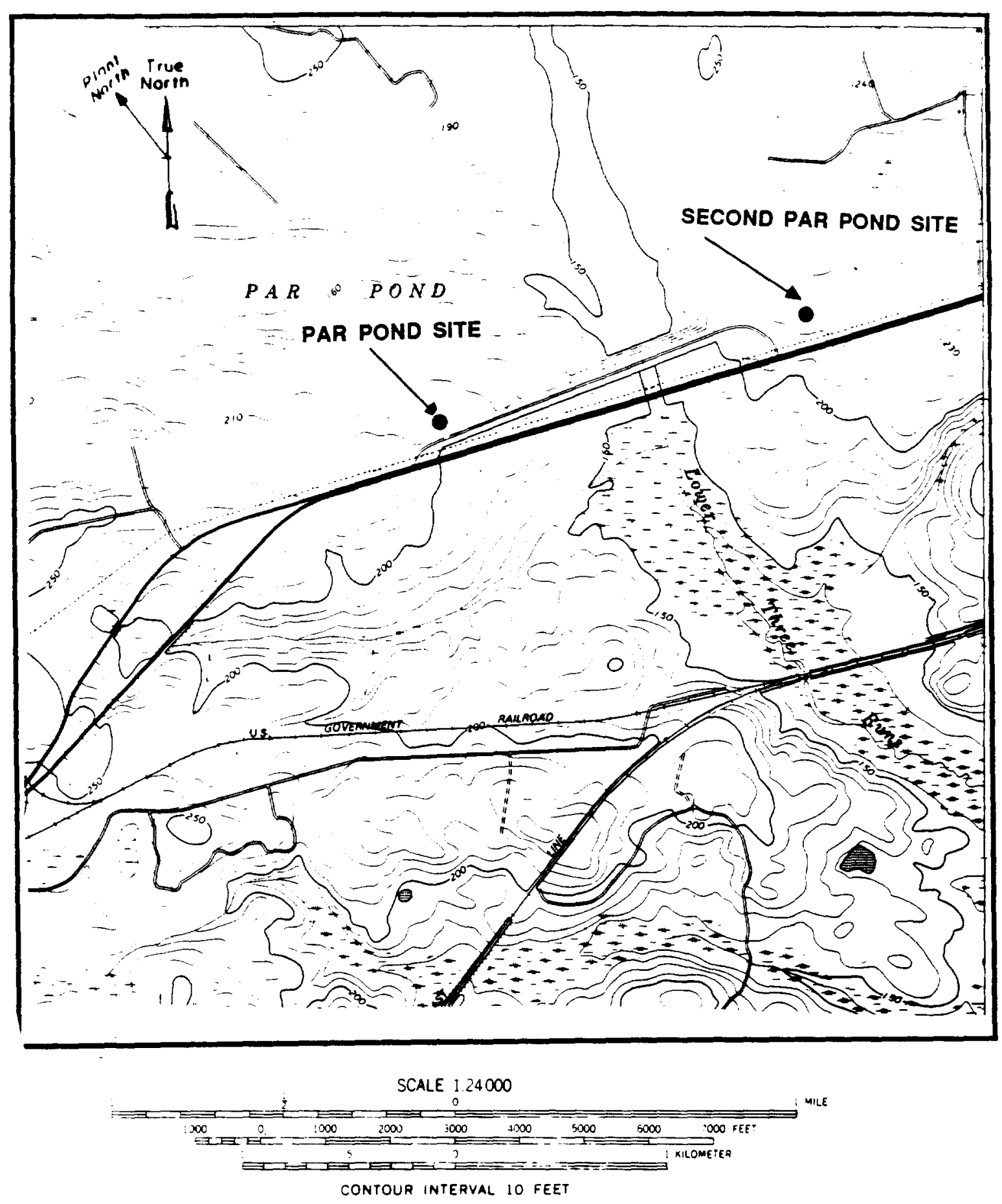

FIGURE PP.5. Location of the Par Pond and Second Par Pond Sludge Application Sites on Girard $\mathrm{NE}$ Quadrangle 7.5 Minute Series Topographic Map 


\section{Review of Available Data}

Following the well installations at the Sludge Application Sites, the permit required that groundwater samples be collected quarterly and analyzed for water depth, $\mathrm{pH}$, conductivity, and concentrations of nitrates (as $\mathrm{N}$ ), TDS, sodium, and chlorides. Additional well samples were to be collected annually and analyzed for orthophosphates, total Kjeldahl (organic) nitrogen (TKN), cadmium, copper, iron, nickel, lead, calcium, magnesium, manganese, and potassium.

The monitoring data from the wells at the Sludge Application Sites indicate that these sites have had no significant influence on local groundwater quality. Concentrations of the tested parameters in downgradient wells were consistent with levels reported for upgradient wells. Groundwater at these sites has been characterized by low dissolved chemical constituent levels compared to South Carolina and federal drinking water standards (Heffner et a1., in press).

\section{Characterization Recommendations}

\section{Sampling}

Based on the results from the monitoring wells at the Sludge Application Sites, no additional characterization is recommended. An additional well to replace abandoned well SSS 27 at the Second Par Pond Borrow Pit is recommended to comply with the sludge application permit.

\section{Chemical and Physical Analyses}

The new monitoring well should be sampled and analyzed annually for the parameters 1 isted in Appendix Table 6. 


\section{Background}

\section{Site History}

The Silverton Road Waste Site (Building 731-3A) was operated until 1974. No waste disposal records were kept, but at the time of closure the waste material was visually inspected and found to be metal shavings, construction debris, tires, drums, tanks, and possibly asbestos. In 1974 the site was bulldozed, graded, and vegetated. Presently the site is covered with soil and vegetation (Scott et a1., 1987a).

\section{Site Description}

The Silverton Road Waste Site is located in the northwest part of SRP on the southwest side of Road C-1.1, near Road 1 (Figure QQ.1). The nearest plant boundary is approximately $1.6 \mathrm{~km}$ northwest of the site. SRP

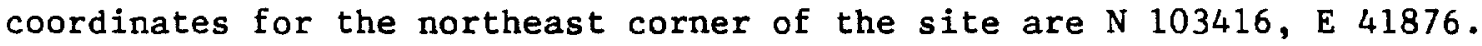
The site had dimensions of $62 \mathrm{~m}$ wide by $212 \mathrm{~m}$ long by $2 \mathrm{~m}$ high. Tota 1 volume was approximately $26,300 \mathrm{~m}^{3}$.

The Silverton Road Waste Site is located at an elevation of about $93 \mathrm{~m}$ (315 ft) on the escarpment of the Aiken P1ateau. Surface drainage at the site is to the southwest along a series of dry-wash tributaries into a broad swampy area that drains into the floodplain of the Savannah River about $2.4 \mathrm{~km}$ to the southwest. The site is approximately $67 \mathrm{~m}$ above the floodplain.

There are seven monitoring well clusters and nine individual monitoring wells in the vicinity of the Silverton Road Waste Site. Five individual wells and one well cluster are located within the boundaries of the waste disposal area. Four individual wells and four clusters are located downgradient of the waste site. Two well clusters are located upgradient of the waste site.

Groundwater flow is toward the southwest, as determined by studies of M-Area groundwater flow and water levels in the existing monitoring wells at the site (Scott et al., 1987a). Data from 1986 indicate that the depth to the water table is approximately $30 \mathrm{~m}$ (Zeigler et al., 1987). 

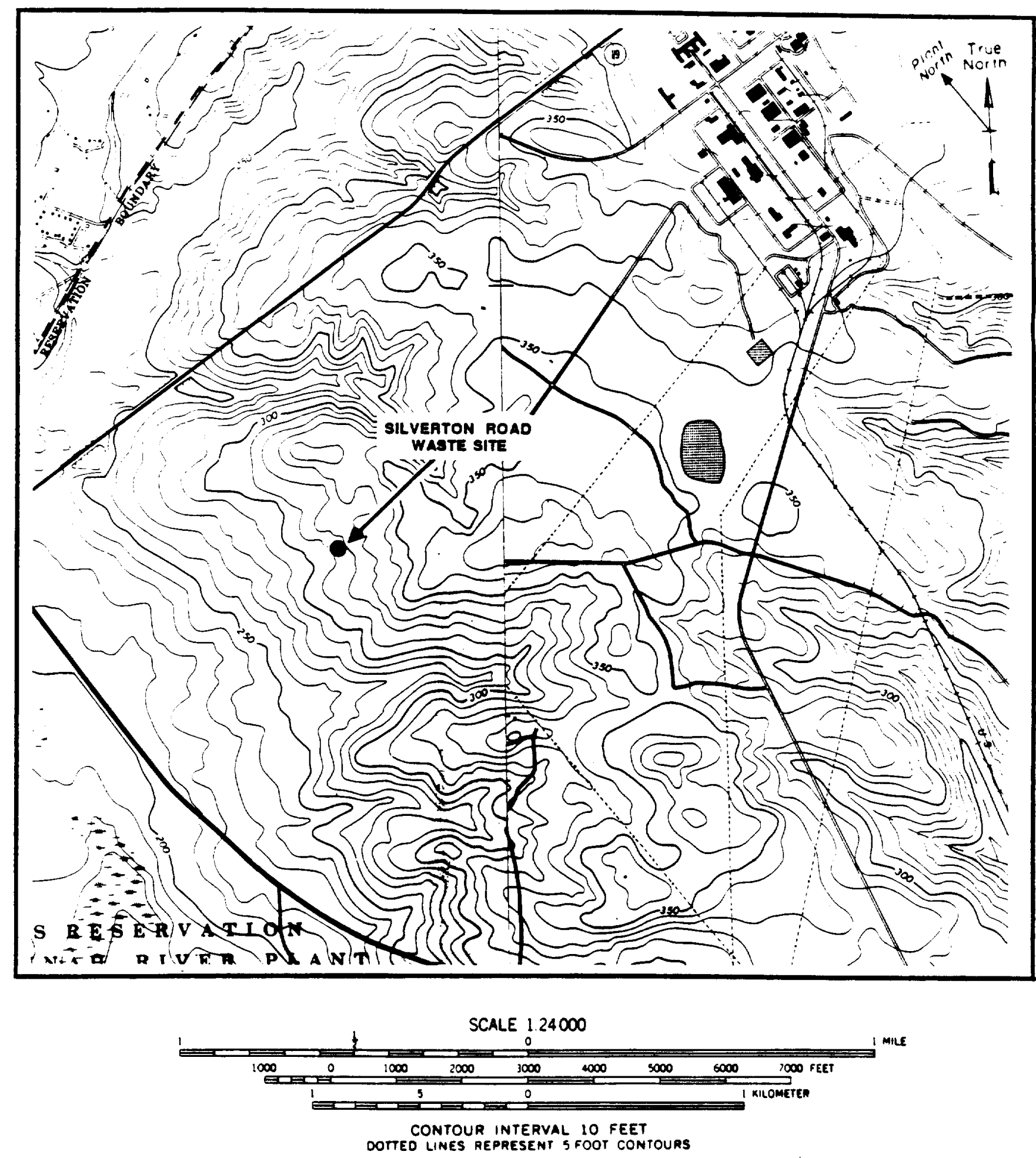

FIGURE 2Q.1. Location of the Silverton Road Waste Site on New Ellenton SW quadrangle 7.5 Minute Series Topographic Map 


\section{Review of Available Data}

Five soil cores within the waste disposal area were taken to a depth of $30 \mathrm{~m}$ in 1983. These cores were analyzed for VoCs. However, all the data collected were found to be invalid because laboratory blanks contained similar concentrations of VOCs.

TOH (up to $35 \mathrm{ug} / \mathrm{L}$ ) have been detected in a number of the monitoring wells (Mikol et al., in press; Zeigler et al., 1987). Most other constituents analyzed in the groundwater were found to be below groundwater quality review criteria (Appendix Table 10). Trichloroethylene, tetrachloroethylene, trichloromethane, and lead were found to be present in the groundwater at levels elevated above SRP background (Scott et a1., 1987a). Elevated levels of lead may, however, be related to water-collection or well-construction techniques. Lead in the groundwater does not exceed groundwater quality review criteria (Appendix Table 10).

A GPR survey was run at the site to determine if metal shavings buried in the pit could be detected. Several strong, discontinuous reflectors were identified at the site. The results suggest that GPR may be a good tool to identify the locations of buried concentrations of metal.

\section{Characterization Recommendations}

\section{Sampling}

A soil gas survey consisting of a grid of approximately 1,350 samples across the area of the site (one sample per $10 \mathrm{~m}$ ) is recommended. This survey will highlight the areas of greatest volatile organic contamination and provide information on the source term (Figure QQ.2).

Soil cores from within the boundaries of the waste site are needed. It is recommended that three soil cores of $6 \mathrm{~m}$ length and one core to the water table (approximately $30 \mathrm{~m}$ ) be taken from within the boundaries of the waste site. These cores should be used to determine the extent of contamination if any at the site. Samples for chemical analysis should be collected according to the parameters given in Appendix Table 1 . The locations of the proposed soil cores are shown in Figure QQ.3. The deep borehole should be geophysically logged for gamma, resistivity, porosity, and caliper. 


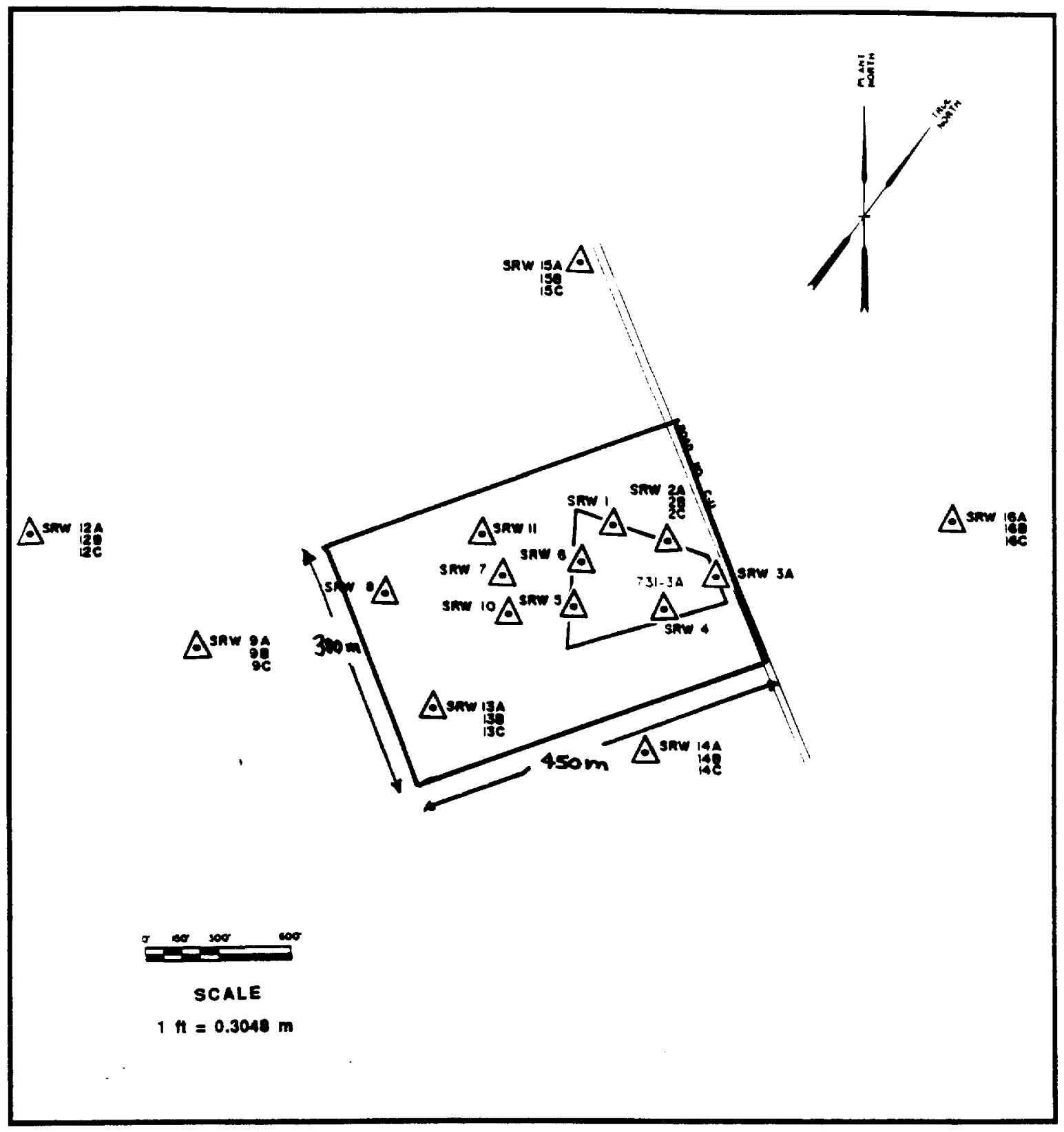

FIGURE QQ.2. Location of Proposed Soil Gas Survey at the Silverton Road Waste Site 
SILVERTON ROAD WASTE SITE

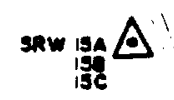

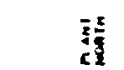

$\Delta^{\text {saw }}$

$\operatorname{sen} \theta A$
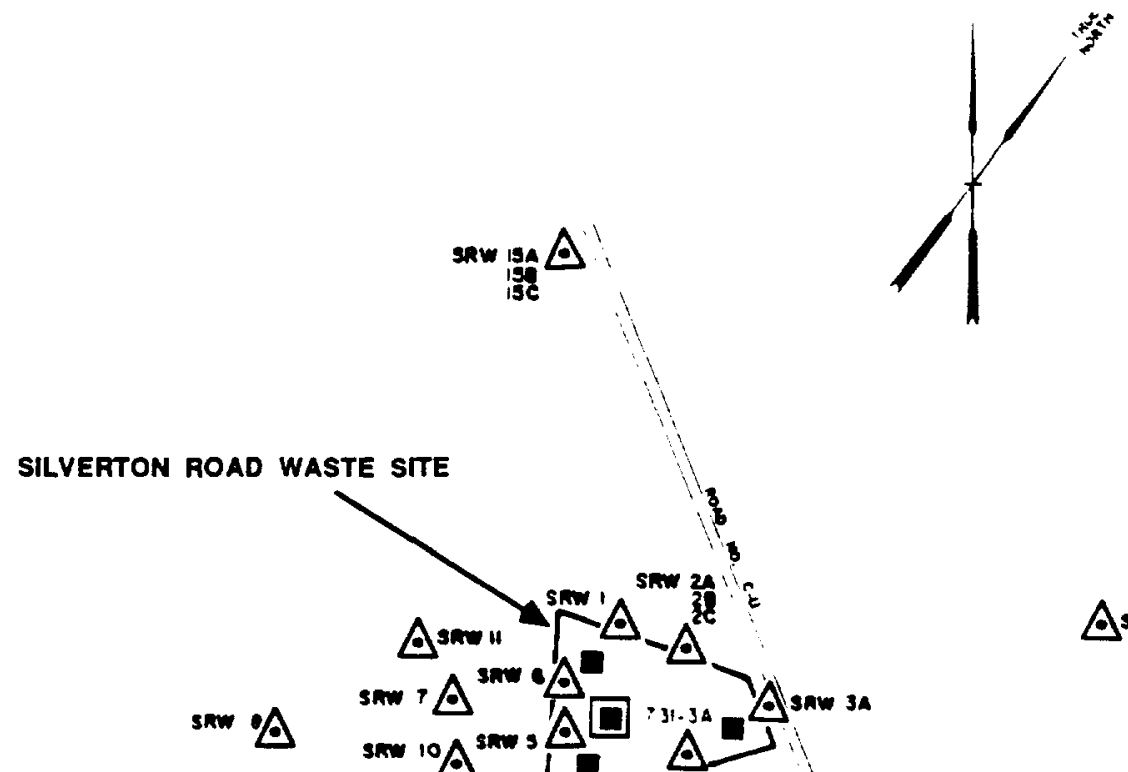

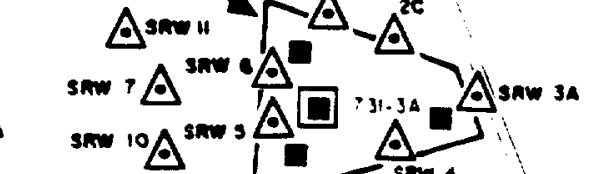

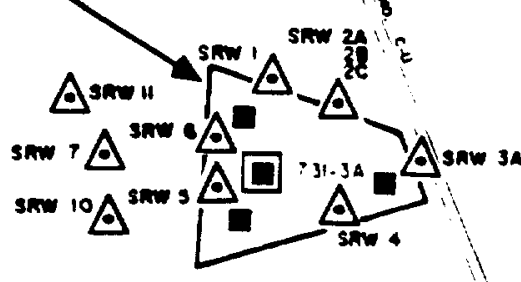

\section{$\Delta \sin 13$}

\section{$\Delta^{\text {sew inf }}$ int}

$\Delta \sin$

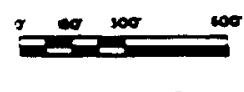

SCALE

$1 n=0.3048 \mathrm{~m}$

\section{LEGEND:}

$\triangle$ MONitorima Well

SOIL CORE

DEEP SOIL CORE

FIGURE 2Q.3. Existing Monitoring Wells and Proposed Sampling Locations at the Silverton Road waste Site 
Hydrogeological information for the site will be extrapolated from the nearby regional hydrogeological well cluster $P 30$.

\section{Chemical and Physical Analyses}

Soil samples should be analyzed according to the parameters outlined in Appendix Table 1. Specific analytes are VOCs (Appendix Table 3) and metals (Appendix Table 2). Groundwater samples should be analyzed according to the parameters 1isted in Appendix Tables 3 and 6 . 


\section{Background}

\section{Site History}

In 1953 an experimental evaporator containing approximately $590 \mathrm{~kg}$ of uranyl nitrate exploded at TNX. Because the SRP Radioactive Waste Burial Grounds were not yet in operation, debris from the explosion was collected and buried at the TNX Burying Ground (Building 643-5T). This debris included materials such as conduit, drums, tin, and structural steel. This waste disposal site also received other waste materials such as depleted uranium. No material was buried at the site after the SRP Radioactive Waste Burial Grounds were placed into operation later in 1953 (Dunaway et a1., 1987c).

Most of the material buried at TNX was excavated and sent to the SRP Burial Grounds from 1980 to 1984 . The remaining waste materials lie buried beneath asphalt, buildings, and transformer pads at depths of approximately 1.8 to $2.4 \mathrm{~m}$ below grade. An estimated $27 \mathrm{~kg}$ of uranyl nitrate remains buried at the site, constituting approximately $5 \%$ of the initial inventory buried.

\section{Site Description}

The TNX Burying Ground consists of three areas known to contain buried waste materials and a fourth suspected burial site. The three known sites are a trapezoidal area located beneath the transformer pad near Building 673-T, a rectangular area beneath Building 711-T, and an L-shaped area beneath office trailer Building 676-8T. A fourth suspected burial site is located east of Building 673-T. A diagram of the burial areas is shown in Figure RR.1. The SRP coordinates for the northeast corner of each burial area location are listed below:

Burial Site

Trapezoidal area

Rectangular area

L-shaped area

Suspected area
SRP Coordinates

N 71447 E 17229

N 71378 E 17190

N 71268 E 17231

N 71472 E 17395 


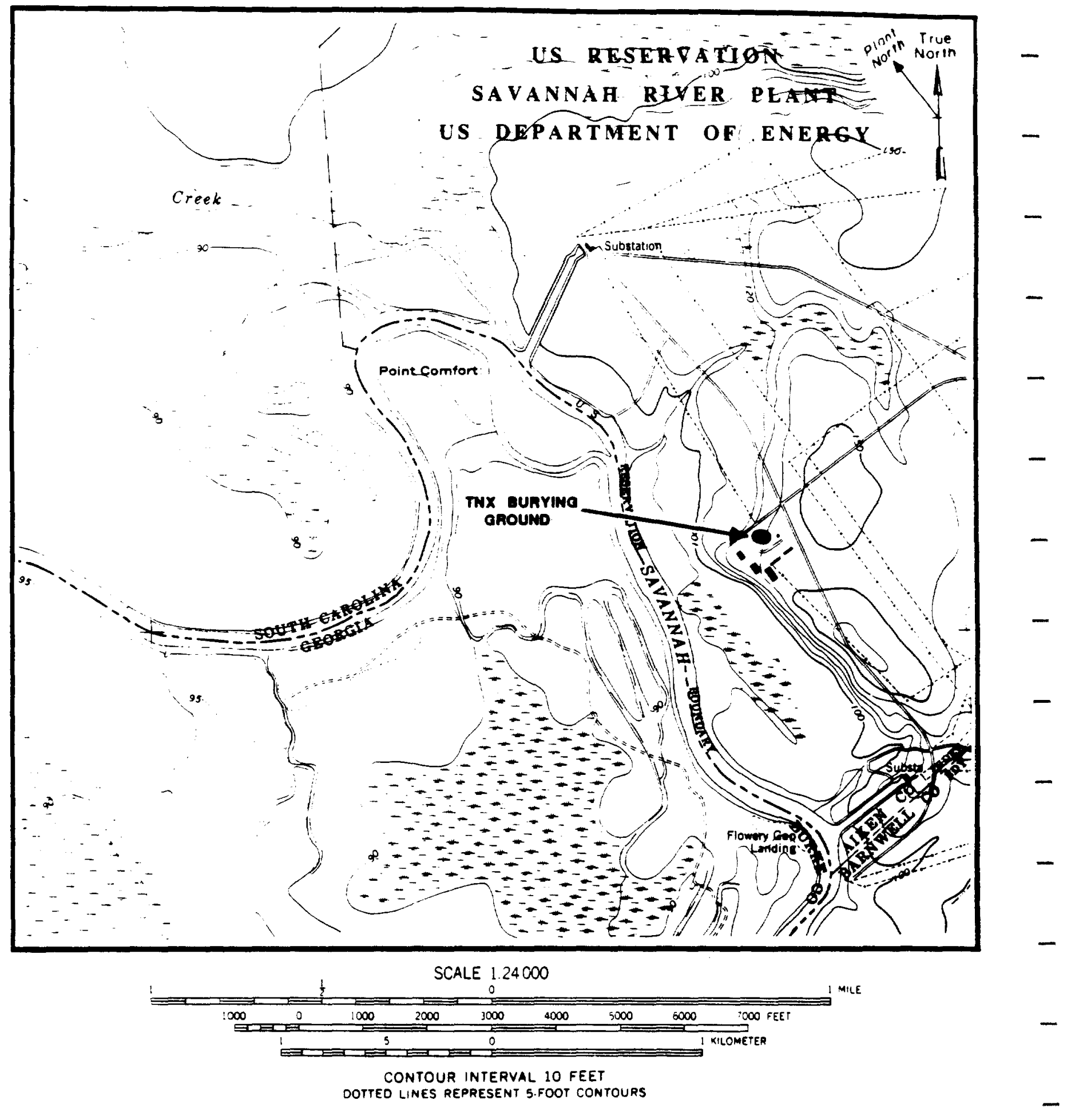

FIGURE RR.1. Location of the TNX Burying Ground on Shell Bluff Landing Quadrangle 7.5 Minute Series Topographic Map 
The TNX Burying Ground is located at an elevation of about $45 \mathrm{~m}$ (148 ft) on a bluff above the Savannah River swamp (Figure RR.2). The water table in the vicinity of the Burying Ground is found within the McBean and Congaree formations at an elevation of approximate $1 \mathrm{y} 30 \mathrm{~m}$. Natural discharge for the water-table aquifer is to the Savannah River swamp. No groundwater monitoring wells exist in the immediate vicinity of the Burying Ground.

Review of Available Data

No soil or groundwater samples have been analyzed from the TNX Burying Ground.

Characterization Recommendations

\section{Sampling}

It is recommended that one soil core sample be taken as close as possible to the center of each of the burial or suspected burial areas (Figure RR.3). The sediment cores should be taken to a total depth of $6 \mathrm{~m}$. The sediment cores should be subdivided into the sampling intervals given in Appendix Table 1.

\section{Chemical and Physical Analyses}

Chemical analyses for the sediment samples should include inorganics, ions, and metals as given in Appendix Table 2. 


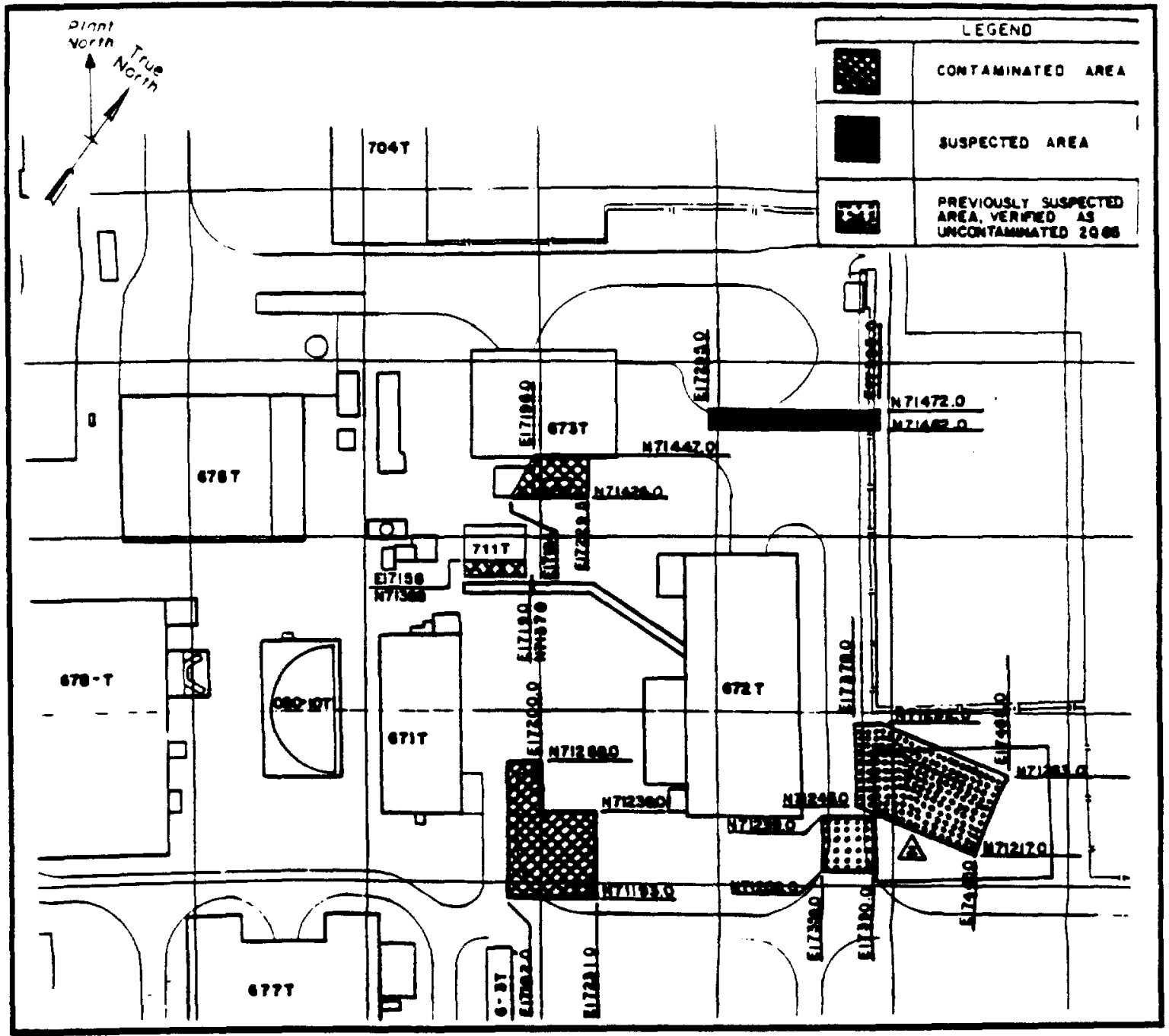

FIGURE RR.2. Location of the Burial Sites at the TNX Burying Ground 


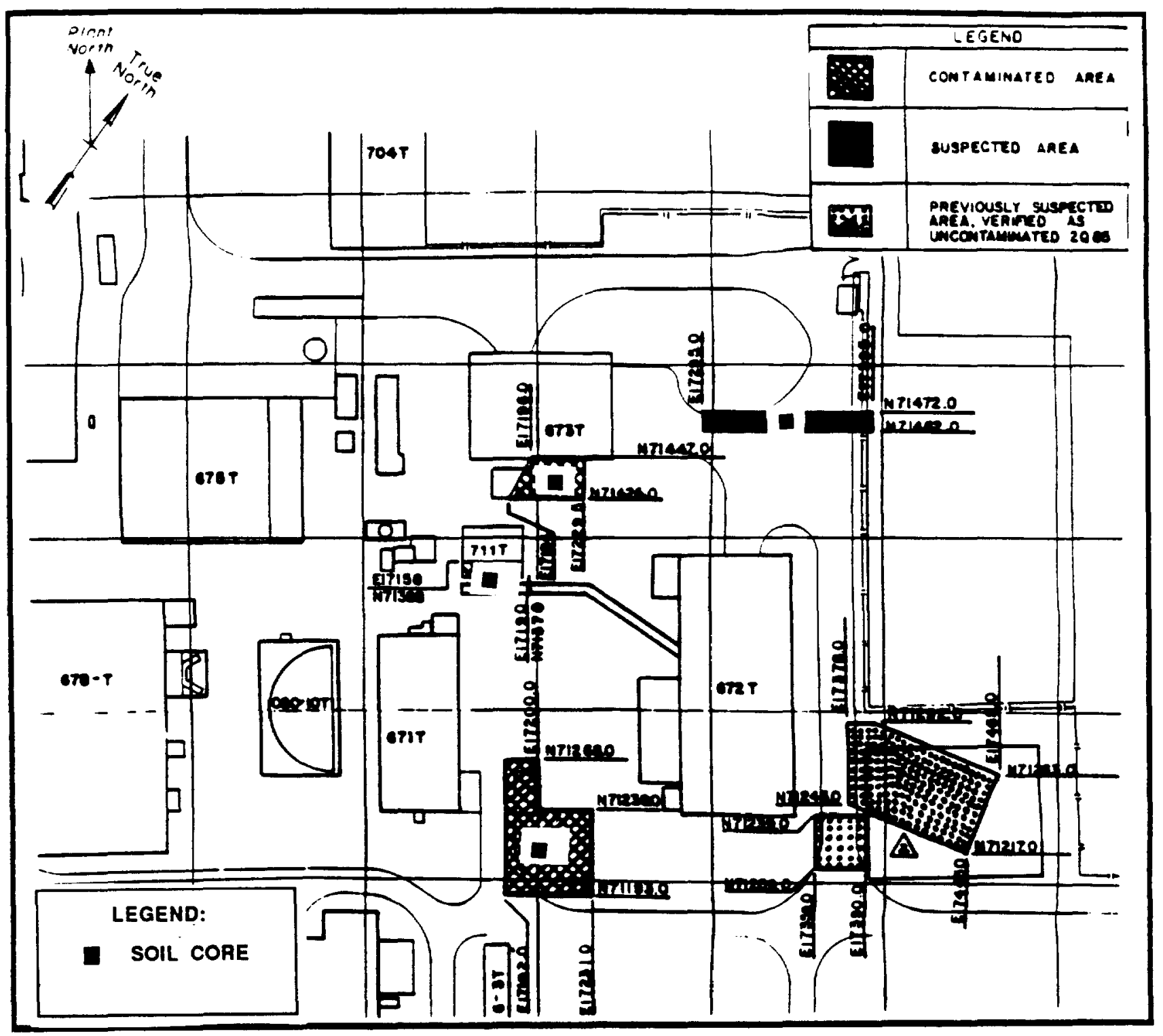

FIGURE RR.3. Proposed Sampling Locations at the TNX Burying Ground $R R-5$ 
WASTE OIL BASINS

\section{Background}

Site History

The Motor Shop Oil Basin (Building 904-101G), located in A Area at SRP, was constructed and placed in service in 1977 to receive liquid waste from the 716-A Motor Shop oil/water separator. Effluent discharges from the Motor Shop included wastewater with trace amounts of engine oil, grease, kerosene, ethylene glycol, and soapy water (Huber et al., 1987b). The 1iquid wastes seeped naturally into the soil beneath the basin. In August 1983, all discharges to the oil basin were terminated.

The D-Area 0il Basin (Building 631-G) is located near the major coal-fired power production facility at SRP. The basin was constructed in 1952 and began receiving waste oil products from $D$ Area that were unacceptable for incineration in the powerhouse boilers (Huber et al., 1987b). These waste oils may have contained hydrogen sulfide, chlorinated organics, and other chemicals. In 1975 the basin was closed and backfilled with soil.

\section{Site Description}

The Motor Shop 0 il Basin is located south of the railroad tracks and adjacent to Building 715-A. The sloping banks of the railroad tracks constitute one side of the basin. The other three sides are constructed of an earthen berm approximately $2 \mathrm{~m}$ high. The Motor Shop is located approximately $2.5 \mathrm{~km}$ to the southeast of the nearest plant boundary. The approximate northeast corner coordinates of the basin are N 102087, E 50762. The dimensions of the Motor Shop 0il Basin are $63.1 \mathrm{~m}$ by $10.7 \mathrm{~m}$ by $2 \mathrm{~m}$ in depth.

The Motor Shop 0il Basin is located at an elevation of about $107 \mathrm{~m}$ $(350 \mathrm{ft}$ ) (Figure SS.1). The ground slopes fairly steeply in the direction of Tims Branch, the closest natural surface water drainage located approximately $1,220 \mathrm{~m}$ east at an elevation of about $67 \mathrm{~m}$. Two groundwater monitoring wells (AOB 1 and 2) were installed in May 1983 to characterize the geologic and hydrogeologic conditions and to monitor the water-table elevation and groundwater quality in the vicinity of the basin. The depth to the water table is approximately $32 \mathrm{~m}$. Groundwater flow direction is difficult to determine due to the $f$ lat nature of the water table in this area and the nearly identical water levels in the two area wells. It is believed, however, that the basin is located in the vicinity of a groundwater divide.

The D-Area Oil Basin in located north of D Area and south of Road A-4.4, approximately $3 \mathrm{~km}$ to the east of the nearest plant boundary. The approximate northeast corner coordinates of the basin are $\mathrm{N} \mathrm{68543,} \mathrm{E} \mathrm{23769.} \mathrm{The} \mathrm{D-Area}$ 0il Basin measures $116.7 \mathrm{~m}$ by $16.4 \mathrm{~m}$ by $2 \mathrm{~m}$ in depth. The basin is located at an elevation of about $46 \mathrm{~m}$ (150 ft) (Figure SS.2). Physiographically, the 

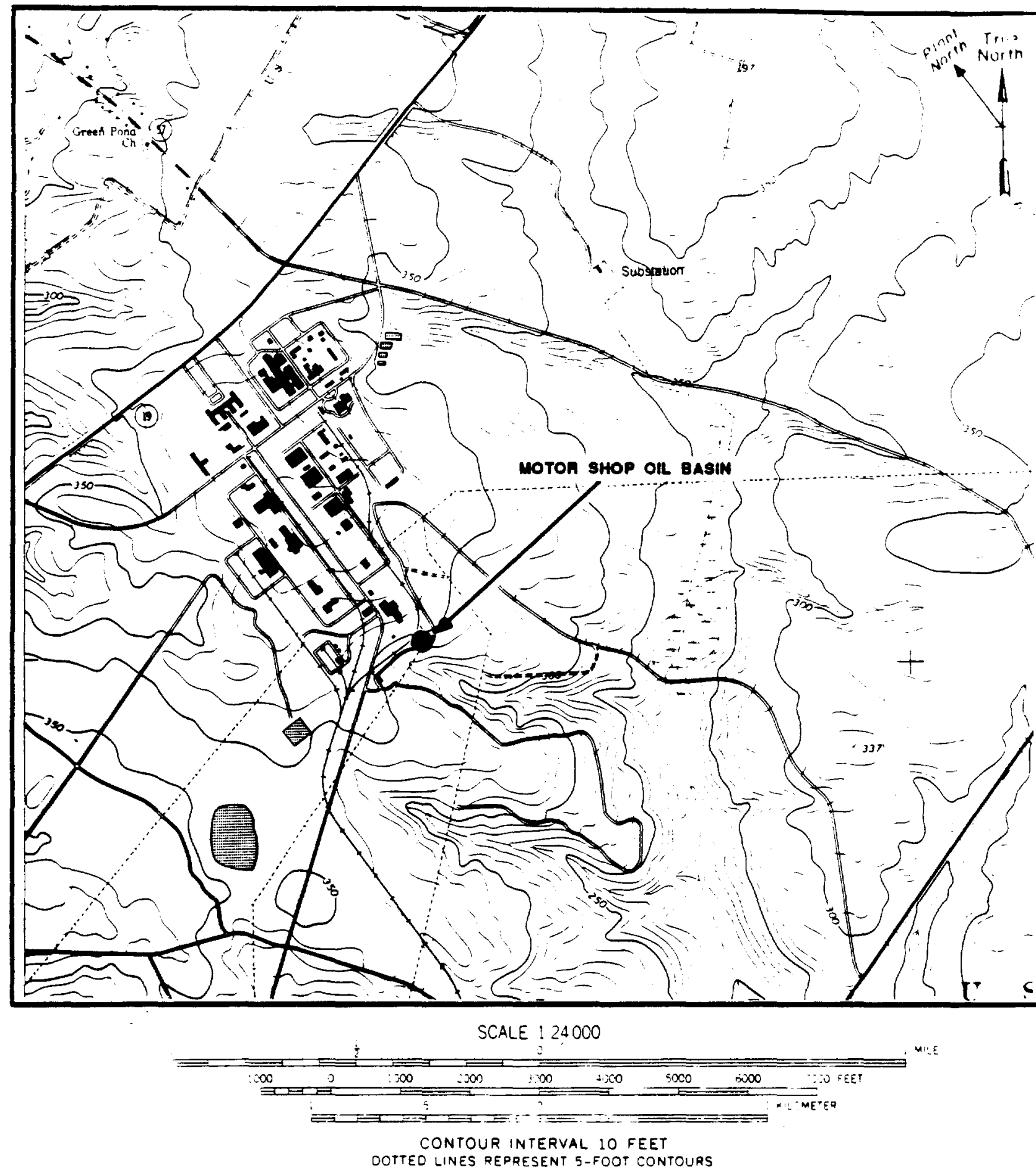

FIGURE SS.1. Location of the Motor Shop Oil Basin on New Ellenton SW quadrangle 7.5 Minute Series Topographic Map 


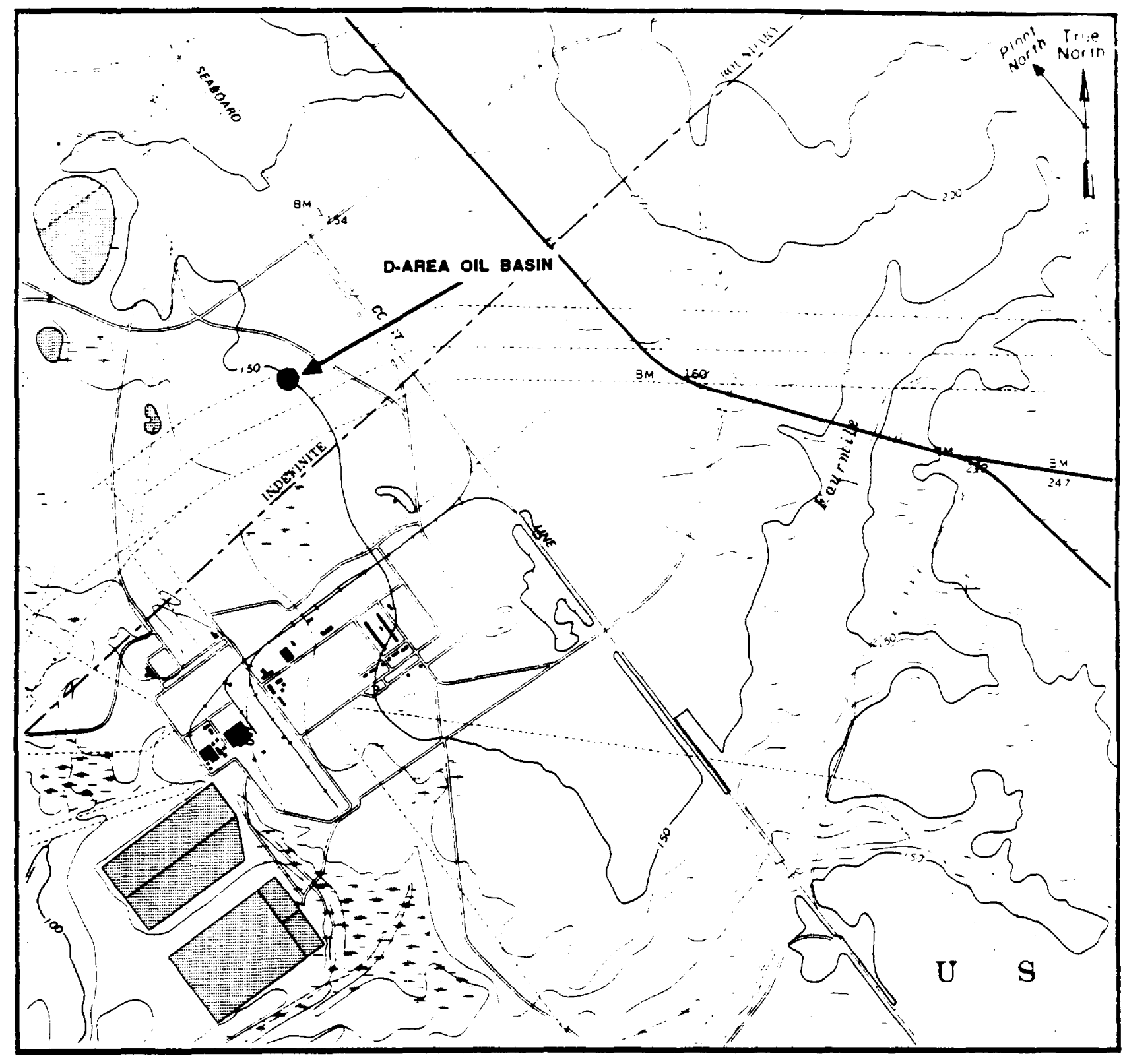

SCALE 124000

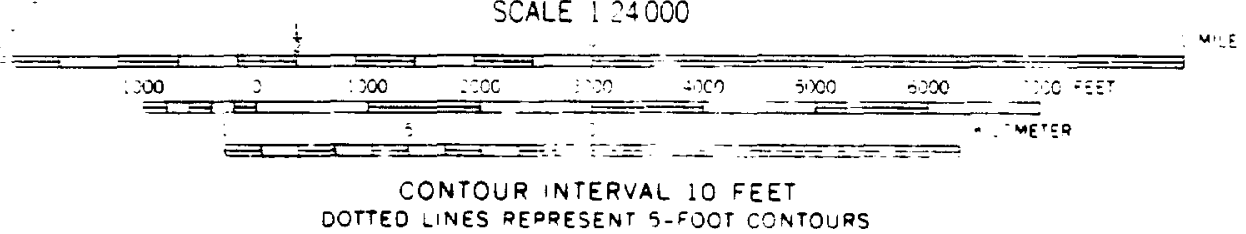

DOTTEO LINES REPRESENT 5-FOOT CONTOURS FIGURE SS.2. Location of the D-Area Oil Basin on Girard NW
Quadrangle 7.5 Minute Series Topographic Map 
basin is located on the Ellenton Plain, the highest of three step-1ike topographic surfaces between the Savannah River to the west and the Aiken Plateau to the east. The major surface drainage is the Savannah River and associated swamps, located approximately $2,100 \mathrm{~m}$ to the west. Four monitoring wells (DOB 1 through DOB 4) were installed to characterize the geologic and hydrogeologic conditions and to monitor the water-table elevation and groundwater quality in the vicinity of the basin. The depth to the water table is approximately $3 \mathrm{~m}$, and groundwater flow is to the west.

\section{Review of Available Data}

A liquid sample taken from the Motor Shop 0il Basin was analyzed for acid-base/neutral organics, volatile organics, EP toxicity parameters, metals, oil and grease, kerosene, ethylene glycol, pH, conductivity, and flashpoint. Results of the EP toxicity metal analyses indicate that metal concentrations were less than RCRA criteria (40 CFR 261.24). Trace quantities of ethylene glycol, kerosene, and oil were found. Most of the acid-base/neutral organics detected were measured at or below analytical detection limits (Huber et al., 1987b).

Groundwater samples from wells $A O B 1$ and $A O B 2$ were below the groundwater quality review criteria in Appendix Table 10 for dissolved chemical constituents and radioactivity with the exception of trichloroethylene, endrin, and chromium in well $\mathrm{AOB} 1$ (Heffner et al., in press). Trichloroethylene levels in well AOB $1(0.006$ to $0.0465 \mathrm{mg} / \mathrm{L})$ exceeded the drinking water standard of $0.005 \mathrm{mg} / \mathrm{L}$ on four occasions. Chromium levels in well AOB $1(<0.004$ to $0.055 \mathrm{mg} / \mathrm{L})$ exceeded the groundwater quality criteria in Appendix Table 10 in a single, isolated excursion.

Conductivity levels ranged from 29 to $51 \mu$ mhos/cm in we11 AOB 1 and from 22 to $42 \mu$ mhos/cm in well AOB 2. TOC levels in wells $A O B 1$ and $A O B 2$ remained less than $9.24 \mathrm{mg} / \mathrm{L}$ except for a single value of $16.6 \mathrm{mg} / \mathrm{L}$ reported in well $A O B$ 1. TOH ranged from 0.072 to $0.260 \mathrm{mg} / \mathrm{L}$ in well $A O B 1$ and from $<0.005$ to $0.027 \mathrm{mg} / \mathrm{L}$ in well $\mathrm{AOB} 2$. Groundwater $\mathrm{pH}$ ranged from 4.0 to 5.2 in the site wells, which is consistent with $\mathrm{pH}$ values reported as naturally occurring in the Barnwell Formation (Heffner et al., in press).

The contents of the D-Area Dil Basin have not been characterized. Comparisons of groundwater monitoring data between the D-Area 0il Basin wells indicate that the basin has had an influence on groundwater quality in the vicinity of we11 DOB 1 . This influence is indicated by the elevated conductivity and TOC levels reported for this well compared to the levels reported for the remaining site wells. Conductivity in well DOB 1 ranged from 96 to $350 \mu \mathrm{mhos} / \mathrm{cm}$. These conductivity values were consistently higher than the conductivity levels reported for wells DOB 2 
through DOB 4 (26 to $77 \mu \mathrm{mhos} / \mathrm{cm}$ ) and the SRP background value of 50.0 umhos/cm. TOC levels in well DOB $1(2.0$ to $18.20 \mathrm{mg} / \mathrm{L})$ were generally higher than the TOC levels reported for wells DOB 2 through DOB 4 (below $7.0 \mathrm{mg} / \mathrm{L}$ ) (Heffner et al., in press).

Groundwater samples from all four site monitoring wells were below the groundwater quality review criteria in Appendix Table 10 of the Appendix except for iron excursions in wells $D O B$, DOB 2, and DOB 3 and manganese and trichloroethylene excursions in wells DOB 1 and DOB 2 . Iron levels in wel1s DOB $1(0.017$ to $0.554 \mathrm{mg} / \mathrm{L})$, DOB $2(0.076$ to $0.982 \mathrm{mg} / \mathrm{L})$, and DOB 3 $(0.017$ to $0.848 \mathrm{mg} / \mathrm{L}$ ) were above the drinking water standard (Heffner et al., in press). Iron levels in these ranges are consistent with iron levels reported as naturally occurring in the Barnwell Formation. Manganese levels in wells DOB $1(0.003$ to $0.074 \mathrm{mg} / \mathrm{L})$ and DOB $2(0.009$ $\mathrm{mg} / \mathrm{L}$ to $0.053 \mathrm{mg} / \mathrm{L}$ ) were above the groundwater quality criteria of Appendix Table 10 in an isolated occurrence for each well. Trichloroethylene levels in wel1s DOB $1(0.009 \mathrm{mg} / \mathrm{L})$ and DOB 2 $(0.037 \mathrm{mg} / \mathrm{L})$ were over the groundwater quality review criteria in Appendix Table 10 in October 1986. Groundwater pH ranged from 4.2 to 6.6 at the site wells. This $\mathrm{pH}$ range is generally consistent with $\mathrm{pH}$ values reported as naturally occurring in the Barnwell Formation (Heffner et al., in press).

\section{Characterization Recomendations}

\section{Sampling}

Three sediment cores should be taken inside the Motor Shop Oil Basin, and three sediment cores should be taken inside the D-Area Oil Basin (Figures SS.3 and SS.4) A11 cores should be $6 \mathrm{~m}$ in length, extending from the bottom of the original basins. The cores should be subdivided into the sampling intervals given in Appendix Table 1 and shipped to an offsite laboratory for analysis. If hydrogeologic data is needed at the D-Area Oil Basin for modeling work, a deep core has been recommended at the D-Area Coal Pile Runoff Containment Basin to be used for all D-Area waste sites.

Because there are only two monitoring wells at the Motor Shop 0il Basin, it is recommended that two additional wells be drilled to the water table to adequately define groundwater flow and direction and the effects of the basin's operation on groundwater quality (Figure SS.3). One of the monitoring wells should be cored continuously, described geologically, and archived. Both monitoring wells should be logged geophysically for gamma, resistivity, porosity, and caliper.

\section{Chemical and Physical Analyses}

The sediment cores from the basins should be measured for the inorganic ions and metals in Appendix Table 2. In addition to inorganic ions and metals analyses, the top $0.25-\mathrm{cm}$ interval along with sediment 


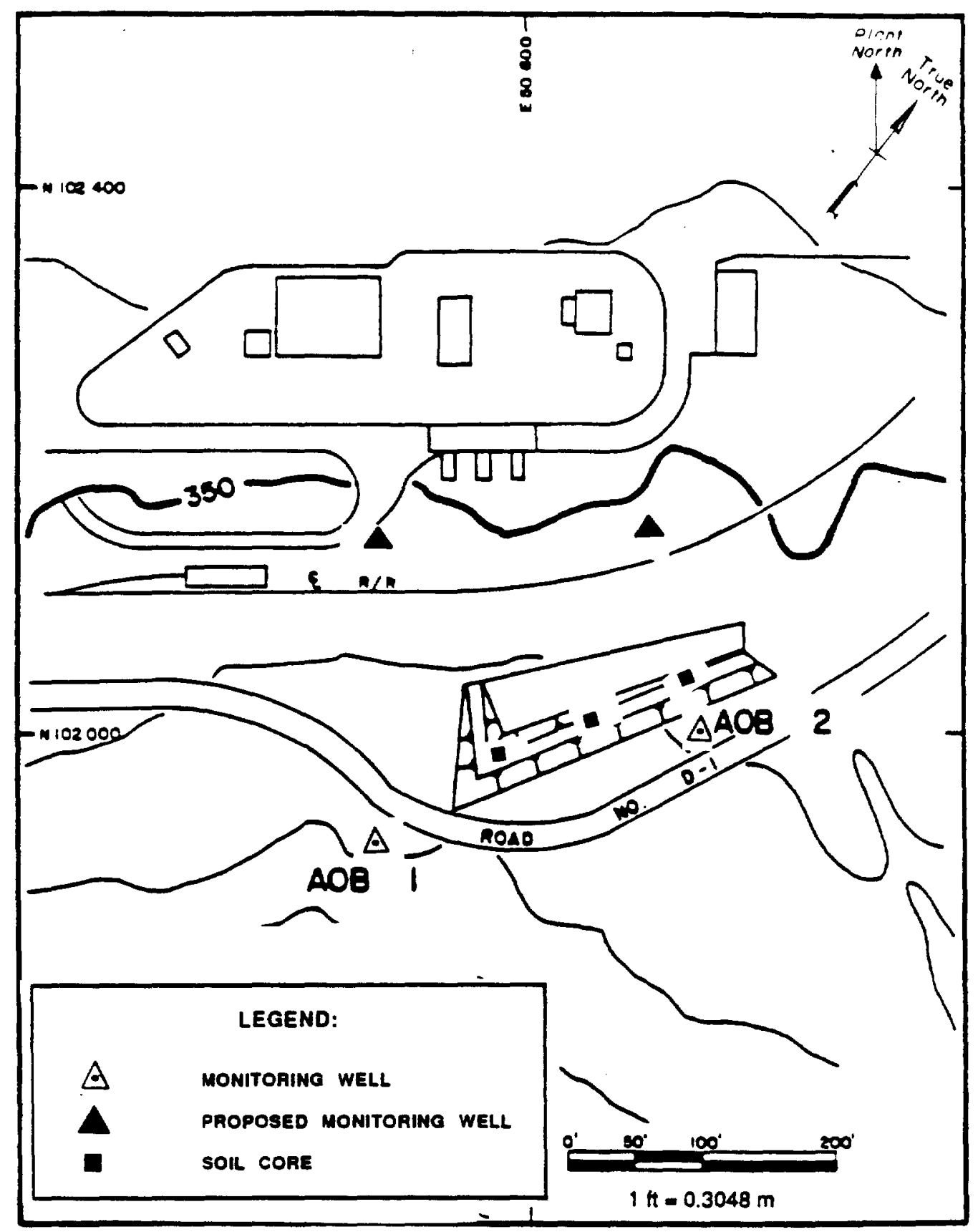

FIGURE SS.3. Proposed Monitoring Well and Sampling Locations for the Motor Shop Oil Basin 


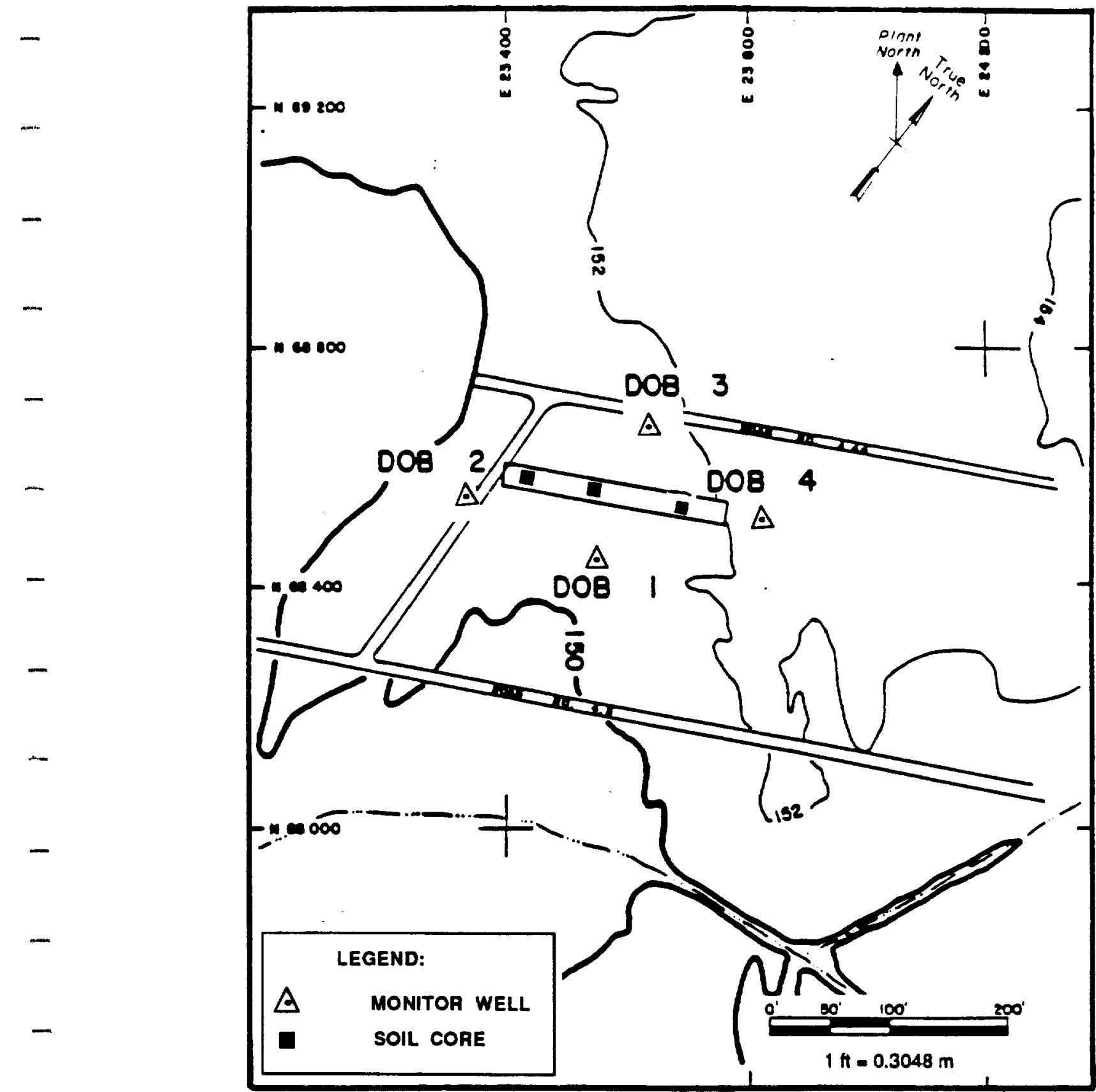

FIGURE SS.4. Proposed Sampling Locations for the D-Area Oil Basin 
samples from the $1,2,3,4,5$, and $6-m$ sample intervals will be tested for the organic compounds in Appendix Table 3 . The top $0.25-\mathrm{cm}$ of sediment below the bottom of the basin should also be sampled for EP toxicity and EPA Appendix IX as listed in Appendix Tables 7 and 8. The sediment from these cores should be analyzed for the same parameters as the basins sediment samples.

The approximate 1ocations of the proposed monitoring wells are indicated on Figure SS.3. In addition, geophysical $\operatorname{logs}$ should be taken at one of the wells to better define the sediment beneath the basin. The wells should be sampled quarterly as part of the Health Protection Department groundwater monitoring program and analyzed for the parameters in Appendix Table 8. 


\title{
Alpha Particle
}

A positively charged particle emitted during radioactive decay. An alpha particle consists of two protons and two neutrons and is identical to a helium nucleus.

\section{Ambient Water-Quality Criteria}

Concentrations set to protect human health and the environment for a range of inorganic and organic constituents. These are based on chronic and acute toxicity studies, bioconcentration factors, and human consumption of water and biota.

\section{Anion}

A negatively charged ion.

Aquifer

A saturated, mappable body of rock (including unconsolidated sediments) that can transmit significant quantities of water under ordinary hydraulic gradients; the water can be pumped to the surface through a well or it can emerge naturally as a spring.

\section{Aquitard}

A less permeable bed, or zone, in a hydrostratigraphic sequence.

ASTM

American Society for Testing and Materials.

\section{Backfill}

Material such as stone, clean rubble, or soil that is used to refill an excavation.

\section{Bedrock}

A general term for the rock that underlies soil and other unconsolidated surface material.

\author{
Glossary-1
}




\section{Beta Particle}

An elementary particle emitted from a nucleus during radioactive decay; it is negatively charged, identical to an electron, and easily stopped, as by a thin sheet of metal.

\section{Calcareous Zone or Formation}

A stratigraphic unit composed largely of calcium carbonate (calcite or limestone).

\section{Carolina Bay}

Any of the various shallow, oval or elliptical, generally marshy depressions in the Atlantic Coastal plain. These range from about $100 \mathrm{~m}$ to several kilometers in diameter and often contain vegetation that is different than the surrounding area. Their origin is unknown. In this document, the term Carolina Bay is applied to all upland depressions providing characteristic wetland habitat.

\section{Cation}

A positively charged ion.

CFR

Code of Federal Regulations.

\section{Concentration}

The quantity of a substance contained in a unit quantity of a sample (e.g., mg/L or $\mu \mathrm{g} / \mathrm{g}$ ).

\section{Confining Unit}

A mappable body of rock (including unconsolidated sediments) that has significantly lower permeability than the adjacent aquifer and serves as an aquitard between water-bearing zones.

CPRB

Coal Pile Runoff Containment Basin. 


\section{Curie $(\mathrm{Ci}\rangle$}

A unit of radioactivity equal to $3.7 \times 10^{10}$ ( 37 billion) disintegrations per second; also a quantity of any nuclide or mixture of nuclides having 1 curie of radioactivity.

\section{Decay, Radioactive}

The spontaneous transformation of one nuclide into a different nuclide or into a different energy state of the same nuclide; the process results in the emission of nuclear radiation (alpha, beta, or gamma radiation).

\section{Defense Waste Processing Facility (DWPF)}

Facility designed to process high-level defense waste into a suitable form for permanent storage or disposal; under construction at SRP.

\section{Dip}

The angle that a structural surface (e.g., a bedding or fault plane) makes in relationship to a horizontal line.

DOC

Dissolved Organic Carbon.

DOE

United States Department of Energy.

\section{Downgradient}

A location that has a lower hydraulic head than a reference location. Water flows downgradient, i.e., from higher hydraulic head toward lower hydraulic head.

\section{DWPF}

Defense Waste Processing Facility. 


\section{Effluent}

A 1 iquid waste discharged into the environment, usually into surface streams.

EID

Environmental Information Document (a technical support document related to environmental activities).

EIS

Environmental Impact Statement.

\section{Environmental Impact Statement}

A document prepared pursuant to Section 102(2) (c) of the National Environmental Policy Act (NEPA) of 1969 for a major Federal action significantly affecting the quality of the human environment.

\section{Environmental Transport}

The movement of a substance through the environment; includes the physical, chemical, and biological processes.

\section{EP Toxicity Test}

Extraction Procedure Toxicity Test. A leach test defined by EPA in 40 CFR 261 to determine if a waste is toxic. A new test method (TCLP, toxicity characteristic leach procedure) has recently been proposed by EPA.

EPA

United States Environmental Protection Agency.

\section{Fal1 Line}

Imaginary line where rivers in an area drop steeply from the uplands to the lowlands. Near SRP, the Fall Line marks the boundary between the ancient and resistant rocks of the Piedmont Plateau and the younger and softer sediments of the Atlantic Coastal Plain. 


\section{Geophysical Techniques}

A survey based on one or more measurements of the physical properties of the earth. These geophysical measurements include temperature, heat flow, magnetic/gravity field strength, seismic reflection/refraction, electromagnetic resistivity/conductivity, and radioactivity.

GPR

Ground Penetrating Radar.

Groundwater, Ground Water

Water that is present in the pores and fractures beneath the earth's surface.

\section{Ground Penetrating Radar}

A surface geophysical technique that uses high frequency electromagnetic signals (radio waves) to identify shallow $(<15 \mathrm{~m}$ ) underground features based on contrasts in electrical properties. Signals reflected to the surface indicate subsurface objects, edges of backfilled disposal basins, or saturated features.

\section{Hydraulic Conductivity}

A measure of the ease with which water can be transmitted through a porous material. Water flow rate in volume per unit time through a unit cross-section under a unit hydraulic gradient.

\section{Hydraulic Gradient}

The difference in hydraulic head per unit distance between two locations.

\section{Hydraulic Head}

A measure of the elevation and pressure at a point in a saturated medium. This is often measured as the elevation of standing water in a tube that is slotted in the interval of interest. 


\section{Hydrograph}

Graph of a measurement of a water system (such as velocity, flow, or elevation) in relation to time.

\section{Hydrology}

The science dealing with the properties, distribution, and circulation of natural water systems.

\section{Hydrostratigraphic Unit}

A body of rock or sediment that is related by a continuity of hydrologic properties (e.g., permeability) rather than the properties associated with traditional stratigraphic nomenclature (e.g., depositional environment and age). The geologic framework for a reasonably distinct hydrologic system.

Ion

An atom or molecule that has gained or lost one or more electrons and has become electrically charged.

\section{Ion Exchange}

The process in which a solution passes over a solid medium. Soluble ions are exchanged with ions previously sorbed to the medium; this process is reversible, so the waste constituents can be eluted from the medium and the medium can be regenerated.

\section{Ionizing Radiation}

Radiation capable of displacing electrons from atoms or molecules, thereby producing ions.

\section{Isotope}

An atom of a chemical element with a specific atomic number and atomic weight; isotopes of the same element have the same number of protons but different numbers of neutrons. 


\section{Leaching}

The process whereby a soluble component of a solid or mixture of solids is extracted as a result of percolation of a liquid around and through the solid.

\section{Maximum Contaminant Level}

Maximum permissible level of a contaminant in drinking water, based on a $70-\mathrm{kg}$ adult consuming $2 \mathrm{~L}$ of water a day (from National Primary Drinking Water Standards).

MCL

Maximum Contaminant Level.

\section{Mrem}

Millirem--a unit of radiation dose. Doses to individuals are of ten expressed in mrem.

MWMF

Mixed Waste Management Facility.

NEPA

National Environmental Policy Act.

NPDES

National Pollutant Discharge Elimination System--a set of regulations governing discharges to surface waters.

\section{Outcrop}

Part of a geologic formation exposed at the surface of the earth.

\section{Permeability}

A measure of the ability of water to flow through porous rock, fractured rock, or sediment. 
pH

A measure of the hydrogen ion concentration activity in aqueous solution; specifically, the negative logarithm of the hydrogen ion concentration. Acidic solutions have a $\mathrm{pH}$ from 0 up to 7 , basic solutions have a $\mathrm{pH}$ greater than 7 .

\section{Piezometric Maps}

A map showing lines of equal hydraulic head. Some investigators use the term potentiometric maps.

\section{Piezometric Surface}

The surface to which water in an aquifer would rise by hydrostatic head. Some investigators use the term potentiometric surface.

PQL

Practical Quantitation Limit--a reasonable lower limit for reporting concentrations in environmental samples based on current technology.

PVC

Polyvinyl Chloride.

\section{Radiation}

The emitted particles or photons from the nuclei of radioactive atoms. Some elements are naturally radioactive; others are induced to become radioactive by bombardment in a reactor.

RCRA

Resource Conservation Recovery Act.

\section{Recommended Maximum Contaminant Level}

Tentative acceptable concentration of a contaminant in drinking water based only on health effects and conservative assumptions. 
REM

Roentgen Equivalent in Man--a unit of dose for biological absorption; equal to the product of the absorbed dose in rads, a quality factor, and a distribution factor.

\section{Resource Conservation Recovery Act}

Federal legislation that regulates the transport, treatment, and disposal of solid and hazardous wastes.

RFI

RCRA Facility Investigation.

RKCL

Recommended Maximum Contaminant Leve1.

\section{SAS}

Statistical Analysis System--a database and statistical analysis software package used for environmental data at SRP.

\section{Savannah River Ecology Laboratory}

An ecological research institution operated by the University of Georgia under contract from DOE.

\section{Savannah River Laboratory}

A research facility operated by E. I, du Pont de Nemours and Company under contract from DOE.

\section{Savannah River Plant}

A $780-\mathrm{km}^{2}$ (192,700-acre) controlled-access area near Aiken, South Carolina, containing industrial facilities that produce nuclear materials. 


\section{SCDHEC}

South Carolina Department of Health and Environmental Control.

SCS

Soil Conservation Service.

SREL

Savannah River Ecology Laboratory.

SRL

Savannah River Laboratory.

SRP

Savannah River Plant.

\section{Stratigraphy}

Division of geology dealing with the definition of sediments and rocks into mappable units. Units are defined by lithologic characteristics and similarity of depositional processes and times.

\section{Surface Water}

All water on the earth's surface, as distinguished from groundwater.

\section{Terrain Conductivity}

A surface geophysical technique that relies on the electrical conductivity of shallow subsurface layers or objects.

TOH

Total Organic Halogens.

$$
\text { Glossary }-10
$$




\section{Total Organic Halogens}

Organic chemicals that have one or more halogens (chlorine, bromine, fluorine, etc.) in the molecule. Typically, these are low molecular weight solvents or refrigerants.

\section{Transmissivity}

The rate at which water is transmitted through a unit width under a unit hydraulic gradient.

\section{Tritiun}

${ }^{3} \mathrm{H}-$-a radioactive isotope of hydrogen, a weak beta emitter with a half-life of $12.3 \mathrm{yr}$.

\section{Upgradient}

A location that has a higher hydraulic head than a reference location. Water flows from upgradient locations toward downgradient locations, i.e., from higher hydraulic head toward lower hydraulic head.

\section{Vadose Zone}

The partially saturated zone in soil above the water table (other names include unsaturated zone and zone of aeration).

VOCs

Volatile Organic Compounds.

\section{Volatile Organic Compounds}

A broad range of organic compounds that have high vapor pressures at ambient or relatively low temperatures, such as benzene, acetone, chloroform, and methanol.

\section{Waste, Hazardous}

Any solid waste (can also be semisolid or liquid, or contain gaseous material) having the characteristics of ignitability, corrosivity, toxicity, or reactivity, defined by RCRA and identified or 1 isted in 40 CFR 261 . (RCRA) 
In some cases in this document, the term hazardous is used to indicate that a site might have received wastes containing hazardous constituents.

\section{Waste, Mixed}

Waste having both hazardous and radioactive constituents.

\section{Water Table}

The uppermost water surface that is underlain by completely saturated sediments. Water-table monitoring wells measure characteristics of the uppermost water bearing zone. This zone is characterized by a free water surface (i.e., not a confined zone). 
Alberts, J. J., M. C. Newman, and D. W. Evans, 1985. "Seasonal Variations of Trace Elements in Dissolved and Suspended Loads for Coal Ash Ponds and Pond Effluents," Water Air Soil Pollut. 26:111-128.

Alberts, J. J., M. F. Weber, and D. W. Evans, in press. "The Effect of $\mathrm{pH}$ and Contact Time on the Concentration of As(III) and As(V) in Coal Ash Systems," Environ. Technol. Lett.

Bransford, J. L., H. W. Bledsoe, and R. V. Simmons, 1984. Technical Data Summary: Chemical Characterization of the Sediments and Groundwater at the SRI Seepage Basins, DPSTD-84-110, E. I. du Pont de Nemours and Company, Savannah River Laboratory, Aiken, SC.

Cherry, D. S. and R. K. Guthrie, 1979. "The Uptake of Chemical Elements from Coal Ash and Settling Basin Effluent by Primary Producers II. Relation Between Concentrations in Ash Deposits and Tissues of Grasses Growing on the Ash," Sci. of the Total Environ. 13:27-31.

Cherry, D. S., R. K. Guthrie, F. F. Sherberger, and S. R. Larrick, 1979. The Influence of Coal Ash and Thermal Discharges upon the Distribution and Bioaccumulation of Aquatic Invertebrates." Hydrobiologia 62(3):257-267.

Christensen, E. J. and D. E. Gordon, 1983. Technical Summary of Groundwater Quality Protection Program at Savannah River Plant, Vol. I: Site Geohydrology, and Solid and Hazardous Wastes, DPST-83-829, E. I. du Pont de Nemours and Company, Savannah River Laboratory, Aiken, SC.

Christensen, E. J. and J. B. Pickett, 1987. Documentation of 1982 Soil Analyses from Seepage Area Near M-Area Settling Basin and Lost Lake, DPST-87-231, E. I. du Pont de Nemours and Company, Savannah River Laboratory, Aiken, SC.

Coker, S. E., 1979. 300-M Seepage Basin Data, DPSP-87-1101, E. I. du Pont de Nemours and Company, Savannah River Plant, Aiken, SC.

Corbo, P., M. V. Kante1o, and C. B. Fliermans, 1985. Basin Characterization Summary: Analytical Results, Database Management, and Quality Assurance for Analysis of Soil Cores from the F- and H-Area Seepage Basins, DPST-85-921, E. I. du Pont de Nemours and Company, Savannah River Laboratory, Aiken, SC.

Colven, W. P., J. B. Pickett, and C. F. Muska, 1985. Closure Plan for the M-Area Settling Basin and Vicinity at the Savannah River Plant, DPSPU-84-11-11 (Rev. 11/85), E. I. du Pont de Nemours and Company, Savannah River Plant, Aiken, SC. 
DOE, 1984. Groundwater Protection Plan for the Savannah River Plant, Prepared in Accordance with Public Law 98-181, Department of Energy, Savannah River Operations office, Aiken, SC.

DOE, 1987. Radiation Protection of the Public and the Environment, DOE Order 5480.XX, U.S. Department of Energy, Washington, DC (Draft March 31, 1987 ).

Dunaway, J. K. W., W. F. Johnson, L. E. Kingley, R. V. Simmons, and H. W. Bledsoe, Jr., 1987a. Environmental Information Document: New TNX Seepage Basin, DPST-85-698, E. I. du Pont de Nemours and Company, Savannah River Laboratory, Aiken, SC.

Dunaway, J. K. W., W. F. Johnson, L. E. Kingley, R. V. Simmons, H. W. Bledsoe, Jr., and J. A. Smith 1987b. Environmental Information Document: Old TNX Seepage Basin, DPST-85-710, E. I. du Pont de Nemours and Company, Savannah River Laboratory, Aiken, SC.

Dunaway, J. K. W., W. F. Johnson, L. E. Kingley, R. V. Simmons, and H. W. Bledsoe, Jr., 1987c. Environmental Information Document: TNX Burying Ground, DPST-85-711, E. I. du Pont de Nemours and Company, Savannah River Laboratory, Aiken, SC.

EPA, 1977. National Interim Primary Drinking Water Regulations, USEPA-570/9-76-003, U.S. Environmental Protection Agency, Washington, DC.

EPA, 1981. National Secondary Drinking Water Regulations, January 19, 1981, U.S. Environmental Protection Agency, Washington, DC.

EPA, 1985a. Hazardous Waste Management System: Identification and Listing of Hazardous Waste, U.S. Environmental Protection Agency, Federa1 Register, November 27, 1985, pp. 48886-48967 and public docket.

EPA, 1985b. Hazardous Waste Management System Identification and Listing of Hazardous Waste, U.S. Environmental Protection Agency, Federa1 Register, May 15, 1985, p. 20247.

EPA, 1985c. National Primary Drinking Water Regulations; Volatile Synthetic Organic Chemicals and Microorganisms, U.S. Environmental Protection Agency, Federal Register, November 13, 1985, pp. 46902-46933.

EPA, 1985d. National Primary Drinking Water Regulations; Fluoride, Final Rule, U.S. Environmental Protection Agency, Federal Register, November 14, 1985, pp. 47142-47155.

Fallaw, W. C. and K. A. Sargent, 1986. "Subsurface Geology of the A and M Areas at the Savannah River Plant, Aiken, South Carolina," in Du Pont, 1986 Groundwater Quality Assessment Report, Second Quarter, 1986, Vol. II, Appendices M-A through M-J, E. I. du Pont de Nemours and Company, Savannah River Plant, Aiken, SC. 
Fenimore, J. W. and J. H. Horton, Jr., 1974. Radionuclides in the Ground at the Savannah River Plant, DPST-74-319, E. I. du Pont de Nemours and Company, Savannah River Laboratory, Aiken, S. C.

Fowler, B. F., B. B. Looney, R. V. Simmons, and H. W. Bledsoe, 1987. Environmental Information Document: Savannah River Laboratory Seepage Basins, DPST-85-688, E. I. du Pont de Nemours and Company, Savannah River Laboratory, Aiken, SC.

Gordon, D. E., 1982. Preliminary Technical Data Summary, M-Area Groundwater Cleanup Facility, DPST-82-69, E. I. du Pont de Nemours and Company, Savannah River Laboratory, Aiken, SC.

Heffner, J. D., et al., in press. Impact of Waste Disposal on Groundwater Quality at the Savannah River Plant, DPSP-87-xxx, E. I. du Pont de Nemours and Company, Savannah River Plant, Aiken, SC.

Huber, L. A. and H. W. Bledsoe, Jr., 1987. Environmental Information Document: Gun Site 720 Rubble Pit, DPST-85-713, E. I. du Pont de Nemours and Company, Savannah River Laboratory, Aiken, SC.

Huber, L. A. and H. W. Bledsoe, Jr., 1987. Environmental Information Document: Hydrofluoric Acid Spill Area, DPST-85-696, E. I. du Pont de Nemours and Company, Savannah River Laboratory, Aiken, SC.

Huber, L. A., W. G. Holmes, R. V. Simmons, and I. W. Marine, 1987a. Environmental Information Document: Ford Building Waste Site, DPST-85-708, E. I. du Pont de Nemours and Company, Savannah River Laboratory, Aiken, SC.

Huber, L. A., W. F. Johnson, and H. W. Bledsoe, Jr., 1987b. Environmental Information Document: Waste Oil Basins, DPST-85-701, E. I. du Pont de Nemours and Company, Savannah River Laboratory, Aiken, SC.

Huber, L. A., W. F. Johnson, and I. W. Marine, 1987c. Environmental Information Document: Burning/Rubble Pits, DPST-85-690, E. I. du Pont de Nemours and Company, Savannah River Laboratory, Aiken, SC.

Jaegge, W. J., N. L. Kolb, B. B. Looney, I. W. Marine, 0. A. Towler, and J. R. Cook, 1987. Environmental Information Document: Radioactive Waste Burial Grounds, DPST-85-694, E. I. du Pont de Nemours and Company, Savannah River Laboratory, Aiken, SC.

Johnson, W. F., H. W. Bledsoe, and L. E. Kingley, 1987a. Chemical Characterization of Sediments and Groundwater at the Metallurgical Laboratory Basin, DPST-85-120, E. I. du Pont de Nemours and Company, Savannah River Laboratory, Aiken, SC. 
Johnson, W. F., J. B. Pickett, and H. W. Bledsoe, Jr., $1987 \mathrm{~b}$.

Environmental Information Document: SRL Oil Test Site, DPST-85-697,

E. I. du Pont de Nemours and Company, Savannah River Laboratory, Aiken, SC.

Killian, T. H., N. L. Kolb, P. Corbo, and I. W. Marine, 1987a.

Environmental Information Document: F-Area Seepage Basins, DPST-85-704,

E. I. du Pont de Nemours and Company, Savannah River Laboratory, Aiken, SC.

Killian, T. H., N. L. Kolb, P. Corbo, and I. W. Marine, 1987b.

Environmental Information Document: H-Area Seepage Basins, DPST-85-706,

E. I. du Pont de Nemours and Company, Savannah River Laboratory, Aiken, SC.

Looney, B. B. and J. B. Pickett, 1987. Caveats Related to Organic Solvent Disposal Masses Calculated from Total Organic Halogen Measurements in Groundwater, DPST $-\delta 1-8=6$, E. I. du Pont de Nemours and Company, Savannah River Laboratory, Aiken, SC.

Looney, B. B., J. B. Pickett, C. M. King, W. G. Holmes, W. F. Johnson, and J. A. Smith, 1987. Selection of Chemical Constituents and Estimation of Inventories for Environmental Analysis of Savannah River Plant Waste Sites, DPST-86-291, E. I. du Pont de Nemours and Company, Savannah River Laboratory, Aiken, SC.

Marine, I. W. and H. W. Bledsoe, 1985. Supplemental Technical Data Summary: M-Area Groundwater Investigation, DPSTD-84-112, E. I. du Pont de Nemours and Company, Savannah River Laboratory, Aiken, SC.

Michael, L. M., W. F. Johnson, and H. W. Bledsoe, Jr., 1987. Environmental Information Document: Metallurgical Laboratory Basin, DPST-85-689, E. I. du Pont de Nemours and Company, Savannah River Laboratory, Aiken, SC.

Mikol, S., E. M. Heath, J. Todd, and L. Burkhalter, in press. U.S. Department of Energy Savannah River Plant Environmental Report, Annual Report for 1987. DPSPU-88-30-1 (Vo1. 1 and 2), E. I. du Pont de Nemours and Company, Savannah River Plant, Aiken, SC.

Odum, J. V., B. S. Christie, C. B. F1iermans, and I. W. Marine, 1987.

Environmental Information Document: Old F-Area Seepage Basins, DPST-85-692, E. I. du Pont de Nemours and Company, Savannah River Laboratory, Aiken, SC.

Pekkala, R. 0., C. E. Jewe11, W. G. Holmes, and I. W. Marine, Jr., 1987a. Environmental Information Document: Reactor Seepage Basins, DPST-85-707, E. I. du Pont de Nemours and Company, Savannah River Laboratory, Aiken, SC.

Pekkala, R. 0., C. E. Jewe11, V. Price, and H. W. Bledsoe, 1987b. Environmental Information Document: L-Area Oil \& Chemical Basin, DPST-85-700, E. I. du Pont de Nemours and Company, Savannah River Laboratory, Aiken, SC. 
Pekkala, R. 0., C. E. Jewe11, V. Price, and I. W. Marine, Jr., 1987c. Environmental Information Document: Bingham Pump Outage Pits, DPST-85-695, E. I. du Pont de Nemours and Company, Savannah River Laboratory, Aiken, SC.

Pekkala, R. O., C. E. Jewe11, W. G. Holmes, R. V. Simmons, and I. W. Marine, Jr., 1987d. Environmental Information Document: Ford Building Seepage Basin, DPST-85-709, E. I. du Pont de Nemours and Company, Savannah River Laboratory, Aiken, SC.

Pickett, J. B., 1985. Technical Data Summary, Extended Characterization of the M-Area Settling Basin and Vicinity, DPSTD-85-121 (Rev. 10/85), E. I. du Pont de Nemours and Company, Savannah River Laboratory, Aiken, SC.

Pickett, J. B. and B. B. Looney, 1986. Documentation of Groundwater

Monitoring Results at the Sewage Sludge Application Sites, DPST-86-309, E. I. Du Pont de Nemours and Company, Savannah River laboratory, Aiken, SC.

Pickett, J. B., W. P. Colven, and H. W. Bledsoe, Jr., 1987a. Environmental Information Document: M-Area Settling Basin and Vicinity, DPST-85-703, E. I. du Pont de Nemours and Company, Savannah River Laboratory, Aiken, SC.

Pickett, J. B., C. F. Muska, and H. W. Bledsoe, 1987b. Environmental Information Document: Road A Chemical Basin, DPST-85-699, E. I. du Pont de Nemours and Company, Savannah River Laboratory, Aiken, SC.

Pickett, J. B., C. F. Muska, and I. W. Marine, Jr., 1987c. Environmental Information Document: Metals Burning Pit/Miscellaneous Chemical Basin, DPST-85-691, E. I. du Pont de Nemours and Company, Savannah River Laboratory, Aiken, SC.

Pickett, J. B. and C. B. Shedrow, 1986. Analytical Detection Limits for Soil, Sediment, and Liquid Samples at SRP Waste Sites, DPST-86-675, E. I. du Pont de Nemours and Company, Savannah River Laboratory, Aiken, SC.

Price, V., B. B. Looney, and L. Huber, 1987. Soil Gas Studies for Volatile Organic Compounds at Selected SRP Waste Sites, DPST-87-403, E. I. du Pont de Nemours and Company, Savannah River Laboratory, Aiken, SC.

Price, V. and B. Shedrow, in Press. Technical Data Summary: Chemical Characterization of Sediments in the L-Area Oil and Chemical Basin, DPSTD-87-6, E. I. du Pont de Nemours and Company, Savannah River Laboratory, Aiken, SC.

Ryan, J. P. 1984. Effluent Characterization Study for the 200-Area Effluent Treatment Facility, DPST-84-511, E. I. du Pont de Nemours and Company, Savannah River Laboratory, Aiken, SC. 
Scott, S. C., T. H. Killian, N. L. Kolb, P. Corbo, and H. W. Bledsoe, Jr., 1987a. Environmental Information Document: Silverton Road Waste Site, DPST-85-702, E. I. du Pont de Nemours and Company, Savannah River Laboratory, Aiken, SC.

Scott, S. C., T. H. Killian, N. L. Kolb, P. Corbo, and I. W. Marine, 1987b. Environmental Information Document: Separations Area Retention Basins, DPST-85-693, E. I. du Pont de Nemours and Company, Savannah River Laboratory, Aiken, SC.

Scott, S. C., N. L. Kolb, V. Price, and H. W. Bledsoe, Jr., 1987c.

Environmental Information Document: CMP Pits, DPST-85-712, E. I. du Pont de Nemours and Company, Savannah River Laboratory, Aiken, SC.

Shedrow, C. B., 1986. A Characterization Study of the Old F-Area Seepage Basin at the United States Department of Energy's Savannah River Plant, CORR-87-0117, Report by C. B. Shedrow Consultants for E. I. du Pont de Nemours, Savannah River Plant, Aiken, SC.

Simmons, R. V., H. W. Bledsoe, and J. L. Bransford, 1985. Technical Data Summary: Chemical and Radionuclide Characterization Study of the Old TNX Seepage Basin, DPSTD-85-115, E. I. du Pont de Nemours and Company, Savannah River Laboratory, Aiken, SC.

Skinner, S. P., J. B. Gentry, and J. P. Giesy, Jr., 1978. "Cadmium Dynamics in Terrestrial Food Webs of a Coal Ash Basin," in Environmental Chemistry and Cycling Processes, D. C. Adriano and I. L. Brisbin, Jr. (eds.), DOE Symposium Series 45, CONF-760429, National Technical Information Service, Springfield, VA, pp. 658-672.

Stone, J. A. and E. J. Christensen, 1983. Technical Summary of Groundwater Quality Protection Program at Savannah River Plant, Vol. II: Radioactive Waste, DPST-83-829, E. I. du Pont de Nemours and Company, Savannah River Laboratory, Aiken, SC.

USPHS, 1962. Drinking Water Standards, U.S. Public Hea1th Service, Publication 1956, Government Printing Office, Washington, DC.

Ward, J. W., W. F. Johnson, and I. W. Marine, 1987. Environmental Information Document: Acid/Caustic Basins, DPST-85-705, E. I. du Pont de Nemours and Company, Savannah River Laboratory, Aiken, SC.

Watts, J. R., J. C. Corey, and K. W. Mcleod, 1982. "Land Application Studies of Industrial Waste Oils," Environmental Pollution (Series A), Great Britain, 28: $165-175$. 
Wetze1, R. G., 1983. Limnology, 2nd Edition, Saunders College Publishing, New York.

Wiener, J. G., 1979. "Aerial Inputs of Cadmium, Copper, Lead, and Manganese into a Freshwater Pond in the Vicinity of a Coal-Fired Power Plant," Water Air Soil Pollut. 12:343-353.

Zeigler, C. C., E. M. Heath, L. B. Taus, J. L. Todd, and J. E. Till, 1987. U.S. Department of Energy Savannah River Plant Environmental Report, Annual Report for 1986, DPSPU-87-30-1 (Vo1. 1 and 2), E. I. du Pont de Nemours and Company, Savannah River Plant, Aiken, SC. 
APPENDIX

Appendix-1 
TABLE 1

Recommended Soil/Sediment Sampling Intervals and Analyses

Interva1 $\left(\mathrm{m}^{*}\right)$

$0.00-0.25$

$0.25-0.50$

$0.50-1.00$

$1.00-1.50$

$1.50-2.00$

$2.00-2.50$

$2.50-3.00$

$3.00-4.00$

$4.00-5.00$

$5.00-6.00$
Recommended Analyses **

$1,2,3,4$

2,4

2,4

$2,3,4$

2,4

2,4

2,4

2,4

$2,3,4$

2,4

* The 1isted intervals are recommended for sampling cores for waste-site characterization. The total depth of the cores is specified in the individual sections of the text. The intervals applicable to a particular core should be analyzed according to the above table. Unless stated otherwise, these depths are measured from the interface at the bottom of the waste site and the top of the soil column. In some cases, a separate sample of sludge or waste is recommended (as specified in text).

** Specific analytes or procedures are designated by 1 istings in subsequent tables and in the codes below.

Class 1: EPA Appendix IX (see Table 7)

EP Toxicity (see Table 8)

Class 2: SCS Soil Classification

ASTM C1assification

Soil $\mathrm{pH}$

Cation Exchange Capacity

Class 3: Exchangeable Acidity

Exchangeable Base Metals

Percentage Base Saturation

Soil Organic Content

Particle Size Distribution

Mineral Content

Class 4: Analytes specified in individual sections of the text. These will be metals/inorganics (see Table 2), volatile organics (see Table 3 ), radionuclides (see Table 4 or 5 ), or other chemicals. 
In addition to the analyses listed above, the following data should be available at each of the waste sites from either correlation to a nearby regional hydrogeological well cluster or other high-quality, site-wide data or from a waste-site specific analysis: porosity, effective porosity, hydraulic conductivity (as a function of water content), bulk density, and moisture content. Several of these analyses require undisturbed samples. A description of groundwater hydrogeology is also required. Data required include characteristics of important water-bearing zones (aquifers) and aquitards, locations and effect of hydrologic boundaries, thickness of the unsaturated zone, presence or absence of calcareous zones, and a summary of groundwater flow directions. 


\section{TABLE 2}

Inorganic Analyses for Soil, Sediment, Waste, and Sludge Samples

Analyte

Arsenic

Barium

Cadmium

Chromium

Copper

Cyanide

Fluoride

Iron

Lead

Manganese

Mercury

Nicke1

Nitrate

Phos phate

Selenium

Silver

Sodium

Sulfate

Uranium

Zinc
EPA Recommended Method

$3050 \& 7060$
$3050 \& 6010$
$3050 \& 7131$
$3050 \& 7191$
$3050 \& 6010$
9010
$*$
$3050 \& \& *$
$3050 \& 7421$
$3050 \& 6010$
7471
$3050 \& 6010$
$*$
$*$
$3050 \& 7740$
$3050 \& 6010$
$3050 \& 7770$
$*$
$* * *$
$3050 \& 6010$

$3050 \& 7060$

$3050 \& 6010$

$3050 \& 7131$

$3050 \& 7191$

$3050 \& 6010$

9010

$3050 \& * *$

$3050 \& 7421$

$3050 \& 6010$

7471

$3050 \& 6010$

$x$

$3050 \& 7740$

$3050 \& 6010$

$3050 \& 7770$

$3050 \& 6010$

* Major anions will be analyzed by anion chromatography.

** Iron and manganese will be analyzed by atomic absorption.

$* * *$ Uranium will be analyzed by a wet-chemical fluorimetric or colorimetric method. 
TABLE 3

Volatile Organic Analyses for Water, Soil, Sediment, Waste, and Sludge Samples

\author{
Recommended Methods* \\ Test Water Solids \\ Volatile aromatic hydrocarbons 601 or $624 \quad 5030 / 8010$ or 8240 \\ Halogenated volatile organics 602 or $624 \quad 5030 / 8020$ or 8240
}

\begin{tabular}{|c|c|c|}
\hline Constituent & Water PQL (ug/L) & Solids PQL (ug/g) \\
\hline Benzene & 2.0 & $0.02-0.20$ \\
\hline Bromodichlorome thane & 1.0 & $0.01-0.10$ \\
\hline Bromoform & 2.0 & $0.02-0.20$ \\
\hline Bromome thane & -- & $-\ldots$ \\
\hline Carbon Tetrachloride & 1.2 & $0.01-0.12$ \\
\hline Chlorobenzene & 2.0 & $0.02-0.20$ \\
\hline Chloroe thane & 5.2 & $0.05-0.52$ \\
\hline 2-Chloroethyl viny1 ether & 1.3 & $0.01-0.13$ \\
\hline Chlorof orm & 0.5 & $0.01-0.05$ \\
\hline Chlorome thane & 0.8 & $0.01-0.08$ \\
\hline Dibromochlorome thane & 0.9 & $0.01-0.09$ \\
\hline 1,2-Dichlorobenzene & 1.5 & $0.02-0.15$ \\
\hline 1,3-Dichlorobenzene & 3.2 & $0.03-0.32$ \\
\hline 1,4-Dich1orobenzene & 2.4 & $0.02-0.24$ \\
\hline Dichlorodif luorome thane & $-\infty$ & --- \\
\hline 1,1-Dichloroethane & 0.7 & $0.01-0.07$ \\
\hline 1,2-Dichloroethane & 0.3 & $0.01-0.03$ \\
\hline 1,1-Dichloroethylene & 1.3 & $0.01-0.13$ \\
\hline trans $-1,2-$ Dichloroe thy lene & 1.0 & $0.01-0.10$ \\
\hline Dichlorome thane & --- & --- \\
\hline 1,2-Dich1oropropane & 0.4 & $0.01-0.04$ \\
\hline trans-1,3-Dichloropropene & 3.4 & $0.03-0.34$ \\
\hline Ethylbenzene & 4.0 & $0.04-0.40$ \\
\hline Toluene & 2.0 & $0.02-0.20$ \\
\hline $1,1,2,2$-Tetrach1oroethane & 0.3 & $0.01-0.03$ \\
\hline Tetrachloroethene & 0.3 & $0.01-0.03$ \\
\hline $1,1,1$-Trichloroe thane & 0.3 & $0.01-0.03$ \\
\hline $1,1,2$-Trichloroethane & 0.2 & $0.01-0.02$ \\
\hline Trichloroethene & 1.2 & $0.01-0.12$ \\
\hline Trichlorof luorome thane & -- & --- \\
\hline Viny 1 chloride & 1.8 & $0.02-0.18$ \\
\hline
\end{tabular}


TABLE j, Cantả

Volatile Organic Analyses for Water, Soil, Sediment, Waste, and Sludge Samples

* Methods in bold type are slightly preferred. Methods 601, 602, and 624 are documented in US EPA, 40 CFR 136, Guidelines Establishing Test Procedures for Analysis Under the Clean Water Act; Final Rule and Interim Final Rule and Proposed Rule, October 26, 1984. Methods 8010, 8020, and 8240 are documented in US EPA, SW 846, Test Methods for Evaluating Solid Waste, November, 1986.

** See Table 9 of the Appendix for a cross-referenced list of names. The values given are highly matrix dependent and may not be achievable in some cases. Note that the PQLs for solids are on a wet-weight basis. If no PQL is listed (-), then the data to calculate a value were not provided in methods 8010,8020 , or 8240 . 
TABLE 4

Radioactivity Analyses for Soil, Sediment, Waste, and Sludge Samples

Gross alpha

Nonvolatile beta

Tritium

Total radium 


\section{TABLE 5}

Expanded Radioactivity Analyses for Water, Soil, Sediment, Waste,
and Sludge Samples

Alpha Emitters

americium-241

curium-244

neptunium-237

plutonium-238

plutonium-239

plutonium-240

radium-226

radium-228

thorium-232

uranium-233

uranium-235

uranium-238

Beta Emitters

iodine-129

strontium-90

technetium-99

tritium

Gamma Emitters

antimony- 125

cesium-134

cesium-137

coba $1 t-60$

europium-152

europium-154

europium-155

promethium-147

ruthenium-106

Gross alpha

Gross beta

Gross ganma
Half-Life (yrs)

Methodology

470

17.6

2. $2 E+06$

86.4

$24.3 E+03$

$6.6 \mathrm{E}+03$

1,600

5.7

$1.4 \mathrm{E}+10$

$1.6 \mathrm{E}+05$

$7.1 \mathrm{E}+08$

$4.5 E+09$

$1.7 \mathrm{E}+07$

28.1

2. $1 E+05$

12.3

2.7

2.3

30

5.2

13

16

1.7

2.6

1

HASL300DE83010805: ESRO5 HASL300DE83010805: ETCO1 EPA 520/5-84-006: H-02

EPA 520/5-84-006: 00-04 EPA 520/5-84-006: 00-04 EPA 520/5-84-006: 00-04 EPA 600/4-80-032: 904.0 EPA 520/5-84-006: 00-07 EPA 520/5-84-006: 00-07 EPA 520/5-84-006: 00-07 EPA 520/5-84-006: 00-07

EPA 600/4-80-032: 901.1 EPA 600/4-80-032: 901.1 EPA 600/4-80-032: 901.1 EPA 600/4-80-032: 901.1 EPA 600/4-80-032: 901.1 EPA 600/4-80-032: 901.1 EPA 600/4-80-032: 901.1 EPA 600/4-80-032: 901.1 EPA 600/4-80-032: 901.1 EPA 600/4-80-032: 903.0; 903.1

EPA 600/4-80-032: 900.0 EPA 600/4-80-032: 900.0 EPA 600/4-80-032: 901.1 
TABLE 6

Parameters for Groundwater Analyses for Waste-Site Characterization

\section{Field Measurements}

Depth to water

$\mathrm{pH}$

Alkalinity

Temperature

Specific conductance

Eh and dissolved oxygen

Laboratory Analysis

$\mathrm{pH}$

Specific conductance

Silver

Arsenic

Barium

Beryllium

Calcium

Cadmium

Chloride

Chromium

Copper

Cyanide

Fluoride

Iron

Mercury

Potassium

Magnesium

Manganese

Sodium

Nickel

Nitrate (as $\mathrm{N}$ )

Lead

Selenium

Silica

Sulfate

Zinc

Total dissolved solids

Total phosphates

Total organic carbon

Total organic halogens

Trichloroe thylene
Drinking Water

Standards $(\mathrm{mg} / \mathrm{L})$

NA
NA
50
50
1,000
$\mathrm{NA}$
10
150,000
50
1,000
200
4,000
300
2
$\mathrm{NA}$
$\mathrm{NA}$
50
$\mathrm{NA}$
350
10,000
50
10
$\mathrm{NA}$
250,000
5,000
500,000
$\mathrm{NA}$
$\mathrm{NA}$
$\mathrm{NA}$
5


TABLE 6, Contd

Parameters for Groundwater Analyses for Waste-Site Characterization

Laboratory Analysis

Tetrachloroethylene

$1,1,1-\operatorname{Tr}$ ichlore thane

Carbon tetrachloride

Chloroform*

Phenols

Gross alpha

Nonvolatile beta

Tritium

Total Radium
Drinking Water

Standards (mg/L)

Note: The drinking water standards are primary or secondary U.S. EPA standards.

* Assumes the absence of other trihalomethanes. 
TABLE 7

EPA Appendix IX Constituents

Common Name (1)

CAS RN (2)

Acenaphthene

$83-32-9$

Acenaph thylene

208-96-8

Ace tone

67-64-1

Ace tophenone

$98-86-2$

Acetonitrile

$75-05-8$

2-Ace tylaminof luorene

$53-96-3$

Acrolein

107-02-8

Acrylonitrile

Aldrin

Allyl chloride

4-Aminobipheny 1

Aniline

Anthracene

Antimony

$107-13-1$

309-00-2

107-05-1

92-67-1

62-53-3

120-12-7

(Tota1)

Aramite

140-57-8

Arsenic

(Total)

Barium

(Tota1)

Benzene

71-43-2

Benzo[a] anathracene

$56-55-3$

Benzo[b]fluoranthene

205-99-2

Benzo[k]fluoranthene

207-08-9

Benzo[ghi] perylene

191-24-2

Benzo[a]perylene

$50-32-8$

Benzyl alcohol

$100-51-6$

Bery1lium

(Total)

alpha-BHC

319-84-6

beta-BHC

$319-85-7$

de1 ta-BHC

$319-86-8$

58-89-9

gamma-BHC; Lindane

Bis (2-chloroethoxy) methane

$111-91-1$

Bis (2-chloroethyl) ether

Bis (2-ch1oro-1-methylethy1) ether

$111-44-4$

$108-60-1$

Bis(2-ethylhexy1) phthalate

$117-81-7$

$75-27-4$

$75-25-2$

Bromoform

4-Bromopheny1 pheny1 ether

$101-55-3$

Butyl benzyl phthalate

85-68-7

Cadmium

(Total)

Carbon disulfide

75-15-0

$56-23-5$

Carbon tetrachloride

57-74-9

Appendix-11 
TABLE 7, Contd

EPA Appendix IX Constituents

Common Name (1)

p-Chloroaniline

Chlorobenzene

Chlorobenzilate

p-Chloro-m-cresol

Chloroethane

Ch1orof orm

2-Chloronaph thalene

2-Chlorophenol

4-Chlorophenyl phenyl ether

Chloroprene

Chromium

Chrysene

Cobalt

Copper

m-Creso 1

o-Cresol

p-Cresol

Cyanide

2,4-Dichlorophenoxyacetic acid

$4,4^{\prime}-D D D$

$4,4^{\circ}-\mathrm{DDE}$

$4,4^{\circ}-\mathrm{DDT}$

Diallate

Dibenz $[\mathrm{a}, \mathrm{h}]$ anthracene

Dibenzofuran

Dibromochlorome thane

1,2-Dibromo-3-ch1oropropane (DBCP)

1,2-Dibromoe thane

Di-n-buty 1 phthalate

o-Dichlorobenzene

m-Dichlorobenzene

p-Dichlorobenzene

3,3'-Dichlorobenzidine

trans-1,4-Dichloro-2-butene

Dichlorodifluorome thane

1,1-Dichloroethane

1,2-Dichloroethane

1,1-Dichloroe thylene

trans-1,2-Dichloroethylene

2,4-Dich1oropheno1

2,6-Dichloropheno1
CAS RN (2)

$106-47-8$

$108-90-7$

510-15-6

59-50-7

75-00-3

$67--66-3$

91-58-7

95-57-8

7005-72-3

126-99-8

(Total)

281-01-9

(Total)

(Total)

108-39-4

$95-48-7$

106-44-5

57-12-5

94-75-7

$72-54-8$

$72-55-9$

$50-29-3$

2302-16-4

$53-70-3$

132-64-9

124-48-1

96-12-8

106-93-4

84-74-2

95-50-1

541-73-1

106-46-7

$91-94-1$

110-57-6

75-71-8

$75-34-3$

107-06-2

$75-35-4$

156-60-5

120-83-2

87-65-0

Appendix-12 
TABLE 7, Contd

EPA Appendix IX Constituents

Common Name (1)

1,2-Dichloropropane

cis-1,3-Dichloropropene

trans-1,3-Dich1oropropene

Dieldrin

Diethyl phthalate

Thionazin

Dimethoate

p-(Dimethylamino)azobenzene

7,12-Dime thylbenz [a] anthracene

3,3'-Dimethylbenzidine

alpha, al pha-Dime thyl phene thylamine

2,4-Dime thyl phenol

Dimethyl phthalate

m-Dinitrobenzene

4,6-Dinitro-o-cresol

2,4-Dinitrophenol

2,4-Dinitrotoluene

2,6-Dinitrotoluene

DNBP

Di-n-octy1 phthalate

1,4-Dioxane

Diphenylamine

Disulf oton

Endosulfan I

Endosulfan II

Endosulfan sulfate

Endrin

Endrin aldehyde

Ethylbenzene

Ethyl methacrylate

Ethyl methanesulfonate

Famphur

Fluoranthene

Fluorene

Heptach1or

Heptachlor epoxide

Hexachlorobenzene

Hexachlorobutadiene

Hexachlorocyclopent adiene

Hexachloroethane

Hexachlorophene

Hexachloropropene
CAS RN (2)

$$
\begin{aligned}
& 78-87-5 \\
& 10061-01-5 \\
& 10061-02-6 \\
& 60-57-1 \\
& 84-66-2 \\
& 297-97-2 \\
& 60-51-5 \\
& 60-11-7 \\
& 57-97-6 \\
& 119-93-7 \\
& 122-09-8 \\
& 105-67-9 \\
& 131-11-3 \\
& 99-65-0 \\
& 534-52-1 \\
& 51-28-5 \\
& 121-14-2 \\
& 606-20-2 \\
& 88-85-7 \\
& 117-84-0 \\
& 123-91-1 \\
& 122-39-4 \\
& 298-04-4 \\
& 959-98-8 \\
& 33213-65-9 \\
& 1031-07-8 \\
& 72-20-8 \\
& 7421-93-4 \\
& 100-41-4 \\
& 97-63-2 \\
& 65-50-0 \\
& 52-85-7 \\
& 206-44-0 \\
& 86-73-7 \\
& 76-44-8 \\
& 1024-57-3 \\
& 118-74-1 \\
& 87-68-3 \\
& 77-47-4 \\
& 67-72-1 \\
& 70-30-4 \\
& 1888-71-7 \\
&
\end{aligned}
$$

Appendix-13 


\section{TABLE 7, Contd}

\section{EPA Appendix IX Constituents}

Common Name (1)

2-Hexanone

Indenol (1,2,3-cd) pyrene

Isobutyl alcohol

Isodrin

Isophorone

Isosafrole

Kepone

Lead

Mercury

Methacrylonitrile

Methapyrilene

Methoxychlor

Bromome thane

Chlorome thane

3-Methylcholanthrene

Dibromome thane

Dichlorome thane

Methyl ethyl ketone

Iodome thane

Methyl methacrylate

Methy 1 methanesulfonate

2-Me thy Inaph thalene

Methyl parathion

4-Methy1-2-pentanone

Naphthalene

1,4-Naph thoquinone

1-Naph thylamine

2-Naph thylamine

Nickel

o-Nitroaniline

$\mathrm{m}-\mathrm{Nitroaniline}$

p-Nitroaniline

Nitrobenzene

o-Nitropheno1

p-Nitrophenol

4-Nitroquinoline-1-oxide

$\mathrm{N}$-Nitrosodi-n-butylamine

$\mathrm{N}$-Nitrosodiethylamine

$\mathrm{N}-\mathrm{Nitrosodime} \mathrm{thylamine}$

$\mathrm{N}$-Nitrosodipheny lamine

$\mathrm{N}$-Nitrosodipropylamine
CAS RN (2)

$591-78-6$

193-39-5

78-83-1

465-73-6

78-59-1

120-58-1

143-50-0

(Tota1)

(Total)

126-98-7

91-80-5

72-43-5

74-83-9

74-87-3

56-49-5

74-95-3

75-09-2

78-93-9

74-88-4

$80-62-6$

$66-27-3$

91-57-6

298-00-0

108-10-1

91-20-3

130-15-4

134-32-1

91-59-8

(Tota1)

88-74-4

99-09-2

100-01-6

98-95-3

88-75-5

100-02-7

56-57-5

924-16-3

55-18-5

62-75-9

86-30-6

621-64-7 
TABLE 7, Contd

EPA Appendix IX Constituents

Common Name (1)

CAS RN (2)

$\mathrm{N}-\mathrm{Ni}$ t rosome thy le thy lamine

$\mathrm{N}$-Nit rosomorpholine

$\mathrm{N}-\mathrm{Nit}$ rosopiperidine

$\mathrm{N}$-Nitrosopyrrolidine

10595-95-6

$59-89-2$

$100-75-4$

$930-55-2$

5-Nitro-o-toluidine

$99-55-8$

Parathion

Polychlorinated biphenyls

$56-38-2$

Polychlorinated dibenzo-p-dioxins

see note 3

Polychlorinated dibenzofurans

see note 4

Pentachlorobenzene

Pentachloroethane

Pentachloronitrobenzene

Pentachlorophenol

Phenacetin

Phenanthrene

see note 5

$608-93-5$

$76-01-7$

$82-68-8$

$87-86-5$

$62-44-2$

85-01-8

Phenol

p-Phenylenediamine

$108-95-2$

$106-50-3$

Phorate

298-02-2

2-Picoline

109-06-8

Pronamide

Propionitrile, Ethyl cyanide

23950-58-5

Pyrene

Pyridine

Saf role

Selenium

Silver

Silvex $(2,4,5-\mathrm{TP})$

107-12-0

129-00-0

$110-86-1$

94-59-7

(Tota1)

(Total)

93-72-1

$100-42-5$

18496-25-8

Sulfide

2,4,5-T; 2,4,5-Trich1orophenoxy-

$93-76-5$

acetic acid

$2,3,7,8-T C D D$

$1,2,4,5$-Tetrachlorobenzene

1746-01-6

95-94-3

$1,1,1,2-$ Tetrachloroe thane

$630-20-6$

$79-34-5$

$127-18-4$

58-90-2

Tetrachloroethylene

$2,3,4,6$-Tetrach1oropheno1

Sulfotepp

3689-24-5

(Total)

(Total)

Tin

108-88-3

Appendix-15 
TABLE 7, Contd

EPA Appendix IX Constituents

Common Name (1)

o-Toluidine

Toxaphene

1,2,4-Trichlorobenzene

1,1,1-Trichloroethane

1,1,2-Trichloroethane

Trichloroethene

Trichlorofluorome thane

2,4,5-Trichlorophenol

2,4,6-Trichlorophenol

1,2,3-Trich1oropropane

0,0,0-Triethyl phosphorothioate

sym-Trinitrobenzene

Vanadium

Vinyl acetate

Vinyl chloride

Xylene (tota1)

Zinc

\section{CAS RN (2)}

95-53-4

$8001-35-2$

$120-82-1$

71-55-6

79-00-5

79-01-6

75-69-4

95-95-4

88-06-2

96-18-4

126-68-1

99-35-4

(Total)

108-05-4

75-01-4

1330-20-7

(Total)

1. Common names are those widely used by EPA, government regulations, scientific publications, and commerce; synonyms exist for many chemicals (see Appendix Table 9).

2. Chemical Abstracts Service registry number. Where "Total" is entered, all species in the groundwater that contain this element are included.

3. Polychlorinated biphenyls; (CAS RN 1336-36-3); this category contains congener chemicals, including constituents of Aroclor-1016 (CAS RN 12674-11-2), Aroclor-1221 (CAS RN 11104-28-2), Aroclor-1232 (CAS RN 11141-16-5), Aroclor-1242 (CAS RN 53469-21-9), Aroclor-1248 (CAS RN 12672-29-6), Aroclor-1254 (CAS RN 11097-69-1), and Aroc1or-1260n (CAS RN 11096-82-5).

4. This category contains congener chemicals, including tetrachlorodibenzo-p-dioxins (see also 2,3,7,8-TCDD), pentachlorodibenzo-p-dioxins, and hexachlorodibenzo-p-dioxins.

5. This category contains congener chemicals, including tetrachlorodibenzofurans, pentachlorodibenzofurans, and hexachlorodibenzof urans. 


\section{TABLE 8}

EP Toxicity Analyses for Soil, Sediment, Waste, and Sludge Samples

\section{Metals}

Arsenic

Barium

Chromium

Lead

Mercury

Selenium

Silver

Note: Samples need not be analyzed for pesticides or herbicides unless specifically called for in the text. 


\section{TABLE 9}

Cross-Referenced Names for Chemicals on the EPA Appendix IX List

The following table 1 ists chemical and trade names that are in reasonably common use or are 1isted in the Chemical Abstract Service. All of these names are cross referenced to the designations on the EPA Appendix IX List. In some cases, the names on the Appendix IX List are actually groups of related chemica1s. For example, polychlorinated bipheny1s (CAS RN 1336-36-3) are actually composed of chlorinated biphenyl congeners. They were sold (and are of ten measured) as commercial mixtures designated by names 1ike Aroclor-1242 (the last two digits represent the weight percentage of chlorine in the structure of the mixture). Aroclor-1016 (CAS RN 12674-11-2), Aroclor-1221 (CAS RN 11104-28-2), Aroclor-1232 (CAS RN 11141-16-5), Aroclor-1242, (CAS RN 53469-21-9), Aroclor-1248 (CAS RN 12672-29-6), Aroclor-1254 (CAS RN

11097-69-1), and Aroclor-1260 (CAS RN 11096-82-5) were al1 common commercial mixtures. These mixtures are composed of individual congeners such as 2,4'-Dich1orobipheny1 (CAS RN 34883-43-7, 7.7\% of Aroclor-1242), $2,2^{\prime}, 5,5^{\prime}$-Tetrachlorobipheny1 (CAS RN 35693-99-3, 4.6\% of Aroc1or-1242, 3.9\% of Aroclor-1254), and 2,2'4,5,5'-Pentachlorobiphenyl (CAS RN 37680-73-2, 0.3\% of Aroclor $-1242,7.0 \%$ of Aroclor-1254). Similar complexity is found in the polychlorinated dibenzo-p-dioxins and the polychlorinated dibenzofurans. 


\begin{tabular}{|c|c|}
\hline Cross Reference Name & Name in Appendix IX List \\
\hline 1,1'-Biphenyl, chloro derivatives & Polychlorinated biphenyls \\
\hline $1,1,1,2$. Tetrachloroethane & $1,1,1,2-$ Tetrachioroethane \\
\hline 1,1,1-Trichloroelhane & 1,1,1-Trichloroethane \\
\hline 1,1,2,2,-Tetrachloroethane & $1,1,2,2$, -Telrachloroethane \\
\hline $1,1,2$-Trichloroethane & 1,1,2-Trichloroethane \\
\hline 1,1-Dichloroethane & 1,1-Dichloroethane \\
\hline 1.1-Dichloroethylene & 1,1-Dichloroethylene \\
\hline 1,2,3-Trichloropropane & 1,2,3-Trichloropropane \\
\hline 1,2,4,5-Tetrachiorobenzene & $1,2,4,5$-Tetrachlorobenzene \\
\hline 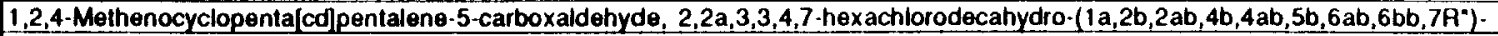 & Endrin aldehyde \\
\hline 1,2,4-Trichlorobenzene & 1,2,4-Trichlorobenzene \\
\hline 1,2,Ethanediamine, N,N-dimethyl-N'-2-pyridinyl-N'-(2-thienylmethyl)- & Methapyrilene \\
\hline 1,2 -Benzanthracene & Benzo[a]anathracene \\
\hline 1,2-Benzenedicarboxylic acid, bis(2-elhylhexyl)ester & Bis(2-ethylhexyl) phthalate \\
\hline 1,2-Benzenedicarboxylic acid, butyl phenylmethyl ester & Butyl benzyl phthalate \\
\hline 1,2-Benzenedicarboxylic acid, dibutyl ester & Di-n-butyl phthalate \\
\hline 1,2-Benzenedicarboxylic acid, diethyl ester & Diethyl phthalate \\
\hline 1,2-Benzenedicarboxylic acid, dimethyl ester & Dimethyl phthalate \\
\hline 1,2-Benzenedicarboxylic acid, dioctyl ester & Di-n-oclyl phthalate \\
\hline 1,2-Dibromo-3-chloropropano & DBCP \\
\hline 1,2-Dibromoethane & 1,2-Dibromoethan $\theta$ \\
\hline 1,2-Dichlorobenzene & o-Dichlorobenzene \\
\hline 1,2-Dichloroethane & 1,2-Dichloroethane \\
\hline 1,2-Dichloropropane & 1,2-Dichloropropane \\
\hline 1,3,4-Metheno-2H-cyclobuta- [colpentalen-2-one,1,1a,3,3a,4,5,5a,5b,6-decachlorooctahydro- & Kepone \\
\hline 1,3-Benzodioxole, 5-(1-propenyl). & Isosafrole \\
\hline 1,3-Benzodioxole, 5-(2-propenyl). & Safrole \\
\hline 1,3-Butadiene, 1,12,3,4,4-hexachioro- & Hexachlorobutadiene \\
\hline 1,3-Butadiene, 2-chloro- & Chloroprene \\
\hline 1,3-Cyclopentadiene, 1,2,3,4,5,5-hexachloro- & Hexachlorocyclopentadiene \\
\hline 1,3-Dichlorobenzene & m-Dichiorobenzene \\
\hline 1,4,5,8-Dimethanonaphthalen $\theta, 1,2,3,4,10,10$-hexachloro- $1,4,4 a, 5,8,8 a$ hexahydro- $(1 a, 4 a, 4 a b, 5 b, 8 b, 8 a b)$. & Isodrin \\
\hline 1,4-Benzenediamine & p-Phenylenediamine \\
\hline 1.4-Dichlorobenzene & p-Dichlorobenzene \\
\hline 1,4-Dioxane & 1, 4-Dioxane \\
\hline 1,4-Naphthalenedione & 1,4-Naphthoquinone \\
\hline 1,4-Naphthoquinone & 1.4-Naphthoquinone \\
\hline 1,4:5,8-Dimethanonaphthalene, $\quad 1,2,3,4,10,10$-hexachloro-1,4,4a,5,8,8a-hexahydro-(1a,4a,4ab,5a,8a,8ab)- & Aldrin \\
\hline 1-Butanamine, N-butyl-N-nitroso- & N-Nitrosodi-n-butylamine \\
\hline 1-Naphithalenamine & 1-Naphthylamine \\
\hline 1-Naphthylamine & 1-Naphthylamine \\
\hline 1.Propanamine, N-nitroso-N-propyl- & N-Nitrosodipropylamine \\
\hline
\end{tabular}

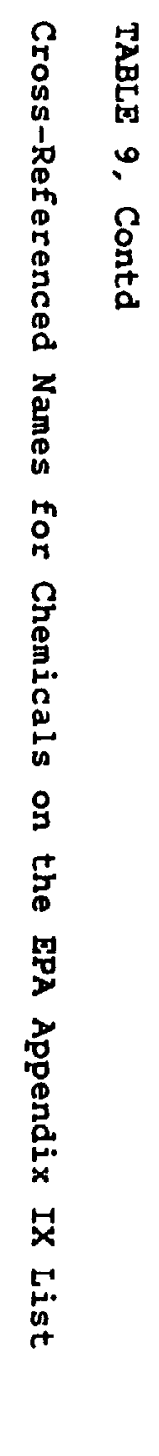




\begin{tabular}{|c|c|}
\hline Cross Relerence Name & Name in Appendix IX List \\
\hline 1-Propanol, 2-methyl- & Isobutyl alcohol \\
\hline 1-Propene, $1,1,2,3,3,3$-hexachloro- & Hexachloropropene \\
\hline 1.Propene, 1,3-dichloro- (E)- & trans-1,3-Dichloropropene \\
\hline 1-Propene, 1,3-dichloro-, (z)- & cis-1,3-Dichloropropene \\
\hline 1-Propene, 3-chloro- & Allyl chloride \\
\hline 2,2'-Dichlorodiiso-propyl other & Bis(2-chloro-1-methylethyl) ether \\
\hline 2,3,4,6-Tetrachlorophend & 2,3,4,6-Tetrachlorophenol \\
\hline $2,3,7,8-\mathrm{TCDD}$ & $2,3,7,8-T C D D$ \\
\hline 2,3,7,8-Tetrachlorodibenzo-p-dioxin & $2,3,7,8-T C D D$ \\
\hline $2,4,0$ & $2,4-D$ \\
\hline $2,4,5-T$ & $2,4,5-T$ \\
\hline $2,4,5-\mathrm{TP}$ & $2,4,5-\mathrm{TP}$ \\
\hline 2,4,5-Trichlorophenol & 2,4,5-Trichlorophenol \\
\hline 2,4,5-Trichlorophenoxyacetic acid & $2,4,5 \cdot \mathrm{T}$ \\
\hline 2,4,6-Trichlorophenol & 2,4,6-Trichlorophenol \\
\hline 2,4-Dictlorophenol & 2,4-Dichlorophenol \\
\hline 2.4-Dichlorophenoxyacetic acid & 2,4-D \\
\hline 2,4-Dimethyiphenol & 2,4-Dimethylphenol \\
\hline 2,4-Dinitrophenol & 2.4-Dinitrophenol \\
\hline 2,4-Dinitrotoluene & 2,4-Dinitrotoluene \\
\hline 2,5-Methano-2H-indeno(1,2-b]oxirene, 2,3,4,6,7,7-heptachloro-1a,1b,5,5a,6,6a,-hexahydro-,(1aa,1bb,2a,5a,5ab,6b,6aa)- & Heplachlor epoxide \\
\hline 2,6-Dichlorophenal & 2,6-Dichlorophenol \\
\hline 2,6-Dinitrololuene & 2,6-Dinitrotoluene \\
\hline 2,7:3,6-Dimethanonaphth|2,3-b]oxirene, 3,4,5,6,9,9-hexachloro-1a,2,2a,3,6,6a,7,7a-octahydro,(1aa,2b,2aa,3b,6b,6aa,7b,7aa)- & Dieldrin \\
\hline 2,7:3,6-Dimethanonaphth[2,3-bloxirene, $3,4,5,6,9,9$-hexachloro-1a,2,2a,3,6,6a,7,7a-octahydro-(1aa,2b,2ab,3a,6a,6ab,7b,7aa)- & Endrin \\
\hline 2-AAF & 2-Acelylaminofluorene \\
\hline 2-Acetylaminotluorene & 2.Acelylaminofluorene \\
\hline 2-Butanone & Methyl ethyl ketone \\
\hline 2-Butene, 1,4-dichloro-, (D)- & Irans-1,4-Dichloro-2-bulene \\
\hline 2-Chloronaphthalene & 2.Chloronaphthalene \\
\hline 2-Chlorophenal & 2-Chlorophenol \\
\hline 2-Cyclohexen-1-one, 3,5,5-trimethyl- & Isophorone \\
\hline 2. Hexanone & 2-Hexanone \\
\hline 2-Hexanone & 2. Hexanone \\
\hline 2-Methylnaphthalene & 2-Methylnaphithalene \\
\hline 2. Naphthalenamine & 2-Naphthylamine \\
\hline 2-Naphthylamine & 2-Naphthylamine \\
\hline 2.Pentanone, 4-methy- & 4-Methyl-2-pentanone isobutyl ketone \\
\hline 2-Picoline & 2-Picoline \\
\hline 2-Propanone & Acetone \\
\hline 2.Propenal & Acrolein \\
\hline 2.Propenenitrile & Acrylonitrile \\
\hline
\end{tabular}




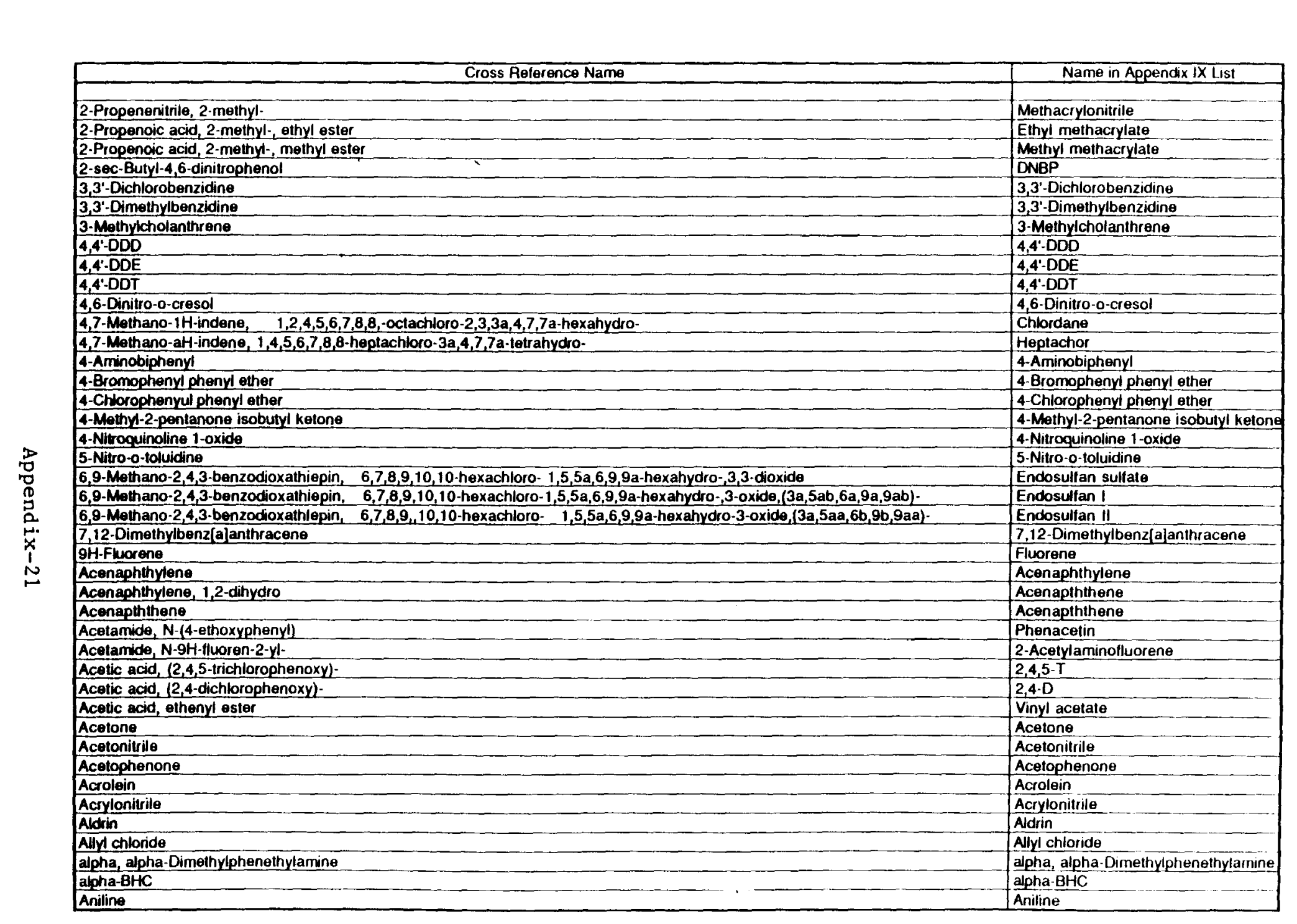




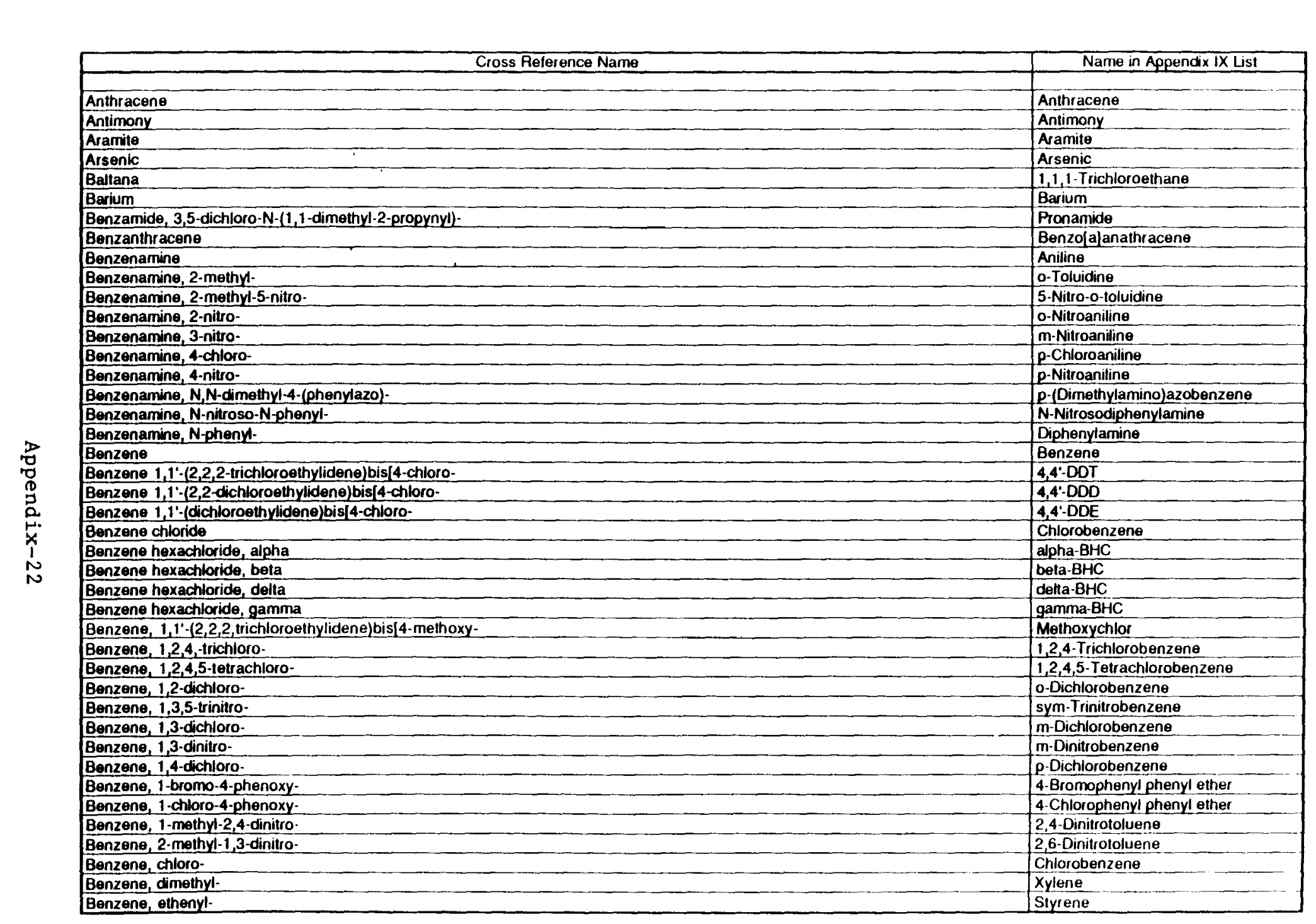

Benzene, dimethy

Xylene
Styrene

1




\begin{tabular}{|c|c|}
\hline Cross Relerenco Name & Name in Appendix IX List \\
\hline Benzene, ethyl- & Ethylbenzene \\
\hline Benzene, hexachloro- & Hexachlorobenzene \\
\hline Benzene, methyl- & Toluene \\
\hline Benzens, nitro- & Nitrobenzene \\
\hline Benzene, pentachloro- & Pentachlorobenzene \\
\hline Benzene, pentachloronitro- & Pentachloronitrobenzene \\
\hline Benzeneacelic acid, 4-chloro-a-4-chlorophenyl)-a-hydroxy, ethyl ester & Chlorobenzilate \\
\hline Benzeneethanamine, a, a-dimethyl- & alpha, alpha-Dimethylphenethylamine \\
\hline Benzenemethanol & Benzyl alcohal \\
\hline Benzinolorm & Carbon tetrachloride \\
\hline Benzo[alanathracene & Benzolalanathracene \\
\hline benzolalpyrane & benzo[alpyrene \\
\hline Benzo(bllluoranthene & \begin{tabular}{|l|l|l|l} 
Benzolbylliuoranthene \\
\end{tabular} \\
\hline Benzo[ghilperylene & Benzolghilperylene \\
\hline Benzo (k) kluoranthene & Benzo[kffluoranthene \\
\hline Benzyl alcohol & Benzyl alcohol \\
\hline Bonzyl butyl phthalate & Bulyl benzyl phthalate \\
\hline Benzlalanthracene, 7, 12-dimethyl- & 7,12-Dimethylbenzalajthracene \\
\hline Benzlejacephenanthrylene & Benzo[b]fluoranthene \\
\hline Benzillaceanthrylene, 1,2-dihydro-3-methyl- & 3-Methylcholanthrene \\
\hline Beryllium & Beryllium \\
\hline beta-BHC & bela-BHC \\
\hline Bis(2-chloro-1-methylethyl) ether & Bis(2-chloro-1-methylethyl) ether \\
\hline Bis(2-chloroethoxy)methane & Bis(2-chloroethoxy)methane \\
\hline Bis(2-chloroethyl)ether & Bis(2-chloroethyl)ether \\
\hline Bis(2-ethythexyl) phthalate & Bis(2-ethylhexyl) phthalate \\
\hline Bromodichloromethane & Bromodichloromethane \\
\hline Bromoform & Bromoform \\
\hline Bromomethane & Bromomethane \\
\hline Butrd benzyd phithalate & Butyl benzyl phithalale \\
\hline Cadmium & Cadmium \\
\hline Carbamothioic acid, bis(1-methylethyl)-, S-(2,3-dichloro-2-propenyll) ester & Diallate \\
\hline Carbon disulfide & Carbon disulfide \\
\hline Carbon hexachloride & Hexachloroethane \\
\hline Carbon tetractioride & Carbon telrachloride \\
\hline Chlordane & Chlordane \\
\hline Chlorobenzene & Chilorobenzene \\
\hline Chlorobenzilate & Chlorobenzilate \\
\hline Chlorodibromomethane & Dibromochloromethane \\
\hline Chloroethane & Chloroethane \\
\hline Chloroethene & Vinyl chloride \\
\hline Chlorolorm & Chlorolorm \\
\hline
\end{tabular}




\begin{tabular}{|c|c|}
\hline Cross Relerence Name & Name in Appendix IX List \\
\hline Chloromethane & Chloromethane \\
\hline Chlorophen & Pentachlorophenol \\
\hline Chtoroprene & Chloroprene \\
\hline Chlorotene & 1,1,1-Trichloroethane \\
\hline Chromium & Chromium \\
\hline Chrysene & Chrysene \\
\hline cis-1,3-Dichloropropene & cis-1,3-Dichjoropropene \\
\hline Cobalt & Cobalt \\
\hline Copper & Copper \\
\hline Cyanide & Cyanide \\
\hline Cyclohoxane, $1,2,3,4,5,6$-hex achloro- $(1 \mathrm{a}, 2 \mathrm{a}, 3 \mathrm{a}, 4 \mathrm{~b}, 5 \mathrm{a}, 6 \mathrm{~b})$ - & della-BHC \\
\hline Cyclohexane, $1,2,3,4,5,6$-hexachloro- $(1 \mathrm{a}, 2 \mathrm{a}, 3 \mathrm{~b}, 4 \mathrm{a}, 5 \mathrm{a}, 6 \mathrm{~b})$ & gamma-BHC \\
\hline Cyclohexane, $1,2,3,4,5,6$-hexachioro- $(1 \mathrm{a}, 2 \mathrm{a}, 3 \mathrm{~b}, 4 \mathrm{a}, 5 \mathrm{~b}, 6 \mathrm{~b})-$ & alpha-BHC \\
\hline Cyclohexane, $1,2,3,4,5,6$-hexactiloro-, (1a,2b,3a,4b,5a,6b)- & bela-BHC \\
\hline d-Dictilorobenzene & o-Dichlorobenzens \\
\hline DACP & OBCP \\
\hline detta-BHC & delta-BHC \\
\hline Di-n-butyl phthalate & Di-n-butyl phithalate \\
\hline Oi-n-octy phthalate & Di-n-octyl phithalate \\
\hline Di-n-propynitrosamine & N-Nitrosodipropylamine \\
\hline Diallate & Diallate \\
\hline Dibenzofuran & Dibenzoturan \\
\hline Dibenzofuran, chloro derivatives & Polychlorinated dibenzofurans \\
\hline Dibenzo[b,el[1,4]dioxin, 2,3,7,8-tetrachloro- & $2,3,7,8-\mathrm{TCDD}$ \\
\hline Dibenzo[b,el[1,4]dioxin, chloro derivatives & Polychlorinated dibenzo-p-dioxins \\
\hline Dibenzla, hlanthracene & Dibenz]a,h]anthracene \\
\hline Dibromochloromethane & Dibromochloromethane \\
\hline Dibromomethane & Dibromomethan $\theta$ \\
\hline Dichlorodifluoromethane & Dichiorodifluoromethane \\
\hline Dictioromethane & Dichloromethane \\
\hline Dialdrin & Dieldrin \\
\hline Diethyl phthalate & Diethyl phthalate \\
\hline Dimethoate & Dimethoate \\
\hline Dimethyl phthalate & Dimethyl phithalate \\
\hline Dinoseb & DNBP \\
\hline Diphenylamine & Diphenylamine \\
\hline $\begin{array}{l}\text { Disultoton } \\
\end{array}$ & Disulfolon \\
\hline DNBP & DNBP \\
\hline Endosulfan I & Endosulfan 1 \\
\hline Endosulian II & Endosulfan II \\
\hline Endosulfian sulfate & Endosulfan sulfate \\
\hline Endrin & Endrin \\
\hline
\end{tabular}

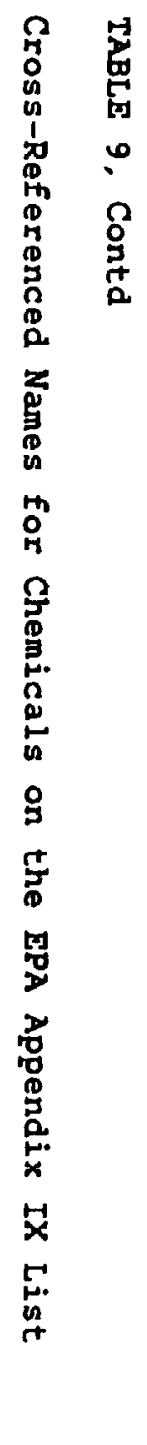

1




1

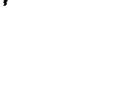

\begin{tabular}{|c|c|}
\hline Cross Reference Name & Name in Appendix IX List \\
\hline Endrin aldehyde & Endrin aldehyde \\
\hline Ethanamine, N-ethyl-N-nitroso- & N-Nitrosodiethylamine \\
\hline Ethanamine, $\mathrm{N}$-methyl-N-nitroso- & N-Nitrosomeihylethylamine \\
\hline Ethane, 1,1-oxybis[2-chloro- & Bis(2-chloroethyl)ether \\
\hline Ethane, 1,1'-\{methylenebis (oxy)]bis [2-chloro- & Bis(2-chloroethoxy)methane \\
\hline Eihane, 1,1,1,2-1etrachioro- & 1,1,1,2-Tetrachloroethane \\
\hline Eithane, $1,1,1$-tictiloro- & $\begin{array}{l}1,1,1 \text {-Trichloroethane } \\
\end{array}$ \\
\hline Ethane, 1,1,2,2-tetrachloro- & $1,1,2,2$, -Tetr achloroethan $\theta$ \\
\hline Ethane, $1,1,2$-trichloro- & $1,1,2$-Trichloroethane \\
\hline Ethane, 1,1-dichloro- & 1,1-Dichloroethane \\
\hline Ethane, 1,2-dibromo- & 1,2-Dibromoethane \\
\hline Ethane, 1,2-dichloro- & 1,2-Dichloroethane \\
\hline Ethano, chloro- & Chloroethane \\
\hline Ethane, hexachloro- & Hexachloroethane \\
\hline Ethane, pentachloro- & Pentachloroethane \\
\hline Ethanone, 1-phenyl- & Acelophenone \\
\hline Ethene, 1,1-dichloro- & 1,1-Dichloroethylene \\
\hline Ethene, 1,2-dichloro-, (E)- & trans-1,2-Dichloroethylene \\
\hline Ethene, chloro- & Vinyl chloride \\
\hline Ethene, tetrachloro- & Tetrachioroethylene \\
\hline Ethene, trichloro- & Trichloroethylene \\
\hline Ethyl chloride & Chloroethane \\
\hline Ethyl cyanide & \begin{tabular}{|l} 
Propionitrile \\
\end{tabular} \\
\hline Ethyl methacrylate & Ethyl methacrylate \\
\hline Ethyl methanesulfonate & Ethyl methanesultionale \\
\hline Ethylbenzene & \begin{tabular}{|l} 
Ethylbenzene \\
\end{tabular} \\
\hline Ethylene dibromide & 1,2-Dibromoethane \\
\hline Ethylene dichloride & 1,2-Dichloroethane \\
\hline Ethylidine chloride & 1,1-Dichloroethane \\
\hline Famphur & Famphur \\
\hline Fluoranthene & Fluoranthene \\
\hline $\begin{array}{ll}\text { Fluorene } \\
\text { Flons }\end{array}$ & Fluorene \\
\hline gamma-BHC & gamma-BHC \\
\hline Genklene & $1,1,1$-Trichloroethan $\theta$ \\
\hline HCB & Hexachlorobenzene \\
\hline Heplachlor epoxide & Heplachlor epoxide \\
\hline Heplachor & Heplachor \\
\hline Hexachlorobenzene & Hexachlorobenzene \\
\hline Hexachlorobutadiene & Hexachlorobutadiene \\
\hline Hexachlorocydohexane, alpha & alpha-BHC \\
\hline Hexachlorocyclohexane, beta & beta-BHC \\
\hline Hexachlorocyclohexane, della & delta BHC \\
\hline
\end{tabular}




\begin{tabular}{|c|c|}
\hline Cross Reterence Name & Name in Appendix IX List \\
\hline Hexachlorocyclohexane, gamma & gamma-BHC \\
\hline Hexactilorocyclopentadiene & Hexachlorocyclopentadiene \\
\hline Hexachloroethane & Hexachloroethane \\
\hline Hexachlorophene & Hexachlorophene \\
\hline Hexachloropropene & Hexachloropropene \\
\hline Hydrochloric other & Chloroethane \\
\hline Hydroxytoluene, alpha & Benzyl alcohol \\
\hline Indeno $(1,2,3-\mathrm{cd})$ pyrene & Indeno $(1,2,3-c d)$ pyrene \\
\hline Indeno[ $1,2,3-c d]$ pyrene & indeno(1,2,3-cd)pyrene \\
\hline lodomethane & lodomethane \\
\hline Isobutyl alcohol & Isobutyl alcohol \\
\hline Isodrin & Isodrin \\
\hline Isophorone & isophorone \\
\hline Isosafrole & Isosafrole \\
\hline Kepone & Kepone \\
\hline Lead & Lead \\
\hline Lindane & gamma-BHC \\
\hline m-Cresol & m-Cresol \\
\hline m-Dichlorobenzeng & m-Dichlorobenzene \\
\hline m-Dinitrobenzene & m-Dinitrobenzene \\
\hline m-Nitroaniline & m-Nitroaniline \\
\hline MEK & Methyl ethyl ketone \\
\hline Mercury & Mercury \\
\hline Methacrylonitrile & Methacrylonitrile \\
\hline Mothanamine, N-methyl-N-nitroso- & N-Nitrosodimethylamine \\
\hline Methane tetrachloride & Carbon tetrachloride \\
\hline Mothane, bromo- & Bromomethane \\
\hline Methane, bromodichloro- & Bromodichloromethane \\
\hline Methane, chloro- & \begin{tabular}{|l} 
Chloromethane \\
\end{tabular} \\
\hline Mothane, dibromo- & Dibromomethane \\
\hline Methane, dibromochioro- & Dibromochloromethane \\
\hline Methane, dichloro- & Dichloromethane \\
\hline Methane, dichlorodifluoro- & Dichlorodiffuoromethane \\
\hline Methane, iodo- & lodomethane \\
\hline Methane, tetrachioro- & Carbon tetrachioride \\
\hline Methane, tribromo- & Bromoform \\
\hline Methane, trichloro- & Chlorotorm \\
\hline Methane, trichlorofluoro- & Trichlorofluoromethane \\
\hline Methanesulfonic acid, ethyl ester & Eithyl methanesulfonale \\
\hline Mothanesulfonic acid methyl ester & Methyl methanesulfonate \\
\hline Methapyrilene & Methapyrilene \\
\hline Methoxychlor & Methoxychlor \\
\hline
\end{tabular}

1




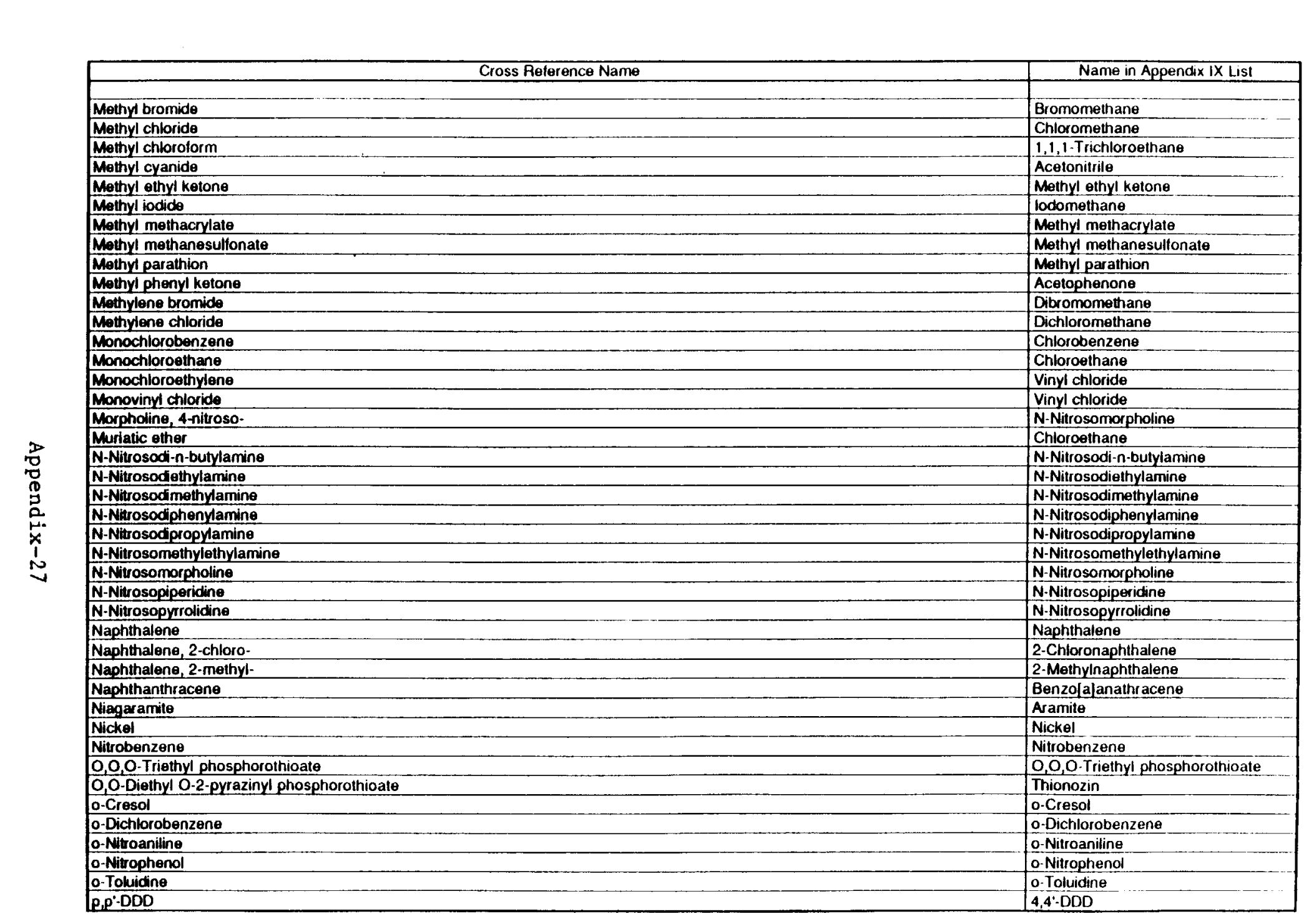




\begin{tabular}{|c|c|}
\hline Cross Peterence Name & Name in Appendix IX List \\
\hline p.p'-DDE & $4,4^{\prime} \cdot \mathrm{DDE}$ \\
\hline P, $\rho^{\prime}-\mathrm{DDT}$ & $4,4^{4}$.DDT \\
\hline p.(Dimethylamino)azobenzene & p-(Dimethylamino)azobenzene \\
\hline p-Chloro-m-cresol & p-Chloro-m-cresol \\
\hline p-Chtoroaniline & p-Chloroaniline \\
\hline p-Cresol & p-Cresol \\
\hline p.Dichlorobenzene & p-Dichlorobenzene \\
\hline p-Nitroaniline & p-Nitroaniline \\
\hline p-Nitrophenol & p-Nitrophend \\
\hline p-Phenylenediamine & p-Phenylenediamine \\
\hline Parathion & Parathion \\
\hline Parathion methyl & Methyl parathion \\
\hline PCBs & Polychlorinated biphenyls \\
\hline PCDDs & Polychlorinated dibenzo-p-dioxins \\
\hline PCOFs & Polychlorinaled dibenzofurans \\
\hline Penta & Pentachlorophenol \\
\hline Pentachlorobenzene & Pentachlorobenzene \\
\hline Pentachloroethane & Pentachloroethane \\
\hline Pentachlorol & Pentachlorophenol \\
\hline Pontachloronitrobenzene & Pentachloronitrobenzene \\
\hline Pontachlorophenol & Pentachilorophenol \\
\hline Perchlorobenzene & Hexachlorobenzene \\
\hline Perchloroethane & Hexachloroethane \\
\hline Perchloroethylene; & Tetrachloroethylene \\
\hline Perchloromethane & Carbon tetrachloride \\
\hline Perclene & Tetrachloroethylene \\
\hline Phonacotin & Phenacetin \\
\hline Phenanthrene & Phenanthrene \\
\hline Phenol & Phenol \\
\hline Phend, 2,2'-methylenebis $[3,4,6$-trichloro- & Hexachlorophene \\
\hline Phend, 2,3,4,6-1elrachloro- & $2,3,4,6$-Tetrachlorophenol \\
\hline Phend, 2,4,5-trichloro- & 2,4,5-Trichlorophanol \\
\hline Phend, 2,4,6-trichloro- & 2,4,6-Trichlorophenol \\
\hline Phend, 2,4-dichloro- & 2,4-Dichlorophenol \\
\hline Phenol, 2,4-dimethyl- & 2,4-Dimethyiphenol \\
\hline Phenol, 2,4-dinitro- & 2.4-Dinitrophenol \\
\hline Phenol, 2,6-dichloro- & 2,6-Dichlorophenol \\
\hline Phenol, 2-(1-methylpropyl)-4,6-dinitro- & DNBP \\
\hline Phend, 2-chloro- & 2-Chlorophenol \\
\hline Phenol, 2-methyl- & o-Cresol \\
\hline Phenol, 2-methyl-4,6-dinitro- & 4,6.Dinitro-o-cresol \\
\hline Phenol, 2-nitro- & o-Nitrophenol \\
\hline
\end{tabular}

nenol, 2-methyl-4,6-dinitro

o-Nitrophenol 


I

\begin{tabular}{|c|c|}
\hline Cross Reference Name & Name in Appendix IX List \\
\hline Phenol, 3-methyl- & m-Cresol \\
\hline Phenol, 4-chloro-3-melthyl- & p-Chloro-m-cresol \\
\hline Phenol, 4-methyl- & p-Cresol \\
\hline Phenol, 4-nitro- & p-Nitrophenol \\
\hline Phenol, pentachloro- & Pentachloraphenol \\
\hline Phenylamine & Aniline \\
\hline Phorate & Phorate \\
\hline Phosphorodithioic acid, 0,O-diethyl S.f(ethylthio)methyl] ester & Phorale \\
\hline Phosphorodithioic acid, O,O-diethyl S-[2-(othyythio)-S-[2-ethylester & Disultoton \\
\hline Phosphorodithioic acid, 0,0-dimethyl S-[2-(methylanino)-2-oxoethyl] ester & Dimethoate \\
\hline Phosphorothioic acid, O-[4-[(dim thylamino) sultionylloheny] 0 , 0 -dimethyl ester & Famphur \\
\hline Phosphorothioic acid, $0,0,0$-triethyl aster & $0,0,0$-Triethyl phosphorothioate \\
\hline Phosphorothioic acid, 0,0-diethyl O-pyrazinyl ester & Thionozin \\
\hline Phosohorothioic acid, O, O-diethyl-O-(4-nitrophenyl) ester & Parathion \\
\hline Phosphorothiolc acid, 0,0-dimethyl 0-(4-nitrophenyl) ester & Methyl parathion \\
\hline Piperidine, 1-nitroso- & N-Nitrosopiperiding \\
\hline Polychlorinated biphenyls & Polychlorinated biphenyls \\
\hline Polychlorinated dibenzo-p-dioxins & Polychlorinaled dibenzo-p.dioxins \\
\hline Polychlorinated dibenzolurans & Polychlorinated dibenzolurans \\
\hline Pronamide & Pronamide \\
\hline Propane, 1,2,3-trictioro- & 1,2,3-Trichloropropane \\
\hline Propane, 1,2-dibromo-3-chloro- & DBCP \\
\hline Propane, 1,2-dichloro- & 1,2-Dichloropropane \\
\hline Propane, 2,2'-oxybis [1-chloro- & Bis(2-chloro-1-methylathyl) ether \\
\hline Propanenitrile & Propionitrile \\
\hline Propanoic acid, 2-(2,4,5-trichlorophenoxy)- & $2,4,5-\mathrm{TP}$ \\
\hline Propionitrile & Propionitrile \\
\hline Pyrene & Pyrene \\
\hline Pyridine & Pyridine \\
\hline Pyridine, 2-methyl- & 2.Picoline \\
\hline Pyrrolidina, 1-nitroso- & N-Nitrosopyrrolidine \\
\hline Quinoline, 4-nitro-, 1-oxide & 4-Nitroquinoline 1-oxide \\
\hline Safrole & Safrole \\
\hline Selenium & Selenium \\
\hline Silver & Silver \\
\hline Silvex & $2.4 .5 \cdot \mathrm{TP}$ \\
\hline Styrene & Styrene \\
\hline Sulfide & Sulfide \\
\hline Sulfotepp & Sultotepp \\
\hline Sulfurous acid, 2-chloroethyl 2-[4-(1,1-dimethylethyl)phenoxy] 1 -methylethyl ester & Aramite \\
\hline Sym-Trinitrobenzene & sym-Trintrobenzene \\
\hline Tetrachloroethene & Tetrachloroethylene \\
\hline
\end{tabular}




\begin{tabular}{|c|c|}
\hline Cross Relerence Name & Name in Appendix IX List \\
\hline Tetrachloroethylene & Tetrachloroethylene \\
\hline Tetrachloromethane & Carbon tetrachloride \\
\hline Totraethyl dithiopyrophosphate; & Tetraethyl dithiopyrophosphate; \\
\hline Thallium & Thallium \\
\hline Thiodiphosphoric acid $([(\mathrm{HO}) 2 \mathrm{P}(\mathrm{S})] 2 \mathrm{O})$, tetraethyl ester & Tetraethyl dithiopyrophosphate; \\
\hline Thionazin & Thionozin \\
\hline In & Tin \\
\hline Toluene & Toluene \\
\hline Toxaphene & Toxaphene \\
\hline trans-1,2-Dichioroethylens & Irans-1,2-Dichloroethylene \\
\hline trans-1,3-Dichloropropene & Irans-1,3-Dichloropropene \\
\hline trans-1,4-Dichloro-2-butene & Irans-1,4-Dichloro-2-butene \\
\hline Tribromomethane & Bromoform \\
\hline Trichloroethene & Trichloroethylene \\
\hline Trichloroethylene & Trichloroethylene \\
\hline Trichlorofluoromethane & Trichlorofluoromelthane \\
\hline Trichloromethane & Chloroform \\
\hline Vanadium & Vanadium \\
\hline Vinyl acetate & Vinyl acelate \\
\hline Vinyl chloride & Vinyl chloride \\
\hline Vinyl trichloride & 1,1,2-Trichloroethane \\
\hline Vinylidene chloride & 1,1-Dichloroethylene \\
\hline Xylent & Xylene \\
\hline Zinc & Zinc \\
\hline$\left(1,1^{\prime} \text {-Bipheny }\right)^{-4} 44^{\prime}$-diamine, 3,3'-dichloro- & 3,3'-Dichlorobenzidine \\
\hline$\left[1,1^{\prime}\right.$-Biphenyll $-4,4^{\prime}$-diamine, 3,30-dimethyl- & 3,3'-Dimethylbenzidine \\
\hline$\left[1,1^{1}\right.$-Biphenyl]-4-aming & 4-Arninobiphenyl \\
\hline
\end{tabular}


TABLE 10

Groundwater Quality Review Criteria

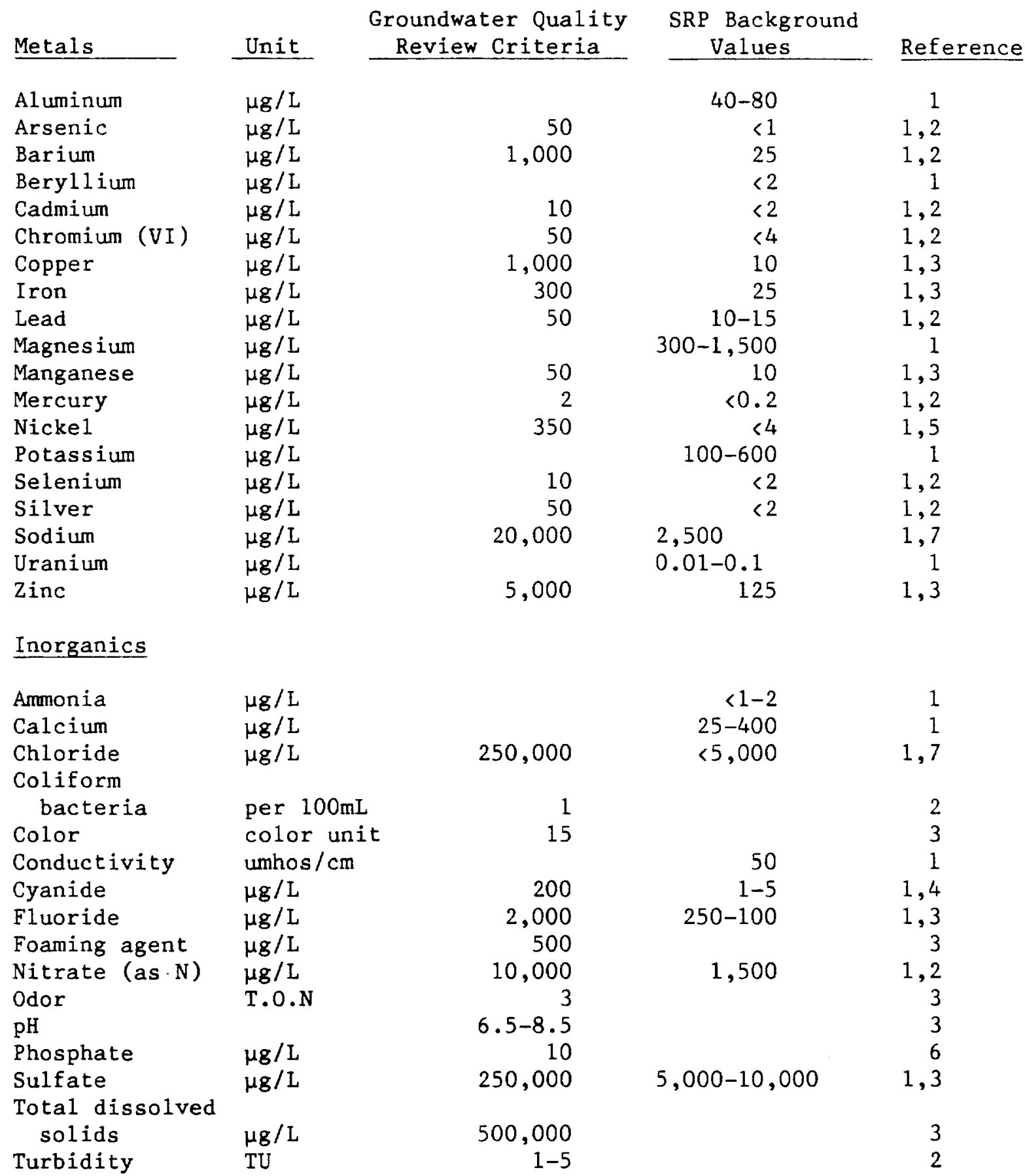


TABLE 10, Contd

Groundwater Quality Review Criteria

\begin{tabular}{|c|c|c|c|c|c|}
\hline Organics & Unit & $\begin{array}{l}\text { Groundwater Quality } \\
\text { Review Criteria } \\
\end{array}$ & $\begin{array}{l}\text { SRP Background } \\
\text { Values }\end{array}$ & Reference & - \\
\hline $1,1,1$-Trichloroethane & $\mu g / L$ & 200 & & 2 & \\
\hline $1,1,2$-Trich1oroethane & $\mu \mathrm{g} / \mathrm{L}$ & 0.60 & & 9 & \\
\hline 1,1-Dichloroethylene & $\mu \mathrm{g} / \mathrm{L}$ & 7 & & 2 & - \\
\hline 1,2-Dichloroethane & $\mu \mathrm{g} / \mathrm{L}$ & 5 & & 2 & \\
\hline 1,1-Dich1oroethylene & $\mu \mathrm{g} / \mathrm{L}$ & 350 & & 9 & \\
\hline $2,4,5-T P$ (Si1vex) & $\mu \mathrm{g} / \mathrm{L}$ & 10 & & 2 & - \\
\hline $2,4-D$ & $\mu \mathrm{g} / \mathrm{L}$ & 100 & & 2 & \\
\hline Benzene & $\mu \mathrm{g} / \mathrm{L}$ & 5 & & 2 & \\
\hline Bis (2-ethylhexy 1 ) & & & & & \\
\hline phthalate & $\mu g / L$ & 20,000 & & 9 & - \\
\hline Carbon tetrachloride & $\mu g / L$ & 5 & & 2 & \\
\hline Chlorobenzene & $\mu \mathrm{g} / \mathrm{L}$ & 1,000 & & 9 & \\
\hline Chloroform & $\mu g / L$ & 0.50 & & 9 & - \\
\hline Di-n-buty1 phthalate & $\mu g / L$ & 44,000 & & 9 & \\
\hline Dichlorobenzenes & $\mu \mathrm{g} / \mathrm{L}$ & 3,000 & & 9 & \\
\hline Dichlorome thane & $\mu \mathrm{g} / \mathrm{L}$ & 60 & & 9 & - \\
\hline Diethyl phthalate & $\mu \mathrm{g} / \mathrm{L}$ & 500,000 & & 9 & \\
\hline Endrin & $\mu \mathrm{g} / \mathrm{L}$ & 0.20 & & 2 & \\
\hline Ethylbenzene & $\mu \mathrm{g} / \mathrm{L}$ & 3,500 & & 9 & \\
\hline Fluroranthene & $\mu \mathrm{g} / \mathrm{L}$ & 5 & & 9 & - \\
\hline Forma1dehyde & $\mu \mathrm{g} / \mathrm{L}$ & 15 & & 9 & \\
\hline Lindane & $\mu \mathrm{g} / \mathrm{L}$ & 4 & & 2 & \\
\hline Methoxychlor & $\mu g / L$ & 100 & & 2 & - \\
\hline Methyl ethyl ketone & $\mu \mathrm{g} / \mathrm{L}$ & 2,000 & & 9 & \\
\hline Naphthalene & $\mu \mathrm{g} / \mathrm{L}$ & 5 & & 9 & \\
\hline p-Dichlorobenzene & $\mu g / L$ & 750 & & 2 & - \\
\hline Phenols & $\mu g / L$ & 3,500 & & 9 & \\
\hline Tetrachloroethylene & $\mu g / L$ & 0.70 & & 9 & \\
\hline Toluene & $\mu \mathrm{g} / \mathrm{L}$ & 10,000 & & 9 & \\
\hline Total organic carbon & $\mu \mathrm{g} / \mathrm{L}$ & & 2,500 & 1 & - \\
\hline Total organic halogens & $\mu \mathrm{g} / \mathrm{L}$ & 10 & & 8 & \\
\hline Toxaphene & $\mu \mathrm{g} / \mathrm{L}$ & 5 & & 2 & \\
\hline Trichloroethylene & $\mu g / L$ & 5 & & 2 & - \\
\hline Trichlorof luorome thane & $\mu \mathrm{g} / \mathrm{L}$ & 10,000 & & 9 & \\
\hline Trifluorotrichloroethane & $\mu g / L$ & 955 & & 9 & \\
\hline Vinyl chloride & $\mu g / L$ & 2 & & 2 & \\
\hline
\end{tabular}


TABLE 10, Contd

Groundwater Quality Review Criteria

\begin{tabular}{|c|c|c|c|c|}
\hline Radionuclides & Unit & $\begin{array}{l}\text { Groundwater Quality } \\
\text { Review Criteria } \\
\end{array}$ & $\begin{array}{l}\text { SRP Background } \\
\text { Values }\end{array}$ & Reference \\
\hline Americium-241 (a1pha) & $\mathrm{pCi} / \mathrm{L}$ & 15 & & 10 \\
\hline Americium-243 (alpha) & $\mathrm{pCi} / \mathrm{L}$ & 15 & & 10 \\
\hline Antimony-125 (gamma) & $\mathrm{pCi} / \mathrm{L}$ & 300 & & 10 \\
\hline Cesium-137 (gamma) & $\mathrm{pCi} / \mathrm{L}$ & 900 & & 10 \\
\hline Cobalt-60 (gamma) & $\mathrm{pCi} / \mathrm{L}$ & 100 & & 10 \\
\hline Curium-243 (alpha) & $\mathrm{pCi} / \mathrm{L}$ & 15 & & 10 \\
\hline Curium-244 (alpha) & $\mathrm{pCi} / \mathrm{L}$ & 15 & & 10 \\
\hline Curium-246 (a1pha) & $\mathrm{pCi} / \mathrm{L}$ & 15 & & 10 \\
\hline Gross alpha & $\mathrm{pCi} / \mathrm{L}$ & 15 & 3 & 1,2 \\
\hline Iodine-129 (beta) & $\mathrm{pCi} / \mathrm{L}$ & 1 & & 10 \\
\hline Nonvolatile beta & $\mathrm{pCi} / \mathrm{L}$ & 45 & 5 & 1,11 \\
\hline Plutonium-238 (alpha) & $\mathrm{pCi} / \mathrm{L}$ & 15 & & 10 \\
\hline Plutonium-239 (alpha) & $\mathrm{pCi} / \mathrm{L}$ & 15 & & 10 \\
\hline P1utonium-240 (a1pha) & $\mathrm{pCi} / \mathrm{L}$ & 15 & & 10 \\
\hline P1utonium-242 (alpha) & $\mathrm{pCi} / \mathrm{L}$ & 15 & & 10 \\
\hline Radium-226,228 & $\mathrm{pCi} / \mathrm{L}$ & 5 & 1 & 1,2 \\
\hline Sodium-22 & $\mathrm{pCi} / \mathrm{L}$ & 400 & & 10 \\
\hline Strontium-90 (beta) & $\mathrm{pCi} / \mathrm{L}$ & 8 & & 2 \\
\hline Technicium-99 (beta) & $\mathrm{pCi} / \mathrm{L}$ & 900 & & 10 \\
\hline Tritium (beta) & $\mathrm{pCi} / \mathrm{L}$ & 20,000 & & 2 \\
\hline
\end{tabular}

\section{References}

1. SRP background values from Pickett and Shedrow, 1986.

2. Primary drinking water standards (EPA, 1977).

3. Secondary drinking water standards (EPA, 1981).

4. USPHS, 1962.

5. EPA, $1985 \mathrm{~b}$.

6. Wetzel, 1983. Value associated with ecological effect in surface waters.

7. EPA, 1985c. (Included to protect high risk individuals on a sodium restricted diet).

8. Looney and Pickett, 1986. A guideline of $10 \mu \mathrm{g} / \mathrm{L}$ was selected because constituents of concern are rarely present when the average $\mathrm{TOH}$ is less than $10 \mu \mathrm{g} / \mathrm{L}$.

9. EPA, 1985a and public docket. (These are "Health Based Standards" or levels that are explicitly described as of no regulatory concern.)

10. EPA, 1977. Based on 4 mrem dose.

11. This concentration corresponds to a dose of $4 \mathrm{mrem} / \mathrm{yr}$, assuming that the nonvolatile beta is $90_{\mathrm{SR}}$ and that the exposed individual consumes $2 \mathrm{~L}$ of water per day. 